\title{
STUDIES ON THE GLACIOVOLCANIC AND MAGMATIC EVOLUTION OF RUAPEHU VOLCANO, NEW ZEALAND
}

by

Christopher Edward Conway

\author{
A thesis \\ submitted to Victoria University of Wellington \\ in fulfilment of the requirements for the degree of \\ Doctor of Philosophy in Geology
}

Victoria University of Wellington

School of Geography, Environment and Earth Sciences

Wellington, New Zealand

January 2016 



\section{ABSTRACT}

This thesis undertakes a detailed case study of the processes and timescales of arc andesite-dacite magma generation and lava flow emplacement at a continental composite volcano. This has been achieved through the collection and integration of high-resolution field, geochronological and geochemical datasets for lava flows that form the edifice of Ruapehu.

The influence of syn-eruptive lava-ice interaction on the distribution and preservation of lava flows on glaciated composite volcanoes is investigated by characterising the morphology and fracture characteristics of effusive products at Ruapehu. Ice-bounded and ice-dammed lava flows display over-thickened (50-100 m-high) margins adjacent to or within glaciated valleys, are intercalated with till and have lateral margins that are pervasively fractured by quench-contraction cooling joints. These characteristics can be accounted for by impoundment and chilling of lava flows that were emplaced against large flank glaciers. In contrast, lava flows located within valleys have minimal moraine cover and glacial striae and are characterised by fracture networks indicative of only localised and minor interaction with ice/snow. These lavas were emplaced onto a relatively ice-free edifice following glacial retreat since $\sim 18 \mathrm{ka}$.

New high-precision ${ }^{40} \mathrm{Ar} /{ }^{39} \mathrm{Ar}$ eruption ages and whole-rock major element geochemistry for lava flows are interpreted in the context of geologic mapping, volcano-ice interaction processes and previous chronostratigraphic studies. This provides a high-resolution eruptive history and edifice evolution model for Ruapehu. Sub-glacial to ice-marginal effusive eruption of basaltic-andesite and andesite constructed the northern portion of the exposed edifice between 200 and $150 \mathrm{ka}$ (Te Herenga Formation) and the wide southeastern planèze as well as parts of the northern, eastern and western flanks of Ruapehu between $\sim 166$ and $80 \mathrm{ka}$ (Wahianoa Formation). No ages were returned for lava flows for the period from 80-50 ka, indicating one or a combination of: an eruptive hiatus; subsequent erosion and burial of lavas; or syn-eruptive glacial conveyance of lava flows to the ring-plain. The greater part of the modern edifice was constructed via effusion of lava flows of the syn-glacial Mangawhero Formation (50-15 ka) and post-glacial Whakapapa Formation ( $<15 \mathrm{ka}$ ). Syn-glacial edifice growth occurred primarily via effusion of andesite-dacite lava flows that formed ice-bounded ridges adjacent to valleyfilling glaciers. Post-glacial summit cones were constructed in the presence of remnant 
upper flank glaciers between 15 and $10 \mathrm{ka}$. Debuttressing of two northern summit cones and a southern summit cone as ice underwent continued post-glacial retreat resulted in two major Holocene sector collapses and deposition of debris avalanche deposits on the northern and south-eastern flanks of Ruapehu, respectively. The northern collapse scar was infilled by a new cone comprising <10 ka lava flows that form the modern upper northern and eastern flanks of the volcano. Late Holocene to historic eruptive activity has occurred through Crater Lake, which occupies the site of the collapsed southern cone.

New whole-rock major and trace element compositions for lavas and their mineral and melt inclusion geochemical characteristics are evaluated within the context of the improved chronostratigraphic framework. The new constraints are combined with existing whole-rock isotopic data to establish the long-term development of the magma generation system beneath Ruapehu. Basaltic-andesite lavas erupted between $\sim 200$ and 150 ka contain low- $\mathrm{K}_{2} \mathrm{O}(2-3$ wt. \%) melt inclusions and have whole-rock compositions characterised by low incompatible element (K, Rb, Ba, Th, U) abundances and high ${ }^{143} \mathrm{Nd} /{ }^{144} \mathrm{Nd}-$-low ${ }^{87} \mathrm{Sr} /{ }^{86} \mathrm{Sr}$ when compared to younger eruptive products. In particular, basaltic-andesite to dacite lavas that were erupted between 50-35 ka define a high-K/Ca trend over a range of $\sim 8 \mathrm{wt}$. $\% \mathrm{SiO}_{2}$ as well as elevated incompatible trace element contents when compared to all other documented eruptive products from Ruapehu. Rhyodacitic to rhyolitic melt inclusions, interstitial glass and melt pockets in partially fused feldspathic xenoliths contained within the dacite lavas from this latter period contain high $\mathrm{K}_{2} \mathrm{O}$ (5-6 wt. \%) and Rb contents (250-280 ppm). The whole-rock and glass characteristics of 50-35 ka lavas reflect the generation and assimilation of partial melts of the greywacke-argillite basement within the magma system beneath Ruapehu during this period. Selective partial melting and assimilation of fertile, $\mathrm{K}$ - and Rb-rich mineral phases (e.g. biotite) within the meta-sedimentary mineral assemblage is inferred to explain the enriched nature of these melts. A reversion to progressively less silicic and less potassic lavas with lower incompatible element abundances erupted since $26 \mathrm{ka}$ is matched by the recurrent incorporation of crystals that trapped low- $\mathrm{K}_{2} \mathrm{O}$ melt inclusions. The trend is interpreted to reflect the exhaustion of fertile phases within assimilated continental source rocks as the crust was progressively heated during long-term thermal conditioning of the arc lithosphere beneath Ruapehu. 


\section{Acknowledgements}

I have been supported by an incredible supervisory team, and my great thanks go to Colin Wilson, John Gamble, Graham Leonard and Dougal Townsend for guiding me through the last four years. Advice on topics that covered mapping (Dougal), geochronology (Graham), petrology (John) and all things volcanology (Colin) have been readily provided and greatly appreciated. The constant supply of coffee from Colin during the final writeup has kept me going and the ensuing discussions have been a source of motivation. Your dedication to your students and their discoveries is something I am proud to have been part of. Graham and Colin worked hard to get me to overseas conferences in Japan and the US, which I am especially grateful for. Dougal was a role model for fieldwork, from whom I have learnt a lot, and John gave me daily encouragement to dig deeper into the andesite 'hot zone'. I have been privileged to work with you all and look forward to many more years of collaboration and friendship.

Monika Hanson and Patricia Stein are thanked for their mastery of finances and enrolments, respectively. Thanks to the Department of Conservation and Harry Keys for help with field support, and to Mark Rattenbury for providing accommodation in Rangataua. Shaun Eaves provided great company in the field and many valuable discussions. James Brigham-Watson, Jason Marshall and Kirsten Henden provided field and lab assistance. Thanks to Andy Calvert and the USGS Menlo Park geochronology lab for all of the work that went into acquiring the ${ }^{40} \mathrm{Ar} /{ }^{39} \mathrm{Ar}$ data. Thanks to Sabrina Lange for support in the geochemistry and crushing labs. Stewart Bush provided thin sections. Thank you to Monica Handler for helping with solution ICPMS analyses, and to Dan Sinclair for operating the LA-ICPMS. Thanks to Ian Schipper for assistance with the probe and for many valuable discussions. Special thanks to Alexa van Eaton for hosting me in Portland and setting up a pot-luck CVO seminar and a trip to Mt St Helens. Thanks to Lucy Porritt and Dan Woodell for providing a private tour of volcano-ice features and craft beer establishments in British Columbia. It has been rewarding to discuss various aspects of Ruapehu's geology with Richard Price, Manuela Tost, Annika Greve, Lizzie Ingham, Gillian Turner, Cecile Massiot and James Cowlyn. Guiding me through every step of this $\mathrm{PhD}$ was my big-bird-bro Simon Barker. From sample prep in the volc-lab to setting up the ICPMS, and the countless beers and laughs in between, you have been a truly great friend. To all my other post-grad siblings - Melissa, Aidan, George, Katy, Marc, Alexa, James, Katie, Jenni, Jiao, Elliot, Denise, Rich, Juliet, Bella, Calum, Emily, Shane, Celine, Loretta and Connie - thanks for the support. Thanks to all my other friends at VUW who have made my years of study a great experience, and especially to Matt, Dez, Ignacio, Evan, Ben, Steve, Cam, Chris K, and Kosta. Special thanks to my officemates for looking after me over the last few months. Thank you to John, Jess and Jackson for your friendship and support over the years. Thanks Bella for your constant supply of good tunes and yarns. Thanks to everyone at Miramar Rangers AFC for providing the distraction of football, and to Shane and Danielle, Flynn (and all the Salters), Lenny, the Leadbitters, Torzie and Ramona for your encouragement.

My greatest love and thanks to Mum, Dad, Tom, Juliet and Nick, who have supported me throughout this journey. 


\section{TABLE OF CONTENTS}

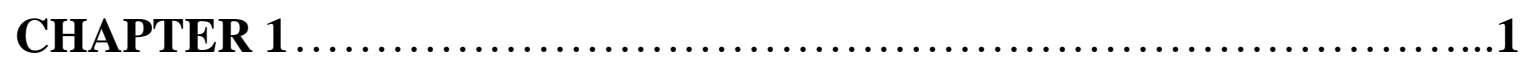

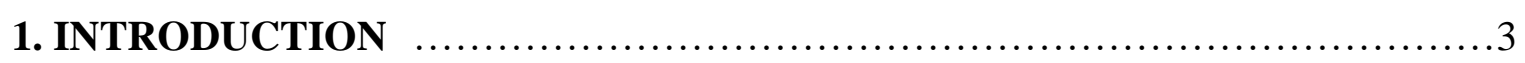

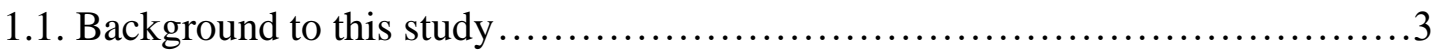

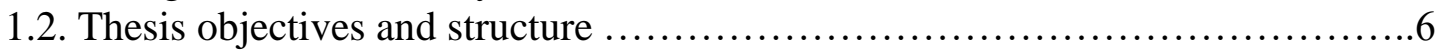

1.3. Origin and importance of composite volcanoes within continental arcs ..............8

1.3.1. Convergent continental margins and the global subduction

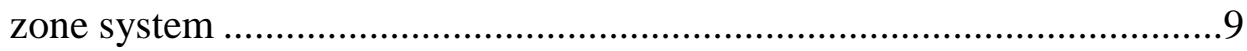

1.3.2. Characteristics and petrogenesis of intermediate composition arc magmas .............................................................. 10

1.3.3. Reconstructing eruption histories and magma flux rates at

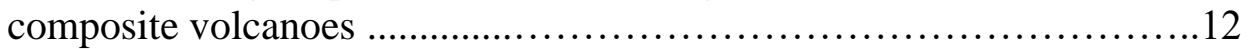

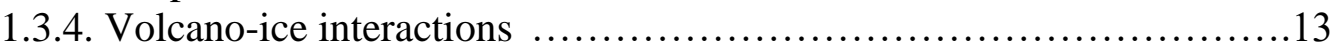

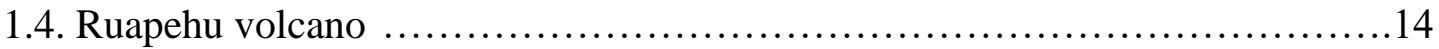

1.4.1. Arc setting and basement geology .....................................14

1.4.2. Volcanic and glacial histories ........................................16

1.4.3. Petrology, composition and magma genesis of eruptive products.........18

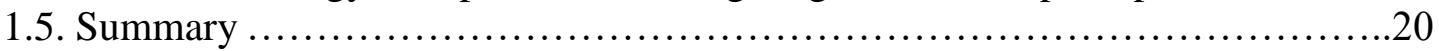

CHAPTER 2 ........................................................

2. LAVA-ICE INTERACTION ON A LARGE COMPOSITE VOLCANO: A CASE STUDY FROM RUAPEHU, NEW ZEALAND .......................................25

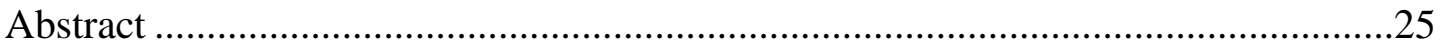

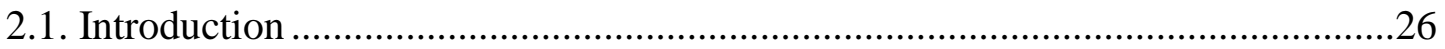

2.2. Geological setting and glacial history of Ruapehu ............................................27

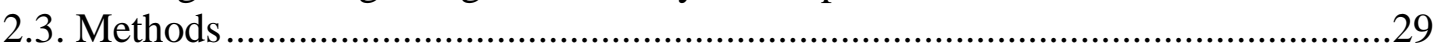

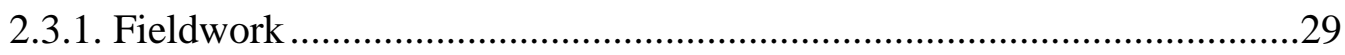

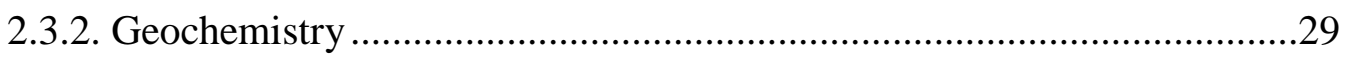

2.3.3. Geochronology ....................................................................................

2.4. Evidence for lava-ice interaction at Ruapehu ………………….......................... 31

2.4.1. Lava flow fracture types ......................................................................31

2.4.1.1. Column-forming joints .........................................................31

2.4.1.2. Pseudopillow fractures ...........................................................32

2.4.1.3. Kubbaberg joints ..................................................................

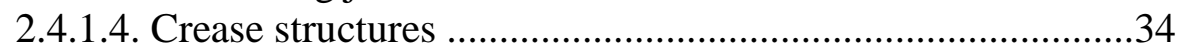

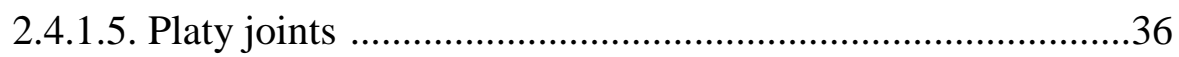

2.4.2. Lava flow morphology ...........................................................................

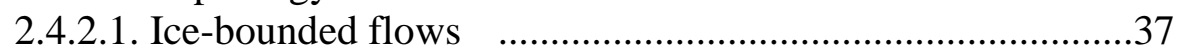

2.4.2.2. Ice-dammed flows …………………………………........

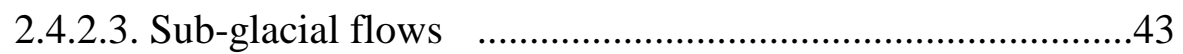

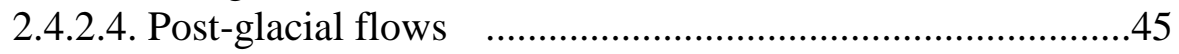




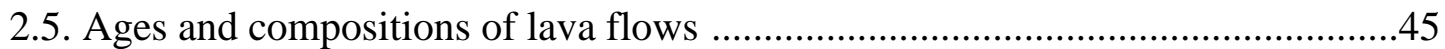

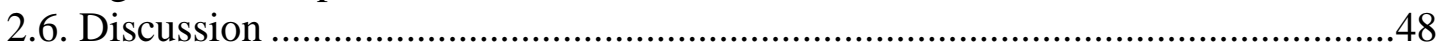

2.6.1. Ice-marginal lava flow emplacement ................................................... 48

2.6.2. Origin of crease structures in ice-marginal flows .................................51

2.6.3. Implications for paleoclimate reconstructions ..................................52

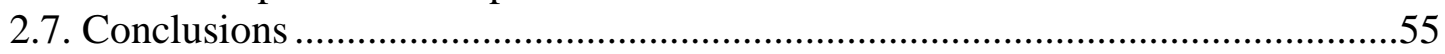

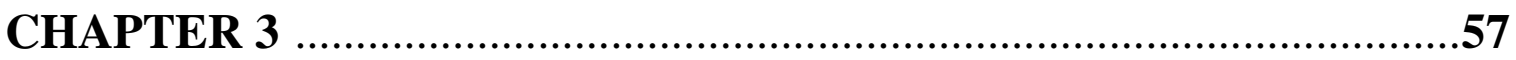

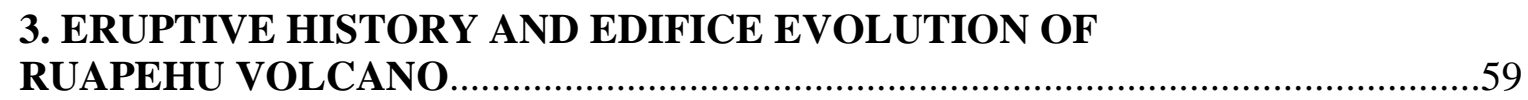

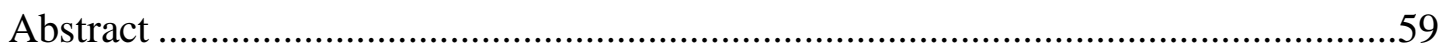

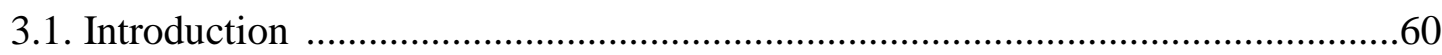

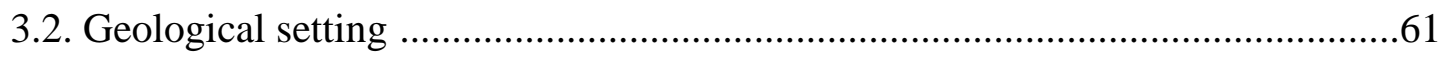

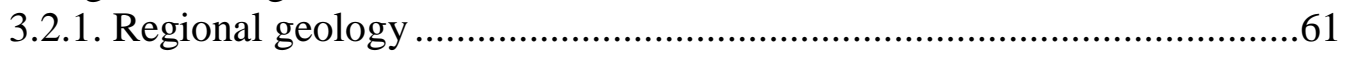

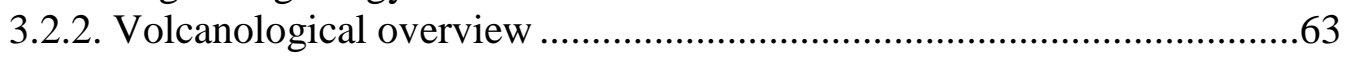

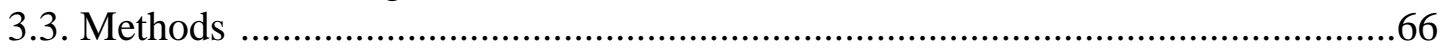

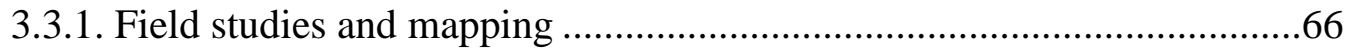

3.3.2. Whole-rock analyses by X-ray fluorescence .......................................66

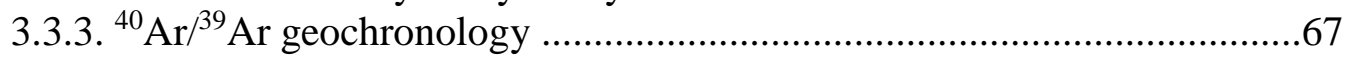

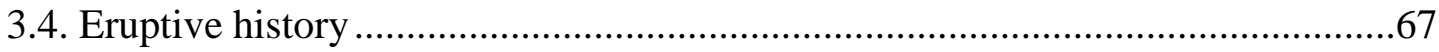

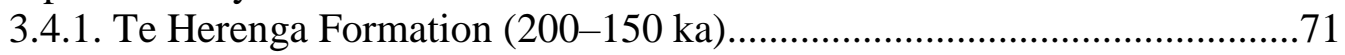

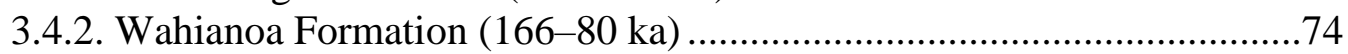

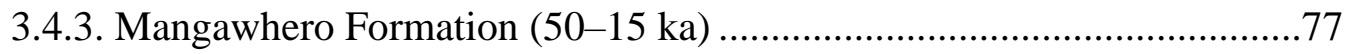

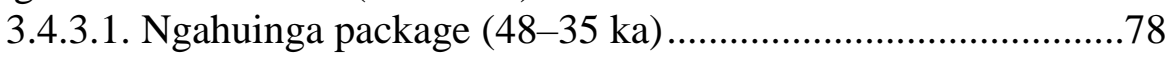

3.4.3.2. Mangaehuehu package (47-40 ka)................................... 79

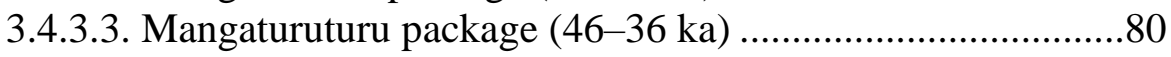

3.4.3.4. Te Kohatu package (44-36 ka) ........................................ 80

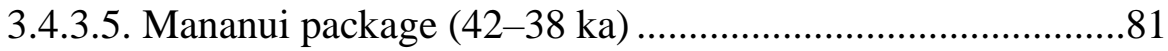

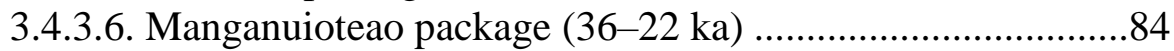

3.4.3.7. Whakapapaiti package (30-22 ka) ..................................... 84

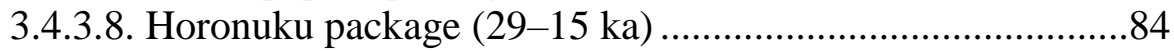

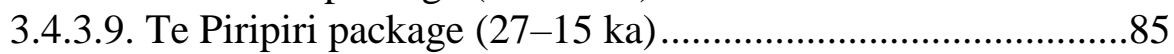

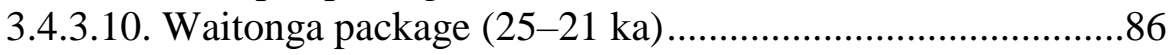

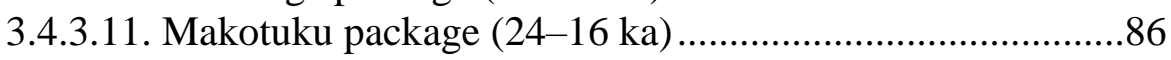

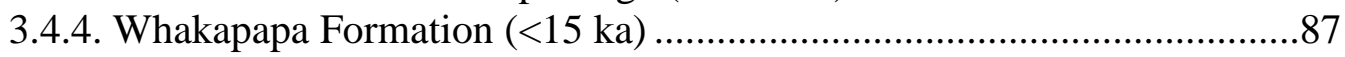

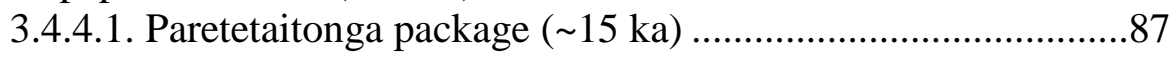

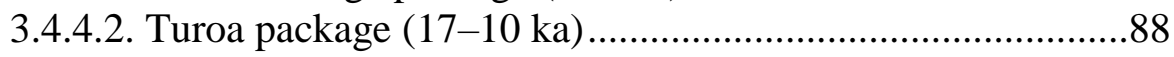

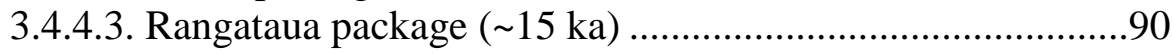

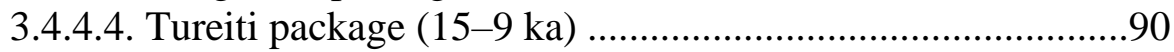

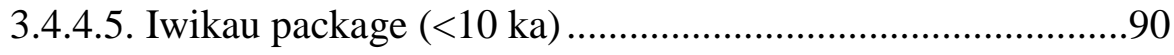

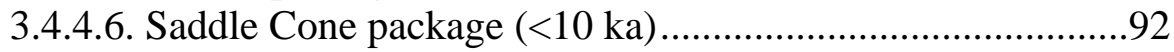

3.4.4.7. Pinnacle Ridge fall deposit $(\sim 10 \mathrm{ka})$.................................992

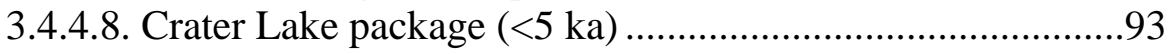

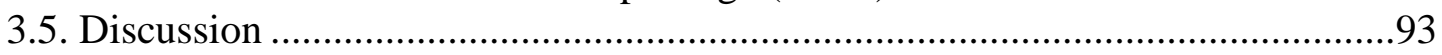

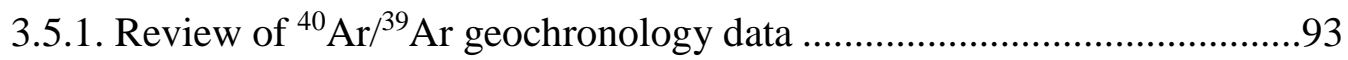

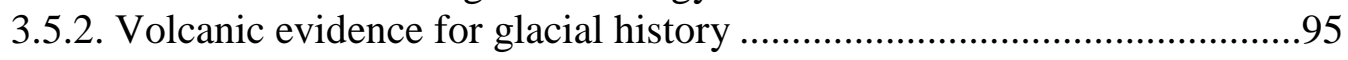

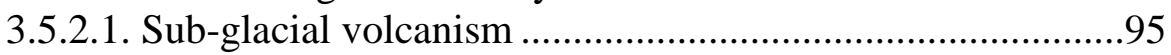


3.5.2.2. Preservation and exposure of MIS 5 volcanic products at Ruapehu

3.5.2.3. Glacier reconstructions using ice-marginal lava flows

3.5.3. Compositional evolution of Ruapehu lava flows ................................100

3.5.4. Integrating explosive and effusive records at Ruapehu ........................103

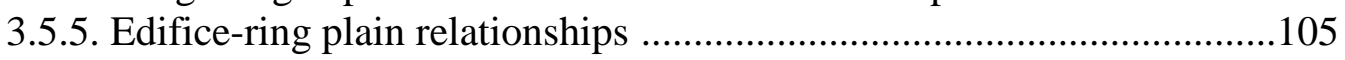

3.5.5.1. Links between syn-glacial volcanism and ring

plain deposits

3.5.5.2. Causes of Holocene sector collapse events at Ruapehu

3.5.6. Eruptive volumes and rates

3.6. Evolutionary model for Ruapehu

CHAPTER 4

4. NEW PETROLOGICAL, GEOCHEMICAL AND GEOCHRONOLOGICAL CONSTRAINTS ON ANDESITEDACITE MAGMA GENESIS AT RUAPEHU

Abstract

4.1. Introduction

4.2. Background and previous work

4.3. Methods

4.3.1. XRF: whole-rock major elements ....................................................122

4.3.2. Solution ICP-MS: whole-rock trace elements ....................................124

4.3.3. EPMA: mineral and glass major elements ..........................................125

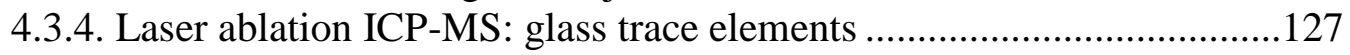

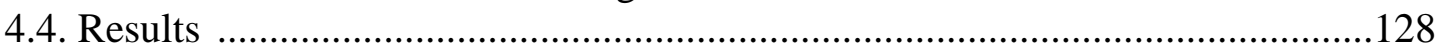

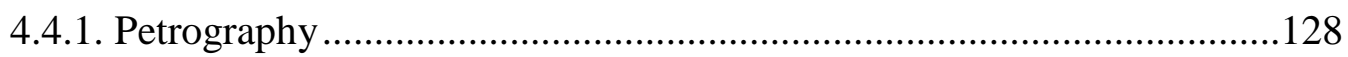

4.4.2. Whole-rock major and trace element compositions ...........................130

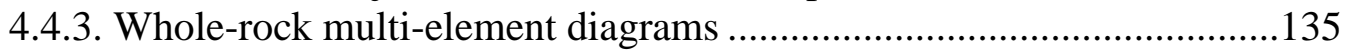

4.4.4. Whole-rock isotopic compositions ......................................................137

4.4.5. Groundmass, melt inclusion and xenolith glass compositions ..............138

4.4.6. Crystal chemistry and compositional zoning ......................................142

4.4.6.1. Te Herenga Formation .................................................144

4.4.6.2. Mangawhero Formation ..................................................144

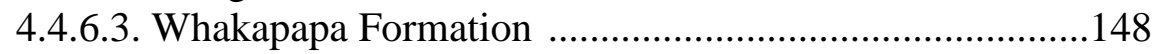

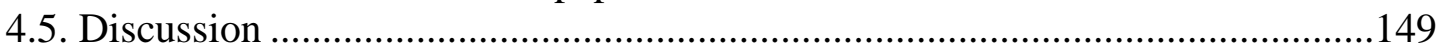

4.5.1. Long-term whole-rock compositional trends .....................................149

4.5.1.1. Compositional evolution of Ruapehu lava flows.............150

4.5.1.2. Potential role of density filtering of magma compositions

4.5.2. Nature and origin of silicic melts in Ruapehu lavas ............................158

4.5.3. A case for mafic recharge recorded in high- $\mathrm{Mg}$ andesite-

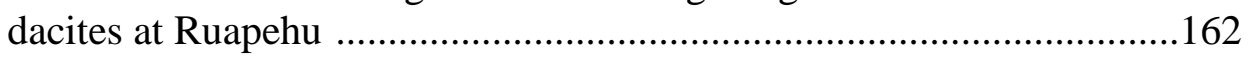

4.5.4. Evolutionary model of the magma system at Ruapehu .......................166

4.5.5. Occurrence and formation of cristobalite in Ruapehu lava flows .........168

4.6. Conclusions 169 
CHAPTER 5

\section{SYNTHESIS: GLACIOVOLCANICAND PETROGENETIC PROCESSES PLACED WITHIN A HIGH-RESOLUTION LAVA CHRONOLOGY FOR RUAPEHU VOLCANO}

5.1. Key findings

5.1.1. Were ridge-top lava flows eroded by glaciers or emplaced against ice at Ruapehu?

5.1.2. Can ice-marginal lava flows be used to inform paleoclimate reconstructions of former glacier extents?

5.1.3. Did Ruapehu grow via discrete episodes of construction punctuated by erosion, or are eruptive hiatuses biased by nonpreservation of volcanic products?

5.1.4. What are the ages of the oldest and youngest lava flows exposed on the edifice, and can the ${ }^{40} \mathrm{Ar} /{ }^{39} \mathrm{Ar}$ geochronometer be applied to Holocene andesite lava flows?

5.1.5. What processes controlled the timing of two major Holocene sector collapse events?

5.1.6. Has edifice erosion, sector collapse and deglaciation since $\sim 20 \mathrm{ka}$ caused elevated eruption rates?

5.1.7. How has the varying magma flux through the lithosphere influenced the composition of erupted products over time?

5.1.8. Are high-magnesian andesites the products of mantle-derived magmas or mafic-felsic interaction?

5.1.9. Cristobalite in Ruapehu lavas

\section{APPENDICES}

A1. Locations of ice-marginal flows and fractures ..............................................211

A2. Fracture measurements for ice-marginal lava flow ........................................213

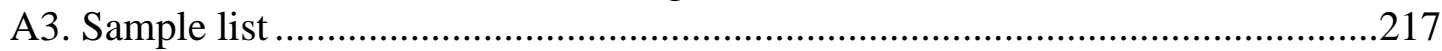

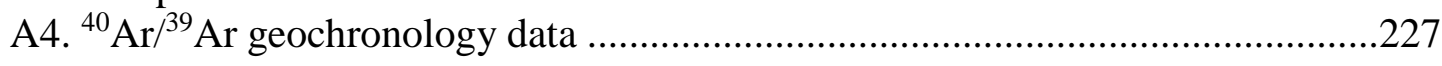

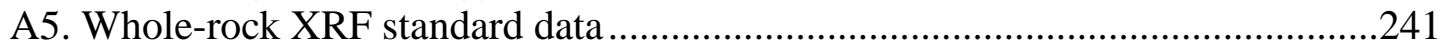

A6. Whole-rock solution ICPMS trace element standard data ...............................245

A7. EPMA: glass major element standard and sample data .................................251

A8. EPMA: mineral major element standard data .............................................257

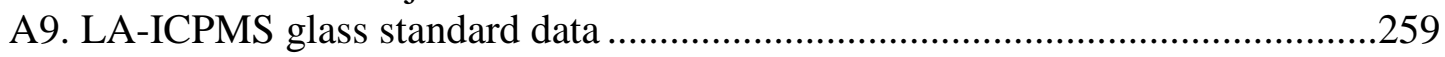




\section{LIST OF FIGURES}

Figure 1.1. Global distribution of continental arc composite volcanoes...........................10

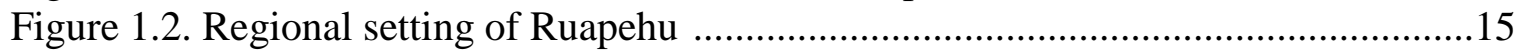

Figure 1.3. Geological and glacier reconstruction maps for Ruapehu ............................17

Figure 1.4. Compositional overview of Ruapehu volcanic rocks ....................................19

Figure 1.5. Summary cartoon of thesis objectives in the Ruapehu context .......................21

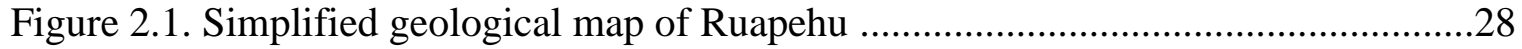

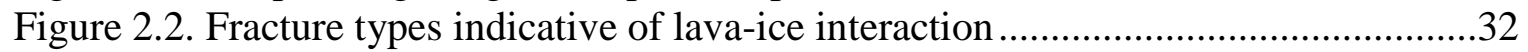

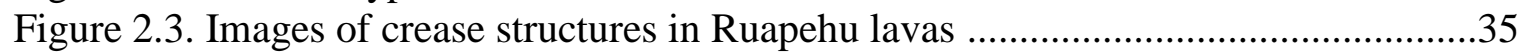

Figure 2.4. Mapped distribution of ice-marginal flow types at Ruapehu ...........................37

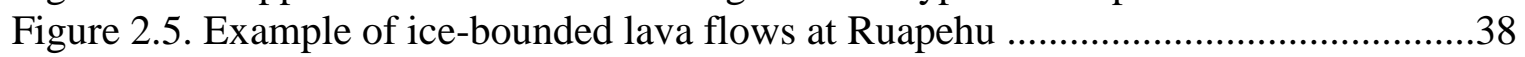

Figure 2.6. Fracture characteristics of ice-bounded flows at Ruapehu .............................39

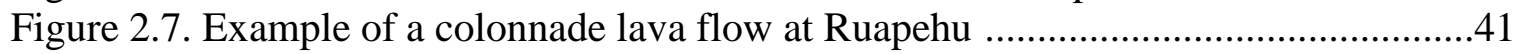

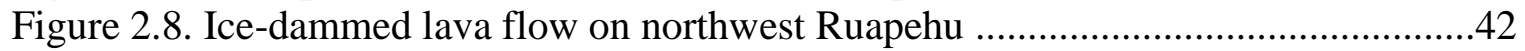

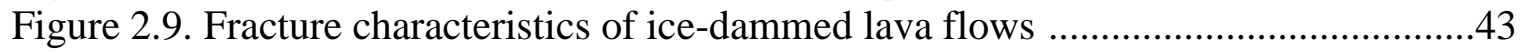

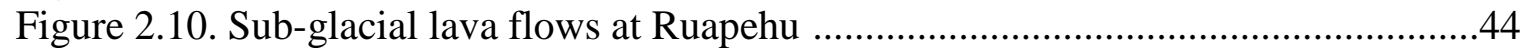

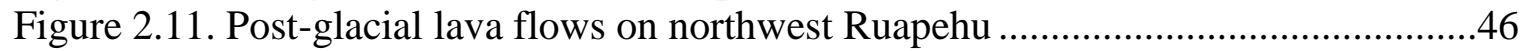

Figure 2.12. Volcano-ice reconstruction for northwest Ruapehu ...................................49

Figure 2.13. Ice-marginal lava flows and global marine isotope stages ...........................53

Figure 2.14. Elevation and thickness graph of ice-marginal lavas ..................................54

Figure 3.1. Location map for Ruapehu and the Tongariro Volcanic Centre .....................62

Figure 3.2. Index map for local geographic features......................................................65

Figure 3.3. Summary of ages and sectional distributions for Ruapehu

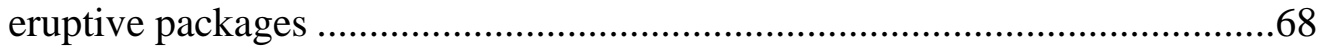

Figure 3.4. Map of eruptive products of the Te Herenga and Wahianoa formations ........71

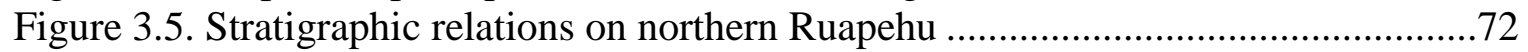

Figure 3.6. Examples of eruptive products of the Te Herenga Formation ........................73

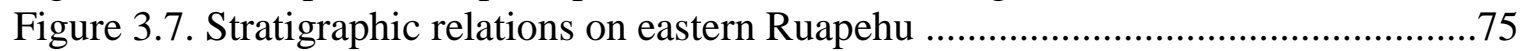

Figure 3.8. Examples of eruptive products of the Wahianoa Formation ...........................76

Figure 3.9. Map of eruptive packages of the Mangawhero Formation (50-35 ka) ...........78

Figure 3.10. Map of eruptive packages of the Mangawhero Formation (35-15 ka).........81

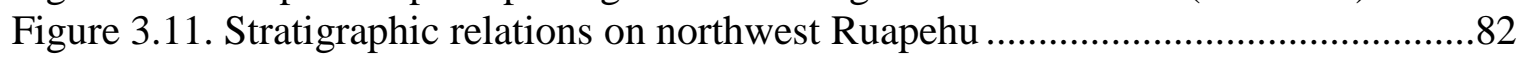

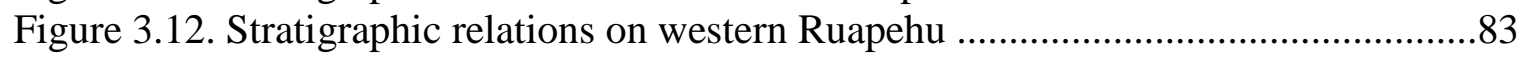

Figure 3.13. Examples of eruptive products of the Mangawhero Formation ....................85

Figure 3.14. Map of eruptive packages of the Whakapapa Formation .............................8

Figure 3.15. Examples of eruptive products of the Whakapapa Formation ......................89

Figure 3.16. Summary graph of ${ }^{40} \mathrm{Ar} /{ }^{39} \mathrm{Ar}$ geochronology data ......................................94

Figure 3.17. Graph of the spatial and temporal distribution of ice-marginal lavas ...........99

Figure 3.18. Compositional evolution of Ruapehu lavas ................................................101

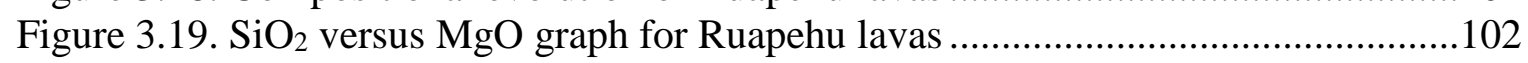

Figure 3.20. Comparison of post-50 ka lava and pyroclast compositions ........................104

Figure 3.21. Pre- and post-collapse lavas on the northern flank ...................................108

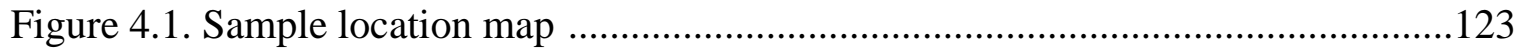

Figure 4.2. BSE images of cristobalite in Ruapehu lavas ...........................................129

Figure 4.3. Bivariate major element plots for Ruapehu lavas .....................................130

Figure 4.4. Bivariate trace element plots for Ruapehu lavas ........................................135 


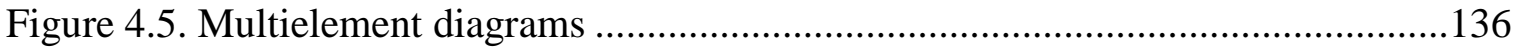

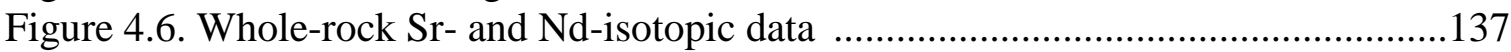

Figure 4.7. BSE images of groundmass, melt inclusion and xenolith glasses .................138

Figure 4.8. $\mathrm{SiO}_{2}$ versus $\mathrm{K}_{2} \mathrm{O}$ graphs for Ruapehu whole-rock and glass data .................140

Figure 4.9. Summary of range of mineral compositions ................................................142

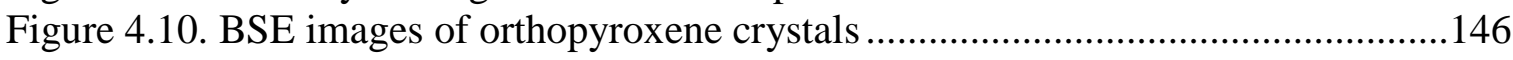

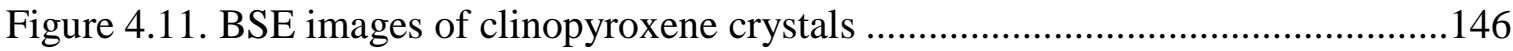

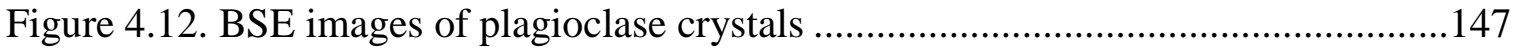

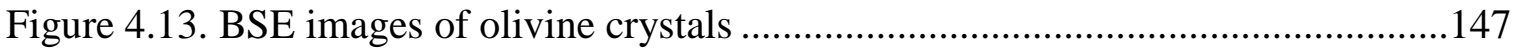

Figure 4.14. Time-composition relationships for Ruapehu lavas ...................................151

Figure 4.15. Compositional and spatial features of 50-35 ka lavas ..............................153

Figure 4.16. $\mathrm{SiO}_{2}$ versus $\mathrm{K}_{2} \mathrm{O}$ graph for Ruapehu and Taupo glasses ..........................160

Figure 4.17. REE plot glasses and lavas from the Taupo Volcanic Zone .......................161

Figure 4.18. BSE images of reverse zoned orthopyroxenes from high-Mg lavas............164

Figure 4.19. Bivariate major element plots for cristobalite ..........................................168

Figure 5.1. Volcano-ice features on southwest Ruapehu ...........................................178

Figure 5.2. Summary graph of the effusive growth history of Ruapehu ........................181

Figure 5.3. Age versus $\mathrm{SiO}_{2}$ for dated Ruapehu lavas ...............................................186

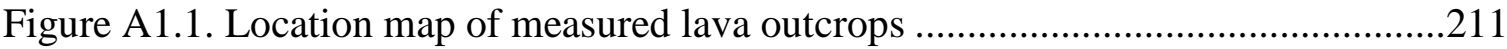

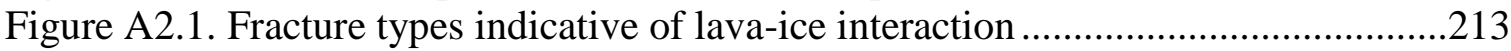

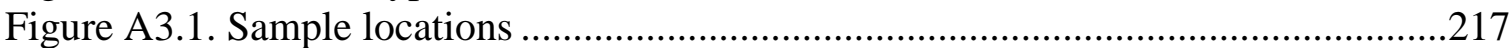

Figure A4.1. Sample sheets for ${ }^{40} \mathrm{Ar} /{ }^{39} \mathrm{Ar}$ geochronology data...................................229

\section{LIST OF TABLES}

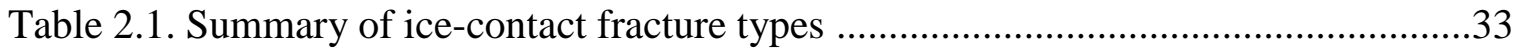

Table 2.2. Age and geochemistry data for selected Ruapehu ice-marginal lavas ..............47

Table 3.1. Existing chronostratigraphic formations for Ruapehu volcano.......................63

Table 3.2. ${ }^{40} \mathrm{Ar} /{ }^{39} \mathrm{Ar}$ geochronology data for Ruapehu lavas ..........................................69

Table 3.3. Summary of the compositional ranges for eruptive packages ...........................70

Table 3.4. Volumes and eruptive rates for arc composite volcanoes ..............................110

Table 4.1. Representative whole-rock major and trace element data ............................132

Table 4.2. Chronostratigraphic divisions within the Mangawhero Formation .................134

Table 4.3. Summary of glass major element compositions ..........................................139

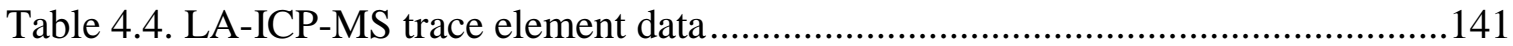

Table 4.5. Summary of mineral major element data ......................................................143

Table A1.1. Locations of measured lava outcrops ......................................................22

Table A2.1. Measurement data for ice-contact fractures ..............................................2. 214

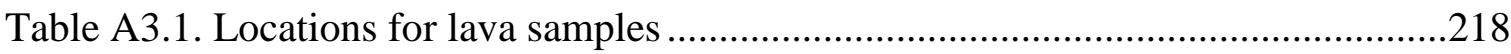

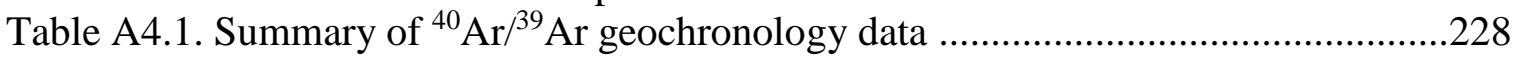

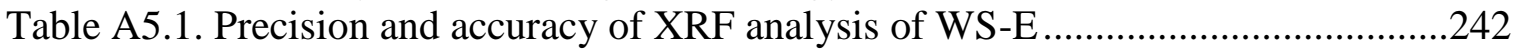

Table A5.2. Precision and accuracy of XRF analysis of OU-3 ......................................243

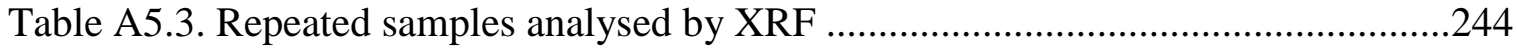


Table A6.1. Precision and accuracy of solution ICP-MS analysis of BCR-2 .................247

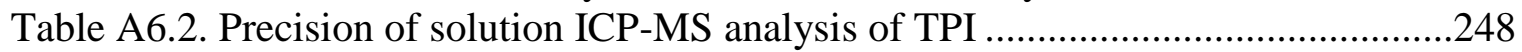

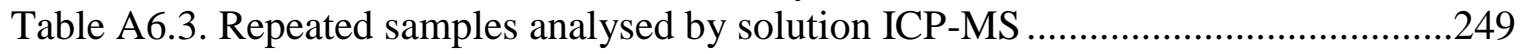

Table A7.1. Precision and accuracy of EPMA glass analyses .....................................251

Table A7.2. Major element data for glass in Ruapehu lava samples ............................252

Table A8.1. Precision and accuracy of EPMA pyroxene analyses ................................257

Table A8.2. Precision and accuracy of EPMA plagioclase standards.............................257

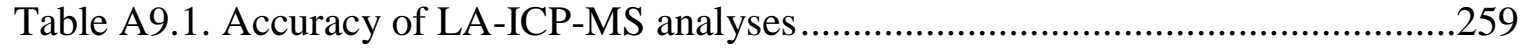




\section{Publications arising from this thesis}

\section{Journal articles}

Conway, C.E., Townsend, D.B., Leonard, G.S., Wilson, C.J.N., Calvert, A.T., Gamble, J.A., 2015, Lava-ice interaction on a large composite volcano: a case study from Ruapehu, New Zealand: Bulletin of Volcanology, v. 77, article 21.

Eaves, S.R., Anderson, B.M., Mackintosh, A.N., Doughty, A.M., Townsend, D.B., Conway, C.E., Winckler, G., Schaefer, J.M., Leonard, G.S., and Calvert, A.T., (2016b), The Last Glacial Maximum in central North Island, New Zealand: paleoclimate inferences from 2D glacier modelling: Climate of the Past, v. 12, p. 943-960.

Greve, A., Turner, G.M., Conway, C.E., Townsend, D.B., and Calvert, A.C., (2016 manuscript under review), Secular variation and new paleomagnetic age constraints on lava flows from the Tongariro Volcanic Centre, New Zealand: Geophysical Journal International, Manuscript ID: GJI-S-15-0993.

\section{Map bulletin}

Townsend, D.B., Leonard, G.S., Conway, C.E., Eaves, S.R., and Wilson, C.J.N., (2016 in preparation), Geology of the Tongariro National Park area: Institute of Geological and Nuclear Sciences Map Bulletin, 1:60,000 series.

\section{Conference abstracts}

Conway, C.E., Gamble, J.A., Wilson, C.J.N., Townsend, D.B., and Leonard, G.S., 2015, Insights into andesite petrogenesis: implications from melt inclusions from Ruapehu volcano, Taupo Volcanic Zone: Oral presentation at Geoscience Society of New Zealand Annual Meeting, Wellington, New Zealand.

Conway, C.E., Leonard, G.S., Townsend, D.B., Calvert, A.T., Eaves, S.R., Wilson, C.J.N., and Gamble, J. A., 2015, Game of cones: a story of lava and ice to explain the cause of Holocene sector collapses at Ruapehu volcano: Poster presented at Geoscience Society of New Zealand Annual Meeting, Wellington, New Zealand.

Eaves, S.R., Anderson, B.M., Mackintosh, A.N., Townsend, D.B., Conway, C.E., and Leonard, G. S., 2015, The Last Glacial Cold Period in central North Island: Paleoclimate inferences from 2D glacier modelling: Oral presentation at Geoscience Society of New Zealand Annual Meeting, Wellington, New Zealand.

Leonard, G.S., Townsend, D.B., Conway, C.E., Eaves, S.R., Gamble, J.A., Wilson, C.J.N., Calvert, A. T., Ingham, E. M., and Turner, G. M., 2015, A detailed geological map and eruptive history for Tongariro National Park, New Zealand: integrating mapping, geochronology, geochemistry, paleomagnetism and glaciology: Oral presentation at the International Union of Geodesy and Geophysics General Assembly, Prague, Czech Republic. 
Ingham, E.M., Roberts, A.P., Turner, G.M., Heslop, D., Ronge, T., Conway, C.E., Leonard, G.S., Townsend, D.B., Tiedemann, R., Lamy, F., and Calvert, A.T., 2014, Sedimentary and volcanic records of the Laschamp and Mono Lake excursions from Australia and New Zealand: Poster presented at the AGU fall meeting, San Francisco, U.S.A.

Conway, C.E., Townsend, D.B., Leonard, G.S., Wilson, C.J.N., Calvert, A.T., Gamble, J.A., 2014, Lava-ice interaction on a large composite volcano: a case study from Ruapehu, New Zealand: Oral presentation at the Geological Society of America Annual Meeting, Vancouver, British Columbia, Canada.

Conway, C.E., Leonard, G.S., Townsend, D.B., Calvert, A.T., Gamble, J.A., and Wilson, C.J.N., 2013, Constraining the magmatic evolution of Ruapehu Volcano: new highprecision ${ }^{40} \mathrm{Ar} /{ }^{39} \mathrm{Ar}$ geochronology and geochemistry: Oral presentation at the Geological Society of America Annual Meeting, Denver, Colorado, U.S.A.

Conway, C.E., Leonard, G.S., Townsend, D.B., Eaves, S., Gamble, J.A., Wilson, C.J.N., and Calvert, A.T., 2013, A new detailed glacio-eruptive history for Tongariro National Park, New Zealand: results from mapping, geochronology, geochemistry and glaciology: Oral presentation at the International Association of Volcanology and Chemistry of the Earth's Interior Scientific Assembly, Kagoshima, Japan. 
CHAPTER 1 


\section{INTRODUCTION}

\subsection{BACKGROUND TO THIS STUDY}

Andesite-dacite composite volcanoes are the surficial emblems of arc-related subduction zone magmatism that occurs along Earth's continental convergent margins. On one hand, these volcanoes are the sites of frequent, unpredictable and hazardous volcanic phenomena, and on the other hand they represent valuable windows into the subduction factory that destroys oceanic crust and generates continental crust. In both cases, constraining the processes and timescales of magma generation and eruption remains at the centre of research efforts to understand how and why arc volcanoes erupt. Establishing high-resolution volcanic stratigraphies is vital to such research because they reveal the tempo and types of past eruptive behaviour. Within these frameworks, a comprehensive story of a volcano's growth and degradation can be achieved and modelling the petrogenesis and evolution of magmas can be undertaken with confidence.

Composite volcanoes are complex entities that are shaped by an interplay between volcanic, magmatic, tectonic and climatic processes. Many have lofty heights and are located along volcanic arcs at mid- to high-latitudes (e.g. Cascade and Andean arcs) that have sustained substantive ice volumes in past glacial periods as well as at present. Glacial erosion of composite volcanoes provides exposure through eruptive sequences that would otherwise be hidden on the flanks of composite volcanoes. However, in addition to sector collapse, glaciation is a key agent for disturbing conformable or continuous eruptive stratigraphies, through eroding primary volcanic deposits and burying them under till (e.g. Singer et al., 1997).

For settings with coeval eruptive and glacial histories, the presence of ice on edifice flanks imposes a major influence on the preservation and distribution of effusive products during eruptions because glaciers can deflect and impound lava flows (Lescinsky and Sisson, 1998; Edwards et al., 2013). Because local ice volumes fluctuate over timescales of tens of kyr in response to global climate cycles (Denton and Hughes, 1983; Lisiecki and Raymo, 2005), complex stratigraphic relationships between lava flows of different age are produced (e.g. Lescinsky and Fink, 2000). To ensure the fidelity of eruption histories in such settings, accurate radiometric age dating of comprehensive sample suites 
needs to be undertaken within frameworks that take into account the stratigraphic consequences of volcano-ice interaction.

Magmas erupted at arc volcanoes represent the final products of multi-stage melting, mixing, fractionation and assimilation processes that begin in the asthenosphere and continue throughout the lithosphere (e.g. DePaolo, 1981; Hildreth and Moorbath, 1988; Gamble et al., 1999). Flux melting of the mantle wedge adjacent to subduction zones due to dehydration of the downgoing slab and its sediment cover is most widely regarded as the origin of primary arc magmas (e.g. McCulloch and Gamble, 1991), although direct derivation from slab and sediment melting is also feasible in some settings (e.g. Defant and Drummond, 1993).

Magmas subsequently pass through the crustal filter of arc lithosphere and are differentiated by crystal fractionation and crustal anatexis as they ascend toward Earth's surface. Despite a global correlation between continental convergent margins and andesites with crust-like compositions (Gill, 1981; Rudnick and Gao, 2003), the wide variation of the lithological characteristics and dynamics of the slab, mantle wedge and overlying arc lithosphere at individual subduction zones makes it difficult to define a consensus model for the generation of their source magmas. This is further compounded by the complexity of sequences of volcanic rocks within eruption episodes ranging from timescales of <1-20 yr (Clynne, 1999; Coombs et al., 2000) to >10 kyr (Gamble et al., 2003; Frey et al., 2004). Thus, whereas whole-rock geochemical and isotopic constraints enable the identification of a crustal signature in arc andesite volcanic rocks (e.g. Hildreth and Moorbath, 1988; Sisson et al., 2013), micro-scale investigations of discrete mineral and melt populations allows interrogation of the origin of this signature, and the nature and timescales of magma assembly and eruption processes (Davidson et al., 2005).

Located in the central North Island of New Zealand, Ruapehu is a typical large, midlatitude, continental arc volcano, which has been constructed throughout a >200 kyr lifetime with coeval eruptive and glacial histories. Ruapehu has been New Zealand's most active volcano in historical time, with notable magmatic or phreatomagmatic explosive episodes in 1895, 1945 and 1995-6. The latter of these eruptions resulted in widespread tephra dispersal that affected tourism, aviation, agriculture, and electricity generation industries in central North Island, New Zealand (Cronin et al., 1998; Johnston et al., 2000). The location of Ruapehu within the Tongariro National Park, a World Heritage 
Site that attracts $\sim 800,000$ visitors annually, underlines the importance of having wellconstrained temporal frameworks of eruptive behaviour at this active volcano.

Furthermore, Ruapehu presents an ideal candidate for establishing a high-resolution eruptive chronology that integrates volcano-ice interactions and allows investigation of the compositional evolution of a productive arc magma system. Three key shortcomings of previous research have precluded the generation of a detailed geological map, eruption history and edifice evolution model for Ruapehu volcano:

\section{1) Oversight of the effects of syn-eruptive lava-ice interaction on the preservation} and distribution of eruptive products. Although glaciation of the edifice has been widely cited to explain stratigraphic unconformaties (e.g. Hackett and Houghton, 1989), only one previous study recognised that lava flows interacted with glacial ice during effusive eruptions on Ruapehu (Spörli and Rowland, 2006). The complex stratigraphic relations resulting from volcano-ice interaction has made the relative sequencing of lavas with disparate distributions difficult.

\section{2) Sparse geochronology data to constrain the timing and duration of periods of} effusive growth of the volcano. Existing radiometric age data for lavas have relatively large uncertainties that make discrimination of effusive eruption phases difficult and only limited data have been collected for post-50 ka lavas (Gamble et al., 2003).

3) Fragmentary sampling of the edifice. Comprehensive sampling of accessible parts of Ruapehu has been undertaken (e.g. Waight et al., 1999), however, there is a conspicuous lack of petrological and geochemical data for lava flows from the more remote western and southern portions of the edifice.

The net result of these limitations is that current models of edifice growth and magma system evolution (e.g. Price et al., 2012) rely on an incomplete chronostratigraphic framework. This $\mathrm{PhD}$ research is motivated by the need to overcome these limitations in order to advance the contemporary understanding of continental arc volcanism and the development of composite volcanoes in New Zealand and globally. 


\subsection{THESIS OBJECTIVES AND STRUCTURE}

The aim of this $\mathrm{PhD}$ research is to generate a high-resolution lava flow chronological framework in order to document the magmatic and glaciovolcanic evolution of Ruapehu volcano. Detailed geological and glaciovolcanic mapping and high-precision ${ }^{40} \mathrm{Ar} /{ }^{39} \mathrm{Ar}$ geochronology data are combined with whole-rock geochemical data acquired from lava flows. This allows investigation of the long-term morphological and magmatic evolution of this prototypical arc volcano. Micro-analytical techniques are utilised to define the textural and chemical characteristics of crystal and melt components within andesitedacite lava flows to unravel the processes that have operated within Ruapehu's magma generation system over the last $\sim 200 \mathrm{kyr}$.

Key questions I address in this thesis include:

- Were ridge-top lava flows eroded by glaciers or emplaced against ice at Ruapehu?

- Can ice-marginal lava flows be used to inform paleoclimate reconstructions of former glacier extents?

- Did Ruapehu grow via discrete episodes of construction punctuated by erosion, or are apparent eruptive hiatuses biased by non-preservation of volcanic products?

- What are the ages of the oldest and youngest lava flows exposed on the edifice, and can the ${ }^{40} \mathrm{Ar} /{ }^{39} \mathrm{Ar}$ geochronometer be applied to andesite flows as young as the Holocene?

- What processes controlled the timing of two major Holocene sector collapse events?

- Has edifice erosion, sector collapse and deglaciation since 20 ka cause elevated eruption rates?

- How has the varying magma flux through the lithosphere influenced the composition of erupted products over time?

- Are high-magnesian andesites the products of elevated meta-igneous crustal contamination, primary mantle-derived magmas or mafic-felsic interaction?

These questions relate to the broader topics of glaciovolcanism, geochronology and magmagenesis that form central themes to current global volcanological research, and are addressed within 5 main chapters in this thesis: 
Chapter 1 introduces the motivation for carrying out this research. Key questions and objectives of the study are outlined. The geological context and previous research carried out on Ruapehu are presented to highlight the reasons for undertaking this $\mathrm{PhD}$ research.

Chapter 2 describes the morphology and fracture characteristics of effusive products resulting from the interaction between lava flows and former glaciers at Ruapehu volcano. Methods used to measure lava flow morphologies and fractures are described and processes of lava flow emplacement and fracture generation are discussed. This chapter has been published in the Bulletin of Volcanology (Conway et al., 2015).

Chapter 3 presents a high-resolution lava flow chronology for Ruapehu volcano within the context of new geological mapping and pre-existing chronostratigraphic studies. Analytical techniques used for the measurement of ${ }^{40} \mathrm{Ar} /{ }^{39} \mathrm{Ar}$ ages and whole-rock major element compositions of lava flows are defined here. These new geochronological and geochemical data are used to define eruptive packages within previously defined chronostratigraphic formations. Ages for ice-marginal lava flows are used to constrain the timing and extent of former glaciation on the volcano, and overall time-composition relationships for lava flows are outlined. A new interpretation is presented for the generation of Holocene sector collapse events at Ruapehu based on the post-glacial debuttressing and failure of originally ice-bounded summit cones. This chapter has been prepared as an article to be submitted to the Journal of Volcanology and Geothermal Research.

Chapter 4 characterises the magmatic and crustal sources and processes that have generated arc andesite-dacite lava flows at Ruapehu within the chronostratigraphic framework established in Chapter 3. Analytical techniques used to determine whole-rock and in-situ mineral and melt compositions are described herein. The revised chemical chronology of effusive products reveals wide magma composition diversity at $\sim 50-35 \mathrm{ka}$. High-magnesian andesites and dacites that contain potassic melt inclusions and glass hosted in xenoliths erupted during this time reflect contamination of stalled magmas by enriched partial melts (high-K and $-\mathrm{Rb}$ ) derived from continental crust and interaction with recharging mafic magmas. The progressive reversion to less silicic, potassic and radiogenic isotope compositions of lavas erupted since $26 \mathrm{ka}$ reflects decreasing levels of crustal assimilation in derivative andesite magmas below Ruapehu. This chapter has been prepared as an article to be submitted to the Journal of Petrology. 
Chapter 5 integrates the datasets and key findings presented in the three previous chapters. Key questions introduced in Chapter 1 are answered and future research objectives are suggested.

Chapters 2, 3 and 4 are written in the style of stand-alone journal articles with individual abstract, introduction, methods, results and discussion sections, but their formats adhere to the overall thesis style. Additional descriptions of analytical techniques and sample information for this thesis are presented in the appendices. Geological, geochemical and geochronological data collected during this study contributed directly to, and are also presented within, the publication of a GNS Science volcanic geology map and bulletin (Townsend et al., 2016). Levels of input consistent with normal requirements for coauthorship for journal articles have been provided by supervisors and co-authors throughout the term of this $\mathrm{PhD}$. G. Leonard and A. Calvert operated the mass spectrometer and collected ${ }^{40} \mathrm{Ar} /{ }^{39} \mathrm{Ar}$ data at the U.S. Geological Survey geochronology laboratory in Menlo Park, CA. D. Townsend digitised boundaries of eruptive packages in ArcGIS that were modified by C. Conway in the drafting of map figures in Chapters 2 and 3.

\subsection{ORIGIN AND IMPORTANCE OF COMPOSITE VOLCANOES WITHIN CONTINENTAL ARCS}

Composite volcanoes (also termed compound volcanoes, stratovolcanoes and composite cones) are polygenetic constructional volcanic edifices formed by repeated eruptions from single or multiple vents that are related to a common magma system (Davidson and de Silva, 2000). If progressive eruption of lavas and pyroclastic deposits occurs throughout the lifetime of the volcano from a persistent summit vent, a conical and steep-sided edifice will be constructed (Thouret, 1999). Eruptive vents or centres commonly migrate over time or are synchronously active at spatially discrete foci, however, which results in the formation and juxtaposition of overlapping edifices and a complex intercalation of volcanic products (e.g. Hobden et al., 1996). Composite volcanoes formed in this way often resemble asymmetric cones, broad massifs or ridge-like edifices.

Composite volcanoes are the typical volcanic landform associated with convergent continental margins due to: (1) the persistence of subduction zones that supplies a steady 
source of magma and results in long-lived polygenetic eruptive centres; and (2) the intermediate composition and viscosity of typical arc andesite-dacite magmas, which results in construction of steep edifices with conical morphologies. Continental arc volcanoes are dominant sites of subaerial volcanism on Earth and represent the interface between the atmosphere and subduction zone-derived magmas and volatile elements. As such they hold key importance for regulating the global climate and the flux of elements through Earth's mantle and crust. Moreover, they present significant natural hazards to human populations due to their frequent, unpredictable and often violent eruptions and potential to generate lahars and catastrophic sector collapse events.

This section introduces (1) the tectonic setting and significance of convergent continental margins, (2) key petrogenetic models for how intermediate magmas are generated in these settings, (3) how understanding the tempo and types of eruptive activity at composite volcanoes is informed by studying long-term eruption histories, and (4) basic principles of glaciovolcanism that are relevant to temperate-latitude composite volcanoes.

\subsubsection{Convergent continental margins and the global subduction zone system}

Subduction zones are regions on Earth where the convergence of tectonic plates results in the descent of dense oceanic crust beneath the opposing and overriding plate and into the underlying asthenosphere. In the case of convergent continental margins, the overriding plate is composed of continental crust. Convergent continental margins are located around most of the Pacific Ocean and along the southern margin of Eurasia (Fig. 1.1).

Subducted plates consist of upper mantle lithosphere, altered oceanic crust and sediment (von Huene and Scholl, 1991). During descent, altered oceanic crust and sediments are heated and release $\mathrm{H}_{2} \mathrm{O}$-rich fluids and melts into the overlying mantle wedge, which consequently lower the solidus temperature of mantle peridotite by several hundred ${ }^{\circ} \mathrm{C}$ and triggers partial melting (McCulloch and Gamble, 1991; Gaetani and Grove, 1998; Grove et al., 2012). The zone of melting is generally located where the subducted plate is at a depth of 100-130 km (Gill, 1981; Tatsumi, 1986; Syracuse and Abers, 2006). The derivative basalts contain high $\mathrm{H}_{2} \mathrm{O}$ contents (of up to 6 wt. \% compared to $<0.5$ wt. \% in mid-ocean ridge basalt; Sobolev and Chaussidon, 1996; Grove et al., 2002; Wallace, $2005)$ and fluid-mobile trace elements $(\mathrm{K}, \mathrm{Rb}, \mathrm{Ba}, \mathrm{Sr}, \mathrm{U}, \mathrm{Pb})$ that are sourced from 
subducted sediments and altered oceanic crust (McCulloch and Gamble, 1991; Plank and Langmuir, 1998).

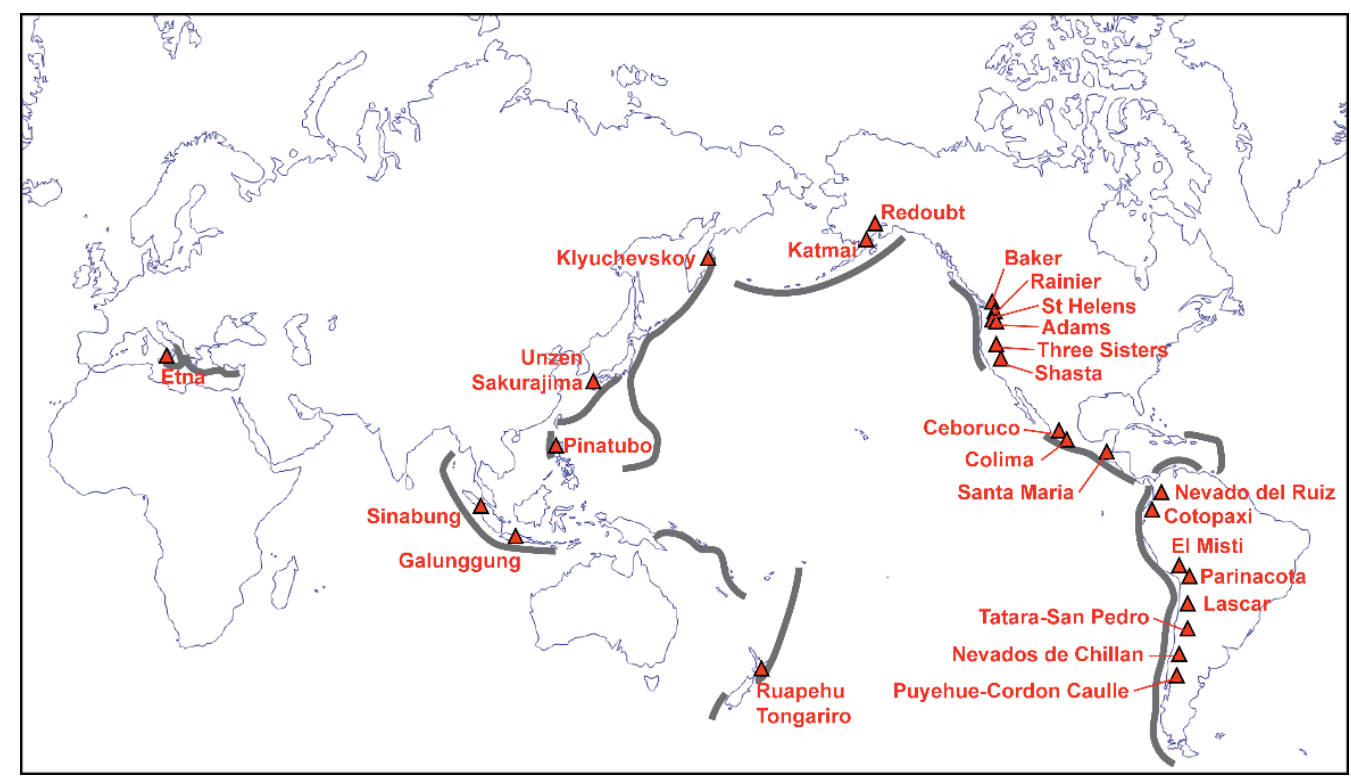

Figure 1.1. Location of composite volcanoes associated with continental convergent margin magmatism that are referred to in this thesis. Grey lines represent major subduction zone plate boundaries. Red triangles are locations of the labelled volcanoes.

Due to their high $\mathrm{H}_{2} \mathrm{O}$ contents, the basaltic melts are highly buoyant and rise into hotter portions of the mantle wedge, where further melting occurs. The basaltic magmas from this zone are only very rarely erupted at the surface within arc settings to provide information about the mantle conditions in which they equilibrated. This is because the magmas must first transit through the lithosphere of the overriding plate where they invariably stall and are consequently differentiated. The lithospheric processing of arc magmas is introduced below in section 1.3.2.

\subsubsection{Characteristics and petrogenesis of intermediate composition arc magmas}

Andesite typifies the intermediate composition ( $\left.~ 58-63 \mathrm{wt} . \% \mathrm{SiO}_{2}\right)$ of volcanic products erupted at continental arc volcanoes, and closely resembles that of the continental crust (Taylor and McLennan, 1995; Rudnick and Gao, 2003). Constraining the genesis of andesite magmas is therefore important for understanding the origin of Earth's crust and processes of element recycling at subduction zones (e.g. Carmichael, 2002). Andesite magmas are proposed to originate via four main end-member models: direct partial 
melting of a hydrous mantle source (e.g. Grove et al., 2012); partial re-melting of altered basaltic crust (e.g. Jackson et al., 2003); crystal fractionation of arc basalts in the crust (e.g. Pichavant et al., 2002); and mixing between mafic and felsic composition magmas and/or crust (e.g. Kent, 2013). For continental arc settings it is evident that crustal filtering of primary magma occurs and, thus, composite scenarios that combine these interrelated melting, mixing, crystallisation and assimilation processes are invoked to explain the genesis of intermediate compositions magmas (e.g. Hildreth and Moorbath, 1988; Dungan et al., 2001; Price et al., 2012; Sisson et al., 2013).

Many studies of andesite petrogenesis implicate the base of the crust above the zone of mantle melting associated with subduction as an important staging site of magma differentiation because it is progressively intruded by ascending basaltic magmas, which stall, cool and crystallise (Dufek and Bergantz, 2005). Subduction zones prevail over timescales of Myr, thereby facilitating progressive intrusion of basalt into the crust and the development of a 'hot zone' (Annen and Sparks, 2002). It is here that the mafic magmas transfer heat and volatiles to the crust, leading to melting. In such settings the lower crust represents a mix of partially crystallised basalt, partially melted crust and its refractory residue, and $\mathrm{H}_{2} \mathrm{O}$ released from basalt crystallisation (Annen et al., 2006). Conductive zones in the crust or uppermost mantle that have been mapped by geophysical imaging are consistent with the presence of molten material and significant volumes of liberated $\mathrm{H}_{2} \mathrm{O}$ (e.g. Cascades, Stanley et al., 1990; Andes, Brasse et al., 2002; New Zealand, Heise et al., 2010). Fractionated magmas will tend to ascend toward the upper crust, where further textural and chemical modification takes place.

Upper crustal magma systems beneath andesitic arc volcanoes are envisioned as complex networks of interconnected melt and mush bodies (e.g. Gamble et al., 1999; Humphreys et al., 2006). These volcanic plumbing systems allow dynamic interaction between magma and melt batches of varied composition. Widespread documentation of disequilibrium petrographic textures in andesite lavas (Eichelberger, 1978; Gamble et al., 1999; Coombs et al., 2000; Dungan and Davidson, 2004; Reubi and Blundy, 2008; Ruprecht et al., 2012; Millet et al., 2014 among many) and the dominant bimodality of basaltic and dacitic-rhyolitic compositions of mineral-hosted melt inclusions (Reubi \& Blundy, 2009) indicates that mixing between mafic and silicic end-member components is an important process within individual eruptive products and over the lifetime of a volcano. 
In contrast, some recent compilations of global datasets for arc volcanic rocks surmise that, despite the irrefutable evidence for magma mixing, the general chemical systematics of andesite-dacites are primarily governed by (1) the composition of melts extracted from the mantle (Turner and Langmuir, 2015) and (2) high-pressure crystal fractionation of hydrous basalts (Lee and Bachmann, 2014). While a consensus model is unlikely to be applicable to all arc settings due to their individual tectonic and geodynamic characteristics, resolving the source signatures of arc magmas and the genesis of andesite remains a critical debate in volcanology now as it did 65 years ago (Tilley, 1950).

\subsubsection{Reconstructing eruption histories and magma flux rates at composite volcanoes}

Eruptive behaviour at arc composite volcanoes ranges from effusive eruption of lava flows and domes through to explosive eruptions that generate pyroclastic flow and fall deposits. Eventual effusive or explosive eruption will ultimately be governed by the final volatile budget and degassing history of the derivative magma as well as the crustal stress regime and conduit conditions (e.g. Martel et al., 1998; Szramek et al., 2006; Pardo et al., 2014). Diverse eruptive styles may therefore occur simultaneously or vary over long timescales at composite volcanoes due to the complex crustal conditioning of arc magmas (see section 1.3.2). Interactions between eruptive products and water/snow/ice at the summit, in the subsurface or on the flank of a volcano can also produce phreatic or phreatomagmatic eruptions and generate lahars. Summit and flank zones of composite volcanoes comprise intercalated lava flows and pyroclastic material that have been emplaced proximal to vents. Sequences of pyroclastic fall and volcaniclastic deposits are better-preserved on surrounding ring plains that provide a record of the explosive activity and degradation of a volcanic edifice. Complete eruption histories incorporate records from both the edifice and ring plain, however, sequences of lava flows and associated breccias provide the best possible in situ record of edifice growth.

Eruption ages for andesite-dacite lava flows at Quaternary composite volcanoes are most commonly determined by the ${ }^{40} \mathrm{Ar} /{ }^{39} \mathrm{Ar}$ geochronometer (Singer et al., 1997; Hildreth et al., 2003; Frey et al., 2004; Fierstein et al., 2011). This technique has almost entirely replaced the K/Ar method due to its ability to provide information on the volume and compositions of argon gas released throughout cumulative heating of a sample. In this 
way, the effects of alteration can be identified and mitigated. Developments to highprecision instrumentation (e.g. Coble et al., 2011), improved understanding of the behaviour of argon in volcanic glass (e.g. Clay et al., 2015), and methods to counter argon recoil processes that affect fine-grained rocks (e.g. Fleck et al., 2014) have established ${ }^{40} \mathrm{Ar} /{ }^{39} \mathrm{Ar}$ dating as a means for determining accurate eruption ages for Pleistocene and, potentially, Holocene volcanic rocks. Comprehensive geological mapping accompanied by accurate high-resolution geochronological and geochemical datasets can be used to constrain detailed constructional histories of composite volcanoes (e.g. Dungan et al., 2001; Hildreth et al., 2003; Escobar-Wolf et al., 2010). Defining the rates of eruption and the durations of cone-building phases helps to interpret the longevity of magma reservoirs in the crust as well as fundamental relationships between subduction zone parameters (plate convergence rate, age of subducted slab, crustal thickness) and magma flux (e.g. Frey et al., 2004; Turner and Langmuir, 2015).

\subsubsection{Volcano-ice interactions}

Interactions between volcanism and glaciation represent an important part of the eruptive histories of many composite volcanoes globally, particularly those high-elevation examples located at mid- to high-latitudes, which hosted significant accumulations of ice during past glacial periods (e.g. Mt Baker, Hildreth et al., 2003). Observations from historical eruptions and analogue experiments have indicated the ability of ice to impound and deflect lava flows (Edwards et al. 2013). As a result, volcanism in the presence of ice (i.e. glaciovolcanism; cf. Kelman et al. 2002) produces distinct lava morphologies and has a primary impact on the spatial distribution of effusive products.

The general model for ice-marginal effusive volcanism on composite volcanoes invokes the emplacement of lava flows onto ridges adjacent to the lateral margins of valley-filling glaciers on the flanks of a volcano following an eruption from the summit (Lescinsky and Sisson, 1998). Lava is excluded from the valley by the glacier mass and is confined between the glacier margin and the adjacent ridge, resulting in thickening of the flow as it fills the available space. Retreat of the ice during an interglacial period results in exposure of ridge-bounded overthickened flows and subsequent lavas will be emplaced at lower elevations within the ice-free valley. This has two general implications: (1) eruptive histories for glaciated composite volcanoes must incorporate the effects that the former 
presence of valley glaciers and ice caps have on the spatial and stratigraphic position of lava flows (e.g. Stevenson et al. 2006); and (2) glaciovolcanic deposits are useful paleoclimate proxy indicators that can be used in combination with glacial moraine distributions to infer the former presence, extent, and thickness of terrestrial ice (e.g. Smellie, 2008). Detailed mapping and dating of effusive glaciovolcanic products at composite volcanoes has been undertaken in few studies to date (Mee et al., 2009; Lachowycz et al., 2015), but glaciovolcanism is often inferred to have had general influences on the long-term eruption histories and morphological development of composite volcanoes (e.g. Schmidt and Grunder, 2009).

\subsection{RUAPEHU VOLCANO}

Ruapehu is the largest currently active volcano in New Zealand, with an estimated volume of $\sim 150 \mathrm{~km}^{3}$ for the modern edifice (Gamble et al., 2003). Ruapehu attracts national attention because of its frequent historical explosive eruptions coupled with its growing popularity as a tourist destination. To the international community, Ruapehu represents a long-lived composite volcano and a site to investigate the development of a productive magma system in a continental arc setting. This section introduces the geologic setting and volcanic and glacial histories of Ruapehu, and reviews published material on the composition and genesis of its eruptive products.

\subsubsection{Arc setting and basement geology}

Ruapehu volcano is located at the southern end of the Taupo Volcanic Zone (TVZ), an active continental rifted-arc in central North Island, New Zealand (Fig. 1.1). Volcanism in the TVZ is associated with westward subduction of oceanic crust of the Pacific Plate beneath continental crust of the Australian Plate along the Hikurangi Trench system (Cole, 1979; Reyners et al., 2006). The subduction front is located $\geq 100 \mathrm{~km}$ southeast of the North Island along the Hikurangi Trough, where the Pacific Plate is currently moving obliquely westward at $\sim 45 \mathrm{~mm} \mathrm{yr}^{-1}$ relative to the Australian Plate (DeMets et al., 2010). The southernmost portion of the TVZ includes the Tongariro and Ruapehu composite volcanoes, which are the dominant edifices within the Tongariro Volcanic Centre (TgVC; Grindley, 1960; Cole, 1978). Extension in the TgVC occurs at a direction of $\sim 115^{\circ}$ and a 
rate of $2.3 \pm 1.2 \mathrm{~mm} \mathrm{yr}^{-1}$ (Villamor and Berryman, 2006a). The tectonic structure that is manifested by this motion is the $40 \mathrm{~km}$-wide Mount Ruapehu Graben, which is bound by the Rangipo and Raurimu faults to the east and west, respectively, and by the Karioi and Ohakune fault sets to the south (Fig. 1.2; Villamor and Berryman, 2006a).

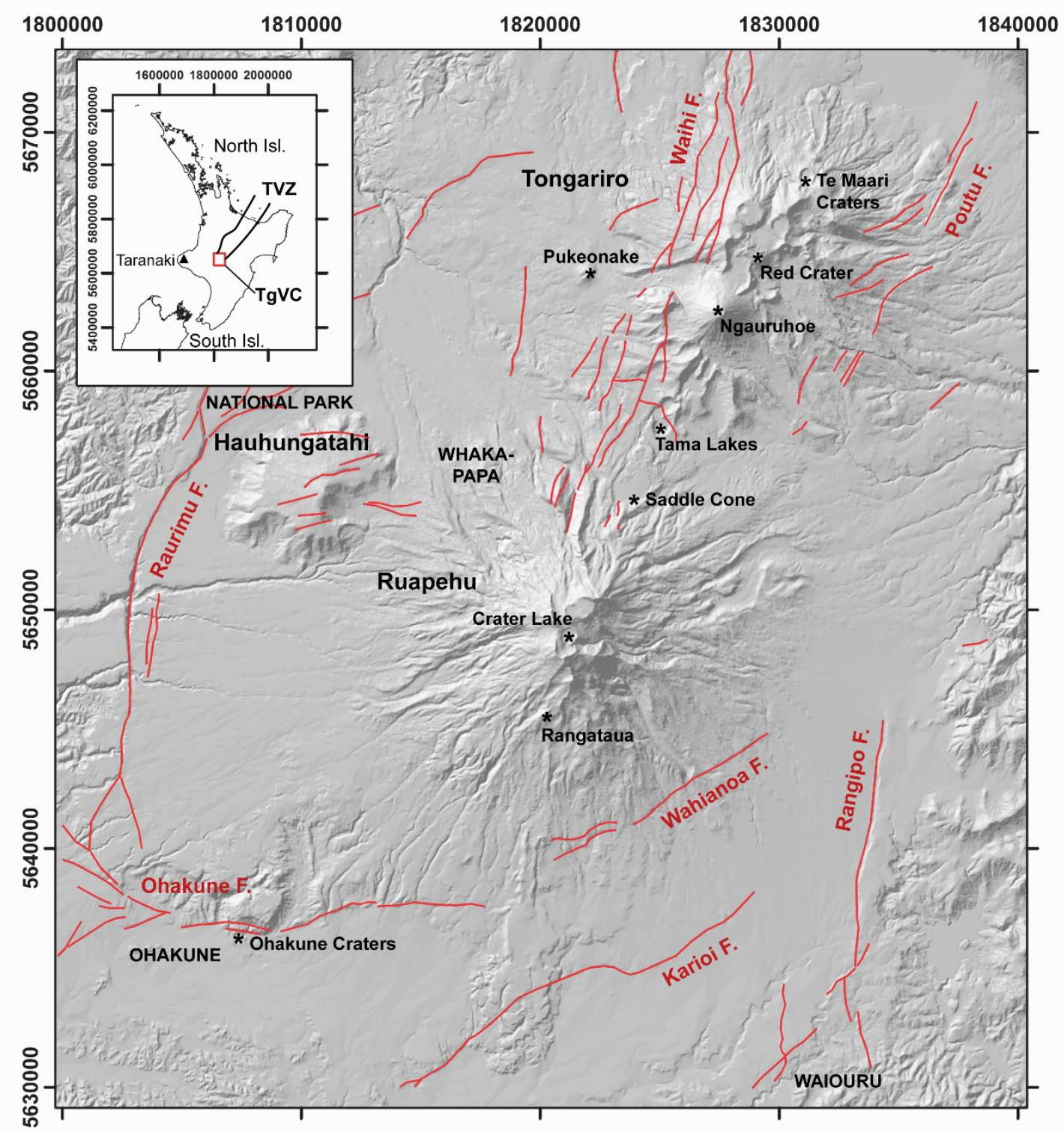

Figure 1.2. Regional setting of Ruapehu volcano within the Tongariro Volcanic Centre (TgVC) at the southern end of the Taupo Volcanic Zone (TVZ) in central North Island, New Zealand (inset). Major faults and townships within the TgVC are labelled in the main figure. Recently active and peripheral vents of the Tongariro and Ruapehu composite volcanoes are labelled.

The Ruapehu and Tongariro composite volcanoes of the $\mathrm{TgVC}$ are constructed on late Tertiary sediments and Mesozoic basement. The latter comprises the predominantly 
Jurassic Torlesse Supergroup greywacke sequence that outcrops along the ranges east of the Rangipo fault. To the west of the Tongariro Domain, the ranges are composed of Jurassic Waipapa Terrane rocks, derived from more mafic sources (Adams et al., 2009; Price et al., 2015). Although poorly constrained, the Kaweka Terrane is inferred to extend westwards from the Axial Ranges under Ruapehu volcano (Sissons and Dibble, 1981; Rowland et al., 2010). The crustal thickness beneath Ruapehu is interpreted to be $40 \mathrm{~km}$ (Villamor and Berryman, 2006a; Salmon et al., 2011).

\subsubsection{Volcanic and glacial histories}

Earliest geological mapping of the Tongariro region in the 1920s and 1930s led to the recognition of Ruapehu as a multiple-vent composite volcano with a complex growth history that involved erosion of an older edifice and subsequent emplacement of young lava flows that constructed steeper portions of the upper cone (Grange and Hurst, 1929). Later workers incorporated ring plain and glacial deposits into the geological history of the volcano (Gregg, 1960; Topping, 1973). Hackett (1985) undertook the first detailed geologic study of Ruapehu volcano and established a chronostratigraphic framework for the growth history of the edifice, which was aided by sparse pre-existing whole-rock $\mathrm{K} / \mathrm{Ar}$ radiometric age data (Stipp, 1968).

The growth history was later constrained by ${ }^{40} \mathrm{Ar} /{ }^{39} \mathrm{Ar}$ geochronological data acquired primarily for pre-100 ka lava flows (Gamble et al., 2003). Volcanic products are grouped within the Te Herenga (250-180 ka), Wahianoa (160-115 ka), Mangawhero (60-15 ka) and Whakapapa (<15 ka) formations, which represent the eruptive products of four main phases of edifice growth (Fig. 1.3; Hackett, 1985). Ages and durations of the phases were constrained by ${ }^{40} \mathrm{Ar} /{ }^{39} \mathrm{Ar}$ ages for lava flows from the Te Herenga Formation ( 3 samples), Wahianoa Formation (11 samples) and Mangawhero Formation (7 samples) by Gamble et al. (2003). Their dating study concentrated on the clear stratigraphic sequence of Wahianoa Formation lava flows exposed within the deeply glaciated Wahianoa and Whangaehu valleys on the southeast flank of Ruapehu. 

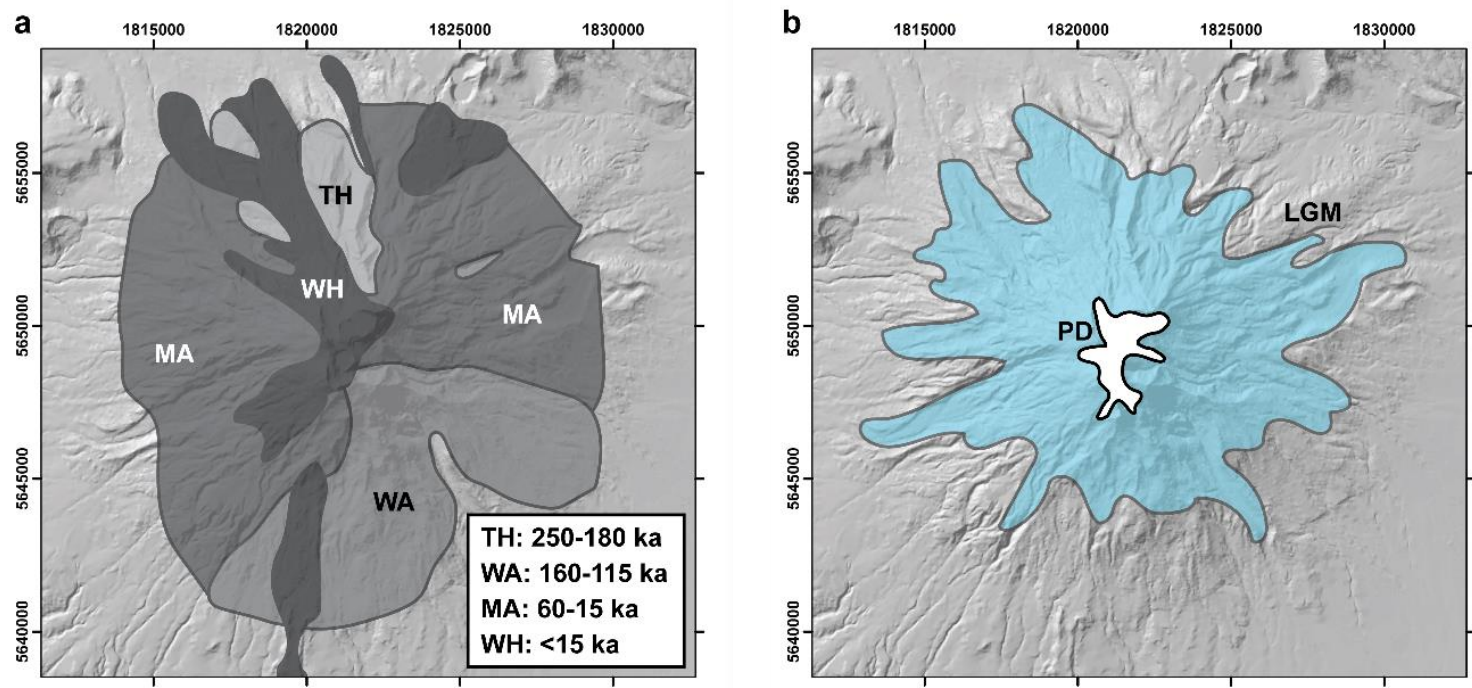

Figure 1.3. Schematic maps of the distribution of effusive eruptive products (a) and glacier extents (b) for Ruapehu volcano. Abbreviations and age ranges are shown for the Te Herenga (TH), Wahianoa (WA), Mangawhero (MA), and Whakapapa (WH) formations. Map modified from Hackett and Houghton (1989) and Price et al. (2012). Idealised ice extents are modified from McArthur and Shepherd (1990) and Eaves (2015) are displayed for the Last Glacial Maximum (LGM) and present-day (PD).

Lavas of the Mangawhero Formation were inferred to have been erupted during discrete pulses of effusive activity centred on $\sim 45$ and $\sim 22 \mathrm{ka}$ (Gamble et al., 2003). Complex stratigraphic relationships between lavas of this and the subsequent Whakapapa Formation were interpreted as the result of rapid transitions between construction and intense degradation of the edifice (Hackett and Houghton, 1989). A chronostratigraphic model of rapid and discrete constructional phases of growth separated by erosion formed the basis of numerous petrochemical investigations that were summarised by Price et al. (2012) in a review of the magma system evolution.

The ring plain holds a thick apron of stacked pyroclastic and volcaniclastic material consisting of debris flow, debris avalanche and hyperconcentrated stream flow deposits interbedded with local andesitic tephras and distal rhyolitic tephras sourced from farther north in the TVZ (Cronin and Neall, 1997; Lecointre et al., 1998; Donoghue and Neall, 2001). Aggradation has likely been rapid following eruptive phases (Hackett and Houghton, 1989) and during glacial periods (Cronin and Neall, 1997), while large-scale sector collapse events may have occurred following the transition from glacial to interglacial periods (Tost et al., 2014). The explosive eruptive history of Ruapehu since $\sim 27 \mathrm{ka}$ has been documented for the tephrostratigraphic record preserved on the eastern 
flank and ring plain of Ruapehu (Donoghue et al., 1995a). A series of Plinian eruptions occurred during the period from $\sim 22$ to $10 \mathrm{ka}$, while coeval but volumetrically minor pyroclastic flow deposits are also preserved on the eastern flank of the edifice (Donoghue et al., 1995a; Pardo et al., 2012). The past 2 kyr of volcanic activity at Ruapehu have been characterised by low-volume $\left(<0.05 \mathrm{~km}^{3}\right)$ but frequent ( $25-30 \mathrm{yr}$ periodicity) phreatomagmatic eruptions through Crater Lake (Donoghue et al., 1997), with additional phreatic eruptions as often as annually. The lake drains into the Whangaehu River valley, which is the principal modern lahar drainage pathway (Cronin et al., 1997).

Past glaciation of Ruapehu is evident from the deep U-shaped valleys that indent the flanks of the edifice as well as the presence of large lateral moraines and striated lava flow surfaces (McArthur and Shepherd, 1990; Waight et al., 1999). The most recent period of major glaciation of the edifice occurred at $\sim 31-17 \mathrm{ka}$, which coincides with the global Last Glacial Maximum, when the termini of valley glaciers were advanced greatly compared to modern ice extents (Fig. 1.3; Eaves, 2015). The impact of pre-historical glaciation of Ruapehu between phases of eruptive activity has been recognised as having generated major stratigraphic unconformities (Hackett and Houghton, 1989). The timing of emplacement of Mangawhero Formation lavas (60-15 ka) and glaciation during the last glacial cycle (71-15 ka; Lisiecki and Raymo, 2005) suggests that syn-eruptive interaction between lava and ice was also an important aspect of the edifice growth history (Spörli and Rowland, 2006). Glaciers have retreated rapidly in historical times (Heine, 1963), and only sparse accumulations of permanent ice are now present around the uppermost western, southern and eastern flanks, and over the broad ice-filled northern portion of the summit area (Fig. 1.3).

\subsubsection{Petrology, composition and magma genesis of eruptive products}

Edifice-forming lava flows from Ruapehu are most succinctly defined as complex lithic and crystal cargoes hosted within dacitic or rhyolitic melts (Price et al., 2012). The effusive products contain diverse mineral assemblages of plagioclase, orthopyroxene, clinopyroxene, olivine, and ubiquitous but volumetrically minor oxide phases (Graham and Hackett, 1987). Oscillatory and reverse zoning patterns are ubiquitous throughout the cargo of crystals, and evidence of reaction and resorption suggests a complex suite of processes operate within Ruapehu magma storage systems (Price et al., 2005). Rather 
than being true phenocrysts that were grown within the host magma, most crystals instead represent antecrysts derived from previously cooled magmas or xenocrysts incorporated from disaggregated wall rocks (Davidson et al., 2007; Price et al., 2012). Lava groundmasses comprise felted microcrystalline aggregates of plagioclase, pyroxene and magnetite, with minor relative volumes of brown glass that have dacite to rhyolite bulk compositions (Price et al., 2012). Hornblende is extremely rare and where present is bordered by reaction coronas (Price et al., 2012).

Whole-rock compositions range from medium- $\mathrm{K}$ basaltic-andesites to high- $\mathrm{K}$ dacites, and one basalt flow has been sampled (Fig. 1.4; Cole, 1978; Price et al., 2012). Lava flow compositions have become progressively more evolved with time, as constrained by existing radiometric age data (Gamble et al., 2003; Price et al., 2012). However, the composition of the youngest Ruapehu lavas assigned to the Whakapapa Formation and historic eruptive products apparently also define a wide compositional range equivalent to that defined by all older eruptive products (Gamble et al., 1999).
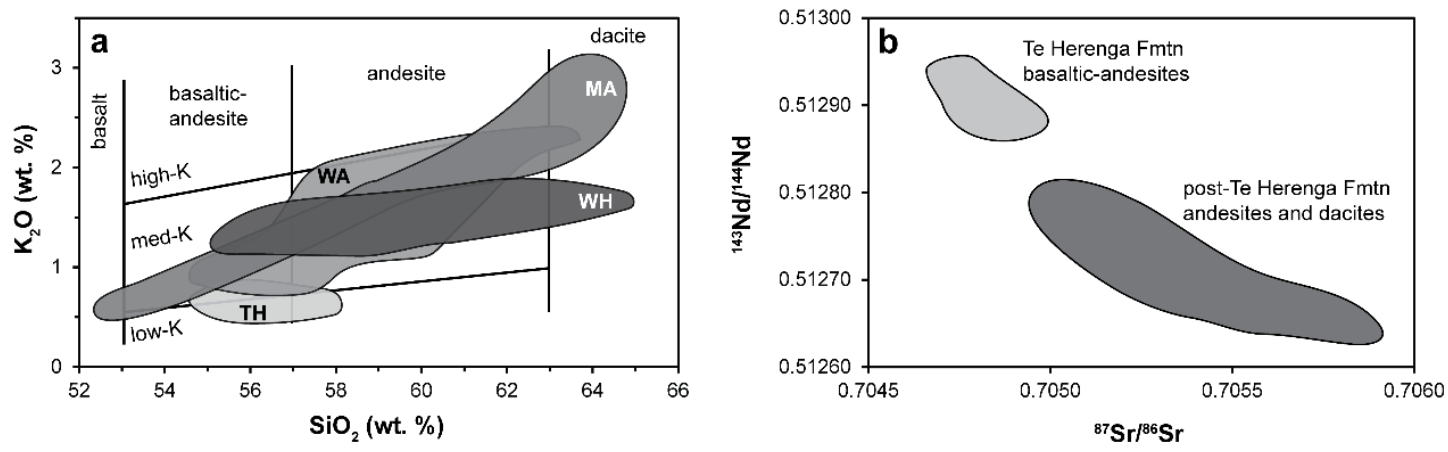

Figure 1.4. Compositional data for Ruapehu volcanic rocks. (a) $\mathrm{SiO}_{2} \mathrm{vs}$. $\mathrm{K}_{2} \mathrm{O}$ diagram for Ruapehu lavas. Data are grouped into fields relating to edifice-forming formations; abbreviations are the same as in Fig. 1.3. (b) ${ }^{143} \mathrm{Nd} /{ }^{144} \mathrm{Nd}$ vs. ${ }^{87} \mathrm{Sr} /{ }^{86} \mathrm{Sr}$ diagram for lava flows from Ruapehu volcano. Both figures are modified from Price et al. (2012).

The broad major and trace element compositional trends are reflected in isotopic data. Basaltic-andesites of the Te Herenga Formation display relatively low ${ }^{87} \mathrm{Sr} /{ }^{86} \mathrm{Sr}$ values at high ${ }^{143} \mathrm{Nd} /{ }^{144} \mathrm{Nd}$ compared to the wide range toward elevated ${ }^{87} \mathrm{Sr} /{ }^{86} \mathrm{Sr}$ values at relatively low ${ }^{143} \mathrm{Nd} /{ }^{144} \mathrm{Nd}$ for post-Te Herenga Formation lava flows that indicate assimilation of continental crust (Figure 1.4; Price et al., 2005, 2012). Compositional data for Te Herenga Formation eruptive products suggest that their derivative magmas were minimally contaminated by continental crust in contrast to the elevated levels of intracrustal 
processing inferred for post-160 ka magmas (Price et al., 2012). Superimposed on the broad long-term compositional trends are non-systematic geochemical variations detailed for eruptive products sampled at the scale of an intra-formation lava flow sequence (1-10 kyr) or historic eruptive phase ( $\sim 0$ years; Waight et al., 1999; Gamble et al., 2003; Price et al., 2012; Kilgour et al., 2013). The short-term compositional variability indicates that magmas are tapped from a complex plumbing system, which is invoked to represent a plexus of dispersed reservoirs through which magmas pass at varying timescales and follow unique fractionation and mixing histories (Gamble et al., 1999; Nakagawa et al., 2002).

\subsection{SUMMARY}

From initial accumulation and differentiation to the eventual emplacement and cooling of the derivative lava flows on the volcano's flanks (Fig. 1.5), the major processes in the lifetime of arc magmas are scrutinised and sequenced in a high-resolution stratigraphy for Ruapehu in this $\mathrm{PhD}$ thesis. The following chapters each deal with three major themes for current global volcanological research:

1. Glaciovolcanism: The morphology and fracture characteristics of effusive glaciovolcanic products have been defined for the Ruapehu edifice. This provides a detailed case study for lava-ice interaction processes at other glaciated composite volcanoes with comparable eruptive and glacial histories.

2. Geochronology: $\mathrm{The}{ }^{40} \mathrm{Ar} /{ }^{39} \mathrm{Ar}$ geochronometer has been applied to a comprehensive sample suite of andesite-dacite lava flows in order to establish a high-resolution eruption history for Ruapehu. Ages for ice-bounded lava flows are used to constrain the timing and extent of former glaciers. The reliability of the dating technique has been proven for Holocene age andesite lavas in this study and has aided interpretation of the causes of sector collapse events.

3. Magma genesis: Whole-rock major and trace element geochemistry and micro-scale mineral and melt compositions for lava flows have been placed within the chronostratigraphic framework established in this study. Time-composition trends for Ruapehu lavas reveal the broad evolution of this productive magma system over the last $\sim 200 \mathrm{kyr}$, and indicate modes of crustal magmatism. 


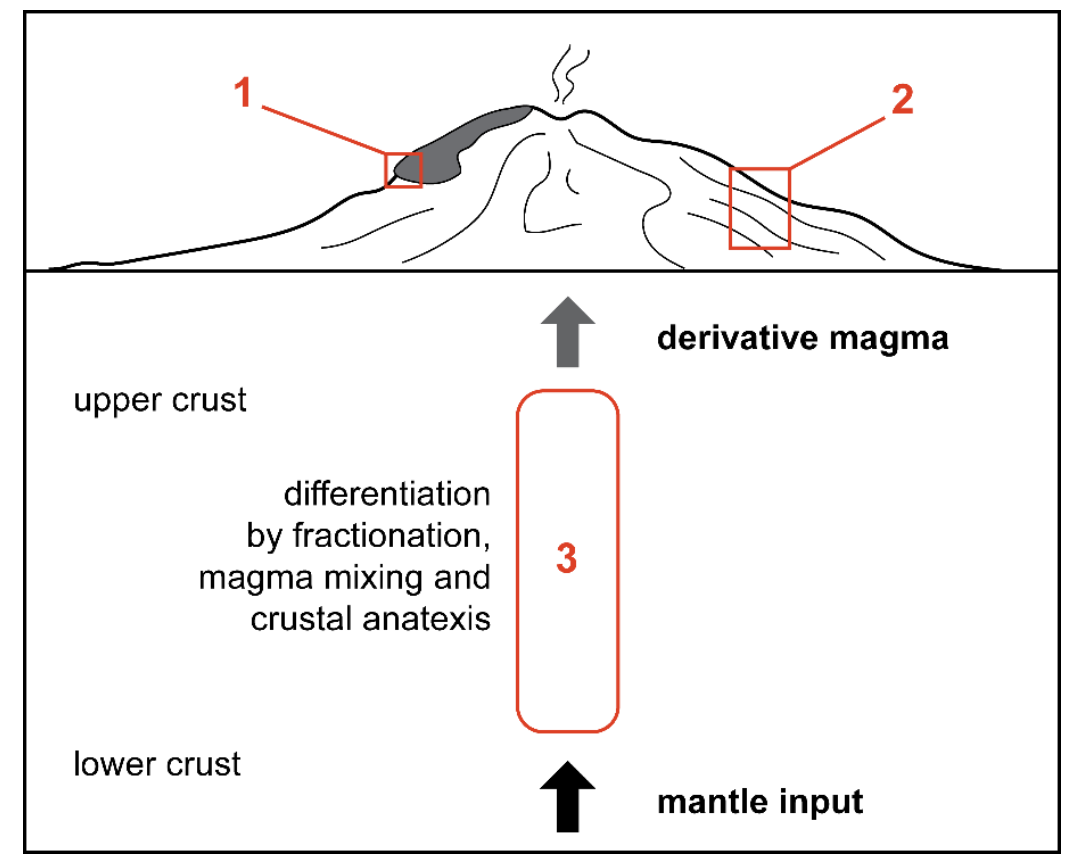

Figure 1.5. Summary cartoon of the regions of lava flow emplacement and magma generation at Ruapehu that are the subject of investigation in this thesis. Numbers refer to the major themes outlined above. 
CHAPTER 2 
This chapter has been published as:

Conway, C.E., Townsend, D.B., Leonard, G.S., Wilson, C.J.N., Calvert, A.T., Gamble, J.A., 2015, Lava-ice interaction on a large composite volcano: a case study from Ruapehu, New Zealand: Bulletin of Volcanology, v. 77, article 21. 


\title{
2. LAVA-ICE INTERACTION ON A LARGE COMPOSITE VOLCANO: A CASE STUDY FROM RUAPEHU, NEW ZEALAND
}

\begin{abstract}
Ice exerts a first-order control over the distribution and preservation of eruptive products on glaciated volcanoes. Defining the temporal and spatial distributions of ice-marginal lava flows provides valuable constraints on past glacial extents, and is crucial for understanding the eruptive histories of such settings. Ice-marginal lava flows are welldisplayed on Ruapehu, a glaciated andesite-dacite composite cone in the southern Taupo Volcanic Zone, New Zealand. Flow morphology, fracture characteristics and ${ }^{40} \mathrm{Ar} /{ }^{39} \mathrm{Ar}$ geochronological data indicate that lavas erupted between $\sim 51$ and $15 \mathrm{ka}$ interacted with large valley glaciers on Ruapehu. Ice-marginal lava flows exhibit grossly overthickened margins adjacent to glaciated valleys, are intercalated with glacial deposits, display finescale fracture networks indicative of chilling against ice, and are commonly ridge-capping due to their exclusion from valleys by glaciers. New and existing ${ }^{40} \mathrm{Ar} /{ }^{39} \mathrm{Ar}$ eruption ages for ice-marginal lava flows indicate that glaciers descending to $1300 \mathrm{~m}$ above sea level were present on Ruapehu between $\sim 51-41 \mathrm{ka}$ and $\sim 27-15 \mathrm{ka}$. Younger lava flows located within valleys are characterised by blocky flow morphologies and fracture networks indicative of only localised and minor interaction with ice and/or snow, mainly in their upper reaches at elevations of $\sim 2600-2400 \mathrm{~m}$. An ${ }^{40} \mathrm{Ar} /{ }^{39} \mathrm{Ar}$ eruption age of $9 \pm 3 \mathrm{ka}(2 \sigma$ error) determined for a valley-filling flow on the northern flank of Ruapehu indicates that glaciers had retreated to near-historical extents by the time of emplacement for this lava flow. The applicability of ${ }^{40} \mathrm{Ar} /{ }^{39} \mathrm{Ar}$ dating to ice-marginal flows on glaciated andesitedacite composite volcanoes makes this technique an additional proxy for paleoclimate reconstructions.
\end{abstract}




\subsection{INTRODUCTION}

Interactions between volcanism and glaciation represent an important part of the eruptive histories of many volcanoes globally. The elevations reached by composite volcanoes means that snow and ice accumulation can be significant, even in equatorial regions at the present day (Major and Newhall, 1989; Cullen et al., 2006), and were important aspects of volcano histories during past glacial periods. Many styles of volcanic activity are influenced strongly by interactions between molten rock and ice/water, whether in the form of magma-water interactions in explosive volcanism (e.g. Houghton et al., 1999) or in controlling the morphology and distribution of effusive products (Lescinsky and Fink, 2000). Observations from historical eruptions and analogue experiments have indicated the ability of ice to impound and deflect lava flows (Edwards et al., 2013). As a result, volcanism in the presence of ice (i.e. glaciovolcanism; cf. Kelman et al., 2002) produces distinct lava morphologies, which can be recognised in pre-historic volcanic products and used to infer the past extent and thickness of ice (e.g. Lescinsky and Fink, 2000; Smellie, 2008).

Eruptive histories for composite volcanoes with glacial histories need to acknowledge the impact that valley glaciers and ice caps have on the spatial and stratigraphic position of lava flows (e.g. Stevenson et al., 2006). Understanding the glaciovolcanic evolution of a volcano provides information on the spatial and temporal relationships between volcanism and glaciation (Kelman et al., 2002). This leads to three fundamental questions: (1) can glaciovolcanic research aid paleoclimate reconstructions?; (2) are there feedback mechanisms between deglaciation and volcanism?; and (3) what are the hazards associated with the disruption of snow/ice during volcanic eruptions? Here the first of these questions is investigated through a case study of lava-ice interaction on a large, mid-latitude, glaciated composite volcano.

A detailed study of the morphologies and fracture characteristics is presented for lava flows erupted during the last $60 \mathrm{kyr}$ at Ruapehu, New Zealand. The observations provide new insights into flow emplacement environments and fracture mechanisms during effusive eruptions on ice-clad volcanoes. In combination with geochemical and geochronological data, the mapped distribution of ice-marginal flows provides valuable constraints on past glacial extents in central New Zealand. 


\subsection{GEOLOGICAL SETTING AND GLACIAL HISTORY OF RUAPEHU}

Ruapehu is situated within the Ruapehu graben at the southern termination of the Taupo Volcanic Zone (TVZ) in the central North Island, New Zealand (Fig. 2.1; Villamor and Berryman, 2006a). The TVZ is a region of high heat flow, extension and volcanism associated with westward subduction of the Pacific plate beneath the Australian plate along the Hikurangi Trench (Fig. 1; Cole and Lewis, 1981). Ruapehu (2797 m) is New Zealand's largest active andesite volcano with a $\sim 150 \mathrm{~km}^{3}$ edifice surrounded by a volcaniclastic ring plain of similar volume (Hackett and Houghton, 1989). The volcano presently hosts several small $\left(<1 \mathrm{~km}^{2}\right)$ summit glaciers and is seasonally covered (May to November) with snow down to elevations of $\sim 1500 \mathrm{~m}$ above sea level (a.s.1.).

The edifice has been constructed over the last $\sim 250 \mathrm{kyr}$ by episodes of voluminous lava effusion punctuated by periods of erosion, sector collapse, and lower intensity volcanic activity (Hackett and Houghton 1989). Edifice-forming deposits consist primarily of blocky lava flows and autobreccias with few dikes and minor pyroclastic fall and laharic deposits (Hackett and Houghton 1989). Effusive eruption of low-K basaltic andesite from 250-60 ka constructed the oldest exposed parts of the Ruapehu edifice, located on the northern and south-eastern flanks (Gamble et al., 2003; Fig. 2.1). Effusive eruption of basaltic-andesite to dacite with accompanying explosive activity has predominated since $60 \mathrm{ka}$ and has built the majority of the modern edifice-forming flanks (Pardo et al., 2012; Price et al., 2012).

Edifice growth since $60 \mathrm{ka}$ has coincided with marine isotope stages (MIS) 3 and 2, when global terrestrial ice cover was relatively extensive (Lisiecki and Raymo, 2005). In New Zealand, large glaciers were hosted along the Southern Alps throughout the Quaternary, although on North Island apparently only the Tongariro and Ruapehu composite cones and south-facing basins of the Tararua Ranges were glaciated (Brook, 2009). Ruapehu edifice displays diagnostic evidence for past glacial activity, including large U-shaped valleys and glacial deposits (till) that cover large areas on all flanks of the volcano (Fig. 2.1). Based on geomorphological mapping of moraines, McArthur and Shepherd (1990) reconstructed a $\sim 140 \mathrm{~km}^{2}$ ice mass on Ruapehu consisting of a cap that covered the summit and fed valley glaciers that descended to $\sim 1200 \mathrm{~m}$ a.s.l. Two advances of valley glaciers between $\sim 60$ and 14 ka have been inferred from regional paleoclimate climate studies and geomorphological mapping (McArthur and Shepherd, 1990). 


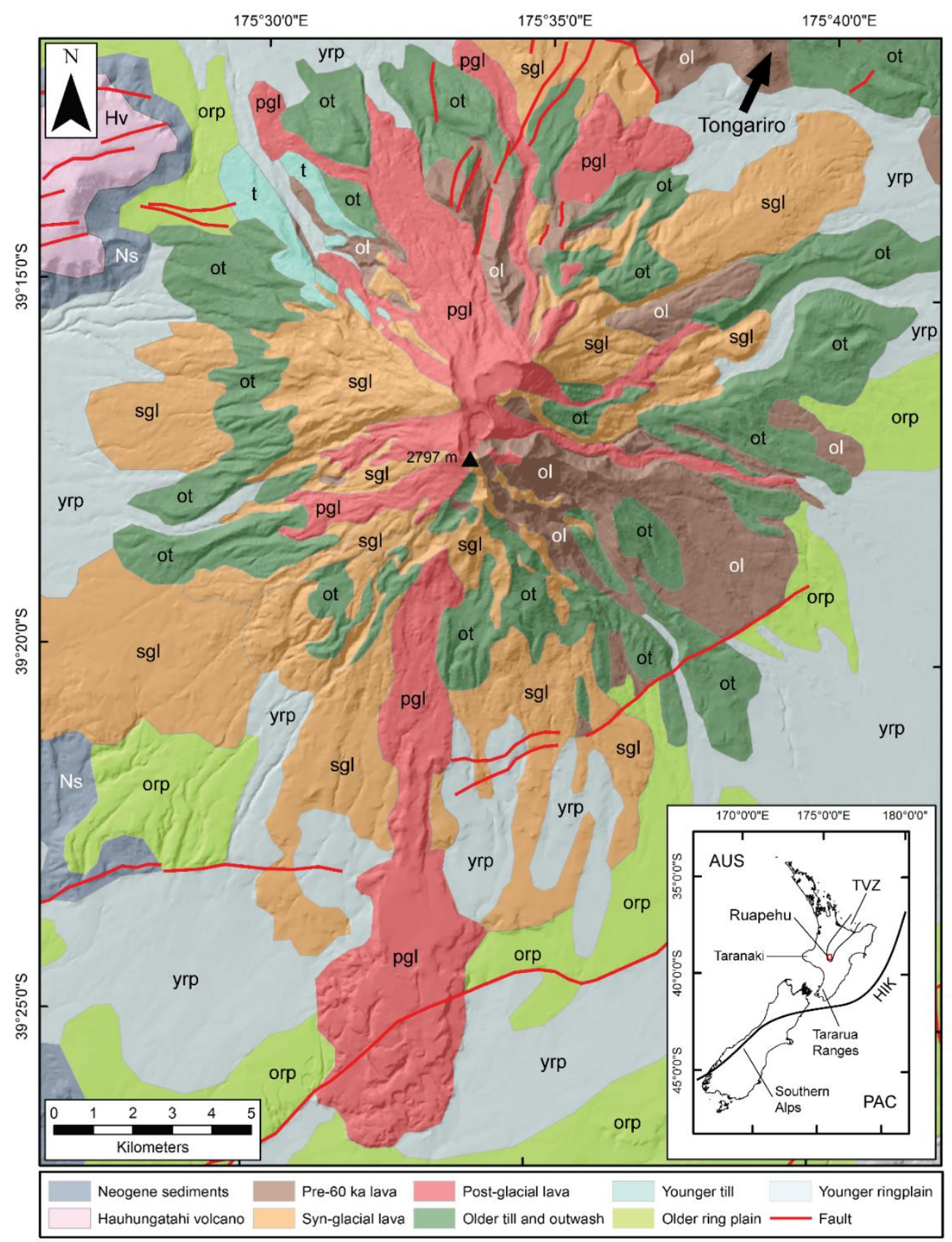

Figure 2.1. Simplified geologic map of Ruapehu. Lava flows are defined as pre-60 ka (ol), syn-glacial (60$15 \mathrm{ka} ; \mathrm{sgl}$ ), and post-glacial (<14 ka; pgl). Glacial deposits are shown in green (older till and outwash; ot). Young till (t) is delineated only for the north-western flank for the purposes of a later figure (see Fig. 12). Older (orp) and younger (yrp) volcaniclastic deposits are categorised for the ringplain. Older lavas of Hauhangatahi volcano (Hv) are situated on exposed Neogene sediments (Ns). Locations of the Taupo Volcanic Zone (TVZ), Tararua Ranges, Southern Alps, and Taranaki volcano are shown in the inset figure. The Hikurangi Trough marks the seafloor expression of westward subduction of the Pacific plate (PAC) beneath the Australian plate (AUS). Extent of the geologic map of Ruapehu is shown by the red box.

One study to date has reported evidence for interaction between lava and ice on southeast Ruapehu during this time period (Spörli and Rowland, 2006). Throughout New Zealand, 
terrestrial evidence from fluvial terraces, loess and paleosol sequences, and paleovegetation patterns indicates that the climate of North Island ameliorated rapidly from $\sim 18-16 \mathrm{ka}$ (Newnham et al., 2003). This inference is consistent with the wholesale retreat of South Island glaciers between $\sim 17.8$ and $15.7 \mathrm{ka}$ in response to climatic warming that accounted for $\sim 86 \%$ of the net temperature rise between $\sim 20 \mathrm{ka}$ and the early Holocene (Putnam et al., 2013a). A pollen sequence from a core located $\sim 150 \mathrm{~km}$ northeast of Ruapehu indicates that the trend of warming was interrupted by a cold climate reversal from 13.6-12.6 ka, but later resumed from $12 \mathrm{ka}$ into the Holocene (Hajdas et al., 2006).

\subsection{METHODS}

\subsubsection{Fieldwork}

Fieldwork campaigns from 2012 to 2014 were dedicated to delineating and describing effusive glaciovolcanic features over the entire Ruapehu edifice, as part of a wider study into the evolution of the volcanoes of Tongariro National Park led by GNS Science (Townsend et al., 2016). Initial sites of interest, particularly steep ridges and bluffs, were identified from digital terrain models (DTMs) and aerial photographs, and subsequently reconnoitred. Lava flow morphology, internal structure, and lithology were described at exposures. Fracture types were classified for lava flows that displayed fracture patterns indicative of cooling due to contact with ice, snow or water (see section 2.4.1). Icemarginal flow margins were mapped with ArcGIS using field evidence and inferences from DTMs based on gross flow morphology that indicated likely interaction between lava and ice. Detailed sections were measured at these localities and fracture plane orientations, and striation spacing and height were recorded. Locations of observed fracture types and their measurements are available in Appendices A1 and A2.

\subsubsection{Geochemistry}

Samples were collected for geochemical analysis from relevant lava flows where their geomorphology was important in constraining the geographical extent of lava-ice interaction. Whole-rock samples were cut using a diamond saw to remove weathered 
parts, crushed using a Rocklabs Boyd crusher, and powdered using a Rocklabs agate or tungsten-carbide ring mill at Victoria University of Wellington. Powders were made into fused lithium metaborate glass discs and analysed for major oxide concentrations by XRay Fluorescence (XRF) following the methods of Ramsey et al., (1995). Disc-making and analyses were carried out at the Open University, Milton Keynes, U.K. Internal standards WS-E (Whin Sill dolerite) and OU-3 (Nanhoron microgranite) were analysed to monitor precision and accuracy of the results. Major oxide analyses were accurate to within 2.0 relative $\%$ of the recommended values for the internal standards. Analytical precision $(2 \sigma)$ was 1.5 relative $\%$ or better for all elements with concentrations $>0.3 \mathrm{wt}$. $\%$.

\subsubsection{Geochronology}

Radiometric ${ }^{40} \mathrm{Ar} /{ }^{39} \mathrm{Ar}$ eruption ages for three lava flows are presented here in order to provide temporal constraints for ice-marginal and post-glacial flows. The ages are a subset of the data presented in Chapter 3. Analysis of crystalline groundmass separates from andesite lava flows has been shown to produce the most reliable results (Hildreth and Lanphere, 1994), and such textures were observed in the interior of thick lava flows at Ruapehu (Gamble et al., 2003). Sufficient K concentrations for analysis require minimum groundmass plagioclase crystal widths of $10 \mu \mathrm{m}$ and a groundmass glass abundance of $<5 \%$. Samples selected for dating were crushed using a Rocklabs Boyd crusher and sieved to retain the 250-350 $\mu$ m size fraction. An LB-1 Barrier type Frantz was used to remove phenocrysts and xenoliths from grains of groundmass in the crushed rock fraction via magnetic separation. To remove altered and adhered material, groundmass separates were washed in water for up to 20 hours in an ultrasonic bath, then washed in acetone to remove any hydrocarbons from grain surfaces, and then rinsed in deionized water. Finally, any remaining grains with adhering phenocrysts, xenoliths or areas of glass were removed by hand-picking. Samples were irradiated at the USGSTRIGA reactor in Denver, Colorado and isotopic analyses were undertaken at the US Geological Survey Geochronology Laboratory in Menlo Park, California following the methods of Calvert et al., (2005). 


\subsection{EVIDENCE FOR LAVA-ICE INTERACION AT RUAPEHU}

\subsubsection{Lava flow fracture types}

Upon contact with a glacier, lava flows conductively transfer heat to the ice, which results in the production of meltwater (Wilson and Head, 2007). As the lava rapidly cools against the ice and water to form glass, the rate of heat transfer slows, the glacier resists further melting and the flow becomes confined against its margin (Lescinsky and Sisson, 1998). Fractures form when the tensile strength of a lava flow is exceeded due to thermal contraction (Lore et al., 2000), and propagate perpendicular to the maximum thermal gradient, i.e. away from the cooling surface (DeGraff and Aydin, 1987). Intermittent propagation produces 'striations' on the fracture plane, which represent the fracture tip stalling in plastic lava, before advancing once the tensile strength is exceeded due to further cooling. Wider spacing between striations and greater striation height (i.e. protrusion from the fracture plane) indicates slower fracture propagation (Lore et al., 2000). In this way, striation spacing and height can be used in ancient lavas to infer the direction and rate of cooling. The anatomies of five fracture types generated by interaction between lava and ice/meltwater are described below and summarised in Table 2.1. These types were arrived at by combining previous studies with our new observations from lava flows at Ruapehu. Existing type names are used for continuity with previous work and the term 'fracture' is employed to describe related features and processes.

\subsubsection{Column-forming joints}

The most widely-studied of the fractures produced by lava-ice interaction are columnforming joints. Intersecting fracture planes that form arrays of horizontally-oriented columns are interpreted as explicit evidence for contact between lava and ice, because the lateral margin of a glacier presents a vertical cooling surface (e.g. Lescinsky and Sisson, 1998). Column-forming joints on lava flow margins at Ruapehu intersect to form 4,5 , or 6-sided polygons in cross-section with diameters of 10-20 cm (Fig. 2.2). Striations (also known as "chisel marks") on the column faces (i.e. fracture planes) are invariably oriented perpendicular to the column axis, spaced at distances $<5 \mathrm{~cm}$ and protrude above the fracture planes by up to $5 \mathrm{~mm}$. Where measurable, striations indicate that fractures propagated inward from the margins of lava flows. Greatest column-forming joint lengths 
extend continuously for up to $30 \mathrm{~m}$ and have orientations that are predominantly nearvertical, but vary in the form of short wavelength $(<1 \mathrm{~m})$ undulations of amplitude $<2 \mathrm{~cm}$, or longer wavelength $(2-10 \mathrm{~m})$ fanning patterns.

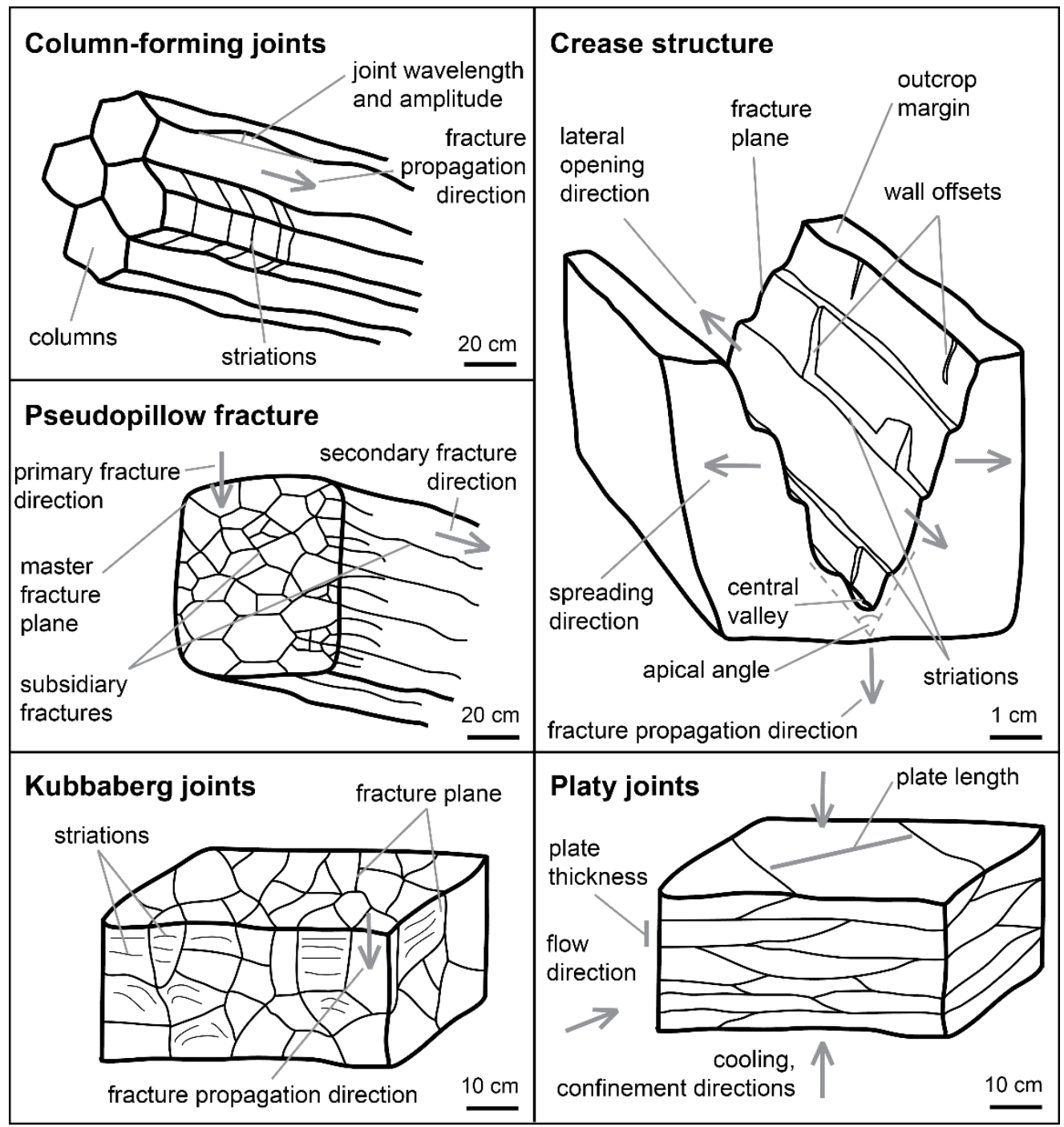

Figure 2.2. Fracture types indicative of interaction between lava and ice at Ruapehu. Refer to text and Table 2.1 for full descriptions of fracture characteristics.

\subsubsection{Pseudopillow fractures}

The term 'pseudopillow fracture' is used to describe a pattern in lavas that is produced by two distinct generations of fracturing (Watanabe and Katsui, 1976; Forbes et al., 2012). Pseudopillow fractures consist of curviplanar 'master' fractures spaced at distances of $>50 \mathrm{~cm}$, and 'subsidiary' fractures oriented perpendicular to the master fracture and spaced at distances of $<50 \mathrm{~cm}$ (Fig. 2.2). 


\begin{tabular}{|c|c|c|c|c|c|}
\hline 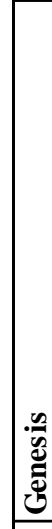 & 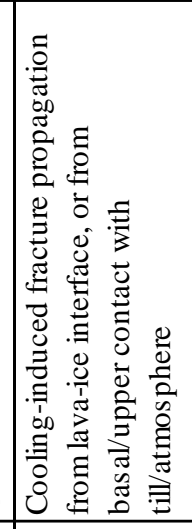 & 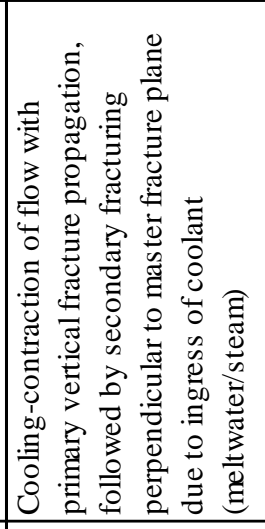 & 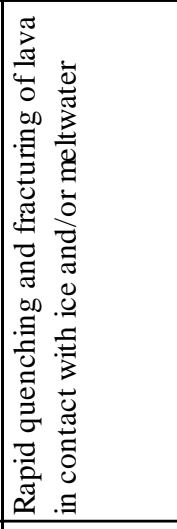 & 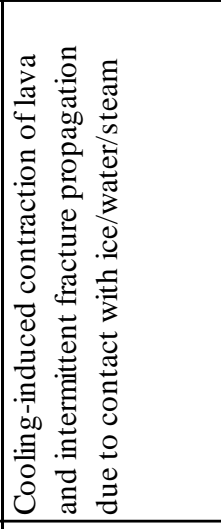 & 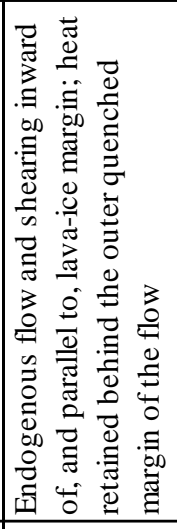 \\
\hline 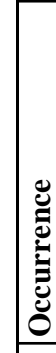 & 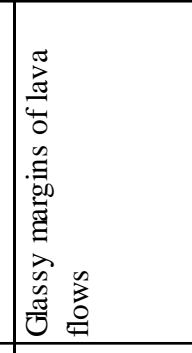 & 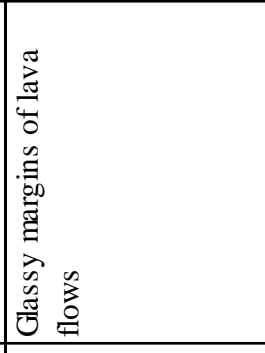 & 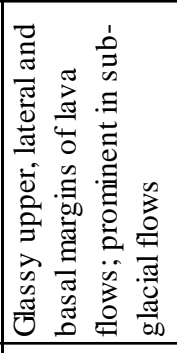 & 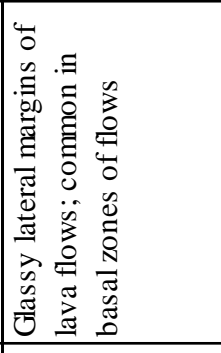 & 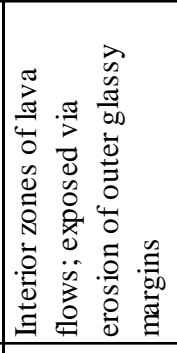 \\
\hline 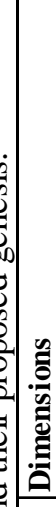 & 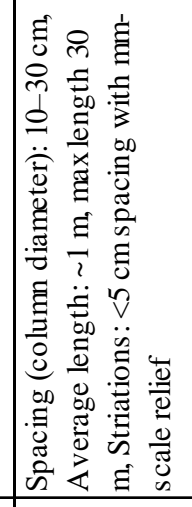 & 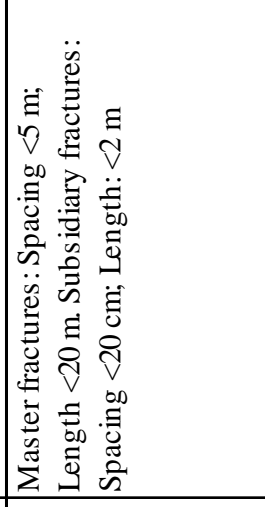 & 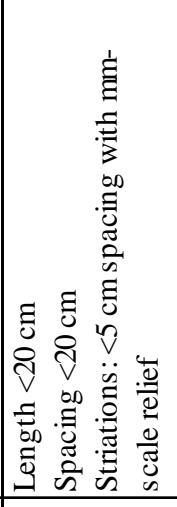 & 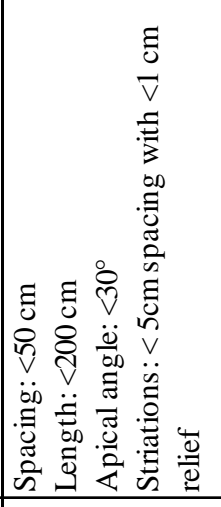 & 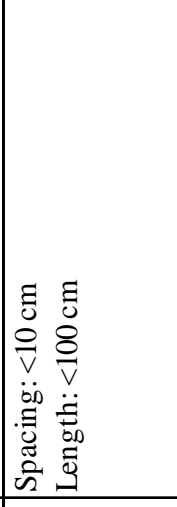 \\
\hline है & 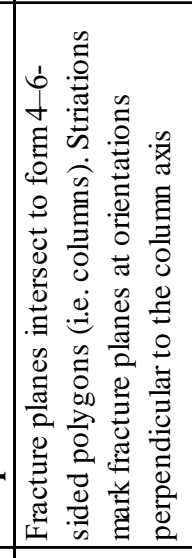 & 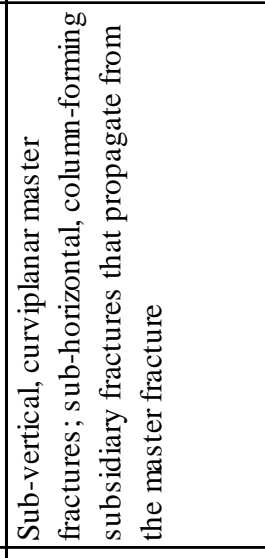 & 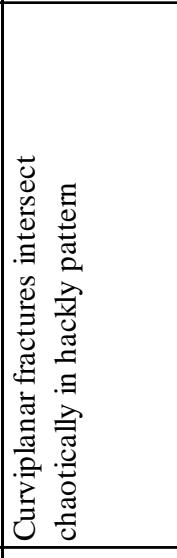 & 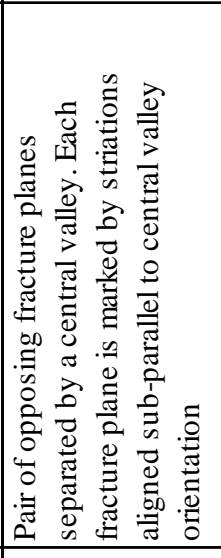 & 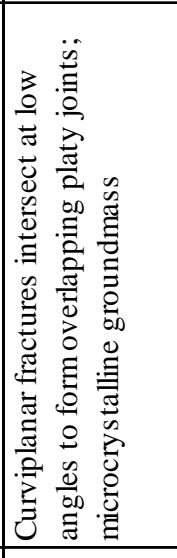 \\
\hline 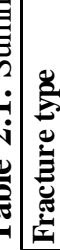 & 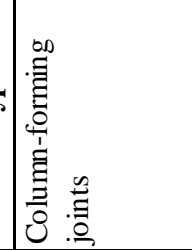 & 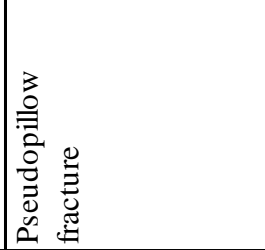 & 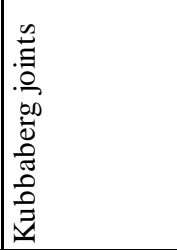 & 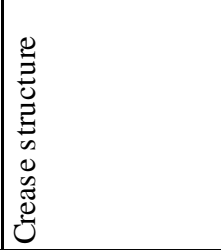 & 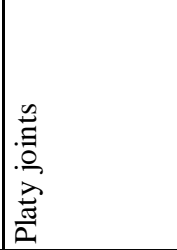 \\
\hline
\end{tabular}


Subsidiary fractures are interpreted to form due to the ingress of water or steam through the initial master fracture, which induces cooling and contraction of the host lava (e.g. Tucker and Scott, 2009). Therefore, the transformation of ice to meltwater is a necessary step in generating this fracture type. Pseudopillow fractures in lava flows on Ruapehu consist of $<20 \mathrm{~m}$-long sub-vertical and curvi-planar master fractures. Master fractures are arranged sub-parallel to each other and spaced at distances of 0.5-5 $\mathrm{m}$ where they are present as networks along the margins of lava flows. Master fracture planes are occasionally corrugated by sub-horizontal striations, which indicate that fracture propagation was sub-vertical, although directions could not be unambiguously determined due to erosion of the fine-scale features. Subsidiary fractures are oriented approximately perpendicular to master fractures, and intersect the master fracture plane to form polygons with diameters $<10 \mathrm{~cm}$ adjacent to the master fracture and $>20 \mathrm{~cm}$ at distances $>1 \mathrm{~m}$ from the master fracture (Fig. 2.2).

\subsubsection{Kubbaberg joints}

Rapid quenching of a lava flow in the presence of water produces an irregular network of arcuate intersecting fractures, called 'kubbaberg' joints. Kubbaberg is an Icelandic term meaning cube-jointed lava or entablature (e.g. Sæmundsson, 1970; Williams, 1995; Forbes et al., 2014). Kubbaberg jointing occurs exclusively in very glassy zones within the lateral, upper or basal margins of lava flows on Ruapehu. Fractures are spaced $<15 \mathrm{~cm}$ apart and cross-cut each other chaotically (Fig. 2.2). Striations on kubbaberg joint planes are spaced at $<5 \mathrm{~cm}$ and are often curved.

\subsubsection{Crease structures}

Crease structures are fractures that form as a result of lateral spreading and thermal contraction of the outer surface of a lava dome or flow (Anderson and Fink, 1992). Tensile stress is concentrated perpendicular to the axis of spreading, which results in tearing of the outer surface of the lava. Ductile lava beneath the crust is then exposed to the ambient atmospheric temperature, and intermittent fracture propagation ensues. Finescale crease structures have not previously been recognised as resulting from lava-ice interaction, but occur in close association with column-forming joints, pseudopillow 
fractures and kubbaberg joints in the glassy marginal zones of lava flows on Ruapehu.

Crease structures in Ruapehu lava flows are fractures that are defined by opposing planes spaced $<20 \mathrm{~cm}$ apart at the flow margin, but taper towards each other to intersect at an apical angle of $<30^{\circ}$ in a central valley inward of the flow's margin (Figs. 2.2, 2.3). Thus, crease structures form open cavities at their open edges on lava flow margins. Central valley directions show no preferential orientation, i.e. can be any angle from vertical to horizontal, but are always sub-parallel to the flow margin.
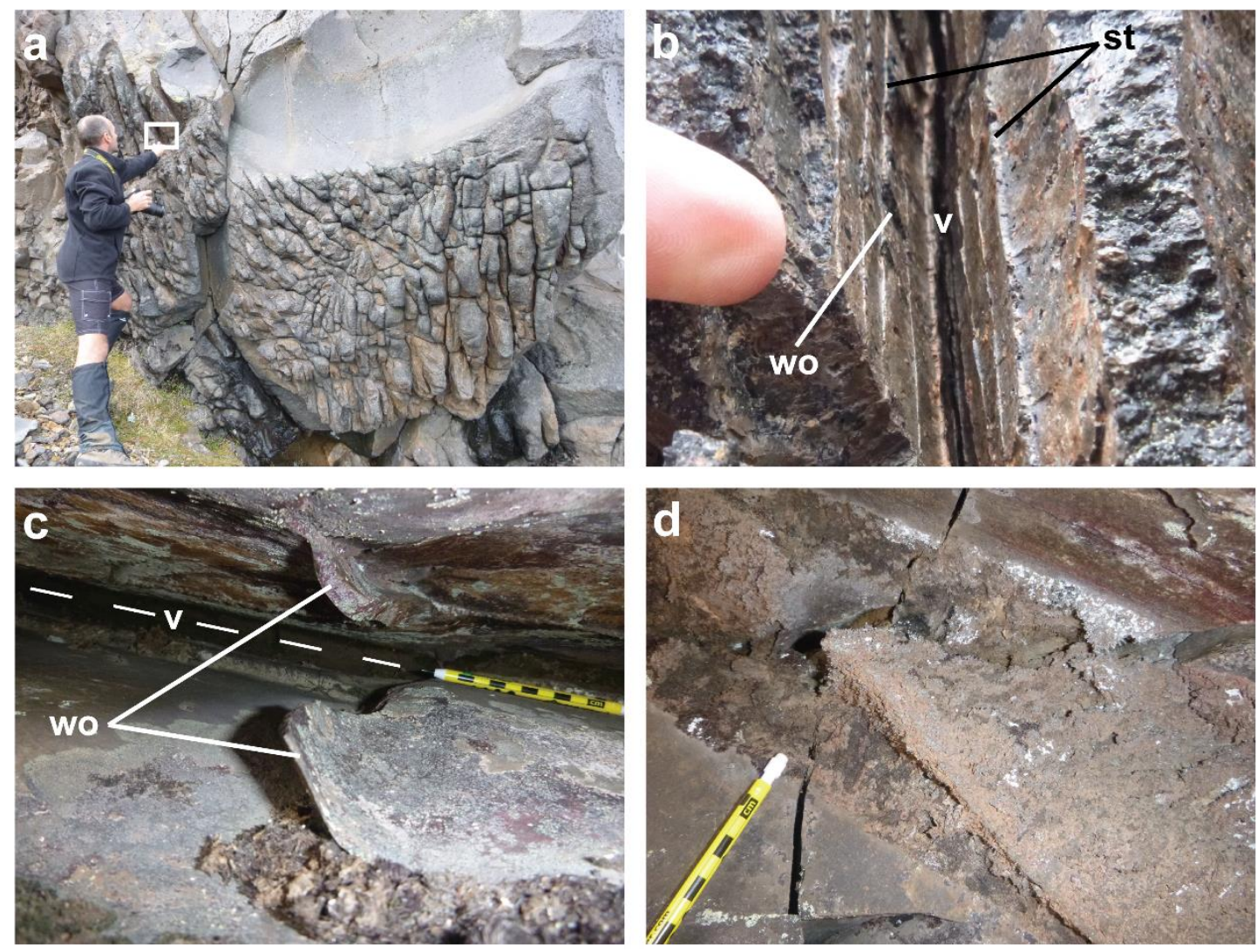

Figure 2.3. Representative images of crease structures in ice-marginal lava flows at Ruapehu. Refer to Figure 2.4 for locations of photographed sites. (a) Lobe of glassy, ice-bounded andesite on western Ruapehu, pervasively cut by closely spaced crease structures inferred to have formed at the original lava-ice contact. (b) Close-up of crease structure located in box outlined in (a). Wall offsets (wo) cut across striations (st), which strike parallel to the central valley (v) and are spaced at $\sim 1 \mathrm{~cm}$. (c) View into a horizontal crease structure shows a ruptured lava bridge consisting of matching wall offsets (wo) on opposing faces of an opened fracture plane. Divisions on pencil are $1 \mathrm{~cm}$. (d) Sheared glassy and spinose lava in the central valley of a crease structure.

Individual crease structures extend along flow margins for 10-200 cm laterally and 5-50 $\mathrm{cm}$ into the lava (Fig. 2.3). Crease structures, spaced at distances of $2-50 \mathrm{~cm}$ and aligned sub-parallel to each other, occur in groups that pervasively fracture flows over areas $<5$ $\mathrm{m}^{2}$ (Fig. 2.3a). Each fracture plane is marked by striations that are aligned sub-parallel to 
the central valley and are spaced at distances of $1-5 \mathrm{~cm}$ with individual reliefs of $<1 \mathrm{~cm}$ (Figs. 2.2, 2.3b). Each striation has a correspondent on the opposite wall of the fracture, such that the planes are approximately symmetrical about the axis of the central valley. Thin bridges of lava ( $<1 \mathrm{~cm}$-thick, $<5 \mathrm{~cm}$-wide) with sigmoidal morphology often connect the opposing planes. These lava bridges were observed as intact, incipiently broken, or completely ruptured (Fig. 2.3c). Where the broken bridges merge with the fracture plane, they form $<1 \mathrm{~cm}$-high wall offsets that trend perpendicular to, and cut across single or several, striations on each plane (Figs. 2.2, 2.3b). Striations form as the crease structure intermittently propagates into the flow and the opposing fracture planes spread apart about the central valley and form a cavity (Fig. 2.2). Ruptured lava bridges represent the lateral propagation of the crease structure (Fig. 2.2). Lava within the central valley of crease structures is very glassy and often finely spinose (Fig. 2.3d), which indicates that ductile shearing of viscoelastic lava occurred during fracture propagation.

\subsubsection{Platy joints}

Platy joints are common in subaerial lavas of intermediate-silicic composition (e.g. Bonnichsen and Kauffman, 1987), but have also been recognised for lava flows that have interacted with ice (Lescinsky and Fink, 2000). The exposed interior zones of thick (10$100 \mathrm{~m}$ ) lava flows at Ruapehu are characterised by curviplanar fractures that intersect at low angles to form overlapping plates with lengths of $\sim 1 \mathrm{~m}$ and thicknesses of $<10 \mathrm{~cm}$ (Fig. 2.2). Platy jointed zones of flows are composed of lava with groundmass textures comprising microcrystalline plagioclase and pyroxene (5-30 $\mu \mathrm{m}$ microlite crystal width) and minimal glass $(<10$ volume \%). Platy joints are dominantly sub-horizontal in the lower 5-30 m of thick flows, although orientations are locally variable and can change by $90^{\circ}$ over lengths of $2 \mathrm{~m}$. The lateral margins of lavas commonly expose vertical plates, whereas the front noses of flows are characterised by platy joints arranged in patterns that curve in a concave pattern from the top (sub-vertical plates) to the base (sub-horizontal plates) of the flow. Approximately vertical fractures ( $>5 \mathrm{~m}$-long with $>1 \mathrm{~m}$-spacing) cut across platy joints. 


\subsubsection{Lava flow morphology}

Ruapehu lava flows studied here are categorised into four types based on their distribution relative to glaciated valleys, dimensions, and fracture types. Their mapped distributions are shown in Figure 2.4.

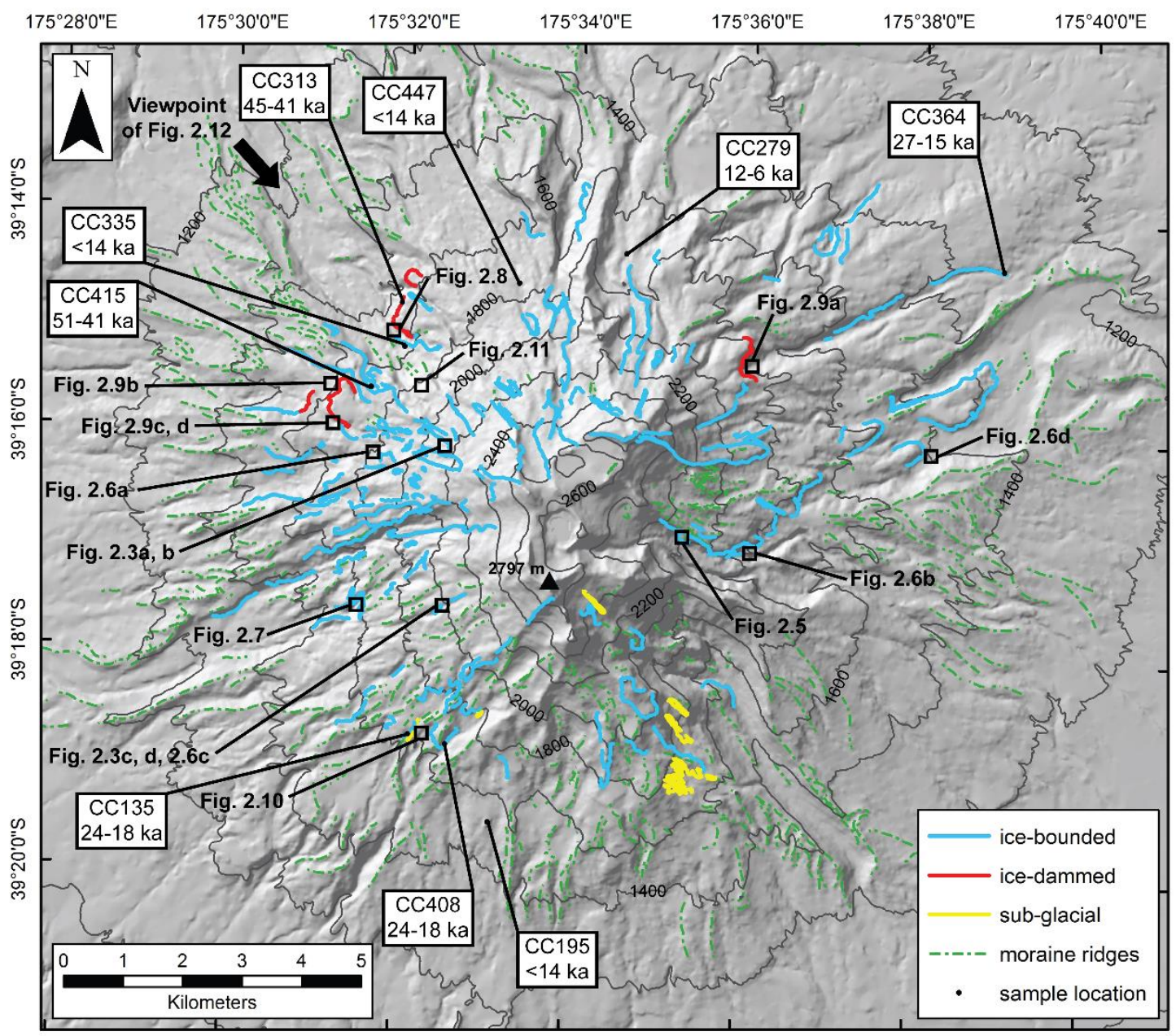

Figure 2.4. Hill-shaded DTM of Ruapehu showing distribution of ice-marginal lava flow types and moraine ridges. Locations of geochemistry and geochronology samples with eruption age ranges are shown, as well as locations of photographed sites in other figures.

\subsubsection{Ice-bounded flows}

Lava flows perched on the tops or sides of ridges and heads of glaciated valleys are located adjacent to all major valleys of the volcano and are especially prominent on the eastern, western and southern flanks between 1300-2100 m a.s.l. (Fig. 2.4). Flows are thinnest on the crests of ridges and thicken towards the adjacent valleys often as discrete 
knuckles of lava, but terminate abruptly to form cliffs 5-50 m-high (Fig. 2.5). Lava flows are intercalated with moraines, which together form valley sides up to $200 \mathrm{~m}$-high. Contacts below the lava with moraines are commonly concealed by autoclastic talus derived from the over-steepened flows (Fig. 2.6a), and above by degradation of overlying moraine material.
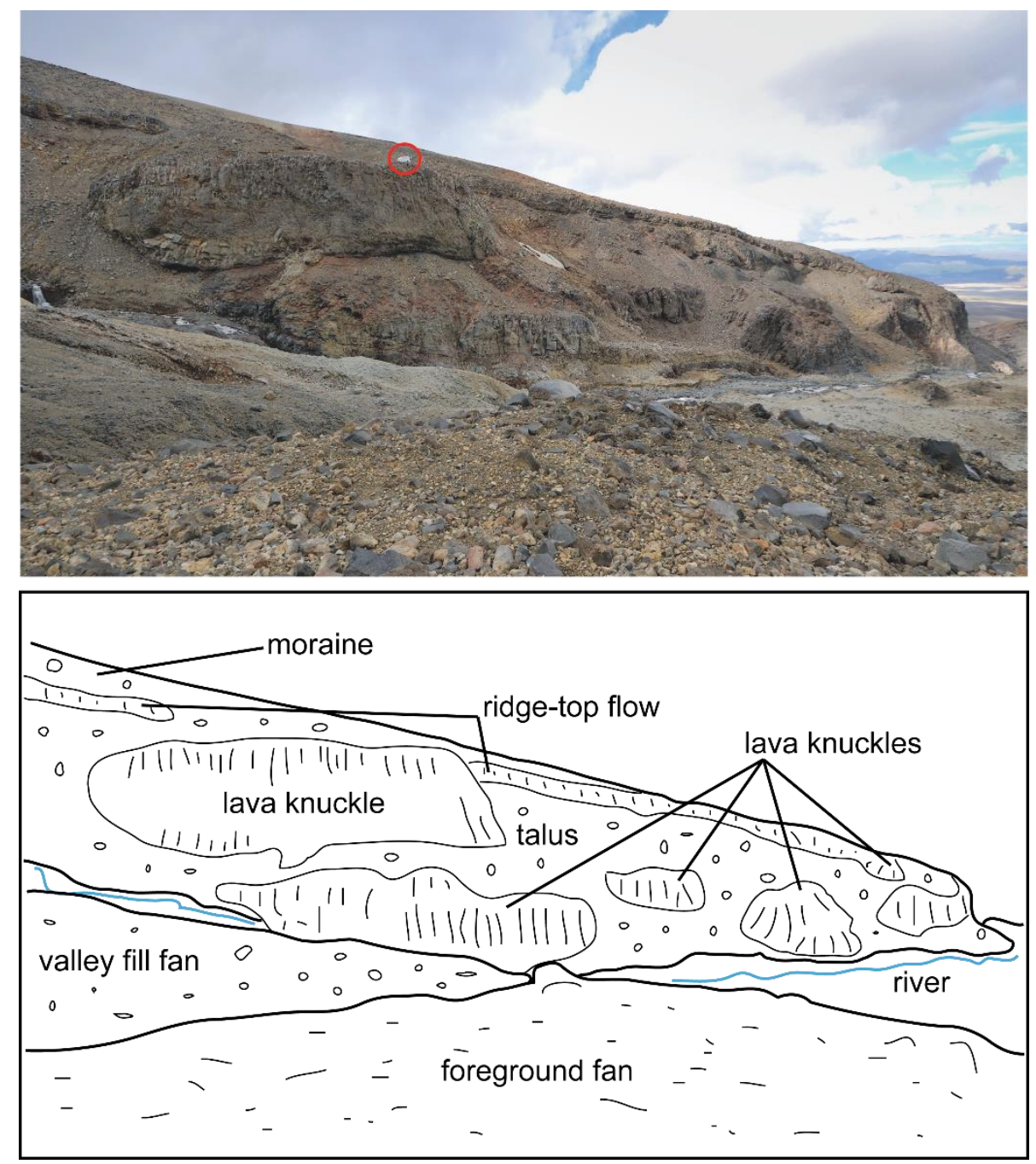

Figure 2.5. Example of ice-bounded lava flows from eastern Ruapehu. Note the fine-scale jointing on the vertical face of this $\sim 30$ m-thick flow (below the NZ Alpine Club Hut; circled in red). Note also the thin ridge-top flow (near skyline), that thickens downslope and terminates in a small, perched knuckle. Refer to Figure 2.4 for location of flow.

Where observed, lava basal contacts are planar and often marked by overhangs and cavities. Basal contacts are characterised by glassy groundmass textures and very fine kubbaberg or column-forming joints ( $<5 \mathrm{~cm}$ spacing). Where glacial till is exposed at the basal contact of a flow, two common features are observed: (1) quenched lobes and clasts 
of lava identical to the overlying flow are present in the adjacent till; (2) gradational contacts between lava with kubbaberg or column-forming joints and till (containing clasts of lava from the adjacent flow) are present (Fig. 2.6b). The observations indicate that the till was deposited prior to (or coeval with) emplacement of the flow. Ridge-top, valley axis-parallel lava flows that display overthickened margins, relationships with till that are indicative of interaction with ice, and lava-ice interaction fracture types (see below) are classified here as ice-bounded flows (cf. Lescinsky and Sisson 1998).
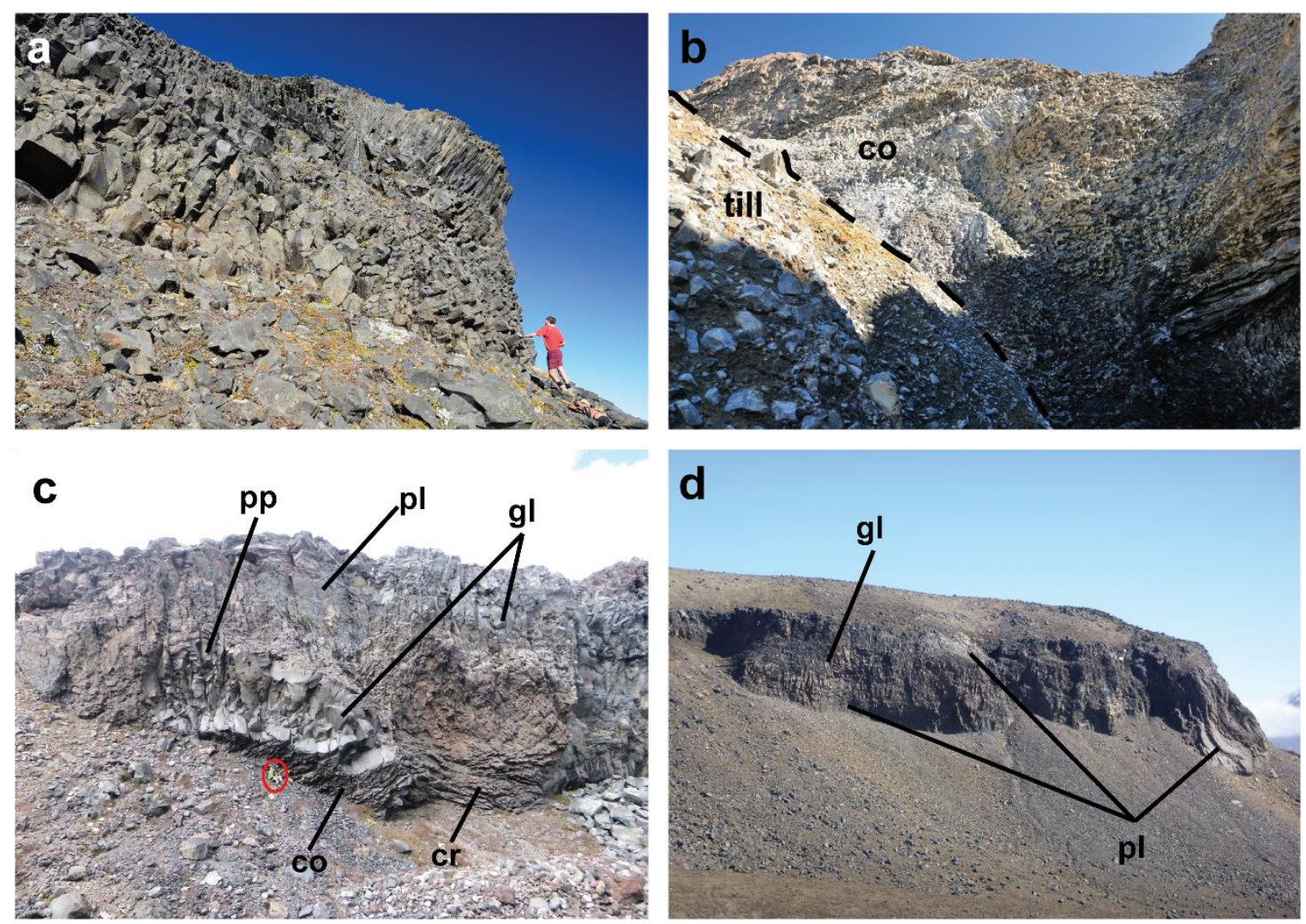

Figure 2.6. Fracture characteristics of ice-bounded lava flows at Ruapehu. Locations of photographed sites are shown in Figure 2.4. (a) Column-forming joints on the margin of an ice-bounded flow on western Ruapehu range in orientation from horizontal (lower margins) to vertical (top of flow). (b) Gradational contact (dashed line) between ice-bounded flow with column-forming joints (co; right) and sheared till containing clasts of the adjacent lava (left). (c) Range of fracture types observed in ice-bounded lava flow on south-western Ruapehu: pseudopillow fractures (pp); platy joints (pl); column-forming joints (co) and crease structures (cr). Glassy zones (gl) are also present throughout the flow. Person (seated) for scale. (d) Side view of ice-bounded flow on eastern Ruapehu. Platy joints ( $\mathrm{pl}$ ) of variable orientation exposed throughout the flow. Note the capping till and talus apron that typically obscure flow contact relationships.

Column-forming joints define the quenched margins of ice-bounded flows and are oriented horizontally on the sides and vertically on the tops of flows (Fig. 2.6a). Small volume $\left(<10 \mathrm{~m}^{3}\right)$ lobes of lava perched on valley walls that can be traced upward to major 
ridge-capping lava flows are composed of fanning arrays of sub-vertical column-forming joints. Column-forming joints occur in close association with pseudopillow fractures, which are arranged in sets of sub-parallel master fractures spaced $<5 \mathrm{~m}$ apart and oriented sub-vertical (Fig. 2.6c).

Kubbaberg joints occur at the basal contact or top surface of ice-bounded flows, and are sometimes preserved along the lateral margins of flows (Fig. 2.6c). Fine-scale crease structures ( $<20 \mathrm{~cm}$-long) are located on glassy lobes of ice-bounded flows, where they are commonly oriented sub-vertical and spaced $<10 \mathrm{~cm}$ apart such that they pervasively fracture glassy zones of $<2 \mathrm{~m}^{2}$ (Fig. 2.3a). Crease structures with greater lengths ( $\left.>1 \mathrm{~m}\right)$, wider spacing (>20 cm) and dominantly sub-horizontal orientations are present in the lower $10 \mathrm{~m}$ of thick ice-bounded flows (Fig. 2.6c).

Flow interiors displaying ubiquitous platy joints have been exposed for ice-bounded flows that are missing their outermost quenched carapaces, which have collapsed or been eroded. The lower 5-10 $\mathrm{m}$ of ice-bounded flows display regularly arranged horizontal plates $\sim 100 \mathrm{~cm}$-long and $<10 \mathrm{~cm}$-thick. Middle to upper levels of ice-bounded flows display concentric platy jointing that is sub-horizontal at the top of the flow and subvertical on the margins of the flow (Fig. 2.6d).

Colonnades are here represented by $\sim 35 \mathrm{~m}$-high outcrops of lava exposed along icebounded flow margins that behead or divert valley drainages. Basal contacts of colonnades are composed of glassy lava fractured by closely spaced kubbaberg or column-forming joints and are commonly marked by overhangs (Fig. 2.7). Above this lowermost zone of colonnades, lava is fractured by broad, approximately vertical, column-forming joints at $>50 \mathrm{~cm}$ spacing that extend for 1-3 $\mathrm{m}$ into the flow. The upper 20-30 m of colonnade outcrops expose fine-scale (10-20 cm diameter) column-forming joints in association with pseudopillow fractures and kubbaberg joints. Column-forming joints are dominantly oriented sub-vertically and display wavy undulations with amplitudes of 1-10 cm over wavelengths of 20-210 cm. Arrays of columns that fan from vertical to horizontal over distances of $<10 \mathrm{~m}$ are common at colonnade outcrops (Fig. 2.7). 


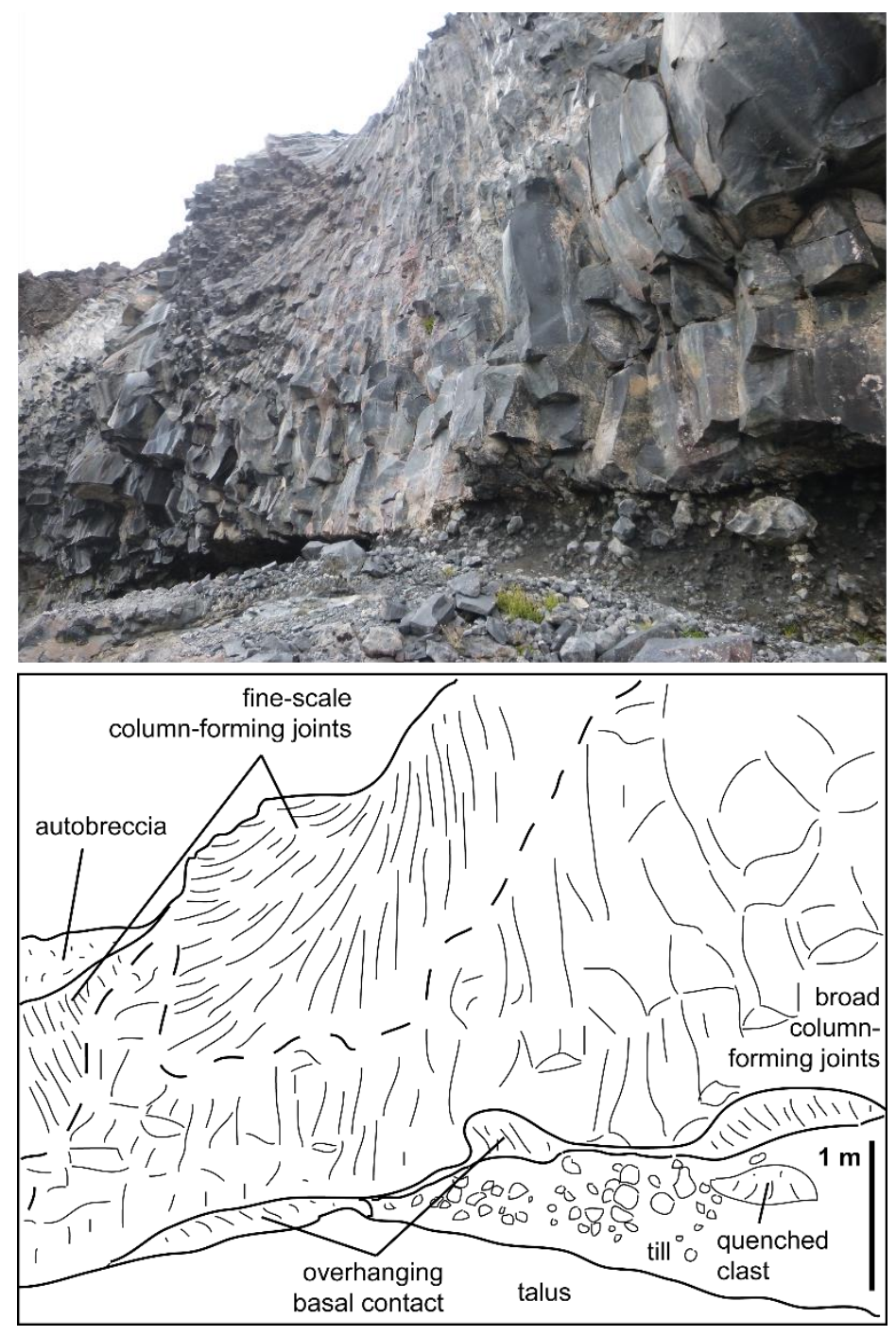

Figure 2.7. Glassy colonnade of an ice-bounded flow overlying till on south-western Ruapehu. Location of flow is shown in Figure 2.4.

\subsubsection{Ice-dammed flows}

Lavas forming cliffs of heights $>50 \mathrm{~m}$ that are located within glaciated valleys at Ruapehu are classified here as ice-dammed flows. Flows have flat tops and thicken downslope toward their frontal terminations, which form near-vertical cliffs up to $100 \mathrm{~m}$ high and $600 \mathrm{~m}$-wide oriented perpendicular to the axes of the valleys below them (Fig. 2.8). Fans of autoclastic debris that formed through gravitational collapse and erosion of the over-steepened terminal bluff fringe the flow fronts and typically obscure their basal contacts such that the true thicknesses of flows are unknown. Ice-dammed flows at Ruapehu are located on the north-eastern, north-western, and western flanks between 1560-1880 m a.s.l. (Fig. 2.4). 


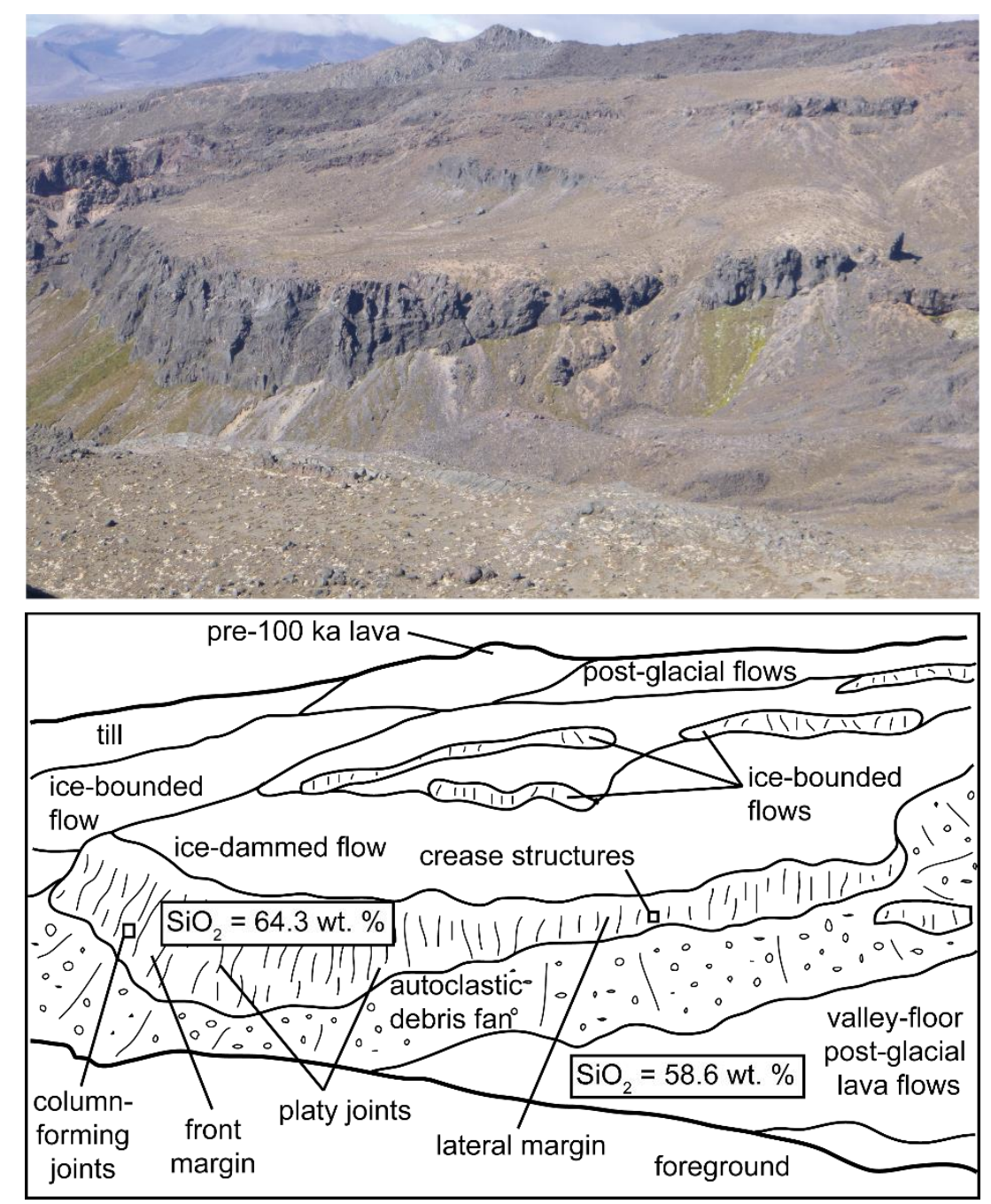

Figure 2.8. Ice-dammed flow on north-western Ruapehu. Location of photographed site is shown in Figure 2.4. Height of front margin is $\sim 80 \mathrm{~m}$. Full compositional data for flows with $\mathrm{SiO}_{2}$ contents displayed are shown in Table 2.2.

Glassy and massive lava with associated autobreccia comprise the upper $10 \mathrm{~m}$ of flows (Fig. 9a, b). The lower 20-40 m of flows are characterised by $<15 \mathrm{~cm}$-thick and $30-100$ cm-long sub-horizontal plates bounded by regularly spaced and oriented fractures (Fig. 2.9a, b). Vertical fractures spaced at distances of 2-5 $\mathrm{m}$ and continuous over lengths of 40-60 m extend through platy and glassy zones in ice-dammed flows (Fig. 2.9a); platy joints are cut by the vertical fractures. Fine-scale, horizontal column-forming joints are present commonly on the lateral margins of ice-dammed flows and, rarely, on the front in close association with pseudopillow fractures, kubbaberg joints and crease structures (Figs. 2.9c, d). The different fracture networks often merge without distinguishable boundaries, resulting in compound arrays and geometries of the joints. 

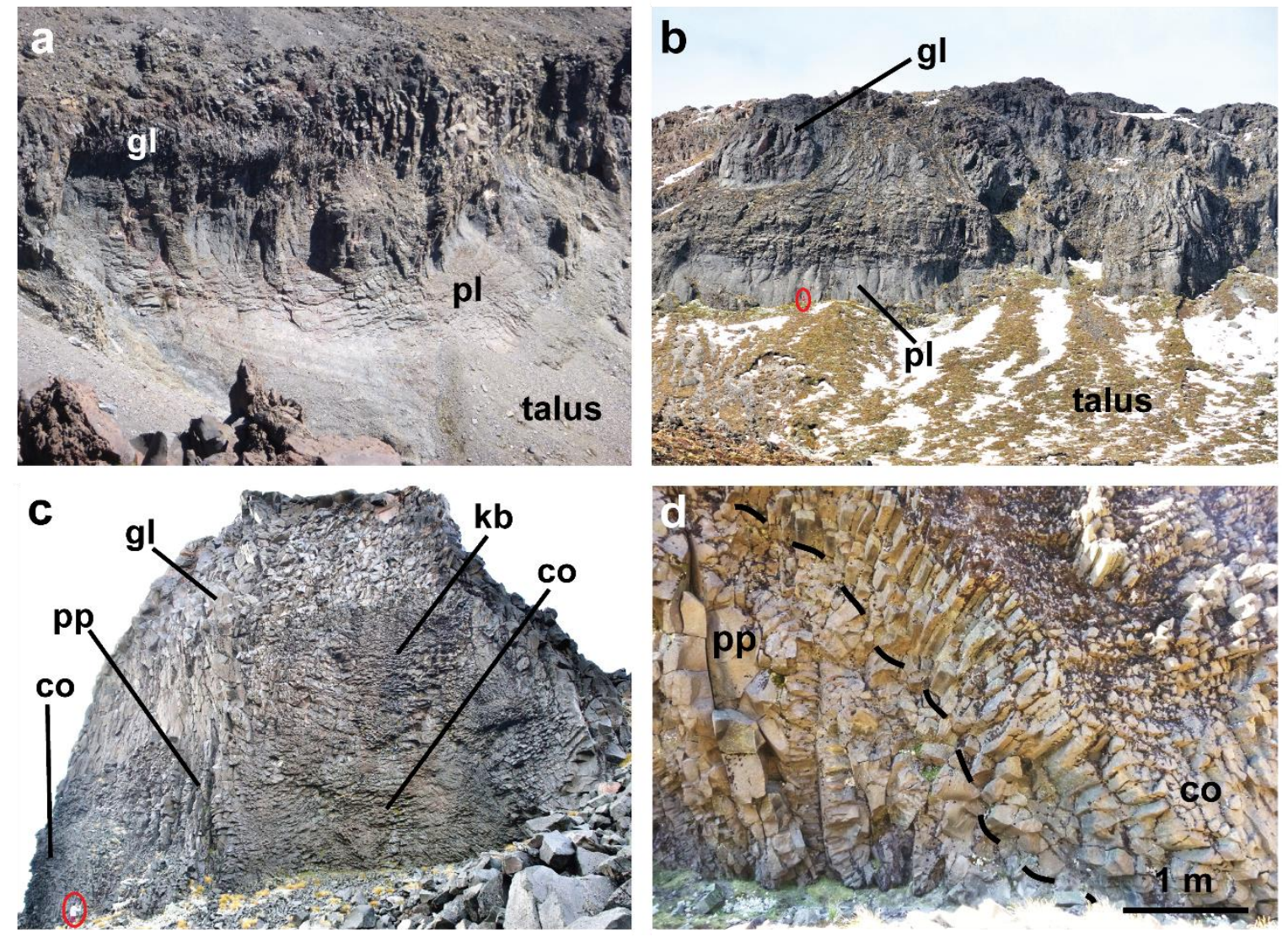

Figure 2.9. Fracture characteristics of ice-dammed lava flows at Ruapehu. Locations of photographed sites are shown in Figure 2.4. (a) Glassy (gl) and platy jointed (pl) lava exposed in terminal face of ice-dammed flow on north-eastern Ruapehu. Flow thickness is $\sim 50 \mathrm{~m}$. (b) Front margin of ice-dammed flow on western Ruapehu exhibits horizontal platy joints (pl) in the lower $\sim 20 \mathrm{~m}$ of the flow, and glassy lava (gl) in the upper zones of the flow. Person for scale circled in red. (c) Left lateral margin of ice-dammed flow on western Ruapehu exhibits a range of fracture types: column-forming joints (co); pseudopillow fractures (pp); glassy lava (gl); kubbaberg joints (kb). Person for scale circled in red. (d) Transition(dashed line) between sub-vertical pseudopillow fractures (pp) and horizontal column-forming joints (co).

Pseudopillow fractures display approximately vertical, curviplanar master fractures with horizontal striations that formed due to intermittent fracture propagation in a vertical direction. Pseudopillow subsidiary fractures intersect each other to form sub-horizontally oriented columns. Crease structures are most common on the lateral margins of icedammed flows and display sub-vertical central valley orientations.

\subsubsection{Sub-glacial flows}

Valley-floor lava flows with sinuous morphological forms and height-to-width ratios $>1: 1$ are observed at three locations at Ruapehu (Figs. 2.4, 2.10a). The flows are located on 
gentle slope gradients on the south-western flank at $1620 \mathrm{~m}$ and south-eastern flank at $1750 \mathrm{~m}$. The lavas exhibit glassy groundmass textures and display fine-scale kubbaberg joints spaced at distances of $<20 \mathrm{~cm}$ in the upper levels of the flows, indicative of rapid cooling in the presence of water (Figs. 2.10c, d).
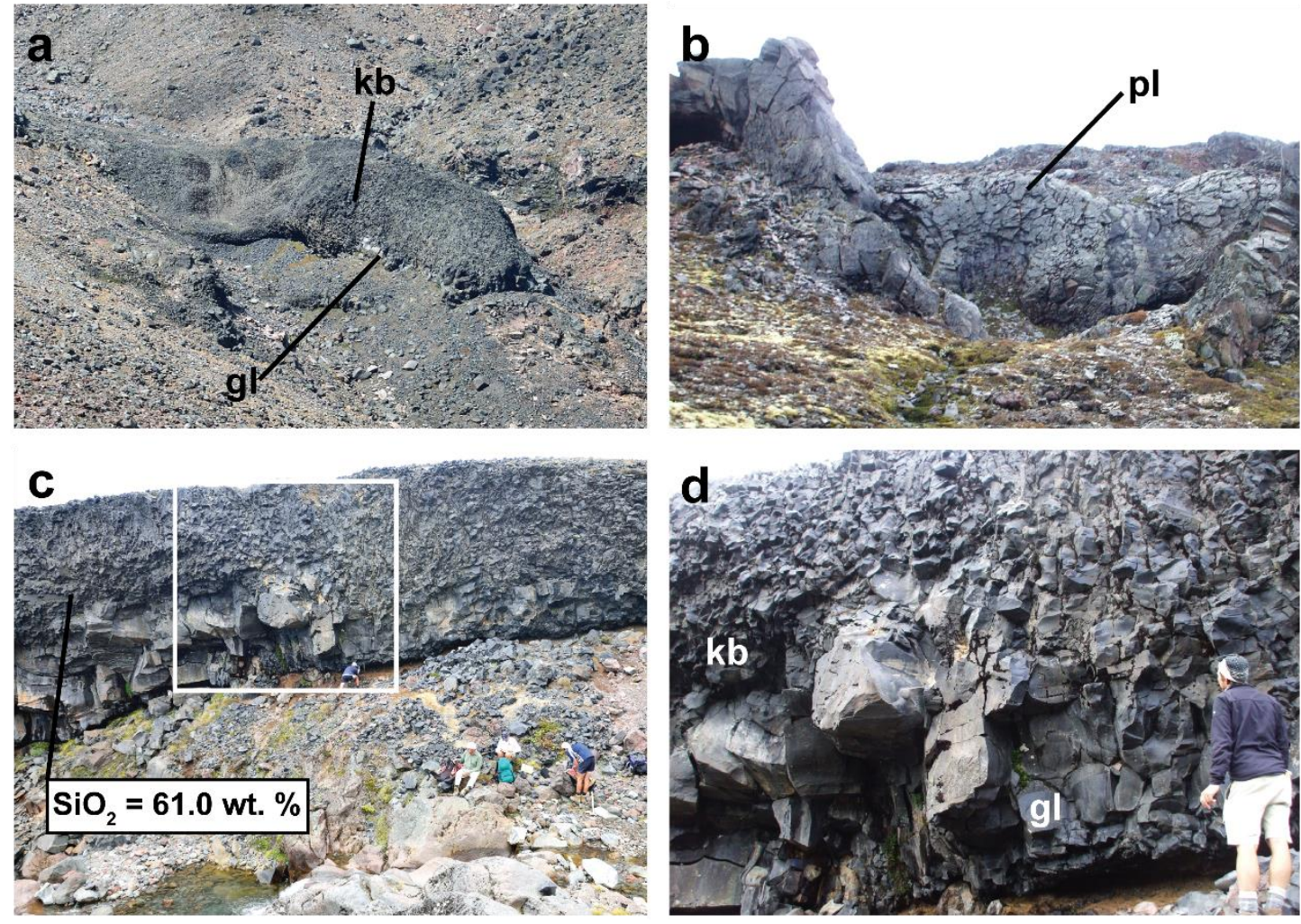

Figure 2.10. Sub-glacial lava flows on Ruapehu. (a) Sinuous, valley-floor flow on south-western Ruapehu exhibits kubbaberg joints (kb) and glassy lava (gl). It was probably emplaced within a meltwater channel beneath a glacier. Flow thickness is $\sim 10 \mathrm{~m}$. (b) Concentric platy joints (pl) on lateral margin of sub-glacial flow on south-western Ruapehu. Flow height is $\sim 5 \mathrm{~m}$. (c and d) Lateral margin of a sub-glacial flow on south-western Ruapehu, exposing kubbaberg joints (kb) and a lower glassy zone (gl). Full compositional data for the lava flow are shown in Table 2.2. Refer to Figure 2.4 for location of photos.

Middle to lower zones have broad column-forming joints and conchoidal fractures spaced at distances of $>1 \mathrm{~m}$ (Figs. 2.10c, d). Concentric platy joint orientations in the lavas replicate flow margin morphologies where the outer glassy carapace has been removed by erosion (Fig. 10b). There is no evidence to suggest that these flows were erupted from a vent source beneath ice (i.e. no hyaloclastite breccia or pillow lavas were observed). These flows are classified here as sub-glacial flows and are analogous to the 'esker-type' flows described by Lescinsky and Fink (2000), albeit on a smaller scale. 


\subsubsection{Post-glacial flows}

Lava flows located within valleys on Ruapehu that have relatively little moraine cover and display minor or no glacial striae are classified as post-glacial flows (i.e. erupted since 14 ka during MIS 1, as defined by Lisiecki and Raymo, 2005). This inference is based on paleoclimate indicators elsewhere in central North Island that the LGM climatic conditions had ameliorated and large-scale retreat of glaciers had occurred by $\sim 14 \mathrm{ka}$ (e.g. Newnham et al., 2003). Post-glacial lavas have relatively low height-to-width ratios $(<1: 10)$ and mantle older ice-marginal flows on the upper slopes of the edifice, in association with autobreccias, welded spatter and pyroclastic flow deposits. Several of the flows are rootless and many are diverted away from glacial catchments on the upper flanks. Post-glacial flows form blocky flow fields that onlap older moraines and lavas on gentle slope gradients within valleys or at lower flank elevations ( $<1700 \mathrm{~m}$ a.s.l.; Fig.

2.11). Lavas display evidence for minor and localised interaction with glaciers or snow: column-forming joints and pseudopillow fractures are present only rarely on flow margins. Column-forming joints have the same dimensions as those in ice-marginal lavas, but are restricted to exposures within areas of $<10 \mathrm{~m}^{2}$. Pseudopillow fractures display relatively small master fracture lengths $(<2 \mathrm{~m})$ and close subsidiary fracture spacings $(<10 \mathrm{~cm})$. No post-glacial flows display gross overthickening or impoundment at their margins.

\subsection{AGES AND COMPOSITIONS OF LAVA FLOWS}

A subset of relevant eruption age and compositional data are presented for this study that are presented in full in Chapter 3. High-precision ${ }^{40} \mathrm{Ar} /{ }^{39} \mathrm{Ar}$ eruption ages were determined for an ice-dammed flow on the north-western flank (43 $\pm 2 \mathrm{ka}$; all errors reported as $2 \sigma)$ and an ice-bounded flow on the south-western flank of Ruapehu (21 \pm 3 ka; Table 2.2; Fig. 2.4). Based on its geomorphology and near-identical major element chemistry, a sub-glacial flow located $600 \mathrm{~m}$ to the west is inferred to have been erupted and emplaced coevally with the $21 \pm 3$ ka ice-bounded flow. 

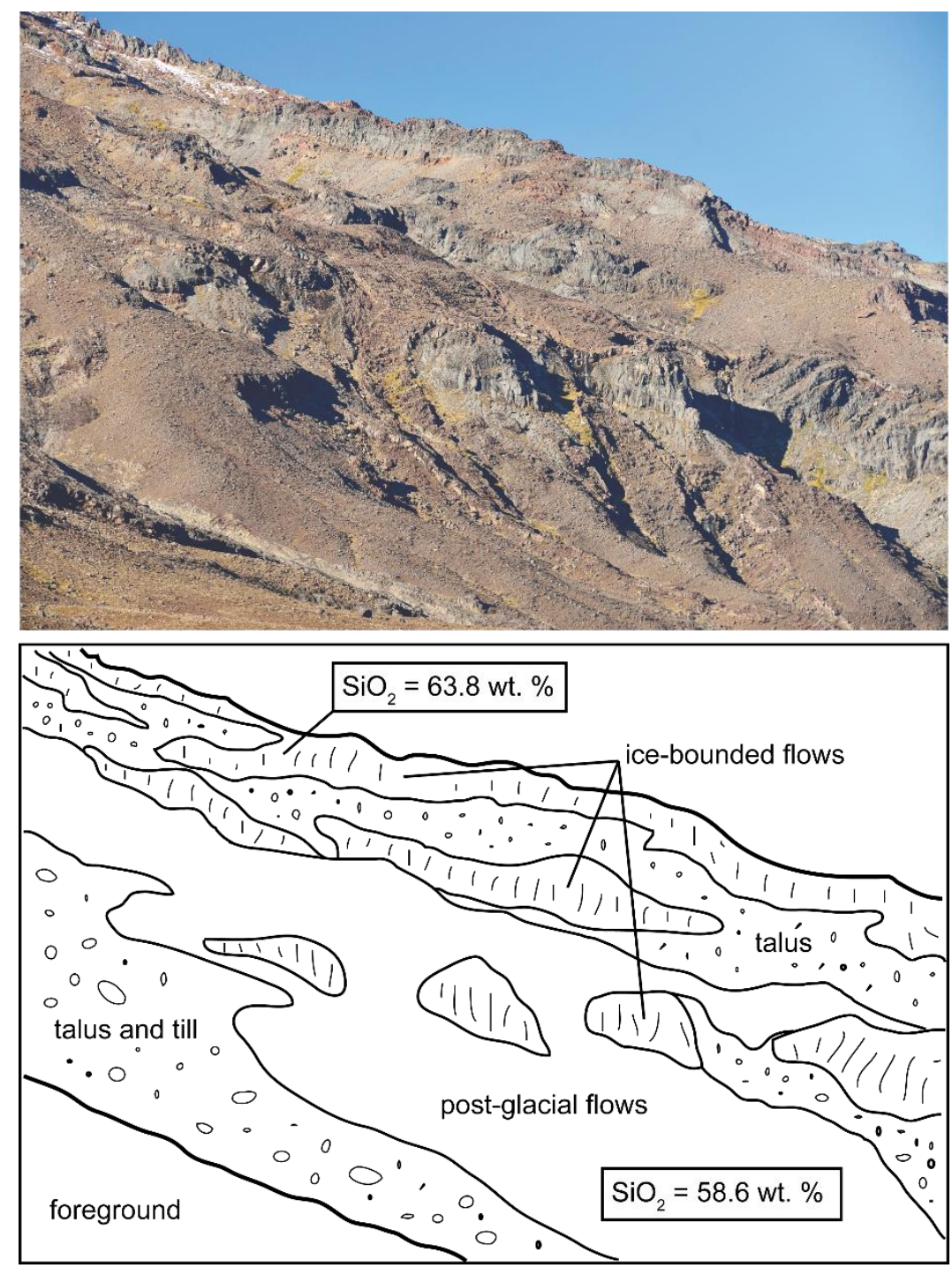

Figure 2.11. Post-glacial lava flows on north-western Ruapehu. These flows are typically $<5 \mathrm{~m}$-thick, drape over topography and have little or no till cover. Distance to skyline is $\sim 1.5 \mathrm{~km}$. Refer to Figure 2.4 for location of photo. Full compositional data for flows, with $\mathrm{SiO}_{2}$ contents displayed, are shown in Table 2.2.

${ }^{40} \mathrm{Ar} /{ }^{39} \mathrm{Ar}$ eruption ages of $46 \pm 5 \mathrm{ka}$ and $21 \pm 6 \mathrm{ka}$ were determined by Gamble et al., (2003) for lava flows that are here identified as being ice-bounded (Table 2.2; Fig. 2.4). The crystalline interior of a post-glacial lava flow exposed in the valley floor on northern Ruapehu yielded an eruption age of $9 \pm 3 \mathrm{ka}$. Post- glacial eruption ages are inferred for lava flow samples CC195, CC335 and CC447 due to their valley-floor locations. Ruapehu lava flows studied here display a 58.3-64.3 wt. \% range in $\mathrm{SiO}_{2}$ content (Table 2.2). Postglacial lavas have compositions intermediate of this range, from approximately 58-60 wt. $\% \mathrm{SiO}_{2}$, whereas lavas that were erupted from $\sim 51-41$ ka generally have higher $\mathrm{SiO}_{2}$ contents. 


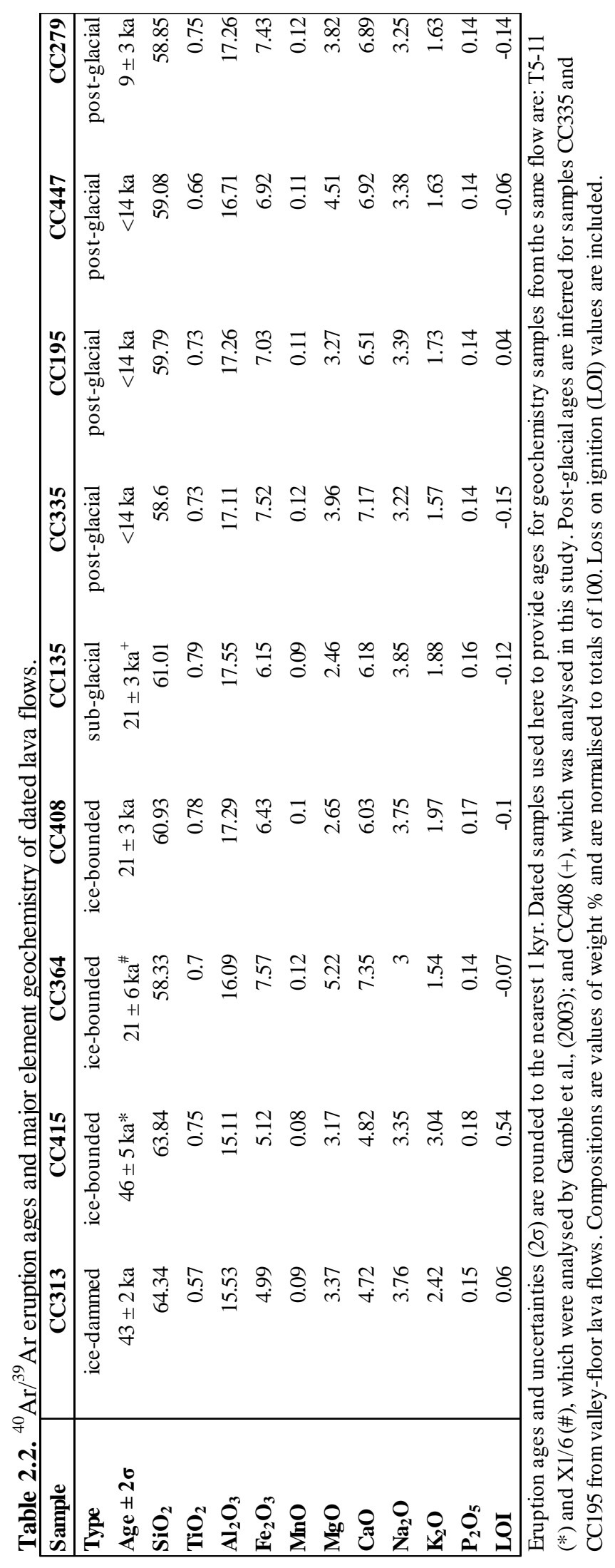




\subsection{DISCUSSION}

\subsubsection{Ice-marginal lava flow emplacement}

The general model for ice-marginal effusive volcanism on composite volcanoes considers the emplacement of andesite-dacite lava onto ridges adjacent to the lateral margins of valley-filling glaciers on the flanks of a volcano following an eruption from the summit (Lescinsky and Sisson, 1998). Lava is excluded from the valley by the glacier mass. Steep-walled channels are formed at the margins of glaciers due to the production and drainage of meltwater resulting from thermal erosion of the ice (Wilson and Head, 2007). Confinement of lava within the channel between the glacier's margin and the adjacent ridge causes the flow to grow thicker as it fills the available space. Ice-marginal flows on Ruapehu display characteristics previously described for those from other locations (e.g. Lescinsky and Fink, 2000): ridge-top locations; over-thickened margins adjacent to glaciated valleys; intercalation with till; and fine-scale cooling fractures and glassy textures.

The morphology of lava flows at Ruapehu provides additional insight into processes of ice-marginal flow emplacement, and the northwest flank of the volcano provides an ideal case study of the different flow types and processes (Fig. 2.12). Lava knuckles (Fig. 2.5) and colonnades (Fig. 2.7) are common features of ice-bounded flows at Ruapehu. Knuckles form thick bluffs adjacent to valleys, and are the product of lava having ponded in discrete void spaces along the lava-ice interface (Fig. 2.12). Lava colonnades were formed where lava was impounded against thick walls of ice along the margins or heads of glacial valleys. The resultant flows solidified as $>20 \mathrm{~m}$-high cliffs of lava that preserve exceptional exposures of column-forming joints (Fig. 2.7).

Lava able to flow into small channels at the margin of the glaciers is now perched on the sides of valleys below ridge-bounded flows as low-volume lobes, or flowed through and cooled within meltwater channels in glaciers to form sub-glacial flows (Figs. 2.10, 2.12). One aspect of effusive glaciovolcanism that is still not well understood is the volume of lava that is erupted supra-glacially and presumably transported to the ringplain (Fig. 2.12). These deposits have not previously been recognised in the geological record at Ruapehu, or for that matter at other glaciated composite cones from New Zealand (e.g. Tongariro) or globally (e.g. Mt. Rainier), but may be able to be identified if their clasts display fracture types indicative of interaction with ice (Fig. 2.2). 


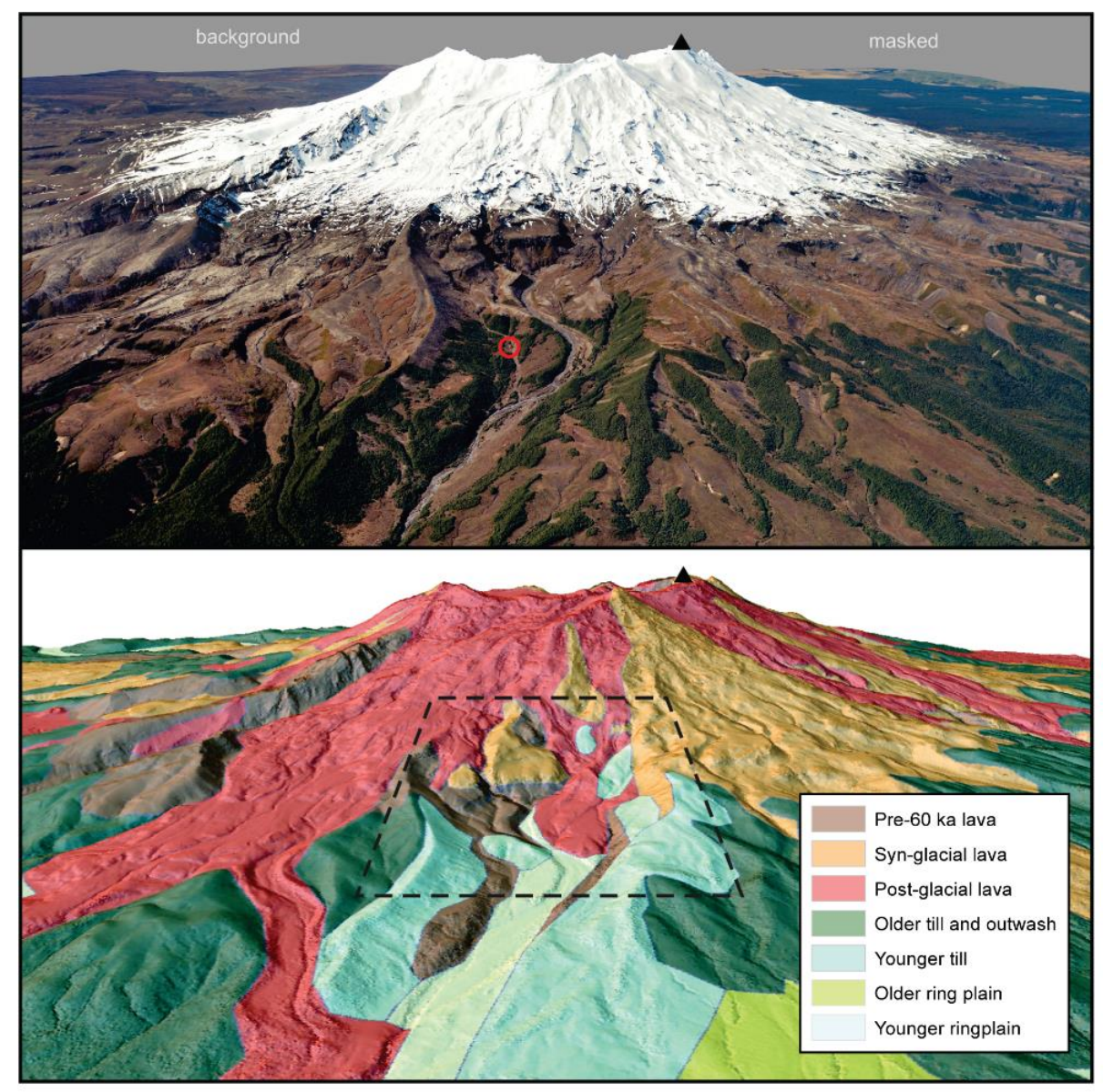

42 ka

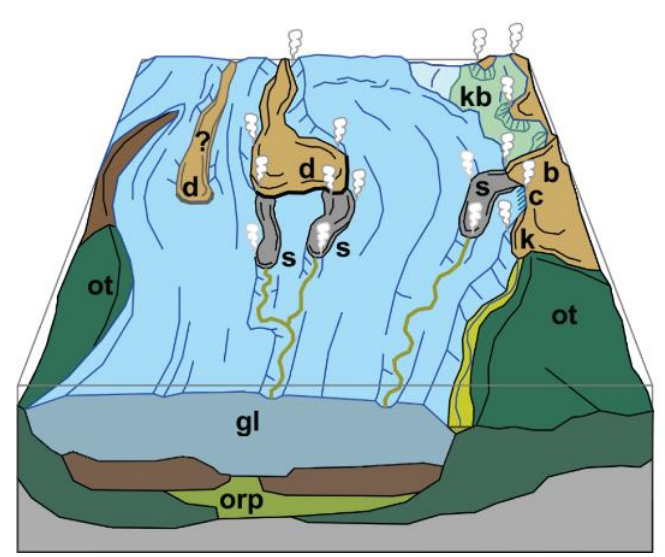

0 ka

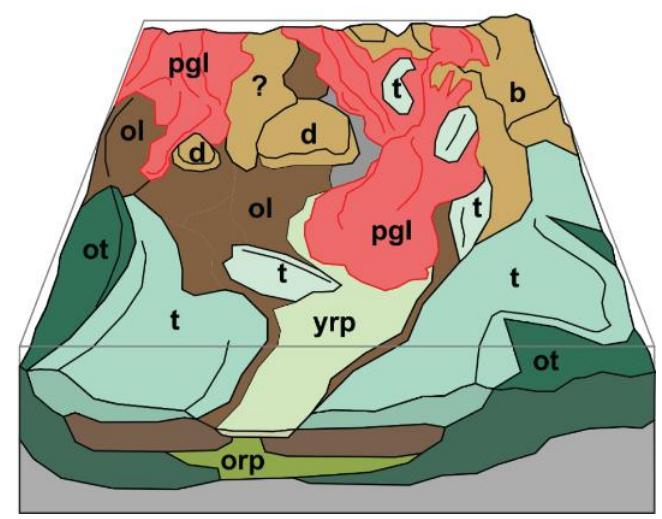

Figure 2.12. Relationships between ice-marginal flows, glaciated valley and post-glacial flows. Aerial photograph (top panel; taken in August 2009) and 3-D view with draped geology (centre panel) of the north-western flank of Ruapehu (view direction shown in Fig. 4). For reference the summit peak is marked with a black triangle, Whakapapaiti Hut is circled in red, and the snowline is $\sim 1700 \mathrm{~m}$ in this image. Lower left: block diagram at $\sim 42 \mathrm{ka}$ showing inferred mechanism of emplacement of ice-marginal flows and relationship to the glacier (gl), old till (ot), young till (t), old and young ringplain deposits (orp and yrp), and pre-60 ka lava (ol). Ice-bounded flow (b, on right) formed knuckles (k) and colonnades (c) with associated fracture types where lava was emplaced along the glaciers' margin. Kubbaberg joints $(\mathrm{kb})$ formed where lava interacted with meltwater generated at the lava-ice interface. Ice-dammed flows (d) were impounded within the valley by the glacier mass. An unknown volume of supra-glacial lava (s) travelled through meltwater channels on top of the glacier and was transported to the ringplain. Lower right: presentday setting of the valley showing the distribution of ice-marginal flows and their talus (grey), post-glacial flows (young lava; pgl) and post-42 ka moraines (young till; t) and young volcaniclastic ringplain deposits (yrp). 
Moreover, the comprehensive geochemical database for Ruapehu should make it possible to correlate these distal deposits to temporally-constrained eruptive formations on the edifice and incorporate them into eruption volume estimates. The brief geochemistry dataset presented here shows that ice-marginal flows range in composition from andesite to dacite, whereas post-glacial flows are exclusively andesites. The effusion of dacite between $\sim 51$ and $41 \mathrm{ka}$ can be linked to the long-term magmatic evolution of Ruapehu (Price et al., 2012).

The different type, spacing and orientation of fractures reflect different emplacement environments, cooling rates and directions in lava flows, and they inform our understanding of flow emplacement processes at glaciated composite cones (Lodge and Lescinsky, 2009). Five distinct fracture types in lavas at Ruapehu that were produced via interaction with ice have been identified and described (Fig. 2.2). Compound arrays of column-forming joints, pseudopillow fractures and kubbaberg joints observed for icemarginal flows (Figs. 2.6c, 2.9c) are interpreted to reflect the rapid quenching, and variable fracture propagation directions and rates within lava emplaced in the presence of ice and associated meltwater. Production, movement and removal of meltwater during and following emplacement of lava against glacial margins created variable cooling directions and consequent fracture propagation directions within flows. The presence of fanning polygonal column patterns in ice-bounded colonnade flows (Fig. 2.7) indicates that a complex arrangement of cooling directions existed between lava and ice-meltwater within a dynamic emplacement environment. The ingress of meltwater (and/or steam) through master fractures induced subsidiary fracture propagation in pseudopillow fractures (Lescinsky and Fink, 2000).

Heat loss to adjacent glaciers from the interior of ice-bounded flows was buffered by their quenched outer rinds (Wilson and Head, 2007). Microcrystalline groundmass textures with microlite lengths of $>5 \mu \mathrm{m}$ indicate that cooling rates for platy jointed zones were significantly slower than for glassy zones. In lava flows where the quenched margins have been eroded, the exposed platy joints are horizontal and regular at lower zones of the flow (Fig. 2.9b), and sub-vertical and concave at upper and marginal zones (Fig. 2.10b). The observed patterns indicate that platy joints formed parallel to (a) flow direction and (b) cooling surfaces (i.e. perpendicular to the direction of cooling and confinement; Fig. 2.2). Platy joints are interpreted as resulting from late-stage shearing of lava due to their flow-parallel orientation, position inwards of the lava flow margin and crystalline 
groundmass textures (Lescinsky and Fink, 2000). The interiors of ice-marginal lava flows at Ruapehu underwent continued endogenous movement parallel to the outer carapace of the flow after they were impounded by glaciers and as they slowly cooled.

The presence of valley-filling ice of thickness $\sim 50-150 \mathrm{~m}$ was required to impede the advance, generate the extraordinary thicknesses, and produce the chilled margins of icedammed lava flows (Fig. 2.12). The pervasive and contiguous fracture patterns in icedammed flows and lack of internal contacts (Figs. 2.9a, b) indicate that they were emplaced as large volume single flows and fractured throughout as cohesive bodies of cooling lava. A high effusion rate (combined with a suitable glacier-valley-ridge geometry) is the probable reason why these lava flows were able to thermally erode such a substantial amount of ice. The north-western ice-dammed flow is a dacite (Table 2.2), and the high viscosity of the lava may also have contributed to its impoundment. There is a notable similarity between Ruapehu ice-dammed flows and The Barrier, a 200 m-high vertical face of an ice-marginal andesite flow resulting from glacial impoundment downslope of Mt. Price in Canada's Garibaldi Volcanic Arc (Fig. 20 in Hickson, 2000).

\subsubsection{Origin of crease structures in ice-marginal flows}

Fine-scale crease structures are present in the glassy lateral and basal margins of icedammed and ice-bounded lava flows on Ruapehu, and are closely associated with kubbaberg joints, column-forming joints and pseudopillow fractures (Fig. 2.6c). These observations are interpreted as evidence that crease structures can form as a result of interaction between lava and ice, a correlation made here for the first time. Prior to this study, the occurrence of crease structures was limited to subaerial lava flows and domes (e.g. Anderson and Fink, 1992). The key features on the fracture planes of crease structures in Ruapehu lavas are (1) striations, which represent the inward propagation of the fracture tip and central valley-normal opening of the fracture and (2) wall offsets, which represent the lateral propagation of the fracture trace parallel to the central valley (Figs. 2.2, 2.3). Crease structures reported here differ from those described for subaerial lavas (Anderson and Fink, 1992) in that they have significantly shorter central valley lengths, shorter flow margin-to-central valley lengths, and more closely-spaced striations. The finer scale of ice-marginal crease structures may be the result of a higher thermal gradient compared with atmospherically-cooled subaerial lavas. The morphology of 
crease structures closely resembles that of spreading cracks in pillow lavas, which also consist of opposing faces that are marked by striations and are approximately symmetrical across a central valley (Goto and McPhie, 2012).

The origin of pillow lava spreading cracks and subaerial lava flow crease structures is evaluated herein to understand how crease structures were formed in ice-marginal flows at Ruapehu. Crease structures in subaerial lava flows form as a result of thermal contraction and lateral spreading of their upper skin, and are therefore located on the top surfaces of flows (Anderson and Fink, 1992). For pillow lavas, spreading cracks must overcome the pressure of the overlying water column in order to fracture. The continued supply of magma allows rupturing and spreading of the chilled outer crust of the pillow to occur (Goto and McPhie, 2012). In contrast to subaerial lava flows and submarine pillow lavas, crease structures in ice-marginal flows at Ruapehu are located at the lateral margins of overthickened lavas (Fig. 2.6c), indicating that they formed adjacent to a vertical and confining cooling surface. The force imposed by the overlying mass of lava had to be overcome in order to achieve fracture opening, particularly for horizontal crease structures. Steam produced from lava-ice interaction (e.g. Edwards et al., 2013) likely played a key role in opening the crease structures in these environments, if it was trapped at the lava-ice interface and/or if it was being generated faster than it could escape, through creating high pressure within the fractures and/or locally lowering the lava viscosity. Fracture expansion may also have been facilitated by bulging of flow margins and continued flow advancement or inflation as ice was melted and meltwater was drained to create void space at the glacier-lava interface. The identification of crease structures on the lateral margins of andesite-dacite lava flows may therefore also be useful to infer interaction between lava and ice at other volcanoes.

\subsubsection{Implications for paleoclimate reconstructions}

Glaciovolcanic deposits are useful paleoclimate proxy indicators that can be used to infer the former presence, extent, and thickness of terrestrial ice (e.g. Smellie, 2008). Evidence for the impoundment of lava flows by valley-filling glaciers at Ruapehu has been presented based on flow morphology and fracture characteristics. The boundaries of icemarginal lava flows therefore represent former extents of glacial ice and provide valuable paleoclimatic information. The absolute temporal and spatial distributions of ice-marginal 
flows determined in this study are compared with previous glacier reconstructions for Ruapehu. During the Last Glaciation (71-14 ka), advances of valley glaciers on Ruapehu are tentatively proposed to have occurred between 40-32 $\mathrm{ka}$ and $25.5-22.5 \mathrm{ka}$, based on geomorphological mapping and inferences of regional climate (McArthur and Shepherd 1990). Glaciers reached $1200 \mathrm{~m}$ a.s.l. with equilibration line altitudes (ELAs) of $1500 \mathrm{~m}$ a.s.l. during the earlier and greater of the two inferred advances (McArthur and Shepherd, 1990).

The advent of high-precision ${ }^{40} \mathrm{Ar} /{ }^{39} \mathrm{Ar}$ age determination for young intermediatecomposition volcanic rocks (e.g. Fierstein et al., 2011) is particularly applicable to icemarginal lava flows at glaciated volcanoes. Glacial impoundment results in the slow cooling of overthickened lavas, which produces crystalline groundmass textures favourable for dating in flow interiors that are exposed via erosion of oversteepened, fractured flow margins. A limited ${ }^{40} \mathrm{Ar} /{ }^{39} \mathrm{Ar}$ geochronology dataset is presented here for two purposes: (1) to identify that ice-marginal lava flows were erupted and emplaced during past glacial periods and (2) to provide some preliminary constraints on the timing of past glaciation at Ruapehu.

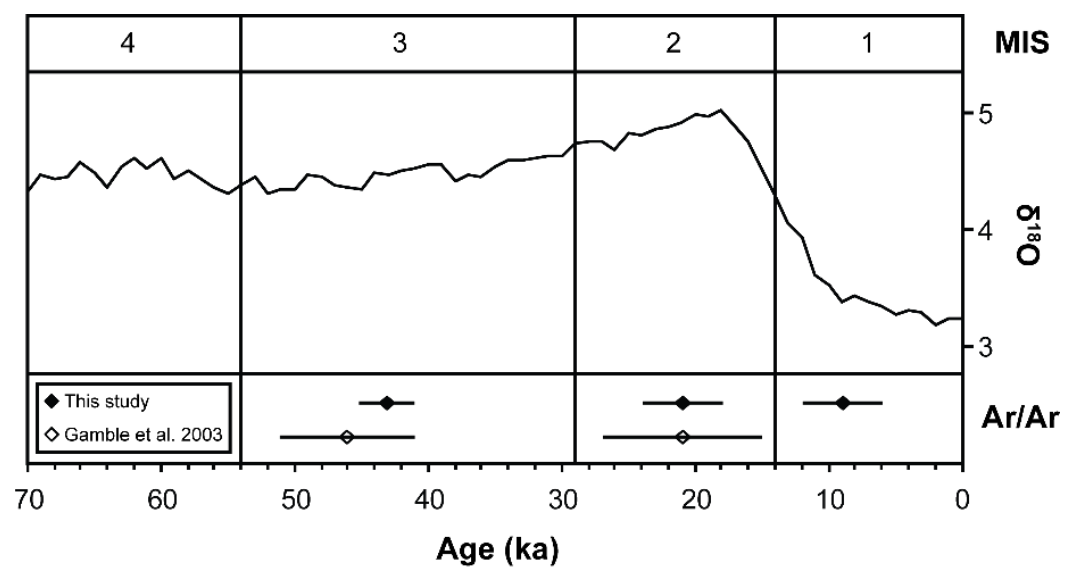

Figure 2.13. Graph of ${ }^{40} \mathrm{Ar} /{ }^{39} \mathrm{Ar}$ eruption ages (diamonds, with bars indicating $2 \sigma$ uncertainties) for selected Ruapehu lava flows. Global $\delta^{18} \mathrm{O}$ fluctuations and marine isotope stages (MIS; data from Lisiecki and Raymo, 2005) are plotted to indicate the coincidence of ice-marginal lava flow eruptions during former glacial periods (higher $\delta^{18} \mathrm{O}$ values, MIS 3-2) and eruption of a valley-floor lava flow during the postglacial period (lower $\delta^{18} \mathrm{O}$ values, MIS 1).

The implications regarding paleoclimate reconstructions are elaborated on in Chapter 3 using the complete geochronologic dataset. New and existing ${ }^{40} \mathrm{Ar} /{ }^{39} \mathrm{Ar}$ eruption ages determined for ice-marginal lava flows provide absolute temporal constraints on past 
glacial extents at Ruapehu: large valley-filling glaciers were present at $47 \pm 4 \mathrm{ka}, 46 \pm 5$ $\mathrm{ka}, 43 \pm 2 \mathrm{ka}, 21 \pm 6 \mathrm{ka}$, and $21 \pm 3 \mathrm{ka}$. Accounting for uncertainties, the range in older eruption ages (51-41 ka) falls within MIS 3 (Fig. 2.13). The range of younger eruption ages (27-15 ka) broadly overlaps timing of the latter glacial advance inferred to have occurred between 25.5-22.5 ka by McArthur and Shepherd (1990).

The location and extent of major ice-marginal flows on Ruapehu, and the thickness of ice required to impound each flow are plotted in Figure 2.14. Approximate glacier thicknesses were estimated by calculating the vertical distance from the top of the flows to the bottom of the adjacent valleys. These are approximate estimates given that valley floor elevations may have subsequently been raised via deposition, or lowered via erosion since the glaciers were present. Upper extents of lava-ice margins are minimum values because younger deposits have covered these flows on upper flank slopes.

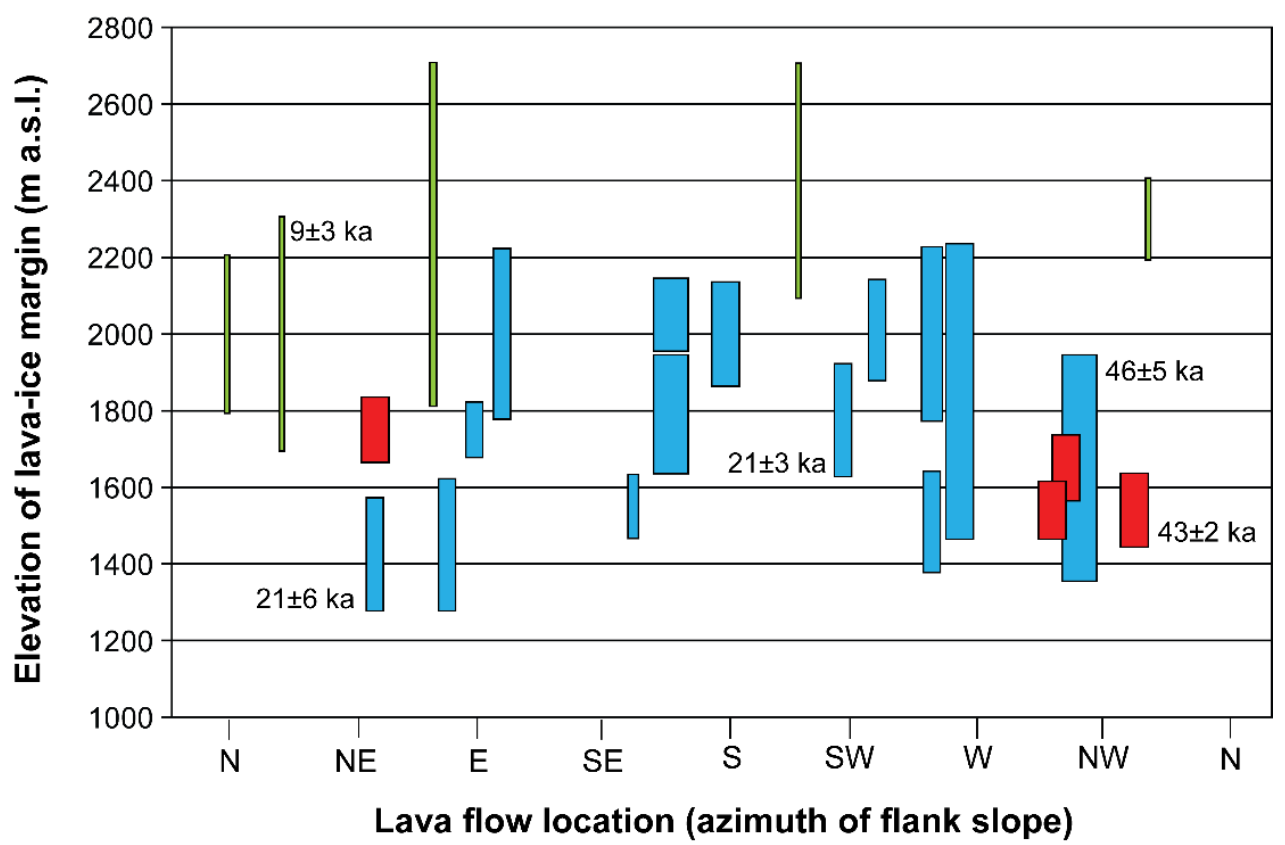

\begin{tabular}{|c|c|c|c|c|c|}
\hline Flow type & \multicolumn{5}{|c|}{ Bar width $=$ inferred ice thickness (in metres) } \\
\hline$\square$ ice-bounded flow (60-15 ka) & & & & & \\
\hline$\square$ ice-dammed flow (60-15 ka) & & U & & & \\
\hline$\square$ ice-bounded flow (<14 ka) & $20 \mathrm{~m}$ & $50 \mathrm{~m}$ & $100 \mathrm{~m}$ & $150 \mathrm{~m}$ & $200 \mathrm{~m}$ \\
\hline
\end{tabular}

Figure 2.14. Elevation of major ice-marginal lava flow extent versus location on Ruapehu. Each bar represents an ice-marginal flow and, therefore, the past position of the glacier against which the flow was emplaced. Thicknesses of glaciers that bounded and dammed lava flows are represented by bar widths (see scale in key for thickness values in metres). ${ }^{40} \mathrm{Ar} /{ }^{39} \mathrm{Ar}$ eruption ages are written next to bars for lava flows that have been dated. 
Overall, the data indicate that a substantial ice mass consisting of flank glaciers $\geq 100 \mathrm{~m}$ thick that descended to $\sim 1300$ m a.s.l. existed on Ruapehu during MIS 3 and 2. There is no discernible difference in ice extent between $\sim 51-41 \mathrm{ka}$ and $~ 27-15 \mathrm{ka}$ inferred from the distribution of dated ice-marginal lava flows, however, the thickness of ice required to impound the younger flows was apparently less than that for older flows (Fig. 2.14). The results corroborate glacial evidence from South Island, New Zealand that there was only minor variation in the maximum extent of glaciers between MIS 3 and 2 (Putnam et al., 2013b).

Widespread glacial retreat occurred from $\sim 18 \mathrm{ka}$ in South Island, New Zealand (Putnam et al., 2013a), and contemporaneous climate amelioration is preserved in terrestrial records from North Island (Newnham et al., 2003). Post-glacial eruption ages for some lava flows at Ruapehu have been inferred from their valley-floor setting, on the basis that glaciers had largely retreated by $\sim 14 \mathrm{ka}$. The ${ }^{40} \mathrm{Ar} /{ }^{39} \mathrm{Ar}$ eruption age of $9 \pm 3 \mathrm{ka}$ for a valley-floor lava flow reported here indicates that valleys dissecting the lower flanks of the Ruapehu cone were largely ice-free by the time of its emplacement.

Valley-floor distributions of lava flows are therefore useful and reliable indicators of post-glacial ages for Ruapehu lava flows. Minor interaction between post-glacial flows and ice or snow occurred, however, as reflected by the presence of column-forming joints and pseudopillow fractures in some post-glacial lavas. This interaction is not surprising, given the presence and extent of glaciers on Ruapehu during historical times (Heine 1963). Post-glacial lava flows were bounded and deflected by summit glaciers on the upper flank, but volumes of ice and snow bodies were probably not great enough to impound lavas or generate overthickened flows (Fig. 2.14).

\subsection{CONCLUSIONS}

Field studies have been combined with preliminary ${ }^{40} \mathrm{Ar} /{ }^{39} \mathrm{Ar}$ eruption age data to provide evidence for large-scale interaction between andesite-dacite lava flows and glaciers during effusive eruptions at Ruapehu from $\sim 51-15 \mathrm{ka}$. Key findings are as follows:

- Ice-bounded and ice-dammed lava flows display grossly overthickened margins adjacent to or within glaciated valleys, are intercalated with till, and have lateral 
margins that are pervasively fractured by column-forming joints, pseudopillow fractures, crease structures and kubbaberg joints.

- These characteristics can be accounted for by impoundment and chilling of lava flows that were emplaced against large flank glaciers. Sinuous and valley-bottom flows were emplaced sub-glacially within channels at the margins and bases of glaciers where protracted melting of ice occurred.

- Fine-scale crease structures present on ice-marginal flows are described here as resulting from lava-ice interaction for the first time. They formed as a result of intermittent fracture propagation following cooling-induced contraction of lava against ice. This process was likely aided by marginal bulging of ice-bounded flows into void space created by thermal erosion of glaciers, and high pressures within fractures due to ingress of steam produced by heating of meltwater.

- New and existing ${ }^{40} \mathrm{Ar} /{ }^{39} \mathrm{Ar}$ eruption ages of ice-marginal lava flows indicate that a substantial ice mass consisting of large flank glaciers existed on Ruapehu from $\sim 51-41 \mathrm{ka}$ and $\sim 27-15 \mathrm{ka}$. Glaciers with thicknesses of $\sim 200-100 \mathrm{~m}$ descended to $1300 \mathrm{~m}$ a.s.l. during MIS 3 and 2.

- $\mathrm{The}{ }^{40} \mathrm{Ar} /{ }^{39} \mathrm{Ar}$ eruption age of $9 \pm 3 \mathrm{ka}$ determined for a valley-floor flow on northern Ruapehu indicates that flank glaciers had retreated to near-historical extents by the time of emplacement for this lava flow. 
CHAPTER 3 


\title{
3. ERUPTIVE HISTORY AND EDIFICE \\ EVOLUTION OF RUAPEHU VOLCANO, NEW ZEALAND
}

\begin{abstract}
Ruapehu is an active $\sim 150 \mathrm{~km}^{3}$ andesite-dacite composite volcano located at the southern end of the Taupo Volcanic Zone, New Zealand. The growth of the edifice has occurred throughout coeval eruptive and glacial histories since $\sim 200 \mathrm{ka}$. High-precision ${ }^{40} \mathrm{Ar} /{ }^{39} \mathrm{Ar}$ eruption ages and whole-rock major element geochemical data for lava flows are presented in this chapter. The data are interpreted in the context of geomorphologic and geologic mapping, volcano-ice interaction processes and glacier reconstructions in order to present a new chronostratigraphic and edifice evolution model for Ruapehu.

Sub-glacial to ice-marginal effusive eruption of medium-K basaltic-andesites and andesites constructed the northern portion of the exposed edifice between $\sim 200$ and 150 $\mathrm{ka}$, and the wide southeast planèze as well as parts of the northern, eastern and western flanks between $~ 160$ and $80 \mathrm{ka}$. No eruption ages were returned for lava flows during the period from $80-50 \mathrm{ka}$, which may reflect an eruptive hiatus or alternatively is the result of erosion and burial of lavas and syn-eruptive glacial conveyance of lava flows to the ringplain due to glacial advance at 70-60 ka. Edifice growth from $\sim 50-15 \mathrm{ka}$ occurred via effusive eruptions onto the glaciated flanks of the volcano, resulting in construction of ice-bounded planèzes and ridges. The distribution of dated ice-marginal lavas indicates a general decrease in glacier thicknesses over this time, excepting a short-lived period centred on $\sim 31 \mathrm{ka}$ when peak ice cover was reached. The compositional ranges of medium- to high-K andesite and dacite lava flows within 50-36 ka eruptive packages define broadly bimodal high- and low-MgO trends. Lavas erupted at 35-22 ka have compositions that fill a transitional geochemical field between older dacites and younger andesites.
\end{abstract}

Large-scale retreat of flank glaciers since $\sim 15$ ka have resulted in intra-valley lava flow emplacement at elevations below $\sim 1500 \mathrm{~m}$ on the edifice. Between 15 and $10 \mathrm{ka}$ unstable 
cones were constructed through effusive activity in the presence of remnant summit and upper flank glaciers and the emplacement of eruptive deposits on top of hydrothermally altered and fragmental sub-glacial and ice-marginal deposits. Debuttressing of two northern summit cones and a southern summit cone as ice underwent continued postglacial retreat pre-conditioned two major sector collapses and deposition of debris avalanche deposits on the northern and south-eastern flanks, respectively. Ultimate triggering of the collapse events may have been the result of tectonic or volcanic activity. The northern collapse scar is infilled by a new cone comprising < 10 ka lava flows that form the upper northern and eastern flanks of the edifice. Late Holocene-recent eruptive activity has occurred through Crater Lake, which occupies the site of the collapsed southern cone.

Deglaciation did not induce enhanced magma flux rates at Ruapehu as indicated by calculated eruptive volumes and their chronologies. However, volcano-ice interactions have had a fundamental influence on eruptive styles, sector collapse events, and the shape of the edifice by modifying the distribution, morphology and preservation of eruptive deposits for at least $200 \mathrm{kyr}$.

\subsection{INTRODUCTION}

Continental composite volcanoes are the typical surficial features of convergent margin magmatism where volcanic products are erupted, often in proximity to human populations. Sequences of lavas generally provide the best preserved record of volcanic edifice growth and allow investigation of the tempo of eruptive activity in such settings. High-resolution eruptive records constrained by precise temporal frameworks are required in order to document the stratigraphies of such volcanoes. These records underpin hazard assessment and enhance the value of geochemical and petrological datasets that inform evolutionary models of arc magma systems (e.g. Hildreth and Lanphere, 1994; Dungan et al., 2001). The ${ }^{40} \mathrm{Ar} /{ }^{39} \mathrm{Ar}$ radioisotopic system is a widely used geochronometer for measuring the eruption ages of Quaternary volcanic rocks with intermediate compositions (e.g. Gamble et al., 2003; Hildreth et al., 2003; Fierstein et al., 2011). Despite its general suitability, application of this technique has generally been restricted to Pleistocene volcanic rocks with sufficient $\mathrm{K}_{2} \mathrm{O}$ concentrations ( $>1$ wt. \%) and non-glassy groundmass textures. High-precision instrumentation (Coble et al., 2011), 
improved understanding of the behaviour of argon in volcanic glass (Clay et al., 2015), and development of methods to counter argon recoil processes that affect fine-grained rocks (Fleck et al., 2014) have increased the potential for this technique to be applied to Holocene age lavas. Despite these advances, incomplete exposure of volcanic edifices remains a hindrance to establishing comprehensive and cohesive eruptive chronologies. Glaciation and sector collapse are the principal agents of erosion and edifice destruction that generate stratigraphic unconformities and inhibit accurate reconstructions of eruptive events and volumes for composite volcanoes (e.g. Singer et al., 1997). The recognition and integration of volcano-ice interactions within eruptive stratigraphies of glaciated volcanoes is crucial to unravelling their evolution (Schmidt and Grunder, 2009). Moreover, deposits resulting from volcano-ice interactions can provide powerful paleoclimate proxies when paired with precise geochronology (e.g. Lescinsky and Fink, 2000; Mee et al., 2009). In this contribution, new high-precision ${ }^{40} \mathrm{Ar} /{ }^{39} \mathrm{Ar}$ ages and whole-rock major element geochemistry for lava flows are integrated with geological mapping, glacier reconstructions and existing chronostratigraphic studies to interrogate the mid-Pleistocene to Holocene evolution of Ruapehu as a case study of typical arc volcanism. The foremost purpose of this study is to present a detailed $~ 200 \mathrm{kyr}-$ long eruptive chronology and edifice evolution model for New Zealand's largest active composite volcano.

\subsection{GEOLOGICAL SETTING}

\subsubsection{Regional geology}

Volcanism in central North Island, New Zealand is associated with westward subduction of oceanic crust of the Pacific Plate at $\sim 45 \mathrm{~mm} \mathrm{yr}^{-1}$ beneath the Australian Plate along the Hikurangi Trench system (Fig. 3.1; Cole and Lewis, 1981; Reyners et al., 2006; De Mets et al., 2010). Most volcanic activity is manifested in the Taupo Volcanic Zone (TVZ), which is an extending arc that comprises northern and southern segments dominated by andesite-dacite composite cones and a central segment of highly productive silicic volcanism (Wilson et al., 1995). The southern TVZ segment comprises the prominent Tongariro and Ruapehu composite volcanoes as well as several smaller volcanic edifices (Cole, 1978). Extension in the southern TVZ occurs at a direction of $\sim 115^{\circ}$ and a rate of $2.3 \pm 1.2 \mathrm{~mm}$ yr-1 (Villamor and Berryman, 2006a). This motion is manifested by the 40 
km-wide Mount Ruapehu Graben, which is bounded by the Rangipo and Raurimu faults to the east and west, respectively, and by the NE-striking Karioi and the ENE-trending Ohakune fault sets to the south (Fig. 3.1; Villamor and Berryman, 2006a). Ruapehu volcano sits upon late Tertiary sediments and Mesozoic basement rocks. The latter is generally inferred to be the Kaweka terrane, a Jurassic greywacke-argillite sequence of felsic composition that outcrops in the ranges east of the Rangipo fault (Adams et al., 2009; Price et al., 2015). An index map of Ruapehu with geographical features referred to throughout the text is provided in Figure 3.2.

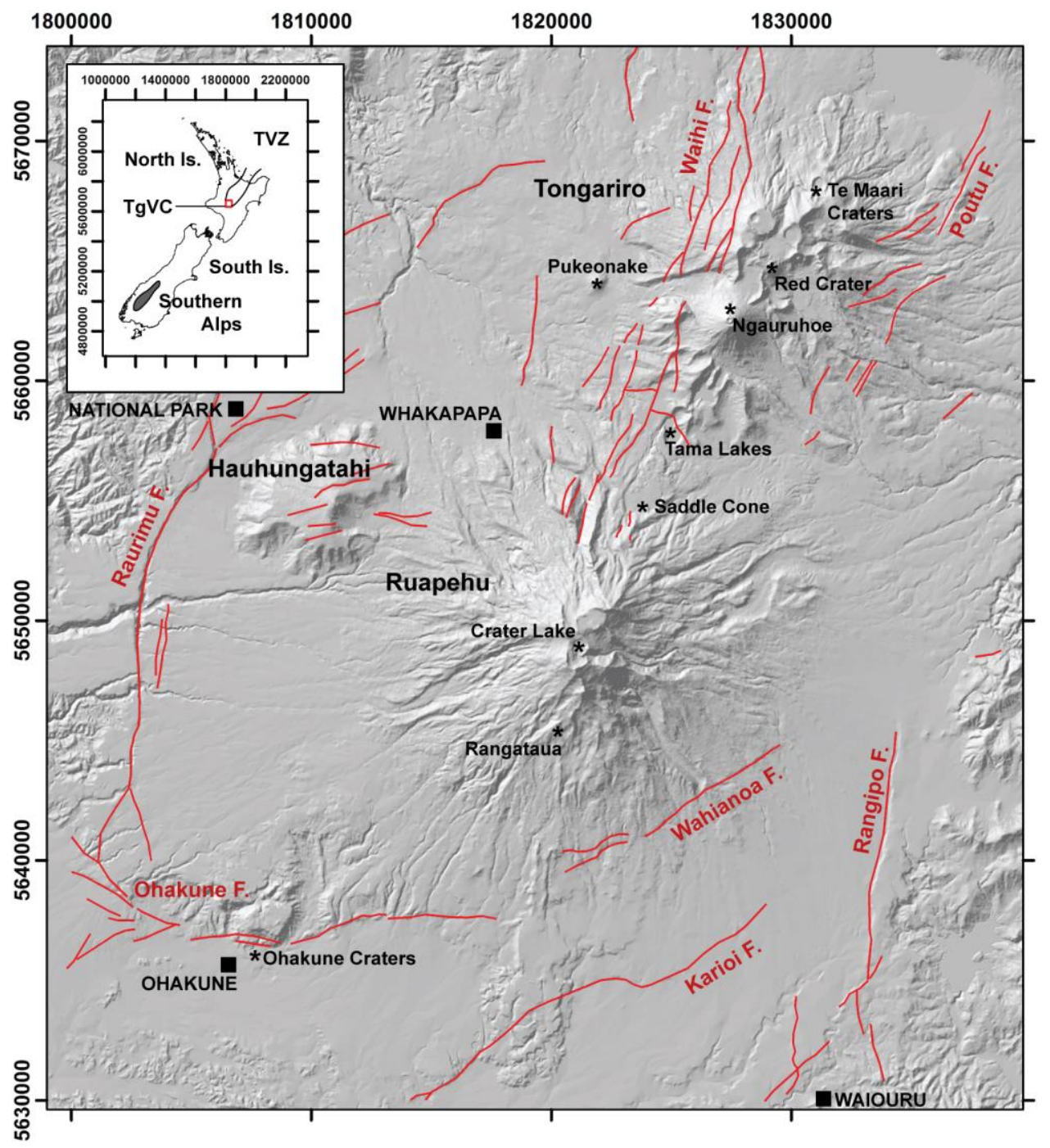

Figure 3.1. Digital elevation model (DEM) map of the Tongariro Volcanic Centre (red box on inset figure) at the southern end of the Taupo Volcanic Zone (TVZ) in North Island, New Zealand. The maps use the New Zealand Transverse Mercator 2000 projection (NZTM2000). Inset also shows the position of glaciated Southern Alps in South Island (grey shaded area). Key townships at Waiouru, Ohakune, National Park and Whakapapa Village are labelled. The major volcanic edifices in the map area are Hauhangatahi, Ruapehu and Tongariro. Main <15 ka vents are labelled with black stars. Note also the peripheral vents at Pukeonake cone and Ohakune Craters. 


\subsubsection{Volcanological overview}

Ruapehu is New Zealand's largest active andesite volcano, with a $\sim 150 \mathrm{~km}^{3}$ edifice surrounded by a volcaniclastic ring plain of similar volume (Hackett and Houghton, 1989; Gamble et al., 2003). The flanks of the edifice are composed of lava flows and autobreccias intercalated with glacial and pyroclastic deposits (Cole, 1978). Coneforming lavas and autobreccias were grouped by Hackett (1985) into formations that represent the eruptive products of four main phases of edifice growth. These formations are the Te Herenga (250-180 ka), Wahianoa (160-115 ka), Mangawhero (60-15 ka) and Whakapapa (<15 ka). Ages and durations of the phases were subsequently constrained by ${ }^{40} \mathrm{Ar} /{ }^{39} \mathrm{Ar}$ eruption ages for lava flows from the Te Herenga (3 samples), Wahianoa (11 samples) and Mangawhero (7 samples) formations (Table 3.1; Gamble et al., 2003).

Table 3.1. Existing chronostratigraphic formations for Ruapehu volcano.

\begin{tabular}{|c|c|l|l|}
\hline Formation & Eruptive period & Sample & WMPA $\pm 2 \sigma(k a)$ \\
\hline Whakapapa & $<15 \mathrm{ka}$ & $\mathrm{n} / \mathrm{a}$ & $\mathrm{n} / \mathrm{a}$ \\
\hline Mangawhero & $60-15 \mathrm{ka}$ & $\mathrm{X} 1-6$ & $21 \pm 6$ \\
& & X1-16 & $22 \pm 7$ \\
& & $\mathrm{R} 99 / 1$ & $23 \pm 4$ \\
& & $\mathrm{R} 97 / 39$ & $23 \pm 8$ \\
& & T5-11 & $45 \pm 6$ \\
& & $\mathrm{R}-\mathrm{S} 44-10$ & $47 \pm 4$ \\
\hline Wahianoa & $160-115 \mathrm{ka}$ & $\mathrm{R} 95 / 22$ & $119 \pm 12$ \\
& & $\mathrm{R} 96 / 5$ & $129 \pm 15$ \\
& & $\mathrm{R} 95 / 26$ & $130 \pm 23$ \\
& & $\mathrm{R} 96 / 16$ & $131 \pm 27$ \\
& & $\mathrm{R} 95 / 28$ & $133 \pm 11$ \\
& & $\mathrm{R} 96 / 17$ & $134 \pm 12$ \\
& & $\mathrm{R} 95 / 27$ & $135 \pm 14$ \\
& & $\mathrm{X} 1-10$ & $138 \pm 14$ \\
& & $\mathrm{R} 97-50$ & $147 \pm 10$ \\
& & $\mathrm{R} 96 / 9$ & $147 \pm 12$ \\
& & $\mathrm{R} 96 / 20$ & $154 \pm 12$ \\
\hline Te Herenga & $250-180 \mathrm{ka}$ & $\mathrm{T} 6-8$ & $183 \pm 13$ \\
& & T6-24 & $197 \pm 12$ \\
& & T6-27 & $205 \pm 27$ \\
\hline
\end{tabular}

${ }^{40} \mathrm{Ar} /{ }^{39} \mathrm{Ar}$ WMPA (weighted mean plateau age) and $2 \sigma$ uncertainty for lava flows measured by Gamble et al. (2003). Sample locations are displayed in Figures 3.4, 3. 9 and 3.10.

Gamble et al. (2003) concentrated on the clear stratigraphic sequencing of lava flows within the Wahianoa Formation exposed in the deeply glaciated Wahianoa and 
Whangaehu valleys on the southeast flank of Ruapehu. Lavas of the Mangawhero Formation were inferred to have been erupted during discrete pulses of effusive activity centred on $\sim 45 \mathrm{ka}$ and $\sim 22 \mathrm{ka}$ whereas no eruption ages were determined for lavas of the Whakapapa Formation (Gamble et al., 2003). Complex stratigraphic relationships between lavas of the same and subsequent formations have been interpreted as the result of rapid transitions between construction and degradation of the edifice (Hackett and Houghton, 1989).

The ring plain comprises a thick apron of stacked pyroclastic and volcaniclastic material consisting of debris flow, debris avalanche and hyperconcentrated stream flow deposits interbedded with locally andesitic and distally derived rhyolitic tephras (Cronin and Neall, 1997; Donoghue and Neall, 2001; Tost et al., 2014). Aggradation has likely been rapid following eruptive phases (Hackett and Houghton, 1989) and during glacial periods (Cronin and Neall, 1997), while large-scale sector collapse events may have occurred following the transition from glacial to interglacial periods (Tost et al., 2015).

Explosive activity at Ruapehu since $\sim 27 \mathrm{ka}$ is recorded within tephra sequences on the eastern flank and ring plain (Donoghue et al., 1995a). During the period from 22-10 ka, the largest known Plinian eruptions occurred at Ruapehu (Pardo et al., 2012), while apparently coeval but volumetrically minor pyroclastic flow deposits are also preserved on the eastern flank of the edifice (Donoghue et al., 1995a). The past $2 \mathrm{kyr}$ of volcanic activity at Ruapehu have been characterised by low-volume $\left(<0.05 \mathrm{~km}^{3}\right)$ but frequent (25-30 yr periodicity) phreatomagmatic eruptions through Crater Lake (Donoghue et al., 1997) with additional phreatic eruptions occurring as often as annually (Houghton et al., 1987).

Past glaciation of Ruapehu is evident from the deep U-shaped valleys that indent the flanks of the edifice (Figure 3.2) as well as the presence of large lateral moraines and striated lava flow surfaces (McArthur and Shepherd, 1990; Waight et al., 1999). The most recent period of major glaciation of the edifice occurred between $\sim 31$ and $17 \mathrm{ka}$ (Eaves, 2015), which overlaps with the $\sim 20$ ka global Last Glacial Maximum at (LGM; Clark et al., 2009), when the termini of valley glaciers reached $\sim 1200 \mathrm{~m}$ a.s.l. The impact of prehistoric glaciation of Ruapehu between phases of eruptive activity has been recognised as having generated major stratigraphic unconformities (Hackett and Houghton, 1989). The coincidence of emplacement of Mangawhero Formation lavas (60-15 ka) and glaciation 
during the last glacial cycle (71-15 ka; Lisiecki and Raymo, 2005) suggests that syneruptive interaction between lava and ice was also an important aspect of the edifice growth history (Spörli and Rowland, 2006). Widespread evidence for lava-ice interaction during emplacement of flows of the Mangawhero Formation has now been documented (Conway et al., 2015). Glaciers have retreated rapidly in historical times (Heine, 1963), and only sparse accumulations of permanent ice are now present around the uppermost western, southern and eastern flanks, and over the broad ice-filled northern portion of the summit.

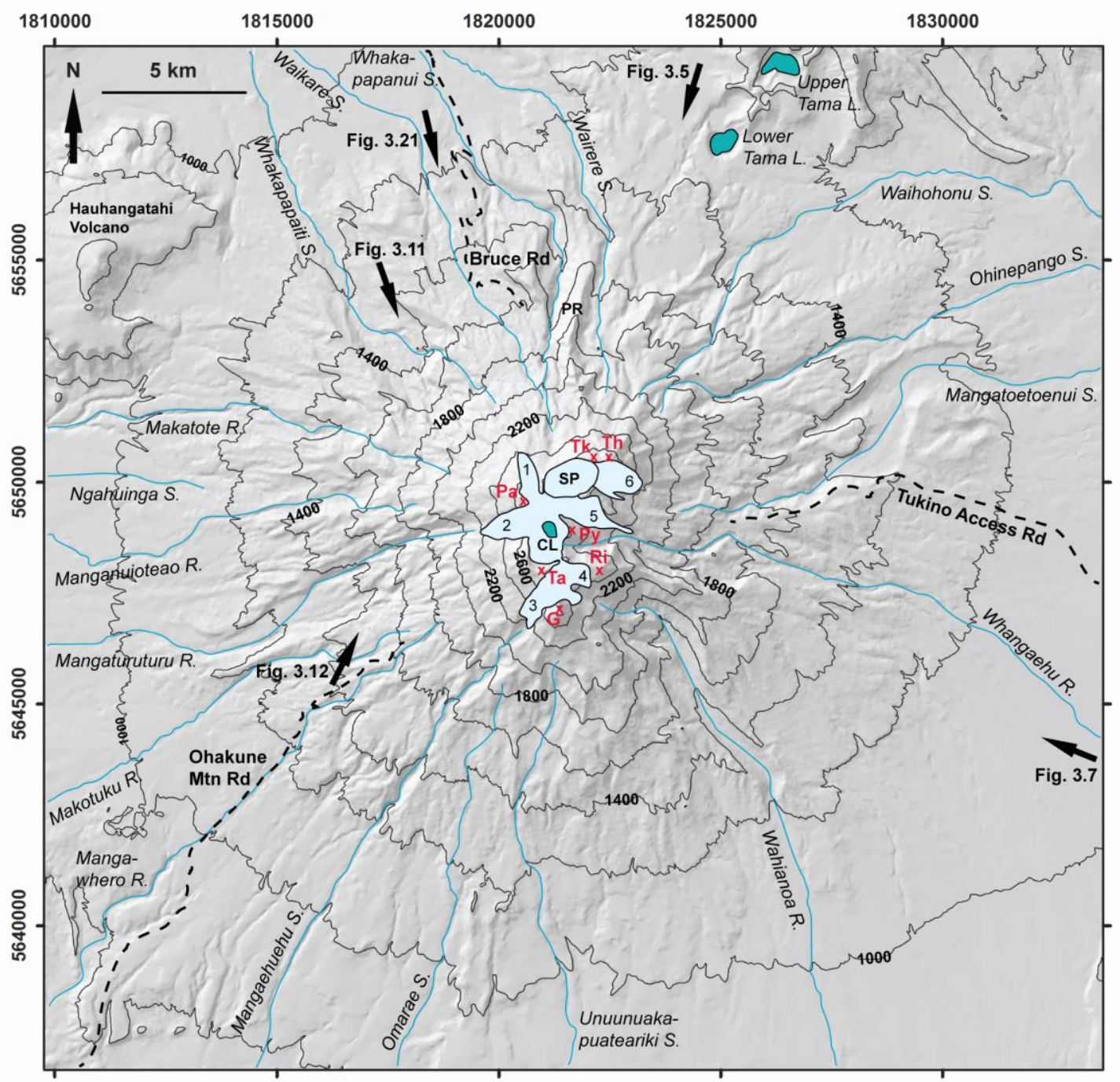

Figure 3.2. Index map for Ruapehu volcano, displaying major roads, river valleys and summit features referred to in the text. The major peaks of Tahurangi (Ta, $2797 \mathrm{~m}$ ), Paretetaitonga (Pa, $2662 \mathrm{~m})$, Tukino (Tk), Te Heuheu (Th), Girdlestone (G), Pyramid Peak (Py) and Ringatoto (Ri) are marked with x symbols. Modern glaciers are numbered: Whakapapa (1); Mangaturuturu (2); Mangaehuehu (3); Wahianoa (4); Whangaehu (5); Mangatoetoenui (6). The summit also comprises the ice-filled Summit Plateau (SP) and active vent beneath Crater Lake (CL). Arrows indicate view directions for Figures 3.5, 3.7, 3.11, 3.12 and 3.21 . 


\subsection{METHODS}

\subsubsection{Field studies and mapping}

Field campaigns were conducted on foot with occasional helicopter assistance throughout the months of January-May from 2012 to 2015 as part of a wider mapping project (Townsend et al., 2016). The edifice is largely snow-free during these months, and the lack of vegetation above $1500 \mathrm{~m}$ above sea-level (a.s.l.) is advantageous for exposure on the mid- to upper elevation flanks of the volcano. Access is aided by ski fields on the eastern, northern and southern flanks, and the numerous recreational tracks. Stratigraphic and lithological boundaries for eruptive packages were drawn, largely on geomorphologic characteristics and later refined by petrological, geochemical and geochronological analyses. Lava flow volumes were calculated from observed extents and thicknesses of lava flows.

\subsubsection{Whole-rock analyses by X-ray fluorescence}

Lava flow samples were cleaned by using a diamond saw to cut away any weathered material. Samples were then crushed using a jaw crusher, and powdered using an agate or tungsten-carbide ring mill. Powders were made into fused lithium metaborate glass discs and analysed for major oxide concentrations by x-ray fluorescence spectroscopy (XRF) following the methods of Ramsey et al. (1995). Disc-making and analyses were carried out at the Open University, Milton Keynes, U.K. Internal standards WS-E (Whin Sill dolerite) and OU-3 (Nanhoron microgranite) were analysed once for every 20 sample analyses to monitor precision and accuracy of the results. Major oxide analyses were accurate to within $2 \%$ of the recommended values for the internal standards. Analytical precision $(2 \sigma)$ was better than $2 \%$ for all elements with concentrations $>0.3$ wt. $\%$. Duplicate disks were made for three different Ruapehu lava sample powders and analysed as unknowns: duplicate analyses were accurate to within $5 \%$ of each other for all major elements. Standard data are presented in Appendix A5. 


\subsection{3. ${ }^{40} \mathrm{Ar} /{ }^{39} \mathrm{Ar}$ geochronology}

Radiometric ${ }^{40} \mathrm{Ar} /{ }^{39} \mathrm{Ar}$ dating was undertaken using crystalline groundmasses from interior zones of lava flows to produce reliable results (e.g. Gamble et al., 2003; Fierstein et al., 2011). Analysis required minimum groundmass plagioclase widths of $10 \mu \mathrm{m}$ (to avoid reactor recoil) and groundmass glass abundances of $<5 \%$ (to minimise any erroneous contribution from glass-derived argon). Samples selected for radiometric dating were crushed and sieved, and the 250-350 $\mu \mathrm{m}$ fraction used. An LB-1 Barrier type Frantz magnetic separator was used to remove phenocrysts and xenoliths from the pure groundmass fraction. To remove altered and adhered material, groundmass separates were washed in water in an ultrasonic bath and repeatedly decanted for up to 20 hours, then washed in acetone to remove any hydrocarbons from grain surfaces, and finally rinsed in deionized water. Any remaining grains with adhering phenocrysts, xenoliths or areas of glass were removed by hand-picking. Encapsulated packets of $\sim 200 \mathrm{mg}$ of groundmass were irradiated for $1 \mathrm{~h}$ in the central thimble of the USGS-TRIGA reactor in Denver, Colorado (Dalrymple et al., 1981). Samples were shielded from thermal neutrons and neutron flux was measured using Taylor Creek Rhyolite sanidine (TCR-2) fluence monitors with an assigned age of $27.87 \mathrm{Ma}$ (M.A. Lanphere, written communication), equivalent to the widely used Fish Canyon sanidine at $27.63 \mathrm{Ma}(\mathrm{R}=1.00881 \pm$ 0.00046). The reactor vessel was rotated continuously during irradiation to minimise any lateral neutron flux gradients. Fluence monitors were analyzed using a continuous laser system and a MAP 216 mass spectrometer described by Dalrymple (1989). Argon was extracted from feldspar separates using a Mo crucible in a Staudacher-type custom resistance furnace attached to the MAP 216 mass spectrometer following analytical procedures outlined in Calvert et al. (2005). Heating temperatures were monitored with an optical fiber thermometer and controlled with a LabView PID controller. Gas was purified continuously during extraction using two SAES ST-172 getters operated at $4 \mathrm{~A}$ and $0 \mathrm{~A}$.

\subsection{ERUPTIVE HISTORY}

New and existing geochronological and geochemical data are used here to describe edifice-forming eruptive products at Ruapehu. This section is divided into the four chronostratigraphic formations defined by Hackett (1985), however, new data are used 
here to refine the temporal ranges and compositional characteristics of these formations.

The Mangawhero and Whakapapa formations are further broken down into eruptive packages that are defined based on the age, location, morphology, petrography and major element composition of lava flows. These packages will be formally classified as stratigraphic members by Townsend et al. (2016) where appropriate definition of type localities and characteristics will be presented. The temporal and spatial distribution of the packages is summarised in Figure 3.3, and shown in detailed maps in Figures 3.4, 3.9, 3.10 and 3.14 .

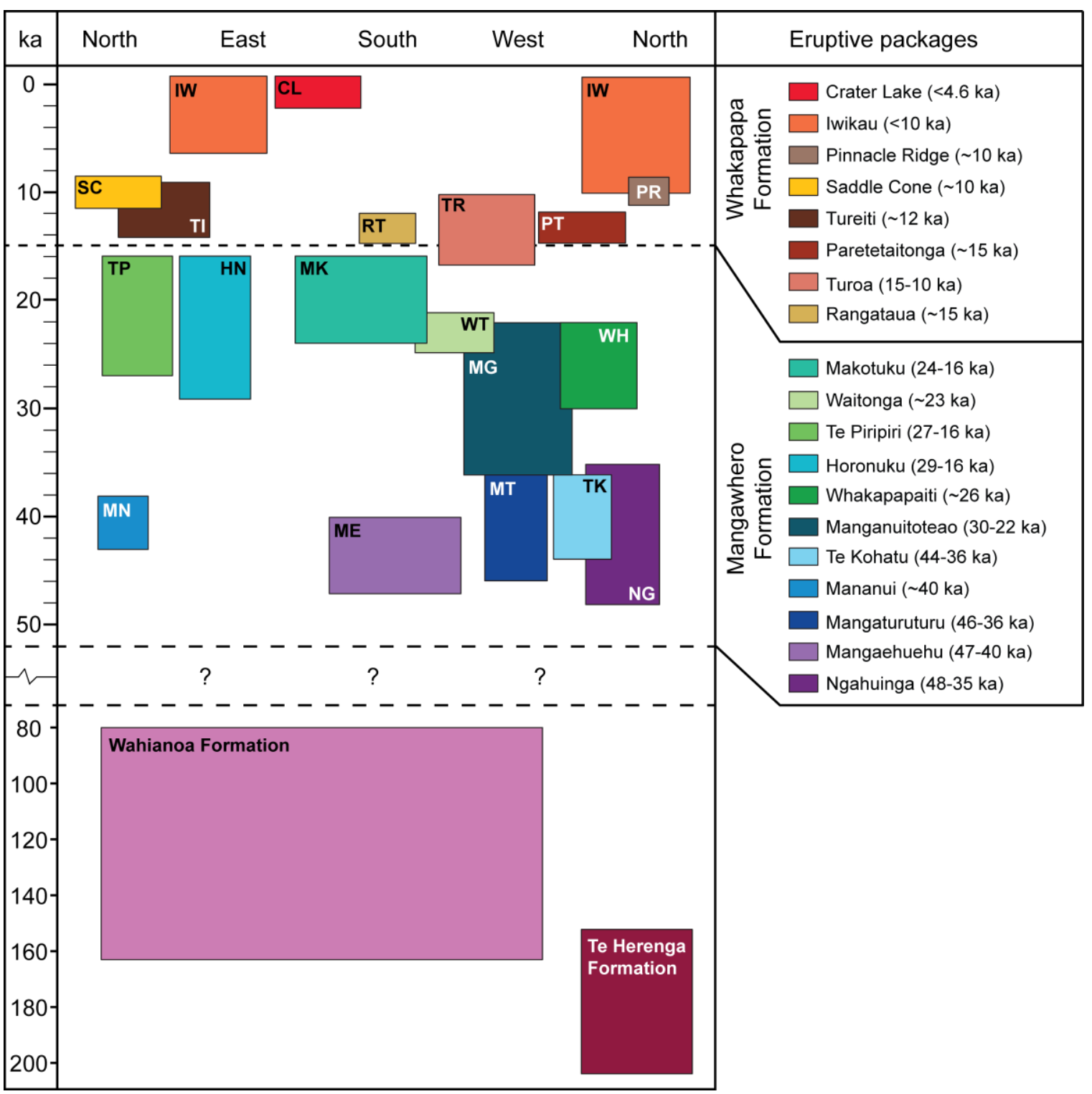

Figure 3.3. Summary of the spatial and temporal distribution of effusive volcanic products at Ruapehu volcano that are mapped in Figures 3.4, 3.9, 3.10 and 3.14. Key for eruptive packages of the Mangawhero and Whakapapa formations is displayed at right. Temporal ranges for packages and formations take into account $2 \sigma$ uncertainties of ${ }^{40} \mathrm{Ar} /{ }^{39} \mathrm{Ar}$ eruption ages for the relevant flows. 
Table 3.2. ${ }^{40} \mathrm{Ar} /{ }^{39} \mathrm{Ar}$ geochronology data for Ruapehu volcano lava flows.

\begin{tabular}{|c|c|c|c|c|c|c|c|}
\hline Sample & Fmtn-Package & $\mathbf{N}$ & ${ }^{39} \mathrm{Ar} \%$ & $\begin{array}{l}\text { Plateau ag } \\
\text { MSWD }\end{array}$ & $(\mathrm{ka}, \pm 2 \sigma)$ & $\begin{array}{c}\text { Total gas age } \\
\quad(\mathrm{ka}, \pm \mathbf{2 \sigma})\end{array}$ & $\begin{array}{c}\text { Isochron age } \\
(\mathrm{ka}, \pm \mathbf{2 \sigma})\end{array}$ \\
\hline GL1983 & WH-Crater Lake & 6 & 79.8 & 1.06 & $0.2 \pm 2.2$ & $-1.8 \pm 2.2$ & $1.4 \pm 8.8$ \\
\hline CC564 & WH-Iwikau & 7 & 86.0 & 0.67 & $0.8 \pm 5.6$ & $-0.8 \pm 5.6$ & $4 \pm 13.4$ \\
\hline GL1030 & WH-Iwikau & 11 & 100.0 & 1.10 & $6.0 \pm 2.4$ & $6.5 \pm 2.4$ & $1.4 \pm 7.4$ \\
\hline $\mathrm{CC} 279$ & WH-Iwikau & 6 & 63.9 & 0.79 & $8.8 \pm 2.8$ & $8.6 \pm 3.0$ & $10.5 \pm 17.2$ \\
\hline CC569 & WH-Iwikau & 4 & 60.8 & 0.13 & $9.2 \pm 8.0$ & $-0.3 \pm 8.6$ & $22.2 \pm 47.8$ \\
\hline $\mathrm{CC} 236$ & WH-Turoa & 5 & 62.7 & 0.61 & $11.9 \pm 2.2$ & $9.3 \pm 2.2$ & $15.4 \pm 15.2$ \\
\hline CC393 & WH-Tureiti & 10 & 100.0 & 0.65 & $11.9 \pm 2.8$ & $12.3 \pm 2.8$ & $11.9 \pm 8.8$ \\
\hline CC397 & WH-Tureiti & 7 & 83.9 & 0.90 & $12.5 \pm 2.6$ & $10.2 \pm 2.6$ & $14.4 \pm 5.0$ \\
\hline CC335 & WH-Paretetaitonga & 7 & 79.8 & 0.80 & $14.8 \pm 3.0$ & $22.1 \pm 3.0$ & $10.8 \pm 12.4$ \\
\hline $\mathrm{CC} 130$ & WH-Turoa & 11 & 100.0 & 0.46 & $15.1 \pm 2.4$ & $15.2 \pm 2.4$ & $13.9 \pm 6.0$ \\
\hline $\mathrm{CC} 226$ & MA-Makotuku & 10 & 100.0 & 0.34 & $17.8 \pm 2.2$ & $18.1 \pm 2.6$ & $16.8 \pm 4.2$ \\
\hline $\mathrm{CC} 408$ & MA-Makotuku & 8 & 94.7 & 0.39 & $20.9 \pm 2.8$ & $19.6 \pm 3.0$ & $22.7 \pm 7.4$ \\
\hline $\mathrm{CC} 143$ & MA-Waitonga & 10 & 99.5 & 0.80 & $23.0 \pm 1.6$ & $23.0 \pm 1.8$ & $22.2 \pm 4.6$ \\
\hline CC513 & MA-Whakapapaiti & 3 & 67.9 & 0.50 & $25.7 \pm 3.8$ & $6.7 \pm 4.4$ & $39.4 \pm 28.6$ \\
\hline $\mathrm{CC} 441$ & MA-Manganuioteao & 6 & 86.6 & 1.34 & $25.7 \pm 2.6$ & $20.3 \pm 2.8$ & $34.1 \pm 8.2$ \\
\hline CC553 & MA-Manganuioteao & 10 & 100.0 & 0.40 & $27.2 \pm 4.8$ & $25.8 \pm 5.8$ & $29.0 \pm 7.2$ \\
\hline CC547 & MA-Manganuioteao & 6 & 72.6 & 0.77 & $30.7 \pm 5.2$ & $43.9 \pm 4.6$ & $28.6 \pm 10.4$ \\
\hline $\mathrm{CC} 462$ & MA-Manganuioteao & 9 & 94.6 & 0.54 & $30.9 \pm 2.2$ & $30.4 \pm 2.6$ & $30.8 \pm 5.4$ \\
\hline CC508 & MA-Te Kohatu & 3 & 57.4 & 1.11 & $37.6 \pm 1.4$ & $46.2 \pm 1.4$ & $37.8 \pm 21.8$ \\
\hline CC556 & MA-Ngahuinga & 7 & 90.8 & 0.53 & $38.3 \pm 3.4$ & $30.0 \pm 4.0$ & $37.9 \pm 8.4$ \\
\hline $\mathrm{CC} 414$ & MA-Te Kohatu & 11 & 100.0 & 1.78 & $39.1 \pm 1.4$ & $40.7 \pm 1.4$ & $36.5 \pm 2.0$ \\
\hline CC511 & MA-Te Kohatu & 9 & 97.7 & 0.44 & $39.2 \pm 2.0$ & $40.2 \pm 2.4$ & $38.4 \pm 3.6$ \\
\hline $\mathrm{CC} 424$ & MA-Ngahuinga & 10 & 100.0 & 0.96 & $39.6 \pm 2.8$ & $40.3 \pm 3.2$ & $38.6 \pm 5.2$ \\
\hline CC570 & MA-Mananui & 8 & 91.7 & 0.28 & $40.3 \pm 2.2$ & $37.7 \pm 2.6$ & $41.7 \pm 3.6$ \\
\hline CC545 & MA-Mangaturuturu & 8 & 91.6 & 1.33 & $38.4 \pm 2.4$ & $35.9 \pm 2.6$ & $40.7 \pm 4.6$ \\
\hline $\mathrm{CC} 470$ & MA-Mangaturuturu & 9 & 99.4 & 0.96 & $41.3 \pm 1.8$ & $41.2 \pm 2.0$ & $42.9 \pm 4.2$ \\
\hline $\mathrm{CC} 140$ & MA-Mangaehuehu & 11 & 100.0 & 0.52 & $41.8 \pm 1.8$ & $41.2 \pm 2.0$ & $44.6 \pm 4.0$ \\
\hline $\mathrm{CC} 313$ & MA-Te Kohatu & 4 & 70.5 & 1.73 & $42.6 \pm 1.8$ & $39.5 \pm 1.4$ & $49.6 \pm 7.0$ \\
\hline $\mathrm{CC} 127$ & MA-Mangaehuehu & 8 & 84.4 & 0.66 & $42.8 \pm 1.0$ & $43.9 \pm 1.0$ & $42.9 \pm 2.2$ \\
\hline $\mathrm{CC} 216$ & MA-Mangaehuehu & 12 & 100.0 & 1.32 & $43.1 \pm 1.4$ & $43.8 \pm 1.4$ & $41.5 \pm 2.6$ \\
\hline CC119 & MA-Mangaehuehu & 11 & 100.0 & 1.46 & $43.3 \pm 1.6$ & $42.6 \pm 1.6$ & $45.3 \pm 2.4$ \\
\hline CC552 & MA-Mangaturuturu & 6 & 91.8 & 0.68 & $43.4 \pm 2.4$ & $45.1 \pm 3.0$ & $41.9 \pm 6.0$ \\
\hline CC081 & MA-Mangaehuehu & 8 & 86.7 & 1.17 & $44.2 \pm 1.8$ & $46.8 \pm 1.8$ & $41.9 \pm 6.2$ \\
\hline $\mathrm{CC} 453$ & MA-Ngahuinga & 8 & 96.7 & 1.43 & $44.8 \pm 3.0$ & $45.4 \pm 2.8$ & $45.8 \pm 5.8$ \\
\hline CC089 & MA-Mangaehuehu & 9 & 96.9 & 1.72 & $45.4 \pm 2.0$ & $46.0 \pm 1.6$ & $47.2 \pm 8.0$ \\
\hline CC562 & WA & 6 & 83.7 & 0.51 & $88.1 \pm 6.4$ & $85.2 \pm 9.0$ & $85.0 \pm 19.4$ \\
\hline $\mathrm{CC} 350$ & WA & 10 & 100.0 & recoil & $95.9 \pm 7.0$ & $95.5 \pm 4.2$ & $98.6 \pm 16.8$ \\
\hline CC209 & WA & 9 & 98.9 & 0.75 & $120.7 \pm 4.0$ & $119.5 \pm 5.0$ & $123.6 \pm 5.4$ \\
\hline $\mathrm{CC} 213$ & WA & 4 & 54.2 & 1.25 & $121.4 \pm 2.8$ & $122.2 \pm 2.4$ & $123.7 \pm 16.0$ \\
\hline CC375 & WA & 7 & 89.2 & 1.64 & $121.7 \pm 4.2$ & $119.6 \pm 3.4$ & $125.8 \pm 9.8$ \\
\hline CC197 & WA & 9 & 97.2 & 0.72 & $133.6 \pm 6.4$ & $136.0 \pm 6.8$ & $138.1 \pm 13.6$ \\
\hline CC518 & $\mathrm{TH}$ & 10 & 100.0 & 0.36 & $158.8 \pm 8.2$ & $157.6 \pm 9.6$ & $158.9 \pm 13.4$ \\
\hline $\mathrm{CC} 322$ & $\mathrm{TH}$ & 9 & 99.1 & 2.02 & $169.4 \pm 7.8$ & $171.0 \pm 6.0$ & $176.4 \pm 17.2$ \\
\hline $\mathrm{CC} 276$ & $\mathrm{TH}$ & 10 & 94.5 & 0.86 & $174.6 \pm 3.4$ & $171.0 \pm 5.8$ & $169.2 \pm 7.2$ \\
\hline CC348 & $\mathrm{TH}$ & 7 & 81.5 & 1.00 & $186.2 \pm 6.8$ & $173.1 \pm 7.2$ & $203.3 \pm 22.4$ \\
\hline CC306 & $\mathrm{TH}$ & 10 & 100.0 & recoil & $187.9 \pm 34.4$ & $146.6 \pm 11.4$ & $207.5 \pm 22.2$ \\
\hline
\end{tabular}

Formation abbreviations are: WH (Whakapapa); MA (Mangawhero); WA (Wahianoa); TH (Te Herenga). $\mathrm{N}$ is number of heating steps, $\%{ }^{39} \mathrm{Ar}$ is the proportion of released radiogenic gas, and MSWD is the mean standard weighted deviation of each age plateau calculation. Bold numbers are the preferred ages for each sample, which are all mean weighted plateau ages, except for CC545 where the isochron age was preferred. 
Table 3.3. Summary of the compositional ranges for eruptive packages.

\begin{tabular}{|c|c|c|c|c|}
\hline Formation & Eruptive package & $\mathrm{SiO}_{2}$ & $\mathrm{~K}_{2} \mathrm{O}$ & Mg\# \\
\hline Whakapapa & $\begin{array}{l}\text { Crater Lake^ } \\
\text { Iwikau } \\
\text { Saddle Cone* } \\
\text { Tureiti } \\
\text { Paretetaitonga } \\
\text { Rangataua } \\
\text { Turoa }\end{array}$ & $\begin{array}{c}61 \\
57-59 \\
56-59 \\
60 \\
57-59 \\
59-60 \\
59-60\end{array}$ & $\begin{array}{c}2.2 \\
1.2-1.6 \\
1.2-1.7 \\
1.7-1.8 \\
1.5-1.7 \\
1.7-1.8 \\
1.5-2.0\end{array}$ & $\begin{array}{c}55 \\
50-60 \\
53-56 \\
48 \\
51-56 \\
48 \\
50-60\end{array}$ \\
\hline Mangawhero & $\begin{array}{c}\text { Makotuku } \\
\text { Waitonga } \\
\text { Te Piripiri } \\
\text { Horonuku }^{\#} \\
\text { Whakapapaiti } \\
\text { Manganuioteao } \\
\text { Mananui } \\
\text { Te Kohatu } \\
\text { Mangaturuturu } \\
\text { Mangaehuehu } \\
\text { Ngahuinga }\end{array}$ & $\begin{array}{c}60-62 \\
61-63 \\
58-60 \\
60-62 \\
65 \\
60-63 \\
64 \\
64-65 \\
63-64 \\
57-62 \\
57-61 \\
\end{array}$ & $\begin{array}{c}1.8-2.1 \\
1.8-2.0 \\
1.4-1.9 \\
1.8-1.9 \\
2.1 \\
1.9-2.6 \\
2.8 \\
2.9-3.3 \\
2.7-3.0 \\
1.4-2.3 \\
1.6-2.1\end{array}$ & $\begin{array}{c}44-50 \\
51-58 \\
56-60 \\
54-60 \\
57 \\
45-52 \\
50 \\
54-57 \\
42-45 \\
60-69 \\
48-58 \\
\end{array}$ \\
\hline Wahianoa & undifferentiated & $56-60$ & $0.9-1.7$ & $42-62$ \\
\hline Te Herenga & undifferentiated & $54-57$ & $0.7-0.9$ & $51-62$ \\
\hline
\end{tabular}

Range of $\mathrm{SiO}_{2}$ and $\mathrm{K}_{2} \mathrm{O}$ contents and $\mathrm{Mg} \#[100 \mathrm{Mg} /(\mathrm{Mg}+\mathrm{Fe})]$ shown. Composition for Crater Lake ${ }^{\wedge}$ is based off the dated lava flow (GL1983). Compositional ranges for Saddle Cone* and Horonuku ${ }^{\#}$ packages are constrained by data from Price et al. (2012).

${ }^{40} \mathrm{Ar} /{ }^{39} \mathrm{Ar}$ geochronology data are presented here for 46 lava samples (Table 3.2), including three ages that were reported in Conway et al. (2015). Total gas, isochron and weighted mean plateau ages (WMPA) were calculated for each sample experiment. Total gas ages were calculated from the sums of radiogenic ${ }^{40} \mathrm{Ar}$ and potassium-derived ${ }^{39} \mathrm{Ar}$ in all step-heating increments of the analysis. Isochron ages were calculated from ${ }^{40} \mathrm{Ar} /{ }^{36} \mathrm{Ar}$ versus ${ }^{39} \mathrm{Ar} /{ }^{36} \mathrm{Ar}$ correlation using the algorithm of York (1969). Plateau ages are the inverse-variance weighted means calculated for the steps of an age spectrum comprising contiguous gas fractions that represent $>50 \%$ of the total ${ }^{39} \mathrm{Ar}$ released from the sample. Total gas ages are similar to plateau ages (within $2 \sigma$ uncertainty) for nearly all samples. There are 2 exceptions for post-glacial lavas and 4 exceptions for syn-glacial samples: the difference between plateau and total gas ages in these cases can be explained by the low numbers of heating steps $(n=3-7)$ included in plateau age calculation for these samples. The isochron age was preferred as the most suitable eruption age estimate for sample CC545 because the ${ }^{40} \mathrm{Ar} /{ }^{36} \mathrm{Ar}$ intercept was not within $2 \sigma$ error of the atmospheric value. Two experiments resulted in recoil spectra patterns indicative ${ }^{39} \mathrm{Ar}$ loss during irradiation. To preclude an underestimation of the eruption age due to reduced ${ }^{40} \mathrm{Ar} /{ }^{39} \mathrm{Ar}$ values at high temperature increments, recoil model ages were calculated from the entire spectra 
( $100 \%$ fraction of ${ }^{39} \mathrm{Ar}$ released) of the two affected samples using the method outlined in Fleck et al. (2014). Major element compositions for eruptive packages are summarised in Table 3.3 and full data are available in Appendix 5.

\subsubsection{Te Herenga Formation (200-150 ka)}

The oldest exposed volcanic products on Ruapehu are medium-K basaltic-andesite dikes, lava flows and volcaniclastic breccias of the Te Herenga Formation that form the eroded remnants of an edifice on the northern flank of Ruapehu (Figs. 3.4, 3.5).

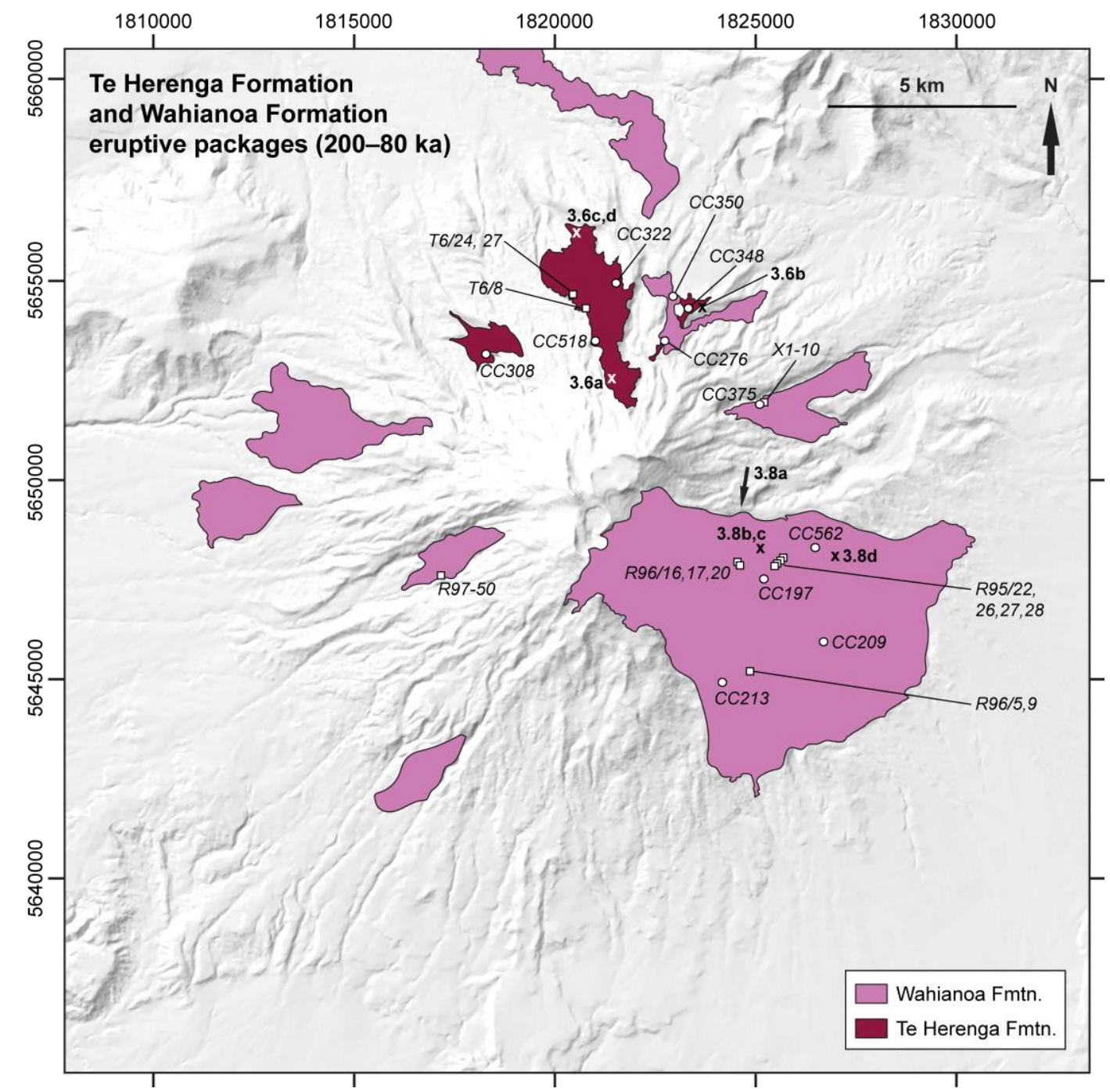

Figure 3.4. Distribution of Te Herenga Formation and Wahianoa Formation eruptive products. Locations for dated samples (open circles with sample numbers in italics) and relevant figures (cross or arrow, with bold numbers) are displayed. Sample locations for lavas dated by Gamble et al. (2003) that are referred to in this study are also displayed (open squares with numbers with a ' $R$ ' prefix). 
The timing of this volcanism is constrained by three existing and five new ${ }^{40} \mathrm{Ar} /{ }^{39} \mathrm{Ar}$ ages

(Tables 3.1, 3.2). The oldest exposed volcanic product dated in this study yielded an imprecise eruption age of $187.9 \pm 34.4 \mathrm{ka}$ (age $\pm 2 \sigma$ error), which is comparable to the existing value of $205 \pm 27 \mathrm{ka}$ for the oldest exposed products measured by Gamble et al. (2003). An older limit of $200 \mathrm{ka}$ is used for the Te Herenga Formation here in order to reflect the most precise eruption ages measured for early lavas (Tables 3.1, 3.2). Ruapehu volcano has a lifetime inferred to extend back to at least 340 ka (Gamble et al., 2003).
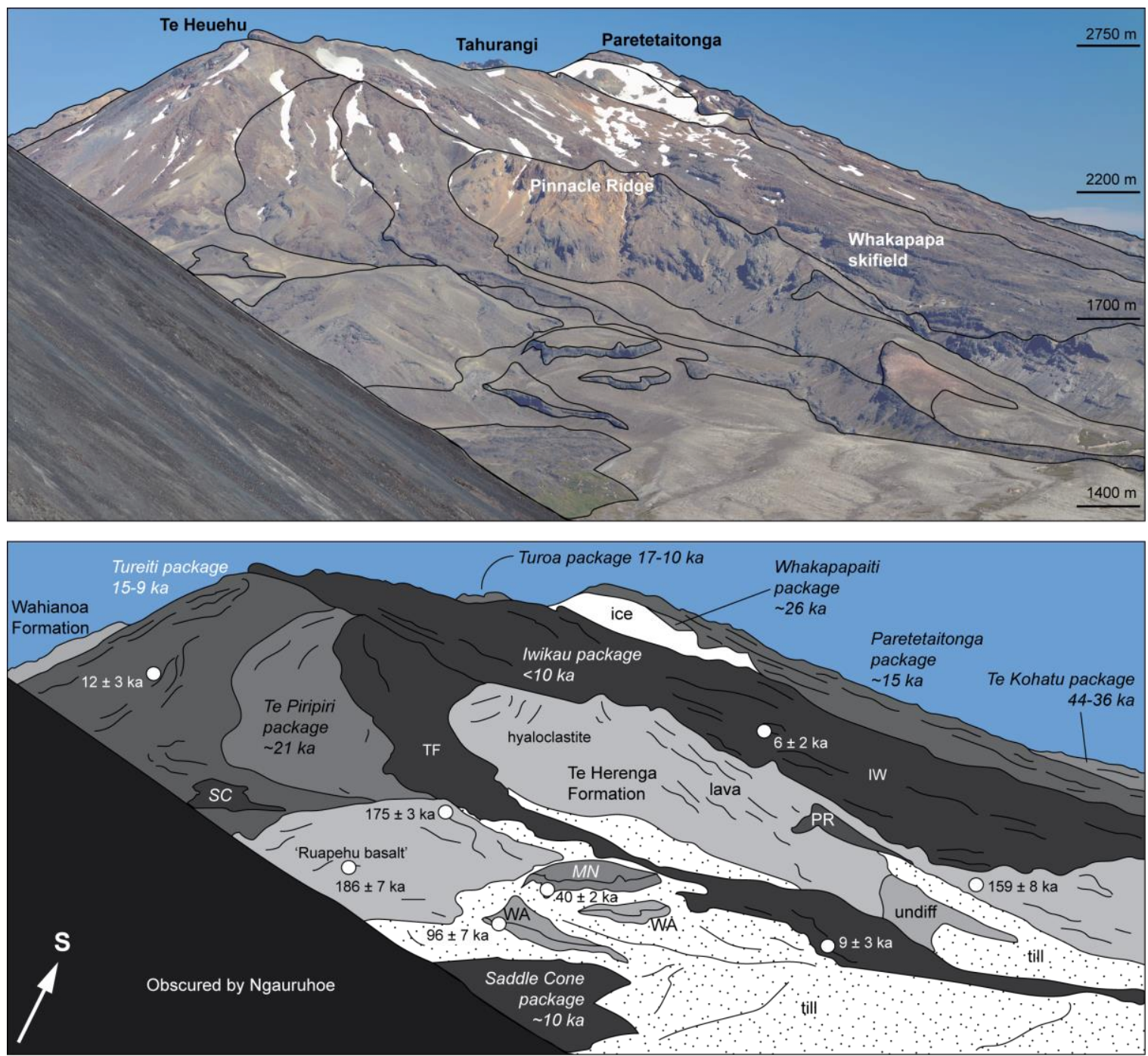

Figure 3.5. View of the eroded Te Herenga Formation edifice and post-glacial Whakapapa Formation lavas on the northern flank of Ruapehu. Distinct geographical features and elevations are marked in the top panel. Mapped extents of eruptive deposits are drawn in the bottom panel. Locations and eruption ages (weighted mean plateau ages: WMPA $\pm 2 \sigma$ ) of dated samples from this study are displayed. The location of the most mafic lava flow sampled on Ruapehu ('Ruapehu Basalt'; Price et al., 2012) is noted. Abbreviations are: WA (Wahianoa Formation); MN (Mananui package), and SC (Saddle Cone package); PR (Pinnacle Ridge fall deposit); and the Iwikau (IW) and Taranaki Falls (TF) flow groups within the Iwikau package. 
An age of $186.2 \pm 6.2 \mathrm{ka}$ was measured for the most mafic lava flow sampled from Ruapehu (53.8 wt. \% $\mathrm{SiO}_{2}$; 'Ruapehu basalt' in Price et al., 2012), which had previously been assigned to the Mangawhero Formation. This flow is one within a series of flows forming the nose of a ridge elevated $\sim 150 \mathrm{~m}$ above younger deposits (Fig. 3.5). Three eruption ages and their uncertainties (WMPA $\pm 2 \sigma$ ) bridge the previously interpreted hiatus between 180-160 ka (Gamble et al., 2003) and, thus, the younger limit of Te Herenga Formation is adjusted here to $150 \mathrm{ka}$. The oldest deposits of the northern edifice form much of Pinnacle Ridge and are a 100 m-thick unit of monomict volcaniclastic breccias intruded by dikes and quenched lobes of lava exposed at elevations up to $2000 \mathrm{~m}$ a.s.1. (Figs. 3.5, 3.6a). Breccia clasts display radial fractures indicative of quenchcontraction cooling and are hosted in a palagonitised ash matrix (Fig. 3.6a). These deposits are interpreted here to represent hyaloclastite breccias that were erupted under ice/meltwater. From the core of the northern edifice at Pinnacle Ridge, lava flows and breccias flowed north and are now exposed in deep valleys and along prominent ridges, where they were depositionally impounded by large glaciers (Fig. 3.5).
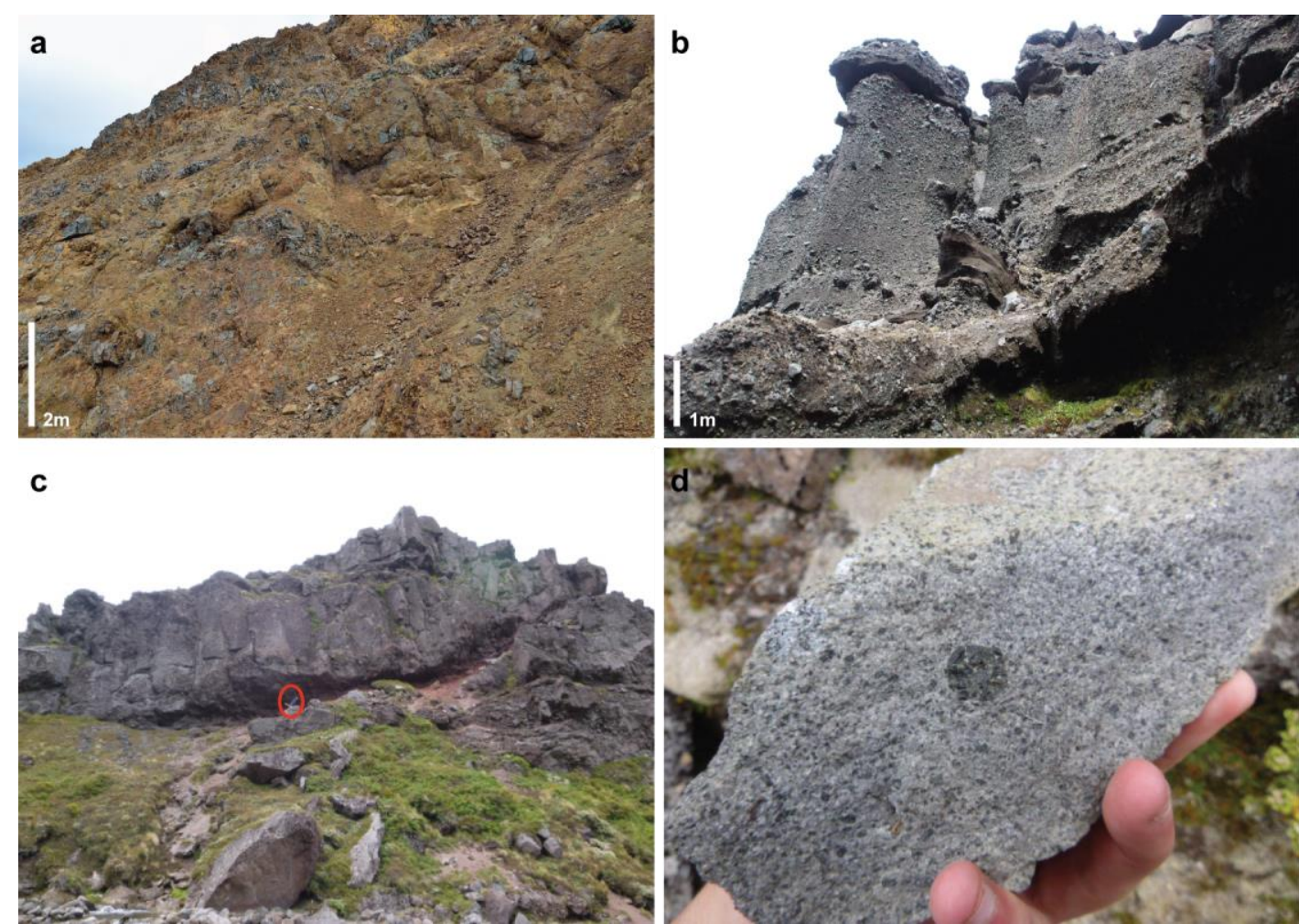

Figure 3.6. Examples of eruptive products of the Te Herenga Formation. Locations of images are labelled in Figure 3.4. a) Hyaloclastite breccia unit exposed beneath Pinnacle Ridge is composed of dense, fresh lava within an orange palagonite matrix. b) Breccia and laminated ash unit exposed on the northeast flank of the edifice. c) Thick lavas located north of Pinnacle Ridge. Person circled for scale. d) Characteristic pyroxene glomerocryst within a lava sample. 
Breccia units are monomict, encompassed in steep lensoidal packets, range from poorlyto moderately-sorted with maximum clast sizes of $80 \mathrm{~cm}$, and occasionally display weak bedding and rare lenses of finely laminated ash (Fig. 3.6b). The distribution of lavas and characteristics of breccias indicate that ice- and meltwater-marginal fragmentation, transportation and emplacement/deposition occurred during this time. Te Herenga Formation volcanics are petrographically distinguished from younger lavas by their devitrified groundmass textures and prominent pyroxene glomerocrysts that range in diameter from 4-12 mm (Fig. 3.6d). Lavas range from 54-57 wt. \% $\mathrm{SiO}_{2}$ and 0.7-0.9 wt. $\% \mathrm{~K}_{2} \mathrm{O}$, making them the least evolved products exposed on Ruapehu (Table 3.3).

\subsubsection{Wahianoa Formation (166-80 ka)}

Lava flows of the Wahianoa Formation (Hackett, 1985) flowed primarily to the southeast from a vent focus located south of the exposed Te Herenga Formation eruptives. Wahianoa Formation lava flows are medium-K basaltic-andesites and andesites (56-60 wt. $\% \mathrm{SiO}_{2}$ ) that exhibit slightly elevated $\mathrm{K}_{2} \mathrm{O}$ contents compared to Te Herenga Formation lavas (Table 3.3). The lower boundary (154 $\pm 12 \mathrm{ka}$; Gamble et al., 2003) for the Wahianoa Formation is constrained by an age for the stratigraphically lowest lava flow within the Whangaehu valley. The lava is at the base of a planèze comprised of a $\sim 300$ m-thick sequence of alternating lava flows, pyroclastic flows and debris flows between the deeply incised Wahianoa and Whangaehu valleys (Figs. 3.4, 3.7, 3.8a). Individual flows within the sequence generally exhibit planar thicknesses of 1-2 m, but occasionally swell into $15 \mathrm{~m}$-thick knuckles indicative of ponding in paleo-topographic depressions, and/or against ice (Fig. 3.8c). Lavas are intercalated with autobreccias and debris avalanche deposits on metre scales (Fig. 3.8c). Wahianoa Formation lava flows are also exposed within the Ohinepango River valley to the northeast and the Mangaturuturu River valley to the west, and beneath younger syn-glacial lavas on the northwest and northern flanks of the volcano (Fig. 3.4). At the core of the southeastern planèze, a voluminous mound of breccia, intruded by dykes and lava lobes, is inferred to have a subglacial or subaqueous origin. The unit comprises monomict, sub-angular to subrounded clasts displaying radial fractures and quenched rinds that are cemented in an orange-pink palagonitized ash matrix, interpreted to be a hyaloclastite breccia (Figs. 3.8a, b). 

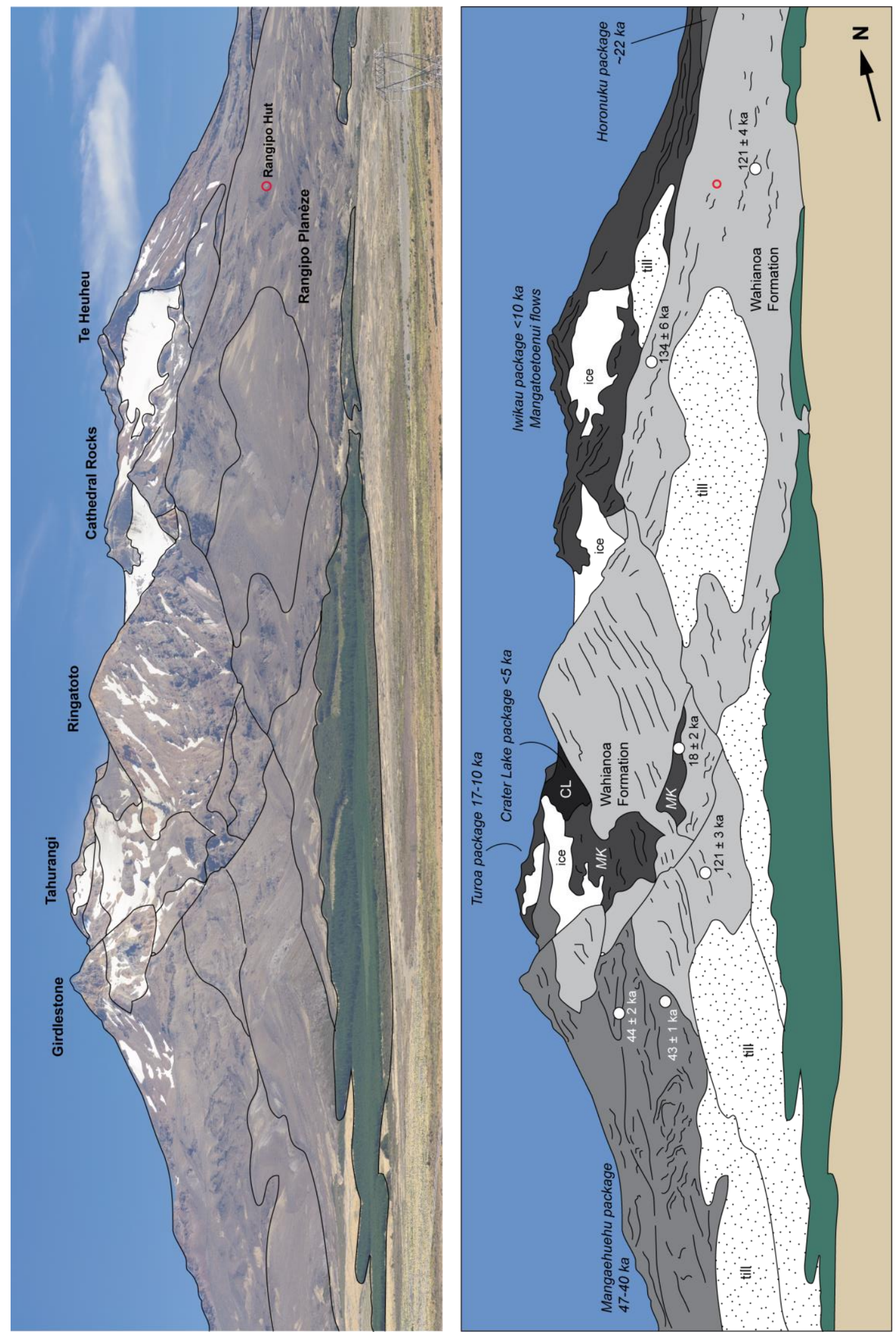

Figure 3.7. View of the eastern side of Ruapehu volcano. Distinct geographical features are marked in the top panel. Mapped extents of eruptive products are drawn in the bottom panel. Locations and eruption ages $(\mathrm{WMPA} \pm 2 \sigma)$ of dated samples from this study are displayed. Abbreviations are: MK (Makotuku package) and CL (Crater Lake package). 
A minimum age constraint of $154 \pm 12 \mathrm{ka}$ for this breccia is provided by overlying dated lava flows (Gamble et al., 2003). However, an unconformity separates these lavas of the southeast planèze from the breccia and may indicate that the latter is significantly older than $\sim 160 \mathrm{ka}$. Comparison of existing and new geochronology data presented for Te Herenga Formation above indicates that coeval effusion may have occurred from northern (Te Herenga) and southern (Wahianoa) vents at 160-150 ka.
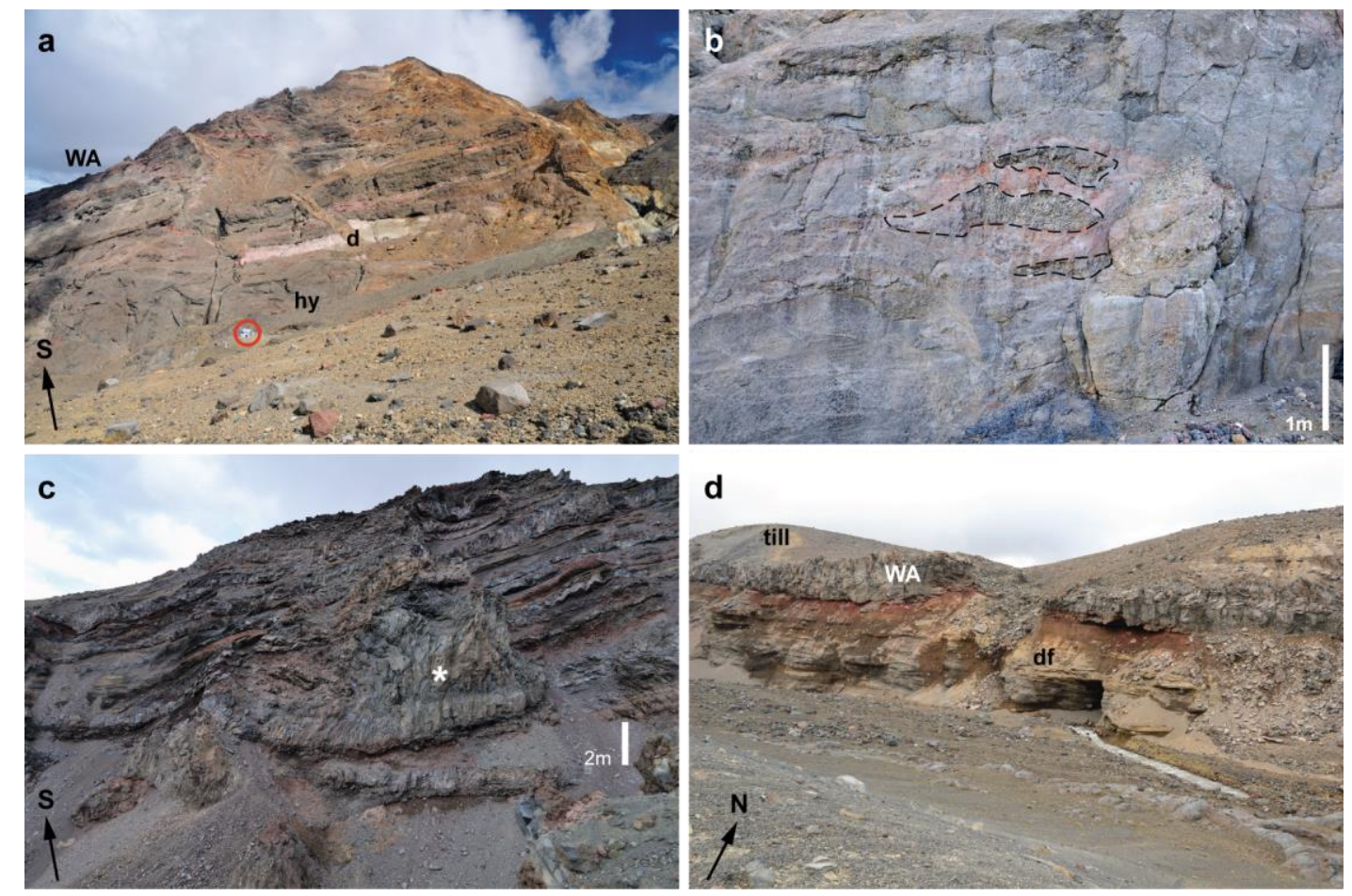

Figure 3.8. Characteristic features of breccias and lava flows of the Wahianoa Formation. a) Unconformity between voluminous mound of hyaloclastite breccia (hy) and lava flows, autobreccias and debris flows of the Wahianoa Formation (WA). Red circle shows position of Whangaehu Alpine Club hut. b) Intrusion of lava within hyaloclastite breccia. c) Overthickened knuckle of lava (*) within sequence of alternating planar lava flows, autobreccias and debris flows on the true right bank of the Whangaehu River valley. d) Planar and platy jointed Wahianoa Formation andesite lava flow (WA; 88.2 \pm 6.4 ka) overlying debris flow deposits (df) in the Whangaehu River valley.

New ages of $120.7 \pm 4.0$ and $121.4 \pm 2.8$ ka were determined for flows located at 1400 and $1500 \mathrm{~m}$ a.s.l. on the southeast flank of Ruapehu that correspond to the upper sequence of the Wahianoa Formation as defined by Gamble et al. (2003). A similar sequence is exposed on the northeast flank, with an age of $121.7 \pm 4.2$ ka measured for a flow sampled on the upper true right bank of the Ohinepango Stream valley. The existing age range for the Wahianoa Formation is extended here to account for lavas that are exposed on the lower northern $(95.9 \pm 7.0 \mathrm{ka})$ and eastern $(88.1 \pm 6.4 \mathrm{ka})$ flanks (Fig. 3.4). These 
lavas have very low slope angles, are covered by till, and are located at low elevations within glacially eroded valleys (Fig. 3.8d). The characteristics indicate that the flows were emplaced onto an edifice that was relatively ice-free during this period, which coincides with part of a previously inferred eruptive hiatus at Ruapehu (Gamble et al., 2003). Despite the disparate distribution of interglacial andesites on southwest, west and northwest flanks, the lavas are interpreted to have been sourced from one central magma system contiguous to that which sourced older lavas of the Wahianoa Formation.

\subsubsection{Mangawhero Formation ( $50-15 \mathrm{ka})$}

The Mangawhero Formation was interpreted to encompass volcanic products erupted during effusive episodes centred at $\sim 45 \mathrm{ka}$ (based on two lava flow ages) and $\sim 22 \mathrm{ka}$ (based on five lava flow ages; Gamble et al., 2003). Twenty-five lava flow ages measured for this study span a near-continuous range from $\sim 48-15 \mathrm{ka}$, and are used to redefine the chronological and areal extent of lava flows that comprise the Mangawhero Formation. The majority of WMPA $(n=17)$ fall within a period from $\sim 45-38 \mathrm{ka}$.

No eruption ages were returned between 37 and $31 \mathrm{ka}$, although this period is bridged by $2 \sigma$ uncertainties of the plateau ages for three new samples and one sample from Gamble et al. (2003). The majority of Mangawhero Formation flows display strong evidence for interaction with ice and were emplaced on moraine ridges along the lateral margins of glaciers or dammed behind large volumes of valley-filling ice (Conway et al., 2015).

As a result of excellent exposure and optimal groundmass textures for dating Mangawhero Formation lava flows were sampled extensively, which has allowed for the detailed discrimination between eruptive packages presented below and in Figure 3.9 ( 50-36 ka) and Figure 3.10 ( 35-15 ka). New Zealand indigenous Māori names have been adopted for these eruptive packages that relate to local geographical features and places. These names will be classified as formal Members by Townsend et al. (2016). Time brackets for the eruptive packages are defined by taking into account individual ${ }^{40} \mathrm{Ar} /{ }^{39} \mathrm{Ar}$ WMPA and $2 \sigma$ uncertainties for all relevant flows in the package. 


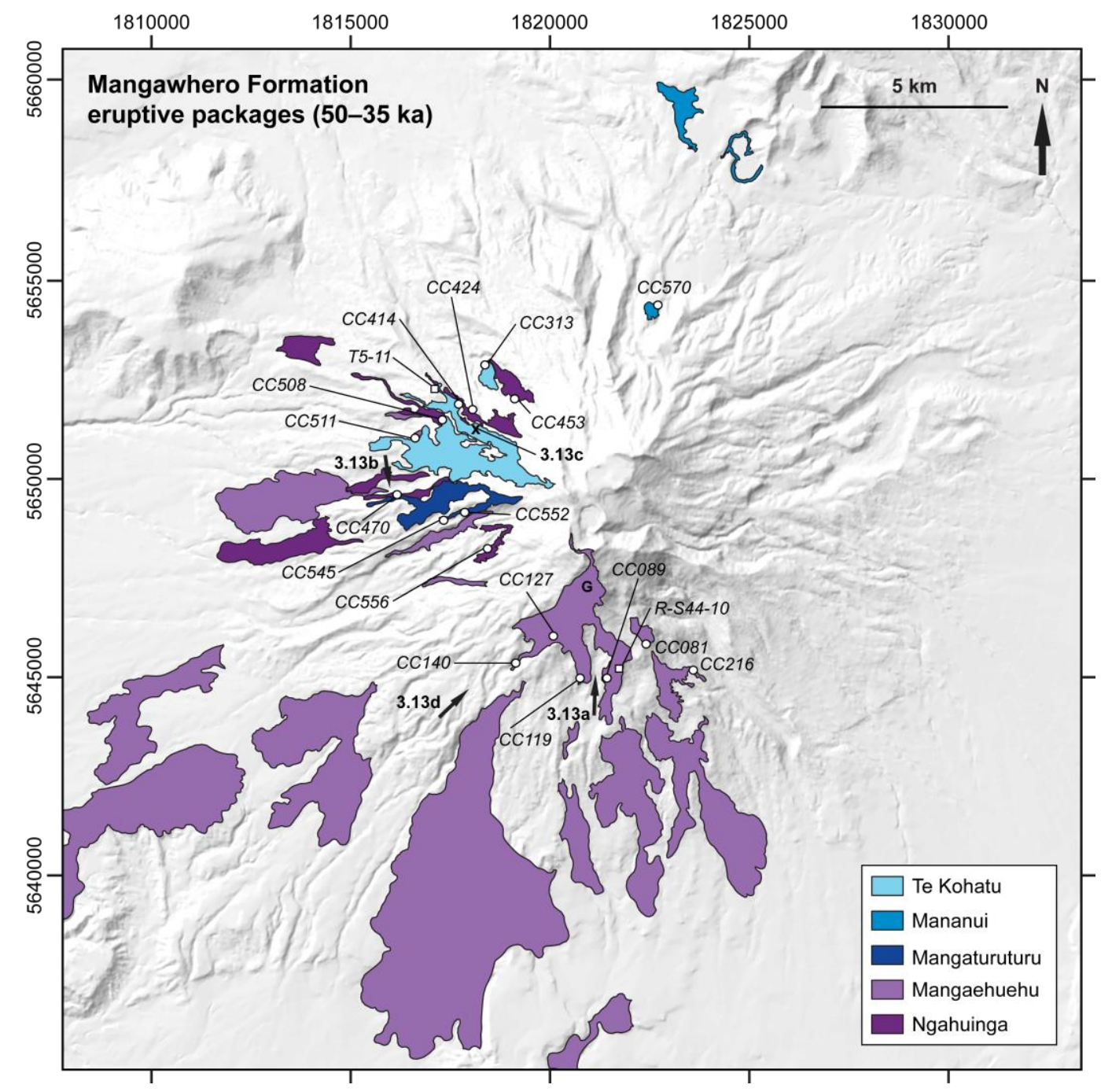

Figure 3.9. Distribution of earlier Mangawhero Formation eruptive packages ( $50-35 \mathrm{ka})$. Locations for dated samples and relevant figures are displayed, as in Fig. 3.4. Girdlestone Peak is marked 'G'.

\subsubsection{Ngahuinga package (48-35 ka)}

This sequence of andesite flows border the Whakapapaiti Stream valley and are exposed on the western and northwestern flanks. The timing of this effusive activity is bounded by an eruption age of $44.8 \pm 3.0 \mathrm{ka}$ for the deepest exposed flow. The true left ridge of the Whakapapaiti Stream valley includes a series of at least four individual $\leq 5 \mathrm{~m}$-thick icebounded flows (Fig. 3.11), the second-oldest of which yielded an eruption age of $39.6 \pm$ $2.8 \mathrm{ka}$. On western Ruapehu, an ice-bounded Ngahuinga package andesite flow was emplaced at $38.3 \pm 3.4 \mathrm{ka}$. 


\subsubsection{Mangaehuehu package (47-40 ka)}

The Mangaehuehu package comprises voluminous andesitic lava flows that form the southern portion of the Ruapehu edifice between the Wahianoa and Mangaturuturu river valleys, as well as western parts of the edifice (Fig. 3.7). Eruption of Mangaehuehu package lavas is tightly constrained between 47 and 40 ka when taking into account all 6 new individual ${ }^{40} \mathrm{Ar} /{ }^{39} \mathrm{Ar}$ WMPA and $2 \sigma$ uncertainties measured for these flows. The eruption age of $47 \pm 4 \mathrm{ka}$ (and duplicate age of $53 \pm 4 \mathrm{ka}$ ) determined by Gamble et al. (2003, sample R-S44-10) was not used to define the eruptive package age range because of the low number of heating steps used in the analyses.

The flows are defined by distinctly high $\mathrm{MgO}$ contents (and Mg-values; Table 3.3) compared to other Ruapehu lavas at equal $\mathrm{SiO}_{2}$ contents, which enables undated distal flows to be unambiguously assigned to this package. Lava samples collected from Girdlestone Peak by Hackett (1985) display identical compositional characteristics to Mangaehuehu package lavas and the glacially sculpted peak, which exposes dikes (Hackett, 1985), is interpreted to represent an eroded vent-proximal region. Mangaehuehu package lavas cover an area of $\sim 100 \mathrm{~km}^{2}$, with distal flows exposed up to $18 \mathrm{~km}$ from Girdlestone Peak on the western flank of Ruapehu (Fig. 3.9).

Mangaehuehu package lavas were bounded by glaciers between elevations of 2600 and $1500 \mathrm{~m}$ a.s.l. and have been partly eroded and buried by subsequent glacial activity such that much of the surface of the southern flank is composed of glacial till and outwash. Exposures of stacked flows (Fig. 3.13a) and the distinct $\mathrm{MgO}$ and $\mathrm{K}_{2} \mathrm{O}$ contents of each sample within the total $\sim 57-62 \mathrm{wt} . \% \mathrm{SiO}_{2}$ continuum indicate that the samples represent a package of flows that were erupted from a common magma source that was tapped throughout the $\sim 7 \mathrm{kyr}$ eruptive period. The remote southern flank of the Ruapehu volcanic edifice had previously been sparsely sampled and was mapped predominantly as Wahianoa Formation (Hackett and Houghton, 1989; Price et al., 2012), meaning that this substantial cone-building episode had not previously been recognised. As their age range indicates, Mangaehuehu and Ngahuinga package lavas were emplaced contemporaneously, and no clear stratigraphic ordering between them can be ascertained due to their disparate spatial distributions. However, Mangaehuehu package is inferred to underlie some Mangaturuturu and Ngahuinga lavas on western flank (Fig. 3.11). 


\subsubsection{Mangaturuturu package (46-36 ka)}

This eruptive package is represented by ice-bounded dacite lava flows erupted between 46 and 36 ka that form a planèze on the western flank between the Mangaturuturu and Manganuioteao river valleys (Fig. 3.12). The flows overlie Wahianoa Formation lavas and breccias in the deeply incised upper catchment of the Mangaturuturu River (Fig. 3.12) and cap Whakapapaiti andesites along the northern part of the once ice-bounded planèze (Fig. 3.13b). In addition to their distinct spatial location (Fig. 3.9), Mangaturuturu package lavas are differentiated from other dacite flows erupted during this time by their lower $\mathrm{MgO}$ contents at equivalent $\mathrm{SiO}_{2}$ and $\mathrm{K}_{2} \mathrm{O}$ contents (Table 3.3).

\subsubsection{Te Kohatu package (44-36 ka)}

Te Kohatu package dacite lavas were emplaced adjacent to large valley glaciers on the northwest flank between $\sim 44$ and $36 \mathrm{ka}$ to form prominent ice-bounded and ice-dammed flows between 1500 and $2100 \mathrm{~m}$ a.s.l. (cf. Conway et al., 2015; Figs. 3.11, 3.13c). The eruption age of $46 \pm 5 \mathrm{ka}$ determined for dacite sample T5-11 by Gamble et al. (2003) was not used to define the age range of the Te Kohatu package because it conflicts with the stratigraphic order of several dated flows on the northwest flank as constrained by new data. Te Kohatu dacites are observed to overlie remnants of the Te Herenga and Wahianoa formations, and Mangaehuehu and Ngahuinga eruptive packages. A Te Kohatu package ice-bounded flow emplaced at $39.1 \pm 1.4$ ka caps Ngahuinga package andesites exposed on the true left of the Whakapapaiti Valley (Fig. 3.11). The dacites also comprise two $>100$ m-thick ice-dammed flows emplaced at $39.2 \pm 2.0 \mathrm{ka}$ and $37.6 \pm 1.4 \mathrm{ka}$ at $\sim 1500 \mathrm{~m}$ a.s.l. on the western flank; the distinct WMPA are consistent with the flows' stratigraphic positions. Another large ice-dammed flow within this package was emplaced within the broad, glaciated Whakapapaiti Stream valley at $42.6 \pm 1.8 \mathrm{ka}$. Based on their spatial distribution and ice-contact margins, Te Kohatu package lavas were erupted from a central summit vent. Compared to other Ruapehu dacites, Te Kohatu package flows have higher $\mathrm{MgO}$ contents. 


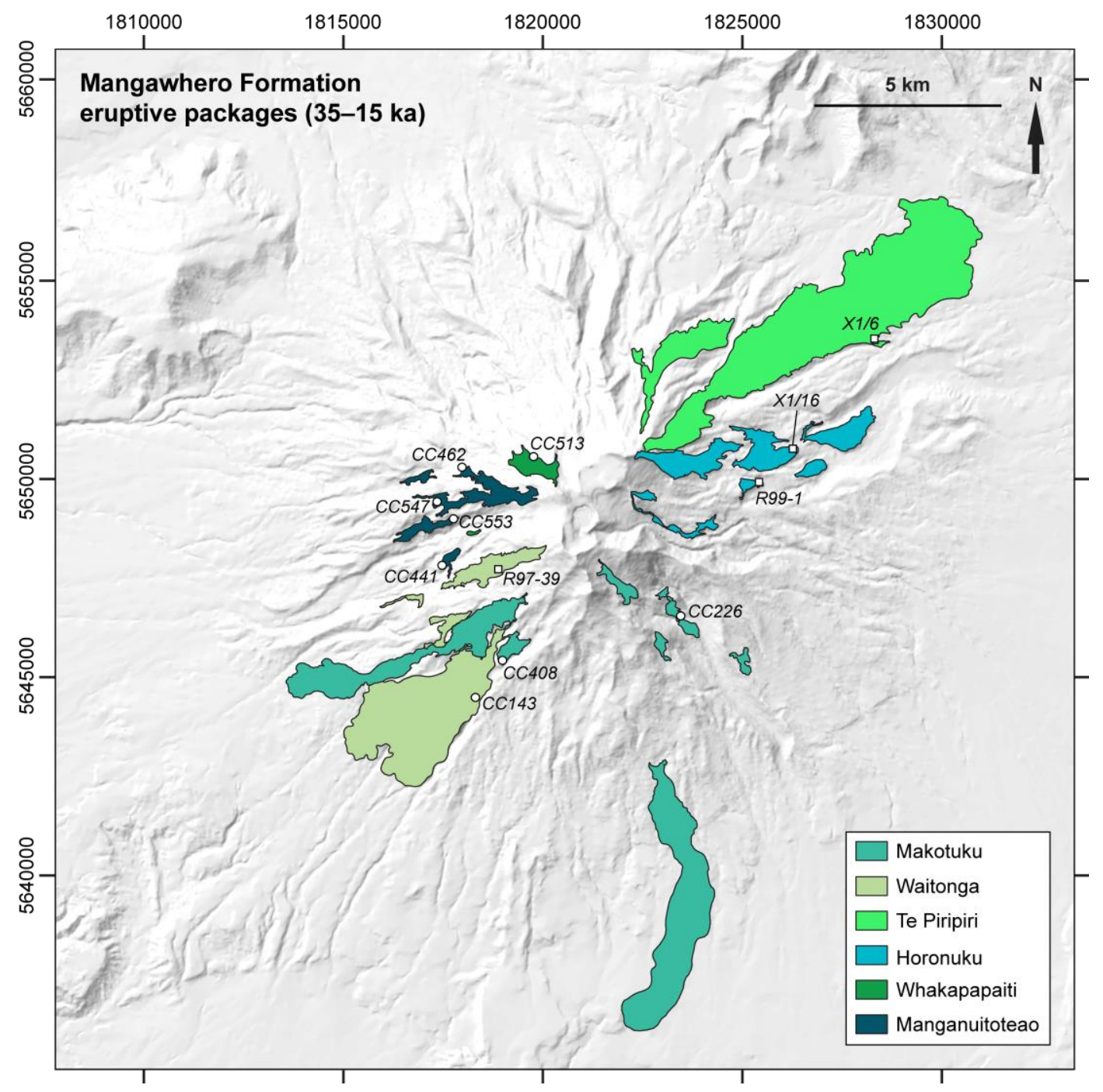

Figure 3.10. Distribution of later Mangawhero Formation eruptive packages (35-15 ka). Locations for dated samples and relevant figures are displayed, as in Fig. 3.4. Sample locations for lavas dated by Gamble et al. (2003) that are referred to in this study are also shown (numbers with a ' $\mathrm{X}$ ' prefix).

\subsubsection{Mananui package (42-38 ka)}

This package comprises a single ice-dammed dacite flow that was emplaced against a glacier on the lower northern flank at $40.3 \pm 2.2 \mathrm{ka}$ (Fig. 3.5). The flow is isolated stratigraphically and spatially from other dacite flows higher on the edifice but is compositionally identical to flows of unknown age exposed at the Lower Tama Lake crater (Hackett, 1985). The Mananui dacite flow is characterised by $\mathrm{MgO}$ contents $(2.8$ wt. \%) midway between that of the Mangaturuturu (2.2 wt. \%) and Te Kohatu (3.3 wt. \%) package flows at equivalent $\mathrm{SiO}_{2}\left(\sim 64\right.$ wt. \%) and $\mathrm{K}_{2} \mathrm{O}(\sim 2.8$ wt. \%) contents. These geochemical characteristics are shared by a dacite clast sampled by Hackett (1985) from 
the $\sim 10.5$ ka Murimotu Formation debris avalanche deposit, the source area of which coincides with a central vent location inferred for the Mananui dacite lava. Dacite exposed at the Tama Lakes also shares a similar composition, and is here grouped within the eruptive package (Fig. 3.9).
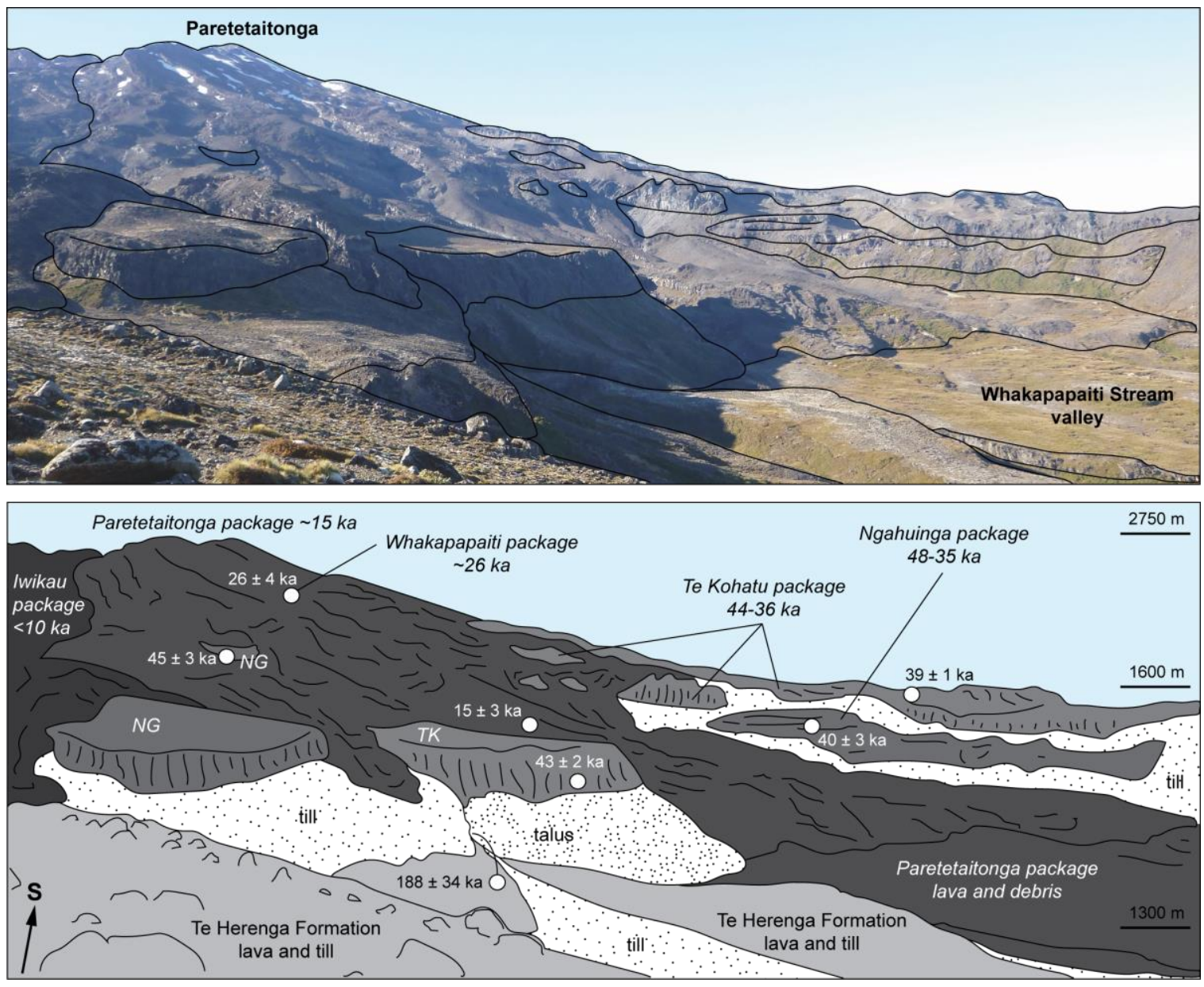

Figure 3.11. View of the Whakapapaiti River valley on the northwest flank of Ruapehu volcano. Distinct geographical features are marked in the top panel. Mapped extents of eruptive units are drawn in the bottom panel. Locations and eruption ages (WMPA $\pm 2 \sigma$ ) of dated samples from this study are displayed. NG and TK are abbreviated labels for Ngahuinga and Te Kohatu packages, respectively.

Figure 3.12. (opposite). View of the Mangaturuturu Valley on the western flank of Ruapehu. Elevations are marked in the top panel and mapped extents of eruptive units are drawn in the bottom panel. Locations and eruption ages (WMPA $\pm 2 \sigma$ ) of dated samples from this study are displayed. ME and MT are abbreviated labels for Mangaehuehu and Mangaturuturu packages, respectively. 


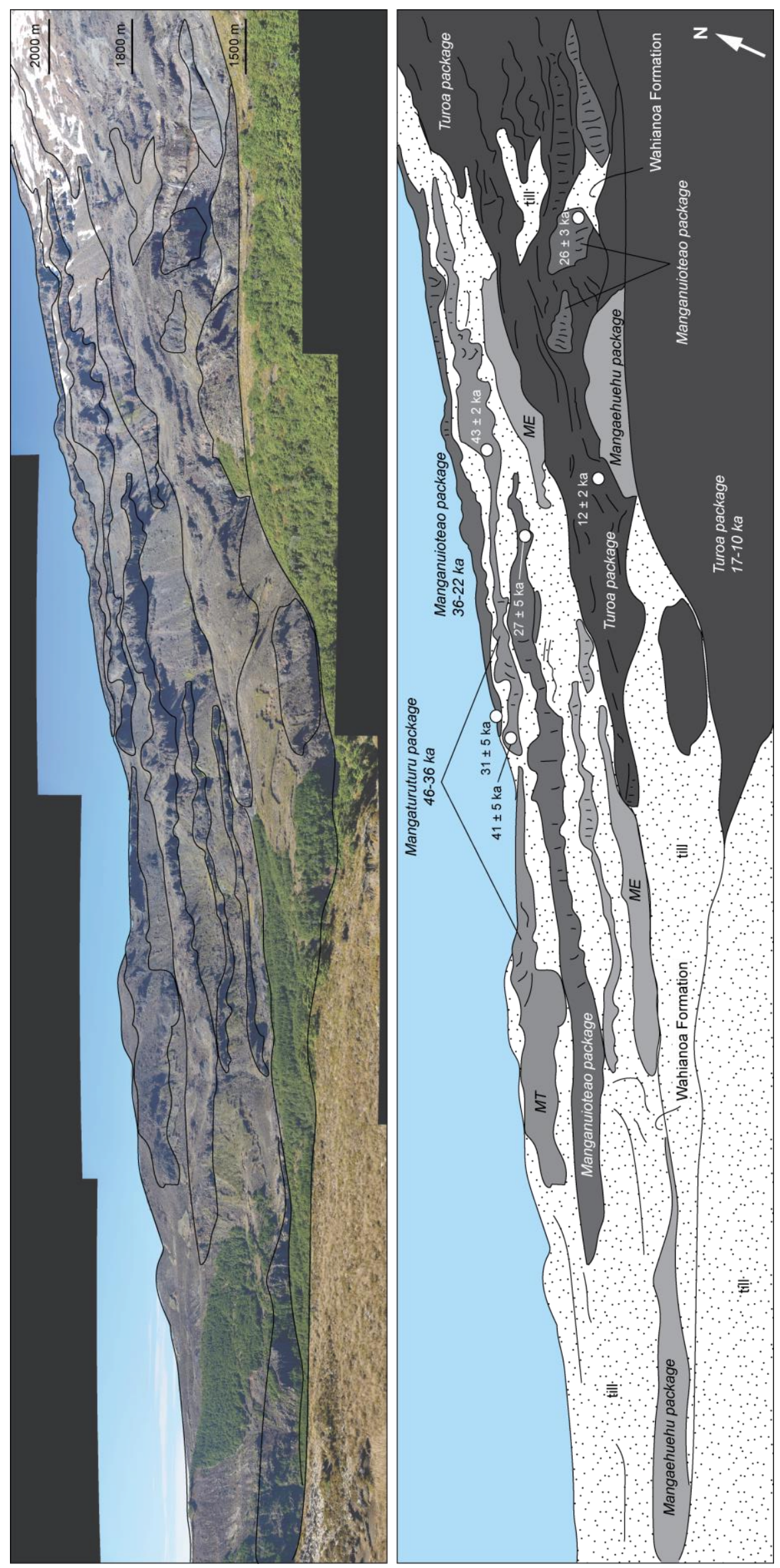




\subsubsection{Manganuioteao package (36-22 ka)}

Manganuioteao package andesite lavas were emplaced as ice-bounded flows on the western flank of Ruapehu at $30.9 \pm 2.2 \mathrm{ka}$ and on the true right ridge that bounds the glaciated Mangaturuturu River valley at $30.7 \pm 5.2 \mathrm{ka}$ (Fig. 3.12). These flows cap older Te Kohatu and Mangaturuturu package dacites, however, a younger Manganuioteao andesite dated at $27.2 \pm 4.8 \mathrm{ka}$ forms an ice-bounded flow that is inset within the Mangaturuturu valley relative to the older, morphologically higher $\sim 41$ ka ice-bounded dacites and $\sim 31 \mathrm{ka}$ andesites (Fig. 3.12). The youngest dated lava within the Manganuioteao package is an ice-bounded flow emplaced at $25.7 \pm 2.6 \mathrm{ka}$, which is exposed at $1600 \mathrm{~m}$ a.s.l. on the southwestern flank. These andesites are significant because they bridge the period between previously interpreted pulses of effusion at $\sim 45$ and $22 \mathrm{ka}$ (Gamble et al., 2003), thus revealing the continuity of effusive activity at this time. Moreover, the compositions of the flows (60-63 wt. \%) fill a transitional geochemical field between older dacites and younger andesites.

\subsubsection{Whakapapaiti package (30-22 ka)}

Whakapapaiti package dacite flows are exposed at the base of the now-dissected Paretetaitonga Peak as an ice-bounded flow on the outboard eastern side of the formerly more extensive Whakapapaiti Glacier, and on the upper western and southwestern flanks of Ruapehu (Fig. 3.10). Only one lava has been dated, at $25.7 \pm 3.8 \mathrm{ka}$. The lavas are distinguished by their low $\mathrm{K}_{2} \mathrm{O}$ contents relative to dacite flows erupted from $46-35 \mathrm{ka}$.

\subsubsection{Horonuku package (29-15 ka)}

Horonuku package andesite lavas form major ice-bounded flows on eastern Ruapehu between elevations of 1600 and $1300 \mathrm{~m}$ a.s.l. (Fig. 3.10). Thicknesses of the flows and their heights above valley floors indicates that these flows were emplaced against $\sim 100$ m-thick glaciers. Two of these flows were dated by Gamble et al. (2003) at $23 \pm 4 \mathrm{ka}$ and $22 \pm 7 \mathrm{ka}$ (Table 3.1), and have not been further dated in this study. The flows are overlain by till and, at higher elevations on the edifice, by younger lava flows and pyroclastic deposits related to growth of the present summit cones. 


\subsubsection{Te Piripiri package (27-15 ka)}

Te Piripiri package lavas form the lower northeast flank of the Ruapehu edifice and have later been blanketed by thick tephra on the predominantly downwind side of the edifice. The flows exhibits evidence of lava-ice interaction (Conway et al., 2015) and were emplaced at $21 \pm 6 \mathrm{ka}$, as constrained by Gamble et al. (2003). Andesite lavas of this package range from $58-60$ wt. $\% \mathrm{SiO}_{2}$ and have average $\mathrm{MgO}$ contents of $\sim 5$ wt. $\%$ (Table 3.3).
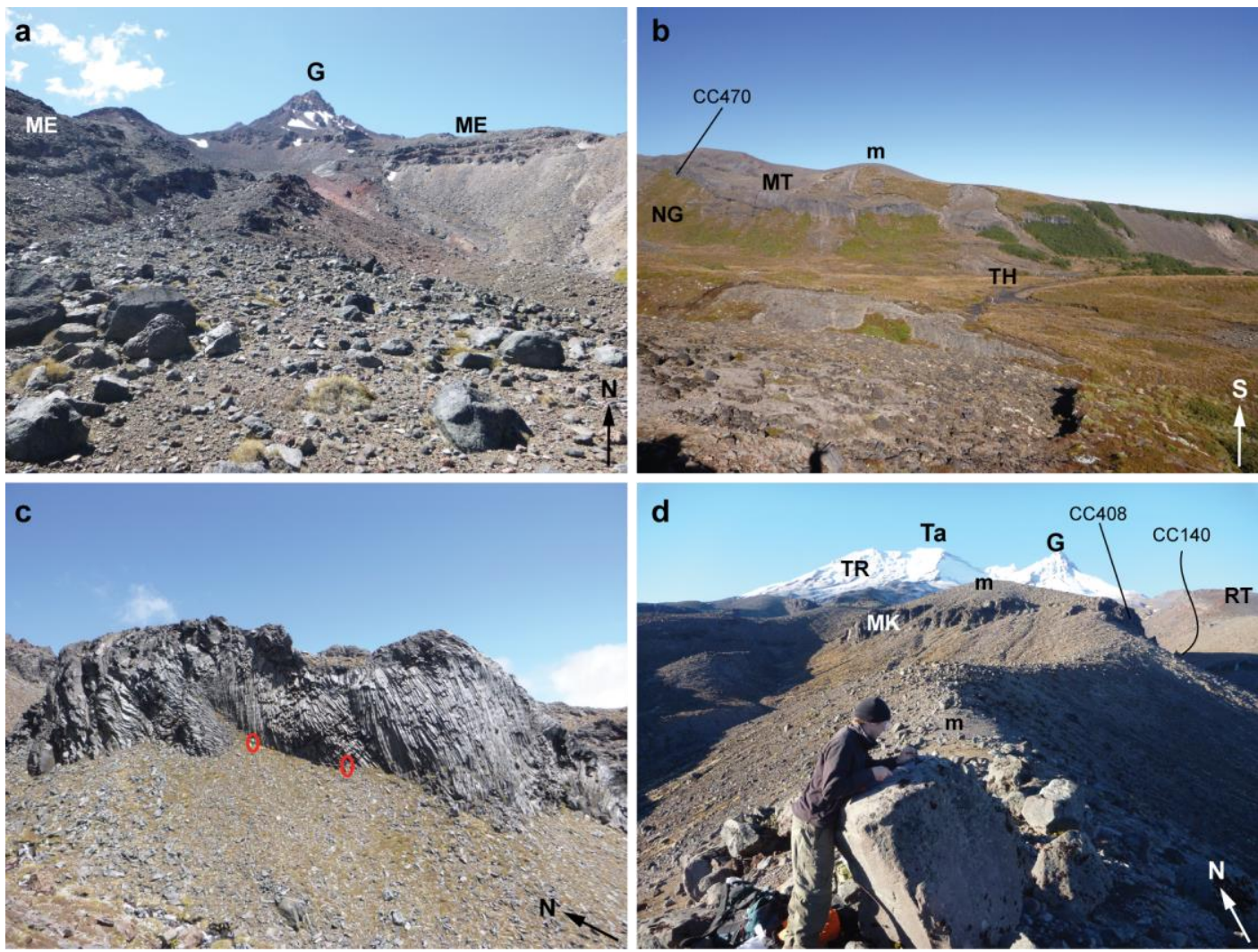

Figure 3.13. Features of Mangawhero Formation lavas. a) Northward view toward Girdlestone Peak (G) showing multiple flows within the Mangaehuehu eruptive package (ME). b) An ice-bounded Mangaturuturu eruptive package (MT) dacite lava overlies Ngahuinga eruptive package (NG) andesite lava and is capped by younger moraine $(\mathrm{m})$ on the western flank of Ruapehu. A lava flow of the Te Herenga Formation (TH) is exposed on the valley floor at the base of the ridge. c) Column-forming joints on the margin of a Te Kohatu eruptive package ice-bounded dacite lava flow on northwest Ruapehu. Red circles are drawn around people separated by a distance of $\sim 15 \mathrm{~m}$. d) Northeast-looking view toward Girdlestone (G) and Tahurangi (Ta) of lava flows and moraines. An ice-bounded lava of the Makotuku eruptive package (MK) with an age of $20.9 \pm 2.2 \mathrm{ka}$ (sample CC408) is overlain by moraines with $\sim 15-11 \mathrm{ka}{ }^{3} \mathrm{He}$ exposure ages (Eaves, 2015). The locations of post-glacial Turoa eruptive package (TR) and Rangataua eruptive package (RT) lava flows are also displayed. 


\subsubsection{Waitonga package (25-21 ka)}

This eruptive package is exposed on the southwest flank of Ruapehu and is constrained by eruption ages of $23.0 \pm 1.6 \mathrm{ka}$ (Table 3.2) and $23 \pm 8 \mathrm{ka}$ (Gamble et al., 2003). Despite covering a wide spatial extent and with exposure from 2200-1200 m a.s.l., the flows exhibit a tight compositional range with $\sim 62.1$ wt. $\% \mathrm{SiO}_{2}, \sim 3.6$ wt. $\% \mathrm{MgO}$ and 2.0 wt. $\% \mathrm{~K}_{2} \mathrm{O}$. Flows display evidence for interaction with glaciers, particularly at higher elevations (e.g. Fig. 3.6c in Conway et al., 2015), and are overlain by moraines at lower elevations, which have been dated by ${ }^{3} \mathrm{He}$ surface exposure geochronology at $\sim 15-11 \mathrm{ka}$ (Eaves, 2015).

\subsubsection{Makotuku package (24-16 ka)}

Makotuku package lavas are located as ice-bounded and sub-glacial flows at midelevations on the southwestern flank and an extensive break-out flow, which overlies the Waitonga package lavas on the southwest flank of Ruapehu at $~ 1300 \mathrm{~m}$ a.s.l. (Figs. 3.10, 3.13d; Conway et al., 2015). This stratigraphic ordering is supported by an age of $20.9 \pm$ $2.8 \mathrm{ka}$ measured from an ice-bounded flow at $1720 \mathrm{~m}$ a.s.1. Lavas of this unit were also emplaced on southeast Ruapehu as ice-bounded or possibly sub-glacial flows (Conway et al., 2015). An eruption age of $17.8 \pm 2.2 \mathrm{ka}$ was measured for one flow, which is overlain by till, interpreted to have been deposited at $\sim 15-11 \mathrm{ka}$ (Eaves, 2015). Despite the interaction with glacial ice, the fine-scale columns ( $\sim 10 \mathrm{~cm}$-wide) are remarkably wellpreserved, suggesting that only minor glaciation occurred in the valley after emplacement of the flow and/or that the glacier was already retreating. Additionally, Makotuku andesites unconformably overlie the core of the Wahianoa planèze beneath Mitre Peak on southeastern Ruapehu (Fig. 3.7), and the flows may have run onto and spilled over the edges of the former glacier to be sporadically preserved high above the valley on its northern and southern sides. Makotuku package flows are characterised by relatively low $\mathrm{SiO}_{2}$ and $\mathrm{MgO}$ contents compared to Waitonga package lavas. 


\subsubsection{Whakapapa Formation $(<15$ ka)}

The Whakapapa Formation comprises post-glacial lava flows erupted at $<15 \mathrm{ka}$ at Ruapehu (Hackett, 1985). Some lava flows assigned to this formation by Hackett (1985) and Price et al. (2012) are now re-mapped to older formations, while conversely some flows previously assigned to the Mangawhero Formation are now assigned to the Whakapapa Formation here. New ${ }^{40} \mathrm{Ar} /{ }^{39} \mathrm{Ar}$ geochronology data presented here provide the first absolute ages for these flows (Table 3.2). Whakapapa Formation lavas are categorised into eruptive packages that form the mid-upper flanks of the edifice (Fig. 3.14). Of the post-glacial flows, two samples yielded positive eruption ages within $2 \sigma$ uncertainty of $0 \mathrm{ka}$ (Table 3.2). While the dating method precludes more precise chronological control, these are nevertheless valuable data that indicate late Holocene $(<5$ ka) eruption ages for these lavas, consistent with their geomorphological characteristics. A further 8 samples yielded WMPA of $\leq 15 \mathrm{ka}$ (Table 3.2). Time brackets for the eruptive packages are defined by taking into account individual ${ }^{40} \mathrm{Ar} /{ }^{39} \mathrm{Ar}$ WMPA and $2 \sigma$ uncertainties for all relevant flows in the package, or are given an approximate central age for packages with one dated flow. For flows without ${ }^{40} \mathrm{Ar} /{ }^{39} \mathrm{Ar}$ data, ages are inferred from stratigraphic and geomorphic relationships.

\subsubsection{Paretetaitonga package ( 15 ka)}

A sequence of 1-2 m-thick lava flows, breccias and pyroclastic material caps the peak of Paretetaitonga (2751 m a.s.1.; Fig. 3.15c) and the upper northwest flank (Fig. 3.11). Lavas flowed into the Whakapapaiti Stream valley down to $1300 \mathrm{~m}$ a.s.l. Interaction of lava with snow and ice at upper levels (>2200 $\mathrm{m}$ a.s.1.) is evident in the form of deflected and impounded flow morphologies and the presence of fine-scale column-forming joints and pseudopillow fractures on flow margins (Conway et al., 2015). However, evidence for wholesale damming of these flows is absent, suggesting that ice volumes were of lesser extent than during eruption of Mangawhero Formation lavas. Similarly the summit geometry of a partial cone of successive lavas suggests a relatively ice-free vent area was established. The timing of flow emplacement is constrained by an age of $14.8 \pm 3.0 \mathrm{ka}$, measured for a mid-sequence lava flow within the Paretetaitonga package. Further age constraints come from the flows' emplacement above Whakapapaiti dacite $(25.7 \pm 3.8 \mathrm{ka})$ and the switch to northern flank construction following sector collapse and emplacement 
of the Murimotu Formation debris avalanche deposit at $10.5 \mathrm{ka}$ (see Iwikau package below). Individual flows were emplaced relatively rapidly, as they are stacked in a similar manner within the Whakapapaiti valley and share similar compositions $\left(58.5\right.$ wt. \% $\mathrm{SiO}_{2}$; 4.5 wt. $\% \mathrm{MgO} ; 1.6$ wt. $\left.\% \mathrm{~K}_{2} \mathrm{O}\right)$.

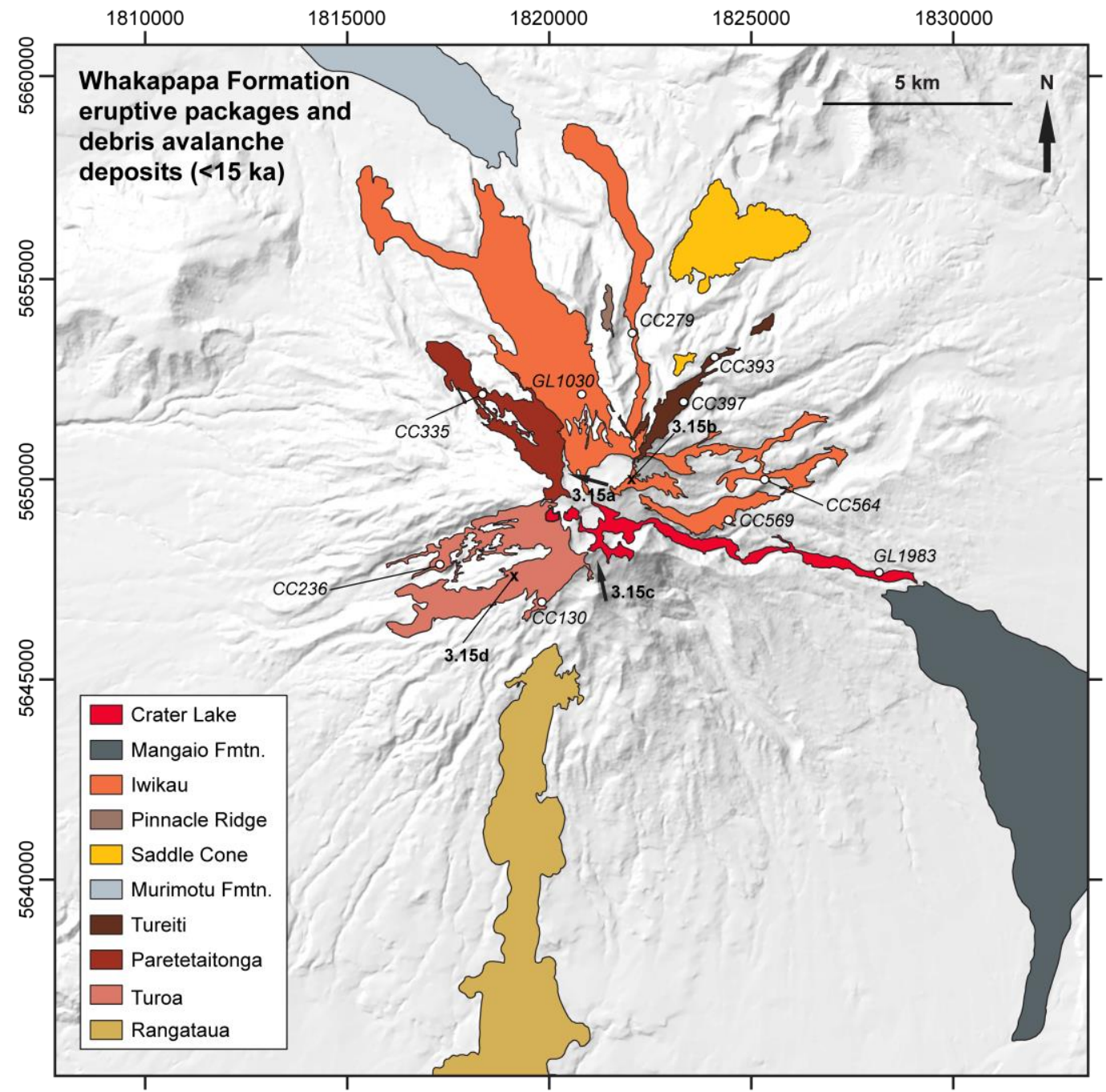

Figure 3.14. Distribution of Whakapapa Formation eruptive products and debris avalanche deposits. Locations for dated samples and relevant figures are displayed, as in Fig. 3.4.

\subsubsection{Turoa package (17-10 ka)}

Andesite lavas within the Turoa package were emplaced above and adjacent to older icemarginal flows over much of the upper southwest flank at 1500-2800 $\mathrm{m}$ a.s.1. of the Ruapehu edifice between the Mangaturuturu and Mangaehuehu valleys. Timing of effusion is constrained by an age of $15.1 \pm 2.4 \mathrm{ka}$ for a lava flow that was bounded to the 
south by a glacier that had a greater volume than the current Mangaehuehu Glacier. The youngest lavas of the Turoa package are a group of at least three andesite flows erupted in quick succession that exhibit complex stratigraphic relationships with older ice-marginal flows on the flank west of Tahurangi. The middle of the three observed flows yielded an eruption age of $11.9 \pm 2.2 \mathrm{ka}$ (Table 3.2). The flows exhibit fracture textures indicative of interaction between lava and ice/snow at $~ 1600 \mathrm{~m}$ a.s.l., however, evidence of wholesale impoundment by ice is absent. The remnant southwest Turoa cone exhibits a relatively intact sequence of lavas to the west-southwest, indicating that a relatively ice-free vent area was established. The northern and eastern portions of the cone are absent (Fig.

3.15c), however, and are inferred to have collapsed to form the Mangaio Formation debris avalanche deposit, which was emplaced down the eastern flank at $\sim 4.6 \mathrm{ka}$ (Donoghue and Neall, 2001).
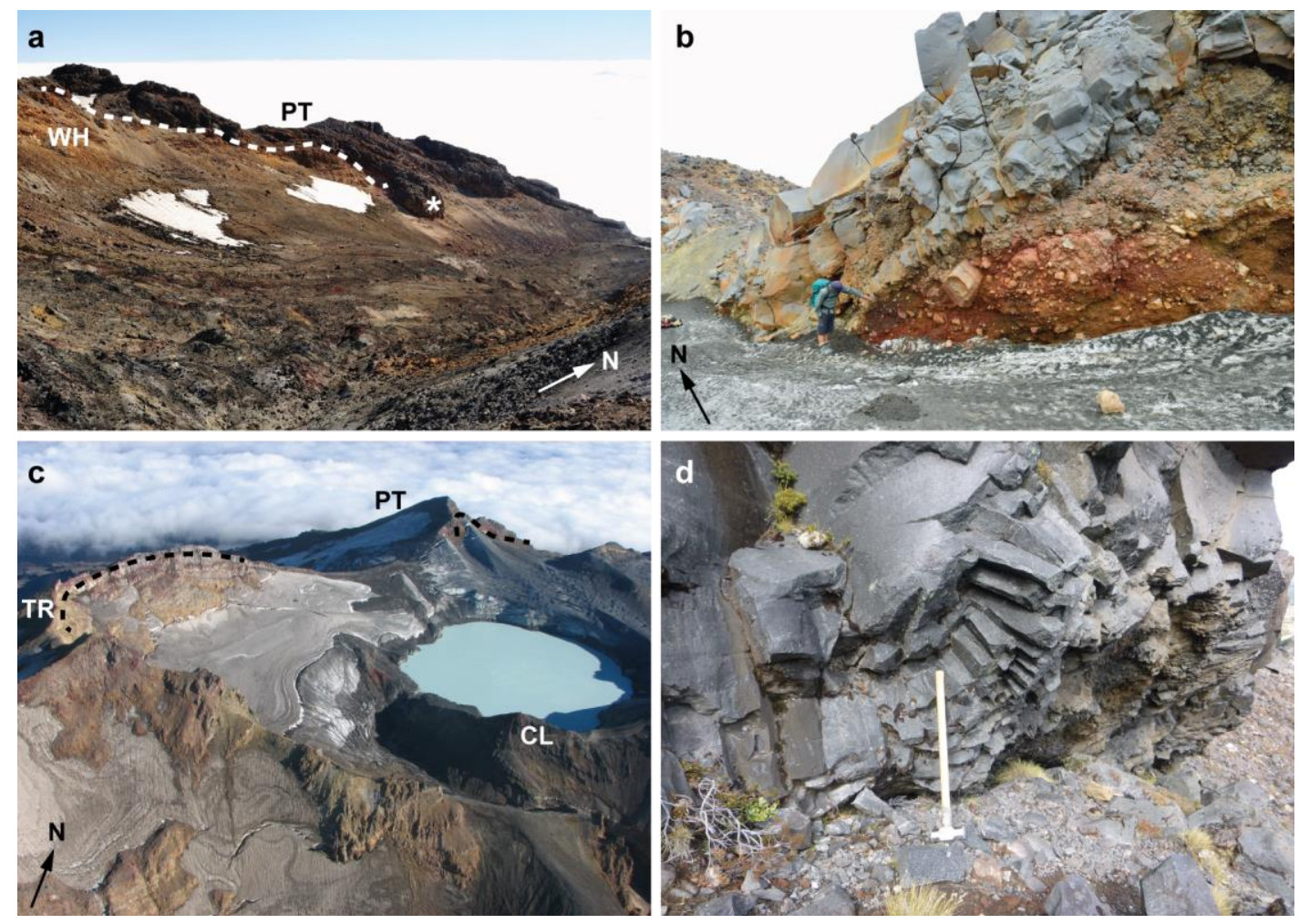

Figure 3.15. Features of Whakapapa Formation package lavas. a) Contact (dotted line) between $\sim 26 \mathrm{ka}$ Whakapapaiti eruptive package dacite lavas (WH; orange) and overlying $~ 15$ ka Paretetaitonga package andesite lavas (PT; dark). Star marks ice-bounded knuckle. b) Exposure of the chilled base of an Iwikau package andesite lava flow with column-forming joints, which grades into baked till on the eastern Summit Plateau. c) View of the western side of the summit reveals the collapse scars (dotted lines) inward of summit cones comprised of Turoa (TR) and Paretetaitonga (PT) package lava flows. The collapsed southern cone has been infilled by eruptive products of the Crater Lake package (CL). d) Fine-scale column-forming joints at the base of a glassy Turoa package andesite lava on southwest Ruapehu. Sledgehammer is $\sim 1 \mathrm{~m}-$ long. 


\subsubsection{Rangataua package ( 15 ka)}

Rangataua package consists of a $\sim 15 \mathrm{~km}$-long series of overlapping flow lobes and pyroclastic deposits on Ruapehu's southern flank (Hackett, 1985; Price et al., 2012). The source of the flow is uncertain: the topographically highest outcrop is at $1980 \mathrm{~m}$, where welded spatter and pyroclastic material was interpreted by Hackett (1985) to represent a collapsed vent. Alternatively, the vent may have been higher on the volcano and the lava flowed initially down the Mangaehuehu Glacier before it was diverted off the glacier through a low saddle to be emplaced on the relatively ice-free southern flank. Whichever hypothesis is correct, the Rangataua eruptive package was excluded from the Mangaehuehu valley to the west, likely due to the presence of valley-filling ice at the time of eruption. At lower elevations ( 1600-1400 m a.s.l.) the flow laps onto 15-11 ka moraines (Eaves, 2015). Rangataua package andesites are uniformly glassy, and no samples suitable for ${ }^{40} \mathrm{Ar} /{ }^{39} \mathrm{Ar}$ geochronology could be obtained. The $\sim 15 \mathrm{ka}$ age is therefore inferred from contact relationship with the moraines and their exclusion from the Mangaehuehu Valley by then present ice.

\subsubsection{Tureiti package (15-9 ka)}

This package consists of glassy, flow-banded, slope-mantling lavas and pyroclastic material on the upper northeast flank of Ruapehu. The lavas, two of which are dated at $12.5 \pm 2.6 \mathrm{ka}$ and $11.9 \pm 2.8 \mathrm{ka}$, overlie Te Piripiri package andesite lavas of the Mangawhero Formation and exhibit evidence (ice-contact fracture networks and flow morphologies) for interaction with $\sim 20$ m-thick accumulations of ice/snow at 1400-1800 $\mathrm{m}$ a.s.l. The remnant Tureiti cone is well-formed and appears to have established a relatively ice-free vent area, however, its uppermost portion is not preserved. Distinct vent foci and magma systems are inferred for Tureiti and Paretetaitonga cones based on the compositional characteristics of their respective lava flows (Fig. 3.14; Table 3.3).

\subsubsection{Iwikau package $(<10 \mathrm{ka})$}

This package comprises andesite lava flows erupted from a cone that is concealed beneath the present-day Summit Plateau ice field (Fig. 3.14). The north-western and eastern rims 
of the cone sit at a lower elevation $(<2700 \mathrm{~m})$ than upper outcrops of lavas of the Paretetaitonga $(2751 \mathrm{~m})$ and Tureiti $(2732 \mathrm{~m})$ packages, indicating that the summit height had been reduced prior to eruption of Iwikau package lavas. Changes to the summit morphology coincide with: (1) cessation of construction of the west-northwest Paretetaitonga package-forming cone ( 15 ka) and northeast Tureiti package-forming cone ( 12 ka), and (2) emplacement of the $10.5 \mathrm{ka}$ Murimotu Formation debris avalanche deposits at $<1100 \mathrm{~m}$ a.s.l. on north-eastern Ruapehu from a sector collapse event (Palmer and Neall, 1989; Eaves et al., 2015). Iwikau eruptive package lavas were emplaced atop the Murimotu Formation on the north-western flank of Ruapehu and are therefore inferred to be younger than $10.5 \mathrm{ka}$. Three distinct flow groups within the Iwikau eruptive package are defined on the basis of spatial distribution and geochemistry and are temporally constrained by the first radiometric ages for these Holocene lava flows:

1. The Taranaki Falls lava flow $(8.8 \pm 2.8 \mathrm{ka})$ is rootless from the summit vent perhaps due to emplacement over, or erosion by, a now-retreated glacier. Below $1700 \mathrm{~m}$ a.s.l. the flow is confined to the floor of the Wairere Stream valley and displays levees perched up to $80 \mathrm{~m}$ above the adjacent valley sides at the narrowest point in the valley (Fig. 3.5), suggesting that the lava was emplaced as a single flow that filled the valley before being drained. The flow terminates at $1120 \mathrm{~m}$ a.s.l. with a $40 \mathrm{~m}$-high bluff, which likely formed as the flow attenuated on nearly flat ground rather than due to glacial impoundment.

2. The Iwikau group of flows is a voluminous sequence of lavas that forms the northern flank of the edifice from west of Pinnacle Ridge to the easternmost part of the upper Whakapapaiti Stream catchment, (Fig. 3.5). They uncomformably overlie Tureiti package flows and form the prominent Te Heuheu and Tukino peaks on northern Ruapehu (Figs. 3.2, 3.14). Evidence for lava-ice interaction above $1800 \mathrm{~m}$ a.s.l. is present in the form of overthickened flow margins with fine-scale fracture networks indicative of chilling against ice (Conway et al., 2015). The timing of flow emplacement is constrained by a new ${ }^{40} \mathrm{Ar} /{ }^{39} \mathrm{Ar}$ eruption age of $6.0 \pm 2.4 \mathrm{ka}$ (Table 3.2), which was collected from a mid-sequence flow within the group.

3. The Mangatoetoenui group of flows lies unconformably above Wahianoa Formation and Mangawhero Formation Tukino package flows on the eastern flank of Ruapehu volcano (Fig. 3.7). Interaction of flows with ice and till occurred on the summit 
(Fig. 3.15b) and upper flanks. Eruption of these flows is constrained by an age of $9.2 \pm$ $8.0 \mathrm{ka}$ for a flow at the Tukino ski field, which is ice-bounded and shows evidence for impoundment against a $\sim 60$ m-thick glacier, consistent with an early Holocene eruption age. An age of $0.8 \pm 5.6 \mathrm{ka}$ was measured for a flow on the eastern flank at $1300 \mathrm{~m}$ a.s.l. that appears to have not been affected by lower flank ice (consistent with a late Holocene eruption age) and laps onto the lateral margin of an ice-bounded Tukino package andesite flow within the Mangawhero Formation. Mangatoetoenui lavas were previously recognised as having encountered ice by Spörli and Rowland (2006), and were assigned to the Mangawhero Formation on the assumption that ice of sufficient volume to bound the flow must have been present at or before $20 \mathrm{ka}$. The new age data presented here instead indicate that ice thicknesses sufficient to impound 20-80 m-thick lava flows were present on the upper eastern flank at 1500-2200 m a.s.l. during the early Holocene. Glacial striae observed on the top of Mangatoetoenui lavas further indicate they were overrun, but not substantially eroded, by Holocene glaciers after their emplacement.

\subsubsection{Saddle Cone package $(<10 \mathrm{ka})$}

The Saddle Cone package comprises the Holocene northern flank-vent-sourced Saddle Cone lavas and an isolated glassy lava flow on the northern flank at $\sim 1850 \mathrm{~m}$ a.s.l. (Figs. $3.5,3.14)$. Previously inferred to have been erupted from a flank vent at $1990 \mathrm{~m}$ a.s.l. (Hackett, 1985), the upper isolated flow may instead have originated from a summit vent eruption that delivered the lava down an ice- or snow-covered flank to its current termination. Saddle Cone andesites $\left(\sim 58.5\right.$ wt. \% $\left.\mathrm{SiO}_{2}\right)$ were erupted from the Saddle Cone vent at $1500 \mathrm{~m}$ a.s.l. The freshness of Saddle Cone package lavas and minimal tephra cover is consistent with their proposed $\sim 10$ ka eruption ages based on tephra cover sequences (Nairn et al., 1998).

\subsubsection{Pinnacle Ridge fall deposit ( 10 ka)}

The Pinnacle Ridge fall deposit is an isolated unit of the post-glacial Whakapapa Formation (Figs. 3.5, 3.14; Hackett and Houghton, 1989). It is a welded pyroclastic fall deposit that has a distinctly higher $\mathrm{SiO}_{2}$ content ( 61 wt. \%) when compared to Iwikau 
eruptive package lavas (Hackett, 1985). It was vented from a source close to its outcrop location on lower Pinnacle Ridge (Hackett and Houghton, 1989).

\subsubsection{Crater Lake package (<5 ka)}

This eruptive package comprises volcanic products erupted from Crater Lake, which consists of the unconsolidated mound of tephra and lava that forms Pyramid Peak (Figs. $3.2,3.14$ ) and a glassy andesite lava flow located within the Whangaehu valley (Fig. 3.12). The Whangaehu andesite lava flow can be traced from its termination at $\sim 1300 \mathrm{~m}$ a.s.l. to a vent source at Crater Lake, and yielded a WMPA within error of present day $(0.2 \pm 2.2 \mathrm{ka})$. In contrast to all other post-glacial flows, this lava has a relatively high $\mathrm{SiO}_{2}$ content of $\sim 61.5$ wt. $\%$, but lies within the wide compositional spectrum for historical products erupted through the Crater Lake ( 58-64 wt. \% $\mathrm{SiO}_{2}$ : Gamble et al., 1999; Nakagawa et al., 2002; Kilgour et al., 2013).

\subsection{DISCUSSION}

\subsubsection{Review of ${ }^{40} \mathrm{Ar} /{ }^{39} \mathrm{Ar}$ geochronology data}

Sequential sampling of stacked lava flows at composite volcanoes permits testing of the stratigraphic integrity of radioisotopic eruption age data and robust investigation of timecomposition relationships. Excepting flows of the Wahianoa Formation, thick sequences of lavas are rarely exposed at Ruapehu, however, due to the relationship between volcano growth and glacier fluctuations, resulting in complex stratigraphic contacts and lava flows with disparate, non-overlapping distributions (Conway et al., 2015). New and existing ${ }^{40} \mathrm{Ar} /{ }^{39} \mathrm{Ar}$ eruption ages now form a high-fidelity $200 \mathrm{kyr}$-long chronostratigraphic framework (Fig. 3.16), which constrains eruptive events and episodes in detail and allows interpretation of time-composition-volume relationships at Ruapehu. The timing of eruption history is compared to a global paleoclimate record from Lisiecki and Raymo (2005) for purposes of comparing the timing of volcanism to general periods of cool and warm climate as represented by the marine isotope stages (MIS) that are labelled in Figure 3.16. 
Previous workers have postulated that Ruapehu has an eruptive history that began $>100$ kyr prior to the age of its oldest 200 ka lavas (Tanaka et al., 1997; Gamble et al., 2003), although no eruptive products of such age have been described from the edifice. Age constraints from marine terraces, cover bed stratigraphy and ${ }^{40} \mathrm{Ar} /{ }^{39} \mathrm{Ar}$ eruption ages for lava clasts (geochemically associated with Ruapehu) within distal debris avalanche deposits indicate that initial edifice growth began at $340 \mathrm{ka}$ (Tost and Cronin, 2015).

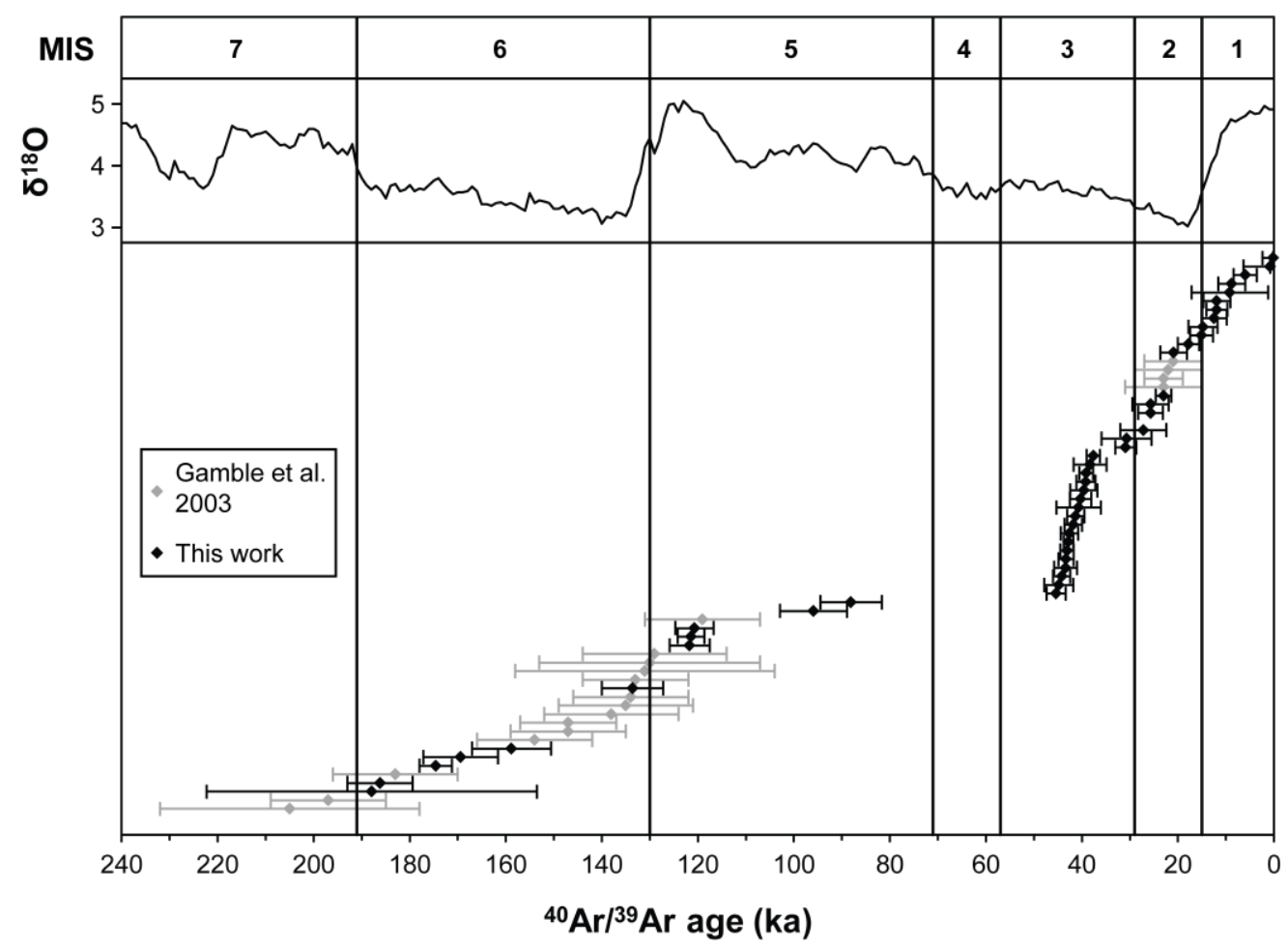

Figure 3.16. Effusive history of Ruapehu volcano compared to the global $\delta^{18} \mathrm{O}$ record and marine isotope stages (MIS; Lisiecki and Raymo, 2005). ${ }^{40} \mathrm{Ar} /{ }^{39} \mathrm{Ar}$ ages are displayed for samples from this study (black diamonds) and Gamble et al. (2003; grey diamonds) with $2 \sigma$ uncertainties (bars).

At the opposite extreme, a key objective of this study was to test the limitations of the ${ }^{40} \mathrm{Ar} /{ }^{39} \mathrm{Ar}$ geochronometer for young flows. WMPA eruption ages of $<5 \mathrm{ka}$ determined for this study (Table 3.2) are consistent with late Holocene ages from field evidence for the relevant flows. Three experiments on Holocene lavas produced $2 \sigma$ uncertainties of $2.2-$ $2.8 \mathrm{ka}$, which are comparable to those for older Mangawhero Formation lava flows and permitted the discrimination of lava flows into early $(10-5 \mathrm{ka})$ or late Holocene $(<5 \mathrm{ka})$ timeframes. This level of precision has previously not been achieved in any other studies of such young andesite lavas (e.g. Jicha et al., 2012). The results of this study support the application of ${ }^{40} \mathrm{Ar} /{ }^{39} \mathrm{Ar}$ dating to determine eruption ages for Holocene andesite lavas 
with optimal $2 \sigma$ uncertainties of $\sim 2 \mathrm{kyr}$. Several Holocene flows were unable to be dated because emplacement and erosion of the lava had not exposed slowly cooled holocrystalline interior zones. These include andesite lava flows of the Rangataua and Saddle Cone eruptive packages.

\subsubsection{Volcanic evidence for glacial history}

Recognising and incorporating volcano-ice interactions into geological mapping of glaciated composite volcanoes is important for understanding their eruptive histories and morphologies, and can also provide valuable paleoclimate information (Stevenson et al., 2006). The crystalline or well-lithified nature of glaciovolcanic deposits (i.e. lava flows and volcanic breccias that have interacted with ice; Edwards et al., 2015) makes them resistant to erosion and, therefore, useful for extracting geochronological information that is pertinent to former ice extents (Russell et al., 2014). This gives them an advantage over glacial deposits and landforms such as till and moraines, which are susceptible to erosion between and during subsequent glaciations. Ruapehu has coeval eruptive and glacial histories and the past presence of ice on the edifice has strongly influenced emplacement of effusive products (Conway et al., 2015). Defining the temporal distributions of effusive glaciovolcanic products using ${ }^{40} \mathrm{Ar} /{ }^{39} \mathrm{Ar}$ geochronology enables former glacier extents at Ruapehu volcano to be constrained. Glacial impoundment and the associated overthickening and slow cooling of the interior zones of thick flows of the Mangawhero Formation have produced favourable groundmass textures for ${ }^{40} \mathrm{Ar} /{ }^{39} \mathrm{Ar}$ dating. These zones have been exposed via erosion of the steep and finely fractured quenched lava flow margins. Fortuitously, Mangawhero Formation lava flows also contain relatively high $\mathrm{K}_{2} \mathrm{O}$ contents that further aid ${ }^{40} \mathrm{Ar} /{ }^{39} \mathrm{Ar}$ measurement. The precision of the age measurements here permit ice extent reconstructions that are resolvable on timescales of 2-3 kyr during the period 50-15 ka.

\subsubsection{Sub-glacial volcanism}

Edifice-forming units of volcaniclastic breccia that underlie sequences of lava flows emplaced from $200 \mathrm{ka}$ (Te Herenga Formation) and 166 ka (Wahianoa Formation) were originally interpreted as hydrothermally altered vent-association breccias (Hackett 
and Houghton, 1989; Smith et al., 1999). Their volcanic origins are re-interpreted here as hyaloclastite breccia formed via magma-water/ice interaction. Basaltic and rhyolitic hyaloclastites have been described from Iceland and Antarctica (e.g. McGarvie, 2009; Skilling, 2009; Smellie et al., 2011), however, intermediate composition subglacial hyaloclastite breccias have only been observed or documented very rarely (e.g. Kerlingarfjöll, Iceland; Stevenson et al., 2009). Emplacement of the hyaloclastite mounds was also associated with ice-marginal effusion of basaltic-andesite lava flows. Once eruptive vents breached the surface of the confining glaciers and meltwater, lavas flowed downslope between glaciers and were sequentially emplaced marginal to glaciers at lower elevations. The northern ridges (Te Herenga Formation) and southeast planèze (Wahianoa Formation) are interpreted to have formed in this way. These older edifices resemble tindar ridges or complex tuyas, however, without the wide coherent lava caps typical of basaltic tuyas (Russell et al., 2014). Exposed thicknesses of basal hyaloclastite breccias of the Te Herenga and Wahianoa formations are $\geq 100 \mathrm{~m}$, indicating that glaciers of at least equivalent ice thicknesses were present.

The most precise eruption ages measured for Te Herenga Formation lavas are between $\sim 190$ and 170 ka (Fig. 3.16). Emplacement of Te Herenga Formation hyaloclastite breccias are therefore inferred to have occurred during this time, which coincides with the glacial MIS 6 (Fig. 3.16; Lisiecki and Raymo, 2005). Hyaloclastite breccias beneath the Wahianoa Formation on the southeastern flank of Ruapehu are also assigned a MIS 6 emplacement age based on their position beneath lavas with eruption ages of $<160 \mathrm{ka}$. This reconstruction implies that the large ice caps and glaciers were sustained on Ruapehu at elevations of 2200-1500 m a.s.l. throughout MIS 6. An earlier edifice, reflecting volcanism at Ruapehu at $\sim 340 \mathrm{ka}$ (Gamble et al., 2003; Tost et al., 2015), provided sufficient elevation to host the ice mass. The elevation information taken from the distribution of the Te Herenga and Wahianoa formation breccias should be considered in the context of subsidence associated with a tectonic overprint of down-faulting and extension, however, suitably precise slip rates are not available to quantify this issue (Villamor and Berryman, 2006a). 


\subsubsection{Preservation and exposure of MIS 5 volcanic products at Ruapehu}

It has been proposed that the deflection of lava flows by valley glaciers toward emergent ridges occurs during glacial periods in contrast to emplacement of lavas within valleys during interglacial periods (Lescinsky and Sisson, 1998). While the relationship between an interglacial climate and consequent valley-floor lava emplacement is evident for Holocene flows at Ruapehu volcano (Conway et al., 2015), it is harder to ascertain the same link for older interglacial lavas that may have been subsequently eroded and/or buried.

The hypothesis of valley-floor lava emplacement was tested for MIS 5, a relatively warm period and a previously inferred period of eruptive inactivity in Ruapehu's history (Fig. 3.16; Gamble et al., 2003), by measuring eruption ages for lava flows with characteristics of interglacial flows (i.e. intra-valley locations, low slope angles, long-run-out distances, covered by till). Eruption ages of $95.9 \pm 3.5$ and $88.1 \pm 3.2$ ka were measured for two such lava flows, which fall within MIS 5 (Lisiecki and Raymo, 2005). The lava flows have comparable compositions to older planèze-forming lava flows of the Wahianoa Formation, and are therefore inferred to represent products from a continued magma system rather than being sourced from a new system that commenced at $\sim 100 \mathrm{ka}$. The previously interpreted eruptive hiatus at $\sim 115-80 \mathrm{ka}$ (Gamble et al., 2003) reflected a sampling gap for poorly preserved lavas erupted during middle-late MIS 5 (Fig. 3.16). This is likely to be a common feature at glaciated composite volcanoes globally (e.g. Volcán Parinacota; Hora et al., 2007).

\subsubsection{Glacier reconstructions using ice-marginal lava flows}

In a compilation of paleoclimate records from speleothems, Williams et al. (2015) identified that during the last glaciation (i.e. MIS 4-2; Lisiecki and Raymo, 2005), maximum ice extents in New Zealand occurred at $\sim 66-61 \mathrm{ka}$, an advance of mountain glaciers occurred at $\sim 42-38 \mathrm{ka}$, and the timing of the New Zealand equivalent of the global LGM (i.e. 26-19 ka; Clark et al., 2009) occurred at 32-28 ka. Exposure age dating of moraines in the South Island of New Zealand has led to the identification of moraine-building events under full glacial conditions at $\sim 42 \mathrm{ka}, \sim 28-25 \mathrm{ka}, 21 \mathrm{ka}$ and 18 ka (Putnam et al., 2013a, 2013b; Kelley et al., 2014). Two discrete glacial advances are 
recorded by moraine formation at $>57 \mathrm{ka}$ and $\sim 30-18 \mathrm{ka}$ at nearby Tongariro volcano (Eaves et al., 2016a). The distribution of ice-marginal lava flows erupted since $\sim 50 \mathrm{ka}$ at Ruapehu provides a valuable independent record of glaciation at this location in New Zealand.

Former ice extents at Ruapehu through time are constrained by a compilation of the elevations, extents, distances above glaciated valleys, and ages for lava flows that were emplaced against major valley-filling glaciers (Fig. 3.17). The vertical offset of icemarginal flows above glaciated valley floors is used to estimate former glacier thicknesses (values rounded to nearest $10 \mathrm{~m}$ ). The data indicate that former glaciers were 100-160 m-thick at elevations of $\sim 1500 \mathrm{~m}$ a.s.l. between $\sim 48$ and $35 \mathrm{ka}$. Moraines and lower extents of ice-marginal flows indicate that glaciers descended to elevations of $\sim 1200 \mathrm{~m}$ a.s.1., which is consistent with full glacial conditions at this time (McArthur and Shepherd, 1990; Eaves et al., 2016a). Synchronous cooling between Antarctica and New Zealand at $\sim 42 \mathrm{ka}$ has been proposed from moraine evidence in the Pukaki glacier region in South Island, New Zealand (Kelley et al., 2014). The age data for ice-marginal dacite lava flows on northwest Ruapehu serve to indicate the period of cooling may have lasted until at least $38 \mathrm{ka}$.

A sequence of ice-bounded flows that form the true right side of the deeply glaciated Mangaturuturu River valley allows a detailed interpretation of glacier volume fluctuation during MIS 3-2. With increasing height above the glaciated valley floor, lava flows yielded ages of $27.2 \pm 4.8 \mathrm{ka}, 43.4 \pm 2.4 \mathrm{ka}, 40.7 \pm 4.6 \mathrm{ka}$, and $30.7 \pm 5.2 \mathrm{ka}$ (Fig. 3.12). A separate but proximal lava flow within the Manganuioteao package dated at $30.9 \pm 2.2$ $\mathrm{ka}$ is also elevated above its adjacent glacial valley by $\sim 180 \mathrm{~m}$. The distribution of dated lava flows indicates that the glacier volume within the Mangaturuturu valley was greater at $\sim 31 \mathrm{ka}$ than at $\sim 44-35 \mathrm{ka}$.

The glacier is inferred to have retreated rapidly after $\sim 31$ ka to account for the icemarginal emplacement of the flow closest to the valley floor at $\sim 27 \mathrm{ka}$. Emplacement of eruptive products and/or edifice collapse may have changed the summit and flank morphology of Ruapehu and, in doing so, altered ice pathways to restrict or enhance glacier flow into different catchments. This may have resulted in glacier dynamics unrelated to climate over the time period of emplacement of these lava flows. Notably, the $\sim 31$ ka timing of maximum glacier thicknesses on western Ruapehu is broadly 
consistent with full glacial conditions in the New Zealand Southern Alps at Pukaki at 28 ka (Kelley et al., 2014) and Waimakariri prior to 26 ka (Rother et al., 2015) and the incidence of New Zealand's global LGM equivalent at 32-28 ka inferred by Williams et al. (2015). The distribution of ice-bounded flows erupted between 28 and $18 \mathrm{ka}$ on southwest Ruapehu indicate former glacier thicknesses during this period were $<100 \mathrm{~m}$ at elevations of 1500-1700 m a.s.l. The data imply that glacial conditions at Ruapehu volcano during the global LGM at $20 \mathrm{ka}$ were not as fully developed as during former periods of cooling centred at $\sim 42$ and $\sim 31 \mathrm{ka}$.
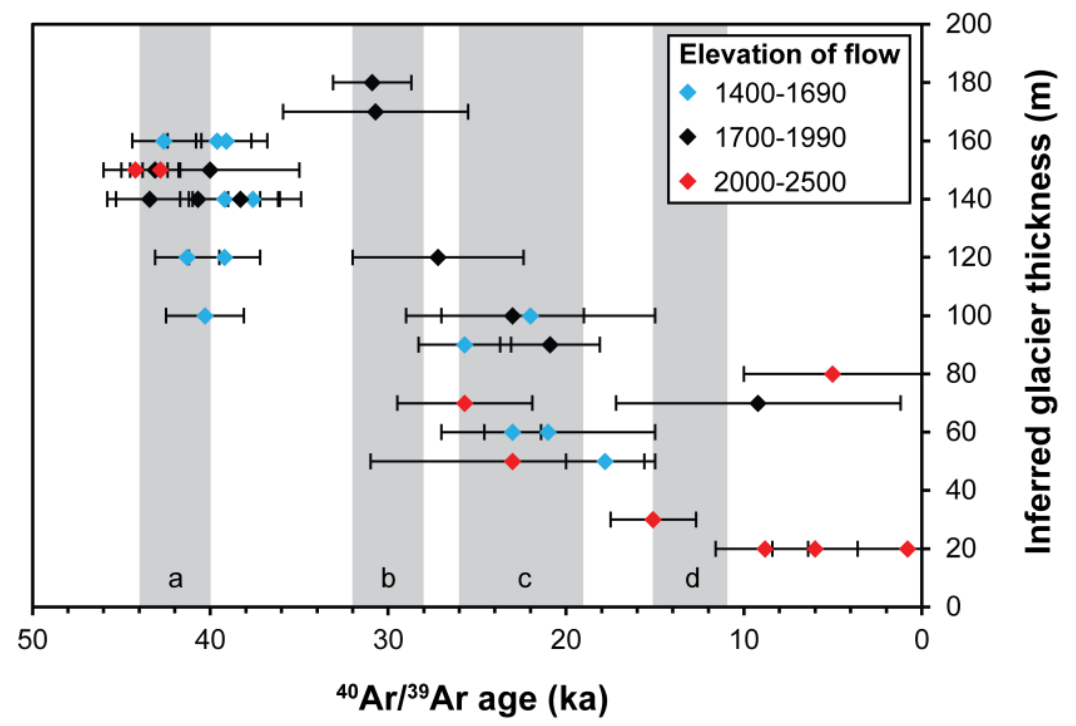

Figure 3.17. Ice extent at Ruapehu over the last $50 \mathrm{kyrs}$. Glacier thicknesses are inferred from the height of dated ice-marginal lava flows above glaciated valley-floors and rounded to the nearest $10 \mathrm{~m}$. Age data are presented in Table 3.2. Samples are coloured according to their elevation on the edifice. Shaded areas represent periods of glacial advance in New Zealand. The timing of cooling periods (a) and (b) is inferred from Southern Alps glacial moraines (Putnam et al., 2013a; Kelley et al., 2014) and speleothem records (Williams et al., 2015). The timing of period (c) correspond to the global Last Glacial Maximum (Clark et al., 2009). The timing of period (d) is inferred from moraines on Ruapehu and Tongariro volcanoes (Eaves, 2015).

Lava flows emplaced at $<20$ ka provide key clues to the rate of deglaciation at Ruapehu.

The $17.8 \pm 2.2 \mathrm{ka}$ age of an ice-bounded andesite flow that was emplaced against a $>50$ m-thick ice-wall within the Wahianoa River valley indicates that glacial retreat was underway by this time. Although the flow interacted with ice, it is $\sim 200 \mathrm{~m}$ lower than moraine crests bounding a valley that was fully glaciated at $\sim 43 \mathrm{ka}$ as indicated by eruption ages for ice-bounded lavas on its western side (Fig. 3.7). Any post-LGM glacial 
advances within the valley were not sufficient to have significantly eroded the fine columns that characterise this ice-bounded lava flow. Changes in the distribution and morphology of lava flows erupted since $\sim 15 \mathrm{ka}$ are linked to the post-LGM history of Ruapehu. On the upper flanks (>2200 m a.s.l.) of the edifice <15 ka lava flows display evidence (i.e. localised ice-contact fracture networks, metre-scale overthickening, superficial glacial striae) for minor interaction with glaciers similar in extent to those present in historic times (Heine, 1963). At <1700 m a.s.l., <15 ka lava flows were emplaced on the floors of the previously glaciated valleys. Eruption ages for these flows constrain wholesale glacier retreat at Ruapehu between 18 and $15 \mathrm{ka}$. However, glacial fluctuations in response to short-term climate variability since $\sim 18 \mathrm{ka}$ on Ruapehu are complex (Eaves, 2015) and beyond the resolution of the ${ }^{40} \mathrm{Ar} /{ }^{39} \mathrm{Ar}$ geochronology dataset. The geomorphic distinction between ice-bounded lava of the syn-glacial Mangawhero Formation and intra-valley lavas of the post-glacial Whakapapa Formation is underpinned by the new geochronology data reported in this study.

\subsubsection{Compositional evolution of Ruapehu lava flows}

Whole-rock geochemical analyses of Ruapehu lavas show archetypical continental crustlike major and trace element characteristics of global orogenic andesites and dacites (Cole, 1978; Gill, 1981). On closer inspection, they comprise diverse crystal cargoes hosted within dacitic to rhyolitic melts and are interpreted to represent the products of a complex interplay of assimilation, crystal fractionation, crustal anatexis and magma mixing processes within the lithosphere (Hildreth and Moorbath, 1988; Gamble et al., 1999; Price et al., 2012). The extent of magma differentiation generated by the combination of these processes has been inferred to have generally increased with time as reflected by increasing $\mathrm{SiO}_{2}$ contents and ${ }^{87} \mathrm{Sr} /{ }^{86} \mathrm{Sr}$ values in progressively younger eruptive products (Graham and Hackett, 1987; Price et al., 2012). However, a lack of age data for post-50 ka lava flows has precluded a detailed investigation of this trend. A principal goal when studying composite volcanoes is to assess the variation in magma compositions over time-scales of tens to hundreds of kyr. The time-sequenced compositional variation of Ruapehu lava flows represents the $\sim 200 \mathrm{kyr}-l$ ong development of the overall magmatic system. While this idea has been explored for Ruapehu in previous work using a combination of petrology, major and trace element geochemistry, 
and radiogenic isotope characteristics (Graham and Hackett, 1987; Gamble et al., 1999; 2003; Price et al., 2005; 2012), the improved chronological control and sampling resolution achieved in this study permits further interrogation.

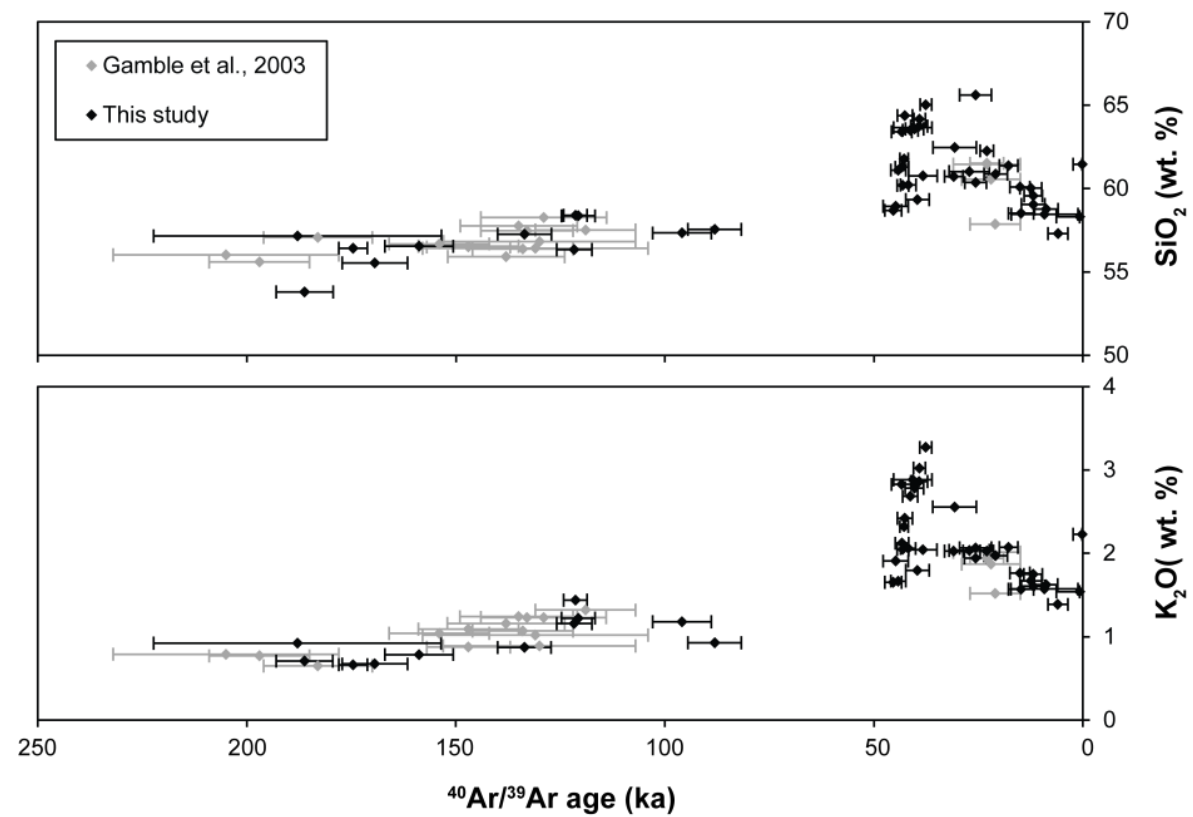

Figure 3.18. Compositional evolution of lava flows versus eruption ages determined in this study (black diamonds) and by Gamble et al. (2003; grey diamonds). Error bars are $2 \sigma$ uncertainties of the eruption age measurements.

Ruapehu lava flows display a gradual increase in $\mathrm{SiO}_{2}$ and $\mathrm{K}_{2} \mathrm{O}$ from $\sim 200$ to $80 \mathrm{ka}$ (Fig. 3.18). The $186.2 \pm 6.8$ ka eruption age determined for the most mafic lava exposed on Ruapehu (CC348; 'Ruapehu basalt' of Price et al., 2012) amends its previous assignment to the Mangawhero Formation by Hackett (1985). Following a gap in effusive activity between 80 and $50 \mathrm{ka}$, compositional diversity was greatest during the period from $\sim 48-$ $35 \mathrm{ka}$ and, despite a lack of lavas with $\mathrm{SiO}_{2}$ contents between 62 and 63 wt. \%, effusion of dacite was prevalent during this time. Based on their $\mathrm{MgO}$ contents, lavas that were erupted between 48 and 35 ka define a broad bimodal diversity (Fig. 3.19). Mangaehuehu package andesites and Te Kohatu package dacites form a high-MgO trend when plotted against $\mathrm{SiO}_{2}$, whereas Ngahuinga package andesites and Mangaturuturu package dacites align with a lower- $\mathrm{MgO}$ compositional array, which is also representative of all other Ruapehu lavas (Fig. 3.19). The only other lavas from Ruapehu that plot on the high-MgO trend are 26 ka Whakapapaiti package dacite flows, however, these have distinctly lower $\mathrm{K}_{2} \mathrm{O}$ concentrations (Table 3.3). The coeval eruption of compositionally 
distinct andesite and dacite packages, some of which have wide-ranging linear trends, implies the presence of a complex magma system for Ruapehu volcano at this stage of edifice growth. A gap in lava flow ages at $\sim 80-50$ ka precedes this phase (Fig. 3.16) and may represent a period during which magma bodies were stalled and differentiated by a range of processes, including mixing, crystal fractionation and crustal assimilation.

Lava flows erupted at $\sim 30$ ka have a relatively narrow range of compositions that are intermediate within the range defined by the 48-35 ka lavas and fall within the 62-63 wt. $\% \mathrm{SiO}_{2}$ compositional gap mentioned above. Post-25 ka lava flows display a trend to progressively less silicic and less potassic compositions with time, following eruption of Whakapapaiti package dacites (Fig. 3.18). The one exception to this trend is the late Holocene Whangaehu lava flow within the Crater Lake eruptive package $(61.5$ wt. \% $\mathrm{SiO}_{2}$ ). The strength of this trend contrasts with prior studies that surmised that Ruapehu eruptive products have generally become more evolved and compositionally variable with time (Graham and Hackett, 1987; Gamble et al., 1999; Price et al., 2012). This inference was influenced by inaccurate age control and incomplete sampling and has been refined with the improved chronostratigraphy provided here.

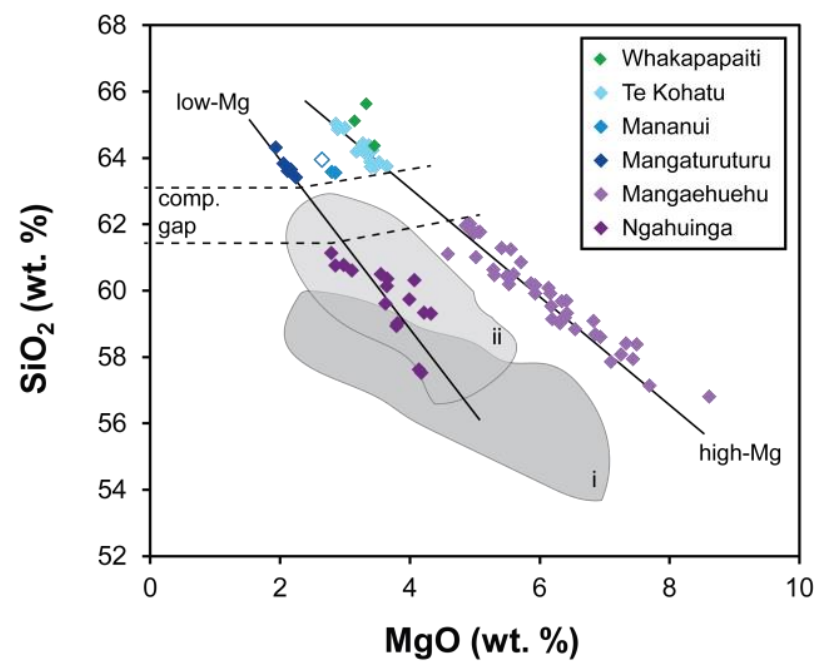

Figure 3.19. $\mathrm{SiO}_{2}$ versus $\mathrm{MgO}$ (wt. \%) diagram for 50-36 ka lava flows and $26 \mathrm{ka}$ Whakapapaiti package dacite. Open blue diamond is the dacite clast sample from the Murimotu Formation (Hackett, 1985). Lines are drawn for high- and low-MgO trends. Dotted lines correspond to the compositional gap for 50-36 ka lavas. Shaded fields indicate compositional ranges for pre-80 ka (i) and post-25 ka lavas (ii).

A model of random tapping of small batches of magma that have followed distinct lithospheric pathways of mixing and contamination has been inferred to explain the 
generation of magmas and the complex and non-systematic geochemical changes over timescales of tens of years to tens of kyr observed in erupted products at Ruapehu (Gamble et al., 1999, 2003; Price et al., 2005, 2012) as well as globally (e.g. Dungan et al., 2001; Frey et al., 2004). In contrast, the enlarged dataset and careful sequencing of lavas presented here reveals a systematic and coherent long-term compositional evolution of effusive products. These trends are explored in detail in Chapter 4.

\subsubsection{Integrating explosive and effusive records at Ruapehu}

Effusive and explosive records are only rarely integrated in the study of complex volcanoes or volcanic fields (e.g. Hildreth and Fierstein, 2012) due to the different distributions and preservation potentials of lava flows and pyroclastic deposits. Amalgamating the two is important for understanding the hazards and periodicity of eruptive behaviour at arc volcanoes and requires high-resolution geochemical and geochronological control for both lava flows and pyroclastic deposits. Pyroclastic deposits on Ruapehu volcano are documented for the period from 27-10 ka (Donoghue et al., 1995a; Cronin and Neall, 1997; Pardo et al., 2012). This period coincides in time with frequent effusive activity (Fig. 3.16), which allows for the investigation of compositional, spatial and temporal relationships between effusive and explosive andesitic volcanism at Ruapehu. Lava flows with different compositions and spatial distributions were erupted at this time (Figs. 3.9, 3.10, 3.14), indicating that vents plumbed multiple different magma reservoirs during this period.

The composition, age and spatial distribution of Mangawhero Formation lavas and Whakapapa Formation lavas that formed post-glacial cones (northwest cone comprising 15 ka Paretetaitonga package lavas; southwest cone comprising 17-10 ka Turoa package lavas; and northeast cone comprising Tureiti package lavas at $~ 15-9 \mathrm{ka}$ ) are compared with tephras to test whether these cones were the sources for both effusive and explosive eruptions (Fig. 3.20). Te Piripiri package lavas (21 $\pm 6 \mathrm{ka})$ and Mangatoetoenui eruptive unit tephras ( $22 \mathrm{ka})$ on northeast Ruapehu display distinctly lower $\mathrm{SiO}_{2}$ and $\mathrm{K}_{2} \mathrm{O}$ contents than other eruptive products of this age, however, they do not overlap (Fig. 3.20). Tephras of the Shawcroft ( 13 ka), Oruamatua (13-12 ka), and Okupata-Pourahu (11.6 ka) eruptive units (terms from Donoghue et al., 1995a) define a compositional range that also overlaps with lava flows of the same age (Fig. 3.20). 
Pardo et al. $(2012,2014)$ suggested that the vent focus changed from north to south on Ruapehu's summit plateau for the $\sim 11.6$ ka eruptive phase based on isopach maps for tephra deposits. New results presented here indicate that voluminous effusive activity was occurring from both northern and southern vents during this period giving rise to emplacement of Tureiti and Turoa package lavas, respectively. Effusive activity later continued from a northern vent that erupted the Taranaki Falls flow $(8.8 \pm 2.8 \mathrm{ka})$, Iwikau flows $(6.0 \pm 2.4 \mathrm{ka})$ and Mangatoetoenui flows $(0.8 \pm 5.6 \mathrm{ka})$. These lava flow extents and ages preclude a complete switch to a southern eruptive vent at $11.6 \mathrm{ka}$ as inferred by Pardo et al. (2012, 2014).

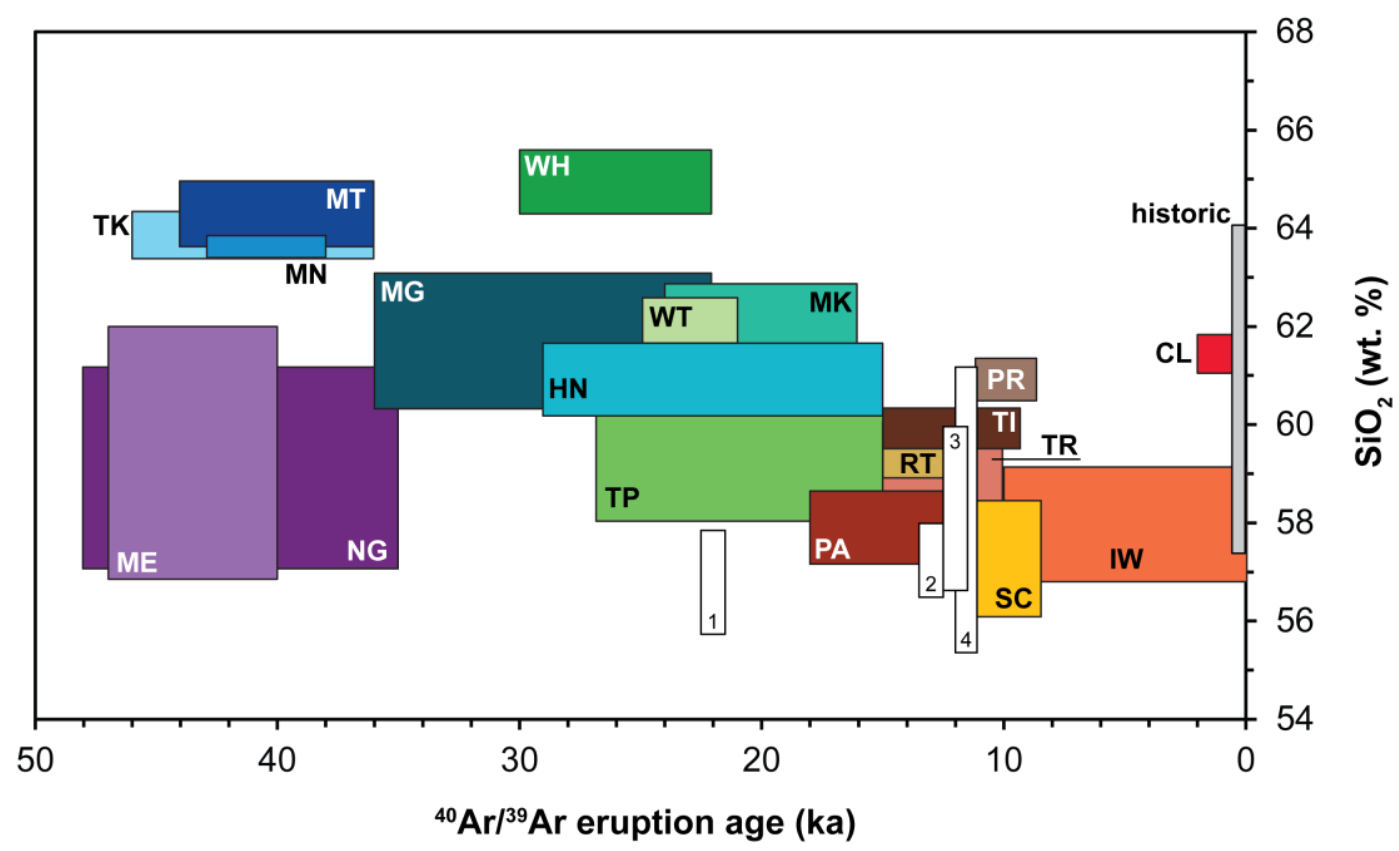

Figure 3.20. $\mathrm{SiO}_{2}$ (wt. \%) versus eruption age for Mangawhero and Whakapapa formation lava flows and pyroclastic deposits. Boxes represent $\mathrm{SiO}_{2}$ and age ranges for each eruptive package (colour key and abbreviations in Fig. 3.3). Numbered bars represent whole-rock compositional ranges (data from Pardo et al., 2012) for pyroclasts from Plinian eruptions forming the: Mangatoetoenui Tephra (1); Shawcroft Tephra (2); Oruamata Tephra (3); Okupata-Pourahu Tephra (4). Whole-rock compositional range for pyroclasts from historical eruptions (grey bar) uses data from Gamble et al. (1999), Nakagawa et al. (2002) and Kilgour et al. (2013).

The systematic long-term variation of lava flow compositions outlined in the preceding section (Compositional evolution) contrasts with the wide compositional array of historic pyroclastic deposits, which encompasses the $\mathrm{SiO}_{2}$ content of most post-glacial Whakapapa Formation lavas (Gamble et al., 1999; Nakagawa et al., 2002; Kilgour et al., 2013; Fig. 3.20). This distinction likely reflects a difference in the sizes of the magma bodies involved in the respective eruptive styles: lavas were sourced from larger and 
more homogenized magma bodies whereas historical pyroclastic eruptions have tapped small, ephemeral and isolated magma bodies. Both effusive and explosive activity have occurred in parallel through to the late Holocene, however, only volumetrically minor lava eruptions have occurred historically (Houghton et al., 1987). Conversely, pyroclastic eruptions with volumes similar to historic events have not been well-preserved in the prehistoric geological record.

\subsubsection{Edifice-ring plain relationships}

Composite volcanoes are inherently unstable due to the deposition of complexly intercalated lavas and pyroclastic deposits at high elevations on steep slopes. Glaciated volcanoes are additionally prone to sector collapse due to the prevalence of glacial erosion and ice-marginal lava emplacement processes in addition to hydrothermal alteration, all of which act to destabilise volcanic material. The recognition of glacial debuttressing as a key factor in the generation of landslides in alpine settings (e.g. Cossart et al., 2008) also applies to glaciated volcanoes (e.g. Capra et al., 2013). The volume of Ruapehu's edifice is matched by its surrounding ring plain (Hackett and Houghton, 1989), reflecting a high flux of volcaniclastic material. Previous workers have suggested that erosion during glacial periods MIS 4 and 2 resulted in accelerated lahar deposition on northeast Ruapehu (Cronin and Neall, 1997). In contrast, Tost et al. (2014) inferred that large volume sector collapse events from Ruapehu occurred at the transition from glacial to interglacial periods during the period of $~ 340-200$ ka. Links between Ruapehu's edifice and ringplain are evaluated here through consideration of the processes that governed edifice instability throughout its growth history.

\subsubsection{Links between syn-glacial volcanism and ring plain deposits}

The recognition of volcano-ice interaction processes at Ruapehu has significant implications for understanding the generation of pre-historic debris avalanches and lahars. First, widespread evidence for lava-ice interaction for flows of the Mangawhero Formation (50-15 ka) indicates that large flank glaciers were then extant on Ruapehu. Modelling indicates that glaciers of such volume were likely fed by a large summit ice mass (Eaves, 2015). Lavas could only be emplaced on glaciated flanks of the edifice if 
eruptive vents were able to penetrate the summit ice field and feed material to emergent planèze flanks between valley glaciers (Lescinsky and Sisson, 1998). In doing so magmaice interaction must have generated (1) large quantities of meltwater as the ice was thermally eroded (Wilson and Head, 2007), and (2) volcaniclastic deposits that were subject to intense hydrothermal alteration as lava was fragmented and fluxed by meltwater and steam (e.g. Tuffen et al., 2001).

Mixtures of lava, ash and meltwater would have produced syn-eruptive lahars, and the presence of hydrothermally altered deposits especially in the summit vent area may have had a longer-lasting impact by forming an unsteady base upon which subsequent summit lavas were emplaced. Such deposits are exposed between Tahurangi and Girdlestone Peak. Second, widespread ice-marginal emplacement of lavas at Ruapehu during MIS 3-2 produced steep flows perched above or on the side of valleys. Steep, thick, and pervasively fractured lava flows are liable to collapse and produce debris avalanches (e.g. Hickson, 2000). The collapse of steep ice-marginal lava flows onto glaciers during glacial periods (when ice extent fluctuated) or into valleys during interglacial periods are likely to have generated debris avalanches at Ruapehu. Third, a proportion of lava flows was likely emplaced onto glaciers during eruption and eventually conveyed to the ring-plain as clastic material fragmented by quench-contraction and glacier motion. The revised chemostratigraphy of Ruapehu volcano will enable dated ice-marginal lavas on the edifice to be matched with corresponding ring plain debris avalanche and laharic deposits using geochemical correlation in future studies.

\subsubsection{Causes of Holocene sector collapse events at Ruapehu}

Recognition and dating of major stratigraphic unconformities can provide understanding of the factors that promote sector collapses at composite volcanoes (e.g. Ownby et al., 2007). The cause of two major Holocene sector collapse events that resulted in the emplacement of debris avalanche deposits on the northern and southeastern flanks of Ruapehu are explored in this section. The Murimotu Formation comprises a hummocky debris field on northern Ruapehu that was emplaced at 10.5 ka (Palmer and Neall, 1989; Eaves et al., 2015). The Mangaio Formation comprises debris flow diamictons emplaced on the southeastern flank of Ruapehu at $4.6 \mathrm{ka}$ (Donoghue and Neall, 2001). The $10.5 \mathrm{ka}$ timing of emplacement of the Murimotu Formation follows the emplacement of lava 
flows of the Paretetaitonga $(14.8 \pm 3.0 \mathrm{ka})$ and Tureiti $(12.5 \pm 2.6 \mathrm{ka} ; 11.9 \pm 2.8 \mathrm{ka})$ eruptive packages on the upper northwest and northeast flanks respectively. These lavas form now-truncated summit cone structures that correspond to the inferred source position of the collapse (Figs. 3.14, 3.21). The cones are inferred to have been icebounded at the summit due to evidence for ongoing lava-ice interaction for upper flank lava flows of this age (Fig. 3.15a) and the deposition of $\sim 15-11$ ka moraines at elevations of $\sim 1800 \mathrm{~m}$ a.s.l. (Eaves, 2015). The presence of a summit ice cap during cone construction likely resulted in the production of clastic deposits during interaction with ice and/or water and extensive hydrothermal alteration of deposits (Fig. 3.15b). Due to the preceding $~ 30$ kyrs of volcano-ice interaction during MIS 3-2, the summit region was likely composed of steep topography, hydrothermally altered and fragmental deposits, which also provided an inherently unstable base beneath the younger cones (Fig. 3.15a).

Previous hypotheses for the generation of the northern sector collapse have invoked destabilisation of the northwest flank due to emplacement of a dacite cryptodome (McClelland and Erwin, 2003) or intrusion of dykes (Hackett and Houghton, 1989; Palmer and Neall, 1989). Emplacement of a dacite lava dome was proposed based on the measurement of $\sim 350^{\circ} \mathrm{C}$ emplacement temperatures for clasts within the deposit (McClelland and Erwin, 2003). Geochemical analyses were not undertaken for the clasts from which geomagnetic data and emplacement temperatures were acquired, however, and only one analysis has reported a dacitic composition for a clast within the Murimotu Formation (Hackett, 1985). Substantial dacite effusion occurred between 46 and $36 \mathrm{ka}$ (Figs. 3.9, 3.18), with a later episode at $\sim 26 \mathrm{ka}$, that produced lava flows on the northern and western flanks. There is no precedent for dome-forming activity during these periods of dacite effusion at Ruapehu recorded on the exposed edifice. Contrary to the conclusion from Hackett and Houghton (1989), dacite flows have now been mapped on the upper northwest flank of the Ruapehu edifice (Figs. 3.9, 3.10) and are exposed within the sector collapse scar region at $2600 \mathrm{~m}$ a.s.1. (Fig. 3.15a). Furthermore, effusion of dacite at $\sim 10.5$ $\mathrm{ka}$ is contradictory to the coherent trend towards basaltic-andesite compositions seen in eruptive products since $\sim 25 \mathrm{ka}$ (Fig. 3.18).

The occurrence of dacite clasts within the deposit can be accounted for by incorporation of older Mangawhero Formation dacite flows from the source area, as proposed by Palmer and Neall (1989). The characterisation of distinct compositions for dacite within the Mangawhero Formation allows correlation of the clast analysed from the Murimotu 
Formation by Hackett (1985) with the Mananui package flow (Fig. 3.19). This dacite flow on northern Ruapehu is inferred to have been erupted from a central or northern vent that coincides with the area of edifice collapse (Figs. 3.9, 3.21).
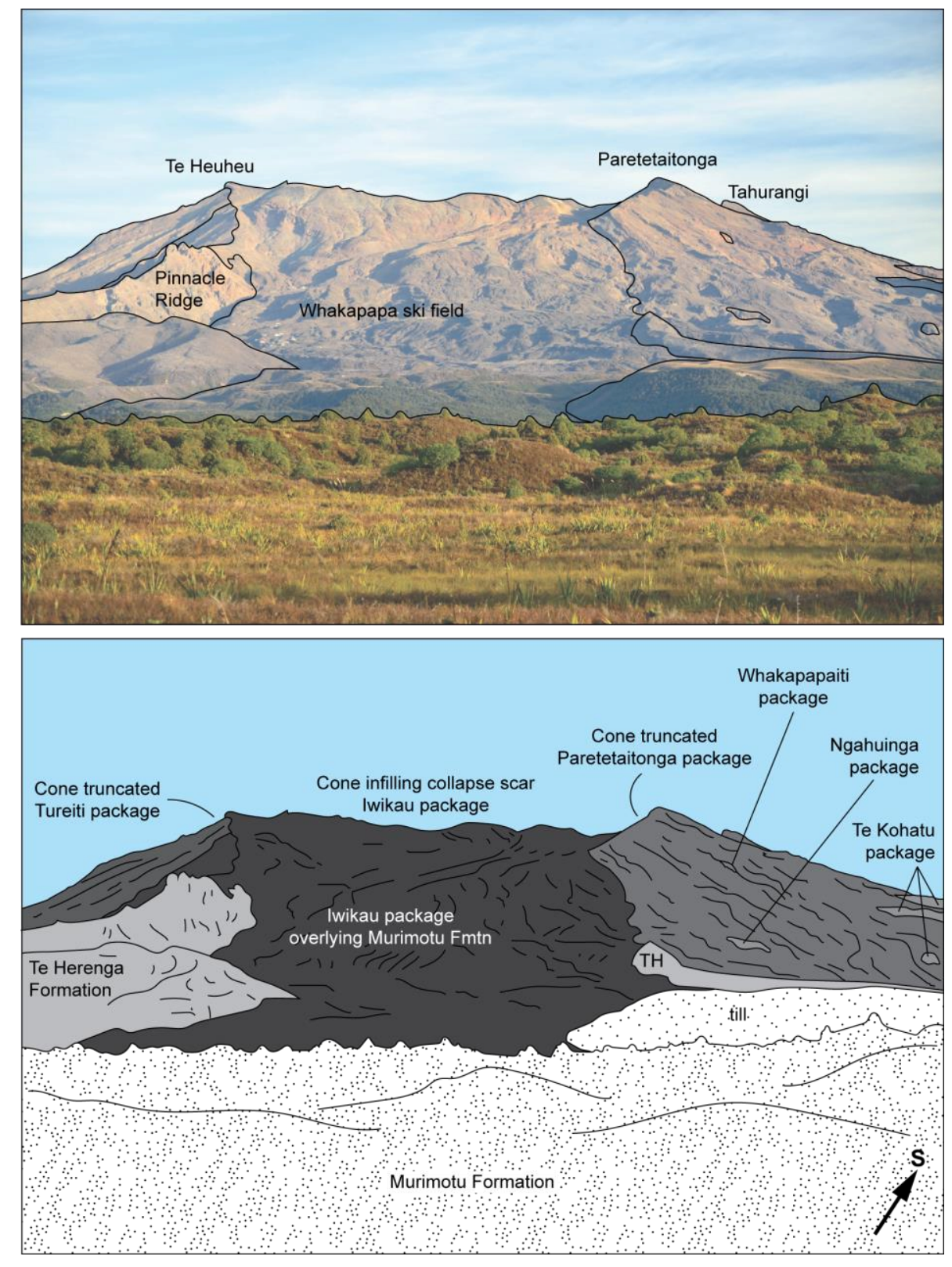

Figure 3.21. View of the northern flank of Ruapehu. The 10.5 ka Murimotu Formation debris avalanche deposit is inferred to have originated from collapse of pre-Holocene cones comprised of Tureiti and Paretetaitonga eruptive packages. The sector collapse source area and pathway has been infilled and covered by Iwikau package andesite lava flows. Timing of emplacement of the lava flows is constrained by a measured eruption age of $6.0 \pm 2.4 \mathrm{ka}$.

Deglaciation is here considered a primary factor for the $10.5 \mathrm{ka}$ sector collapse of northern Ruapehu, however, an earthquake or eruption may have provided the immediate 
trigger for failure of the edifice. Post-LGM warming is inferred to have been a global trigger for sector collapses at glaciated volcanoes, due to the debuttressing of volcanic material emplaced against ice or undercut by glacial erosion, lithospheric unloading and associated faulting, increased fluid circulation, and initiation of a more humid climate (Capra, 2006). Wholesale deglaciation of the Ruapehu edifice is inferred to have occurred from 18-15 ka, as discussed above (see Glacier reconstructions using ice-marginal lava flows), although a summit ice cap and upper flank glaciers are likely to have remained for several kyrs after the initial onset of deglaciation at $18 \mathrm{ka}$. Rapid climate amelioration from $\sim 11 \mathrm{ka}$ is indicated by regional records (e.g. Newnham et al., 2003). The retreat of glaciers and summit ice would have debutressed the Paretetaitonga and Tureiti cones and resulted in destabilisation of the steep, hydrothermally altered edifice underlying the cones.

The collapse coincides with a period of regional extension and elevated volcanic activity around the northern flank of Ruapehu (Nairn et al., 1998). Disruption via seismic or volcanic activity may have provided the eventual trigger for the collapse of the cones. A similar process is invoked for emplacement of the Mangaio Formation debris avalanche deposit on southeast Ruapehu at $\sim 4.6 \mathrm{ka}$. The northeastern portion of the southern cone that is composed of Turoa package lava flows has collapsed. Destabilisation of the cone during Holocene glacial retreat is here proposed to have caused its collapse into the Whangaehu River valley following emplacement of the cone's uppermost lavas at $11.9 \pm$ $2.2 \mathrm{ka}$. The inferred link between deglaciation and sector collapse at Ruapehu volcano serves as a warning for future potential hazards during the current period of rapid warming and deterioration of ice masses on glaciated composite volcanoes in midlatitudinal regions (e.g. Rivera et al., 2006).

\subsubsection{Eruptive volumes and rates}

The long-term eruptive rate for Ruapehu of $0.6 \mathrm{~km}^{3} \mathrm{kyr}^{-1}$ since $\sim 250 \mathrm{ka}$ using a total edifice volume of $150 \mathrm{~km}^{3}$ was previously determined by Hackett and Houghton (1989) and Gamble et al. (2003). The rate is $1.2 \mathrm{~km}^{3} \mathrm{kyr}^{-1}$ when the equivalent volume of ring plain deposits is included. These rates are broadly comparable to those calculated for Mt. Katmai (0.79 $\mathrm{km}^{3} \mathrm{kyr}^{-1}$; Hildreth et al., 2003) and El Misti $\left(0.63 \mathrm{~km}^{3} \mathrm{kyr}^{-1}\right.$; Thouret et al., 2001), but are substantially greater than those for most other well-dated composite 
volcanoes, which are $<0.35 \mathrm{~km}^{3} \mathrm{kyr}^{-1}$ (Table 3.4). Conservative volumes for eruptive products of Ruapehu were calculated here using the revised mapping results of this study (Table 3.4).

Table 3.4. Volumes and eruptive rates for global examples of arc composite volcanoes.

\begin{tabular}{|lcccl|}
\hline Volcano & Volume $\left(\mathbf{k m}^{\mathbf{3}}\right)$ & Duration $(\mathbf{k y r})$ & Avg rate $\left.\mathbf{( k m}^{\mathbf{3}} \mathbf{~ k a}^{\mathbf{- 1}}\right)$ & Reference \\
\hline Mt Baker (stratocone) & 15 & 43 & 0.35 & Hildreth and Lanphere, 2003 \\
Parinacota & 46 & 160 & 0.28 & Hora et al., 2007 \\
Tatara-San Pedro & 55 & 930 & 0.06 & Singer et al., 1997 \\
El Misti & 70 & 112 & 0.63 & Thouret et al., 2001 \\
Katmai & 70 & 89 & 0.79 & Hildreth et al., 2003 \\
Puyehue & 80 & 320 & 0.25 & Singer et al., 2008 \\
Seguam & 80 & 320 & 0.25 & Jicha and Singer, 2006 \\
Ceboruco-San Pedro & 81 & 810 & 0.1 & Frey et al., 2004 \\
Tanaga & 90 & 300 & 0.3 & Jicha et al., 2012 \\
Mt Adams (stratocone) & 200 & 520 & 0.38 & Hildreth and Lanphere, 1994 \\
\hline Ruapehu & & & & \\
Te Herenga Formation & 28 & 50 & 0.56 & \\
Wahianoa Formation & 74 & 60 & 1.23 & \\
Mangawhero Formation & 28 & 35 & 0.8 & \\
Whakapapa Formation & 12 & 15 & 0.8 & \\
\hline
\end{tabular}

References for global examples indicated in table. Revised volumes, durations and eruptive rates for Ruapehu formations in this thesis are defined here.

A large volume of the modern edifice is composed of till that within any one glacial catchment can represent a diverse assemblage of clasts of variable age and composition. It is therefore impossible to reconstruct the volumes of lava from individual formations and eruptive packages that comprise moraines and outwash fans on the Ruapehu edifice. However, estimated volumes of glacially eroded eruptive products from the Te Herenga, Wahianoa and Mangawhero formations are incorporated into the measurements made in this section. Half-volumes of right-angle circular cones were calculated to approximate pre-eroded volumes of $28 \mathrm{~km}^{3}$ and $74 \mathrm{~km}^{3}$ for the Te Herenga and Wahianoa formations, respectively (Table 3.4). These calculations oversimplify the geometry of the volcanic edifices formed during these periods of volcanism but are intended to account for the substantial amount of material that has been eroded and transported to the ring plain.

A total eruptive volume of $28 \mathrm{~km}^{3}$ for the Mangawhero Formation was calculated by applying average lava flow thicknesses based on field observations to the measured areal extent of syn-glacial lava flows. The estimate also incorporates the inferred volume of lava flows emplaced onto glaciers and eroded by glacial and fluvial activity. The volume 
of lava transported to the ring plain by glaciers both during (via supra-glacial emplacement of lava) and following effusive eruptions is difficult to quantify. Furthermore, a low degree of certainty is assigned to this calculation to reflect the generalised thickness estimates that are biased by outcrops at flow margins where lavas were impounded and overthickened against ice. Conversely, the recognition of icemarginal flow emplacement improves the accuracy of the estimate by discounting the back-calculation of eruptive volumes inferred to have been lost via valley incision. Postglacial lava flows of the Whakapapa Formation were calculated to total $12 \mathrm{~km}^{3}$ in volume. This value has a higher degree of confidence than that given to volumes for pre15 ka eruptive products due to the minimal post-emplacement erosion and burial of Whakapapa Formation lavas. The abnormally shallow and consistent slope gradient observed for the northern flank of Ruapehu is considered to be the result of infilling of a deeper glaciated valley by debris avalanche deposits of the Murimotu Formation, upon which Iwikau package lavas were subsequently emplaced (Fig. 3.21).

The volume of Te Herenga Formation eruptive products is likely underestimated due to burial and limited exposure of the edifice constructed at $\sim 200-150 \mathrm{ka}$. The value of $\sim 28$ $\mathrm{km}^{3}$ is significantly lower than previously determined $\left(65 \mathrm{~km}^{3}\right.$; Hackett and Houghton, 1989), which likely assumed a much greater mass beneath the current composite volcano. Much of this buried volume may be able to be accounted for by earlier volcanic products (i.e. erupted between 340 and $200 \mathrm{ka}$ ). The revised volume estimate of $74 \mathrm{~km}^{3}$ for Wahianoa Formation eruptive products reported here is greater here than in previous studies because it incorporates lavas erupted during MIS 5 that are interpreted to be poorly preserved.

No lava flow eruption ages have yet been returned that lie during or in the $10 \mathrm{kyr}$ either side of MIS 4 (Fig. 3.16). Two hypotheses are presented to explain this absence: 1) there was an eruptive hiatus, perhaps forced by loading of the edifice due to voluminous edifice growth over the previous $>100 \mathrm{kyr}$ and compounded by particularly voluminous ice cover centred on $60 \mathrm{ka}$; or 2) effusive activity continued but, due to extensive glaciation of the edifice, lava flows were not emplaced on flanks and were instead transported supraglacially to the ring plain. Full glacial conditions in alpine regions during MIS 4 have been inferred from speleothem records (Williams et al., 2015), and extensive glaciation of Ruapehu is implied by exposure age dating of moraines on nearby Tongariro at $\sim 60 \mathrm{ka}$ (Eaves, 2015). If lavas were either unable to break through a thick ice cap that covered 
eruptive vents or were erupted onto fully glaciated flanks with no emergent topography resulting in conveyance to the ring plain, they would not be recognised in the lava record on the Ruapehu edifice. Alternatively, compositional characteristics of lavas erupted during the following period of $\sim 48-35 \mathrm{ka}$ indicate that their source magmas underwent an extended period of differentiation, which may implicate a preceding eruptive hiatus and indicates that the former hypothesis is probable.

Voluminous effusion occurred during glacial MIS 3 and 2, and continued into the current interglacial MIS 1 (Fig. 3.16). A central question to glaciovolcanic studies is whether glacial retreat after $\sim 20 \mathrm{ka}$ and the associated reduction of confining pressures on magma chambers led to increased rates of eruption in post-glacial times (Tuffen, 2010).

Qualitative arguments for accelerated volcanic activity following deglaciation have been presented for Mazama in western USA (Bacon and Lanphere, 2006) and three Chilean volcanoes (Gardeweg et al., 1998; Singer et al., 2008; Mee et al., 2009). Approximately equal eruption rates have been calculated here for the syn- and post-glacial effusive periods, indicating that deglaciation did not lead to elevated volcanic activity at Ruapehu.

\subsection{EVOLUTIONARY MODEL FOR RUAPEHU}

Geomorphological, geological, glaciological, geochronological and geochemical datasets acquired from this study have been combined with pre-existing data to reveal the evolution of Ruapehu. This is summarised in a 10-stage development model outlined below:

1. Sub-glacial eruption and emplacement of Te Herenga Formation breccias and lavas occurred onto a pre-existing ice-capped edifice that had been active for a previous $\sim 140$ kyr. The vent-proximal section of this complex edifice is exposed at Pinnacle Ridge. Breccias were deposited in meltwater corridors and ice-marginal lava flows were emplaced on ice-free flanks and ridges extending north from the vent area from $~ 200-150$ ka.

2. Sub-glacial eruption of Wahianoa Formation breccias and dykes occurred prior to 166 ka. Ice-marginal emplacement of a voluminous lava flow and breccia sequence constructed the southeast planèze flank from 166-110 ka. 
3. Eruptions of andesite lavas from a central vent onto an edifice with reduced ice mass continued from $\sim 100-80 \mathrm{ka}$. These lava flows were emplaced within glacially eroded valleys due to the absence of flank glaciers during MIS 5.

4. An eruptive hiatus and period of magma accumulation, storage and fractionation occurred from $\sim 80-50 \mathrm{ka}$. The Ruapehu edifice was covered in ice during this time, corresponding to the advance of glaciers during MIS 4.

5. Eruption of andesite-dacite lava flows onto a glaciated edifice from $\sim 48-36$ ka resulted in ice-marginal emplacement of lava flows and construction of high planèzes and ridges on the mid-lower southern and western flanks of the edifice. Ice-dammed and icebounded flows were overthickened by 100-160 m at elevations of $1500 \mathrm{~m}$ a.s.l. Wide compositional ranges within individual eruptive packages and substantial effusion of dacite indicate that this eruptive period was preceded by magma storage and fractionation, as inferred above.

6. Effusive activity continued from $\sim 35-25 \mathrm{ka}$, with ice-marginal emplacement of lavas onto the glaciated edifice. The positions of ice-bounded flows indicate that ice cover during the last glacial period (MIS 4-2) was most extensive at $\sim 31 \mathrm{ka}$.

7. Eruption of lavas onto the glaciated Ruapehu edifice continued from 25-15 ka, with coeval explosive activity. Impoundment of flows occurred at lower elevations than the preceding $\sim 20$ kyrs and ice-bounded lava flows were thickened by up to $100 \mathrm{~m}$.

8. Construction of glacially-bound summit cones and emplacement of upper flank lavas occurred between 15-10 ka. Turoa, Paretetaitonga, and Tureiti cones were built adjacent to summit glaciers prior to $10 \mathrm{ka}$, atop steep, altered underlying vent-proximal eruptives.

9. Deglaciation during rapid warming resulted in destabilisation of the perched, icebuttressed summit cones and led to a sector collapse event at $10.5 \mathrm{ka}$, resulting in emplacement of the Murimotu Formation debris avalanche deposit on the northern flank of Ruapehu. Iwikau package lava flows ( $<10 \mathrm{ka})$ were emplaced on top of the Murimotu Formation to the north and on the upper-mid eastern flank. The lavas form a cone that sits within the 10.5 ka collapse scar and is now filled by ice within the Summit Plateau.

10. Destabilisation and collapse of the southern summit cone, composed of Turoa package lavas resulted in another sector collapse event and deposition of the Mangaio 
Formation on eastern Ruapehu at $\sim 4.6 \mathrm{ka}$. Activity over at least the last $\sim 2 \mathrm{ka}$ has been focussed through Crater Lake within the scar of the collapsed southern cone. This activity has included the effusive eruption of Ruapehu's youngest andesite lava flow into the Whangaehu valley, the formation of the small-volume scoria cone surrounding the lake, and historic phreatomagmatic and lahar events. 
CHAPTER 4 


\title{
4. NEW PETROLOGICAL, GEOCHEMICAL
}

\section{AND GEOCHRONOLOGICAL CONSTRAINTS \\ ON ANDESITE-DACITE MAGMA GENESIS AT RUAPEHU}

\begin{abstract}
The geochemical variation of lavas erupted at Ruapehu provides information on the development and evolution of a magma system feeding a large composite volcano in a continental volcanic arc setting. New petrological, geochemical and microanalytical data are integrated here with existing published data, and placed within the high-resolution stratigraphic framework from Chapter 3 to document the evolution of the exposed portions of the Ruapehu edifice.
\end{abstract}

A general increase in $\mathrm{SiO}_{2}, \mathrm{~K}_{2} \mathrm{O}$ and incompatible trace element contents (e.g. $\mathrm{Rb}, \mathrm{Zr}$ ) and ratios $(\mathrm{La} / \mathrm{Yb})$ in basaltic-andesite and andesite lavas erupted from $\sim 200$ to $80 \mathrm{ka}$ is matched by increasing values of ${ }^{87} \mathrm{Sr} /{ }^{86} \mathrm{Sr}$, as constrained by existing isotopic data. Following an apparent $\sim 30 \mathrm{kyr}$ eruptive hiatus, magma compositional diversity was relatively large for the eruptive period from 50-35 ka. Over a $\sim 8 \mathrm{wt}$ \% $\mathrm{SiO}_{2}$ range, the basaltic-andesite to dacite lavas erupted during this period define a high-K/Ca trend and elevated incompatible trace element contents compared to all other documented eruptive products from Ruapehu. Melt inclusion, interstitial glass and melt pockets in partially fused feldspathic xenoliths contained within dacite lavas from this period contain high $\mathrm{K}_{2} \mathrm{O}$ (5-6 wt. \%) and Rb contents (250-280 ppm). The whole-rock characteristics are interpreted to reflect the generation and assimilation of partial melts of the greywackeargillite basement within the magma system beneath Ruapehu following $>150 \mathrm{kyr}$ of progressive heating of the lithosphere. The glass compositions can be explained by selective partial melting and assimilation of a K-and Rb-rich mineral phase (e.g. biotite) within the meta-sedimentary mineral assemblage. 
Lavas erupted at 50-35 ka are also unique within the lifetime of Ruapehu in that they contain a lineage of highly-magnesian andesites and dacites. The mineral assemblage of the lavas, which also display strong evidence for crustal assimilation (e.g. isotopic data, abundant xenoliths), is characterised by abundant reverse-zoned pyroxene crystals with resorbed and rounded cores overgrown by rims with $\sim \mathrm{Mg \#} \#_{90}$. The pyroxene crystal population records a mixing event between recharging mafic magmas and stalled felsic magmas in the crust. This process has been described elsewhere for several examples of highly-magnesian andesites and dacites but is in contrast to other types of Mg-rich andesites that are arguably derived from mantle melting processes.

Whole-rock compositions of lavas erupted at $\sim 35-26 \mathrm{ka}$ are intermediate between those of the andesites and dacites erupted at 50-35 ka, whereas from $26 \mathrm{ka}$ onwards the lavas display a strong reversion to more mafic and less potassic compositions with time. Furthermore, these lavas have lower whole-rock incompatible trace element contents and ratios, and contain less potassic melt inclusions when compared to the 50-35 ka lavas. Post-26 ka lavas are interpreted to have assimilated less enriched melts due to the exhaustion of fertile phases in the crustal column from prior melting and/or higher degrees of melting of continental crust associated with ongoing magma and heat flux through the volcanic plumbing system beneath the Ruapehu edifice.

The expanded and revised geochronology for Ruapehu has permitted the detailed geochemical sequencing of lava flow compositions in this chapter and consequently revealed systematic changes in the degrees of magma differentiation by fractionation and crustal assimilation processes throughout the $\sim 200 \mathrm{kyr}$ lifetime of the exposed edifice. The results highlight the value of well calibrated chronostratigraphic frameworks for investigating time-composition relationships at composite volcanoes.

\subsection{INTRODUCTION}

The compositional ranges of eruptive products generated over the lifetime of continental arc volcanoes often display linear compositional spectra that extend from basalt to dacite and, occasionally, rhyolite (e.g. Hildreth et al., 2003; Hora et al., 2007; Singer et al., 2008; Hildreth and Fierstein, 2012). The time-sequenced geochemical variations of eruptive products are typically non-systematic, however, and do not necessarily reflect

the long-term evolution of a common magma source by simple progressive fractionation 
and assimilation (cf. Eichelberger et al., 2006). The timescales of compositional heterogeneity specified by the products of short-lived eruptive episodes $(<1-20 \mathrm{yr}$; e.g. Clynne, 1999; Coombs et al., 2000, 2013) or preserved in lava flow sequences (1-10 kyr; Gamble et al., 1999, 2003; Frey et al., 2004), indicate that magmas with diverse parentage are generated and erupted relatively frequently. At an extreme, for the geochemical differences within consecutively erupted samples to be attributed to variations within the initial mantle source region of arc magmas (i.e. different degrees of melting or contribution of fluid or melt from the subducted slab and sediment), eruptive products would need to represent individual aliquots of magma that retained their signature from a mantle source (e.g. Davidson et al., 2005). In most cases, however, compositional sequences are instead likely to reflect the eruption of discrete batches of magma that have followed unique pathways of differentiation in the crust (e.g. Hobden et al., 1999; Gamble et al., 2003; Frey et al., 2004; Eichelberger et al., 2006; Sisson et al., 2013).

The processes of crustal anatexis, magma mixing and crystal fractionation and separation are the primary agents of magma differentiation within the middle to upper crust beneath arc volcanoes (e.g. Price et al., 2012; Kent, 2013; Lee and Bachmann, 2014). Two commonly documented signatures of intermediate arc magmas that arise from these processes are: (a) the generation and entrapment of melts that are substantially more silicic than their host whole-rock compositions (see compilations by Reubi and Blundy, 2009; Kent, 2013), and (b) disequilibrium petrographic textures that reflect mixing between silicic components with mafic magmas and their crystal material and/or evolving intensive parameter such as pressure, temperature and degassing (e.g. Clynne, 1999; Dungan and Davidson, 2004; Kent et al., 2010; Koleszar et al., 2012). Because the felsic and mafic end-members seldom erupt independently at composite volcanoes, their cryptic existence within crustal magma systems is recorded within mineral-hosted melt inclusions or interstitial glass (e.g. Reubi and Blundy, 2008) and the crystal cargo of the derivative intermediate composition magmas (e.g. Streck et al., 2007). Thus, the nature and origin of felsic and mafic sources, and the processes by which they interact, may be elucidated by microanalytical investigations (Davidson et al., 2007). Constraining these magma sources and the subsequent mixing parameters and processes is critical to understanding the assembly of arc magmas and the recycling of elements throughout Earth's subduction zones. 
The longevity of subduction zones results in the repetitive transfer of heat to the lithosphere (e.g. Dufek and Bergantz, 2005) as primary magmas are generated in, and ascend from, the mantle wedge. The composition of eruptive products from composite volcanoes therefore record the cumulative effect of progressive heating and conditioning of the lower, middle, and upper crust because their source magmas have passed through these regions. How magmatic sources and processes vary throughout time and what controls those variations are fundamental questions for understanding both the eruption potential of arc volcanoes and the development of continental crust. Critical to addressing these questions is the collection of high-resolution eruptive histories for arc volcanoes that are constrained by field studies and radiometric age data so that eruptive products can be accurately sequenced (e.g. Dungan et al., 2001; Frey et al., 2004). In this regard, Ruapehu represents an ideal case study to investigate the compositional development of a magma system throughout the lifetime of a composite volcano as represented by exposed rocks. The geochronological framework for the effusive history of Ruapehu outlined in Chapter 3 is used here to sequence whole-rock and microanalytical mineral and melt compositions in order to investigate the genesis of andesite-dacite magmas in a continental arc setting.

\subsection{BACKGROUND AND PREVIOUS WORK}

The mountain that has been named Ruapehu is a $150 \mathrm{~km}^{3}$ composite volcanic edifice primarily composed of stacked sequences of lava flows and associated breccias intercalated with till and subsidiary volumes of proximal pyroclastic flow and fall deposits. The greatest volume of lava flows are porphyritic andesites that comprise mineral assemblages dominated by plagioclase and pyroxene. However, basalticandesites and dacites have also been erupted over the time period studied here, and a range of complex crystal and lithic cargoes are found throughout the eruptive products. The crystals are typically not in equilibrium with the host whole-rock compositions (Price et al., 2012). Furthermore, melt inclusion and matrix glass compositions from lava flows of the Wahianoa and Whakapapa formations (Price et al., 2005, 2012) and from pyroclasts in historical tephra deposits (Donoghue et al., 1995b; Gamble et al., 1999; Kilgour et al., 2013) range from dacite to rhyolite and are significantly more silicic than the host whole-rock compositions. 
Detailed petrographic descriptions were first undertaken by Clark (1960) and later advanced by Cole (1978). Graham and Hackett (1987) described six petrographic types with corresponding models of magma formation, additionally constrained by geochemical and isotopic data. Significantly, these models accounted for the crust-like geochemical and isotopic composition of Ruapehu lavas by invoking partial melting and assimilation of mid-upper crustal greywacke-argillite basement during magma genesis (see also Graham, 1987).

The overall development of the magma system beneath Ruapehu was later explored within stratigraphic contexts by Waight et al. (1999), Gamble et al. (1999, 2003) and Price et al. (2005). A model for the polybaric generation of derivative magmas by multiple episodes of melting, mixing, assimilation and fractionation within an open magmatic system was generated from these studies (see Price et al., 2012 for summary). This model allows for the non-systematic geochemical and isotopic variations observed over timescales ranging from short-lived explosive episodes and cycles (1-50 yr; Gamble et al., 1999; Kilgour et al., 2013) to successive lava flow emplacement phases (1-10 kyr; Waight et al., 1999; Gamble et al., 2003).

Over the >200 kyr lifetime of Ruapehu, however, a general progression towards more evolved compositions with time was proposed based on whole-rock geochemical variations using the available stratigraphic constraints (Graham and Hackett, 1987; Price et al., 2012). The oldest lavas exposed on the edifice (Te Herenga Formation) have distinct ${ }^{143} \mathrm{Nd} /{ }^{144} \mathrm{Nd}-{ }^{87} \mathrm{Sr} /{ }^{86} \mathrm{Sr}$ characteristics that set them apart from all subsequent lavas (Price et al., 2005). On this basis, Graham et al. (1990) and Price et al. (2005, 2012) argued that Te Herenga Formation lavas were contaminated by Phanerozoic oceanic crust whereas younger lavas assimilated partial melts of shallower meta-sedimentary source rocks in the mid-upper crust.

Within the context of prior datasets from Ruapehu there are three key areas that warrant further investigation on the basis of the new data obtained for this thesis:

1. Time-composition relationships. Incomplete sampling of the edifice and a lack of chronological controls have hampered a comprehensive definition of the geochemical evolution of the Ruapehu magma system. Complex stratigraphic relationships as a result of lava-ice interaction and sparse radiometric eruption age constraints (see Chapters 2 and 3) have prohibited accurate definition of the relative and absolute eruption ages for lava 
flows of the Mangawhero and Whakapapa Formations that form much of the modern-day edifice. A new high-resolution, high-precision geochemical stratigraphy for lava flows (Chapter 3 ) allows investigation of the broad evolution and distinct periods and modes of magmatism during the lifetime of Ruapehu.

2. Nature and origin of silicic melts. Melt inclusion and matrix glass data have previously been acquired for lavas of the Wahianoa and Whakapapa formations (Price et al., 2005), but there is a lack of data for Te Herenga Formation eruptive products as well as newly defined packages identified within Mangawhero Formation. Outstanding questions in this regard include: (a) are the rhyolitic melts contained within Ruapehu lavas comparable to the products of silicic volcanism elsewhere in New Zealand's continental volcanic arc, and (b) are the distinct whole-rock compositions of Te Herenga Formation lavas reflected in their melt inclusion compositions?

3. Felsic-mafic interactions. In light of the dominance of silicic melt compositions, is there evidence for mafic recharge in the generation of intermediate (andesite-dacite) magmas, as postulated from local (Nakagawa et al., 2002) and global (Kent et al., 2010) studies? Is this a common process involved in the generation of magnesian andesites and continental crust at volcanic arcs globally?

\subsection{METHODS}

An extensive sample suite of lava flows was acquired during fieldwork from 2012-2015. The distribution of samples collected for this study is compared to previous sample locations in Figure 4.1. A full sample list is available in Appendix A3. The analytical techniques employed to determine whole-rock, mineral and glass compositions are outlined in this section.

\subsubsection{XRF: whole-rock major elements}

Fresh interiors of samples were acquired by using a diamond saw to cut away any remaining weathered surfaces not already removed in the field. Samples were crushed and then milled using an agate or tungsten-carbide ring mill to form a whole-rock powder. 


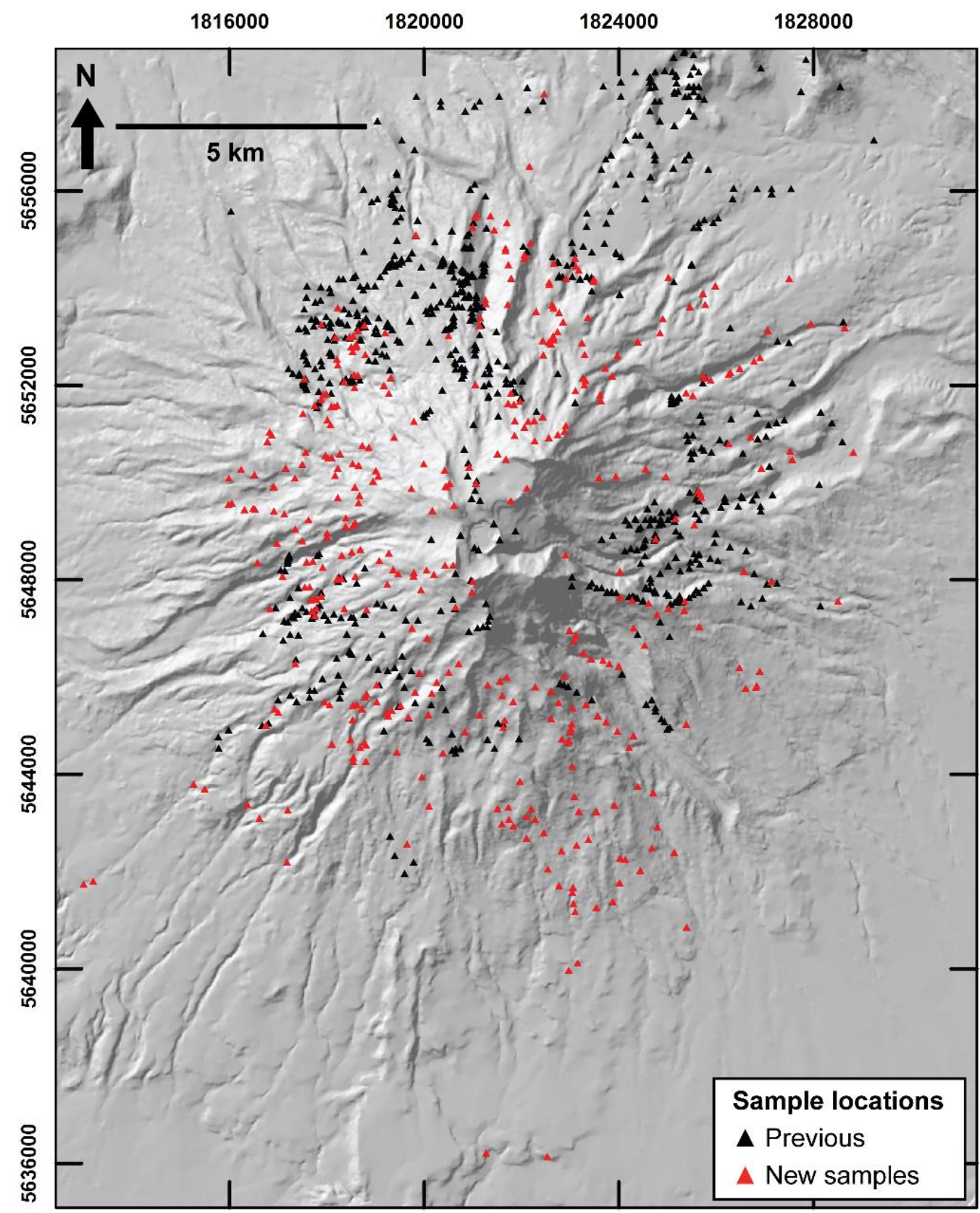

Figure 4.1. Location of previously sampled material (black triangles) and new samples (red triangles) of edifice-forming eruptive products. Previous samples are from Hackett (1985) and Price et al. (2012). A full list of new sample locations is given in Appendix A3. The map projection is New Zealand Transverse Mercator (NZTM 2000) and values next to ticks are accordingly in metres.

Major element compositions for 238 whole-rock powder samples were determined using an $\mathrm{ARL}^{\circledR}{ }^{\circledR} 8420+$ dual goniometer wavelength dispersive X-ray fluorescence (XRF) spectrometer at the Open University, United Kingdom. Fused lithium metaborate glass discs were prepared for each powder and analysed following the methods of Ramsey et al. (1995). Glass disks were formed by mixing 1 part by weight $(0.70 \mathrm{~g})$ of rock powder 
(dried at $110^{\circ} \mathrm{C}$ ) with 5 parts by weight of dried lithium metaborate flux and fusing in a muffle furnace for 15 minutes at $1100{ }^{\circ} \mathrm{C}$ in $95 \% \mathrm{Pt}-5 \%$ Au crucibles. Loss-on-ignition (LOI) measurements were undertaken on dried rock powders by heating in a pre-ignited aluminium crucible to $1000^{\circ} \mathrm{C}$ for $1 \mathrm{hr}$ and recording percentage weight loss. Internal standards WS-E (Whin Sill Dolerite) and OU-3 were analysed repeatedly throughout analysis sessions. Approximate 2 standard deviation (2sd) analytical precisions are $<2$ relative $\%$ for all elements, excepting those with concentrations $<0.5 \mathrm{wt}$. $\%$, for the 22 replicate analyses of each standard. High accuracy is indicated by the close agreement (generally within $\sim 1 \%$ offset) between average values for the standard analyses and recommended values for each element. Similar values (within $\sim 2 \%$ offset) were calculated from the difference between duplicate analyses of samples. XRF standard data are presented in Appendix A5.

\subsubsection{Solution ICP-MS: whole-rock trace elements}

A subset of 73 whole-rock powders was selected for trace element analysis. Samples were prepared for analysis at Victoria University of Wellington (VUW), New Zealand. Aliquots of whole-rock powders prepared for XRF major element analysis were prepared for trace element analysis using methods of acid digestion outlined in Appendix A6. Whole-rock trace element analysis was carried out by solution inductively coupled plasma mass spectrometry (ICP-MS), using a Thermo-Fisher Element2 sector-field ICPMS equipped with an ESCI auto sampler at VUW using methods similar to those of Eggins et al. (1997). The ICP-MS was tuned using a 10 ppb multi-element standard diluted to $1 \mathrm{ppb}$, where instrumental conditions such as torch position and carrier/makeup gas flow were adjusted to achieve the lowest relative standard deviation (RSD), typically $<1-2 \%$, and to optimise sensitivity.

Concentrations were calculated by sample-standard bracketing, thus the analysis sequence followed an order starting with the primary standard (BHVO-2), followed by 3 samples, the secondary standard (USGS standard BCR-2), and finishing back on the primary standard. Total procedural blanks for solution ICP-MS were within background count levels on all measured elements. In this study ${ }^{43} \mathrm{Ca}$ was used for an internal correction, as $\mathrm{CaO}$ concentrations of sample powders had previously been determined by XRF. This 
method allows correction for any major changes or inconsistencies, which may be caused by sample loss during sample preparation.

Trace element abundances in samples were calculated relative to the bracketing standard (BHVO-2) according to equations 1 and 2:

1. Sample $C_{i}=\left(\right.$ Sample $_{C P S} /$ BHVO $\left._{C P S}\right) \times\left(\right.$ Sample $_{\text {Dil }} /$ BHVO $\left._{\text {Dil }}\right) \times C_{\text {ref }}$

2. Sample $C_{i}($ Ca corrected $)=e q .1 . x\left(C_{C a X R F} / C_{C a I C P-M S}\right)$

Where $C_{i}, C_{r e f}$ and $C_{C a}$ are the concentrations of the measured isotope, the reference value for the bracketing standard and $\mathrm{Ca}$, respectively, the latter of which was determined by XRF and ICP-MS. Reference values for BHVO-2 were acquired from Georem preferred values (http://georem.mpch-mainz.gwdg.de/). $X_{D i l}$ is the concentration of material in the aliquot dilution.

International standard BCR-2 was analysed throughout analysis sessions in order to monitor the precision and accuracy of data acquired by solution ICP-MS. Approximate 2 sd analytical precisions calculated from 18 replicate analyses of BCR-2 are $<13$ relative $\%$ for all elements (most are $\sim 8-10 \%)$ except $\mathrm{Nb}(\sim 24 \%)$. Analyses of BCR-2 are accurate to within $5 \%$ of preferred values for all elements (most are within 1-2\%), except $\mathrm{Cr}, \mathrm{U}(\sim 6 \%), \mathrm{Cu}(\sim 18 \%)$ and $\mathrm{Ni}(\sim 30 \%)$. The bulk powder (TPI) of a single large clast from Taupo ignimbrite was used as an additional secondary standard throughout analysis sessions. From replicate analyses of TPI, most trace element analyses are precise to $\pm 5-10 \%$. Separate dilutions of the same sample powder were also analysed to monitor accuracy of the analyses as well as the reliability of the sample preparation procedure and homogeneity of powders. Values of 5-10\% offset for all elements from analyses of duplicate digestions further indicate high levels of reproducibility for the solution ICP-MS technique used in this study. Full standard data are presented in Appendix A6.

\subsubsection{EPMA: mineral and glass major elements}

Major element compositions for minerals and glass in 15 lava samples were analysed by electron probe microanalysis (EPMA) using the JEOL JXA 8230 instrument at VUW. This instrument is equipped with 5 wavelength dispersive X-ray spectrometers (WDS), an 
energy dispersive X-ray spectrometer (EDS) and highly sensitive detectors for acquisition of back-scattered electron (BSE) images. Thin sections were prepared from lava samples and coated with a $\sim 25 \mathrm{~nm}$ film of carbon before analysis.

For quantitative measurements of pyroxene, plagioclase and glass the instrument was calibrated using international mineral (Kakanui augite and labradorite plagioclase) and glass (VG-568) standards of similar composition to the material being analysed for most elements and synthetic oxides for elements in low abundance ( $<1 \mathrm{wt} . \%)$. For each element, calibration was undertaken during a 30 seconds peak-search and a 15 seconds background measurement. Analysis of crystal phases were performed using a focussed electron beam $(\sim 1 \mu \mathrm{m}$-wide) at a current of $12 \mathrm{nA}$ and accelerating voltage of $15 \mathrm{kV}$. The beam was defocussed to a width of $5 \mu \mathrm{m}$ during analysis of melt inclusion and groundmass glass. Due to the commonly small sizes of melt inclusions and interstitial glass patches, a $5 \mu \mathrm{m}$-diameter beam was used (rather than $10 \mu \mathrm{m}$ ). The current was reduced to $8 \mathrm{nA}$ and counting times for $\mathrm{Na}$ were reduced to 15 seconds on the peak and 10 seconds for the background to minimise potential devolatilisation. $\mathrm{Na}$ and $\mathrm{K}$ were measured first during glass analysis sequences also to minimise alkali loss. Element concentrations were calculated using the $\mathrm{ZAF}$ correction method (where $\mathrm{Z}$ is atomic number, $\mathrm{A}$ is absorption and $\mathrm{F}$ is fluorescence; Carpenter, 2008 and references therein).

Calibration and secondary standards were analysed as unknowns to monitor instrumental drift and precision and accuracy of the measurements throughout analytical sessions. All standard data are presented in Appendices A7 (glass analyses) and A8 (mineral analyses). Values of approximate 2sd precisions measured from repeated analysis of glass standard VG-568 are within 1-5 relative \% for major element oxides $\mathrm{SiO}_{2}, \mathrm{Al}_{2} \mathrm{O}_{3}$ and $\mathrm{K}_{2} \mathrm{O}$, and $\sim 14 \%$ for $\mathrm{Na}_{2} \mathrm{O}$. Analyses are accurate to $\leq 2 \%$ for $\mathrm{SiO}_{2}, \mathrm{Al}_{2} \mathrm{O}_{3}$ and $\mathrm{K}_{2} \mathrm{O}$, and to $4 \%$ for $\mathrm{Na}_{2} \mathrm{O}$ of the preferred values of the standard. The level of analytical precision and accuracy is comparable to that obtained using a $10 \mu \mathrm{m}$-wide beam (Barker, 2014) and indicates that using a beam width of $5 \mu \mathrm{m}$ does not result in significant alkali loss under the analytical conditions used. Values for precision and accuracy are high for other (minor) element oxides with concentrations $<1 \mathrm{wt}$. \%. Approximate 2 sd analytical precision from repeated analysis of mineral standards are generally 1-7 relative $\%$ for major element oxides with concentrations $>0.5 \mathrm{wt}$. \%. Analyses of the standards are accurate to within $5 \%$ of the preferred values for those major element oxides. 


\subsubsection{Laser ablation ICP-MS: glass trace elements}

Laser ablation ICP-MS analyses of interstitial glass and xenolith-hosted glass in dacite lava sample CC415 were carried out at VUW using a Resonetics RESOlutionS155-SE laser ablation system equipped with an ATL ArF Excimer laser (wavelength $193 \mu \mathrm{m}$ ), coupled to an Agilent 7500CS ICP-MS. Tuning and optimisation of the ICP-MS was undertaken by rasterising a $50 \mu \mathrm{m}$-diameter circular laser beam across standard specimen NIST 612 at a scan rate of $5 \mu \mathrm{m} \mathrm{s}^{-1}$ and using a $10 \mathrm{~Hz}$ pulse frequency. Instrument conditions were adjusted to achieve optimal sensitivity throughout the tuning stage. US Geological Survey analytical standard GSD-1G was used as a calibration standard for these analyses. The laser diameter was set to 30 or $20 \mu \mathrm{m}$-diameter, and pulsed at a frequency of 10 or $5 \mathrm{~Hz}$ during analysis; the latter parameter options were used for smaller patches of glass in samples. Samples and standards were ablated for 60 seconds followed by a 60 second dwell period prior to the next analysis.

Data was processed using LaserTRAM software developed at Oregon State University (Loewen, 2013). The software was used to select a 20 second background interval and a $\sim 20$ second ablation interval for each analysis. The software corrected for the background and normalised the count rates for each element over the ablation interval to the concentration of ${ }^{29} \mathrm{Si}$ as determined by EPMA for the sample. The selected ablation interval was divided into 5 subintervals of equal duration using the software and background-corrected counts recorded in each of these were binned before calculating normalised ratios for each subinterval. Final normalised ratios for each sample are the median value of the normalised ratios calculated for each subinterval.

Trace element abundances were then calculated using known concentrations in the bracketing standard (GSD-1G). BHVO-2G and BCR-2G were analysed as secondary standards. Because the analysis session was intended as a preliminary exercise for collecting trace element data for Ruapehu glasses, only 2 spots on each standard, and 11 spots on samples were analysed. Analyses of standards were generally accurate to within $15 \%$ of reference values, and mostly $<5 \%$ for the light rare earth elements and elements of interest for the purposes of this study ( $\mathrm{Rb}, \mathrm{Sr}, \mathrm{Zr}, \mathrm{Ba})$. Exceptions to these values were calculated for Tm and $\mathrm{Hf}$ in BCR-2G and $\mathrm{Cs}$, Eu and $\mathrm{Lu}$ in BHVO-2G. The standards data are given in Appendix A9. 


\subsection{RESULTS}

\subsubsection{Petrography}

Petrographic descriptions for Ruapehu lava flows have been presented in numerous previous studies (e.g. Cole, 1978; Graham, 1987; Graham and Hackett, 1987; Graham et al., 1990; Price et al., 2012). Brief descriptions are provided for the sample suite used here for completeness and because new portions of the edifice have been sampled. Compositional features of the mineral phases are summarised in section 4.5.6. Ruapehu lava flows are moderately to highly porphyritic, with only rare examples of crystal-poor types (<10\% phenocrysts). Plagioclase phenocrysts ( $>100 \mu \mathrm{m}$ across) occur in all samples examined and most commonly have sieved cores with complexly zoned rims. Shapes range from anhedral to euhedral and maximum lengths reach $12 \mathrm{~mm}$. Orthopyroxene, clinopyroxene and olivine phenocrysts are present throughout Ruapehu lavas in varying proportions. For the more basaltic-andesite lavas of the Te Herenga and Whakapapa formations, clinopyroxene and orthopyroxene are equally abundant. Orthopyroxene is the major ferromagnesian phase in lavas of the Mangawhero Formation. Amphibole occurs within Mangawhero dacite lavas studied here only as rare pseudomorphs that are replaced by symplectite assemblages of plagioclase, pyroxene, oxides and glass. The groundmasses of Ruapehu lavas typically consist of felted aggregates of microcrystalline plagioclase and orthopyroxene with volumetrically minor but ubiquitous oxide phases and small patches of glass. Magnetite is the dominant oxide phase present throughout the groundmass of Ruapehu lavas, although rare ilmenite and spinel are also present. Patches of glass in microcrystalline-free areas $\sim 5-10 \mu \mathrm{m}$-wide are only rarely present in samples acquired from the margins of ice-bounded Mangawhero Formation flows and fluidal Whakapapa Formation flows that cooled rapidly.

Cristobalite is a significant and, until now, unrecognised constituent of effusive eruptive products at Ruapehu volcano. It is present as prismatic crystals on vesicle walls in moderately glassy samples and felted throughout the groundmass of holocrystalline portions of lava flows (Fig. 4.2). Both vesicle and groundmass types exhibit the typical fish-scale crack textures (cf. Horwell et al., 2013; Fig. 4.2). Tabular or amorphous cristobalite is often intergrown with fibrous biotite in areas of devitrified groundmass (Fig. 4.2e). Biotite is not observed as a phenocryst elsewhere in Ruapehu lavas and so is interpreted in these circumstances to be related to deposition of the cristobalite. The only 
samples in which cristobalite was not observed were from glassy ice-bounded dacite lava flows.

Meta-sedimentary and meta-igneous xenoliths are present in most samples and are particularly common in lavas of the Mangawhero and Whakapapa formations. The former types are typically fine-grained assemblages of plagioclase, orthopyroxene and magnetite, which are likely to be metamorphic equivalents (or refractory residua) of the greywacke crust beneath Ruapehu (Price et al., 2005). Some crustal fragments contain glass and biotite (e.g. Graham, 1987). Meta-igneous granulite xenoliths are composed of plagioclase, orthopyroxene and ilmenite with minor clinopyroxene and olivine and display relic igneous or cumulate textures.
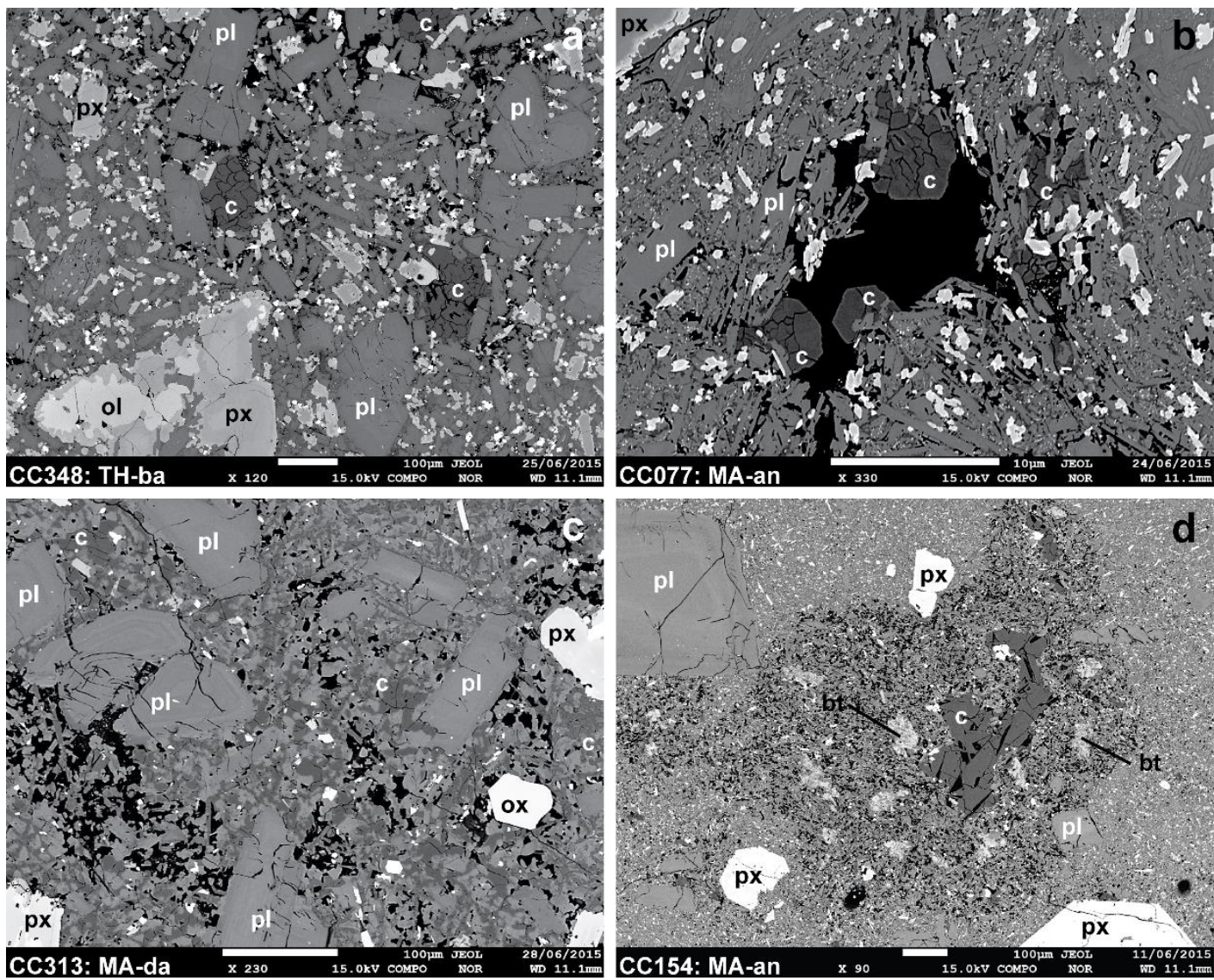

Figure 4.2. Back-scattered electron (BSE) images of cristobalite in Ruapehu lava flows. (a) Cristobalite within the holocrystalline groundmass of Te Herenga basaltic-andesite sample CC348. (b) Prismatic cristobalite crystals within a vesicle in Mangawhero andesite sample CC079. (c) Cristobalite felted through the groundmass of Mangawhero dacite sample CC313. See text for explanation. (e) Tabular cristobalite and patches of biotite within zone of devitrified groundmass in Mangawhero andesite sample CC154. (f) Large tabular cristobalite grain filling a vesicle in Whakapapa andesite sample CC335. Abbreviations are c (cristobalite), px (pyroxene), pl (plagioclase), ol (olivine), ox (oxide), bt (biotite). White scale bars are 100 $\mu \mathrm{m}$. 


\subsubsection{Whole-rock major and trace element compositions}

A summary of whole-rock compositions for Ruapehu volcano lava flows was presented by Price et al. (2012), however, the major and trace element variations between and within edifice-forming formations are re-evaluated here in light of the extended sampling coverage and improved geochronological control from work in this thesis. Representative major and trace element data are presented for Ruapehu lavas in Table 4.1. Full wholerock major and trace element data are presented in Appendix A5 and A6.

Te Herenga Formation lavas are basaltic-andesites with $\mathrm{Mg \#}[100 \mathrm{Mg} /(\mathrm{Mg}+\mathrm{Fe})]$ of $51-$ 62. The most mafic lava flow sampled on Ruapehu volcano $\left(53.8\right.$ wt. $\% \mathrm{SiO}_{2}$ ) was erupted at $186.2 \pm 6.8 \mathrm{ka}$, which now places it within the Te Herenga Formation (Hackett, 1985; Price et al., 2012; see Chapter 3). Te Herenga lavas exhibit a relatively narrow compositional range for all major and trace elements that is generally distinct from younger lavas, excepting some overlap with the Wahianoa Formation (Figs. 4.3, 4.4).
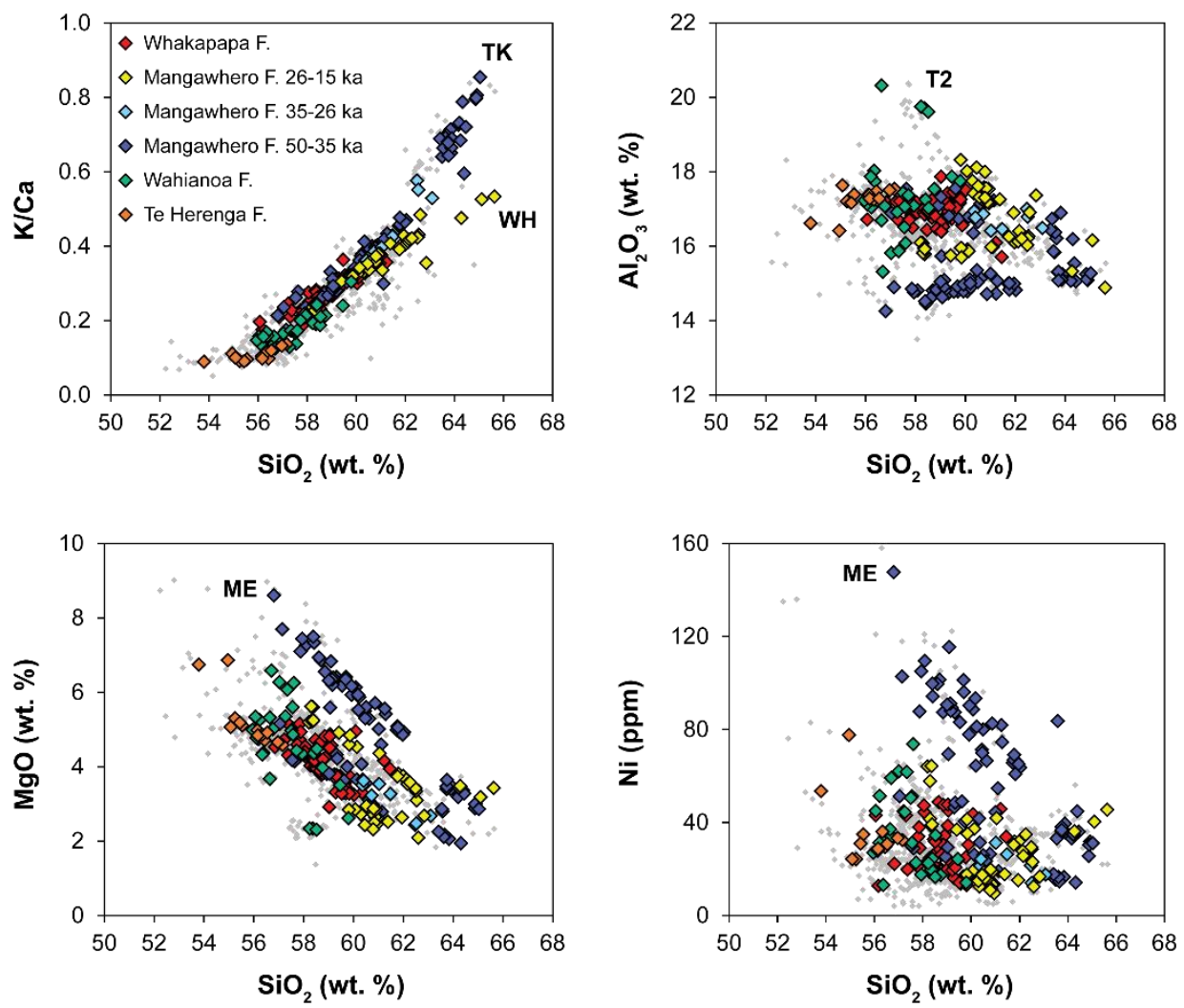

Figure 4.3. Bivariate plots of whole-rock $\mathrm{K} / \mathrm{Ca}, \mathrm{Al}_{2} \mathrm{O}_{3}, \mathrm{MgO}$ and $\mathrm{Ni}$ versus $\mathrm{SiO}_{2}$. Abbreviations for andmember samples referred to in the text are TK (Te Kohatu package, high-K dacite), WH (Whakapapaiti package, low-K dacite) and ME (Mangaehuehu package high-MgO andesite. Grey dots are data from Price et al. (2012). Type 2 plagioclase-phyric andesites of the Wahianoa Formation (Graham and Hackett, 1987) are labelled (T2). 
A notable characteristic of Te Herenga lavas is their low K/Ca values ( 0.11; Fig. 4.3) when compared to younger lavas. Incompatible trace element contents are essentially constant over their $\sim 3$ wt. $\% \mathrm{SiO}_{2}$ range (Fig. 4.4). Wahianoa Formation lavas are basaltic-andesites and andesites with $\mathrm{Mg \#}_{42-62}$ that exhibit slightly elevated $\mathrm{SiO}_{2}$, and incompatible trace element contents when compared with Te Herenga Formation lavas (Figs. 4.3, 4.4). Previously un-sampled lavas erupted from 100-80 ka have major element compositions that match 166-100 ka lavas of the Wahianoa Formation. Values of K/Ca range from $0.12-0.31$ and define a steeper positive trend than that of Te Herenga lavas (Fig. 4.3). Within the Wahianoa Formation, a distinct group of flows is identified by low-MgO, high- $\mathrm{Al}_{2} \mathrm{O}_{3}$ contents indicative of higher modal abundances of plagioclase relative to pyroxene (Graham and Hackett, 1987). Mangawhero Formation lavas are divided on the basis of the age data in Chapter 3 into early (50-35 ka), middle (35-26 ka) and late (26-15 ka) age brackets in this chapter. Lavas of the $\sim 50-35 \mathrm{ka}$ suite are compositionally diverse, covering an 8.2 wt. \% range in $\mathrm{SiO}_{2}$ from basaltic-andesite to dacite. These flows also show strong positive trends for incompatible trace element abundances and a distinct trend defined by high $\mathrm{K} / \mathrm{Ca}$ values over the range in $\mathrm{SiO}_{2}$ compared to older and younger lavas (Figs. 3.4, 4.4). The high-K dacites contain up to 550 ppm Ba, 200 ppm Zr and 150 ppm Rb (Fig. 4.4). Despite the broadly linear relationship between $\mathrm{SiO}_{2}$ and incompatible trace elements, lavas of this age can be categorised into high- and low-MgO types. The high-MgO trend is defined by lavas of the Mangaehuehu and Te Kohatu eruptive packages, and low-MgO andesites and dacites are grouped within the Ngahuinga and Mangaturuturu eruptive packages (Chapter 3; Fig. 4.3). Mananui dacite package, which forms a spatially isolated flow on the northern flank of Ruapehu (Chapter 3), has an intermediate $\mathrm{MgO}$ content. The two main trends exhibit an apparent compositional gap at $\sim 62-63$ wt. $\% \mathrm{SiO}_{2}$. The high-MgO andesites of the Mangaehuehu package (Mg\#60-69) and dacites of the Te Kohatu package ( $\left.\mathrm{Mg \#}_{54-57}\right)$ also exhibit relatively high $\mathrm{Cr}$ and $\mathrm{Ni}$ contents and low $\mathrm{Al}_{2} \mathrm{O}_{3}$ at equivalent $\mathrm{SiO}_{2}$ contents compared to all other eruptive products from Ruapehu volcano (Fig. 4.3). The eruptive phase linked to emplacement of Mangaehuehu package andesite flows, which define a 5.2 wt. \% range in $\mathrm{SiO}_{2}$ contents, is constrained by maximum and minimum ages of $45.4 \pm$ $2.0 \mathrm{ka}$ and $41.8 \pm 1.8 \mathrm{ka}$ (Chapter 3). This is a remarkable feature of the Mangaehuehu package when considering that a comparable range of $\sim 4.8$ wt. $\% \mathrm{SiO}_{2}$ was defined by the 300 m-thick sequence of Wahianoa Formation lavas exposed on southeast Ruapehu that was emplaced between 166 and $115 \mathrm{ka}$ (Gamble et al., 2003). 
Table 4.1. Representative whole-rock major and trace element data for Ruapehu lavas.

\begin{tabular}{|c|c|c|c|c|c|c|c|c|c|c|c|}
\hline Sample & GL1983 & GL1030 & CC335 & CC130 & $\mathrm{CC226}$ & CC364 & $\mathrm{CC408}$ & CC143 & CC513 & CC462 & CC547 \\
\hline Package & CL & IW & PT & TR & MK & TP & MK & WT & WH & MG & MG \\
\hline Age (ka) & $<2$ & 6 & 15 & 15 & 18 & 21 & 21 & 23 & 26 & 30 & 30 \\
\hline $\mathrm{SiO}_{2}$ & 61.45 & 57.30 & 58.51 & 60.08 & 61.37 & 58.29 & 60.87 & 62.26 & 65.61 & 60.73 & 62.46 \\
\hline $\mathrm{TiO}_{2}$ & 0.72 & 0.68 & 0.73 & 0.70 & 0.89 & 0.70 & 0.78 & 0.67 & 0.62 & 0.86 & 0.81 \\
\hline $\mathrm{Al}_{2} \mathrm{O}_{3}$ & 15.71 & 16.71 & 17.09 & 15.91 & 17.25 & 16.08 & 17.28 & 16.20 & 14.88 & 16.87 & 17.00 \\
\hline $\mathrm{Fe}_{2} \mathrm{O}_{3}$ & 6.41 & 7.57 & 7.51 & 6.59 & 6.03 & 7.57 & 6.42 & 5.84 & 5.02 & 6.49 & 5.74 \\
\hline MnO & 0.10 & 0.12 & 0.12 & 0.10 & 0.09 & 0.12 & 0.10 & 0.10 & 0.08 & 0.10 & 0.09 \\
\hline MgO & 3.94 & 5.20 & 3.96 & 4.95 & 2.52 & 5.22 & 2.64 & 3.58 & 3.43 & 3.23 & 2.44 \\
\hline $\mathrm{CaO}$ & 6.03 & 7.67 & 7.16 & 6.51 & 5.91 & 7.34 & 6.02 & 5.59 & 4.50 & 6.10 & 5.15 \\
\hline $\mathrm{Na}_{2} \mathrm{O}$ & 3.25 & 3.21 & 3.22 & 3.25 & 3.68 & 3.00 & 3.75 & 3.56 & 3.69 & 3.41 & 3.56 \\
\hline $\mathrm{K}_{2} \mathrm{O}$ & 2.23 & 1.39 & 1.57 & 1.76 & 2.07 & 1.54 & 1.97 & 2.03 & 2.06 & 2.03 & 2.56 \\
\hline $\mathbf{P}_{2} \mathbf{O}_{5}$ & 0.16 & 0.14 & 0.14 & 0.14 & 0.18 & 0.14 & 0.17 & 0.17 & 0.11 & 0.19 & 0.19 \\
\hline LOI & -0.13 & 0.12 & -0.15 & 0.01 & -0.17 & -0.07 & -0.10 & 0.05 & 0.36 & -0.16 & 0.24 \\
\hline Total & 99.19 & 100.41 & 99.63 & 99.44 & 99.95 & 98.92 & 99.08 & 99.89 & 100.25 & 100.00 & 99.49 \\
\hline${ }^{7} \mathbf{L i}$ & 22.1 & 19.9 & 15.9 & 20.7 & 22.2 & 13.6 & 25.7 & 26.7 & 27.0 & 21.6 & 31.3 \\
\hline${ }^{45} \mathrm{Sc}$ & 19.7 & 25.2 & 24.4 & 22.1 & 17.2 & 27.2 & 17.9 & 17.7 & 15.4 & 19.6 & 15.8 \\
\hline${ }^{51} \mathrm{~V}$ & 159 & 194 & 199 & 161 & 195 & 205 & 172 & 128 & 120 & 172 & 144 \\
\hline${ }^{60} \mathrm{Ni}$ & 34.7 & 65.2 & 18.2 & 66.8 & 13.4 & 41.0 & 7.7 & 52.4 & 49.9 & 19.0 & 14.5 \\
\hline${ }^{63} \mathrm{Cu}$ & 21.6 & 34.6 & 26.3 & 33.3 & 14.6 & 50.8 & 32.7 & 29.9 & 18.4 & 28.9 & 23.5 \\
\hline${ }^{66} \mathrm{Zn}$ & 61.5 & 66.3 & 77.5 & 59.3 & 58.8 & 68.4 & 66.7 & 59.9 & 73.1 & 68.2 & 60.6 \\
\hline${ }^{69} \mathrm{Ga}$ & 17.0 & 18.3 & 19.2 & 17.6 & 18.8 & 16.9 & 19.4 & 18.1 & 17.4 & 18.5 & 18.6 \\
\hline${ }^{85} \mathrm{Rb}$ & 86.3 & 46.8 & 59.2 & 62.7 & 78.4 & 57.4 & 69.0 & 75.5 & 84.7 & 72.6 & 110.2 \\
\hline${ }^{88} \mathrm{Sr}$ & 251 & 299 & 257 & 264 & 304 & 225 & 305 & 266 & 229 & 305 & 258 \\
\hline${ }^{89} \mathbf{Y}$ & 19.7 & 17.9 & 21.2 & 16.8 & 20.8 & 19.8 & 19.6 & 20.0 & 13.7 & 21.9 & 23.2 \\
\hline${ }^{91} \mathrm{Zr}$ & 151 & 96 & 119 & 123 & 153 & 113 & 136 & 133 & 149 & 153 & 172 \\
\hline${ }^{93} \mathrm{Nb}$ & 5.86 & 4.03 & 4.81 & 5.31 & 6.17 & 4.54 & 5.13 & 6.23 & 6.77 & 6.53 & 7.18 \\
\hline${ }^{133} \mathrm{Cs}$ & 3.68 & 1.79 & 2.02 & 2.70 & 2.62 & 2.07 & 2.13 & 2.80 & 3.45 & 2.66 & 2.96 \\
\hline${ }^{137} \mathbf{B a}$ & 408 & 337 & 338 & 355 & 452 & 311 & 417 & 409 & 410 & 425 & 454 \\
\hline${ }^{139} \mathrm{La}$ & 15.0 & 10.0 & 13.7 & 12.5 & 16.0 & 12.2 & 14.9 & 15.6 & 8.7 & 17.9 & 19.9 \\
\hline${ }^{140} \mathrm{Ce}$ & 32.9 & 22.2 & 29.4 & 26.7 & 35.1 & 26.7 & 32.9 & 34.7 & 17.7 & 38.7 & 41.6 \\
\hline${ }^{141} \mathrm{Pr}$ & 4.03 & 2.77 & 3.64 & 3.29 & 4.35 & 3.35 & 3.95 & 4.26 & 2.21 & 4.74 & 5.27 \\
\hline${ }^{146} \mathrm{Nd}$ & 15.8 & 11.9 & 14.7 & 13.1 & 17.1 & 13.6 & 16.1 & 17.1 & 9.1 & 19.0 & 21.0 \\
\hline${ }^{147} \mathrm{Sm}$ & 3.52 & 2.97 & 3.38 & 3.02 & 3.77 & 3.12 & 3.58 & 3.69 & 2.21 & 4.22 & 4.48 \\
\hline${ }^{151} \mathbf{E u}$ & 0.90 & 0.87 & 0.92 & 0.86 & 1.01 & 0.85 & 0.97 & 0.90 & 0.71 & 1.08 & 1.05 \\
\hline${ }^{157} \mathbf{G d}$ & 3.78 & 2.94 & 3.62 & 3.05 & 3.82 & 3.51 & 3.72 & 3.71 & 2.31 & 4.33 & 4.68 \\
\hline${ }^{159} \mathrm{~Tb}$ & 0.55 & 0.49 & 0.57 & 0.47 & 0.57 & 0.53 & 0.54 & 0.58 & 0.37 & 0.63 & 0.66 \\
\hline${ }^{163} \mathbf{D y}$ & 3.39 & 2.99 & 3.59 & 2.97 & 3.46 & 3.38 & 3.44 & 3.42 & 2.34 & 3.82 & 4.07 \\
\hline${ }^{165} \mathrm{Ho}$ & 0.69 & 0.61 & 0.74 & 0.59 & 0.73 & 0.71 & 0.70 & 0.68 & 0.50 & 0.77 & 0.81 \\
\hline${ }^{166} \mathrm{Er}$ & 2.04 & 1.77 & 2.14 & 1.76 & 2.10 & 2.07 & 1.99 & 2.02 & 1.48 & 2.23 & 2.38 \\
\hline${ }^{169} \mathrm{Tm}$ & 0.30 & 0.27 & 0.32 & 0.27 & 0.30 & 0.30 & 0.30 & 0.30 & 0.22 & 0.32 & 0.33 \\
\hline${ }^{173} \mathbf{Y b}$ & 2.02 & 1.78 & 2.13 & 1.75 & 2.05 & 2.03 & 1.94 & 1.86 & 1.47 & 2.07 & 2.26 \\
\hline${ }^{175} \mathrm{Lu}$ & 0.29 & 0.27 & 0.33 & 0.26 & 0.30 & 0.30 & 0.29 & 0.27 & 0.22 & 0.31 & 0.33 \\
\hline${ }^{178} \mathrm{Hf}$ & 4.06 & 2.71 & 3.26 & 3.44 & 4.12 & 3.12 & 3.63 & 3.62 & 4.01 & 4.02 & 4.49 \\
\hline${ }^{208} \mathbf{P b}$ & 12.8 & 7.15 & 9.27 & 10.5 & 10.2 & 7.49 & 9.47 & 17.1 & 12.0 & 10.5 & 9.83 \\
\hline${ }^{232} \mathbf{T h}$ & 8.12 & 4.34 & 5.67 & 5.97 & 7.32 & 5.35 & 6.46 & 6.43 & 6.42 & 7.24 & 8.85 \\
\hline${ }^{238} \mathbf{U}$ & 2.21 & 1.22 & 1.43 & 1.60 & 1.85 & 1.42 & 1.63 & 1.73 & 1.91 & 1.76 & 2.41 \\
\hline
\end{tabular}

Major oxide values are in weight \% and are normalised to anhydrous totals (100 wt. \%) with LOI (loss on ignition) and original analytical totals displayed. Trace elements contents are in ppm. Package abbreviations are: CL (Crater Lake); PT (Paretetaitonga); TR (Tureiti); MK (Makotuku); WT (Waitonga); WH (Whakapapaiti); MG (Manganuioteao). 
Table 4.1. (cont.) Representative whole-rock major and trace element data for Ruapehu lavas.

\begin{tabular}{|c|c|c|c|c|c|c|c|c|c|c|c|}
\hline Sample & CC508 & CC570 & $\mathrm{CC125}$ & CC216 & $\mathrm{CC424}$ & $\mathrm{CC470}$ & CC562 & CC209 & CC213 & CC326 & CC348 \\
\hline Package & TK & MN & ME & ME & NG & MT & WA & WA & WA & TH & TH \\
\hline Age (ka) & 39 & 40 & 43 & 43 & 40 & 41 & 88 & 121 & 121 & 170 & 187 \\
\hline $\mathrm{SiO}_{2}$ & 65.03 & 63.57 & 56.80 & 60.19 & 59.34 & 63.49 & 57.55 & 58.36 & 58.40 & 55.24 & 53.79 \\
\hline $\mathrm{TiO}_{2}$ & 0.71 & 0.85 & 0.70 & 0.77 & 0.76 & 0.83 & 0.62 & 0.68 & 0.70 & 0.65 & 0.67 \\
\hline $\mathrm{Al}_{2} \mathrm{O}_{3}$ & 15.27 & 15.84 & 14.25 & 15.00 & 16.81 & 16.74 & 16.51 & 19.70 & 17.25 & 17.21 & 16.62 \\
\hline $\mathrm{Fe}_{2} \mathrm{O}_{3}$ & 4.74 & 5.51 & 7.44 & 6.55 & 6.52 & 5.27 & 7.38 & 6.06 & 7.40 & 9.16 & 9.20 \\
\hline MnO & 0.07 & 0.08 & 0.12 & 0.10 & 0.10 & 0.08 & 0.12 & 0.09 & 0.12 & 0.15 & 0.15 \\
\hline MgO & 2.86 & 2.80 & 8.61 & 5.53 & 4.22 & 2.21 & 5.60 & 2.34 & 4.36 & 5.30 & 6.75 \\
\hline $\mathrm{CaO}$ & 4.45 & 4.87 & 7.67 & 6.36 & 6.81 & 4.87 & 7.82 & 7.49 & 6.89 & 8.42 & 9.17 \\
\hline $\mathrm{Na}_{2} \mathrm{O}$ & 3.42 & 3.50 & 2.85 & 3.28 & 3.48 & 3.64 & 3.37 & 3.92 & 3.31 & 3.12 & 2.82 \\
\hline $\mathbf{K}_{2} \mathbf{O}$ & 3.27 & 2.78 & 1.41 & 2.05 & 1.80 & 2.68 & 0.93 & 1.22 & 1.44 & 0.66 & 0.71 \\
\hline $\mathbf{P}_{2} \mathbf{O}_{5}$ & 0.18 & 0.20 & 0.14 & 0.18 & 0.16 & 0.20 & 0.11 & 0.13 & 0.13 & 0.09 & 0.11 \\
\hline LOI & 0.10 & -0.02 & -0.10 & -0.02 & -0.11 & 0.20 & -0.09 & 0.06 & 0.11 & 0.01 & -0.25 \\
\hline Total & 100.28 & 99.44 & 99.89 & 100.20 & 99.07 & 99.62 & 99.54 & 100.16 & 99.90 & 99.27 & 99.39 \\
\hline${ }^{7} \mathbf{L i}$ & 36.7 & 31.0 & 19.5 & 23.6 & 20.0 & 24.8 & 14.9 & 13.6 & 21.7 & 10.2 & 8.34 \\
\hline${ }^{45} \mathrm{Sc}$ & 14.3 & 15.8 & 27.1 & 21.6 & 19.9 & 16.0 & 27.0 & 16.8 & 23.9 & 32.0 & 34.5 \\
\hline${ }^{51} \mathbf{V}$ & 121 & 143 & 191 & 164 & 170 & 146 & 196 & 175 & 188 & 233 & 249 \\
\hline${ }^{60} \mathrm{Ni}$ & 30.4 & 36.7 & 175.9 & 123.3 & 49.2 & 12.1 & 54.9 & 15.4 & 30.1 & 28.6 & 54.7 \\
\hline${ }^{63} \mathrm{Cu}$ & 27.9 & 39.1 & 39.2 & 88.5 & 37.4 & 12.3 & 47.6 & 93.8 & 43.1 & 74.0 & 38.3 \\
\hline${ }^{66} \mathrm{Zn}$ & 30.2 & 68.0 & 61.8 & 59.2 & 60.8 & 66.5 & 70.1 & 64.6 & 81.0 & 87.1 & 81.4 \\
\hline${ }^{69} \mathrm{Ga}$ & 17.8 & 18.6 & 15.5 & 17.3 & 18.4 & 19.0 & 17.8 & 20.9 & 18.8 & 17.9 & 17.5 \\
\hline${ }^{85} \mathrm{Rb}$ & 144 & 111 & 52.8 & 79.7 & 61.8 & 105 & 25.4 & 36.2 & 44.9 & 16.6 & 17.5 \\
\hline${ }^{88} \mathrm{Sr}$ & 203 & 232 & 227 & 241 & 252 & 243 & 289 & 327 & 250 & 211 & 226 \\
\hline${ }^{89} \mathbf{Y}$ & 23.2 & 23.5 & 17.5 & 21.8 & 18.5 & 21.3 & 14.6 & 19.1 & 19.2 & 18.9 & 18.7 \\
\hline${ }^{91} \mathrm{Zr}$ & 215 & 199 & 114 & 150 & 130 & 186 & 69.3 & 92.8 & 101 & 59.4 & 58.5 \\
\hline${ }^{93} \mathbf{N b}$ & 9.00 & 8.36 & 4.16 & 6.26 & 4.58 & 7.22 & 3.00 & 3.79 & 4.46 & 1.83 & 1.89 \\
\hline${ }^{133} \mathrm{Cs}$ & 5.15 & 3.83 & 2.32 & 2.38 & 2.00 & 3.30 & 0.61 & 1.07 & 1.56 & 0.42 & 0.37 \\
\hline${ }^{137} \mathbf{B a}$ & 552 & 509 & 302 & 404 & 345 & 495 & 236 & 316 & 332 & 184 & 222 \\
\hline${ }^{139} \mathbf{L a}$ & 20.9 & 20.2 & 10.6 & 16.7 & 12.8 & 16.6 & 6.23 & 11.0 & 11.4 & 5.44 & 6.01 \\
\hline${ }^{140} \mathrm{Ce}$ & 45.3 & 44.0 & 23.5 & 35.7 & 28.4 & 36.5 & 14.5 & 22.8 & 25.7 & 11.3 & 13.5 \\
\hline${ }^{141} \mathrm{Pr}$ & 5.43 & 5.31 & 2.90 & 4.40 & 3.50 & 4.53 & 1.93 & 3.00 & 3.29 & 1.69 & 1.94 \\
\hline${ }^{146} \mathrm{Nd}$ & 21.0 & 21.5 & 12.0 & 18.1 & 14.6 & 18.0 & 8.43 & 12.7 & 13.5 & 7.67 & 8.97 \\
\hline${ }^{147} \mathrm{Sm}$ & 4.53 & 4.56 & 2.95 & 3.92 & 3.29 & 4.01 & 2.10 & 3.05 & 3.22 & 2.17 & 2.38 \\
\hline${ }^{151} \mathbf{E u}$ & 0.91 & 1.01 & 0.82 & 0.93 & 0.87 & 1.03 & 0.71 & 0.92 & 0.87 & 0.74 & 0.81 \\
\hline${ }^{157} \mathbf{G d}$ & 4.59 & 4.60 & 3.08 & 4.09 & 3.40 & 4.18 & 2.29 & 3.12 & 3.27 & 2.55 & 2.81 \\
\hline${ }^{159} \mathrm{~Tb}$ & 0.64 & 0.66 & 0.48 & 0.62 & 0.50 & 0.59 & 0.39 & 0.49 & 0.52 & 0.45 & 0.46 \\
\hline${ }^{163} \mathbf{D y}$ & 3.88 & 4.11 & 2.92 & 3.75 & 3.22 & 3.67 & 2.58 & 3.11 & 3.29 & 3.09 & 3.08 \\
\hline${ }^{165} \mathrm{Ho}$ & 0.80 & 0.82 & 0.60 & 0.75 & 0.65 & 0.74 & 0.53 & 0.65 & 0.68 & 0.68 & 0.67 \\
\hline${ }^{166} \mathrm{Er}$ & 2.23 & 2.35 & 1.78 & 2.18 & 1.83 & 2.16 & 1.51 & 1.90 & 1.94 & 1.97 & 1.98 \\
\hline${ }^{169} \mathrm{Tm}$ & 0.32 & 0.34 & 0.26 & 0.33 & 0.27 & 0.32 & 0.23 & 0.28 & 0.30 & 0.30 & 0.29 \\
\hline${ }^{173} \mathbf{Y b}$ & 2.15 & 2.23 & 1.67 & 2.08 & 1.78 & 2.15 & 1.52 & 1.80 & 1.95 & 1.99 & 1.92 \\
\hline${ }^{175} \mathrm{Lu}$ & 0.32 & 0.33 & 0.25 & 0.31 & 0.26 & 0.32 & 0.24 & 0.28 & 0.29 & 0.31 & 0.30 \\
\hline${ }^{178} \mathrm{Hf}$ & 5.40 & 5.30 & 2.97 & 4.17 & 3.41 & 4.92 & 1.99 & 2.57 & 2.85 & 1.73 & 1.73 \\
\hline${ }^{208} \mathbf{P b}$ & 17.1 & 17.5 & 7.69 & 12.4 & 12.4 & 12.8 & 4.99 & 7.37 & 27.3 & 6.00 & 3.63 \\
\hline${ }^{232} \mathrm{Th}$ & 12.1 & 10.0 & 4.91 & 7.08 & 5.82 & 9.82 & 2.36 & 3.39 & 4.15 & 1.40 & 1.63 \\
\hline${ }^{238} \mathbf{U}$ & 3.58 & 2.70 & 1.29 & 2.02 & 1.49 & 2.59 & 0.65 & 0.93 & 1.10 & 0.44 & 0.43 \\
\hline
\end{tabular}

Major oxide values are in weight \% and are normalised to anhydrous totals (100 wt. \%) with LOI (loss on ignition) and original analytical totals displayed. Trace elements contents are in ppm. Package and Formation abbreviations are: TK (Te Kohatu); MN (Mananui); ME (Mangaehuehu); NG (Ngahuinga); MT (Mangaturuturu); WA (Wahianoa Formation); TH (Te Herenga Formation. 
Table 4.2. Summary of $\mathrm{SiO}_{2}$ ranges for eruptive packages of the Mangawhero Formation.

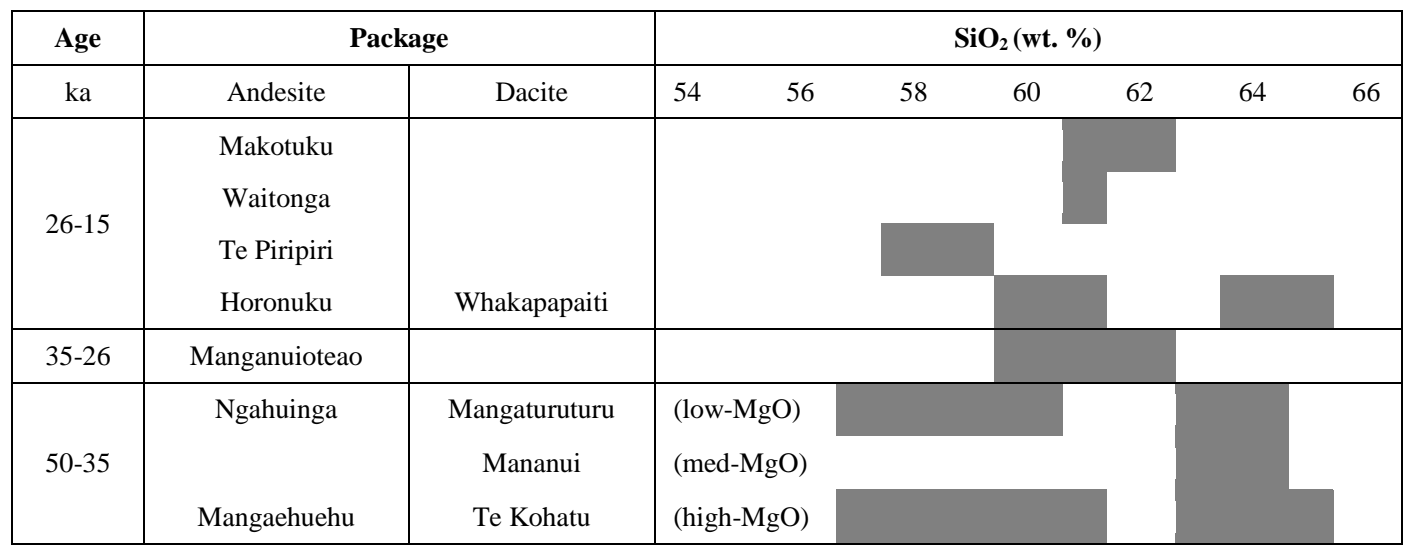

The time periods correspond to early (50-35 ka), middle (35-36 ka), and late (26-15 ka) Mangawhero Formation lavas, as referred to in the text. Early Mangawhero Formation are further subdivided into high-, medium- and low-MgO types.

The low-MgO group of lavas erupted between $\sim 50$ and 35 ka comprises Ngahuinga package andesites that have $\mathrm{Mg \#}_{48-62}$ and major element compositions that overlap with middle ( 35-26 ka) and late ( 26-15 ka) Mangawhero Formation andesites as well as lavas of the older Wahianoa and younger Whakapapa formations. Mangaturuturu package dacites fit the low-MgO trend but are separated from the low- $\mathrm{MgO}$ andesites by a $2.6 \mathrm{wt}$. \% gap in $\mathrm{SiO}_{2}$ content.

Manganuioteao package lava flows emplaced on the western flank of Ruapehu volcano from $\sim 35$ to $26 \mathrm{ka}$ exhibit $\mathrm{SiO}_{2}, \mathrm{~K}_{2} \mathrm{O}$ and trace element contents that are intermediate between the low-MgO andesites and dacites erupted at 50-35 ka. Late Mangawhero Formation lava flows erupted at $\sim 26-15 \mathrm{ka}$ are andesites and rare dacites (Whakapapaiti eruptive package lavas). These flows define distinctly lower trends for $\mathrm{SiO}_{2}$ versus $\mathrm{K} / \mathrm{Ca}$ and incompatible trace elements (e.g. $\mathrm{Rb}, \mathrm{Ba}, \mathrm{Zr}$ ) when compared to middle ( 35-26 ka) and early ( 50-35 ka) Mangawhero Formation lavas (Figs. 4.3, 4.4).

The major and trace element compositions of $~ 26-15$ ka andesites generally overlap with younger flows of the Whakapapa Formation (Fig. 4.3), which are andesites and basalticandesites with Mg\#47-60. Numerous eruptive packages within the Whakapapa Formation that were sourced from discrete vents and summit cones are defined and described in Chapter 3. Taken together, Whakapapa Formation lavas define a $\mathrm{SiO}_{2}-\mathrm{K} / \mathrm{Ca}$ trend contiguous with 26-15 ka Mangawhero Formation lavas (Fig. 4.3). 

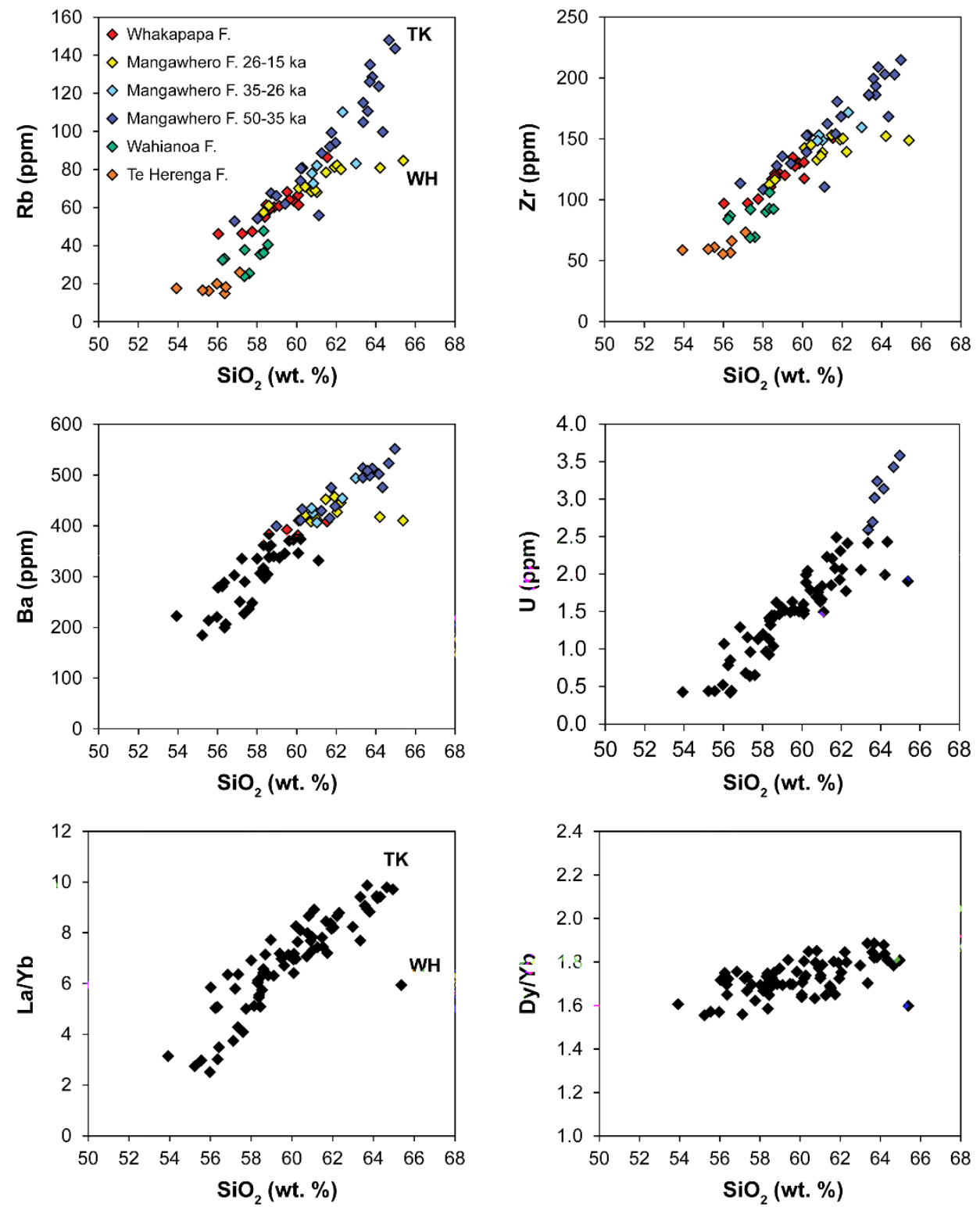

Figure 4.4. Bivariate plots of whole-rock $\mathrm{SiO}_{2}$ (wt. \%) versus selected trace elements (ppm) and trace element ratios. End-member abbreviations are the same as in Figure 4.3.

\subsubsection{Whole-rock multi-element diagrams}

Whole-rock trace element contents for Ruapehu lavas have been normalised with respect to values for average continental crust from Rudnick and Gao (2003) and are plotted on multielement diagrams in Figure 4.5. Representative samples are displayed for the different periods of volcanism. A generalised crustal composition is used to normalise the lava trace element concentrations in order to indicate the effects of upper crustal contamination on Ruapehu magmas. 
Normalised concentrations for all trace elements (except Ti) are $\leq 1$ for Te Herenga

Formation lavas. These flows display positive $\mathrm{Ba}, \mathrm{Sr}$ and $\mathrm{Sm}$ anomalies. Trace element patterns for Wahianoa Formation lavas share general similarities to Te Herenga Formation lavas, however, a notable difference is the slightly higher $\mathrm{Rb}$ values, which causes an associated loss of a positive $\mathrm{Ba}$ anomaly.
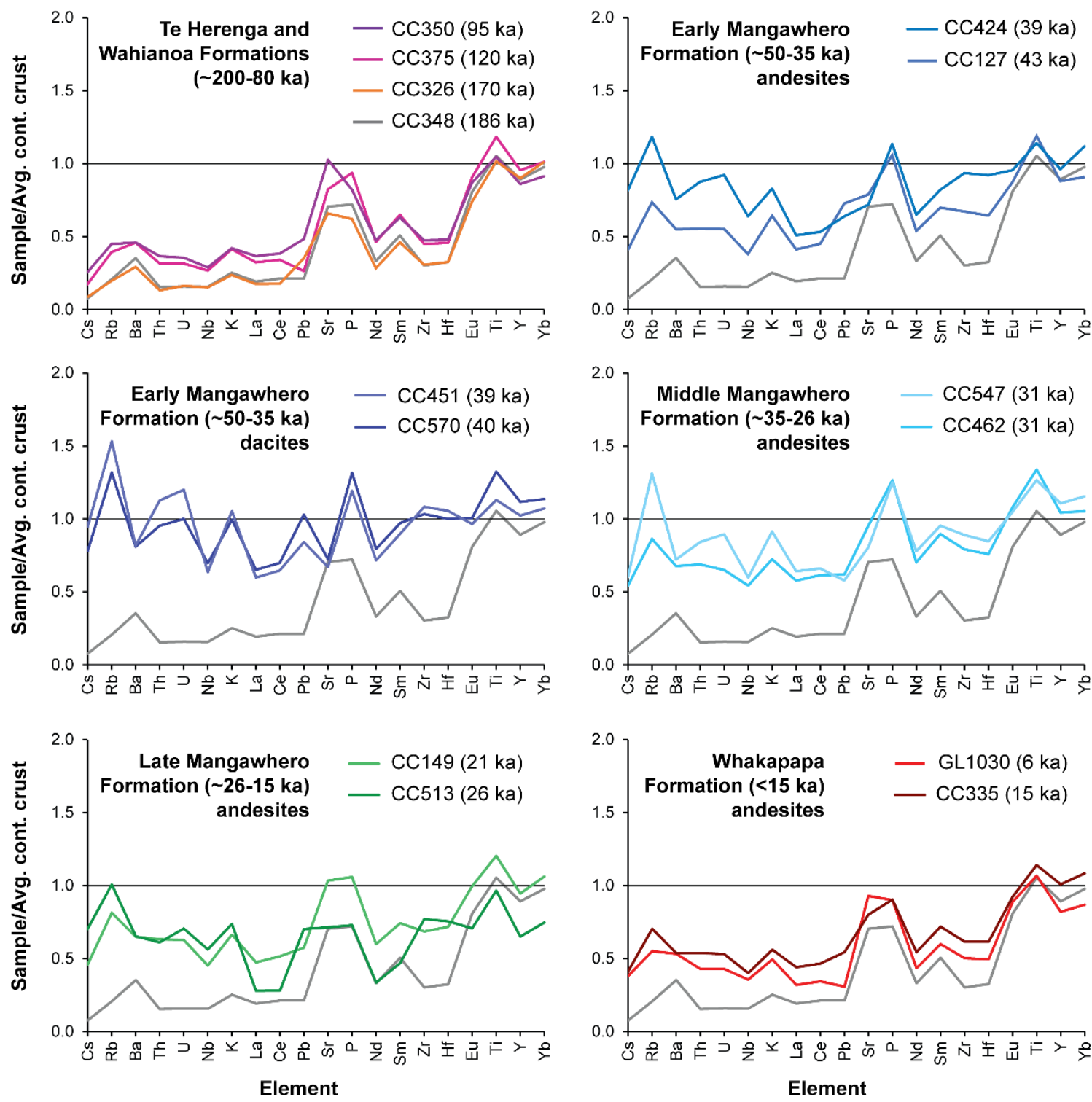

Figure 4.5. Multielement diagrams for Ruapehu lavas. Whole-rock trace element concentrations are normalised to average values of continental crust from Rodnick and Gao (2003). Grey line repeated in all panels is Te Herenga basaltic-andesite sample CC348. Approximate eruption age (ka) is labelled for each sample.

Normalised trace element concentrations for Mangawhero Formation lavas display several distinct features when compared to older eruptive products: positive $\mathrm{Rb}, \mathrm{Pb}$ and $\mathrm{P}$ anomalies, negative $\mathrm{Ba}, \mathrm{Sr}$, and Eu anomalies, and upward-concave $\mathrm{Sm}$ to Eu patterns. 
These anomalies are most pronounced for dacites erupted between 50 and $35 \mathrm{ka}$. One notable difference for $35-26$ ka flows of the Manganuioteao eruptive package compared to older Mangawhero Formation lavas is the subdued positive and negative anomalies for $\mathrm{Pb}$ and $\mathrm{Sr}$, respectively. Andesites erupted at $\sim 26-15 \mathrm{ka}$ display similar but subdued features compared to older Mangawhero Formation andesites. The 26 ka Whakapapaiti package dacite exhibits relatively low $\mathrm{La}, \mathrm{Ce}, \mathrm{Y}$ and $\mathrm{Yb}$. Whakapapa Formation lavas display similar features to Te Herenga and Wahianoa Formation lavas in multielement diagrams, although they generally have higher trace element abundances.

\subsubsection{Whole-rock isotopic compositions}

Existing isotopic data for Ruapehu lavas (from compilation in Price et al., 2012) have been assigned approximate ages here based on new geochronological constraints presented in Chapter 3. Previous studies (Gamble et al., 1999, 2003; Price et al., 2005, 2012) have shown Te Herenga lavas to have distinctly higher ${ }^{143} \mathrm{Nd} /{ }^{144} \mathrm{Nd}$ and lower ${ }^{87} \mathrm{Sr} /{ }^{86} \mathrm{Sr}$ whole-rock isotopic compositions from all subsequent eruptive products (Fig. 4.6). ${ }^{87} \mathrm{Sr} /{ }^{86} \mathrm{Sr}$ isotopic compositions of Wahianoa Formation lavas overlap with the most radiogenic Te Herenga samples ( 0.7050), however they have distinctly lower ${ }^{143} \mathrm{Nd} /{ }^{144} \mathrm{Nd}$ ratios. Lavas erupted from $\sim 50$ to $35 \mathrm{ka}$ display a wide range of ${ }^{87} \mathrm{Sr} /{ }^{86} \mathrm{Sr}$ values that extends to the most radiogenic measurements for Ruapehu volcanic rocks within $\sim 40$ ka Te Kohatu eruptive package dacites (Graham and Hackett, 1987). Lavas erupted at $\sim 26-15 \mathrm{ka}$ and $<15 \mathrm{ka}$ display comparably wide ranges but are generally defined by less radiogenic values.
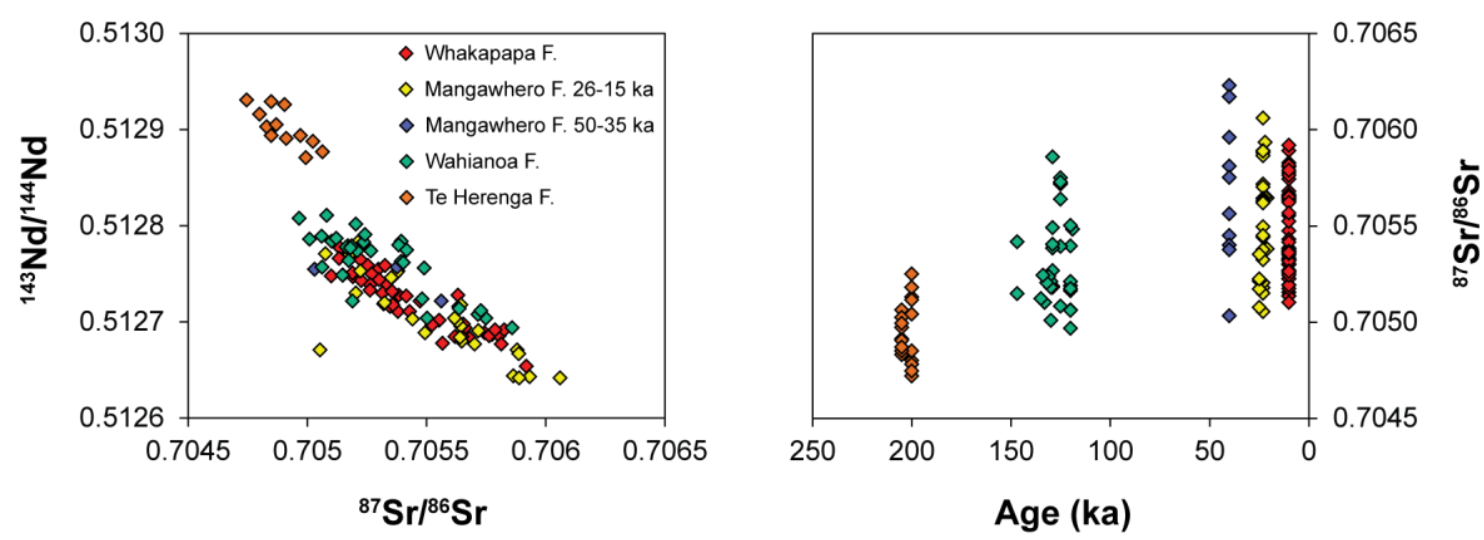

Figure 4.6. Whole-rock ${ }^{143} \mathrm{Nd} /{ }^{144} \mathrm{Nd}$ and ${ }^{87} \mathrm{Sr} /{ }^{86} \mathrm{Sr}$ isotopic compositions for Ruapehu lavas. Data are from Price et al. (2012). Approximate ages were assigned to samples to display general evolution pattern in the right panel. 


\subsubsection{Groundmass, melt inclusion and xenolith glass compositions}

Acquisition of glass analyses from the groundmass of lava samples was hindered by the ubiquity of microcrystalline plagioclase and pyroxene in even the glassiest flows available, however, crystal-free glassy groundmass zones $\sim 10 \mu \mathrm{m}$-wide were present in some samples (Fig. 4.7). Bearing in mind the above caveats, representative groundmass glass compositions were acquired by using a defocussed electron beam ( $5 \mu \mathrm{m}$-diameter) for analysis. A summary of the data is presented in Table 4.3 and a full list of analyses is present in Appendix A7.
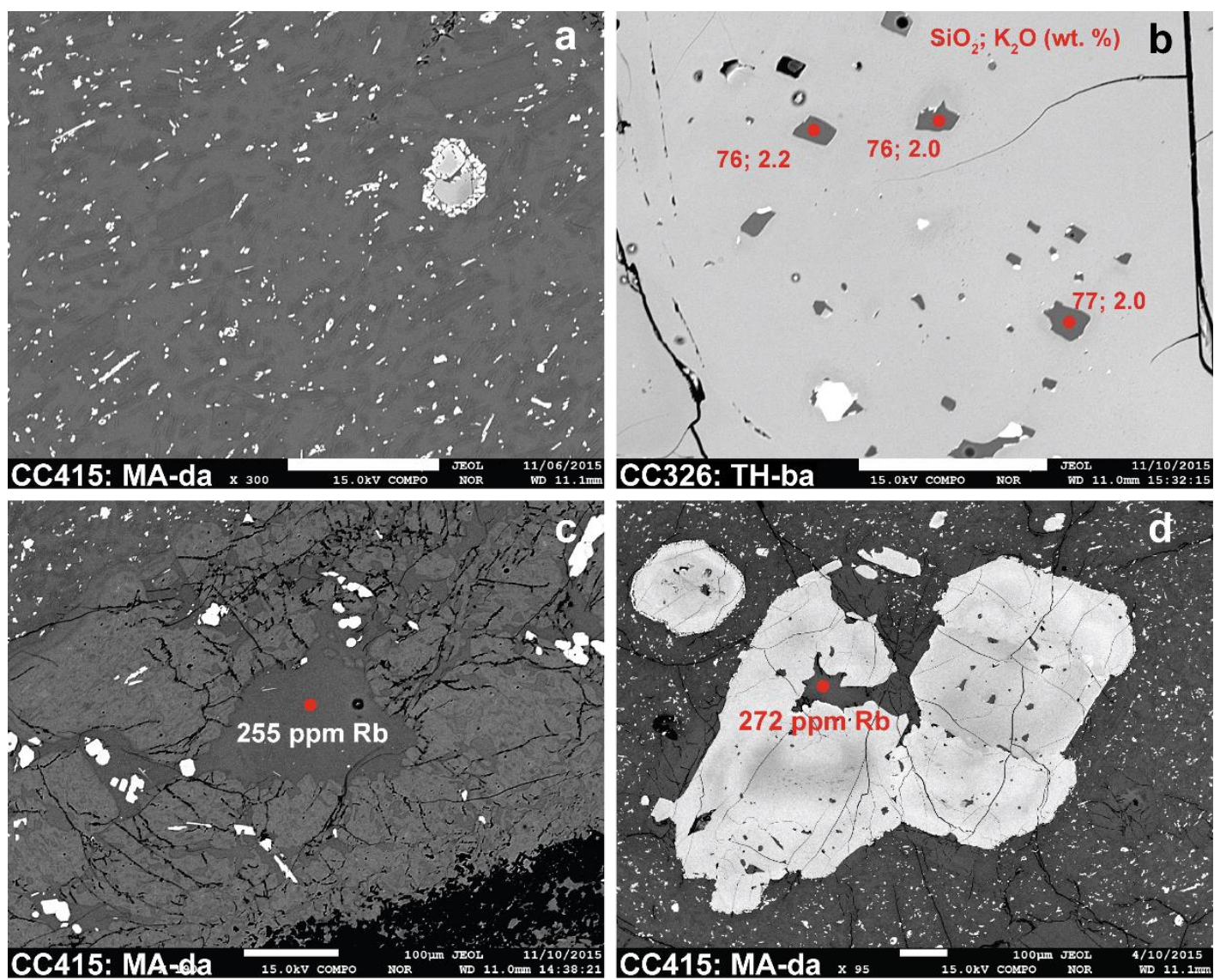

Figure 4.7. EPMA back-scattered electron (BSE) images of glass in Ruapehu lavas. (a) Groundmass texture of glassy Mangawhero dacite sample CC415. Microcrystals of plagioclase (dark, tabular grains) and pyroxene (bright needle-shaped grains) are present throughout the groundmass. Equant pyroxene grain at right is bordered by a microcrystalline reaction corona. (b) Melt inclusions and their $\mathrm{SiO}_{2}$ and $\mathrm{K}_{2} \mathrm{O}$ contents (in weight \%) in a pyroxene host from Te Herenga basaltic-andesite sample CC326. (c) Pocket of quenched glass hosted within a feldspathic xenolith fragment in Mangawhero dacite sample CC415. (d) Interstitial glass embayed within a pyroxene crystal cluster in Mangawhero dacite sample CC415. Rb content (in ppm) displayed for glass in (c) and (d). Scale bar in each panel is $100 \mu \mathrm{m}$.

Te Kohatu package dacites of the early Mangawhero Formation ( $50-35 \mathrm{ka})$ and Turoa package andesites of the Whakapapa Formation (<15 ka) have rhyolitic (73-75 wt. \% 
$\mathrm{SiO}_{2}$ ) groundmass glass with $\mathrm{K}_{2} \mathrm{O}$ contents of 5-6 wt. \%. Mangaehuehu package andesite of the Mangawhero Formation (CC069) has distinctly lower $\mathrm{SiO}_{2}\left(68-70\right.$ wt. \%) and $\mathrm{K}_{2} \mathrm{O}$ (2.5-3.5 wt. \%) contents in groundmass glass than the Mangawhero dacites and Whakapapa andesite. Te Herenga Formation lavas have holocrystalline groundmass textures with felted areas of cristobalite due to devitrification and, thus, no groundmass glass compositions could be measured for these flows.

Table 4.3. Summary of melt inclusion and xenolith and groundmass glass compositions.

\begin{tabular}{|c|c|c|c|c|c|c|c|c|c|}
\hline Group & Value & $\mathrm{SiO}_{2}$ & $\mathrm{TiO}_{2}$ & $\mathbf{A l}_{2} \mathbf{O}_{3}$ & $\mathrm{FeO}$ & $\mathrm{CaO}$ & $\mathrm{Na}_{2} \mathrm{O}$ & $\mathbf{K}_{2} \mathbf{O}$ & Total \\
\hline WH & avg & 74.0 & 0.5 & 14.9 & 1.1 & 1.9 & 3.6 & 3.8 & 99.6 \\
\hline mi & $\max$ & 77.0 & 1.4 & 19.0 & 2.2 & 3.6 & 4.5 & 5.6 & 100.5 \\
\hline \multirow[t]{2}{*}{$n=45$} & $\min$ & 70.3 & 0.2 & 13.0 & 0.5 & 1.0 & 0.8 & 1.8 & 98.4 \\
\hline & $2 \mathrm{sd}$ & 3.7 & 0.4 & 2.6 & 0.8 & 1.4 & 1.3 & 2.2 & 1.3 \\
\hline \multirow{4}{*}{$\begin{array}{c}\text { WH } \\
\text { gms } \\
n=16\end{array}$} & avg & 73.8 & 1.2 & 12.2 & 3.1 & 1.0 & 3.4 & 5.0 & 99.7 \\
\hline & $\max$ & 75.1 & 1.4 & 12.5 & 3.8 & 1.1 & 4.1 & 5.2 & 100.3 \\
\hline & $\min$ & 73.3 & 1.0 & 11.7 & 2.5 & 0.7 & 3.2 & 4.1 & 98.1 \\
\hline & $2 \mathrm{sd}$ & 1.0 & 0.2 & 0.5 & 0.6 & 0.2 & 0.4 & 0.5 & 1.4 \\
\hline \multirow{4}{*}{$\begin{array}{c}\text { TK } \\
\text { mi } \\
n=67\end{array}$} & avg & 73.0 & 0.7 & 13.7 & 2.1 & 1.3 & 3.3 & 5.4 & 99.9 \\
\hline & $\max$ & 75.6 & 1.2 & 16.2 & 3.3 & 2.8 & 4.2 & 6.2 & 100.8 \\
\hline & $\min$ & 70.0 & 0.2 & 12.1 & 1.0 & 0.7 & 1.0 & 4.0 & 98.5 \\
\hline & $2 \mathrm{sd}$ & 3.0 & 0.5 & 2.5 & 0.9 & 1.0 & 0.9 & 1.1 & 1.1 \\
\hline \multirow{4}{*}{$\begin{array}{c}\text { TK } \\
\mathbf{i} / \mathbf{x} \\
\mathbf{n}=17\end{array}$} & avg & 73.8 & 1.0 & 12.7 & 2.3 & 1.0 & 3.0 & 5.8 & 98.0 \\
\hline & $\max$ & 75.2 & 1.3 & 15.5 & 2.8 & 1.4 & 3.7 & 6.3 & 99.0 \\
\hline & $\min$ & 70.5 & 0.7 & 12.1 & 1.7 & 0.9 & 2.7 & 5.5 & 97.1 \\
\hline & $2 \mathrm{sd}$ & 2.7 & 0.4 & 1.9 & 0.6 & 0.2 & 0.4 & 0.4 & 1.1 \\
\hline \multirow{4}{*}{$\begin{array}{c}\text { TK } \\
\text { gms } \\
n=13\end{array}$} & avg & 74.4 & 0.8 & 12.6 & 2.2 & 1.2 & 3.0 & 5.5 & 101.0 \\
\hline & $\max$ & 75.4 & 0.8 & 15.1 & 2.7 & 2.3 & 3.8 & 5.9 & 101.8 \\
\hline & $\min$ & 71.7 & 0.6 & 12.0 & 1.7 & 0.8 & 2.7 & 4.4 & 100.3 \\
\hline & $2 \mathrm{sd}$ & 2.1 & 0.1 & 1.7 & 0.4 & 0.9 & 0.6 & 0.8 & 0.8 \\
\hline \multirow{4}{*}{$\begin{array}{c}\text { ME } \\
\text { mi } \\
\mathbf{n}=\mathbf{3 0}\end{array}$} & avg & 72.8 & 0.6 & 15.1 & 1.3 & 1.8 & 4.0 & 4.2 & 100.0 \\
\hline & $\max$ & 67.6 & 0.1 & 13.0 & 0.4 & 0.6 & 3.0 & 3.2 & 99.0 \\
\hline & $\min$ & 76.6 & 1.9 & 17.5 & 3.0 & 3.6 & 7.2 & 5.6 & 100.6 \\
\hline & $2 \mathrm{sd}$ & 4.9 & 1.0 & 2.0 & 1.4 & 1.6 & 1.4 & 1.1 & 0.8 \\
\hline \multirow{4}{*}{$\begin{array}{c}\text { ME } \\
\text { gms } \\
\mathrm{n}=13\end{array}$} & avg & 69.4 & 1.7 & 13.0 & 5.1 & 2.5 & 4.5 & 3.0 & 99.9 \\
\hline & $\max$ & 70.1 & 1.8 & 13.8 & 5.8 & 2.9 & 5.0 & 3.4 & 100.4 \\
\hline & $\min$ & 69.0 & 1.6 & 12.3 & 4.3 & 2.4 & 4.1 & 2.6 & 99.3 \\
\hline & $2 \mathrm{sd}$ & 0.7 & 0.1 & 0.8 & 0.8 & 0.3 & 0.5 & 0.5 & 0.5 \\
\hline \multirow{4}{*}{$\begin{array}{c}\text { TH } \\
\text { mi } \\
\text { n=24 }\end{array}$} & avg & 72.7 & 0.5 & 15.9 & 1.5 & 2.4 & 4.3 & 2.4 & 100.4 \\
\hline & $\max$ & 78.7 & 1.1 & 17.8 & 2.1 & 3.4 & 5.9 & 3.5 & 101.8 \\
\hline & $\min$ & 69.7 & 0.1 & 12.9 & 0.6 & 1.3 & 1.6 & 1.7 & 98.1 \\
\hline & $2 \mathrm{sd}$ & 5.6 & 0.8 & 3.0 & 0.8 & 1.1 & 1.6 & 0.8 & 2.0 \\
\hline
\end{tabular}

Major oxide values are in weight $\%$ and are normalised to anhydrous totals (100 wt. \%). Table is divided into groups of analyses from mi (melt inclusions), gms (groundmass glass) and $\mathrm{i} / \mathrm{x}$ (interstitial and xenolith glass) from within different formations or packages: WH (Whakapapa Formation), TK (Te Kohatu package, Mangawhero Formation), ME (Mangaehuehu package, Mangawhero Formation), TH (Te Herenga Formation). From multiple analyses of glass within each group values are displayed for avg (average), max (maximum), minimum (minimum) contents for each element, as well as 2 sd (2 standard deviation). 
Melt inclusion data acquired in this study were measured for glass hosted within pyroxene phenocrysts. Plagioclase-hosted melt inclusions were commonly observed to have recrystallized and were therefore not analysed. In addition, evidence for partial (along the crystal rim) or complete replacement of melt inclusions by plagioclase, pyroxene and/or Fe-Ti oxides in pyroxene-hosted types was also observed and such inclusions were not analysed. Pristine (or near-pristine with minimal evidence for postentrapment crystallisation of the host mineral) and sufficiently large inclusions $(\sim 5 \mu \mathrm{m}$ in size; Fig. 4.7) were selected for analysis.

Melt inclusions within Te Herenga Formation basaltic-andesites are rhyolitic (70-79 wt. $\% \mathrm{SiO}_{2}$ ) with $\mathrm{K}_{2} \mathrm{O}$ contents predominantly between $2-3$ wt. \% (Fig. 4.8). Pyroxenes in high-magnesian Mangaehuehu package andesites (CC069, CC077, CC154) contain dacitic to rhyolitic ( $\sim 68-75$ wt. \% $\left.\mathrm{SiO}_{2}\right)$ melt inclusions with $\mathrm{K}_{2} \mathrm{O}$ contents of $3-5$ wt. \%
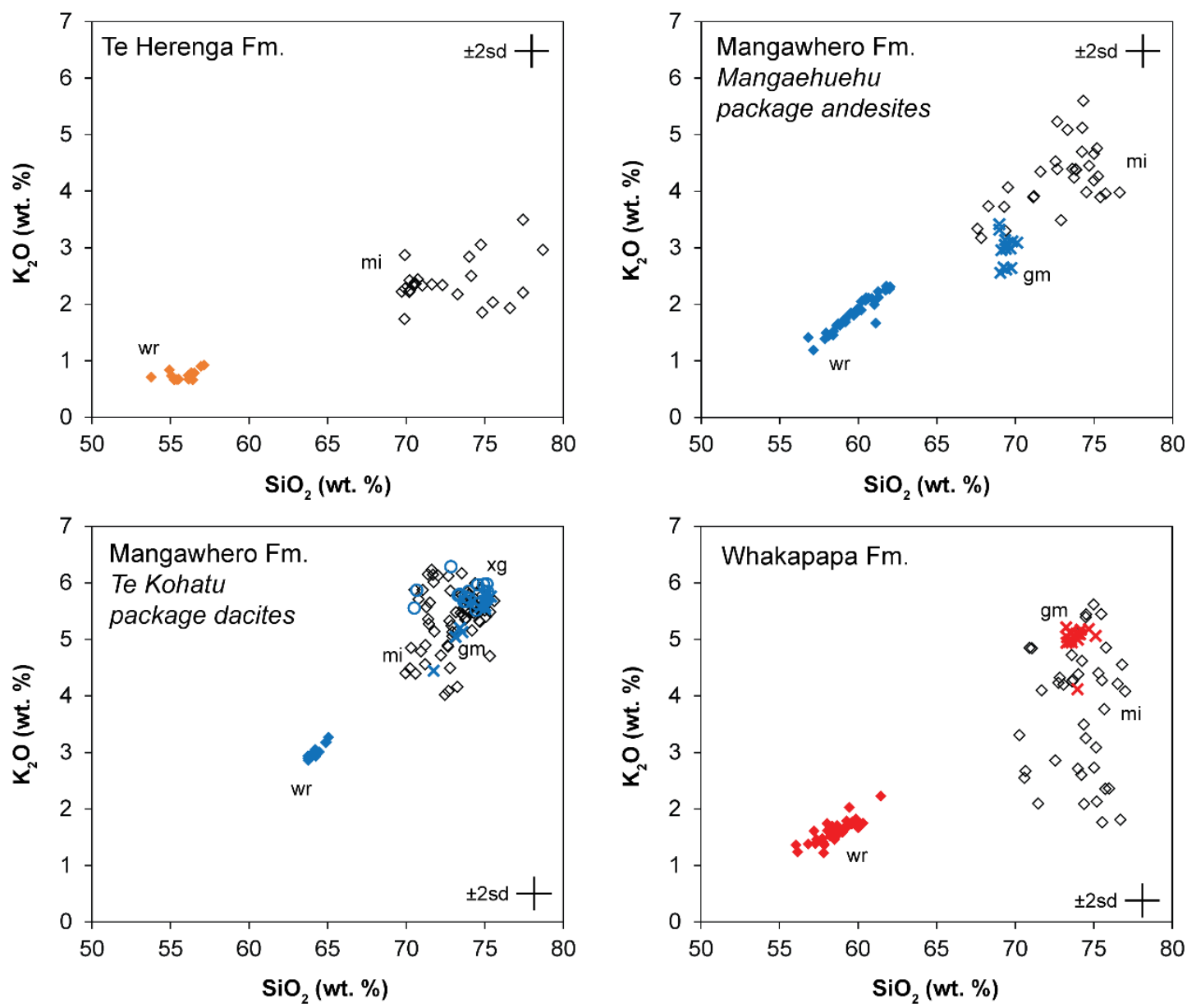

Figure 4.8. $\mathrm{SiO}_{2}-\mathrm{K}_{2} \mathrm{O}$ compositions for glass in Ruapehu lavas. Different symbols are used for whole-rock (wr, coloured diamonds), melt inclusion (mi; open diamonds), groundmass glass (gm; coloured crosses) and xenolith glass (xg; open blue circles). 
Melt inclusions within crystal clots in Te Kohatu package dacites (CC415, CC479) have distinctly high- $\mathrm{K}_{2} \mathrm{O}$ contents ( 4-6 wt. \%) but similar $\mathrm{SiO}_{2}$ contents ( 70-75 wt. \%) when compared to other lavas. Veins of quenched melt within feldspathic xenoliths $\left(\mathrm{An}_{65-68}\right)$ and pockets of interstitial glass in Te Kohatu package dacites (see Fig. 4.7) also have high $\mathrm{K}_{2} \mathrm{O}$ contents ( 5.4-6.2 wt. \%) together with high $\mathrm{Rb}(\sim 250 \mathrm{ppm}), \mathrm{Zr}(\sim 400$ ppm) and $\mathrm{Ba}(\sim 780 \mathrm{ppm})$ and low $\mathrm{Sr}(\sim 60 \mathrm{ppm})$ contents (Table 4.5). These glasses had low EPMA analytical totals ( 97-98 wt. \%) compared to groundmass glass and pyroxene hosted melt inclusions from the same sample ( 100 wt. \%) as well as analytical standards ( 99-100 wt. \%) that were analysed at the same time. Melt inclusion compositions in Whakapapa Formation lava samples are dacitic to rhyolitic (68-77 wt. \% $\left.\mathrm{SiO}_{2}\right)$ and display a wide compositional range from Te Herenga-like low-K types $\left(\sim 2 \mathrm{wt} . \% \mathrm{~K}_{2} \mathrm{O}\right)$ through to high-K types with $\sim 5.5$ wt. $\% \mathrm{~K}_{2} \mathrm{O}$ that overlap with groundmass glass compositions.

Table 4.4. LA-ICPMS trace element data for xenolith and interstitial glass.

\begin{tabular}{|c|c|c|c|c|c|}
\hline Sample & X1-1 & X2-1 & X2-2 & IG40-1 & IG12 $(n=7)$ \\
\hline${ }^{45} \mathrm{Sc}$ & 11.6 & 11.1 & 9.9 & 10.6 & $12 \pm 2$ \\
\hline${ }^{51} \mathbf{V}$ & 64.6 & 52.6 & 32.7 & 70.3 & $57 \pm 28$ \\
\hline${ }^{66} \mathrm{Zn}$ & 40.7 & 33.2 & 46.9 & 50.9 & $50 \pm 7$ \\
\hline${ }^{85} \mathbf{R b}$ & 255.3 & 274.2 & 272.7 & 272.1 & $271 \pm 12$ \\
\hline${ }^{88} \mathrm{Sr}$ & 56.3 & 57.4 & 49.5 & 90.5 & $55 \pm 6$ \\
\hline${ }^{89} \mathbf{Y}$ & 35.5 & 36.1 & 31.9 & 31.4 & $39 \pm 4$ \\
\hline${ }^{91} \mathrm{Zr}$ & 402.2 & 434.7 & 420.3 & 396.6 & $486 \pm 22$ \\
\hline${ }^{93} \mathrm{Nb}$ & 13.1 & 13.7 & 14.8 & 11.8 & $15 \pm 2$ \\
\hline${ }^{133} \mathrm{Cs}$ & 18.0 & 17.8 & 18.3 & 17.4 & $18 \pm 2$ \\
\hline${ }^{137} \mathbf{B a}$ & 788.7 & 785.8 & 741.4 & 1410.6 & $834 \pm 44$ \\
\hline${ }^{139} \mathrm{La}$ & 33.9 & 35.5 & 30.8 & 35.2 & $41 \pm 5$ \\
\hline${ }^{140} \mathrm{Ce}$ & 73.2 & 74.5 & 69.4 & 77.6 & $86 \pm 9$ \\
\hline${ }^{141} \mathrm{Pr}$ & 8.3 & 9.2 & 8.0 & 8.2 & $9 \pm 1$ \\
\hline${ }^{146} \mathrm{Nd}$ & 32.1 & 31.3 & 29.3 & 29.7 & $37 \pm 4$ \\
\hline${ }^{147} \mathrm{Sm}$ & 7.0 & 7.8 & 5.7 & 9.1 & $8 \pm 2$ \\
\hline${ }^{151} \mathbf{E u}$ & 0.5 & 0.6 & 0.7 & 1.0 & $1 \pm 0.5$ \\
\hline${ }^{157} \mathrm{Gd}$ & 7.5 & 7.6 & 3.7 & 8.5 & $8 \pm 3$ \\
\hline${ }^{159} \mathrm{~Tb}$ & 0.9 & 0.7 & 0.6 & 1.2 & $1 \pm 0.2$ \\
\hline${ }^{163} \mathrm{Dy}$ & 6.6 & 4.9 & 5.8 & 5.3 & $6 \pm 2$ \\
\hline${ }^{165} \mathrm{Ho}$ & 1.4 & 1.0 & 0.6 & 1.0 & $1 \pm 0.2$ \\
\hline${ }^{166} \mathrm{Er}$ & 3.6 & 2.8 & 2.9 & 2.5 & $4 \pm 1$ \\
\hline${ }^{169} \mathrm{Tm}$ & 0.7 & 0.5 & 0.7 & 0.2 & $0.5 \pm 0.3$ \\
\hline${ }^{172} \mathbf{Y b}$ & 2.6 & 2.9 & 2.2 & 4.2 & $4 \pm 1.5$ \\
\hline${ }^{175} \mathbf{L u}$ & 0.4 & 0.5 & 0.3 & 0.3 & $0.5 \pm 0.2$ \\
\hline${ }^{178} \mathrm{Hf}$ & 12.2 & 12.4 & 11.9 & 11.8 & $14 \pm 3$ \\
\hline
\end{tabular}

Values are in ppm. Sample prefix X indicates analysis of xenolith glass and IG for interstitial glass. X2-1 and X2-2 are analyses from the same xenolith. Average values \pm 2 standard deviations are shown for 7 analyses from IG12. 


\subsubsection{Crystal chemistry and compositional zoning}

A summary of compositional data for crystals in Ruapehu lavas is presented in Figure 4.9 and in Table 4.5. Typical zoning features of the major mineral phases are displayed in

Figures 4.10-4.13.
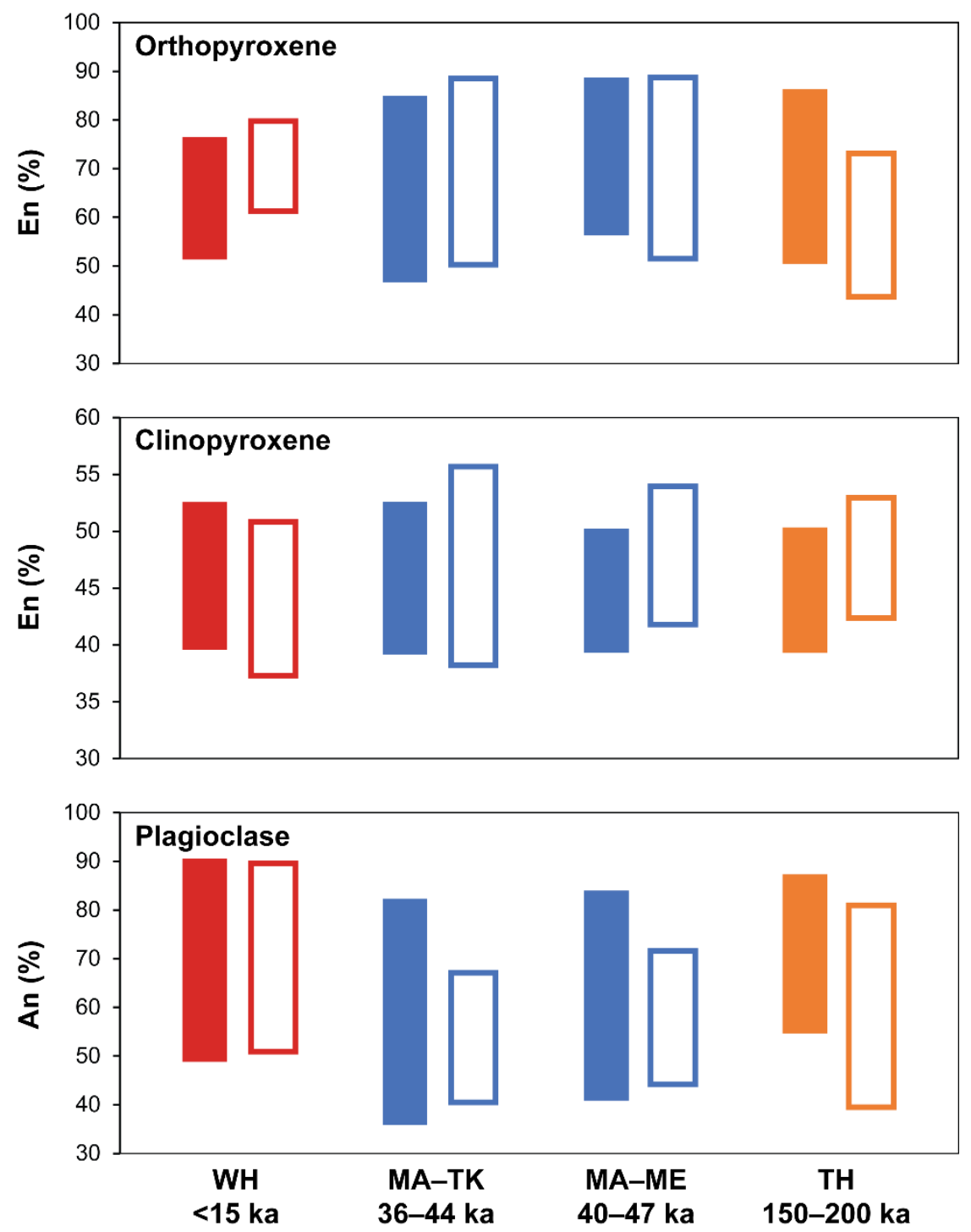

Figure 4.9. Summary of the range of mineral compositions in Ruapehu lavas. Orthopyroxene and clinopyroxene compositions (En \%) are shown in top panels; plagioclase anorthite compositions (An \%) are displayed in the bottom panel. Coloured bars indicate the range of core compositions; open bars indicate the range of rim compositions. Ranges are compiled for samples from the Te Herenga Formation (TH), the Mangawhero Formation Mangaehuehu package (MA-ME), and Te Kohatu package (MA-TK), and the Whakapapa Formation (WH). Age ranges for eruption of the formations and packages are shown in ka. 


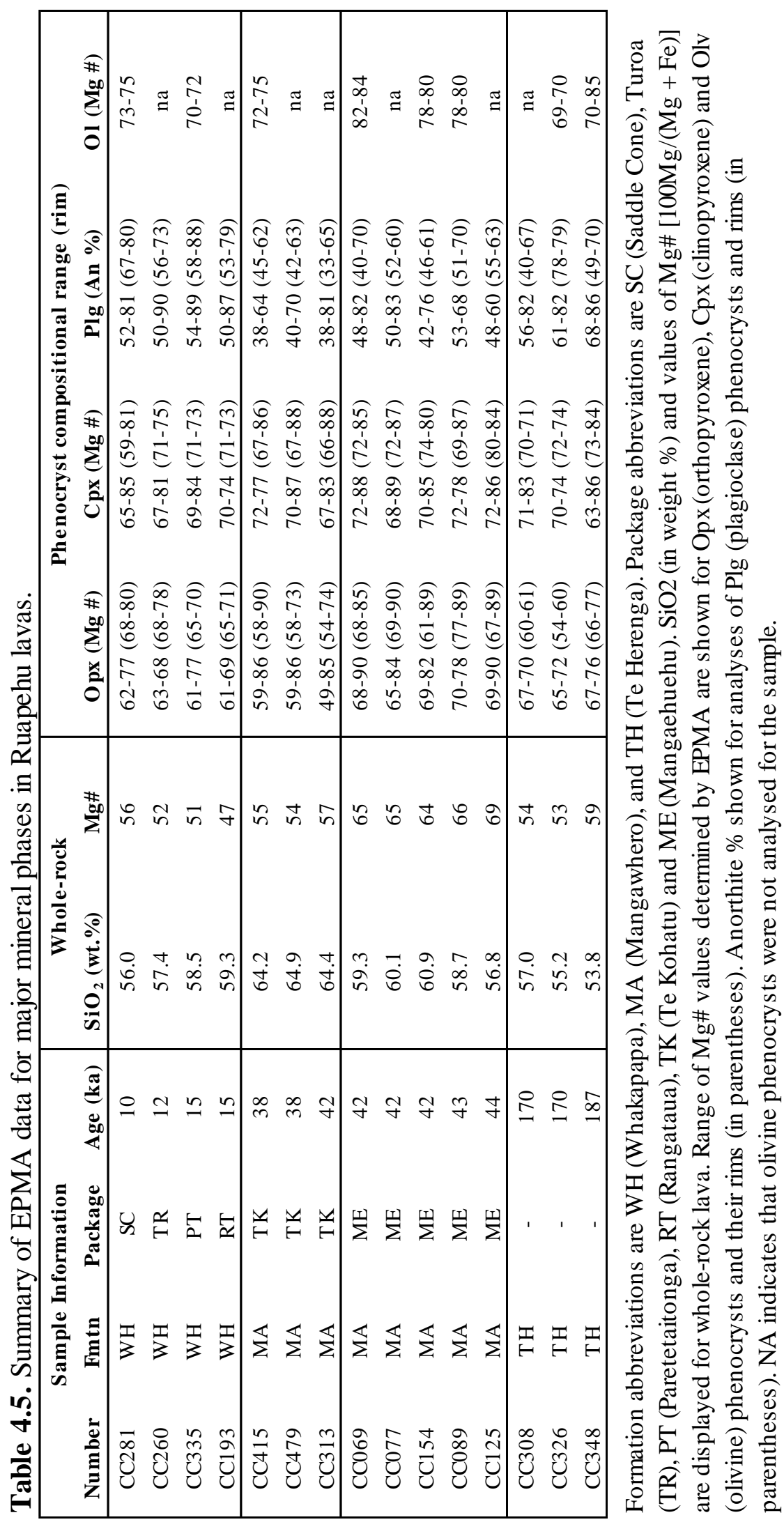




\subsubsection{Te Herenga Formation}

The mineral assemblage of the 200-150 ka basaltic-andesites is dominated by subhedral pyroxene phenocrysts and glomerocrysts that range in size up to $14 \mathrm{~mm}$ and are readily visible in hand specimen. Orthopyroxene phenocrysts exhibit minimal compositional zonation $\left(\sim \mathrm{Mg} \#_{70}\right)$ but commonly have resorbed edges that are overgrown by coronas of orthopyroxene with Mg\#55-60 (Fig. 4.10a). Clinopyroxene often displays complex multiple zoning outward of resorbed or mottled cores (Fig. 4.11a). Rims are typically more magnesian $\left(\mathrm{Mg \#}_{75-80}\right)$ than cores $\left(\mathrm{Mg \#}_{70}\right)$. Plagioclase phenocryst interiors are invariably sieved and often resorbed, whereas the outer $<200 \mu \mathrm{m}$ display faint cyclic zoning towards sub- or euhedral rims that are generally less calcic than the cores (Fig. 4.12a). Plagioclase crystals typically record more complex growth histories than pyroxene and olivine phenocrysts. Within CC348, the least evolved and oldest precisely dated Ruapehu sample collected in this study (see Chapter 3), olivine is relatively common as 100-500 $\mu \mathrm{m}$-wide rounded crystals (either isolated or within clots) that display a gradual decrease from $\mathrm{Mg}_{70-80}$ in cores towards $\mathrm{Mg \#}<70$ in rims (Fig. 4.13a). The rims are often resorbed (wavy) and overgrown by orthopyroxene with similar compositions to groundmass pyroxene $\left(\mathrm{Mg \#}_{70}\right)$.

\subsubsection{Mangawhero Formation}

Within the geochemically diverse Mangawhero Formation, the crystal-specific aspect of this study was restricted to lavas of the Mangaehuehu and Te Kohatu packages erupted during the early stage (50-35 ka).

\section{Mangaehuehu package}

Orthopyroxene and clinopyroxene phenocrysts and glomerocrysts dominate the mineral assemblage of lavas of this eruptive package. Accumulations of subhedral, unzoned and compositionally identical orthopyroxene form clusters $\leq 1.5 \mathrm{~mm}$ across within Mangaehuehu package lavas (Fig. 4.10b). These clots commonly contain glass (which has often partially crystallised to form plagioclase) along grain boundaries, as well as symplectite veins and pools (up to $300 \mu \mathrm{m}$-wide accumulations) of Fe-Ti oxide phases (magnetite). Outermost rims that are in contact with groundmass have $<5 \mu \mathrm{m}$-thick 
reaction coronas composed of prismatic orthopyroxene with lower Mg\# ${ }_{60-70}$. Crystal shapes range from euhedral to resorbed and rounded, with common examples of mechanical breakage. The most conspicuous crystal type is reverse-zoned orthopyroxene (and minor clinopyroxene), which comprises $\sim 8-17 \%$ of the total phenocryst proportion (Fig. 4.10c). This crystal type exhibits rounded and unzoned cores with $\sim \mathrm{Mg} \#_{70}$. Crystals display sharp transitions over 5-10 $\mu \mathrm{m}$ to dark rims with $\mathrm{Mg \#}_{85-90}$. The outer rims are generally euhedral, and average rim width varies between samples from $22-54 \mu \mathrm{m}$ with widest rims observed in lavas with highest whole-rock Mg\#. Outermost crystal margins typically have $<5 \mu$ m-wide reaction coronas composed of orthopyroxene with similar $\mathrm{Mg \#}$ values to the associated groundmass microcrystals $(\sim \mathrm{Mg \#} 70)$. Reverse zoned orthopyroxene are present both as individual grains and within clusters. For clustered crystals, only the outermost grain edges that are in contact with groundmass have $\mathrm{Mg}$-rich rims and rim width varies between adjacent crystals. Many individual crystals display broken edges along which there are thin orthopyroxene coronas but no high- $\mathrm{Mg}$ rims.

Clinopyroxene phenocrysts are subordinate in abundance compared to orthopyroxene and generally exhibit multiple compositional zones outward of resorbed or mottled cores with spongy textures (Fig. 4.11b). Core compositions range from $\mathrm{Mg \#}_{65-85}$; rim compositions lie within this range also. Clinopyroxene rarely ( $<5 \%$ proportion of clinopyroxene) exhibit the strong reverse zoning displayed commonly by orthopyroxene: rounded cores $\left(\mathrm{Mg \#}{ }_{70}\right)$ are sharply overgrown by BSE-dark rims $\left(\mathrm{Mg \#}{ }_{88}\right)$ and the outermost edges are composed of orthopyroxene coronas.

Plagioclase phenocrysts generally lack the intensely sieved and cored interiors that are characteristic of plagioclase crystals within Te Herenga Formation lava flows. They are characterised by cyclic zoning in the outer half of the crystal area and outer rims define sub- to euhedral forms (Fig. 4.12b). Compositions dominantly lie between An50-60, with rare calcic zones of $\mathrm{An}_{80}$.

Interiors of olivine (Mg\#78-84) are unzoned or normally zoned toward grain edges that are strongly resorbed and overgrown by clusters of coalescing orthopyroxene crystals (Fig. $4.13 \mathrm{~b}, \mathrm{c})$. Symplectite veins and 50-80 $\mu \mathrm{m}$-wide patches of Fe-Ti oxide mineral phases are common at the interface between resorbed olivine and outer pyroxene crystals. 


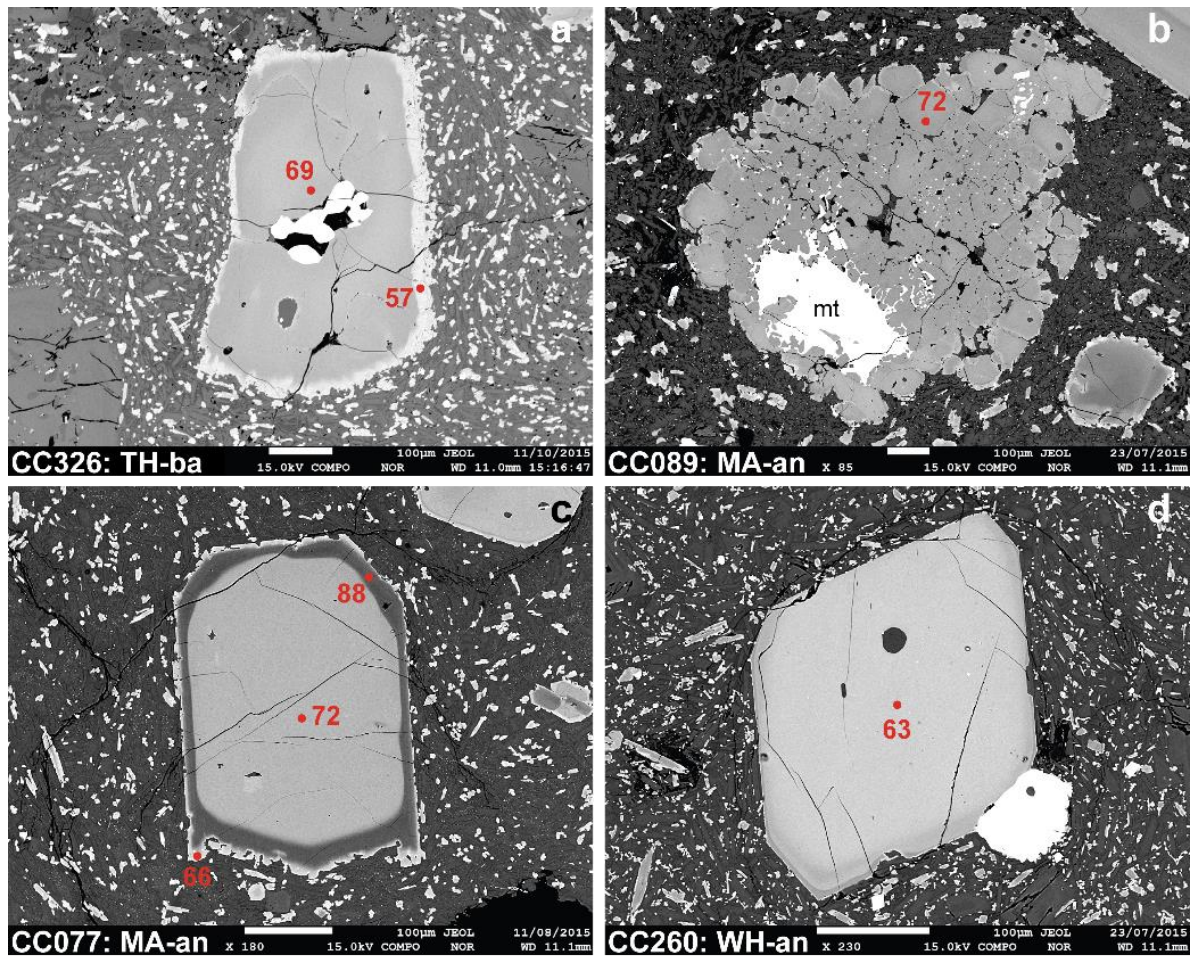

Figure 4.10. EPMA back-scattered electron images of orthopyroxene crystals in Ruapehu lavas. Mg\# values are shown (in red) for analysis sites (red dots). Sample numbers and corresponding Formation and composition are labelled on each panel. Abbreviations are TH (Te Herenga), MA (Mangawhero), WH (Whakapapa), ba (basaltic-andesite), an (andesite), da (dacite). Patch of mnt (magnetite) is labelled in (b). Explanation of textures and features is provided in the text.
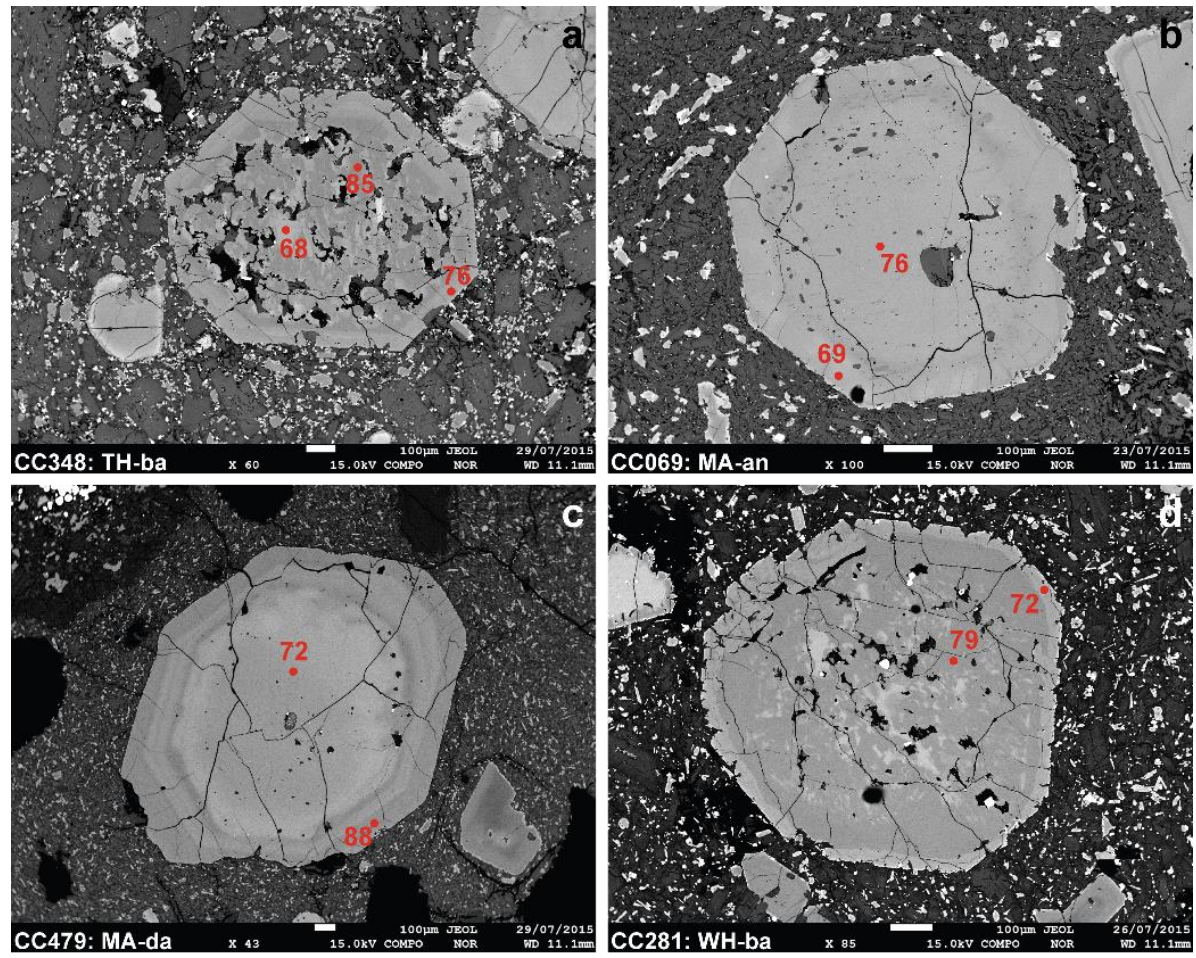

Figure 4.11. EPMA back-scattered electron images of clinopyroxene crystals in Ruapehu lavas. See caption of Figure 4.10 for explanation of abbreviations for sample labels. 

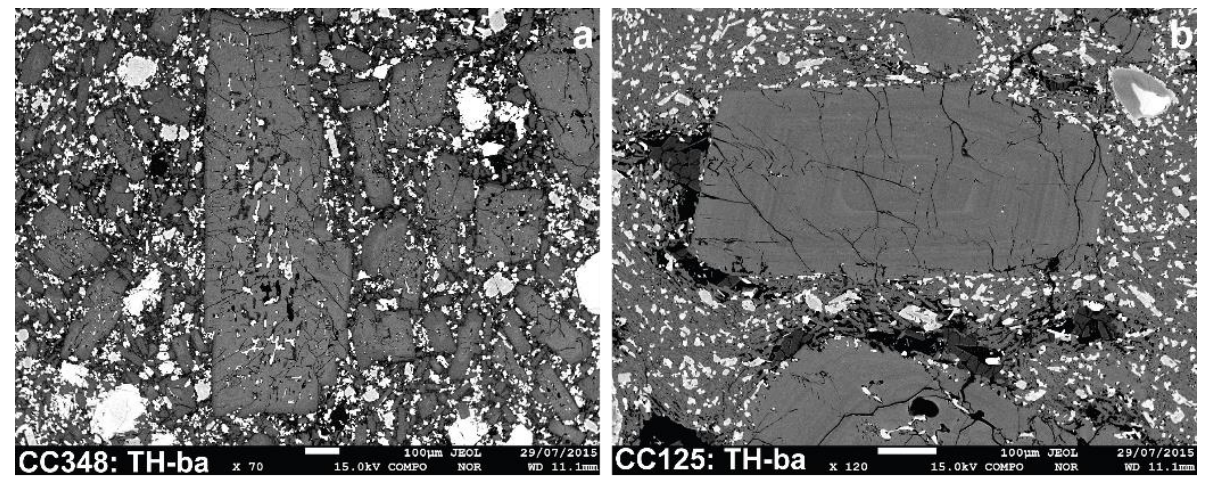

Figure 4.12. EPMA back-scattered electron images of plagioclase crystals in Ruapehu lavas. See caption of Figure 4.10 for explanation of abbreviations for sample labels.
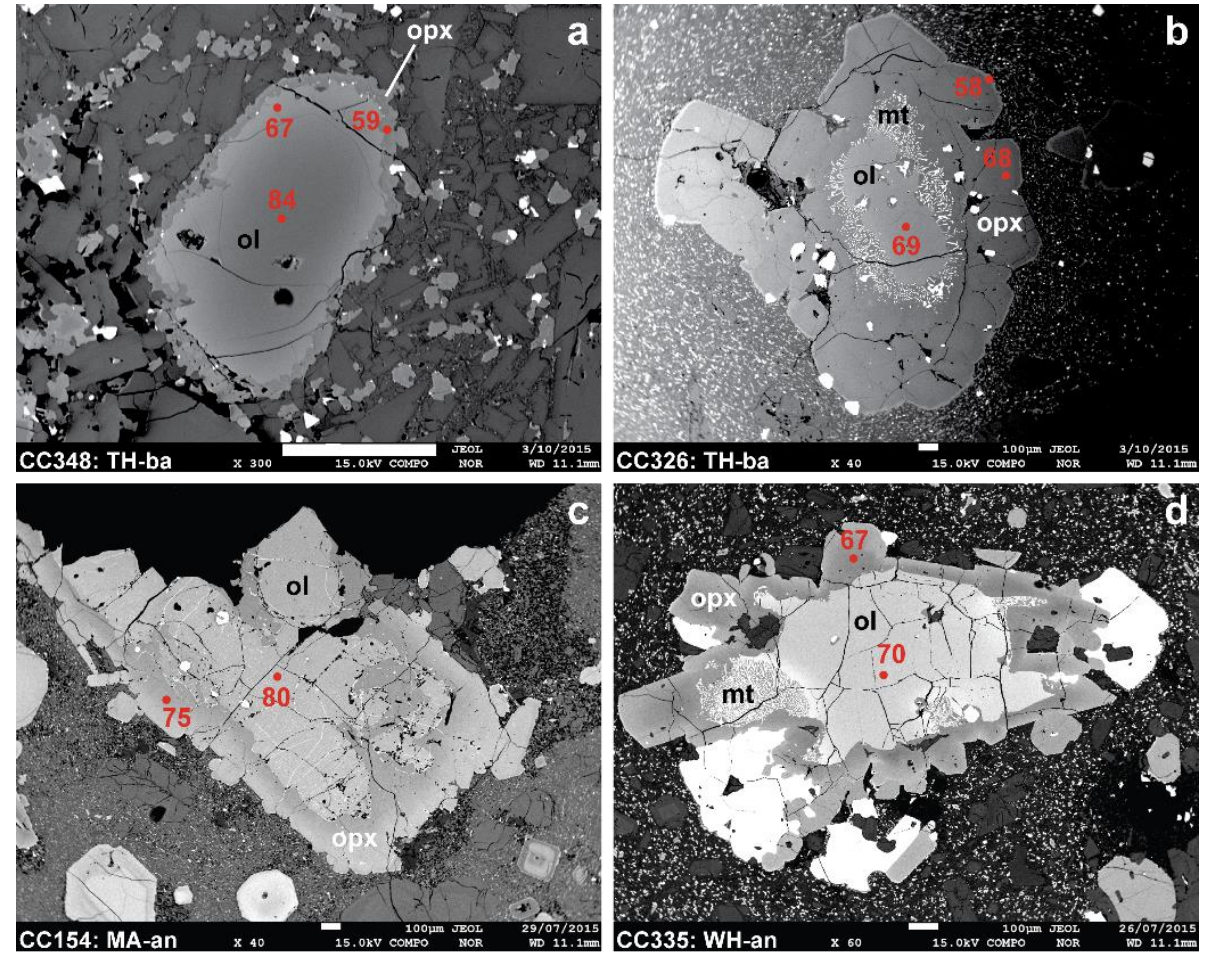

Figure 4.13. EPMA back-scattered electron images of olivine crystals with in Ruapehu lavas. In each example shown, ol (olivine) is bordered by rims of opx (orthopyroxene). Further explanation in text. See caption of Figure 4.10 for explanation of abbreviations for sample labels.

\section{Te Kohatu package}

As with Mangaehuehu package andesites, reverse-zoned orthopyroxenes (and minor clinopyroxenes) are present within Te Kohatu dacites, although in lower abundances ( 7 $\%$ of total phenocryst proportion) compared to the andesites. Mg-rich rims (Mg\#82-88) have sharp boundaries with rounded cores $\left(\mathrm{Mg \#}_{70-76}\right)$ and are overgrown by an outermost $<5 \mu$ m-thick euhedral rim with compositions equivalent to groundmass pyroxene 
microcrystals ( $\left.\mathrm{Mg}_{60-70}\right)$. Unzoned othopyroxene phenocrysts $\left(\mathrm{Mg \#}_{60-70}\right)$ are present as sub- to euhedral grains as well as anhedral and broken crystals within the dacites. Clinopyroxene are generally sub- to euhedral and exhibit multiple compositional zoning patterns (Fig. 4.11c). Plagioclase phenocrysts display a range of complexly zoned types, often comprising sieved or spongy cores that have been resorbed and overgrown by multiple zones and subhedral rims. Anorthite contents range from $45-65 \mathrm{~mol}$. \%, and rims generally display less calcic compositions than cores. Rare euhedral apatite crystals (100-200 $\mu \mathrm{m}$-long) are present along pyroxene rims within glomerocryst clusters. Relict amphibole grains are identified based on their characteristic diamond-shaped crosssectional forms but have been completely replaced by symplectite intergrowths of orthopyroxene + plagioclase $+\mathrm{Fe}$-Ti oxides \pm apatite \pm minor glass. Clusters of crystals comprised of orthopyroxene, clinopyroxene, plagioclase and Fe-Ti oxides form clots up to $12 \mathrm{~mm}$-wide within Te Kohatu dacite lavas. Interstitial glass is preserved between these phases within pockets that are not in immediate contact with groundmass.

\subsubsection{Whakapapa Formation}

Euhedral and subhedral grains of unzoned orthopyroxene with compositions of $\mathrm{Mg \#}_{65-70}$ are the dominant crystal type within Whakapapa Formation lavas (Fig. 4.10a). Rare glomerocrysts of anhedral and unzoned orthopyroxene with $\mathrm{Mg \#}_{65-70}$ occur within the lavas. Reverse zoned types with rim compositions of $\mathrm{Mg \#}_{78-84}$ were observed in basalticandesite lava sample CC281 ( $12 \%$ of total phenocryst proportion) and rarely ( $<5 \%$ phenocrysts) in samples CC193, CC260 and CC335. Clinopyroxene dominantly exhibits mottled cores, similar to those in the older formations (Fig. 4.11d). Resorbed olivine cores $\left(\mathrm{Mg \#} \#_{70-75}\right)$ are overgrown by orthopyroxene (Mg\#60-72), and the boundary between olivine and orthopyroxene is often marked by magnetite symplectites (Fig. 4.13d). Plagioclase phenocrysts display resorbed cores that are often spongy or sieved. Outer zones of crystals exhibit fine-scale cyclic zoning (An60-90) toward subhedral or euhedral rims. 


\subsection{DISCUSSION}

The extended sample coverage and improved geochronological sequencing of lava flows presented here makes it possible to refine published models of the evolution of the Ruapehu magmatic system. The new data bring to light several key questions, including:

- What caused elevated levels of differentiation and diversity in magmas that were erupted between $\sim 50$ and $35 \mathrm{ka}$ ?

- What caused the reversion to more mafic whole-rock compositions (with less potassic melt inclusions) after $26 \mathrm{ka}$ ?

- What is the nature and origin of rhyolitic melts generated in the Ruapehu andesitedacite magma system and what is their link to rhyolites from Taupo volcano?

- What is the petrogenetic significance of the eruption of a suite of high-magnesian andesites and dacites between $\sim 50$ and $35 \mathrm{ka}$ ?

\subsubsection{Long-term whole-rock compositional trends}

The eruptive products of composite volcanoes can cover the compositional spectrum from basalt to rhyolite, however, time-sequenced trends generally do not follow unique pathways of progressive evolution toward the silicic end of the spectrum (cf. Eichelberger et al., 2006). To explain non-systematic geochemical changes observed in volcanic sequences erupted over time periods ranging from $<1 \mathrm{yr}$ to $>10 \mathrm{kyr}$, models of random tapping of individual batches of magma that have followed distinct lithospheric pathways of mixing and contamination have been invoked for Ruapehu and Tongariro (e.g. Hobden et al., 1999; Gamble et al., 1999; Shane et al., 2008; Price et al., 2012) as well as numerous composite volcanoes globally (e.g. Dungan et al., 2001; Frey et al., 2004). Over longer time periods of (>100 kyr), a common conception is that magma systems evolve toward producing more silicic eruptive products. This idea is founded on the association of non-evolved (mafic) eruptive products with stratigraphically old portions of volcanic edifices, and the eruption of more evolved lavas and, in some cases, the incidence of climactic explosive eruptions of silicic magma later in the history of composite volcanoes (e.g. Bacon and Lanphere, 2006; Hora et al., 2007; Singer et al., 2008; Escobar-Wolf et al., 2010). Throughout the cycle of volcanism represented by the eruptive products, the corresponding development of evolved, relatively low-density intrusive complexes in the 
crust will impede higher-density, more mafic magmas from reaching the surface. This provides a feedback loop that may explain such evolutionary trends.

An alternative consideration is that the load imparted on a magma source region during the construction of a surficial volcanic edifice allows only the eruption of progressively more buoyant magmas as the load increases with cumulative growth of the volcano (Pinel and Jaupart, 2000). It then follows that destructive loss of mass from the edifice by sector collapse or erosion would enable the eruption of more dense magmas (Pinel and Jaupart, 2005). In this way, a composite volcano acts as a density filter for eruptible magma compositions.

\subsubsection{Compositional evolution of Ruapehu lava flows}

Investigating the time-sequenced variation of Ruapehu lavas enables assessment of the magmatic and crustal influences on the composition of eruptive products throughout the construction of a composite volcano in a continental arc setting. Ruapehu lavas display a gradual increase in $\mathrm{SiO}_{2}, \mathrm{~K}_{2} \mathrm{O}$, incompatible trace element contents (represented here by $\mathrm{Zr}$ ) and ratios (e.g. La/Yb) from 200 to $80 \mathrm{ka}$ (lavas of the Te Herenga and Wahianoa formations; Fig. 4.14). One of the oldest dated flows in this study is also the most mafic (sample CC348: 190 ka; 53.8 wt. \% $\mathrm{SiO}_{2}$ ).

Following the gap between $\sim 80$ and $50 \mathrm{ka}$, during which no lavas were erupted that were captured by the intensive sampling undertaken previously and for this thesis, magma composition diversity was greatest during the eruptive period from $\sim 50-35 \mathrm{ka}$ (Fig. 4.14). Despite a compositional gap between lava flows with $\sim 62$ and 63 wt. $\% \mathrm{SiO}_{2}$, effusion of dacite was prevalent during this time (Fig. 4.3). Lava flows that were erupted during this period display a wide range in incompatible trace element contents, which extend to the most continental crust-like values for Ruapehu samples, and generally does not overlap with the composition of lava flows in the Te Herenga Formation (Figs. 4.5, 4.14).

Lavas that have erupted since $\sim 35$ ka define a trend opposite to that in the earlier magmatic history: 35-26 ka lava flows have a relatively narrow range of compositions intermediate within the range defined by $\sim 50-35 \mathrm{ka}$ lavas, and younger flows (<26 ka) exhibit progressively less silicic compositions with time (Fig. 4.14). An exceptions to this trend is the late Holocene Whangaehu flow $\left(61.5 \mathrm{wt} . \% \mathrm{SiO}_{2}\right)$ of the Crater Lake package. 
Trends for incompatible major $\left(\mathrm{K}_{2} \mathrm{O}\right)$ and trace $(\mathrm{Zr})$ elements, as well as trace element ratios $\left(\mathrm{La} / \mathrm{Yb}\right.$ ), display the same decreasing pattern as $\mathrm{SiO}_{2}$ for post-35 ka lavas (Fig. 4.14).

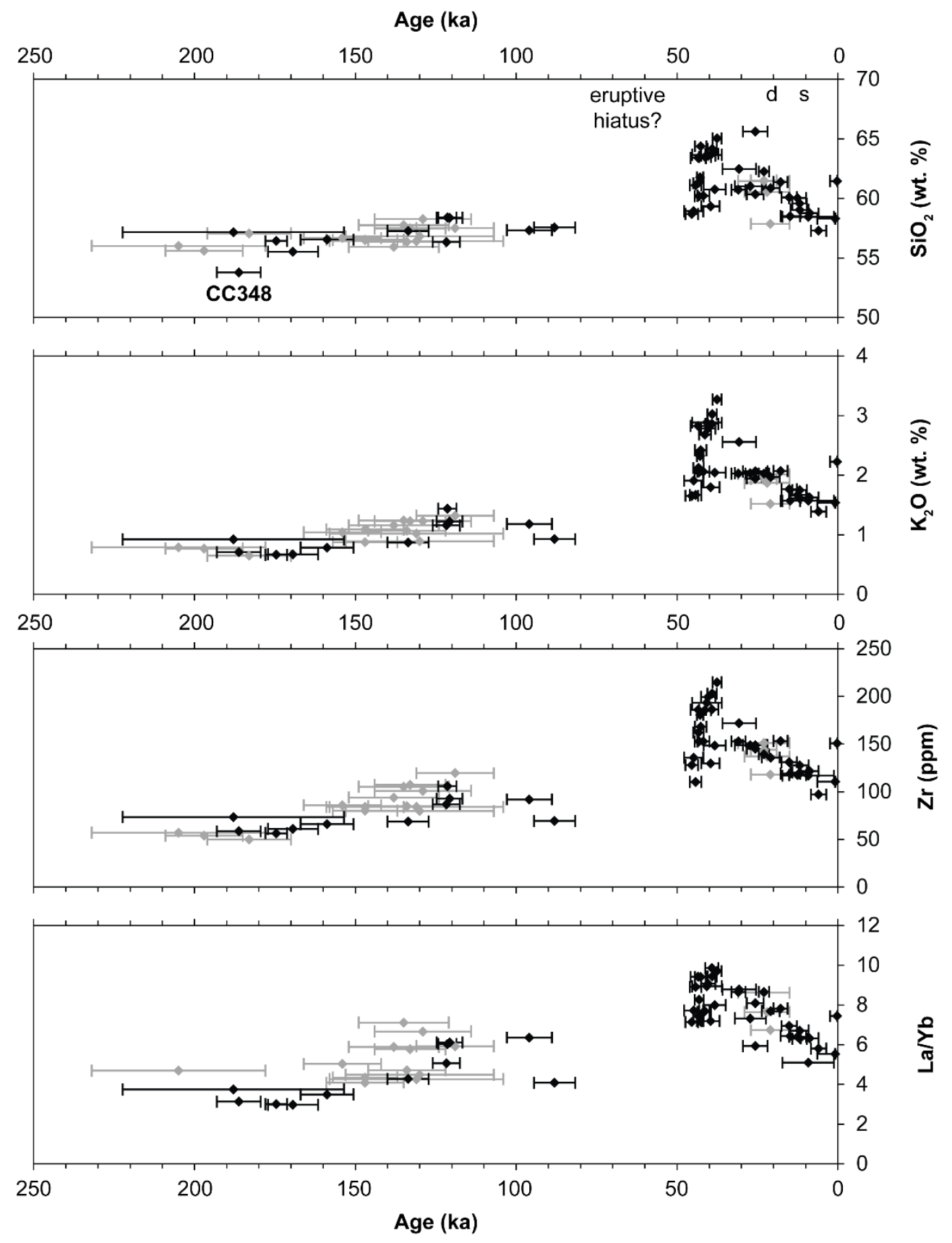

Figure 4.14. Time-composition relationships for Ruapehu lavas. Lava ages are ${ }^{40} \mathrm{Ar} /{ }^{39} \mathrm{Ar}$ weighted mean plateau ages (WMPA) with associated 2sd uncertainties shown by bars. This figure is repeated here from Fig. 3.18 in Chapter 3 with additional trace element data. Grey diamonds are samples dated by Gamble et al. (2003) with corresponding compositional data presented by Price et al. (2012). Black diamonds are samples dated in this study. The timing of an apparent eruptive hiatus, the onset of deglaciation (d) and the sector collapse of the northern flank (s) are labelled in the top panel. 
The matching trends for different elements suggest that some common process (or combination of processes) has controlled compositional variation through time. The linear relationship between ${ }^{87} \mathrm{Sr} /{ }^{86} \mathrm{Sr}$ and $\mathrm{SiO}_{2}, \mathrm{~K}_{2} \mathrm{O}$, and incompatible trace elements indicates that assimilation of basement metasedimentary crust had a primary role, along with crystal fractionation, in the compositional development of post-Te Herenga Formation magmas. Crust-normalised multielement diagrams reflect this trend also. The most 'crustlike' compositions are observed for dacite lavas erupted at $40 \mathrm{ka}$, whereas there are notably low values for lavas of the Te Herenga and Wahianoa formations, and a reversion to less crust-like values for Whakapapa Formation lavas (Fig. 4.14).

Previous bivariate major element plots revealed a scatter of overlapping data for lavas of variable age (e.g. Fig. 10 in Price et al., 2012). In light of the more comprehensive sample suite and better age control presented here, the covariance of molar $\mathrm{K} / \mathrm{Ca}$ with $\mathrm{SiO}_{2}$ contents is shown to be a particularly useful discriminant for lavas from the three broad periods of volcanism at Ruapehu (Fig. 4.3). Pre-80 ka lavas do not form a strong trend toward a unique end-member, but are tightly clustered around relatively low $\mathrm{SiO}_{2}$ and $\mathrm{K} / \mathrm{Ca}$ values (Fig. 4.3). Lavas that were erupted between $\sim 50$ and $26 \mathrm{ka}$ and $<26 \mathrm{ka}$ define distinct $\mathrm{SiO}_{2}-\mathrm{K} / \mathrm{Ca}$ compositional trends: Te Kohatu package dacite (sample CC508; 37.6 $\pm 1.4 \mathrm{ka}$ ) forms a silicic end-member for 50-26 ka lava flows; Whakapapaiti package member dacite (sample CC513; $25.7 \pm 3.8 \mathrm{ka}$ ) forms a silicic end-member for $<26 \mathrm{ka}$ lavas (Fig. 4.3). Although the preserved portion of Whakapapaiti package dacite flows is volumetrically minor (see Chapter 3, Fig. 3.10), their eruptions delineate a significant change in the mechanics of magma genesis after $26 \mathrm{ka}$.

As noted above, lavas erupted during the period from $\sim 50-26 \mathrm{ka}$ appear to be represented by a single silicic end-member in $\mathrm{SiO}_{2}-\mathrm{K} / \mathrm{Ca}$ space (i.e. Te Kohatu package dacite; Fig. 4.4). However, examination of their $\mathrm{MgO}$ contents reveals a bimodal diversity. Mangaehuehu package andesites and Te Kohatu package dacites form a high-MgO trend when plotted against $\mathrm{SiO}_{2}$, whereas Ngahuinga package andesites and Mangaturuturu package dacites align with a lower-MgO compositional array (Fig. 4.15). The lower MgO trend is broadly representative of all other Ruapehu lavas except for the Whakapapaiti package dacite flows, which have distinctive $\mathrm{K}_{2} \mathrm{O}$ concentrations (Figs. 4.3, 4.15). 

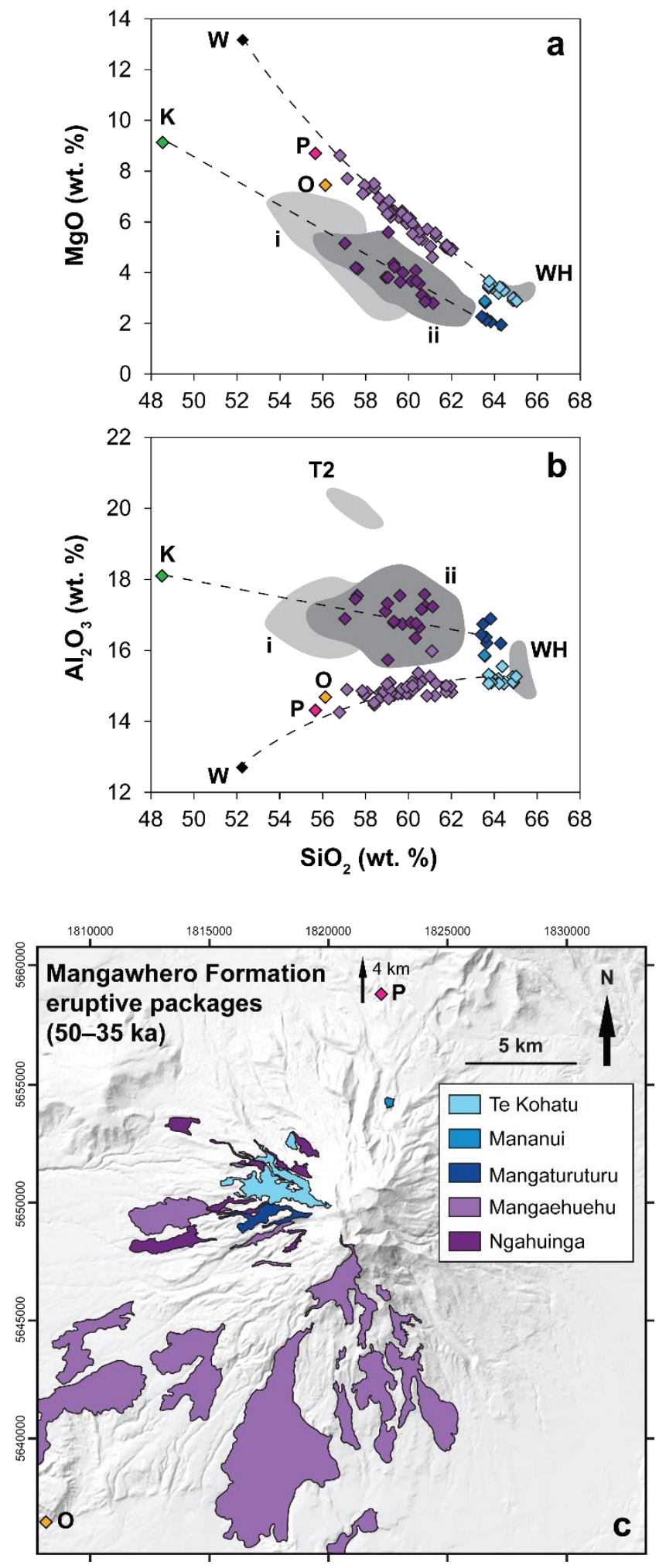

Figure 4.15. Compositional characteristics (a, b) and spatial distribution (c) of early Mangawhero Formation lava flows. (a) $\mathrm{MgO}$ and (b) $\mathrm{Al}_{2} \mathrm{O}_{3}$ versus $\mathrm{SiO}_{2}$ plots for lavas erupted from 50 to $35 \mathrm{ka}$. Colour key for lava packages is shown in (c). Shaded fields show compositional ranges for pre-80 ka Ruapehu lavas (i) and post-35 ka Ruapehu lavas (ii). Additional fields labelled for WH ( 26 ka Whakapapaiti dacite package) and T2 (Type 2 plagioclase-phyric andesites of the Wahianoa Formation; Graham and Hackett, 1987)). Generalised trends (dashed lines) for the low- and high-MgO suites are projected towards towards K (Kakuki basalt) and W (Waimarino basalt), respectively. Basalt compositions from Gamble et al. (1993). Average compositions of $\mathrm{P}$ (Pukeonake andesite) and $\mathrm{O}$ (Ohakune andesite) shown for comparison; data from Cole (1978) and Hackett (1985). Locations of P and O labelled in (c). 
Reasons for the high-MgO compositions are discussed in section 4.6.3., but the trends are here investigated to establish scales of heterogeneity within the magma system beneath Ruapehu. Preliminary comparisons are made between Ruapehu lavas and Waimarino and Kakuki basalts from the Taupo Volcanic Zone (Gamble et al., 1993), as well as Pukeoanake and Ohakune andesite lavas and scoria, which were erupted from small peripheral vents that are located $\sim 20 \mathrm{~km}$ from the central vent area of Ruapehu (Fig. 4.15c). Eruptive activity at the peripheral vents pre-dates the deposition of the Oruanui tephra (25.4 ka; Vandergoes et al., 2013) as indicated by stratigraphic relations (Hacket, 1985; Froggatt and Lowe, 1990), and is likely to have occurred within the period $\sim 40-30$ $\mathrm{ka}$, thus, making them broadly overlapping in time with the eruption of high-Mg lavas from Ruapehu. The discussion of the significance of these peripheral high-magnesian lavas is expanded in section 4.6.3.

Compositions for $\sim 50-35 \mathrm{ka}$ lavas span $\mathrm{SiO}_{2}$ contents that equate to the range of all but the most mafic of pre-80 ka Ruapehu lavas whether sampled for this thesis or by previous work (Fig. 4.14). The compositional range of the high-MgO lineage is disrupted by a 1.5 wt. \% gap in $\mathrm{SiO}_{2}$ contents and a 0.5 wt. \% gap in $\mathrm{K}_{2} \mathrm{O}$ contents, which corresponds to a north-south spatial distinction between the two lava packages (Fig. 4.15). The high-MgO trend can be traced toward the composition of Waimarino basalt, and is approximately intercepted by the composition of Pukeonake and Ohakune andesites (Fig. 4.15).

The low-MgO suite (Ngahuinga and Mangaturuturu packages) displays a 1.9 wt. \% gap in $\mathrm{SiO}_{2}$ contents (Fig. 4.15) and a 0.5 wt. \% gap in $\mathrm{K}_{2} \mathrm{O}$ contents within lavas erupted at this time. This low-MgO group form a general trend from Mangaturuturu dacite toward Kakuki basalt, which is broadly intercepted by all post-35 ka and pre-80 ka lavas from the Ruapehu edifice. The striking geochemical association between the spatially discrete Mangaehuehu package andesite flows (to the south) and Te Kohatu package dacite flows (to the northwest) is notable given the eruption of low-MgO Ngahuinga package andesite and Mangaturuturu package dacite flows that were apparently also erupted from a vent focus that was proximal to that of Te Kohatu package dacites during the same period (Fig. 4.15c). Additionally, the unique geochemical characteristics of Mananui package dacite on northern Ruapehu indicate that this flow was sourced from a magma system separate to that of Te Kohatu and Mangaturuturu package dacites (Fig. 4.15). 
These relationships imply that at least three magma types (Te Kohatu-Mangaehuehu high-MgO; Ngahuinga-Mangaturuturu low-MgO; Mananui mid-MgO) were feeding lavas to the south, west and north flanks of Ruapehu from spatially proximal vent foci during this time period ( $\sim 50-35 \mathrm{ka})$ and yet were able to remain compositionally isolated. Mapping of compositionally distinct eruptive packages with overlapping time periods of emplacement for late ( 35-26 ka) Mangawhero Formation lavas and Whakapapa Formation lavas (see Figs. 3.10, 3.14 in Chapter 3) is further evidence of magma heterogeneity within the magma system beneath the Ruapehu edifice. Despite this heterogeneity, the long-term compositional evolution remains broadly coherent (Fig. 4.14).

\subsubsection{Potential role of density filtering of magma compositions}

Here the possibility is investigated that the time-composition trends in the effusive volcanic record at Ruapehu are biased due to the ability of magmas of certain compositions to erupt is investigated. The mobility of magma depends on rheological properties governed by crystallinity, temperature, viscosity, and volatile content (Marsh, 1981), as well as regional tectonic stress regimes and mantle melt production. The compositions of erupted volcanic rocks are therefore ultimately biased towards those of magmas that overcome the opposing lithostatic load by ascending through the crust and ultimately being erupted. As lithostatic conditions that influence the ease of magma ascent through the crust change (e.g. regional rifting rates and addition or removal of overlying mass through edifice construction/destruction), so too will the potential for magmas of different composition to be erupted. The compositional variations within volcanic sequences at composite volcanoes can potentially trace these changes. One hypothesis that has been explored for the magmatic evolution of composite volcanoes through modelling (Pinel and Jaupart, 2000) and chemostratigraphic studies (Hora et al., 2007; Escobar-Wolf et al., 2010) is that cumulative edifice growth increases lithostatic pressure on magma chambers and inhibits the ascent of dense magmas, thus filtering the composition of erupted products toward more evolved types. With time the density of magmas will be lowered via crystal fractionation, enabling them to overcome the critical density threshold imposed by loading of the edifice in order to ascend and ultimately erupt (Pinel and Jaupart, 2000). Conversely, unloading of an edifice via deglaciation, 
erosion or sector collapse will reduce the confining pressure on magma reservoirs and enable relatively dense magmas to ascend to the surface (Pinel and Jaupart, 2005).

In light of the hypothesised consequences of density filtering at growing volcanic edifices, two observations within the geochemical evolution of Ruapehu lavas are considered significant here. First, the prevalent effusion of dacite following $>150 \mathrm{kyr}$ of edifice construction by effusive eruption of basaltic-andesites and andesites of the Te Herenga and Wahianoa formations. Second, the reversion to more mafic lava compositions, which broadly overlaps with deglaciation of the edifice after $\sim 18 \mathrm{ka}$ and Holocene sector collapse events.

With respect to the first observation, the 50-35 ka effusive episode occurred after an apparent $\sim 30 \mathrm{kyr}$ hiatus in eruptive activity (Fig. 4.14). This followed the construction of a composite edifice comprising the Te Herenga and Wahianoa formations that contributed $\mathrm{a} \geq 110 \mathrm{~km}^{3}$ volume of total eruptive products to the lithosphere above the Ruapehu magmatic system, during which time lava compositions generally became gradually more evolved (Fig. 4.14). The eruptive hiatus may represent the development of a density barrier for the eruption of basaltic-andesite and andesite magmas that had been ongoing for the prior $100 \mathrm{kyrs}$ (Fig. 4.14).

Mangawhero Formation dacite lavas were erupted following the apparent hiatus, but basaltic-andesites were also erupted at the beginning of the 50-35 ka eruptive period (within the Mangaehuehu and Ngahuinga packages) with $\mathrm{SiO}_{2}$ contents comparable to pre-80 ka lavas. The eruption of basaltic-andesite appears to contradict the hypothesis that a density filter biased the eruptible magma compositions at this time. The connection between the apparent compositional gap for lavas with $\mathrm{SiO}_{2}$ between 61.9-63.4 wt. \% erupted at $\sim 50-35 \mathrm{ka}$ (Figs. 4.3, 4.15) and a density control on eruptible magma compositions is ambiguous. The compositional gap was, however, partially filled by the subsequent eruption of Manganuioteao package lavas between 35 and $26 \mathrm{ka}$ (Table 4.2). With respect to the second observation, there is a conspicuous trend toward more mafic lavas erupted since $\sim 26 \mathrm{ka}$ and Holocene lava flows are exclusively andesites to basalticandesites with $\mathrm{SiO}_{2}$ contents $\leq 59$ wt. \% (excepting the late Holocene Whangaehu flow with 61.5 wt. \% $\mathrm{SiO}_{2}$ ). Although not exactly coincident with the onset of this compositional change, wholesale glacial retreat on Ruapehu from $\sim 18 \mathrm{ka}$ is inferred from regional paleoclimate records (Newnham et al., 2003), and corroborated by local moraine 
geochronology (Eaves, 2015) and lava-ice interaction features (Chapter 2; Conway et al., 2015). Furthermore, sector collapse of the northwest summit and upper flank at $\sim 10.5 \mathrm{ka}$ (Palmer and Neall, 1989; Eaves et al., 2015) and the southeast summit at $4.6 \mathrm{ka}$ (Donoghue and Neall, 2001) would have also contributed to a reduction of the vertical component of stress on the sub-volcanic system. From the preserved extents of the resultant debris avalanche deposits, the volume of collapsed material is calculated to be $\sim 1 \mathrm{~km}^{3}$.

The positive relationship between $\mathrm{SiO}_{2}$ and ${ }^{87} \mathrm{Sr} /{ }^{86} \mathrm{Sr}$ values for Ruapehu lavas indicates that crustal assimilation during magma genesis was a fundamental control on the eruptive products (Graham and Hackett, 1987; Price et al., 2012). This does not preclude the influence of a density filter (cf. Pinel and Jaupart, 2000) but is interpreted here to reflect a coupling between magma diversity and crustal assimilation, which relates more to the thermal condition of the crust than the load imposed by construction (or destruction) of a surficial edifice. Moreover, the volume of material reduced from the edifice due to sector collapse $\left(\sim 1 \mathrm{~km}^{3}\right)$ and superficial ice cover is minor compared to total edifice volume $\left(\sim 150 \mathrm{~km}^{3}\right)$. Factors such as tectonic activity and flux of melt from the mantle, although hard to quantify, are also primary influences on the timescales of magma generation and residence in the crust (e.g. Schmidt and Grunder, 2009). To conclude this section of the discussion, it is here considered to be unlikely that systematic trends within the $200 \mathrm{kyr}-$ long chemical evolution of Ruapehu lavas were influenced primarily by density filtering of eruptible magma compositions. Instead, eruptions tapped magmas that had undergone variable degrees of differentiation in the crust via mechanisms of crystal fractionation and crustal assimilation. The extent of magma differentiation has apparently varied systematically (Fig. 4.14) from minimal degrees at $190 \mathrm{ka}$ that increased gradually for lavas erupted between $\sim 160$ and $80 \mathrm{ka}$, to maximum (though variable) degrees at $\sim 50-35$ $\mathrm{ka}$, followed by a reversion to lower degrees since $26 \mathrm{ka}$. Thus, despite evidence for short-term heterogeneity within individual eruptive sequences on annual to $10 \mathrm{kyr}$ timescales (e.g. Gamble et al., 1999, 2003), this study has defined a broadly coherent geochemical trend for Ruapehu eruptive products over the $\sim 200 \mathrm{kyr}$ lifetime of the exposed edifice. The mechanisms of magma differentiation and the reasons for their varied influence through time are now explored in the following sections. 


\subsubsection{Nature and origin of silicic melts in Ruapehu lavas}

Silicic glass compositions (often rhyolite) for groundmass and melt inclusions in arc andesite-dacite volcanic rocks have been widely reported (Reubi and Blundy, 2009; Kent, 2013; Lee and Bachmann, 2014). Determining the origin of silicic melts within volcanic arc systems is of key importance for understanding the distinctive continental signature of arc rocks and element recycling through the mantle and crust. Silicic melts can originate via fractionation of mantle-derived primary basaltic magmas (e.g. Sisson et al., 2005), partial melting of subducted oceanic lithosphere and sediment (e.g. Tatsumi, 2001), partial melting of crustal source rocks (e.g. Jackson et al., 2003) or plutonic crystal cumulates from prior magmatism (Reubi and Blundy, 2008) or some combination of these possibilities. The compositions of melt inclusion glasses that represent trapped portions of melt from the Ruapehu magma system are reviewed and compared to regional and global examples in this section.

Dacite to rhyolite glass compositions ( $\sim 67-78$ wt. \% $\left.\mathrm{SiO}_{2}\right)$ are reported for Ruapehu lava groundmass and pyroxene melt inclusions in this chapter (Fig. 4.8). The range in $\mathrm{SiO}_{2}$ contents broadly overlaps with previously reported data for inclusions in samples from historical eruptions (Gamble et al., 1999; Kilgour et al., 2013) and edifice-forming lavas from the Whakapapa and Wahianoa formations (Price et al., 2005, 2012). The first melt inclusion data from Te Herenga Formation lava flows are presented here, in addition to those for newly defined Mangaehuehu andesite and Te Kohatu dacite eruptive packages of the Mangawhero Formation.

The silicic composition of Te Herenga Formation lava melt inclusions may not be a surprising result considering the ubiquity of such inclusion compositions in younger Ruapehu lavas (Price et al., 2005) and arc volcanic rocks globally (Reubi and Blundy, 2009). However, the new data highlight the notion that even the most basic eruptive products erupted at Ruapehu cannot be considered primary magmas and should be used with caution in petrogenetic models (e.g. Price et al., 2012). The low-K/Ca whole-rock composition of Te Herenga Formation lavas matches the relatively low $\mathrm{K}_{2} \mathrm{O}$ contents of their phenocryst-hosted melt inclusions. Combined with their unique whole-rock ${ }^{143} \mathrm{Nd} /{ }^{144} \mathrm{Nd}$ isotopic compositions, these results provide further evidence that distinct petrogenetic processes operated to generate melts and derivative magmas in the $\sim 200$ 150 ka time period compared to subsequent magmatism. 
Melt inclusions and groundmass glasses within the Mangaehuehu and Te Kohatu packages of the Mangawhero Formation have significantly higher $\mathrm{K}_{2} \mathrm{O}$ contents in comparison to Te Herenga samples (Fig. 4.8). In particular, $\mathrm{K}_{2} \mathrm{O}$ contents of up to 5-6 wt. $\%$ were measured for groundmass glasses, melt inclusions and xenolith-hosted glasses within Te Kohatu dacite lavas. The characteristics of these melts can be best explained by partial melting and assimilation of a meta-sedimentary crustal source with a significant contribution from melting of a K-bearing mineral. Such rocks exist within the Torlesse Terrane that forms the basement and upper to mid-crust beneath Ruapehu, and biotite and K-feldspar are present within the greywacke-argillite mineral assemblage (Graham and Hackett, 1987; Graham et al., 1990; Adams et al., 2009) and is inferred to have provided the high $\mathrm{K}_{2} \mathrm{O}$ in the melt. This process was fortuitously captured by the discovery and analysis of xenolith-hosted glass within dacite sample CC415. Similarly high $\mathrm{K}_{2} \mathrm{O}$ contents were measured in these melt pockets that also display $\mathrm{Rb}$ contents of up to 250 ppm, which further implicates the preferential partial melting of biotite out of the crustal source rocks and into the melt. High ${ }^{87} \mathrm{Sr} /{ }^{86} \mathrm{Sr}$ values for Mangawhero Formation dacites (Fig. 4.6; Price et al., 2012) further underlines the elevated level of crustal contamination of these magmas. The role of assimilation of continental crust within the genesis of postTe Herenga Formation magmas has been widely documented (Graham and Hackett, 1987; Price et al., 2005; Price et al., 2012). The new data in this thesis reveal that this process was most pronounced during the period from $\sim 50-35 \mathrm{ka}$.

Melt inclusions in Whakapapa Formation lava flows exhibit a range of compositions that notably return to lower $\mathrm{K}_{2} \mathrm{O}$ contents (Fig. 4.8). The compositions presented here are consistent with groundmass glass and melt inclusion data for historically erupted samples (Gamble et al., 1999; Kilgour et al., 2013) and previous analyses from Whakapapa Formation lavas (Price et al., 2012) and 11 ka pyroclastic deposits (Donoghue et al., 1995b). Furthermore, the glass data match the lower $\mathrm{K}_{2} \mathrm{O}$ contents within whole-rock compositions and the lower $\mathrm{K} / \mathrm{Ca}$ trends defined by $<26 \mathrm{ka}$ lavas compared to earlier Mangawhero Formation lavas (Fig. 4.4). ${ }^{143} \mathrm{Nd} /{ }^{144} \mathrm{Nd}$ and ${ }^{87} \mathrm{Sr} /{ }^{86} \mathrm{Sr}$ systematics indicate that Whakapapa Formation lavas were derived from magmas that were contaminated by a continental crust assimilant, although to a lesser degree than the earlier Mangawhero Formation lavas (see section 4.5.1). The glass data indicate that these crustal melts were less enriched in $\mathrm{K}_{2} \mathrm{O}$ than earlier melts trapped within lavas erupted at $\sim 50-35 \mathrm{ka}$. This may reflect a lesser contribution from K-rich mineral phases to the partial melts and/or 
higher degrees of partial melting in the crustal source region for the younger eruptive products.

The documentation of silicic melts within Ruapehu eruptive products led to comparisons by Price et al. (2005) with the products of rhyolitic volcanism at Taupo volcano where the basement crust is thinner and hotter than it is beneath Ruapehu (Harrison and White, 2004). Price et al. (2005) postulated that andesitic volcanism at Ruapehu represents a thermally immature stage of arc magmatism that might eventually evolve toward voluminous production of silicic magma (Price et al., 2005).

Eruptions at Taupo volcano evacuated extremely large volumes of silicic magma assembled within upper crustal mush systems where fractionated melts were pooled at shallow levels in the crust (e.g. Allan et al., 2013; Barker et al., 2015). Considering the difference in crustal characteristics beneath Taupo and Ruapehu, are the rhyolitic glasses produced within the two settings comparable?

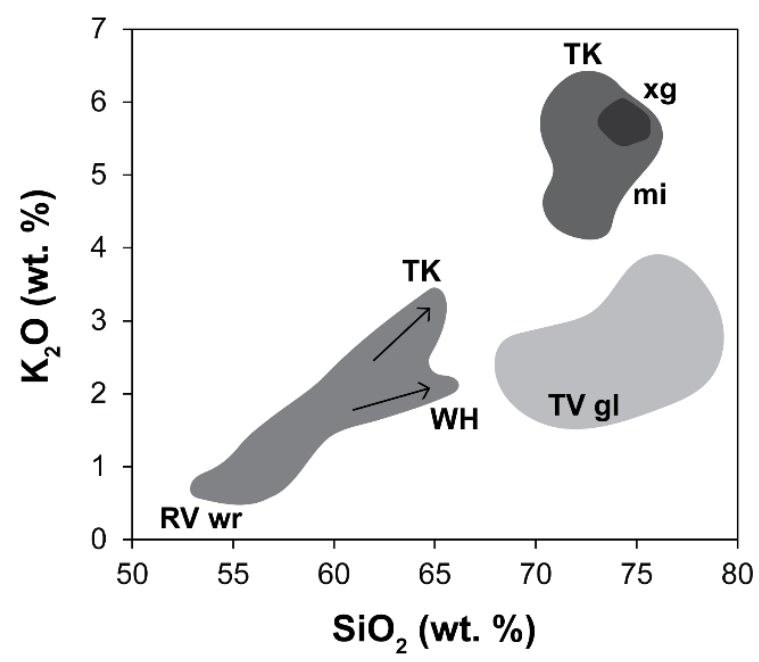

Figure 4.16. $\mathrm{SiO}_{2}-\mathrm{K}_{2} \mathrm{O}$ compositions for Ruapehu lava whole-rock and glass compared to glass from Taupo volcano. Arrows indicate generalised whole-rock trends for 50-35 ka lavas towards TK (Te Kohatu package dacite) and for post-26 ka lavas towards WH (Whakapapaiti package dacite). Glass data are shown for xg (xenolith glass) and mi (melt inclusions) in TK lavas for Ruapehu. Field for TV gl (Taupo volcano glass, post-Oruanui) based on data from Barker et al. (2015).

Glass compositions from Whakapapa Formation lavas broadly overlap with matrix glass and melt inclusion compositions from Oruanui and post-Oruanui eruptive products from Taupo volcano (Barker et al., 2015), whereas glasses from Mangawhero Formation lavas contain substantially higher $\mathrm{K}_{2} \mathrm{O}$ contents (TK in Fig. 4.16). Light rare earth element (LREE) contents in rhyolite glass and whole-rock samples from post-Oruanui eruptives 
from Taupo are similar to those of contents for Ruapehu whole-rock dacite lavas of the Mangawhero Formation (Fig. 4.17). The trace element patterns for the eruptives from the two settings are divergent for heavy REE, with Taupo eruptives displaying relatively higher concentrations. The xenolith-hosted glass from Ruapehu sample CC415 displays slightly elevated contents for LREE compared to Taupo rhyolites (Fig. 4.17). Lower $\mathrm{K}_{2} \mathrm{O}$ contents and higher HREE contents in glasses from post-Oruanui eruptives from Taupo volcano compared to Mangawhero Formation lavas from Ruapehu are interpreted to reflect higher degrees of partial melting of assimilated continental crust in the Taupo silicic magma system, which is reflected by generally high ${ }^{87} \mathrm{Sr} /{ }^{86} \mathrm{Sr}$ values compared to Ruapehu lavas (Price et al., 2005).

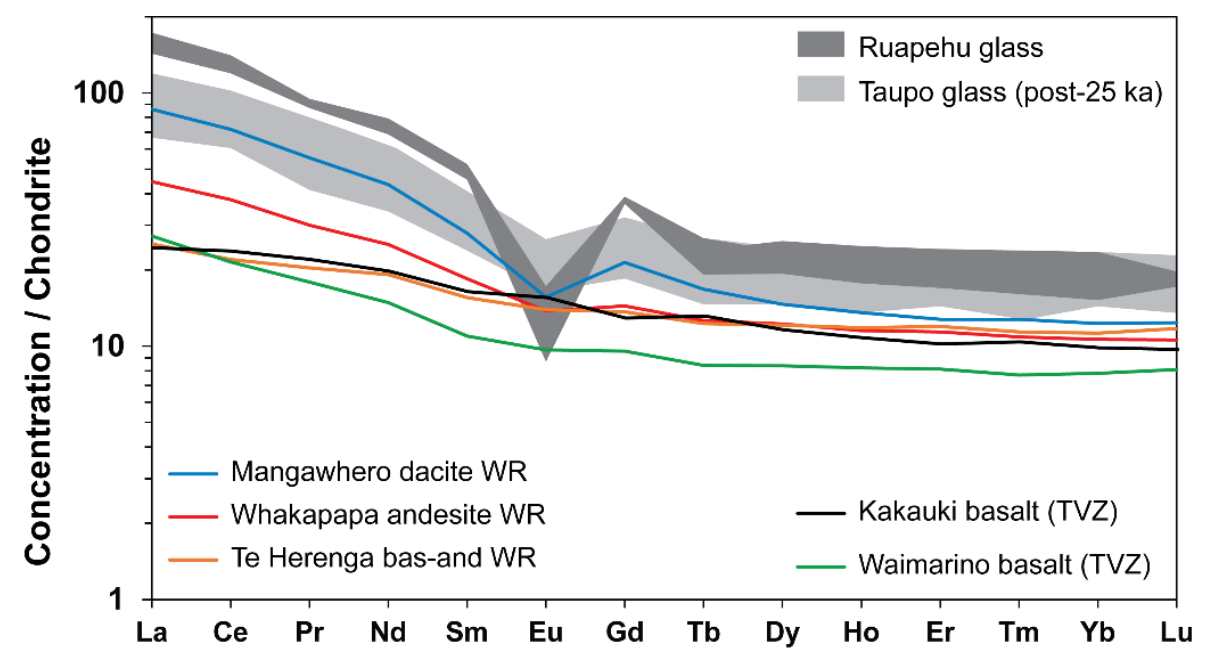

Figure 4.17. Chondrite-normalised Rare earth element plot for Ruapehu lava whole-rock and glass compared to Waimarino and Kakuki basalts, and post-Oruanui dacites and rhyolites from Taupo volcano. Basalt data are from Gamble et al. (1993). Taupo glass data are from Barker et al. (2015). Normalising values are from Sun and McDonough (1989).

Compared to younger lavas at Ruapehu, the high-K nature of glasses within the Mangaehuehu and Te Kohatu eruptive packages of the Mangawhero Formation are considered to represent products of the incipient stages of assimilation of middle to upper continental crust. Lava flows of the Whakapapa Formation encapsulate melts generated in a crustal melting scenario that is more advanced than at $~ 40$ ka beneath Ruapehu.

Progressive heating and melting of the crustal column prior to $26 \mathrm{ka}$ is interpreted to have produced melts that were less enriched than at $\sim 50-35$ ka because of either or both of: (1) the exhaustion of fertile, $\mathrm{K}$ - and Rb-rich phases (e.g. biotite) that were readily fused during early stages of upper crust assimilation; and (2) higher degrees of partial melting as magma flux continued for the magma system beneath Ruapehu. 
The compositional similarity between a crustal partial melt analysed in-situ within its host xenolith fragment that was captured by the derivative magma (i.e. xenolith-hosted glass within dacite sample CC415) and the groundmass of that lava highlights the concept that crustal assimilation has a significant bearing on the geochemical characteristics of eruptive products at continental arc volcanoes. The continental crust-like compositions of arc magmas may reflect either or both of the processes of fluid flux melting of the mantle wedge and crustal assimilation. Resolving the origin of the signature has important implications for tracing the recycling of elements through the 'subduction factory' (Davidson et al., 2005). The addition of 'exotic' melts formed through preferential melting of fusible phases within assimilated xenolithic or antecrystic material has been shown to contribute significantly to the trace element budget of andesitic magmas (e.g. Reubi and Blundy, 2008). In particular, the budget of large-ion lithophile elements (LILE: $\mathrm{K}, \mathrm{Rb}, \mathrm{Cs}, \mathrm{Sr}, \mathrm{Ba}$ ) in arc magmas, which has been traditionally linked to a subducted slab and entrained sediment component (e.g. McCulloch and Gamble, 1991), may be augmented by partial melts from crustal source rocks in the arc lithosphere. A contribution of LILE from partial melts of continental crust to Ruapehu magmas is shown here to also be significant, particularly during the period from $\sim 50-35 \mathrm{ka}$. The contribution from the primary mantle source of Ruapehu magmas is much more difficult to ascertain, because melts from this region have not been sampled.

\subsubsection{A case for mafic recharge recorded in high-Mg andesite-dacites at Ruapehu}

High-magnesian andesites (HMAs) are intermediate arc volcanic rocks (54-65 wt. \% $\mathrm{SiO}_{2}$ ) with high $\mathrm{Mg \#}(\geq 50)$ and high $\mathrm{Cr}$ and $\mathrm{Ni}$ concentrations (Kelemen et al., 2003a). At an extreme, the eruption of primitive HMAs with $\mathrm{Mg \#} 70$, although rare, is of particular importance because such magmas may be produced by partial melting of hydrous mantle peridotite (e.g. Grove et al., 2002, 2005; Wood and Turner, 2009) and play a fundamental role in the genesis of arc magmas and continental crust (Kelemen et al., 2003b). Other models for the petrogenesis of HMAs invoke equilibration of slab-derived melts with ultramafic mantle wedge material (e.g. Kay, 1978; Shimoda et al., 1998; Tatsumi, 2001; Yogodzinski et al., 2001) and felsic-mafic magma mixing combined with entrainment of ultramafic crystal material within arc lithosphere (e.g. Kawabata and Shuto, 2005; Streck et al., 2007). HMAs have been extensively studied at Mt Shasta in the Cascade arc 
(Anderson, 1973; Grove et al., 2002; Streck et al., 2007) and the Setouchi volcanic belt in southwest Japan (Shimoda et al., 1998; Kawabata and Shuto, 2005). Previously studied New Zealand examples have erupted at White Island volcano $\left(\mathrm{Mg \#}_{70}\right.$ : Heyworth et al., 2007) and Hauhungatahi volcano (Mg\#70: Cameron et al., 2010).

Andesite and dacite lavas of the Mangaehuehu and Te Kohatu eruptive packages, respectively, can be classified as HMAs: whole-rock Mg\# for the lavas range from 60-69 (andesites) and 54-57 (dacites). Mangaehuehu andesites exhibit high $\mathrm{MgO}$ contents over a $\sim 5$ wt. $\% \mathrm{SiO}_{2}$ range, and $\mathrm{Te}$ Kohatu dacites ( $\sim 64-65$ wt. $\left.\% \mathrm{SiO}_{2}\right)$ have $\mathrm{MgO}$ contents that are notably higher than other Ruapehu dacite lavas (Fig. 4.3, 4.15). Other remarkable characteristics of Ruapehu HMAs are the elevated Cr and Ni contents of up to $470 \mathrm{ppm}$ and $148 \mathrm{ppm}$, respectively, compared to other eruptive products at equivalent $\mathrm{SiO}_{2}$ contents (Fig. 4.3). An important petrographic feature that distinguishes these HMA lavas from lower $\mathrm{MgO}$ flows at Ruapehu is the high proportion within the mineral assemblage of resorbed orthopyroxene crystals that are mantled by euhedral rims with high $\mathrm{Mg \#}$ values ( 88-90; Fig. 4.18). The HMAs also contain xenolithic material, indicating that their source magmas assimilated crustal rocks. Moreover, crustal partial melts are inferred to have contributed to the high-K compositions of groundmass glasses and melt inclusions within these lavas. The petrographic and geochemical characteristics indicate that derivative magmas underwent substantial fractionation and assimilation processes in the lithosphere and do not represent near-primary melting products from the mantle wedge.

Ruapehu HMAs are interpreted to have been produced via an influx of a deeper-sourced mafic magma that interacted with an upper crustal-level felsic magma. Hotter mafic magma is interpreted to have reactivated stalled crustal reservoirs, mingled and mixed with melts and entrained the cargo of crystalline material. Clusters of orthopyroxene crystals appear to have been incorporated from the felsic magma as evidenced by their resorbed cores (cf. Nakagawa et al., 2002; Fig. 4.18). Subsequent crystal growth occurred within the hotter magma to account for the higher $\mathrm{MgO}$ rims. The rims maintain consistently high $\mathrm{MgO}$ contents across their widths, which measure up to $54 \mu \mathrm{m}$ (Fig. 4.18). Clusters of orthopyroxene preserved in the HMAs display high-MgO rims only on the outermost exposed margins of the crystal clots (Fig. 4.18), indicating that the mafic magma encountered a crystal-rich felsic magma and interacted with crystal margins that were in contact with the mafic magma during disaggregation of the crystal assemblage. 
Mechanically broken edges on reverse-zoned orthopyroxene do not display high-Mg rims, indicating that breakage occurred after the crystals had undergone rim growth in the more mafic magma. Outermost crystal edges have thin coronas of orthopyroxene $\left(\mathrm{Mg \#}_{65}\right.$ 72), which represent reaction rims formed as grains were reincorporated into the final host magma.
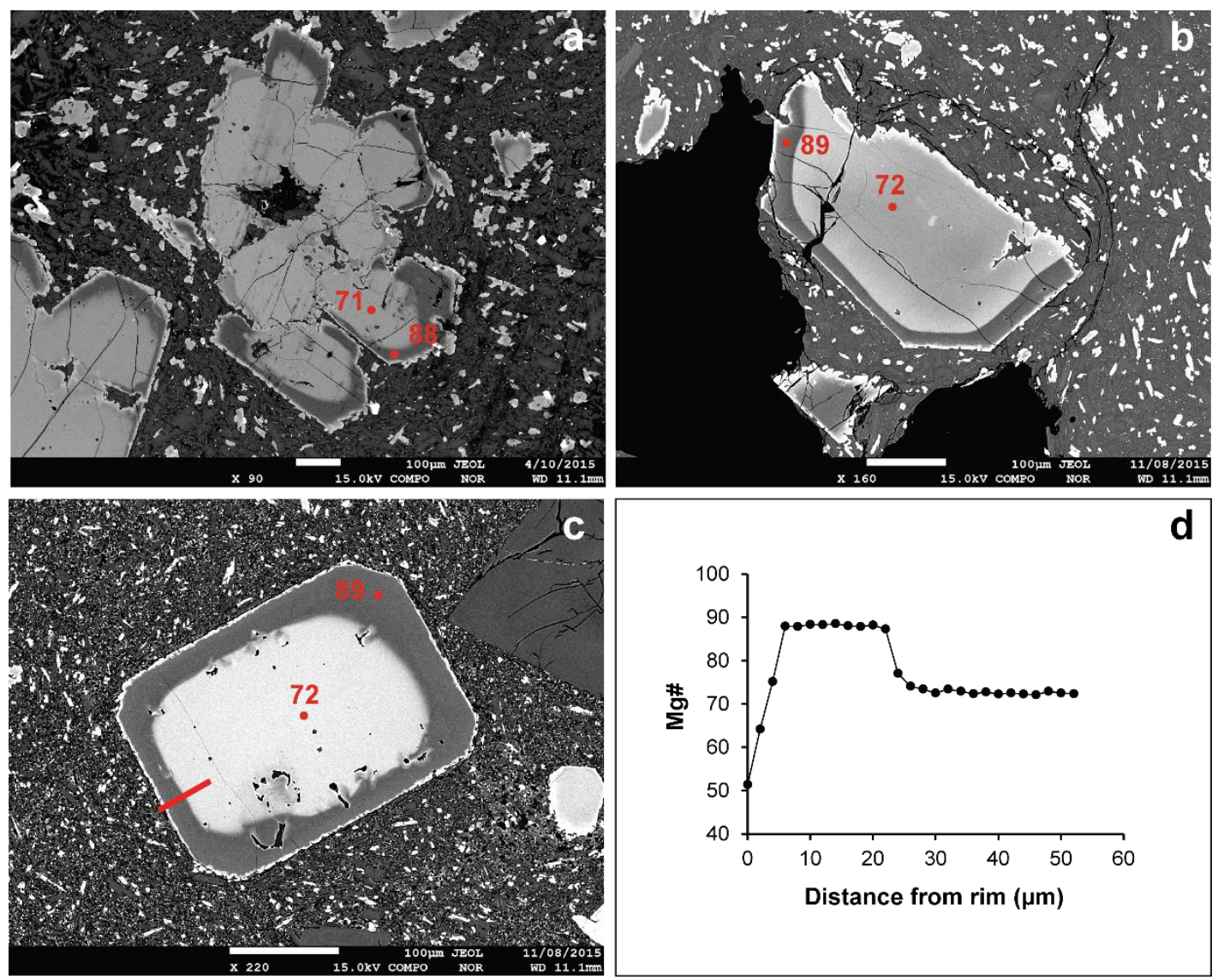

Figure 4.18. EPMA back-scattered electron images of reverse zoned orthopyroxene in high-magnesian andesite lavas in the Mangaehuehu package. (a) Cluster of resorbed crystals that are overgrown by darker, $\mathrm{Mg}$-rich zones and outermost rims in equilibrium with groundmass orthopyroxene microcrystals. (b) Reverse zoned orthopyroxene with broken edge, along which there is no Mg-rich rim. (c) Reverse zoned crystal with rounded core and euhedral Mg-rich rim. (d) Mg\# values along an EPMA traverse along red line marked in (c).

Evidence for interaction between recharging higher temperature magmas and stagnant more felsic magmas has been reported in pyroclasts ejected in the 1995-1996 Ruapehu eruptions (Nakagawa et al., 2002). Whole-rock Mg\# values of $\sim 60$ for the pyroclast samples are not as high as those reported in this study for Ruapehu HMAs of equivalent $\mathrm{SiO}_{2}$ contents, which may reflect a greater contribution from the mafic end-member within the Mangawhero Formation HMAs. The comparable crystal zonation features are interpreted to reflect a similar process for older lavas and younger pyroclasts, however, 
and has been documented in other continental arc settings. In particular, near-identical pyroxene zoning features are displayed in HMAs from Mt Shasta (see Fig. 2 in Streck et al., 2007) and the Setouchi volcanic belt (see Fig. 7 in Kawabata and Shuto, 2005). In both cases, magma mixing processes played a primary role in generating the HMA magmas. Mafic recharge and mafic-felsic interactions have been widely recognised as key processes at numerous arc volcanoes (see review by Kent, 2013). In some cases, this process results in the generation of HMA. It must be noted, however, that different types of HMA correspond to distinct petrogenetic origins and magma mixing is not required in every case. The Ruapehu type presented here lacks the high $\mathrm{Sr} / \mathrm{Y}$ values that are characteristic of many examples, including those from neighbouring $\sim 1.0 \mathrm{Ma}$ Hauhangatahi volcano (Cameron et al., 2010), and are interpreted as being sourced from a melted slab component (e.g. Defant and Drummond, 1990).

Constraining the nature of primitive magmas within the southern end of the Taupo Volcanic Zone is difficult because even relatively primitive basaltic-andesites have generally undergone textural and chemical modification in the crust. The reverse zoned crystal cargo of HMAs provides only a cryptic record of mafic magma intrusion into the crust beneath Ruapehu. Comparison to regional primitive lavas, however, provides an indication of the composition of the mafic end-member involved in their generation and, moreover, yields insight into the spatial distribution of such an end-member with respect to regional volcanism. The high-MgO lineage of Ruapehu HMAs forms a trend towards the composition of Waimarino basalt (Fig. 4.15), which is a rare magnesian type of basalt erupted within the Taupo Volcanic Zone (Gamble et al., 1993). This trend is approximately intercepted by the average compositions of Pukeonake and Ohakune andesites (Fig. 4.15), which were erupted from vents located $\sim 20 \mathrm{~km}$ to the north and southwest, respectively, of the central vent area of Ruapehu (Fig. 4.15). Pukeonake lavas have been described as hybrid andesites and their compositions can be modelled by mixing between Ruapehu dacite and Waimarino basalt (Graham and Hackett, 1987). A similar model of petrogenesis is invoked here for the formation of Ruapehu HMAs (Fig. 4.15). The shared petrogenetic origin of hybrid andesites at Ruapehu and within its periphery indicate the incidence of a common mafic end-member, which may be of key importance to fuelling volcanism within the Tongariro Volcanic Centre as well as the broader Taupo Volcanic Zone. 


\subsubsection{Evolutionary model of the magma system at Ruapehu}

New petrological, geochemical and microanalytical data are here integrated with existing data and placed within a new high-resolution eruptive chronology to present an overview model for the evolution of the Ruapehu magma system over the last 200 kyrs. Key stages of this evolution are summarised below.

Te Herenga Formation lavas that were erupted from 200-150 ka represent magmas that transited through the lithosphere without significant assimilation of meta-sedimentary basement rocks as indicated by $\mathrm{Sr}-\mathrm{Nd}$ isotopic systematics (Fig. 4.6; Price et al., 2005, 2012). Low whole-rock $\mathrm{K} / \mathrm{Ca}$ values and incompatible element concentrations, and the low $\mathrm{K}_{2} \mathrm{O}$ contents of silicic melt inclusions within these lavas reflect assimilation of altered Phanerozoic oceanic crust that is interpreted to underlie the greywacke-argillite sequence of mid-upper crustal rocks (Graham, 1987; Price et al., 2012). This is interpreted to represent the early stages of thermal development of the magma system beneath Ruapehu as captured by the sampling for this thesis and previous studies of the exposed edifice.

The magma system beneath Ruapehu was progressively fluxed by magmas that sourced the eruption of $\geq 74 \mathrm{~km}^{3}$ of Wahianoa Formation lavas from $\sim 166$ to $80 \mathrm{ka}$. Over this time period, erupted lava compositions generally evolved to more silicic compositions (Fig. 4.14), although geochemical variations throughout a $300 \mathrm{~m}$-thick lava sequence exposure reflect non-systematic changes (Gamble et al., 1999, 2003). Compositional characteristics of Wahianoa Formation lavas erupted between 166 and 80 ka indicate their source magmas were contaminated by greywacke-argillite basement (Fig. 4.6; Gamble et al., 2003; Price et al., 2012), although normalised trace element diagrams indicate that this effect was not pronounced (Fig. 4.5). Emplacement of Wahianoa Formation lavas may have been punctuated by an eruptive hiatus from 80 to $50 \mathrm{ka}$, as reflected by the absence of eruption ages for the comprehensive suite of previous and new geochronology samples from the edifice.

Following the apparent hiatus, magma compositional diversity was greatest in lavas of the early Mangawhero Formation erupted during the period from $\sim 50-35 \mathrm{ka}$. The basaltic andesite to dacite lavas erupted over this interval define an elevated $\mathrm{K} / \mathrm{Ca}$ trend compared to all other eruptive products from Ruapehu and, accordingly, record a distinct and discrete stage of magmatic differentiation within the overall evolution of the magma 
system. The most evolved of the lavas erupted during this time exhibit crust-like wholerock trace element compositions and contain $\mathrm{K}_{2} \mathrm{O}$ - and $\mathrm{Rb}$-rich melts preserved within melt inclusions and interstitial glass patches (Fig. 4.7d). Within $~ 40$ ka dacite lavas sampled in this study, fused portions of meta-sedimentary xenoliths that have encapsulated in-situ veins of K- and Rb-rich partial melts were analysed (Fig. 4.7c). These observations essentially record the process of crustal melting and assimilation within the derivative magmas at this time. Assimilation of these melts contributed to the high K/Ca trends, LILE contents and ${ }^{87} \mathrm{Sr} /{ }^{86} \mathrm{Sr}$ values of the derivative magmas and sampled lavas. The enrichment in LILE is inferred to reflect either or both of low degree partial melting and preferential melting of biotite within the metasedimentary crustal source rocks.

During the same $\sim 50-35$ ka period, recharging mafic magmas interacted with crustal level silicic magmas to produce hybrid highly-magnesian andesites and dacites erupted onto the southern and northwestern flanks of Ruapehu. Evidence for crustal assimilation in these lavas and petrographic features reflecting mafic-felsic interaction indicate Ruapehu high-Mg andesites-dacites are complex magmatic products arising from middle to upper crustal-level assimilation and mixing processes (cf. Mt Shasta, Setouchi volcanic belt). Other andesite and dacite lava packages that were erupted from spatially proximal vents $(<1 \mathrm{~km})$ during the same $50-35 \mathrm{ka}$ period were not affected by mafic recharge processes and indicate that distinct magma types were able to remain compositionally isolated beneath Ruapehu.

Mid-Mangawhero Formation lavas were erupted onto the western flank of Ruapehu between $\sim 35$ and $26 \mathrm{ka}$. The composition of these andesites coincides with an apparent gap for lavas with $\sim 62-63 \mathrm{wt}$. $\% \mathrm{SiO}_{2}$ erupted from $\sim 50$ to $35 \mathrm{ka}$. In contrast to prior conclusions by Graham and Hackett (1987) and Price et al. (2012), the revised chemical stratigraphy of Ruapehu lavas reveals a reversion since $26 \mathrm{ka}$ to less silicic and less potassic eruptive products with lower incompatible element contents within the late Mangawhero Formation ( 26-15 ka) and Whakapapa Formation. Melt inclusion compositions also revert to lower $\mathrm{K}_{2} \mathrm{O}$ contents relative to Mangawhero Formation lavas and maximum values of ${ }^{87} \mathrm{Sr} /{ }^{86} \mathrm{Sr}$ are comparatively lower (Fig. 4.6; Price et al., 2012). Post-26 ka magmas are interpreted to have assimilated less enriched melts due to the exhaustion of fertile phases in the middle to upper crustal column and/or higher degrees of melting of crust associated with ongoing magma and heat flux through the magma 
system. Alternatively, the crustal column may have become resistant to cumulative crustal assimilation through injection and crystallisation of a complex of dikes and sills.

\subsubsection{Occurrence and formation of cristobalite in Ruapehu lava flows}

Cristobalite is a high-temperature, low-pressure polymorph of crystalline silica. Despite the temperatures of magmatic systems being substantially lower than that of the stability field for cristobalite $\left(>1470^{\circ} \mathrm{C}\right.$; Deer et al., 1992), it has been widely observed in volcanic products (e.g. Baxter et al., 1999; Horwell et al., 2003; Schipper et al., 2015), and is therefore a key example of metastable crystallization in volcanic systems. Cristobalite most commonly occurs in rhyolitic or dacitic lava, where grows from a silica-saturated vapour phase (e.g. Baxter et al., 1999; de Hoog et al., 2005; Horwell et al., 2013) or forms by devitrification of glass (e.g. Damby et al., 2014). The two processes are inferred to operate coevally but semi-independently of each other, with the latter contributing to the majority of total cristobalite content in a given sample (Schipper et al., 2015).
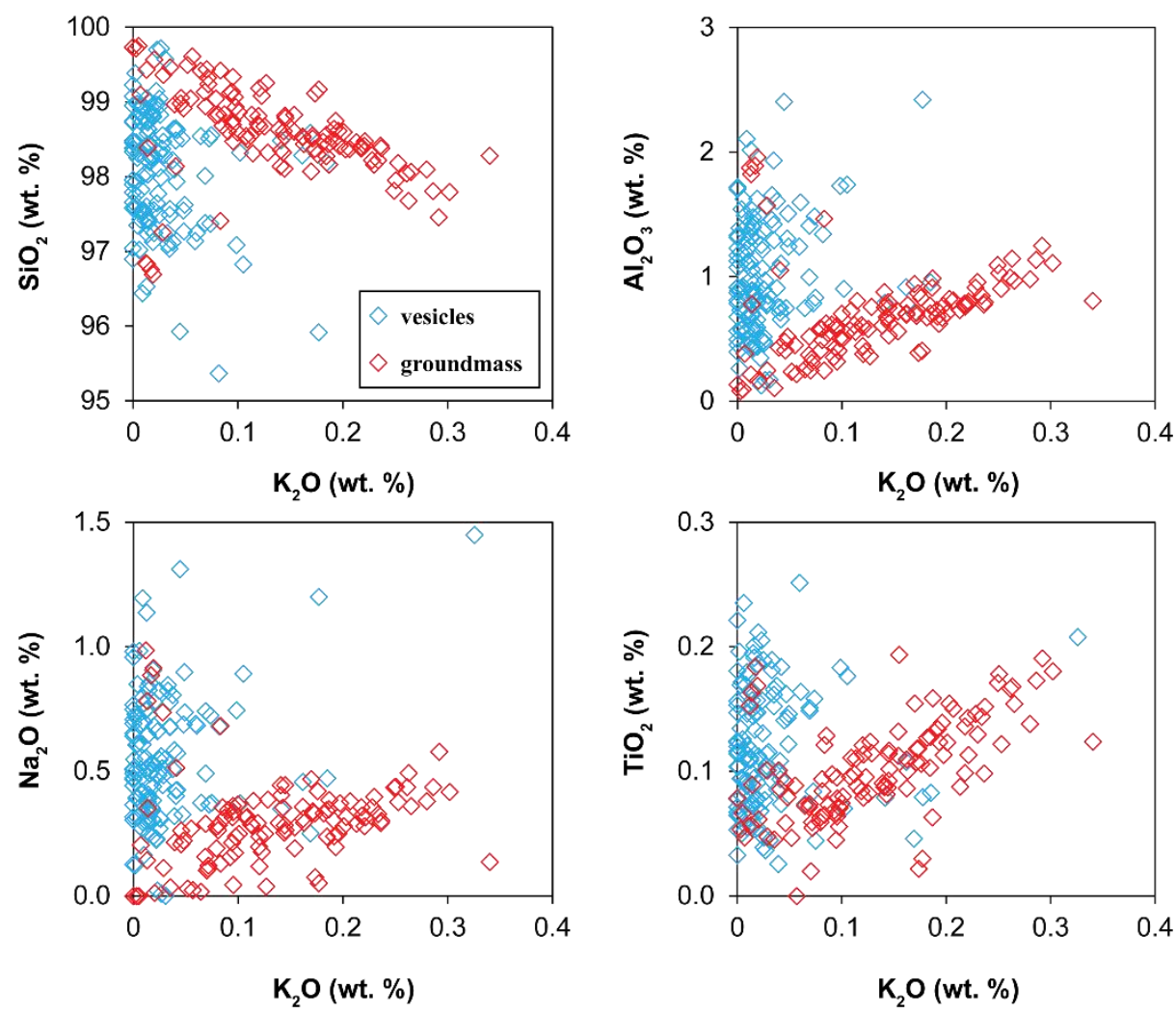

Figure 4.19. Bivariate plots for composition of cristobalite in Ruapehu lavas. Values were measured by EPMA and are normalised to 100 weight \%. Distinct trends are evident for cristobalite within vesicles and within the groundmass. 
This study presents the first recognition and definition of cristobalite in edifice-forming eruptive products at Ruapehu volcano. In addition to $\mathrm{SiO}_{2}$ (96-99 wt. \%), minor oxides with relative abundances of $\mathrm{Al}_{2} \mathrm{O}_{3}>\mathrm{Na}_{2} \mathrm{O}>\mathrm{TiO}_{2}, \mathrm{~K}_{2} \mathrm{O}$ comprise the bulk composition of cristobalite analysed by EPMA in this study. Divergent $\mathrm{K}_{2} \mathrm{O}$ trends for cristobalite within vesicles and groundmass suggest that two distinct processes operated to form each type, with groundmass cristobalite incorporating greater amounts of $\mathrm{K}_{2} \mathrm{O}$ (Fig. 4.19).

It is inferred here that cristobalite formed from a silica-saturated vapour related to dissolution of glass within Ruapehu lava flows as they were emplaced and cooled on the flanks of the edifice. Cristobalite was sparse or absent in glassy flows, thus, rapid quenching of the margins of flows emplaced against ice is inferred to have precluded the formation of cristobalite in glass Te Kohatu package dacite lavas studied here. In contrast, slower cooling in flow interiors increased the potential for cristobalite formation.

Despite a general association with silicic pyroclastic and lava dome-forming eruptions, the results of this study suggest that cristobalite may also be widespread in maficintermediate effusive products from continental arcs due to the high frequency of dacitic to rhyolitic groundmass compositions in such rocks. At Ruapehu, glacial erosion and explosive magmatic and phreatomagmatic eruptions are likely to have made cristobalite readily available to the environment.

A modern motivation for studying the occurrence and formation of cristobalite is its potential to cause respiratory health hazards to populations living proximal to volcanic areas (Baxter et al., 1999). The discovery of cristobalite at Ruapehu and the potential for its widespread occurrence in the central North Island of New Zealand is a significant and unique finding. The reactivity of crystalline silica in human lungs is dependent on its chemical, physical and structural characteristics (Horwell et al., 2012), and the toxicity of pure cristobalite remains under investigation (Damby et al., 2013). Whether cristobalite poses a serious health risk to North Island populations is therefore unknown and requires further investigation.

\subsection{CONCLUSIONS}

Previous workers established a broad distinction between Te Herenga ( $\geq 150 \mathrm{ka})$ and postTe Herenga periods of magmatism at Ruapehu, with magmas of the latter stage 
undergoing progressively increasing levels of assimilation and fractional crystallisation with time since $150 \mathrm{ka}$ (Gamble et al., 2003; Price et al., 2005, 2012). This chapter has utilised existing isotopic data and petrogenetic models from these workers to further elucidate the evolution of the Ruapehu magma system. New whole-rock, mineral and glass compositions have been characterised for edifice-forming effusive products and sequenced within a high-resolution eruption chronology for Ruapehu (Chapter 3). The long-term compositional variability of lava flows displays systematic changes over the 200 kyr lifetime of the exposed Ruapehu edifice and offers valuable snapshots into the crustal mechanics of an arc magma system. Major new findings are summarised as follows.

- The relatively low $\mathrm{K}_{2} \mathrm{O}$ contents of melt inclusions from Te Herenga Formation lava flows are consistent with low whole-rock K/Ca values. Combined with their unique whole-rock ${ }^{143} \mathrm{Nd} /{ }^{144} \mathrm{Nd}$ isotopic compositions, the results provide further evidence that petrogenetic processes generating melts and derivative magmas at 200-150 ka were distinct when compared to subsequent magmatism.

- Magma composition diversity was greatest during the period from 50-35 ka. The range of basaltic-andesite to dacite lavas erupted during this time define an elevated $\mathrm{K} / \mathrm{Ca}$ trend compared to all other eruptive products from Ruapehu. The most evolved of the lavas (high ${ }^{87} \mathrm{Sr} /{ }^{86} \mathrm{Sr}$ and crust-like trace element abundances) erupted during this time contain high- $\mathrm{K}_{2} \mathrm{O}$, high- $\mathrm{Rb}$ melts preserved within melt inclusions, interstitial glass patches and xenolith-hosted melt pockets. These melts were generated via low degrees of partial melting and/or preferential melting and assimilation of biotite-bearing greywacke-argillite source rocks in the continental crust basement. Taken in geochronological context, this suggests a 'bottom-up' heating of the crust beneath Ruapehu.

- Two eruptive packages of high-magnesian andesites and dacites were produced via interaction between crustal level felsic magmas and Mg-rich mafic magmas between $\sim 50$ and $35 \mathrm{ka}$. Clusters of pyroxene were thermally eroded from existing more felsic magma reservoirs by the influx of hotter, more mafic magma, and were then resorbed and overgrown by $\mathrm{Mg}$-rich rims. Ruapehu high-Mg andesitesdacites represent magmas resulting from middle to upper crustal-level assimilation and mixing processes rather than primary magmas derived directly from mantle melting (cf. Mt Shasta, Setouchi volcanic belt). 
- In contrast to conclusions from prior workers, the geochemical data from Ruapehu lavas presented here reveals a reversion to less silicic and less potassic eruptive products with lower incompatible element contents after $26 \mathrm{ka}$. Post-26 ka magmas are interpreted to have assimilated less enriched melts due to exhaustion of fertile phases in the crustal column and/or higher degrees of melting of continental crust associated with ongoing magma and heat flux through the axial magma system.

- Cristobalite was discovered and described within lava flows that span the $\sim 200$ kyr eruptive history of the exposed Ruapehu edifice. Cristobalite occurs as prismatic crystals on vesicle walls within relatively glassy samples and is felted through holocrystalline groundmass in slowly cooled samples. Imaging and compositional data acquired by EPMA for this thesis suggest that cristobalite may be widespread in lava flows with basaltic-andesite through dacite bulk compositions from other continental arc settings due to the high frequency of dacitic to rhyolitic groundmass compositions in such rocks. 
CHAPTER 5 


\section{SYNTHESIS: GLACIOVOLCANIC AND \\ PETROGENETIC PROCESSES PLACED \\ WITHIN A HIGH-RESOLUTION LAVA \\ CHRONOLOGY FOR RUAPEHU VOLCANO}

\subsection{Key findings}

This thesis has presented a high-resolution geochronological framework for studying and interpreting processes and products of volcano-ice interaction, edifice growth and magma genesis at Ruapehu. Insights from these varied fields of research have been combined here to provide a detailed case study overview of arc volcanism at a glaciated composite edifice. The following synthesis revisits the questions that were introduced in Chapter 1 and presents key findings that resulted from testing these hypotheses. Each question turned out to present challenging limitations and open up new avenues for research, therefore, directions for future work are also suggested under the relevant sections.

\subsubsection{Were ridge-top lava flows eroded by glaciers or emplaced against ice at}

\section{Ruapehu?}

Ruapehu presents an ideal locality to investigate volcano-ice interaction processes because of the long-term overlap between effusive volcanic activity (Gamble et al., 2003) and glaciation (Eaves, 2015), particularly from $\sim 50$ and $15 \mathrm{ka}$. Except for small summit region glaciers, the edifice is now almost entirely ice-free and offers excellent exposure of lava flows above the tree-line. Extensive pre-historical glaciation of the Ruapehu edifice is evidenced by the deep glacial valleys that indent the flanks of the volcano. However, the work of Lescinsky and Sisson (1998) indicates that high volcanic ridges adjacent to glacially eroded valleys can also be constructional volcanic features formed by impoundment and constraint of lava against ice margins during glacial periods. I sought to test this hypothesis for Ruapehu by conducting an edifice-wide reconnaissance of glaciovolcanic features (Chapter 2). 
Lava flows located adjacent to formerly glaciated valleys display grossly overthickened margins (50-100 m) indicating flows were obstructed from being emplaced within valleys and grew thicker within a confined space as a result of this impoundment. The margins of these flows exhibit fracture networks that comprise column-forming joints, pseudopillow fractures, kubbaberg joints, crease structures and platy joints that are diagnostic of quenching against ice and/or impounded meltwater. These morphological and fracture characteristics indicate that the ridge-bounded flows formed as a result of emplacement against formerly extensive glaciers on the flanks of Ruapehu. Moraine crests that overlie ice-bounded flows indicate that some post-emplacement erosion of flow edges may have occurred. The primary morphology of the flows reflects, however, the syn-eruptive interaction between lava and ice.

Lava-ice interaction features at Ruapehu were first recognised by Spörli and Rowland (2006) for a limited areal extent of the eastern flank of the edifice. The work in this thesis has established that widespread volcano-ice interaction during edifice growth from $\sim 50$ to $15 \mathrm{ka}$ has resulted in complex lateral and vertical contacts between lava flows. These complexities can now be accounted for by deflection and impoundment of lava away from valleys filled with ice during glacial periods, compared to flow emplacement within valleys during interglacial times (e.g. Lescincky and Sisson, 1998).

While the evidence for glaciovolcanism at Ruapehu is most clearly manifested for icemarginal effusive activity during the period from $\sim 50-15 \mathrm{ka}$, reconciliation of the timing of edifice growth with periods of global glaciation led to a reinterpretation of volcanic breccias within the Te Herenga and Wahianoa formations. The thick mounds of tuff breccias that underlie the corresponding sequences of lavas flows for each formation are classified in Chapter 3 as sub-glacial hyloclastites, which implies the presence of a preexisting glaciated edifice as early as $\sim 200 \mathrm{ka}$. Further investigation of the fragmentation and deposition mechanisms involved in sub-glacial andesite eruptions will provide an interesting case study to contrast with published work that has dominantly described rhyolitic and basaltic eruptive products from Iceland and Antarctica (e.g. Smellie et al., 2011; Tuffen et al., 2001).

The results presented in Chapter 2 and published by Conway et al. (2015) have been recently cited by local (Tost and Cronin, 2015) and international researchers (Lachowycz et al., 2015) and are applicable to other studies of composite volcanoes in New Zealand 
and globally. It is critical that future researchers at Tongariro and Taranaki composite volcanoes of New Zealand investigate and integrate volcano-ice interaction processes within their eruptive histories.

\subsubsection{Can ice-marginal lava flows be used to inform paleoclimate reconstructions of former glacier extents?}

Having established a link between the distribution of ice-marginal lava flows and the presence of glaciers on Ruapehu, constraining the timing of lava emplacement with ${ }^{40} \mathrm{Ar} /{ }^{39} \mathrm{Ar}$ geochronology presents a potentially powerful paleoclimate proxy. Traditional terrestrial ice extent reconstructions that are based on exposure age dating of moraines have been used widely to constrain the timing glacial advances in the South Island of New Zealand (e.g. Putnam et al., 2013a, 2013b; Kelley et al., 2014). Eaves (2015) applied ${ }^{3} \mathrm{He}$ exposure-age dating of lateral moraines in a similar way at Ruapehu to establish that a period of advanced ice extent occurred on the edifice between $~ 31-17 \mathrm{ka}$, during which time glaciers reached as low as $\sim 1200$ m elevation. Moraines indicate the ultimate extent of a glacier's advance, thus recording a unique aspect of local ice volume fluctuation during a glacial cycle. In contrast, the timing of eruption of glaciovolcanic products occurs independently of a glacier's position. Therefore, sequences of ice-marginal lava flows have the potential to act as valuable conservative records of glacier volume fluctuations for times when moraines were not formed, or have since been eroded.

${ }^{40} \mathrm{Ar} /{ }^{39} \mathrm{Ar}$ eruption ages of ice-bounded flows were utilised to interpret glacial extents on Ruapehu since $\sim 50 \mathrm{ka}$ in Chapter 3. Glacial impoundment and the associated overthickening and slow cooling of the interior zones of thick flows of the Mangawhero Formation have combined to produce favourable groundmass textures for ${ }^{40} \mathrm{Ar} /{ }^{39} \mathrm{Ar}$ dating at Ruapehu. These zones have been exposed via erosion of the steep and finely fractured quenched margins of many flows. Consequently, the precision of the ages measured in this study permit ice extent reconstructions that are resolvable on timescales of $2-5 \mathrm{kyr}$.

Full-glacial conditions equating to valley-filling volumes of ice are indicated by the elevation above formerly glaciated valley floors of ice-bounded flows erupted between $\sim 50$ and $25 \mathrm{ka}$. The results are consistent with synchronous cooling between Antarctica 
and New Zealand at $\sim 42 \mathrm{ka}$ as constrained by moraine evidence in the Pukaki glacier region in South Island, New Zealand (Kelley et al., 2014). Age data for ice-marginal dacite lava flows on northwest Ruapehu indicate this period of cooling may have lasted until at least $38 \mathrm{ka}$. This information is not recorded by moraine formation at Ruapehu and serves as an example of the value of glaciovolcanic products for reconstructing past terrestrial ice extents. On the basis of their relatively lower heights within valleys and lesser thicknesses, lavas erupted at 25-18 ka were apparently impounded by smaller volumes of ice than were present at $\sim 31 \mathrm{ka}$. Estimating thicknesses and volumes of ice responsible for impounding lava flows relies on discerning the elevation difference between the lava flows and the floor of the formerly glaciated valley that was. This approach is limited by the uncertainty of how much the valley floor has been subsequently lowered through down-cutting and glacial erosion or raised by fluvial aggradation and volcanic construction since the timing of lava-ice interaction.

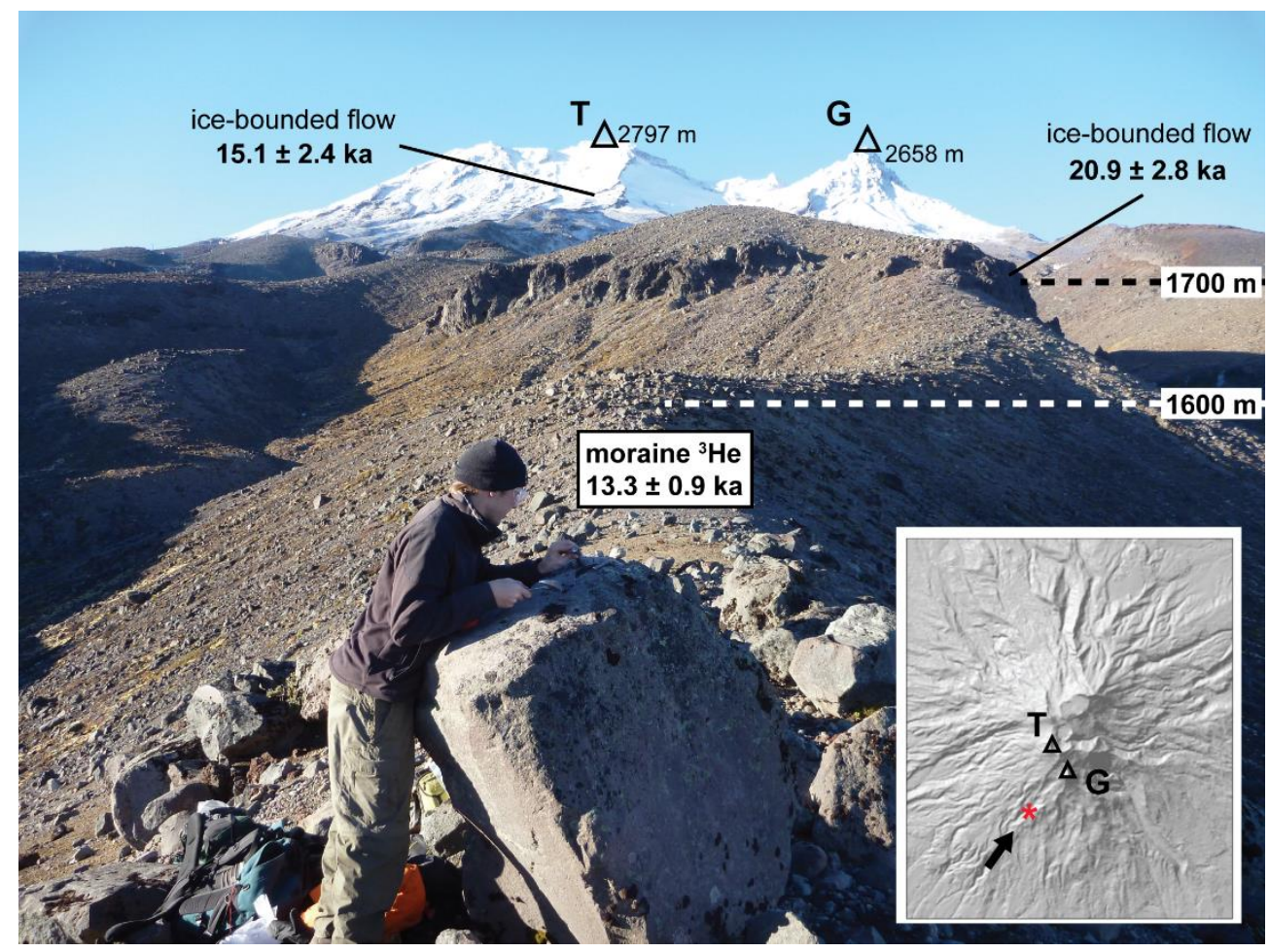

Figure 5.1. Volcano-ice interaction features on southwest Ruapehu. Location of valley labelled (red star) and direction of view noted by arrow in the inset map. Peaks of Tahurangi (T) and Girdleston (G) are labelled. ${ }^{40} \mathrm{Ar} /{ }^{39} \mathrm{Ar}$ ages are labelled for ice-bounded lavas within the glacial valley catchment for the southwest flank. The ${ }^{3} \mathrm{He}$ exposure age indicate moraine formation at $\sim 13 \mathrm{ka}$ (Eaves, 2015), following retreat of the local ice volume that had previously impounded lava flows.

Studies that combine constraints from dated ice-marginal lava flows and moraine exposure ages represent the best approach to accurately interpret glacial histories in 
volcanic settings (Fig. 5.1). This $\mathrm{PhD}$ research has contributed to one such study (Eaves et al., 2016b), in which ages of ice-marginal flows are used to provide temporally constrained tie-points for glacial extents in catchments for which no moraine exposure ages were acquired. In order to provide quantitative paleo-temperature information from ice flow models, the pre-existing topography of Ruapehu at $\sim 20$ ka was reconstructed using the eruptive history outlined in Chapter 3.

Changes in the distribution and morphology of lava flows erupted since $\sim 15 \mathrm{ka}$ are linked to deglaciation at Ruapehu. On the upper flanks (>2200 m a.s.l.) of the edifice $<15 \mathrm{ka}$ lava flows display evidence (i.e. localised ice-contact fracture networks, metre-scale overthickening, superficial glacial striae) for minor interaction with glaciers similar in extent to those present $\sim 50$ years ago (Heine, 1963). At lower elevations ( $<1700 \mathrm{~m}$ a.s.1.) $<15 \mathrm{ka}$ lava flows were emplaced on the floors of the previously glaciated valleys. While eruption ages for these lavas provide valuable constraints for the timing of wholesale glacier retreat at Ruapehu, glacial fluctuations in response to short-term climate variability since $\sim 18 \mathrm{ka}$ on Ruapehu are complex (Eaves, 2015) and beyond the resolution of the ${ }^{40} \mathrm{Ar} /{ }^{39} \mathrm{Ar}$ geochronology dataset.

\subsubsection{Did Ruapehu grow via discrete episodes of construction punctuated by erosion,} or are apparent eruptive hiatuses biased by non-preservation of volcanic products?

A central objective of this research was to establish a high-resolution geochronological framework in order to investigate the growth history of Ruapehu. The traditional model of edifice evolution at composite volcanoes invokes that constructive volcanism occurs via pulses of effusive activity that are separated by periods of erosion and sector collapse (e.g. Hackett and Houghton, 1989; Hildreth and Lanphere, 1994; Hobden et al., 1999). I tested this model by assembling a comprehensive lava flow eruption chronology using previous data from Gamble et al. (2003) and collecting new data from portions of the edifice that had previously been only sparsely sampled. Major findings from this aspect of my thesis are discussed here.

1. The previously interpreted hiatus in effusive activity defined by Gamble et al. (2003) for the period from $~ 115-60 \mathrm{ka}$ has been readjusted to a 'potential' eruptive hiatus at $\sim 80-50 \mathrm{ka}$ (Fig. 5.2). Lavas erupted between $\sim 115$ and 80 ka have low preservation and exposure potentials because they were emplaced within valleys during the last interglacial 
period and have subsequently been either eroded, or buried beneath till and younger volcanic products. These processes may result in a common bias towards nonpreservation of lavas of this age at glaciated continental composite volcanoes globally. The discovery of flows of this age (coincident with interglacial marine isotope stage 5, 129-71 ka; Fig. 5.2) situated deep within valleys rather than exposed on adjacent ridges is further justification of the model proposed by Lescinsky and Sisson (1998; see section 5.1.1). Caution is given to labelling the revised period as a hiatus, because glaciation at this time (MIS 4; Fig. 5.2) may have eroded eruptive products or precluded emplacement of lavas on flanks because of minimal emergent topography adjacent to glaciated valleys.

2. Detailed sampling of lava flows within the Mangawhero Formation yielded ages that define a continuity in effusive activity from $~ 50-15 \mathrm{ka}$ at Ruapehu (Fig. 5.2), rather than pulses centred at $\sim 45 \mathrm{ka}$ and $\sim 22 \mathrm{ka}$ (cf. Gamble et al., 2003). Due to the presence of flank glaciers within valleys throughout this period, growth of the edifice flanks occurred via construction of high ridges and planèzes. The geomorphic distinction between icebounded lavas of the syn-glacial Mangawhero Formation and intra-valley lavas of the post-glacial Whakapapa Formation is in concordance with the new geochronology data reported in this study.

3. The continuity of effusive activity over the last $50 \mathrm{kyr}$ at Ruapehu has formed a volcanic stratigraphy that is now well-calibrated enough such that a high-resolution secular geomagnetic record in the southwest Pacific region can be acquired. This thesis research has contributed to two current projects within this field. A total of 17 eruption ages were measured for lava flows emplaced during the period from 50-35 ka that encompasses the Laschamp geomagnetic excursion event ( $41 \mathrm{ka}$; Guillou et al., 2004; Singer, 2014). New geomagnetic data collected for the flows in a collaborative study has revealed the existence of an excursional magnetic field in New Zealand during the emplacement of Mangaehuehu package lava flows with ${ }^{40} \mathrm{Ar} /{ }^{39} \mathrm{Ar}$ ages ranging from 45.4 $\pm 2.0 \mathrm{ka}$ to $41.8 \pm 1.8 \mathrm{ka}$, but not for Ngahuinga package and Te Kohatu package lava flows with ${ }^{40} \mathrm{Ar} /{ }^{39} \mathrm{Ar}$ ages of $39.6 \pm 2.8 \mathrm{ka}$ and 39.1 $\pm 1.4 \mathrm{ka}$ (Ingham, 2015).

Consequently, the ages of the lavas provide a high-precision constraint on the timing and nature of the excursion in the Southern Hemisphere. New ${ }^{40} \mathrm{Ar} /{ }^{39} \mathrm{Ar}$ ages presented in this thesis have also been used in a co-authored study of secular geomagnetic variation in New Zealand over the last 10 kyr by Greve et al. (2016). 


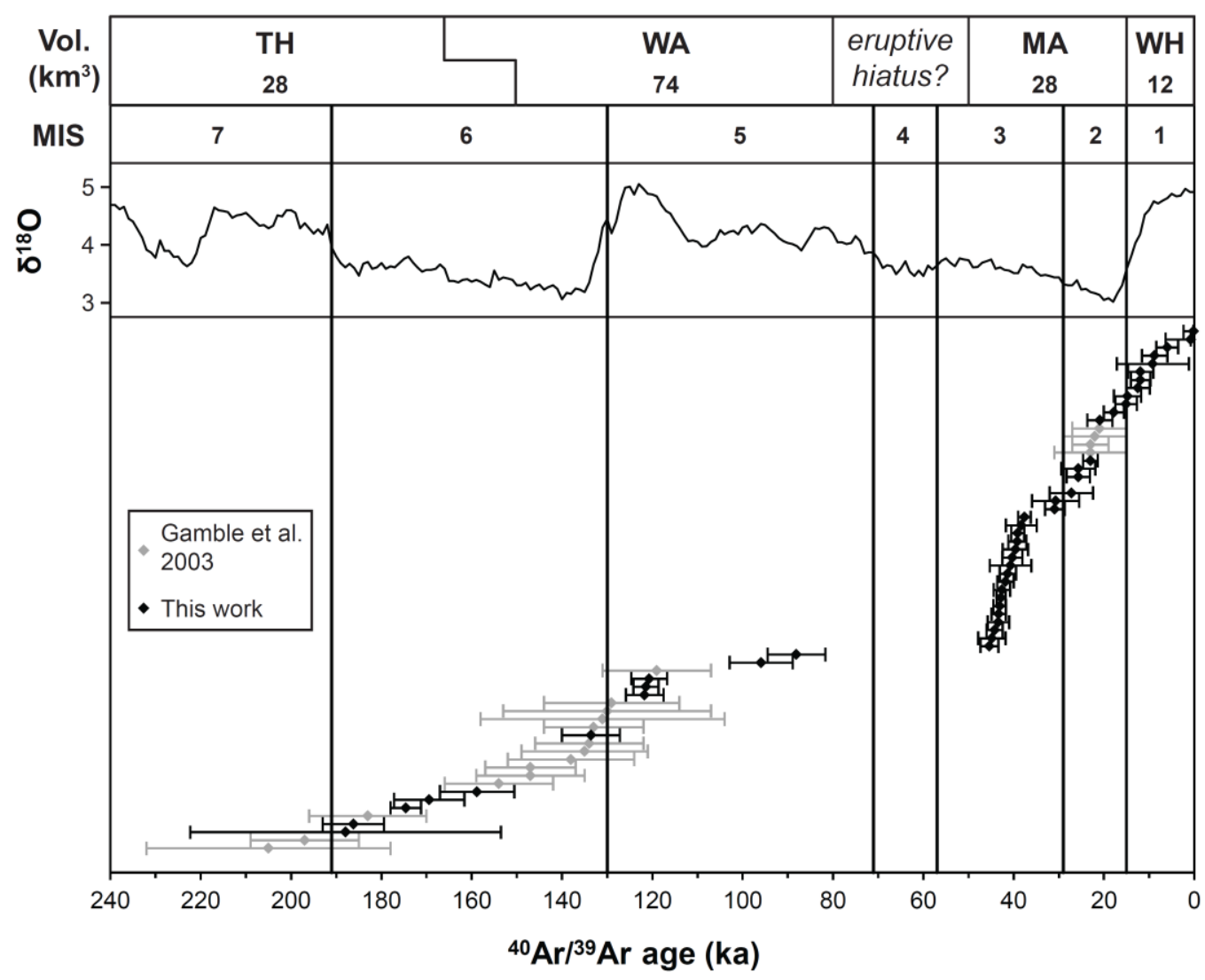

Figure 5.2. Summary diagram of the effusive growth history of Ruapehu. Diamonds are ${ }^{40} \mathrm{Ar} /{ }^{39} \mathrm{Ar}$ weighted mean plateau ages (WMPA) and bars are the associated 2sd uncertainties. Samples from Gamble et al. 2003 (grey) and this study (black) are arranged along the y-axis in chronological order of the WMPA. Timing of marine isotope stages (MIS) and data for the $\delta^{18} \mathrm{O}$ curve are from Lisiecki and Raymo (2005). Eruptive volumes $\left(\mathrm{km}^{3}\right)$ for Te Herenga (TH), Wahianoa (WA), Mangawhero (MA) and Whakapapa (WH) formations, calculated in this thesis are provided in the top row.

4. Effusive products that form composite edifices provide the best opportunity to define the growth history of a volcano through studying the exposed intercalation of primary volcanic products. Complete eruption histories, however, should integrate the records of explosive volcanism and edifice destruction provided by distal deposits on the ring plain. Apart from a preliminary comparison between the compositions of post-50 ka lavas and pyroclastic deposits in Chapter 3, integration of explosive and effusive volcanic records has not been investigated in this thesis. It is, however, part of the wider collaborative mapping project (Townsend et al., 2016) and will receive further attention therein. The well-defined compositional characteristics of lavas for individual eruptive packages presented in this thesis provides the potential to geochemically correlate distal deposits with periods of effusive activity. This is particularly pertinent for the period from $\sim 50-15$ $\mathrm{ka}$, for which lava packages have distinct compositions and the dynamics of ring plain 
aggradation adjacent to the Ruapehu edifice have received little attention (cf. Tost and Cronin, 2015).

5. A further feature of the growth history of Ruapehu that can be illuminated from ring plain studies is the relationship between volcanism and tectonic activity. Comparison of the revised chronology of effusive activity at Ruapehu to slip rates on local faults would allow an investigation of this relationship. At present, however, the uncertainties on slip rate reconstructions for the period $>20$ ka preclude a thorough test of the coupling between extension and magma flux rates (cf. Villamor and Berryman, 2006a, 2006b). This is a fundamental concept that should be further investigated for Ruapehu by refining the constraints on fault displacement rates.

6. A comprehensive study of the growth history of Tongariro composite volcano constrained by new ${ }^{40} \mathrm{Ar} /{ }^{39} \mathrm{Ar}$ ages should be undertaken. Considering the close proximity to Ruapehu, and the similarity of the timescales of eruptive (Hobden et al., 1999) and glacial histories (Eaves et al., 2016a), similar approaches to those used in this thesis are applicable.

\subsubsection{What are the ages of the oldest and youngest lava flows exposed on the edifice,} and can the ${ }^{40} \mathrm{Ar} /{ }^{{ }^{9}} \mathrm{Ar}$ geochronometer be applied to Holocene andesite flows?

The oldest indication of volcanism in the Ruapehu region is manifested by the $\sim 1 \mathrm{Ma}$ basaltic-andesite lavas of Hauhangatahi (Cameron et al., 2010). Early volcanism at the location of the modern Ruapehu edifice has been connected to distal andesitic clasts in $\sim 340 \mathrm{ka}$ marine terraces located $\sim 200 \mathrm{~km}$ to the southwest by Tost and Cronin (2015). However, dating of eruptive deposits within the deepest exposures of the edifice by Gamble et al. (2003) yielded maximum ages of $200 \mathrm{ka}$. I tested whether the Ruapehu edifice exposes any older record of volcanism by sampling deep exposures of Te Herenga Formation eruptive products on the northern flank. The oldest constraint presented in this study is an imprecise weighted mean plateau age (WMPA) of $187.9 \pm 34.4 \mathrm{ka}$ (Fig. 5.2). A more precise measurement with a comparable WMPA was determined for sample CC348 $(186.2 \pm 6.8 \mathrm{ka})$. These results did not extend the age constraints earlier than those set by Gamble et al. (2003) for the timing of eruptive activity relating to the construction of the exposed edifice. The age determined for CC348 which is from the least evolved basaltic-andesite lava sampled at Ruapehu is significant, however, because this lava had 
previously been assigned an erroneous eruption age within the Mangawhero Formation (Price et al., 2012; i.e. 50-15 ka). The new age provides an important temporal tie-point for the geochemical evolution of eruptive products throughout the lifetime of Ruapehu.

At the other end of the age spectrum, I tested whether the ${ }^{40} \mathrm{Ar} /{ }^{39} \mathrm{Ar}$ geochronometer could be applied to dating Holocene age andesite lavas. WMPA eruption ages of $<5 \mathrm{ka}$ determined for this study are consistent with late Holocene ages from field evidence for the relevant flows. Three experiments on Holocene lavas produced $2 \sigma$ uncertainties of 2.2-2.8 ka, which are comparable to those for Mangawhero Formation lava flows and permitted the discrimination of lava flows into early (10-5 ka) or late Holocene (<5 ka) timeframes. This level of precision has previously not been achieved in other studies of such young andesite lavas (e.g. Jicha et al., 2012). The results support using the ${ }^{40} \mathrm{Ar} /{ }^{39} \mathrm{Ar}$ technique to date Holocene andesite lavas and indicate that optimal $2 \sigma$ uncertainties can be as small as $\sim 2 \mathrm{kyr}$.

Several Holocene flows on Ruapehu were, however, unable to be dated because emplacement and erosion of the lavas had not generated or exposed holocrystalline interior zones. These include andesite lava flows of the Rangataua and Saddle Cone eruptive packages. An alternative technique that could be used to constrain ages for these lavas is ${ }^{3} \mathrm{He}$ exposure dating. The local production rate of ${ }^{3} \mathrm{He}$ has recently been calibrated (Eaves et al., 2015) and used to constrain exposure ages of moraines at Tongariro volcano (Eaves et al., 2016a). The fresh margins of the Saddle Cone and Rangataua lavas, their location at low elevations $(\sim 1000 \mathrm{~m})$ that have been minimally affected by seasonal snow and ice, and their pyroxene-dominated mineral assemblages make them suitable targets for ${ }^{3} \mathrm{He}$ exposure dating (cf. Eaves et al., 2015).

\subsubsection{What processes controlled the timing of two major Holocene sector collapse events?}

Major collapses of Ruapehu's northern and southern summit sectors occurred respectively at $10.5 \mathrm{ka}$ (Palmer and Neall, 1989; Eaves et al., 2015) and $4.6 \mathrm{ka}$ (Donoghue and Neall, 2001). These events generated debris avalanche deposits that inundated the flanks and adjacent ring plain in areas that now coincide with ski fields, small townships and state highways. Understanding the causes of edifice instability that led to these events is 
fundamental for determining the future hazard potential at Ruapehu and other composite volcanoes.

The interpretation put forward in this thesis invokes deglaciation to have played a primary role in controlling the timing of Holocene sector collapses at Ruapehu. Wholesale retreat of glaciers is inferred to have occurred from 18-15 ka, although upper flank glaciers and a summit ice cap are likely to have remained for several kyrs. Rapid climate amelioration from $\sim 11 \mathrm{ka}$ is indicated by regional records (e.g. Newnham et al., 2003), which broadly coincides with the cessation of construction of summit cones composed of Paretetaitonga $(14.8 \pm 3.0 \mathrm{ka})$, Tureiti $(11.9 \pm 2.8 \mathrm{ka})$ and Turoa $(11.9 \pm 2.2 \mathrm{ka})$ package flows. The retreat of glaciers and summit ice debutressed the pre-collapse summit cones and exposed parts of the supporting steep, hydrothermally altered edifice that had been under ice. While deglaciation conditioned the instability of the edifice, disruption via seismic or volcanic activity may have provided the eventual trigger for collapse of the cones.

Post-20 ka warming is inferred to have been a global factor in generating sector collapses at glaciated volcanoes (Capra, 2006). Other steep, hydrothermally altered and fractured portions of the Ruapehu (and Tongariro) edifice remain prone to collapse if destabilised by volcanic or tectonic activity and present a real threat to recreational users and local populations of the Tongariro National Park at the current time.

\subsubsection{Has edifice erosion, sector collapse and deglaciation since $\sim 20 \mathrm{ka}$ cause elevated eruption rates?}

Constraining feedback mechanisms between glaciation and volcanism at ice-clad volcanoes is a important question for understanding and reconciling global volcanic records and climate drivers. Moreover, it is a relevant question in light of the rapid thinning and recession of alpine glaciers on many volcanoes in response to contemporary global climate change (e.g. Rivera et al., 2006). Eruptive volumes were calculated and compared for the periods from $50-15 \mathrm{ka}$ and $15-0 \mathrm{ka}$ to test whether the removal of a lithospheric load on the magma storage system at Ruapehu due to deglaciation, sector collapse and erosion led to enhanced eruption rates. Revised eruption rate estimates that were calculated based on the new chronostratigraphy are approximately constant at 0.8 $\mathrm{km}^{3} \mathrm{ka}^{-1}$ since $\sim 50 \mathrm{ka}$, indicating that deglaciation of the edifice did not lead to a heightened magma production rate at Ruapehu. 
Calculating lava flow volumes is an inherently complex process that must take into account numerous complicating factors, particularly the post-emplacement erosion of lava flows. Estimating volumes of syn-glacial lavas for Ruapehu were compounded by several limitations, including the unknown volume of lava transported to the ring plain by glaciers both during (due to supra-glacial emplacement of lava) and following effusive eruptions is difficult to quantify. However, the widespread presence of ice-bounded knuckles of overthickened lava suggests that the latter process of lateral erosion was less significant. Nevertheless, generalised thickness estimates that were used for eruptive packages may be biased by outcrops at flow margins where lavas were impounded and overthickened against ice. Conversely, the recognition of ice-marginal flow emplacement improves the accuracy of the estimate by discounting the back-calculation of eruptive volumes inferred to have been lost via valley incision.

The limitations of defining accurate eruptive rates at glaciated composite volcanoes are illuminated in this study as they have been in many preceding attempts (e.g. Singer et al., 1997; Frey et al., 2004). A note for future workers is that integration of the syn- and posteruptive impacts of glaciation should be considered when undertaking such studies.

\subsubsection{How has the varying magma flux through the lithosphere influenced the composition of erupted products over time?}

New and existing petrological and geochemical data were sequenced into a 200 kyr-long record of the compositional evolution of Ruapehu lavas in Chapter 4. The resolution provided by a more comprehensive sample suite and absolute age constraints for lava flows erupted since $50 \mathrm{ka}$ has revealed compositional trends that were not observed by previous workers (Fig. 5.3). An overview evolution model for the Ruapehu magmatic system constrained by new results and existing petrogenetic models and isotopic data is outlined below.

Time-composition trends reveal a general increase in the degrees of crustal assimilation and crystal fractionation involved in magma genesis from 200 to $80 \mathrm{ka}$ (Fig. 5.3). Following the apparent 30 kyr-long eruptive hiatus, lavas erupted at 50-35 ka exhibit wide compositional heterogeneity ranging from high-magnesian andesite (Mangaehuehu package) to evolved high-K dacite (Te Kohatu package). The latter type defines a discrete 
end-member for all 50-35 ka lavas in $\mathrm{SiO}_{2}$ versus $\mathrm{K} / \mathrm{Ca}$ or $\mathrm{Rb}$ bivariate diagrams when compared to older and younger flows. Analysis of glass hosted within xenolithic fragments of fused metasedimentary basement indicate that Te Kohatu package lavas assimilated highly enriched partial melts of continental crust basement rocks. If a hiatus did precede this period of magmatism it may have provided a time period of progressive intrusion and stalling of magmas from the lower crust that consequently facilitated partial melting and assimilation in the middle to upper crust. This scenario is supported by existing Sr- and $\mathrm{Nd}$-isotopic data that indicate elevated levels of crustal assimilation in 50-35 ka Mangawhero Formation lavas, relative to other time periods. A distinct reversion to less silicic, less potassic compositions is defined by lava flows erupted since $26 \mathrm{ka}$ (Fig. 5.3). These magmas are inferred to have assimilated less enriched melts due to the progressive exhaustion of fertile phases in the crustal column from prior melting and ongoing magma and heat flux through the volcanic plumbing system beneath Ruapehu.

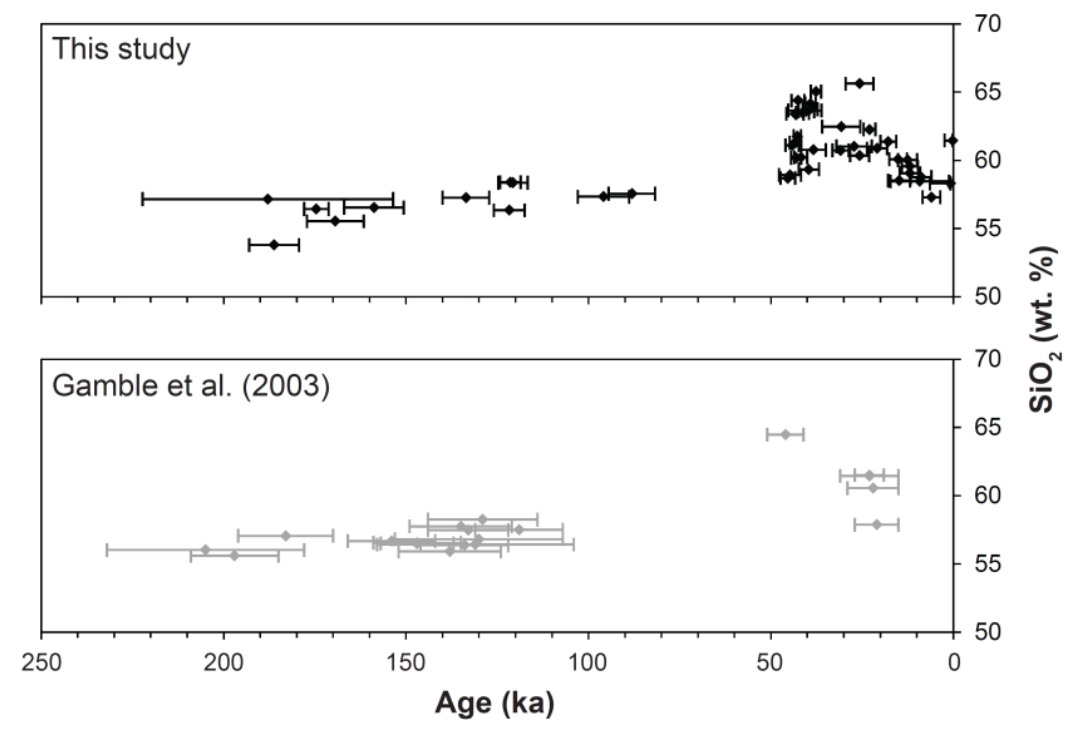

Figure 5.3. Age- $\mathrm{SiO}_{2}$ evolution diagrams for Ruapehu lavas. Top panel displays new data from this study; bottom panel displays data from Gamble et al. (2003).

The coherent evolution of whole-rock compositions therefore appears to reflect the longterm thermal conditioning of the magma system beneath Ruapehu. Superimposed on this general trend are short-term geochemical heterogeneities preserved within lava flow sequences that exhibit non-systematic variability on timescales of 1-10 kyr. These heterogeneities reflect the unique combination of varied extents of melting, mixing, 
fractionation and assimilation that each sequentially erupted magma batch undergoes within the complex crustal plumbing system (Price et al., 2012).

Microanalytical work undertaken in this study has contributed new constraints for the composition of key ingredients that produce the crust-like geochemical signatures of arc andesites and dacites. Preliminary characterisation of glass compositions within a temporal framework was undertaken, but further data are required to detail the evolution of the magma system, particularly for the period from $50-0 \mathrm{ka}$. The scarcity of pristine melt inclusions and areas of groundmass glass larger than $>10 \mu \mathrm{m}$-wide in even the most glassy of Ruapehu lavas is a limiting factor for such work.

This thesis did not present petrogenetic models to attempt quantification of the roles of melting, mixing, crustal assimilation and fractionation processes, but has provided a framework within which such models can now be developed. As noted by Dungan et al. (2001), the meaningful modelling of the origin and evolution of magmas requires highresolution volcanic records with precise temporal constraints. Such a record is now available for Ruapehu lava flows and will contribute to the advancement of researching one of Earth Science's fundamental concepts: the formation of continental crust within the root zones beneath arc volcanoes.

\subsubsection{Are high-magnesian andesites the products of primary mantle-derived magmas} or mafic-felsic interaction?

High-density sampling of the previously sparsely sampled southern and western flanks yielded samples of lavas with distinct geochemical characteristics (Chapter 4). The Mangaehuehu ( 47-40 ka) and Te Kohatu ( 44-36 ka) packages of andesite and dacite lavas, respectively, exhibit elevated $\mathrm{MgO}, \mathrm{Cr}$ and $\mathrm{Ni}$ contents compared to other Ruapehu eruptive products (Fig. 5.4). Based on the corresponding whole-rock Mg\# values (60-69 for Mangaehuehu package and 54-57 for Te Kohatu package) the lavas are classified as high-magnesian andesites (HMAs; Kelemen et al., 2003a).

The eruption of HMAs at arc volcanoes is intriguing because such rocks may be the direct products of partial melting of hydrous mantle peridotite (e.g. Grove et al., 2002, 2005; Wood and Turner, 2009). This model is seemingly contradicted, however, by the irrefutable evidence for crustal assimilation in the Ruapehu HMAs, including the 
presence of xenolithic fragments with metasedimentary assemblages and crust-like ${ }^{87} \mathrm{Sr} /{ }^{86} \mathrm{Sr}$ isotopic values. Alternative models invoke mixing between felsic and mafic magmas (e.g. Kawabata and Shuto, 2005; Streck et al., 2007), for which, in turn, there is strong evidence in Ruapehu HMAs. A population of orthopyroxene with rounded and resorbed $\mathrm{Mg}_{\# 70-72}$ cores that are mantled by euhedral rims with $\mathrm{Mg \#} 88-90$ (Fig. 5.4) is prevalent in the lavas. The crystals occur in clots where only outermost crystal margins are mantled by high-Mg\# rims and as single phenocrysts that are often broken (Fig. 5.4). The characteristics are consistent with a model of interaction between a hot recharging mafic magma and a stalled felsic magma in the crust (cf. Nakagawa et al., 2002).

Constraining the nature of primitive magmas within the southern end of the Taupo Volcanic Zone is difficult because even relatively primitive basaltic-andesites have generally undergone textural and chemical modification in the crust. Cryptic records of mafic magma intrusion into the crust beneath Ruapehu are provided by the reverse zoned crystal cargo of HMAs. Mafic magmas may represent important regulators of not only the composition of arc magmas but also the timing of their eruption and the involvement of mafic recharge events in eruptive episodes at arc volcanoes have been widely cited (see review by Kent, 2013). Future microanalytical efforts should be undertaken to document the composition of mafic magmas and their crystal cargoes that have fed eruptions from the central vent focus at Ruapehu as well as periphery vents (e.g. Ohakune and Pukeonake andesites). Such work will provide further information on the composition of primitive magmas that ultimately fuel arc magmatism.

\subsubsection{Cristobalite in Ruapehu lavas}

A fortuitous finding from this research was the discovery of cristobalite within lava flow samples that cover a wide spatial and temporal range, which represents the first recognition and definition of cristobalite in edifice-forming eruptive products at Ruapehu. Cristobalite occurs as prismatic crystals on vesicle walls within relatively glassy samples and is felted through holocrystalline groundmass in slowly cooled samples. Despite a general association with rhyolitic lava domes (e.g. Schipper et al., 2015), this study indicates that cristobalite may be widespread in lava flows with basaltic-andesite to dacite bulk compositions from continental arcs due to the dominance of dacitic to rhyolitic groundmass compositions in such rocks (Reubi and Blundy, 2009). At Ruapehu, glacial 
erosion and explosive magmatic and phreatomagmatic eruptions are likely to have made cristobalite readily available to the environment. Cristobalite is also likely to be present within other andesite composite cones (e.g. Tongariro) as well as the voluminous rhyolite products throughout the Taupo Volcanic Zone. Physical weathering, mining for construction materials and geothermal energy exploration are likely to have disturbed these volcanic products and, potentially, caused dispersal of cristobalite across North Island, New Zealand. Whether this presents a serious health risk regional populations is unknown and requires further investigation.

\subsection{Epilogue}

This thesis has established a high-resolution chronostratigraphic framework through the collection and integration of geological, geochronological and geochemical datasets. This has permitted investigations of the interrelated magmatic, volcanic and glacial processes that shape glaciated composite edifices. In doing so, I have addressed key questions relating to the growth history and geochemical evolution of Ruapehu. New questions have been suggested in this synthesis and can be tested by future interdisciplinary research at Ruapehu and elsewhere along Earth's active volcanic arcs.

As a final thought, the multi-stage processing of volcanic rocks that originate as partial melts of the mantle wedge above subduction zones, transit through the lithosphere and are eventually emplaced on the flanks of a volcano, can be summarised as follows:

The mantle proposes, the crust imposes, the edifice juxtaposes, the glacier exposes, the ring plain disposes, the student supposes.

\section{The life history of arc andesites}

After Hildreth (2007). 


\section{REFERENCES}


Adams, C.J., Mortimer, N., Campbell, H.J., and Griffin, W.L., 2009, Age and isotopic characteristics of metasedimentary rocks from the Torlesse Supergroup and Waipapa Group in the central North Island, New Zealand: New Zealand Journal of Geology and Geophysics, v. 52, p. 149-170.

Allan, A.S.R., Morgan, D.J., Wilson. C.J.N., and Millet, M.-A., 2013, From mush to eruption in centuries: assembly of the super-sized Oruanui magma body: Contributions to Mineralogy and Petrology, v. 166, p. 143-164.

Anderson, A.T., 1973, The before-eruption water content of some high-alumina magmas: Bulletin Volcanologique, v. 37, p. 243-267.

Anderson, S.W., and Fink, J.H. 1992, Crease structures: Indicators of emplacement rates and surface stress regimes of lava flows: Geological Society of America Bulletin, v. 104, p. 615-625.

Annen, C., and Sparks, R.S.J., 2002, Effects of repetitive emplacement of basaltic intrusions on thermal evolution and melt generation in the crust: Earth and Planetary Science Letters, v. 203, p. 937-955.

Annen, C., Blundy, J.D., Sparks, R.S.J., 2006, The genesis of intermediate and silicic magmas in deep crustal hot zones: Journal of Petrology, v. 47, p. 505-539.

Bacon, C.R., and Lanphere, M.A., 2006, Eruptive history and geochronology of Mount Mazama and the Crater Lake region, Oregon: Geological Society of America Bulletin, v. 118, p. 1331-1359.

Barker, S. J., 2014, Post Oruanui supereruption recovery, reconstruction and evolution of Taupo volcano, New Zealand: Unpublished PhD thesis, Victoria University of Wellington, New Zealand, 268 pp.

Barker, S.J., Wilson, C.J.N., Allan, A.S.R., and Schipper, C.I., 2015, Fine-scale temporal recovery, reconstruction and evolution of a post-supereruption magmatic system: Contributions to Mineralogy and Petrology, v. 170, article 5.

Baxter, P.J., Bonadonna, C., Dupree, R., Hards, V.L., Kohn, S.C., Murphy, M.D., Nichols, A., Nicholson, R.A., Norton, G., Searl, A., Sparks, R.S.J., and Vickers, B. P., 1999, Cristobalite in volcanic ash of the Soufriere Hills volcano, Montserrat, British Windies: Science, v. 283, p. 1142-1145.

Bonnichsen, B., and Kauffmann, D.F., 1987, Physical features of rhyolite lava flows in the Snake River Plain volcanic province, southwestern Idaho: In Fink, J. H. (Ed.), The emplacement of silicic domes and lava flows, Geological Society of America Special Paper 212, p. 119-145.

Brasse, H., Lezaeta, P., Rath, V., Scwalenberg, K., Soyer, W., and Haak, V., 2002, The Bolivian Altiplano conductivity anomaly: Journal of Geophysical Research v. 107, article 11.

Brook, M.S., 2009, Lateral moraine age in Park Valley, Tararua Range, New Zealand: Journal of the Royal Society of New Zealand v. 39, p. 63-69.

Calvert, A.T., Moore, R.B., McGimsey, R.G., 2005, Argon geochronology of late Pleistocene to Holocene Westdahl Volcano, Unimak Island, Alaska: In: Haeussler, P.J., and Galloway, J.P. (Eds.), Studies by the U.S. Geological Survey in Alaska, 2004: US Geological Survey Professional Paper 1709-D:1-16.

Cameron, E. Gamble, J., Price, R, Smith, I., McIntosh, W., and Gardner, M., 2010, The petrology, geochronology and geochemistry of Hauhungatahi volcano, S.W. Taupo Volcanic Zone: Journal of Volcanology and Geothermal Research, v. 190, p. 179191.

Capra, L., 2006, Abrupt climatic changes as triggering mechanisms of massive sector collapses: Journal of Volcanology and Geothermal Research, v. 155, p. 329-333. 
Capra, L., Benal., J.P., Carrasco-Nunez, G., and Roverato, M., 2013, Climatic fluctuations as a significant contributing factor for volcanic collapses. Evidence from Mexico during the Late Pleistocene: Global and Planetary Change, v. 100, p. 194-203.

Carmichael, I.S.E., 2002, The andesite aqueduct: perspectives on the evolution of intermediate magmatism in west-central $\left(105-99^{\circ} \mathrm{W}\right)$ Mexico: Contributions to Mineralogy and Petrology, v. 143, p. 641-663.

Carpenter, P.K., 2008, Electron-probe microanalysis (EPMA): an overview for beginners and status report for experts: Microscopy and microanalysis, v. 14, p. 1150-1151.

Clark, R.H., 1960, Appendix II: Petrology of the volcanic rocks of Tongariro Subdivision, In: Gregg, D.R. (Ed.) The geology of Tongariro Subdivision: New Zealand Geological Survey Bulletin, v. 40, p. 107-123.

Clark, P.U., Dyke, A.S., Shakun, J.D., Carlson, A.E., Clark, J., Wohlfarth, B., and Mitrovica, J.X., 2009, The Last Glacial Maximum: Science, v. 325, p. 710-714.

Clay, P.L., Buseman, H., Sherlock, S.C., Barry, T.L., Kelley, S.P., and McGarvie, D.W., $2015,{ }^{40} \mathrm{Ar} /{ }^{39} \mathrm{Ar}$ ages and residual volatile contents in degassed subaerial and subglacial volcanic rocks from Iceland: Chemical Geology, v. 403, p. 99-110.

Clynne, M.A., 1999, A complex magma mixing origin for rocks erupted in 1915, Lassen Peak, California: Journal of Petrology, v. 40, p. 105-132.

Coble, M.A., Grove, M., and Calvert, A.T., 2011, Calibration of Nu-Instruments Noblesse multicollector mass spectrometers for argon isotopic measurements using a newly developed reference gas: Chemical Geology, v. 290, p. 75-87.

Cole, J.W., 1978, Andesites of the Tongariro Volcanic Centre, North Island, New Zealand: Journal of Volcanology and Geothermal Research, v. 3, p. 121-153.

Cole, J.W., 1979, Structure, petrology, and genesis of Cenozoic volcanism, Taupo Volcanic Zone, New Zealand-a review: New Zealand Journal of Geology and Geophysics, v. 22, p. 631-657.

Cole, J.W., and Lewis, K.B., 1981, Evolution of the Taupo-Hikurangi subduction system: Tectonophysics v. 72, p. 1-21.

Conway, C. E., Townsend, D. B., Leonard, G. S., Wilson, C. J. N., Calvert, A. T., Gamble, J. A., 2015, Lava-ice interaction on a large composite volcano: a case study from Ruapehu, New Zealand: Bulletin of Volcanology, v. 77, article 21.

Coombs, M.L., Eichelberger, J.C., and Rutherford, M.J., 2000, Magma storage and mixing conditions for the 1953-1974 eruptions of Southwest Trident volcano, Katmai National Park, Alaska: Contributions to Mineralogy and Petrology, v. 140, p. 99-118.

Coombs, M.L., Sisson, T.W., Bleick, H.A., Henton, S.M., Nye, C.J., Payne, A.L., Cameron, C.E., Larsen, J.F., Wallace, K.L., and Bull, K.F., 2013, Andesites of the 2009 eruption of Redoubt Volcano, Alaska: Journal of Volcanology and Geothermal Research, v. 259, p. 349-372.

Cossart, E., Braucher, R., Fort, M., Bourlès, D.L., and Carcaillet, J., 2008, Slope instability in relation to glacial debuttressing in alpine areas (Upper Durance catchment, southeastern France): Evidence from field data and ${ }^{10} \mathrm{Be}$ cosmic ray exposure ages: Geomorphology, v. 95, p. 3-26.

Cronin, S.J., and Neall, V.E., 1997, A late Quaternary stratigraphic framework for the northeastern Ruapehu and eastern Tongariro ring plains, New Zealand: New Zealand Journal of Geology and Geophysics, v. 40, p. 185-197.

Cronin, S.,J., Neall, V.E., Lecointre, J.A., and Palmer, A.S., 1997, Changes in Whangaehu river lahar characteristics during the 1995 eruption sequence, Ruapehu 
volcano, New Zealand: Journal of Volcanology and Geothermal Research, v. 76, p. 47-61.

Cronin, S. J., Hedley, M. J., Neall, V. E., and Smith, R. G., 1998, Agronomic impact of tephra fallout from the 1995 and 1996 Ruapehu volcano eruptions, New Zealand: Environmental Geology, v. 34, p. 21-30.

Cullen, N.J., Mölg, T., Kaser, G., Hussein, K., Steffen, K., and Hardy, D.R., 2006, Kilimanjaro glaciers: Recent areal extent from satellite data and new interpretation of observed $20^{\text {th }}$ century retreat rates: Geophysical Research Letters, v. 33, article 6502.

Dalrymple, G.B., 1989, The GLM continuous laser system for ${ }^{40} \mathrm{Ar} /{ }^{39} \mathrm{Ar}$ dating: description and performance characteristics: in New Frontiers in Stable Isotopic Research, Shanks, W.C., and Criss, R.E. (Eds.), U. S. Geological Survey Bulletin 1890, p. 89-96.

Dalrymple, G.B., Alexander, E.C., Lanphere, M.A., and Kraker, G.P., 1981, Irradiation of samples for ${ }^{40} \mathrm{Ar} /{ }^{39} \mathrm{Ar}$ dating using the Geological Survey TRIGA reactor, U. S. Geological Survey Professional Paper 1176, 55 pp.

Damby, D.E., Horwell, C.J., Baxter, P.J., Delmelle, P., Donaldson, K., Dunster, C., Fubini, B., Murphy, F.A., Nattrass, C., Sweeney, S., Tetley, T. D., and Tomatis, M., 2013, The respiratory health hazard of tephra from the 2010 Centennial eruption of Merapi with implications for occupational mining of deposits: Journal of Volcanology and Geothermal Research, v. 261, p. 376-387.

Damby, D. E., Llewellin, E. W., Horwell, C. J., Williamson, B. J., Najorka, J., Cressey, G., and Carpenter, M., 2014, The $\alpha-\beta$ phase transition in volcanic cristobalite: Journal of Applied Crystallography, v. 47, p. 1205-1215.

Davidson, J., and de Silva, S., 2000, Composite volcanoes. In: Sigurdsson, H., Houghton, B.F., Rymer, H., Stix, J., and McNutt, S. (Eds.), Encyclopedia of Volcanoes, Academic Press, p. 663-681.

Davidson, J.P., Hora, J.M., Garrison, J.M., and Dungan, M.A., 2005, Crustal forensics in arc magmas: Journal of Volcanology and Geothermal Research, v. 140, p. 157-170.

Davidson, J.P., Morgan, D.J., Charlier, B.L.A., Harlou, R., and Hora, J.M., 2007, Microsampling and isotopic analysis of igneous rocks: implications for the study of magmatic systems: Annual Reviews of Earth and Planetary Science, v. 35, p. $273-$ 311.

De Hoog, J.C.M., van Bergen, M.J., and Jacobs, M.H.G., 2005, Vapour-phase crystallisation of silica from $\mathrm{SiF}_{4}$-bearing volcanic gases: Annals of Geophysics, $\mathrm{v}$. 48, p. 775-785.

Deer, W.A., Howie, R.A., and Zussman, J., 1992, An introduction to the rock-forming minerals: John Wiley and Sons, 2nd Edition, $371 \mathrm{pp}$.

Defant, M.J., and Drummond, M.S., 1990, Derivation of some modern arc magmas by melting of subducted lithosphere: Nature, v. 347, p. 662-665.

Defant, M.J., and Drummond, M.S., 1993, Mount St. Helens: potential example of the partial melting of the subducted lithosphere in a volcanic arc: Geology, v. 21, p. 547-550.

DeGraff, J.M., and Aydin, A., 1987, Surface morphology of columnar joints and its significance for mechanics and direction of joint growth: Geological Society of America Bulletin, v. 99, p. 605-617.

DeMets, C., Gordon, R.G., and Argus, D.F., 2010, Geologically current plate motions: Geophysical Journal International, v. 181, p. 1-80. 
Denton, G.H., and Hughes, T.J., 1983, Milankovitch theory of ice ages: hypothesis of icesheet linkage between regional insolation and global climate: Quaternary Research, v. 20, p. 125-144.

DePaolo, D.J., 1981, A neodymium and strontium isotopic study of the Mesozoic calkalkaline granitic batholiths of the Sierra Nevada and Peninsular Ranges, California: Journal of Geophysical Research, v. 86, p. 10,470-10,488.

Donoghue, S. L. and Neall, V. E., 2001, Late Quaternary constructional history of the southeastern Ruapehu ring plain, New Zealand: New Zealand Journal of Geology and Geophysics, v. 44, p. 439-466.

Donoghue, S.L., Neall, V.E., Palmer, A.S., 1995a, Stratigraphy and chronology of late Quaternary andesitic tephra deposits, Tongariro Volcanic Centre, New Zealand: Journal of the Royal Society of New Zealand, v. 25, p. 115-206.

Donoghue, S.L., Gamble, J.A., Palmer, A.S., and Stewart, R.B., 1995b, Magma mingling in an andesite pyroclastic flow of the Pourahu Member, Ruapehu volcano, New Zealand: Journal of Volcanology and Geothermal Research, v. 68, p. 177-191.

Donoghue, S.L., Neall, V.E., Palmer, A.S., and Stewart, R.B., 1997, The volcanic history of Ruapehu during the past 2 millennia based on the record of Tufa Trig tephras: Bulletin of Volcanology, v. 59, p. 136-146.

Dufek, J. and Bergantz, G. W., 2005, Lower crustal magma genesis and preservation: a stochastic framework for the evaluation of basalt-crust interaction: Journal of Petrology, v. 46, p. 2167-2195.

Dungan, M.A., and Davidson, J., 2004, Partial assimilative recycling of the mafic plutonic roots of arc volcanoes: an example from the Chilean Andes: Geology, v. 32, p. 773-776.

Dungan, M.A., Wulff, A., and Thompson, R., 2001, Eruptive stratigraphy of the TataraSan Pedro Complex, $36^{\circ} \mathrm{S}$, Southern Volcanic Zone, Chilean Andes: reconstruction method and implications for magma evolution at long-lived arc volcanic centres: Journal of Petrology v. 42, p. 555-626.

Eaves, S.R., 2015, The glacial history of Tongariro and Ruapehu volcanoes, New Zealand: Unpublished PhD thesis, Victoria University of Wellington, $253 \mathrm{pp}$.

Eaves, S.R., Winckler, G., Schefer, J.M., Vandergoes, M.J., Alloway, B.V., Mackintosh, A.N., Townsend, D.B., Ryan, M.T., and Li, X., 2015, A test of the cosmogenic ${ }^{3} \mathrm{He}$ production rate in the south-west Pacific $\left(39^{\circ} \mathrm{S}\right)$ : Journal of Quaternary Science, v. 30, p. 79-87.

Eaves, S.R., Mackintosh, A.N., Winckler, G., Schaefer, J.M., Alloway, B.V., and Townsend, D.B., 2016a, A cosmogenic ${ }^{3} \mathrm{He}$ chronology of late Quaternary glacier fluctuations in North Island, New Zealand $\left(39^{\circ} \mathrm{S}\right)$ : Quaternary Science Reviews, v. 132, p. 40-56.

Eaves, S.R., Anderson, B.M., Mackintosh, A.N., Doughty, A.M., Townsend, D.B., Conway, C.E., Winckler, G., Schaefer, J.M., Leonard, G.S., and Calvert, A.T., (2016b), The Last Glacial Maximum in central North Island, New Zealand: paleoclimate inferences from 2D glacier modelling: Climate of the Past, v. 12, p. 943-960.

Edwards, B.R., Karson, J., Wysocki, R., Lev, E., Bindeman, I., and Kueppers, U., 2013, Insights on lava-ice/snow interactions from large-scale basaltic melt experiments: Geology, v. 41, p. 851-854.

Edwards, B.R., Gudmundsson, M.T., and Russell, J.K., 2015, Glaciovolcanism. In: Sigurdsson, H., Houghton, B., Rymer, H., Stix, J., McNutt, S. (Eds.), Encyclopedia of Volcanoes, $2^{\text {nd }}$ Edition, Academic Press, p. 377-393. 
Eggins, S.M., Woodhead, J.D., Kinsley, L.P.J., Mortimer, G.E., Sylvester, P., McCulloch, M.T., Hergt, J.M., and Handler, M.R., 1997, A simple method for the precise determination of $\geq 40$ trace elements in geological samples by ICPMS using enriched isotope internal standardisation: Chemical Geology, v. 134, p. 311-326.

Eichelberger, J.C., 1978, Andesites in island arcs and continental margins: relationship to crustal evolution: Bulletin Volcanologique, v. 41, p. 480-500.

Eichelberger, J.C., Izbekov, P.E., and Browne, B.L., 2006, Bulk chemical trends at arc volcanoes are not liquid lines of descent: Lithos, v. 87, p. 135-154.

Escobar-Wolf, R.P., Diehl, J.F., Singer, B.S., and Rose, W.I., 2010, ${ }^{40} \mathrm{Ar} /{ }^{39} \mathrm{Ar}$ and paleomagnetic constraints on the evolution of Volcan de Santa Maria, Guatemala: Geological Society of America Bulletin, v. 122, p. 757-771.

Fierstein, J., Hildreth, W., and Calvert, A.T., 2011, Eruptive history of South Sister, Oregon Cascades: Journal of Volcanology and Geothermal Research, v. 207, p. 145-179.

Fleck, R.J., Hagstrum, J.T., and Calvert, A.T., 2014, ${ }^{40} \mathrm{Ar} /{ }^{39} \mathrm{Ar}$ geochronology, paleomagnetism, and evolution of the Boring volcanic field, Oregon and Washington, USA: Geosphere, v. 10, p. 1283-1314.

Forbes, A.E.S., Blake, S., McGarvie, D.W., and Tuffen, H., 2012, Pseudopillow fracture systems in lavas: Insights into cooling mechanisms and environments from lava flow fractures: Journal of Volcanology and Geothermal Research, v. 245-246, p. 68-80.

Forbes, A.E.S., Blake, S., and Tuffen, H., 2014, Entablature: fracture types and mechanisms: Bulletin of Volcanology, v. 76, article 820.

Frey, H.M., Lange, R.A., Hall, C.M., and Delgado-Granados, H., 2004, Magma eruption rates constrained by ${ }^{40} \mathrm{Ar} /{ }^{39} \mathrm{Ar}$ chronology and GIS for the Ceboruco-San Pedro volcanic field, western Mexico: Geological Society of America Bulletin, v. 116, p. 259-276.

Froggatt, P.C., and Lowe, D.J., 1990, A review of late Quaternary silicic and some other tephra formations from New Zealand: their stratigraphy, nomenclature, distribution, volume, and age: New Zealand Journal of Geology and Geophysics, v. 33, p. 89109.

Gaetani, G.A., and Grove, T.L., 1998, The influence of water on melting mantle peridotite: Contributions to Mineralogy and Petrology, v. 131, p. 323-346.

Gamble, J.A., Smith, I.E.M., McCulloch, M.T., Graham, I.J., and Kokelaar, B.P., 1993, The geochemistry and petrogenesis of basalts from the Taupo Volcanic Zone and the Kermadec Island Arc, S.W. Pacific: Journal of Volcanology and Geothermal Research, v. 54, p. 265-290.

Gamble, J.A., Wood, C.P., Price, R.C., Smith, I.E.M., Stewart, R.B., and Waight, T., 1999, A fifty year perspective of magmatic evolution on Ruapehu Volcano, New Zealand: verification of open system behaviour in an arc volcano: Earth and Science Planetary Letters, v. 170, p. 301-314.

Gamble, J.A., Price, R.C., Smith, I.E.M., McIntosh, W.C., and Dunbar, N.W., 2003, ${ }^{40} \mathrm{Ar} /{ }^{39} \mathrm{Ar}$ geochronology of magmatic activity, magma flux and hazards at Ruapehu Volcano, Taupo Volcanic Zone, New Zealand: Journal of Volcanology and Geothermal Research, v. 120, p. 271-287.

Gardeweg, M.C., Sparks, R.S.J., and Matthews, S.J., 1998, Evolution of Lascar Volcano, Northern Chile: Journal of the Geological Society of London, v. 155, p. 89-104.

Gill, J., 1981, Orogenic andesites and plate tectonics: Springer, Berlin, 390 pp. 
Goto, Y., and McPhie, J., 2012, Morphology and formation of spreading cracks on pillow lavas at Cape Grim, northwestern Tasmania, Australia: Bulletin of Volcanology, v. 74, p. 1611-1619.

Graham, I.J., 1987, Petrography and origin of metasedimentary xenoliths in lavas from Tongariro Volcanic Centre: New Zealand Journal of Geology and Geophysics, v. 30, p. 139-157.

Graham, I.J. and Hackett, W.R., 1987, Petrology of calc-alkaline lavas from Ruapehu and related vents, Taupo Volcanic Zone, New Zealand: Journal of Petrology, v. 28, p. 531-567.

Graham, I.J., Blattner, P., and McCulloch, M.T., 1990, Meta-igneous xenoliths from Mount Ruapehu, New Zealand: fragments of altered oceanic crust?: Contributions to Mineralogy and Petrology, v. 105, p. 650-661.

Grange, L.I., and Hurst, J.A., 1929, Tongariro subdivision: New Zealand Geological Survey $23^{\text {rd }}$ Annual Report, 5-8.

Gregg, D.R., 1960, Volcanoes of Tongariro National Park. New Zealand Department Scientific and Industrial Research Information Series 28, 82 pp.

Greve, A., Turner, G.M., Conway, C.E., Townsend, D.B., and Calvert, A.C., (2016 manuscript under review), Secular variation and new paleomagnetic age constraints on lava flows from the Tongariro Volcanic Centre, New Zealand: Geophysical Journal International, Manuscript ID: GJI-S-15-0993.

Grindley, G.W., 1960, Sheet 8 - Taupo: Geological Map of New Zealand 1:250,000, New Zealand Department Scientific and Industrial Research, Wellington.

Grove, T.L., Parman, S.W., Bowring, S.A., Price, R.C., and Baker, M.B., 2002, The role of an $\mathrm{H}_{2} \mathrm{O}$-rich fluid component in the generation of primitive basaltic andesites and andesites from the Mt. Shasta region, N California: Contributions to Mineralogy and Petrology, v. 142, p. 375-396.

Grove, T. L., Baker, M. B., Price, R. C., Parman, S. W., Elkins-Tanton, L. T., Chatterjee, N., and Müntener, O., 2005, Magnesian andesite and dacite lavas from Mt. Shasta, northern California: products of fractional crystallization of $\mathrm{H}_{2} \mathrm{O}$-rich mantle melts: Contributions to Mineralogy and Petrology, v. 148, p. 542-565.

Grove, T.L., Till, C.B., and Krawcynski, M.J., 2012, The role of $\mathrm{H}_{2} \mathrm{O}$ in subduction zone magmatism: Annual Reviews of Earth and Planetary Science, v. 40, p. 413-439.

Guillou, H., Singer, B.S., Laj, C., Kissel, C., Scaillet, S., and Jicha, B.R., 2004, On the age of the Laschamp geomagnetic excursion: Earth and Planetary Science Letters, v. 227, p. 331-343.

Hackett, W.R., 1985, Geology and petrology of Ruapehu volcano and related vents: Unpublished $\mathrm{PhD}$ thesis, Victoria University of Wellington, New Zealand, $467 \mathrm{pp}$.

Hackett, W.R., and Houghton, B.F., 1989, A facies model for a Quaternary andesitic composite volcano, Ruapehu, New Zealand: Bulletin of Volcanology, v. 51, p. 5168.

Hajdas, I., Lowe, D.J., Newnham, R.M., and Bonani, G., 2006, Timing of the late-glacial climate reversal in the Southern Hemisphere using high-resolution radiocarbon chronology for Kaipo Bog, New Zealand: Quaternary Research, v. 65, p. 340-345.

Harrison, A.J., and White, R.S., 2004, Crustal structure of the Taupo Volcanic Zone, New Zealand: stretching and igneous intrusion: Geophysical Research Letters, v. 31, L13615.

Heine, A.J., 1963, Mount Ruapehu ice and snow survey: New Zealand Journal of Geology and Geophysics Research, v. 6, p. 261-267. 
Heise, W., Caldwell, T.G., Bibby, H.M., and Bennie, S.L., 2010, Three-dimensional electrical resistivity image of magma beneath an active continental rift, Taupo Volcanic Zone, New Zealand: Geophysical Research Letters, v. 37, L110301.

Heyworth, Z., Turner, S., Schaefer, B., Wood, B., George, R., Berlo, K., Cunningham, H., Price, R., Cook, C., and Gamble, J., 2007, ${ }^{238} \mathrm{U}-{ }^{230} \mathrm{Th}-{ }^{226} \mathrm{Ra}-{ }^{210} \mathrm{~Pb}$ constraints on the genesis of high-Mg andesites at White Island, New Zealand: Chemical Geology, v. 243, p. 105-121.

Hickson, C.J., 2000, Physical controls and resulting morphological forms of Quaternary ice-capped volcanoes in western Canada: Geomorphology, v. 32, p. 239-261.

Hildreth, W., 2007, Quaternary magmatism in the Cascades-geological perspectives: U.S. Geological Survey Professional Paper 1744, 125 pp.

Hildreth, W., and Fierstein, J., 2012, Eruptive history of Mount Katmai, Alaska: Geosphere, v. 8, p. 1527-1567.

Hildreth, W., and Lanphere, M.A., 1994, Potassium-argon geochronology of a basaltandesite-dacite arc system: the Mount Adams volcanic field, Cascade Range of southern Washington: Geological Society of America Bulletin, v. 106, p. 14131429.

Hildreth, W., and Moorbath, S., 1988, Crustal contributions to arc magmatism in the Andes of Central Chile: Contributions to Mineralogy and Petrology, v. 98, p. 455489.

Hildreth, W. Fierstein, J., and Lanphere, M.A., 2003, Eruptive history and geochronology of the Mount Baker volcanic field, Washington: Geological Society of America Bulletin, v. 115, p. 729-764.

Hobden, B.J., Houghton, B.F., Lanphere, M.A., and Nairn, I.A., 1996, Growth of the Tongariro volcanic complex: new evidence from K-Ar determinations: New Zealand Journal of Geology and Geophysics, v. 39, p. 151-154.

Hobden, B.J., Houghton, B.F., Davidson, J.P., and Weaver, S.D., 1999, Small and shortlived magma batches at composite volcanoes: time windows at Tongariro volcano, New Zealand: Journal of the Geological Society, London, v. 156, p. 865-868.

Hora, J.M., Singer, B.S., and Worner, G., 2007, Volcano evolution and eruptive flux on the thick crust of the Andean Central Volcanic Zone: ${ }^{40} \mathrm{Ar} /{ }^{39} \mathrm{Ar}$ constraints from Volcan Parinacota, Chile: Geological Society of America Bulletin, v. 119, p. 343362.

Horwell, C.J., Sparks, R.S.J., Brewer, T.S., Llewellin, E.W., and Williamson, B.J., 2003, Characterization of respirable volcanic ash from the Soufrière Hills volcano, Montserrat, with implications for human health hazards: Bulletin of Volcanology, $v$. 65, p. 346-362.

Horwell, C.J., Williamson, B.J., Donaldson, K., Le Blond, J.S., Damby, D.E., and Bowen, L., 2012, The structure of volcanic cristobalite in relation to its toxicity; relevance for the variable crystalline silica hazard: Particle and Fibre Toxicology, v. 9 , article 44.

Horwell, C.J., Williamson, B.J., Llewellin, E.W., Damby, D.E., and Le Blond, J.S., 2013, The nature and formation of cristobalite at the Soufrière Hills volcano, Montserrat: implications for the petrology and stability of silicic lava domes: Bulletin of Volcanology, v. 75, article 696.

Houghton, B.F., Latter, J.H., and Hackett, W.R., 1987, Volcanic hazard assessment for Ruapehu composite volcano, Taupo Volcanic Zone, New Zealand: Bulletin of Volcanology, v. 49, p. 737-751. 
Houghton, B.F., Wilson, C.J.N., and Smith, I.E.M., 1999, Shallow-seated controls on styles of explosive basaltic volcanism: a case study from New Zealand: Journal of Volcanology and Geothermal Research, v. 91, p. 97-120.

Humphreys, M.C.S., Blundy, J.D., and Sparks, R.S.J., 2006, Magma evolution and opensystem processes at Shivulech volcano: insights from phenocryst zoning: Journal of Petrology, v. 47, p. 2303-2334.

Ingham, E.M., 2015, Exploring geomagnetic field behaviour during polarity reversals and excursions: Unpublished PhD thesis, Australia National University, Canberra Australia, 179 pp.

Jackson, M.D., Cheadle, M.J., and Atherton, M.P., 2003, Quantitative modelling of granitic melt generation and segregation in the continental crust: Journal of Geophysical Research, v. 108, 2332.

Jarosewich, E., Nelen, J.A., and Norberg, J.A., 1980, Reference samples for electron microprobe analysis: Geostandards Newsletter v. 4, p. 43-47.

Jicha, B.R., and Singer, B.S., 2006, Volcanic history and magmatic evolution of Seguam Island, Aleutian Island arc, Alaska: Geological Society of America Bulletin, v. 118, p. 805-822.

Jicha, B.R., Coombs, M.L., Calvert, A.T., and Singer, B.S., 2012, Geology and ${ }^{40} \mathrm{Ar} /{ }^{39} \mathrm{Ar}$ geochronology of the medium- to high-K Tanaga volcanic cluster, western Aleutians: Geological Society of America Bulletin, v. 124, p. 842-856.

Johnston, D.M., Houghton, B.F., Neall, V.E., Ronan, K.R., and Paton, D., 2000, Impacts of the 1945 and 1995-1996 Ruapehu eruptions, New Zealand: an example of increasing societal vulnerability: Geological Society of America Bulletin, v. 112, p. 720-726.

Kawabata, H., and Shuto, K., 2005, Magma mixing recorded in intermediate rocks associated with high-Mh andesites from the Setouchi volcanic belt, Japan: implications for Archean TTG formation: Journal of Volcanology and Geothermal Research, v. 140, p. 241-271.

Kay, R.W., 1978, Aleutian magnesian andesites: melts from subducted Pacific ocean crust: Journal of Volcanology and Geothermal Research, v. 4, p. 117-132.

Kelemen, P. B., Hanghoj, K., and Green, A. R., 2003a, One view of the geochemistry of subduction-related magmatic arcs, with an emphasis on primitive andesites and the lower crust. In Rudnick, R.L. (Ed.) The Crust, in: Holland, H. D., and Turekian, K. K. (Eds.) Treatise on Geochemistry, Elsevier, Oxford, v. 3, p. 593-659.

Kelemen, P.B., Yogodzinski, G.M., and Scholl, D.W., 2003b, Along-strike variation in the Aleutian island arc: genesis of high-Mg\# andesite and implications for continental crust. In: Eiler, J. (Ed.) Inside the Subduction Factory, Geophysical Monograph, American Geophysical Union, v. 138, p. 223-276.

Kelley, S.E., Kaplan, M.R., Schaefer, J.M., Andersen, B.G., Barrell, D.J.A., Putnam, A.E., Denton, G.H., Schwartz, R., Finkel, R.C., and Doughty, A.M, 2014, Highprecision ${ }^{10} \mathrm{Be}$ chronology of moraines in the Southern Alps indicates synchronous cooling in Antarctica and New Zealand 42,000 years ago: Earth and Science Planetary Letters, v. 405, p. 194-206.

Kelman, M.C., Russell, J.K., and Hickson, C.J., 2002, Effusive intermediate glaciovolcanism in the Garibaldi Volcanic Belt, southwestern British Columbia, Canada: In Snellie, J. L., and Chapman, M. G., (Eds.), Volcano-ice interaction on Earth and Mars, Geological Society, London, Special Publications, v. 202, p. 195211.

Kent, A.J.R., 2013, Preferential eruption of andesitic magmas: implications for volcanic magma fluxes at convergent margins: In Gomez-Tuena, A., Straub, S. M., Zellmer 
G.F. (Eds.), Orogenic Andesites and Crustal Growth, Geological Society, London, Special, Publications, v. 385, p. 257-280.

Kent, A.J.R., Darr, C., Koleszar, A.M., Salisbury, M.J., and Cooper, K.M., 2010, Preferential eruption of andesitic magma through recharge filtering: Nature Geoscience, v. 3, p. 631-636.

Kilgour, G., Blundy, J., Cashman, K., and Mader, H.M., 2013, Small volume andesite magmas and melt-mush interactions at Ruapehu, New Zealand: evidence from melt inclusions: Contributions to Mineralogy and Petrology, v. 166, p. 371-392.

Klügel, A., Hansteen, T.H., and Galipp, K., 2005, Magma storage and underplating beneath Cumbre Vieja volcano, La Palma (Canary Islands): Earth and Science Planetary Letters, v. 236, p. 211-226.

Koleszar, A.M., Kent, A.J.R., Wallace, P.J., and Scott, W.E., 2012, Controls on long-term low explosivity at arc volcanoes: insights from Mount Hood, Oregon: Journal of Volcanology and Geothermal Research, v. 220, p. 1-14.

Lachowycz, S.M., Pyle, D.M., Gilbert, J.S., Mather, T.A., Mee, K., Naranjo, J.A., and Hobbs, L.K., 2015, Glaciovolcanism at Volcán Sollipulli, southern Chile: lithofacies analysis and interpretation: Journal of Volcanology and Geothermal Research, v. 303, p. 59-78.

Lecointre, J.A., Neall, V.E., and Palmer, A.S., 1998, Quaternary lahar stratigraphy of the western Ruapehu ring plain, New Zealand: New Zealand Journal of Geology and Geophysics, v. 41, p. 225-245.

Lee, C.-T.A., and Bachmann, O., 2014, How important is the role of crystal fractionation in making intermediate magmas? Insights from $\mathrm{Zr}$ and $\mathrm{P}$ systematics: Earth and Planetary Science Letters, v. 393, p. 266-274.

Lescinsky, D.T., and Fink, J.H., 2000, Lava and ice interaction at stratovolcanoes: Use of characteristic features to determine past glacial extents and future volcanic hazards: Journal of Geophysical Research, v. 105, p. 23711-23726.

Lescinsky, D.T. and Sisson, T.W., 1998: Ridge-forming, ice-bounded lava flows at Mount Rainier, Washington, Geology, v. 26, p. 351-354.

Lisiecki, L. E., and Raymo, M. E., 2005, A Pliocene-Pleistocene stack of 57 globally distributed benthic $\mathrm{d}^{18} \mathrm{O}$ records: Paleoceanography, v. 20, PA1003.

Lodge, R.W.D., and Lescinsky, D.T., 2009, Fracture patterns at lava-ice contacts on Kokostick Butte, OR, and Mazama Ridge, WA: Implications for flow emplacement and cooling histories: Journal of Volcanology and Geothermal Research, v. 185, p. 298-310.

Loewen, M.W., 2013, Volatile mobility of trace metals in volcanic systems: Unpublished $\mathrm{PhD}$ thesis, Oregon State University, U.S.A., 217 pp.

Lore, J., Gao, H., and Aydin, A., 2000, Viscoelastic thermal stress in cooling basalt flows: Journal of Geophysical Research, v. 105, p. 23695-23709.

Major, J.J., and Newhall, C.G., 1989, Snow and ice perturbations during historical volcanic eruptions and the formation of lahars and floods: Bulletin of Volcanology, v. 52, p. 1-27.

Marsh, B.D., 1981, On the crystallinity, probability of occurrence, and rheology of lava and magma: Contributions to Mineralogy and Petrology, v. 78, p. 85-98.

Martel, C., Pichavant, M., Bourdier, J.-L., Traineau, H., Holtz, F., and Scaillet, B., 1998, Magma storage conditions and control of eruption regime in silicic volcanoes:

experimental evidence from Mt. Pelée: Earth and Planetary Science Letters, v. 156, p. 89-99. 
McArthur, J.L., and Shepherd, M.J., 1990, Late Quaternary glaciation of Mt. Ruapehu, North Island, New Zealand: Journal of the Royal Society of New Zealand, v. 20, p. 287-296.

McClelland, E., and Erwin, P.S., 2003, Was a dacite dome implicated in the 9500 B.P. collapse of Mt Ruapehu? A paleomagnetic investigation: Bulletin of Volcanology, v. 65 , p. 294-305.

McCulloch, M.T., and Gamble, J.A., 1991, Geochemical and geodynamical constraints on subduction zone magmatism: Earth and Planetary Science Letters, v. 102, p. 358-374.

McGarvie, D.W., 2009, Rhyolitic volcano-ice interactions in Iceland: Journal of Volcanology and Geothermal Research, v. 185, p. 367-389.

Mee, K., Gilbert, J.S., McGarvie, D.W., Naranjo, J.A., and Pringle, M.S., 2009, Paleoenvironment reconstruction, volcanic evolution and geochronology of the Cerro Blanco subcomplex, Nevados de Chillán volcanic complex, central Chile: Bulletin of Volcanology, v. 71, p. 933-952.

Millet, M.-A., Tutt, C., Handler, M.R., and Baker, J.A., 2014, Processes and timescales of dacite magma assembly and eruption at Tauhara volcano, Taupo Volcanic Zone, New Zealand: Geochemistry, Geophysics, Geosystems, v. 15, p. 213-237.

Nairn, I.A., Kobayashi, T., and Nakagawa, M., 1998, The $\sim 10$ ka multiple vent pyroclastic eruption sequence at Tongariro Volcanic Centre, Taupo Volcanic Centre, Taupo Volcanic Zone, New Zealand: Part 1. Eruptive processes during regional extension: Journal of Volcanology and Geothermal Research, v. 86, p. 1944.

Nakagawa, M., Wada, K., and Wood, C.P., 2002, Mixed magmas, mush chambers and eruption triggers: evidence from zoned clinopyroxene phenocrysts in andesitic scoria from the 1995 eruptions of Ruapehu volcano, New Zealand: Journal of Petrology, v. 43, p. 2279-2303.

Newnham, R.M., Eden, D.N., Lowe, D.J., and Hendy, C.H., 2003, Rerewhakaaitu Tephra, a land-sea marker for the Last Termination in New Zealand, with implications for global climate change: Quaternary Science Reviews, v. 22, p. 289308.

Ownby, S., Granados, H.D., Lange, R.A., and Hall, C.M., 2007, Volcán Tancítaro, Michoacán, 40Ar/39Ar constraints on its history of sector collapse: Jounral of Volcanology and Geothermal Research, v. 161, p. 1-14.

Palmer, B.A., and Neall. V.E., 1989, The Murimotu Formation - 9500 year old deposits of a debris avalanche and associated lahars, Mount Ruapehu, North Island, New Zealand: New Zealand Journal of Geology and Geophysics, v. 32, p. 477-486.

Pardo, N., Cronin, S.J., Palmer, A.S., and Németh, K., 2012, Reconstructing the largest explosive eruptions of Mt. Ruapehu, New Zealand: lithostratigraphic tools to understand subplinian-plinian eruptions at andesitic volcanoes: Bulletin of Volcanology, v. 74, p. 617-640.

Pardo, N., Cronin, S.J., Wright, H.M.N., Schipper, C.I., Smith, I.E.M., and Stewart, B., 2014, Pyroclast textural variation as an indicator of eruption column steadiness in andesitic Plinian eruptions at Mt. Ruapehu: Bulletin of Volcanology, v. 76, article 822.

Pichavant, M., Martel, C., Bourdier, J.-L., and Scaillet, B., 2002, Physical conditions, structure, and dynamics of a zoned magma chamber: Mount Pelée (Martinique, Lesser Antilles Arc): Journal of Geophysical Research Letters, v. 107, 2093. 
Pinel, V., and Jaupart, C., 2000, The effect of edifice load on magma ascent beneath a volcano: Philosophical Transactions of the Royal Society of London, v. 358, p. $1515-1532$.

Pinel, V., and Jaupart, C., 2005, Some consequences of volcanic edifice destruction for eruption conditions: Journal of Volcanology and Geothermal Research, v. 145, p. 68-80.

Plank, T., and Langmuir, C.H., 1998, The chemical composition of subducting sediment and its consequences for the crust and mantle: Chemical Geology, v. 145, p. 325394.

Price, R.C., Gamble, J.A., Smith, I.E.M., Stewart, R.B., Eggins, S. and Wright, I.C., 2005, An integrated model for the temporal evolution of andesites and rhyolites and crustal development in New Zealand's North Island: Journal of Volcanology and Geothermal Research, v. 140, p. 1-24.

Price, R.C., Gamble, J.A., Smith, I.E.M., Maas, R., Waight, T., Stewart, R.B., and Woodhead, J., 2012, The anatomy of an andesite volcano: a time-stratigraphic study of andesite petrogenesis and crustal evolution at Ruapehu Volcano, New Zealand: Journal of Petrology, v. 53, p. 2139-2189.

Price, R.C., Mortimer, N., Smith, I.E.M., and Maas, R., 2015, Whole-rock geochemical reference data for Torlesse and Waipapa terranes, North Island, New Zealand: New Zealand Journal of Geology and Geophysics, v. 58, p. 213-228.

Putnam, A.E., Schaefer, J.M., Denton, G.H., Barrell, D.J.A., Andersen, B.G., Koffman, T.N.B., Rowan, A.V., Finkel, R.C., Rood, D.H., Schwartz, R., Vandergoes, M.J., Plummer M.A., Brocklehurst S.H., Kelley, S.E., and Ladig, K.L., 2013a, Warming and glacier recession in the Rakaia valley, Southern Alps of New Zealand, during Heinrich Stadial 1: Earth and Planetary Science Letters, v. 382, p. 98-110.

Putnam, A.E., Schaefer, J.M., Denton, G.H., Barrell, D.J.A., Birkel, S.D., Andersen, B.G., Kaplan, M. R., Finkel, R. C., Schwartz, R., and Doughty, A. M., 2013b, The Last Glacial Maximum at $44^{\circ} \mathrm{S}$ documented by a ${ }^{10} \mathrm{Be}$ moraine chronology at Lake Ohau, Southern Alps of New Zealand: Quaternary Science Reviews, v. 62, p. 114141.

Ramsey, M.H., Potts, P.J., Webb, P.C., Watkins, P., Watson, J.S. and Coles, B.J., 1995, An objective assessment of analytical method precision: comparison of ICP-AES and XRF for the analysis of silicate rocks: Chemical Geology, v. 124, p. 1-19.

Reubi, O., and Blundy, J., 2008, Assimilation of plutonic roots, formation of high-K 'exotic' melt inclusions and genesis of andesitic magmas at Volcàn de Colima, Mexico: Journal of Petrology, v. 49, p. 2221-2243.

Reubi, O., and Blundy, J., 2009, A dearth of intermediate melts at subduction zone volcanoes and the petrogenesis of arc andesites: Nature, v. 461, p. 1269-1274.

Reyners, M., Eberhart-Phillips, D., Stewart, G., and Nishimura, Y., 2006, Imaging subduction from the trench to $300 \mathrm{~km}$ depth beneath the central North Island, New Zealand, with $V_{p}$ and $V_{p} / V_{s}$ : Geophysical Journal International, v. 165, p. 565-583.

Rivera, A., Bown, F., Mella, R., Wendt, J., Cassassa, G., Acuna, C., Rignot, E., Clavero, J., and Brock, B, 2006, Ice volumetric changes on active volcanoes in southern Chile: Annals of Glaciology, v. 43, p. 111-122.

Rother, H., Shulmeister, J., Fink, D., Alexander, D., and Bell, D., 2015, Surface exposure chronology of the Waimakariri glacial sequence in the Southern Alps of New Zealand: implications for MIS-2 ice extent and LGM glacial mass balance: Earth and Planetary Science Letters, v. 429, p. 69-81. 
Rowland, J.R., Wilson, C.J.N., and Gravely, D.M., 2010, Spatial and temporal variations in magma-assisted rifting, Taupo Volcanic Zone, New Zealand: Journal of Volcanology and Geothermal Research, v. 190, p. 89-108.

Rudnick, R.L., and Gao, S., 2003, Composition of the continental crust: In Rudnick, R.L. (Ed.) The Crust, in: Holland, H. D., and Turekian, K. K. (Eds.) Treatise on Geochemistry, Elsevier, Oxford, v. 3, p. 1-64.

Ruprecht, P., Bergantz, G.W., Cooper, K.M., and Hildreth, W., 2012, The crustal magma storage system of Volcán Quizapa, Chile and the effects of magma mixing on magma diversity: Journal of Petrology, v. 53, p. 801-840.

Russell, J.K., Edwards, B.R., Porritt, L., and Ryane, C., 2014, Tuyas: a descriptive genetic classification: Quaternary Science Reviews, v. 87, p. 70-81.

Sæmundsson, K., 1970, Interglacial lava flows in the lowlands of southern Iceland and the problem of two-tiered columnar jointing: Jökull, v. 20, p. 62-77

Salmon, M L., Stern, T.A., and Savage, M.K., 2011, A major step in the continental Moho and its geodynamic consequences: the Taranaki-Ruapehu line, New Zealand: Geophysical Journal International, v. 186, p. 32-44.

Schipper, I.C., Castro, J.M., Tuffen, H., Wadsworth, F.B., Chappell, D., Pantoja, A. E., Simpson, M.P., and Le Ru, E.C., 2015, Cristobalite in the 2011-2012 Cordón Caulle eruption (Chile): Bulletin of Volcanology, v. 77, article 34.

Schmidt, M.E., and Grunder A.L., 2009, The evolution of North Sister: A volcano shaped by extension and ice in the central Oregon Cascade Arc: Geological Society of America Bulletin, v. 121, p. 643-662.

Shane, P., Doyle, L.R., and Narin, I.A., 2008, Heterogeneous andesite-dacite ejecta in 2616.6 ka pyroclastic deposits of Tongariro volcano, New Zealand: the product of multiple magma-mixing events: Bulletin of Volcanology, v. 70, p. 517-536.

Shimoda, G., Tatsumi, Y., Hohda, S., Ishizaka, K., and Jahn, B.M., 1998, Setouchi high$\mathrm{Mg}$ andesites revisited: geochemical evidence for melting of subducting sediments: Earth and Planetary Science Letters, v. 160, p. 479-492.

Singer, B.S., 2014, A Quaternary geomagnetic instability time scale: Quaternary Geochronology, v. 21, p. 29-52.

Singer, B.S., Thompson, R.A., Dungan, M.A., Feeley, T.C., Nelson, S.T., Pickens, J.C., Brown, L. L., and Wulff, A. W., 1997, Volcanism and erosion during the past 930 k.y. at the Tatara-San Pedro complex, Chilean Andes: Geological Society of America Bulletin, v. 109, p. 127-142.

Singer, B.S., Jicha, B.R., Harper, M.A., Naranjo, J.A., Lara, L.E., and Moreano-Roa, H., 2008, Eruptive history, geochronology, and magmatic evolution of the PuyehueCordón-Caulle volcanic complex, Chile: Geological Society of America Bulletin, v. 120, p. 599-618.

Sisson, T.W., Ratejeski, K., Hankins, W.B., and Glazner, A.F., 2005, Voluminous granitic magmas from common basaltic sources: Contributions to Mineralogy and Petrology, v. 148, p. 635-661.

Sisson, T.W., Salters, V.J.M., and Larson, P.B., 2013, Petrogenesis of Mount Rainier andesite: magma flux and geologic controls on the constrasting differentiation styles at stratovolcanoes of the southern Washington Cascades: Geological Society of America Bulletin, v. 126, p. 122-144.

Sissons, B.A., and Dibble, R.R., 1981, A seismic refraction experiment southeast of Ruapehu volcano: New Zealand Journal of Geology and Geophysics, v. 24, p. 3138. 
Skilling, I.P., 2009, Subglacial to emergent basaltic volcanism at Hlöðufell, south-west Iceland: A history of ice-confinement: Journal of Volcanology and Geothermal Research, v. 185 , p. 276-289.

Smellie, J.L., 2008, Basaltic subglacial sheet-like sequences: evidence for two types with different implications for the inferred thickness of associated ice: Earth-Science Reviews, v. 88, p. 60-88.

Smellie, J.L., Rocchi, S., Gemelli, M., Di Vincenzo, G., and Armienti, O., 2011, A thin predominantly cold-based Late Miocene East Antarctic ice sheet inferred from glaciovolcanic sequences in northern Victoria Land, Antarctica: Palaeogeography, Palaeoclimatology, Palaeoecology, v. 307, p. 129-149.

Smith, G.A., Grubensky, M.J., and Geissman, J.W., 1999, Nature and origin of coneforming volcanic breccias in the Te Herenga Formation, Ruapehu, New Zealand: Bulletin of Volcanology, v. 61, p. 64-82.

Sobolev, A.V., and Chaussidon, M., 1996, $\mathrm{H}_{2} \mathrm{O}$ concentrations in primary melts from supra-subduction zones and mid-ocean ridges: implications for $\mathrm{H}_{2} \mathrm{O}$ storage and recycling in the mantle: Earth and Planetary Science Letters, v. 137, p. 45-55.

Spörli, K.B., and Rowland, J.V., 2006, 'Column on column' structures as indicators of lava/ice interaction, Ruapehu andesite volcano, New Zealand: Journal of Volcanology and Geothermal Research, v. 157, p. 294-310.

Stanley, W.D., Mooney, W.D., and Fuis, G.S., 1990, Deep crustal structure of the Cascades Range and surrounding regions from seismic refraction and magnetotelluric data: Journal of Geophysical Research, v. 95, p. 19,419-19,438.

Stevenson, J.A., McGarvie, D.W., Smellie, J.L., Gilbert, J.S., 2006, Subglacial and icecontact volcanism at the Öræfajökull stratovolcano, Iceland: Bulletin of Volcanology, v. 68, p. 737-752.

Stevenson, J.A., Smellie, J.L., McGarvie, D.W., Gilbert, J.S., and Cameron, B.I., 2009, Subglacial intermediate volcanism at Kerlingarfjoll, Iceland: Magma-water interactions beneath thick ice: Journal of Volcanology and Geothermal Research, v. 185 , p. 337-351.

Stipp, J.J., 1968, The geochronology and petrogenesis of the Cenozoic volcanics of the North Island, New Zealand: Unpublished PhD thesis, 488p. Australian National University, Canberra, Australia.

Streck, M.J., Leeman, W.P., and Chesley, J., 2007, High-magnesian andesite from Mount Shasta: a product of magma mixing and contamination, not a primitive mantle melt: Geology, v. 35, p. 351-354.

Sun, S.-s., and McDonough, W.F., 1989, Chemical and isotopic systematics of oceanic basalts: implications for mantle compositions and processes: In: Saunders, A.D., and Norry, M.J. (Eds.) Magmatism in the Ocean Basins, Geological Society, London, p. 313-345.

Syracuse, E.M., and Abers, G.A., 2006, Global compilation of variations in slab depth beneath arc volcanoes and implications: Geochemistry, Geophysics, Geosystems, v. 7, Q05017.

Szramek, L., Gardner, J.E., and Larsen, J., 2006, Degassing and microlite crystallization of basaltic andesite magma erupting at Arenal volcano, Costa Rica: Journal of Volcanology and Geothermal Research, v. 157, p. 182-201.

Tanaka, H., Kawamura, K., Nagao, K., and Houghton, B.F., 1997, K-Ar ages and paleosecular variation of direction and intensity from Quaternary lava sequences in the Ruapehu volcano, New Zealand: Journal of Geomagnetism and Geoelectricity, v. 49 , p. 587-599. 
Tatsumi, Y., 1986, Formation of the volcanic front in subduction zones: Geophysical Research Letters, v. 13, p. 717-720.

Tatsumi, Y., 2001, Geochemical modelling of partial melting of subducting sediments and subsequent melt-mantle interaction: generationof high-Mg andesites in the Setouchi volcanic belt, southwest Japan: Geology, v. 29, p. 323-326.

Taylor, S.R., and McLennan, S.M., 1995, The geochemical evolution of the continental crust: Reviews of Geophysics, v. 33, p. 241-265.

Thouret, J.-C., 1999, Volcanic geomorphology-an overview: Earth-Science Reviews, v. 47, p. 95-131.

Thouret, J.-C., Finizola, A., Fornari, M., Legeley-Padovani, A., Suni, J., and Frechen, M. 2001, Geology of El Misti volcano near the city of Arequipa, Peru: Geological Society of America Bulletin, v. 113, p. 1593-1610.

Tilley, C.E., 1950, Some aspects of magmatic evolution: Quarterly Journal of the Geological Society, London, v. 106, p. 37-61.

Topping, W.W., 1973, Tephrostratigraphy and chronology of late Quaternary eruptives from the Tongariro Volcanic Centre, New Zealand: New Zealand Journal of Geology and Geophysics, v. 16, p. 397-423.

Tost, M., and Cronin, S.J., 2015, Linking distal volcaniclastic sedimentation and stratigraphy with the development of Ruapehu volcano, New Zealand: Bulletin of Volcanology, v. 77, article 94.

Tost, M., Cronin, S.J., and Procter, J.N., 2014, Transport and emplacement mechanisms of channelized long-runout debris avalanches, Ruapehu volcano, New Zealand, Bulletin of Volcanology, v. 76, article 881.

Tost, M., Cronin, S.J., Procter, J.N., Smith, I.E.M., Neall, V.E., and Price, R.C., 2015, Impacts of catastrophic volcanic collapse on the erosion and morphology of a distal fluvial landscape: Hautapu River, Mount Rupaehu, New Zealand: Geological Society of America Bulletin, v. 127, p. 266-280.

Townsend, D.B., Leonard, G.S., Conway, C.E., Eaves, S.R., and Wilson, C.J.N., 2016, Geology of the Tongariro National Park area: Institute of Geological and Nuclear Sciences 1:60,000 map series, in preparation.

Tucker, D.S., and Scott, K.M., 2009, Structures and facies associated with the flow of subaerial basaltic lava into a deep freshwater lake: The Sulphur Creek lava flow, North Cascades, Washington: Journal of Volcanology and Geothermal Research, v. 185 , p. 311-322.

Tuffen, H., 2010, How will melting of ice affect volcanic hazards in the twenty-first century?: Philosophical Transactions of the Royal Society, London, v. A368, p. 2535-2558.

Tuffen, H., Gilbert, J. and McGarvie, D.W., 2001, Products of an effusive subglacial eruption: Bláhnúkur, Torfajökull, Iceland: Bulletin of Volcanology, v. 63, p. 179190.

Turner, S.J., and Langmuir, C.J., 2015, The global chemical systematics of arc front volcanoes: evaluating the role of crustal processes: Earth and Planetary Science Letters, v. 422, p. 182-193.

Villamor, P., and Berryman, K.R., 2006a, Late Quaternary geometry and kinematics of faults at the southern termination of the Taupo Volcanic Zone, New Zealand: New Zealand Journal of Geology and Geophysics, v. 49, p. 1-22.

Villamor, P., and Berryman, K.R., 2006b, Evolution of the southern termination of the Taupo Rift, New Zealand: New Zealand Journal of Geology and Geophysics, v. 49, p. 23-37. 
Von Huene, R., and Scholl, D.W., 1991, Observations at convergent margins concerning sediment subduction. Subduction erosion, and the growth of continental crust: Reviews of Geophysics, v. 29, p. 279-316.

Waight, T.E., Price, R.C., Smith, I.E.M., Stewart, R.B., and Gamble, J.A., 1999, Stratigraphy and geochemistry of the Turoa region, with implications for andesite petrogenesis at Mt. Ruapehu, Taupo Volcanic Zone, New Zealand: New Zealand Journal of Geology and Geophysics, v. 42, p. 513-532.

Wallace, P.J., 2005, Volatiles in subduction zones: concentrations and fluxes based on melt inclusion and volcanic gas data: Journal of Volcanology and Geothermal Research, v. 140, p. 217-240.

Watanabe, K., and Katsui, Y., 1976, Pseudo-pillow lavas in the Aso caldera, Kyushu, Japan. The Journal of the Japanese Association of Mineralogists, Petrologists and Economic Geologists v. 71, p. 44-49.

Williams, P.W., McGlone, M., Neil, H., and Zhao, J.-X., 2015, A review of New Zealand paleoclimate from the Last Interglacial to the Last Global Maximum: Quaternary Science Reviews, v. 110, p. 92-106.

Williams, R.S., 1995, Icelandic-English glossary of selected geoscience terms: U.S. Geological Survey, Open File Report 95-807, 31 p.

Wilson, C.J.N., Houghton, B.F., McWilliams, M.O., Lanphere, M.A., Weaver, S.D., and Briggs, R.M., 1995, Volcanic and structural evolution of Taupo Volcanic Zone, New Zealand: a review: Journal of Volcanology and Geothermal Research, v. 68, p. $1-28$.

Wilson, L., and Head, J.W., 2007, Heat transfer in volcano-ice interactions on Earth: Annals of Glaciology, v. 45, p. 83-86.

Wood, B.J., and Turner, S.P., 2009, Origin of primitive high-Mg andesites: Constraints from natural examples and experiments: Earth and Planetary Science Letters, v. 283, p. 59-66.

Yogodzinski, G.M., Lees, J.M., Churikova, T.G., Dorendorf, F., Wöerner, G., and Volynets, O.N., 2001, Geochemical evidence for the melting of subducting oceanic lithosphere at plate edges: Nature, v. 409, p. 500-504.

York, D., 1968, Least squares fitting of a straight line with correlated errors: Earth and Planetary Science Letters, v. 5, p. 320-324. 
APPENDICES 


\section{Appendix 1. Location of ice-marginal lava flows and fractures}

Locations of fracture types identified and measured at outcrops of ice-marginal lava flows during fieldwork between 2012 and 2014 are displayed in Figure A1.1 and Table A1.1. Initial sites of interest, particularly steep ridges and bluffs, were identified from digital terrain models (DTMs) and aerial photographs, and subsequently reconnoitred. Locations were logged using a Garmin GPS unit in the field.

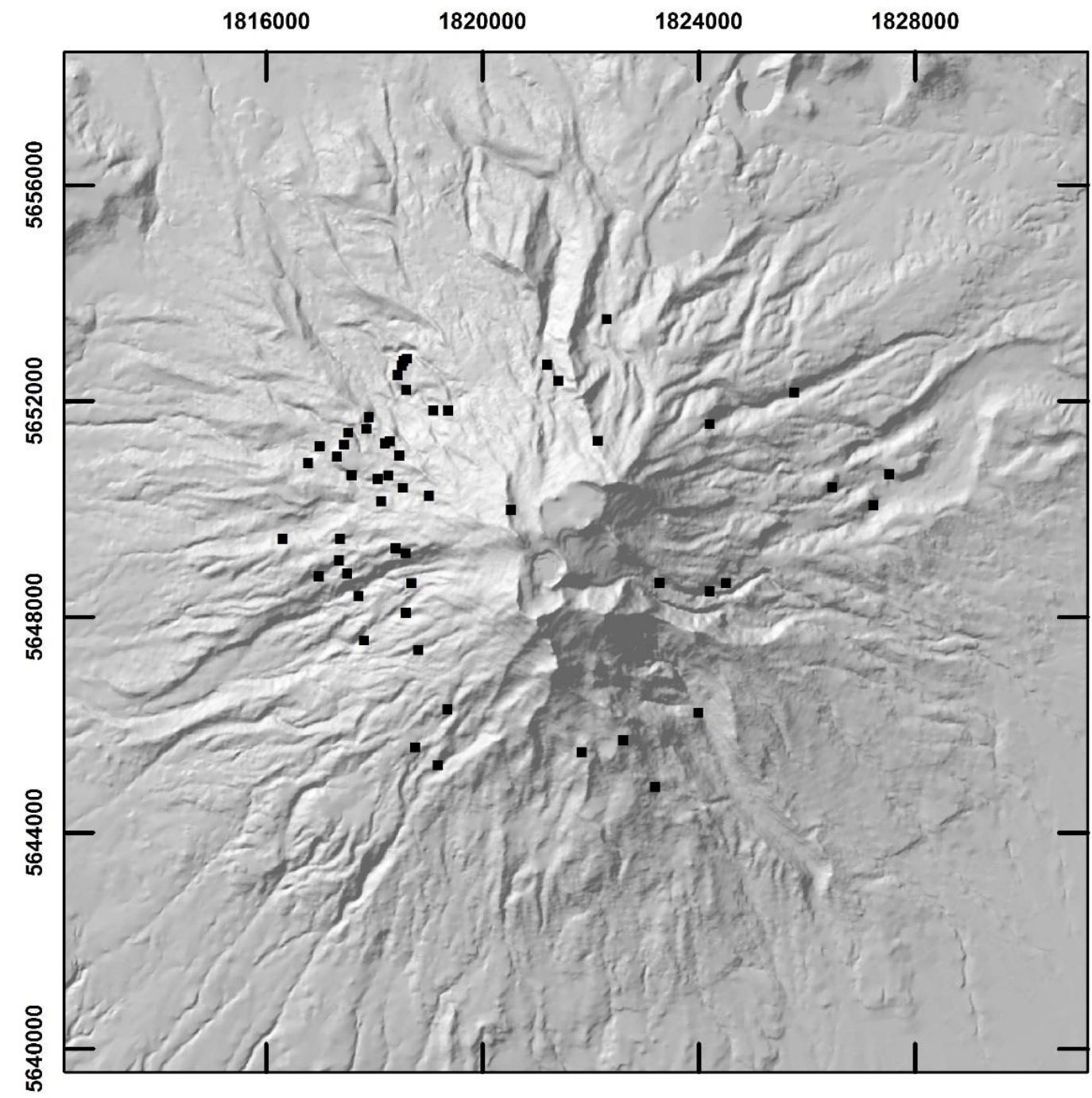

Figure A1.1. Location map of lava outcrops where fractures were identified and measured in the field (black squares). Tick marks are metres in the NZTM projection. Locations are provided in Table A1.1. Measurement data available in Appendix 2. 
Table A1.1. Locations of lava outcrops of where ice-contact fractures were measured.

\begin{tabular}{|c|c|c|c|c|c|c|c|}
\hline Flow type & $\mathbf{E}$ & $\mathbf{N}$ & $\mathrm{CO}$ & PP & CR & PL & KB \\
\hline Ice-dammed & $\begin{array}{l}1818539 \\
1818602 \\
1818588 \\
1818510 \\
1818431 \\
1817581 \\
1817515 \\
1817444 \\
1817307 \\
1816776 \\
1816992 \\
1824201\end{array}$ & $\begin{array}{l}5652739 \\
5652785 \\
5652210 \\
5652662 \\
5652479 \\
5650627 \\
5651414 \\
5651189 \\
5650972 \\
5650850 \\
5651161 \\
5651576\end{array}$ & $\mathrm{x}$ & $\mathrm{x}$ & $\begin{array}{l}\mathrm{X} \\
\mathrm{X}\end{array}$ & $\begin{array}{l}\mathrm{x} \\
\mathrm{x} \\
\mathrm{x} \\
\mathrm{x} \\
\mathrm{x} \\
\mathrm{x} \\
\mathrm{x}\end{array}$ & \\
\hline Ice-bounded & $\begin{array}{l}1820524 \\
1822604 \\
1821834 \\
1818196 \\
1818287 \\
1818465 \\
1817898 \\
1817855 \\
1819363 \\
1818263 \\
1818066 \\
1818528 \\
1817362 \\
1818127 \\
1819009 \\
1816307 \\
1816973 \\
1817346 \\
1818580 \\
1818580 \\
1818392 \\
1817495 \\
1818585 \\
1818815 \\
1817710 \\
1817808 \\
1819177 \\
1819351 \\
1823279 \\
1824505 \\
1824201 \\
1826472 \\
1827232 \\
1827524 \\
1825768\end{array}$ & $\begin{array}{l}5649986 \\
5645717 \\
5645497 \\
5651218 \\
5651253 \\
5650989 \\
5651701 \\
5651482 \\
5651820 \\
5650621 \\
5650558 \\
5650394 \\
5649446 \\
5650145 \\
5650243 \\
5649444 \\
5648753 \\
5649043 \\
5649177 \\
5649177 \\
5649274 \\
5648804 \\
5648075 \\
5647389 \\
5648384 \\
5647564 \\
5645252 \\
5646290 \\
5648634 \\
5648629 \\
5648476 \\
5650407 \\
5650071 \\
5650644 \\
5652155 \\
\end{array}$ & $\begin{array}{l}\mathrm{x} \\
\mathrm{x} \\
\mathrm{x} \\
\mathrm{x} \\
\\
\mathrm{x} \\
\mathrm{x} \\
\mathrm{x}\end{array}$ & $\begin{array}{l}\mathrm{x} \\
\mathrm{x} \\
\mathrm{x}\end{array}$ & $\mathrm{x}$ & $\begin{array}{l}\mathrm{x} \\
\mathrm{x} \\
\mathrm{x} \\
\mathrm{x} \\
\mathrm{x} \\
\mathrm{x}\end{array}$ & $\begin{array}{l}\mathrm{X} \\
\mathrm{x}\end{array}$ \\
\hline Sub-glacial & $\begin{array}{l}1823995 \\
1818756 \\
1818688 \\
\end{array}$ & $\begin{array}{l}5646228 \\
5645587 \\
5648627 \\
\end{array}$ & $\mathrm{x}$ & $\mathrm{x}$ & & & $\begin{array}{l}\mathrm{x} \\
\mathrm{x} \\
\end{array}$ \\
\hline Post-glacial & $\begin{array}{l}1823195 \\
1822135 \\
1822302 \\
1819093 \\
1821403 \\
1821196\end{array}$ & $\begin{array}{l}5644854 \\
5651262 \\
5653514 \\
5651828 \\
5652371 \\
5652670\end{array}$ & $\mathrm{x}$ & $\begin{array}{l}\mathrm{x} \\
\mathrm{x} \\
\mathrm{x}\end{array}$ & & $\begin{array}{l}\mathrm{x} \\
\mathrm{x}\end{array}$ & \\
\hline
\end{tabular}

Easting (E) and Northing (N) values are given in metres for the NZTM projection. Abbreviated fracture types are: CO (column-forming joints); PP (pseudopillow fractures); CR (crease structures); PL (platy joints); KB (kubbaberg joints). 


\section{Appendix 2. Fracture measurements for ice-marginal lava flows}

This appendix provides measurement data for fracture types on ice-marginal lava flows at Ruapehu. Fracture types and attributes are shown in Figure A2.1. (repeated from Chapter 2) as a reference for measurement data in Table A2.1.

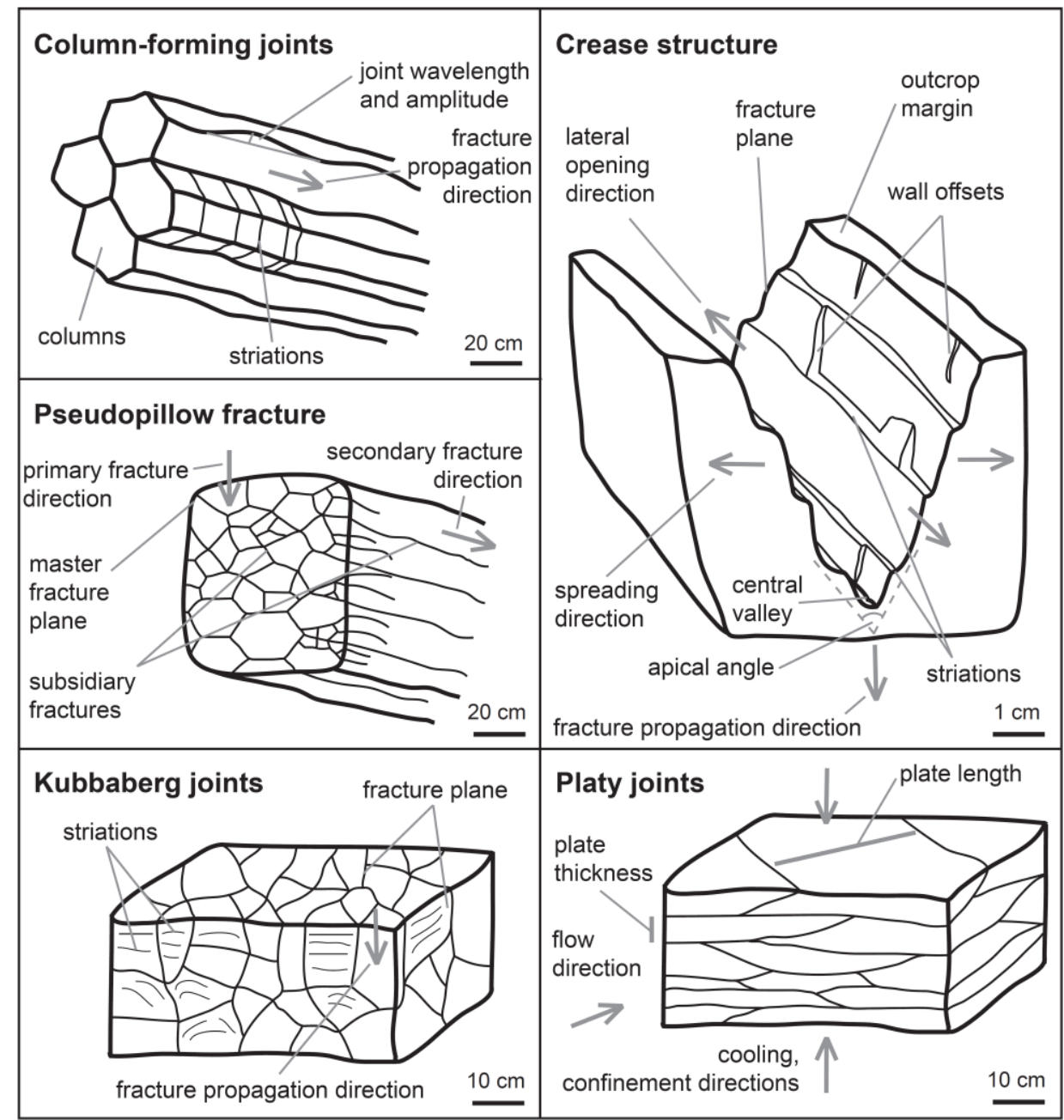

Figure A2.1. Characteristics of fracture types formed by interaction between lava flows and ice at Ruapehu. 


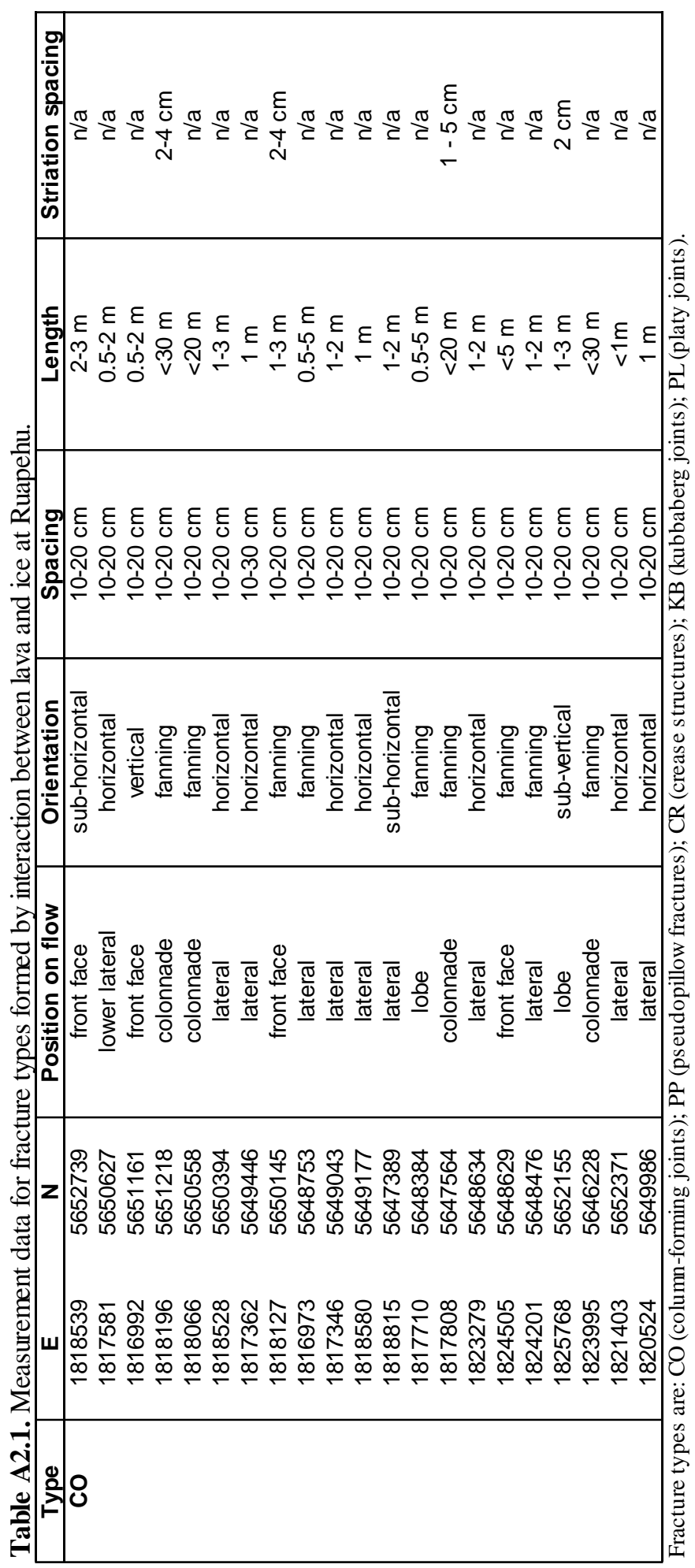




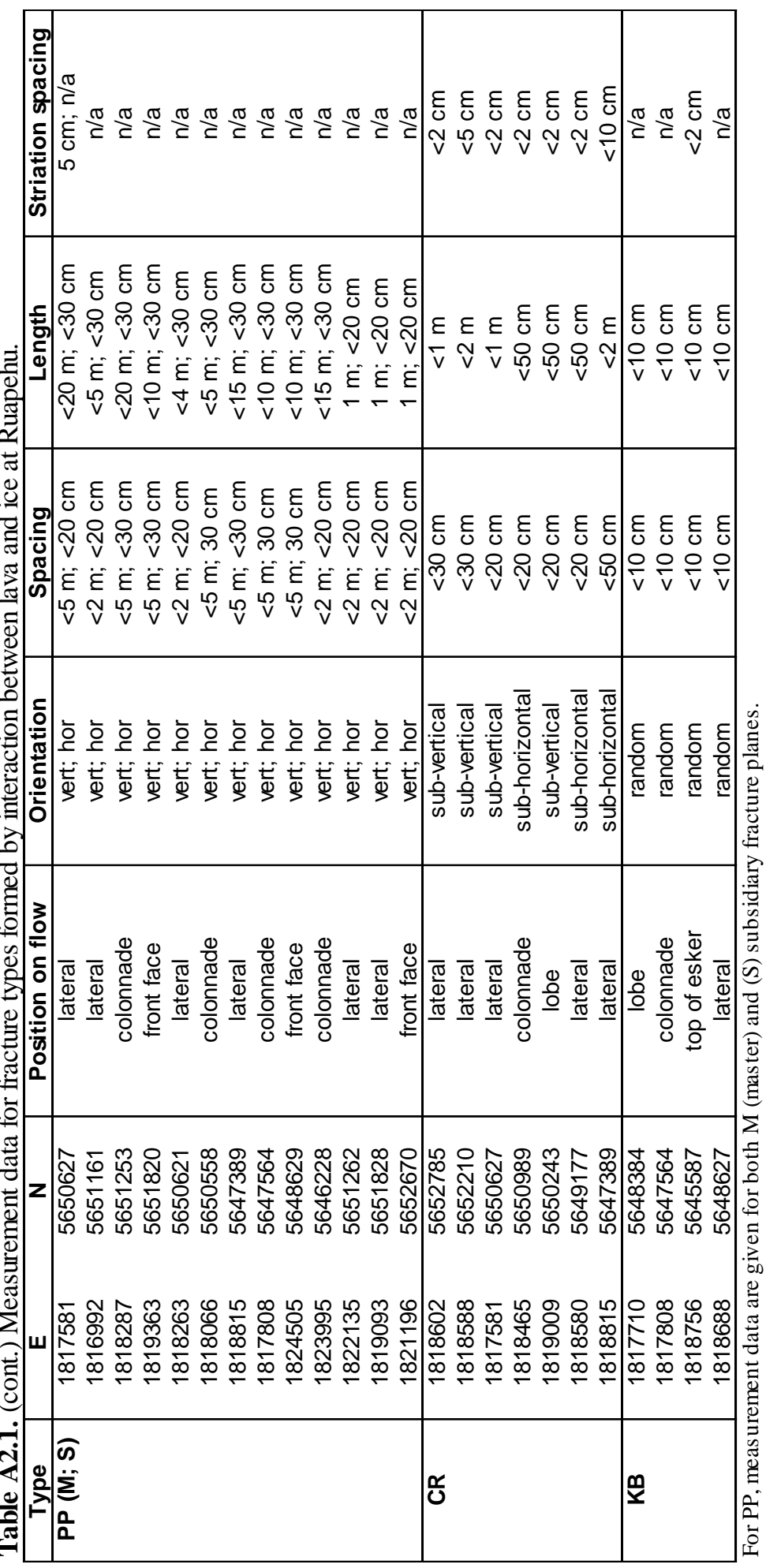




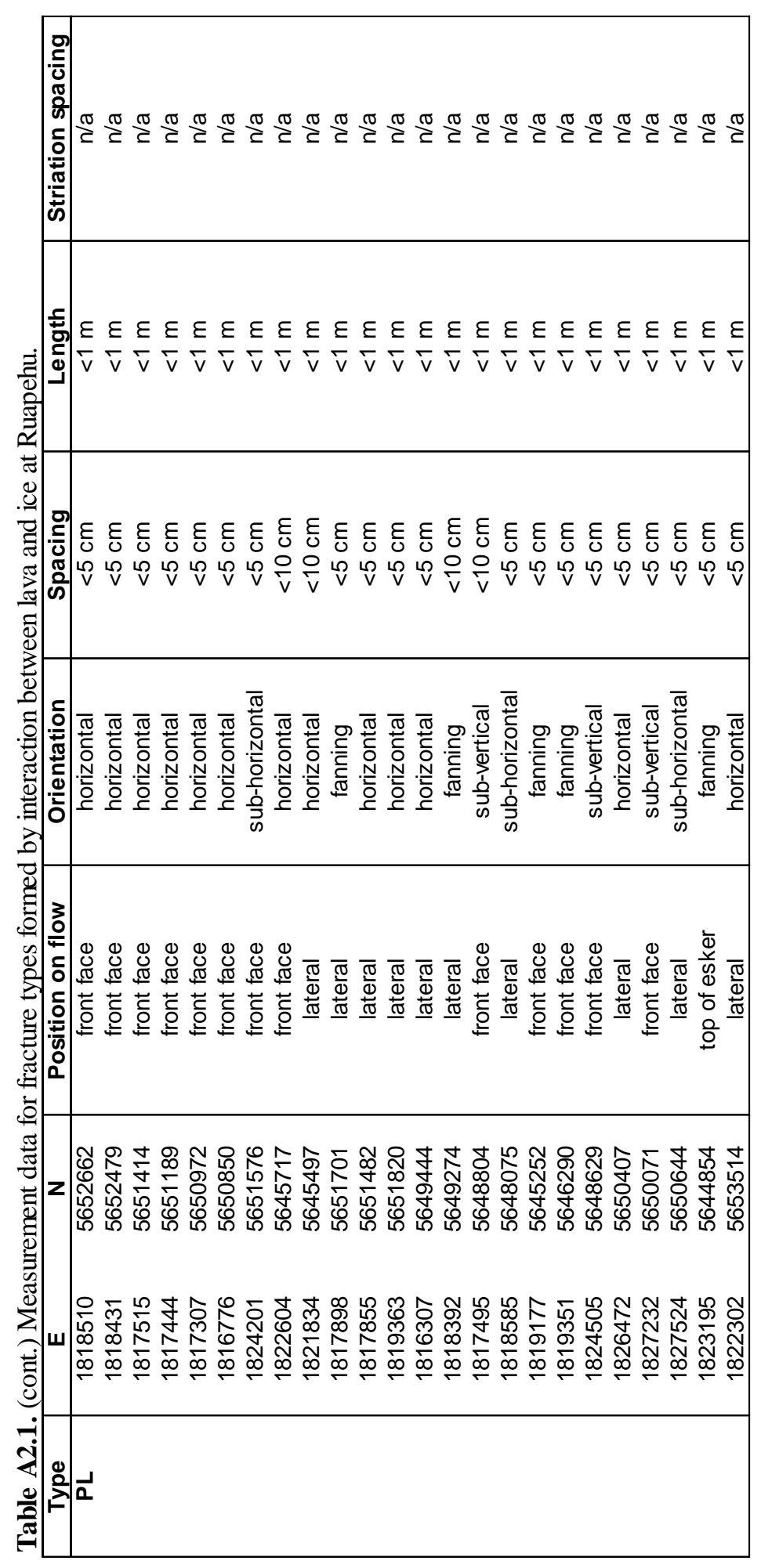




\section{Appendix 3. Sample list}

A total of 413 lava samples were collected during fieldwork from 2012 to 2015 . A subset of these samples were used for ${ }^{40} \mathrm{Ar} /{ }^{39} \mathrm{Ar}$ geochronology and whole-rock and microanalytical geochemical analyses. Remaining sample material has been archived at Victoria University of Wellington. A full list of sample locations and the methods of analysis is provided in Table A3.1. Sample locations are shown in Figure A3.1.

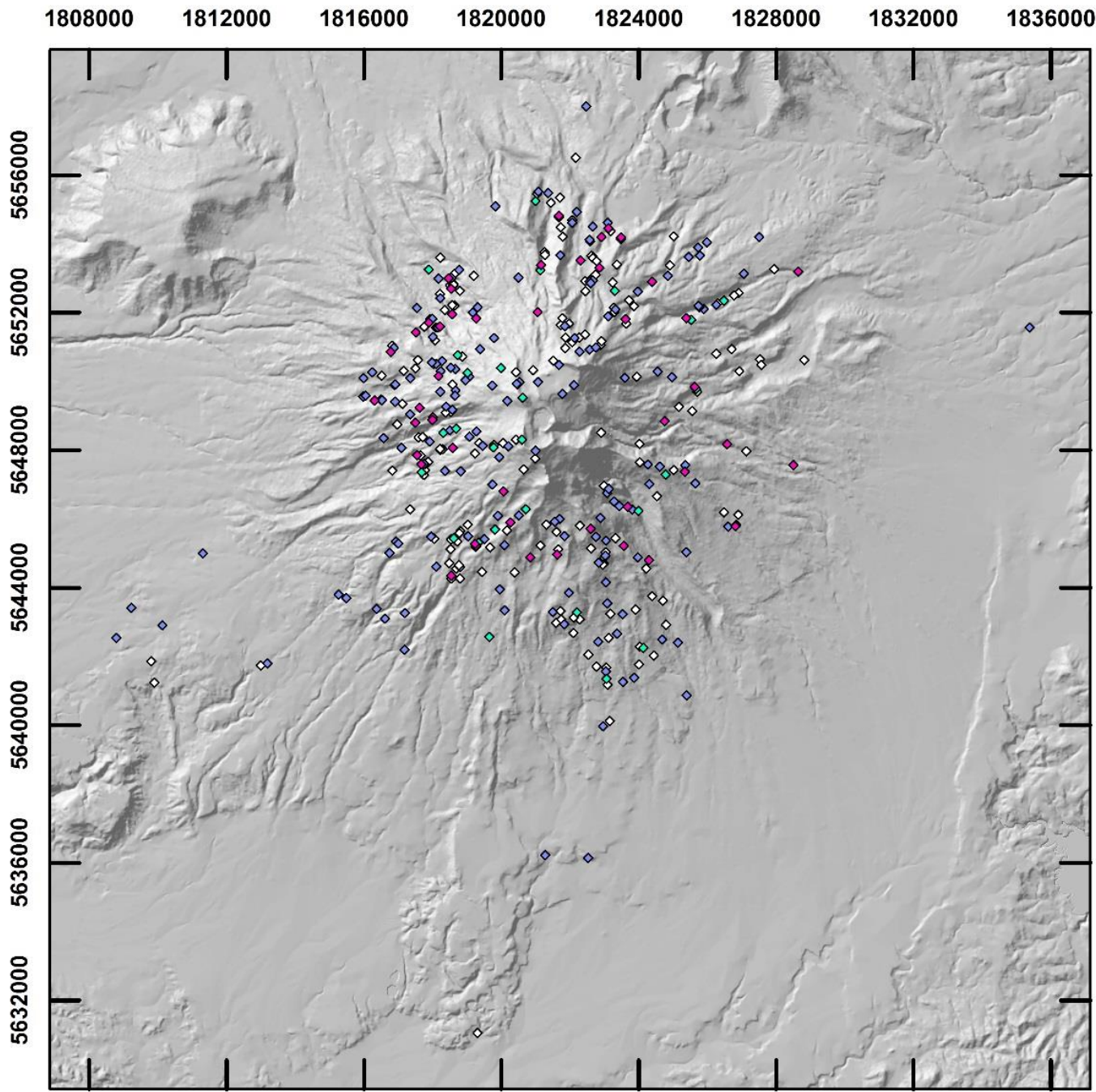

Figure A3.1. Sample location map. Pink diamonds are samples for which eruption ages, and whole-rock major and trace element data were measured. Samples with major and trace element data (green diamonds) and only major element data (purple diamonds) are shown. White diamonds are samples that were not analysed by the above methods during this study. Map projection and grid coordinates are in NZTM metres. 
Table A3.1. Locations for lava samples collected during this study.

\begin{tabular}{|c|c|c|c|c|c|c|}
\hline \multirow{2}{*}{$\begin{array}{l}\text { Sample } \\
\text { number }\end{array}$} & \multicolumn{2}{|c|}{ Location NZTM } & \multicolumn{4}{|c|}{ Analysis method } \\
\hline & East & North & Ar/Ar & XRF & ICPMS & EPMA \\
\hline CC050 & 1823033 & 5645038 & & & & \\
\hline $\mathrm{CC} 051$ & 1823021 & 5644930 & & $\mathrm{X}$ & & \\
\hline $\mathrm{CC} 052$ & 1822999 & 5644882 & & & & \\
\hline $\mathrm{CC} 054$ & 1822981 & 5644697 & & & & \\
\hline $\mathrm{CC} 055$ & 1822953 & 5644666 & & & & \\
\hline $\mathrm{CC} 058$ & 1824390 & 5643756 & & & & \\
\hline CC059 & 1824706 & 5643624 & & & & \\
\hline CC060 & 1824789 & 5642918 & & & & \\
\hline CC061 & 1825141 & 5642398 & & $X$ & & \\
\hline $\mathrm{CC} 062$ & 1824684 & 5642488 & & $X$ & & \\
\hline $\mathrm{CC} 063$ & 1824440 & 5642030 & & & & \\
\hline $\mathrm{CC} 064$ & 1824134 & 5642249 & & $X$ & $\mathrm{X}$ & \\
\hline CC065 & 1824029 & 5642286 & & & & \\
\hline CC066 & 1824013 & 5641776 & & & & \\
\hline $\mathrm{CC} 067$ & 1823873 & 5641387 & & $X$ & & \\
\hline CC069 & 1823539 & 5641265 & & $\mathrm{X}$ & & $\mathrm{X}$ \\
\hline $\mathrm{CC} 070$ & 1823099 & 5641179 & & & & \\
\hline $\mathrm{CC} 071$ & 1823066 & 5641352 & & $\mathrm{X}$ & $\mathrm{X}$ & \\
\hline $\mathrm{CC} 073$ & 1823176 & 5643241 & & & & \\
\hline $\mathrm{CC} 074$ & 1823088 & 5643550 & & $\mathrm{X}$ & & \\
\hline CC075 & 1823043 & 5644160 & & $X$ & & \\
\hline $\mathrm{CC} 077$ & 1822829 & 5644731 & & $\mathrm{X}$ & & $\mathrm{X}$ \\
\hline $\mathrm{CC} 078$ & 1822608 & 5645149 & & & & \\
\hline $\mathrm{CC} 080$ & 1822756 & 5645478 & & $\mathrm{X}$ & & \\
\hline СC081 & 1822604 & 5645717 & $\mathrm{X}$ & $X$ & $X$ & \\
\hline $\mathrm{CC} 082$ & 1822285 & 5645802 & & & & \\
\hline $\mathrm{CC} 083$ & 1821699 & 5645996 & & $X$ & & \\
\hline $\mathrm{CC} 084$ & 1821555 & 5645914 & & $\mathrm{X}$ & & \\
\hline $\mathrm{CC} 085$ & 1821604 & 5645626 & & & & \\
\hline $\mathrm{CC} 087$ & 1821834 & 5645497 & & $\mathrm{X}$ & & \\
\hline CC088 & 1821653 & 5645115 & & & & \\
\hline CC089 & 1821623 & 5644960 & $\mathrm{X}$ & $\mathrm{X}$ & $\mathrm{X}$ & $\mathrm{X}$ \\
\hline CC090 & 1823909 & 5643370 & & & & \\
\hline CC091 & 1823537 & 5643237 & & $\mathrm{X}$ & & \\
\hline $\mathrm{CC} 093$ & 1823376 & 5642667 & & $\mathrm{X}$ & & \\
\hline CC095 & 1823060 & 5641683 & & & & \\
\hline CC096 & 1823043 & 5641569 & & $X$ & & \\
\hline $\mathrm{CC} 097$ & 1822774 & 5641712 & & & & \\
\hline СC099 & 1822540 & 5642057 & & & & \\
\hline CC100 & 1822820 & 5642430 & & $\mathrm{X}$ & & \\
\hline CC101 & 1823132 & 5642541 & & & & \\
\hline $\mathrm{CC} 102$ & 1822461 & 5642803 & & $X$ & $X$ & \\
\hline $\mathrm{CC} 103$ & 1822281 & 5643079 & & & & \\
\hline CC104 & 1822110 & 5643137 & & & & \\
\hline $\mathrm{CC} 107$ & 1822105 & 5642690 & & & & \\
\hline CC108 & 1821834 & 5642936 & & $X$ & & \\
\hline CC109 & 1821741 & 5643080 & & & & \\
\hline $\mathrm{CC} 110$ & 1821595 & 5642985 & & & & \\
\hline $\mathrm{CC} 111$ & 1821506 & 5643297 & & $\mathrm{X}$ & & \\
\hline $\mathrm{CC} 112$ & 1821730 & 5643322 & & & & \\
\hline $\mathrm{CC} 114$ & 1822202 & 5643288 & & $\mathrm{X}$ & $\mathrm{X}$ & \\
\hline $\mathrm{CC} 115$ & 1821966 & 5643855 & & $\mathrm{X}$ & & \\
\hline
\end{tabular}


Table A3.1. continued

\begin{tabular}{|c|c|c|c|c|c|c|}
\hline \multirow{2}{*}{$\begin{array}{l}\text { Sample } \\
\text { number }\end{array}$} & \multicolumn{2}{|c|}{ Location NZTM } & \multicolumn{4}{|c|}{ Analysis method } \\
\hline & East & North & Ar/Ar & XRF & ICPMS & EPMA \\
\hline CC116 & 1820096 & 5643347 & & $\mathrm{X}$ & & \\
\hline $\mathrm{CC} 117$ & 1820386 & 5644444 & & & & \\
\hline $\mathrm{CC} 119$ & 1820841 & 5644880 & $\mathrm{X}$ & $\mathrm{X}$ & $\mathrm{X}$ & \\
\hline $\mathrm{CC} 121$ & 1821139 & 5645231 & & & & \\
\hline $\mathrm{CC} 123$ & 1821305 & 5645838 & & & & \\
\hline $\mathrm{CC} 125$ & 1820706 & 5646278 & & $\mathrm{X}$ & $\mathrm{X}$ & $\mathrm{X}$ \\
\hline CC126 & 1820503 & 5646099 & & $X$ & & \\
\hline $\mathrm{CC} 127$ & 1820258 & 5645899 & $X$ & $\mathrm{X}$ & $\mathrm{X}$ & \\
\hline CC129 & 1819670 & 5645177 & & & & \\
\hline $\mathrm{CC} 130$ & 1820063 & 5646806 & $X$ & $X$ & $X$ & \\
\hline $\mathrm{CC} 134$ & 1818530 & 5645414 & & & & \\
\hline $\mathrm{CC} 135$ & 1818618 & 5645440 & & $X$ & $X$ & \\
\hline CC136 & 1818722 & 5645352 & & & & \\
\hline CC139 & 1819028 & 5645499 & & $\mathrm{X}$ & & \\
\hline CC140 & 1819256 & 5645213 & $\mathrm{X}$ & $X$ & $X$ & \\
\hline CC141 & 1819260 & 5645200 & & & & \\
\hline CC143 & 1818544 & 5644352 & $X$ & $\mathrm{X}$ & $\mathrm{X}$ & \\
\hline $\mathrm{CC} 144$ & 1818540 & 5644273 & & & & \\
\hline CC145 & 1818684 & 5644556 & & & & \\
\hline $\mathrm{CC} 147$ & 1818801 & 5644608 & & & & \\
\hline CC148 & 1818771 & 5644657 & & & & \\
\hline CC149 & 1819335 & 5645320 & & $\mathrm{X}$ & $X$ & \\
\hline CC150 & 1819513 & 5645421 & & $X$ & & \\
\hline $\mathrm{CC} 152$ & 1819812 & 5645692 & & $\mathrm{X}$ & $\mathrm{X}$ & \\
\hline CC154 & 1819901 & 5646086 & & $\mathrm{X}$ & & $\mathrm{X}$ \\
\hline $\mathrm{CC} 155$ & 1816930 & 5645350 & & $X$ & & \\
\hline CC156 & 1817001 & 5645283 & & $\mathrm{X}$ & & \\
\hline $\mathrm{CC} 157$ & 1818107 & 5644618 & & $\mathrm{X}$ & & \\
\hline CC158 & 1818528 & 5645125 & & & & \\
\hline $\mathrm{CC} 159$ & 1818052 & 5645431 & & & & \\
\hline CC160 & 1817953 & 5645491 & & $\mathrm{X}$ & & \\
\hline CC161 & 1815488 & 5643704 & & $\mathrm{X}$ & & \\
\hline CC162 & 1816367 & 5643385 & & $\mathrm{X}$ & & \\
\hline CC163 & 1816612 & 5643102 & & $\mathrm{X}$ & & \\
\hline CC164 & 1817179 & 5642198 & & $\mathrm{X}$ & & \\
\hline CC165 & 1815260 & 5643802 & & $\mathrm{X}$ & & \\
\hline CC166 & 1825551 & 5649136 & & & & \\
\hline CC167 & 1825165 & 5649263 & & & & \\
\hline CC168 & 1825695 & 5649700 & & & & \\
\hline CC169 & 1826707 & 5650941 & & & & \\
\hline CC170 & 1826932 & 5650294 & & & & \\
\hline $\mathrm{CC} 171$ & 1827524 & 5650644 & & & & \\
\hline $\mathrm{CC} 172$ & 1827566 & 5650476 & & & & \\
\hline $\mathrm{CC} 173$ & 1828822 & 5650623 & & & & \\
\hline $\mathrm{CC} 174$ & 1813193 & 5641806 & & $X$ & & \\
\hline $\mathrm{CC} 175$ & 1813001 & 5641741 & & & & \\
\hline CC181 & 1820593 & 5648304 & & $\mathrm{X}$ & $\mathrm{X}$ & \\
\hline CC182 & 1820427 & 5648303 & & & & \\
\hline $\mathrm{CC} 184$ & 1820199 & 5648112 & & $\mathrm{X}$ & & \\
\hline CC185 & 1820050 & 5648202 & & & & \\
\hline CC186 & 1819779 & 5648078 & & $\mathrm{X}$ & $\mathrm{X}$ & \\
\hline $\mathrm{CC} 187$ & 1819239 & 5647907 & & & & \\
\hline
\end{tabular}


Table A3.1. continued

\begin{tabular}{|c|c|c|c|c|c|c|}
\hline \multirow{2}{*}{$\begin{array}{l}\text { Sample } \\
\text { number }\end{array}$} & \multicolumn{2}{|c|}{ Location NZTM } & \multicolumn{4}{|c|}{ Analysis method } \\
\hline & East & North & Ar/Ar & XRF & ICPMS & EPMA \\
\hline CC188 & 1818359 & 5647405 & & $\mathrm{X}$ & & \\
\hline CC189 & 1817194 & 5643265 & & $\mathrm{X}$ & & \\
\hline CC191 & 1820156 & 5645665 & & & & \\
\hline $\mathrm{CC} 193$ & 1820086 & 5645232 & & $\mathrm{X}$ & & $\mathrm{X}$ \\
\hline CC195 & 1819954 & 5643956 & & $\mathrm{X}$ & & \\
\hline CC196 & 1825651 & 5647038 & & $\mathrm{X}$ & & \\
\hline CC197 & 1825342 & 5647375 & $\mathrm{X}$ & $X$ & $X$ & \\
\hline CC198 & 1825355 & 5647559 & & $\mathrm{X}$ & & \\
\hline CC199 & 1825018 & 5647417 & & & & \\
\hline CC200 & 1824783 & 5647288 & & $X$ & $X$ & \\
\hline $\mathrm{CC} 201$ & 1824612 & 5647519 & & $\mathrm{X}$ & & \\
\hline $\mathrm{CC} 202$ & 1824270 & 5647584 & & $X$ & & \\
\hline $\mathrm{CC} 203$ & 1824028 & 5647642 & & & & \\
\hline $\mathrm{CC} 205$ & 1824304 & 5647014 & & $\mathrm{X}$ & & \\
\hline CC206 & 1824527 & 5646658 & & & & \\
\hline $\mathrm{CC} 207$ & 1826896 & 5646125 & & & & \\
\hline $\mathrm{CC} 208$ & 1826832 & 5645828 & & & & \\
\hline CC209 & 1826814 & 5645788 & $\mathrm{X}$ & $\mathrm{X}$ & $\mathrm{X}$ & \\
\hline CC210 & 1826607 & 5645770 & & $X$ & & \\
\hline CC211 & 1826477 & 5646193 & & & & \\
\hline CC212 & 1825386 & 5645031 & & $X$ & & \\
\hline $\mathrm{CC} 213$ & 1824299 & 5644796 & $\mathrm{X}$ & $\mathrm{X}$ & $\mathrm{X}$ & \\
\hline $\mathrm{CC} 214$ & 1823974 & 5644885 & & $X$ & & \\
\hline $\mathrm{CC} 215$ & 1823974 & 5644885 & & & & \\
\hline CC216 & 1823738 & 5645080 & $X$ & $X$ & $X$ & \\
\hline $\mathrm{CC} 217$ & 1823564 & 5645212 & & $X$ & & \\
\hline CC218 & 1823323 & 5645440 & & & & \\
\hline CC219 & 1822885 & 5646025 & & $\mathrm{X}$ & & \\
\hline CC221 & 1823050 & 5645369 & & $X$ & & \\
\hline $\mathrm{CC} 222$ & 1824212 & 5644556 & & & & \\
\hline $\mathrm{CC} 224$ & 1823995 & 5646228 & & $\mathrm{X}$ & $X$ & \\
\hline $\mathrm{CC} 225$ & 1823808 & 5646277 & & $\mathrm{X}$ & & \\
\hline CC226 & 1823673 & 5646350 & $X$ & $\mathrm{X}$ & $X$ & \\
\hline $\mathrm{CC} 228$ & 1823433 & 5646377 & & $\mathrm{X}$ & & \\
\hline $\mathrm{CC} 229$ & 1823275 & 5646504 & & $\mathrm{X}$ & & \\
\hline $\mathrm{CC} 230$ & 1823076 & 5646747 & & $\mathrm{X}$ & & \\
\hline $\mathrm{CC} 231$ & 1822984 & 5646960 & & & & \\
\hline $\mathrm{CC} 232$ & 1823123 & 5646871 & & $\mathrm{X}$ & & \\
\hline $\mathrm{CC} 234$ & 1816829 & 5647409 & & & & \\
\hline $\mathrm{CC} 235$ & 1817751 & 5647605 & & $X$ & & \\
\hline CC236 & 1817546 & 5647853 & $X$ & $X$ & $X$ & \\
\hline $\mathrm{CC} 237$ & 1817648 & 5647851 & & & & \\
\hline $\mathrm{CC} 238$ & 1818307 & 5648503 & & $X$ & $X$ & \\
\hline CC239 & 1818509 & 5648577 & & $\mathrm{X}$ & & \\
\hline $\mathrm{CC} 240$ & 1818688 & 5648627 & & $X$ & $X$ & \\
\hline CC241 & 1819273 & 5648548 & & $X$ & & \\
\hline $\mathrm{CC} 245$ & 1817090 & 5648073 & & $\mathrm{X}$ & & \\
\hline CC246 & 1817585 & 5648373 & & & & \\
\hline $\mathrm{CC} 247$ & 1817710 & 5648384 & & & & \\
\hline CC248 & 1817912 & 5648256 & & $\mathrm{X}$ & & \\
\hline $\mathrm{CC} 253$ & 1824023 & 5648179 & & & & \\
\hline $\mathrm{CC} 254$ & 1822904 & 5648513 & & & & \\
\hline
\end{tabular}


Table A3.1. continued

\begin{tabular}{|c|c|c|c|c|c|c|}
\hline \multirow{2}{*}{$\begin{array}{l}\text { Sample } \\
\text { number }\end{array}$} & \multicolumn{2}{|c|}{ Location NZTM } & \multicolumn{4}{|c|}{ Analysis method } \\
\hline & East & North & Ar/Ar & XRF & ICPMS & EPMA \\
\hline CC260 & 1819749 & 5647008 & & $\mathrm{X}$ & & $\mathrm{X}$ \\
\hline CC261 & 1820646 & 5647442 & & & & \\
\hline $\mathrm{CC} 262$ & 1820980 & 5647752 & & & & \\
\hline $\mathrm{CC} 263$ & 1820997 & 5647975 & & $\mathrm{X}$ & & \\
\hline CC264 & 1821509 & 5650597 & & & & \\
\hline CC267 & 1821858 & 5650968 & & & & \\
\hline CC268 & 1822058 & 5651140 & & & & \\
\hline CC269 & 1822135 & 5651262 & & $\mathrm{X}$ & & \\
\hline $\mathrm{CC} 270$ & 1822266 & 5651273 & & & & \\
\hline $\mathrm{CC} 271$ & 1822435 & 5651359 & & & & \\
\hline $\mathrm{CC} 273$ & 1823240 & 5652876 & & & & \\
\hline $\mathrm{CC} 274$ & 1822159 & 5656503 & & & & \\
\hline CC275 & 1822646 & 5653643 & & & & \\
\hline $\mathrm{CC} 276$ & 1822853 & 5653306 & $\mathrm{X}$ & $\mathrm{X}$ & $\mathrm{X}$ & \\
\hline $\mathrm{CC} 277$ & 1823359 & 5653397 & & & & \\
\hline $\mathrm{CC} 278$ & 1820923 & 5650325 & & & & \\
\hline $\mathrm{CC} 279$ & 1822302 & 5653514 & $\mathrm{X}$ & $\mathrm{X}$ & $\mathrm{X}$ & \\
\hline $\mathrm{CC} 280$ & 1822448 & 5652627 & & & & \\
\hline CC281 & 1823297 & 5652634 & & $\mathrm{X}$ & $X$ & $\mathrm{X}$ \\
\hline CC282 & 1819195 & 5653075 & & & & \\
\hline CC284 & 1818639 & 5653131 & & & & \\
\hline $\mathrm{CC} 287$ & 1818486 & 5644720 & & & & \\
\hline CC289 & 1818802 & 5644269 & & & & \\
\hline CC291 & 1819648 & 5642572 & & $\mathrm{X}$ & $\mathrm{X}$ & \\
\hline CC292 & 1816747 & 5645013 & & $\mathrm{X}$ & & \\
\hline CC300 & 1821722 & 5651633 & & & & \\
\hline CC301 & 1821847 & 5651610 & & $\mathrm{X}$ & & \\
\hline CC302 & 1821863 & 5651276 & & & & \\
\hline CC303 & 1821970 & 5651673 & & & & \\
\hline CC304 & 1821780 & 5651840 & & & & \\
\hline CC305 & 1817884 & 5653257 & & $\mathrm{X}$ & $\mathrm{X}$ & \\
\hline CC306 & 1818460 & 5652994 & $\mathrm{X}$ & $\mathrm{X}$ & $\mathrm{X}$ & \\
\hline CC307 & 1818543 & 5653013 & & $\mathrm{X}$ & & \\
\hline CC308 & 1818174 & 5652988 & & $\mathrm{X}$ & & $\mathrm{X}$ \\
\hline CC309 & 1818500 & 5652794 & & & & \\
\hline $\mathrm{CC} 310$ & 1818599 & 5652850 & & & & \\
\hline CC311 & 1818591 & 5652789 & & & & \\
\hline CC 313 & 1818532 & 5652698 & $X$ & $\mathrm{X}$ & $X$ & $\mathrm{X}$ \\
\hline CC314 & 1818223 & 5653599 & & & & \\
\hline $\mathrm{CC} 315$ & 1821700 & 5655342 & & & & \\
\hline $\mathrm{CC} 316$ & 1822060 & 5654611 & & $\mathrm{X}$ & & \\
\hline CC317 & 1822059 & 5654683 & & & & \\
\hline CC318 & 1821719 & 5653665 & & $X$ & & \\
\hline CC319 & 1821789 & 5654203 & & & & \\
\hline CC 320 & 1821728 & 5654479 & & & & \\
\hline CC 321 & 1821670 & 5654774 & & & & \\
\hline CC322 & 1821672 & 5654821 & $\mathrm{X}$ & $\mathrm{X}$ & $\mathrm{X}$ & \\
\hline CC324 & 1821440 & 5655195 & & & & \\
\hline CC 325 & 1821364 & 5655483 & & $\mathrm{X}$ & & \\
\hline CC326 & 1820996 & 5655249 & & $\mathrm{X}$ & $\mathrm{X}$ & $\mathrm{X}$ \\
\hline CC 327 & 1821045 & 5655460 & & & & \\
\hline CC328 & 1821080 & 5655514 & & $\mathrm{X}$ & & \\
\hline
\end{tabular}


Table A3.1. continued

\begin{tabular}{|c|c|c|c|c|c|c|}
\hline \multirow{2}{*}{$\begin{array}{l}\text { Sample } \\
\text { number }\end{array}$} & \multicolumn{2}{|c|}{ Location NZTM } & \multicolumn{4}{|c|}{ Analysis method } \\
\hline & East & North & $\mathbf{A r} / \mathbf{A r}$ & XRF & ICPMS & EPMA \\
\hline CC330 & 1819823 & 5655089 & & $\mathrm{X}$ & & \\
\hline CC331 & 1819823 & 5655089 & & $\mathrm{X}$ & & \\
\hline CC332 & 1818208 & 5652540 & & & & \\
\hline CC333 & 1818222 & 5652419 & & $\mathrm{X}$ & & \\
\hline CC334 & 1818352 & 5652075 & & & & \\
\hline $\mathrm{CC} 335$ & 1818570 & 5651957 & $\mathrm{X}$ & $\mathrm{X}$ & $\mathrm{X}$ & $\mathrm{X}$ \\
\hline CC336 & 1819168 & 5652000 & & $\mathrm{X}$ & & \\
\hline CC337 & 1819309 & 5652158 & & $\mathrm{X}$ & & \\
\hline CC338 & 1822189 & 5654931 & & $\mathrm{X}$ & & \\
\hline CC339 & 1822567 & 5654120 & & $\mathrm{X}$ & & \\
\hline CC340 & 1822624 & 5653651 & & & & \\
\hline CC341 & 1822659 & 5653585 & & & & \\
\hline $\mathrm{CC} 342$ & 1822770 & 5653498 & & & & \\
\hline CC 343 & 1822652 & 5653016 & & & & \\
\hline CC344 & 1822642 & 5652989 & & & & \\
\hline CC345 & 1822664 & 5652940 & & $\mathrm{X}$ & & \\
\hline CC346 & 1822737 & 5653101 & & & & \\
\hline CC347 & 1823481 & 5654138 & & & & \\
\hline CC348 & 1823483 & 5654189 & $\mathrm{X}$ & $\mathrm{X}$ & $\mathrm{X}$ & $\mathrm{X}$ \\
\hline CC349 & 1823175 & 5654366 & & & & \\
\hline CC350 & 1823117 & 5654452 & $\mathrm{X}$ & $\mathrm{X}$ & $\mathrm{X}$ & \\
\hline CC351 & 1839661 & 5675104 & & & & \\
\hline CC352 & 1839658 & 5675044 & & & & \\
\hline CC353 & 1839416 & 5674947 & & & & \\
\hline $\mathrm{CC} 355$ & 1822434 & 5652920 & & & & \\
\hline CC356 & 1822569 & 5652893 & & $\mathrm{X}$ & & \\
\hline CC357 & 1822603 & 5652856 & & $\mathrm{X}$ & & \\
\hline CC358 & 1822576 & 5654077 & & & & \\
\hline CC360 & 1822664 & 5654505 & & $\mathrm{X}$ & & \\
\hline CC361 & 1819022 & 5645839 & & & & \\
\hline CC362 & 1818814 & 5645655 & & & & \\
\hline $\mathrm{CC} 363$ & 1818783 & 5645596 & & & & \\
\hline CC364 & 1828642 & 5653187 & $\mathrm{X}$ & $\mathrm{X}$ & $\mathrm{X}$ & \\
\hline CC365 & 1827946 & 5653266 & & & & \\
\hline CC366 & 1827061 & 5653131 & & $\mathrm{X}$ & & \\
\hline CC367 & 1826904 & 5652569 & & & & \\
\hline CC368 & 1826779 & 5652497 & & & & \\
\hline CC369 & 1826484 & 5652346 & & $\mathrm{X}$ & $\mathrm{X}$ & \\
\hline CC370 & 1826255 & 5652230 & & $\mathrm{X}$ & & \\
\hline CC371 & 1826296 & 5652264 & & & & \\
\hline CC372 & 1825889 & 5652107 & & $\mathrm{X}$ & & \\
\hline CC373 & 1825768 & 5652155 & & $X$ & & \\
\hline CC374 & 1825738 & 5652193 & & $X$ & & \\
\hline CC375 & 1825383 & 5651844 & $\mathrm{X}$ & $\mathrm{X}$ & $\mathrm{X}$ & \\
\hline CC376 & 1825523 & 5651787 & & $\mathrm{X}$ & $X$ & \\
\hline CC378 & 1826258 & 5650801 & & & & \\
\hline CC379 & 1822270 & 5650863 & & $X$ & & \\
\hline CC381 & 1822564 & 5650927 & & $X$ & & \\
\hline CC382 & 1822747 & 5650989 & & $X$ & & \\
\hline CC383 & 1822886 & 5651056 & & & & \\
\hline CC384 & 1822910 & 5651172 & & & & \\
\hline CC386 & 1823110 & 5651891 & & $X$ & & \\
\hline
\end{tabular}


Table A3.1. continued

\begin{tabular}{|c|c|c|c|c|c|c|}
\hline \multirow{2}{*}{$\begin{array}{l}\text { Sample } \\
\text { number }\end{array}$} & \multicolumn{2}{|c|}{ Location NZTM } & \multicolumn{4}{|c|}{ Analysis method } \\
\hline & East & North & Ar/Ar & XRF & ICPMS & EPMA \\
\hline CC387 & 1823289 & 5652012 & & & & \\
\hline CC389 & 1823266 & 5652149 & & & & \\
\hline CC390 & 1823318 & 5652097 & & $\mathrm{X}$ & & \\
\hline CC391 & 1823717 & 5652356 & & & & \\
\hline CC392 & 1823971 & 5652613 & & $\mathrm{X}$ & & \\
\hline CC393 & 1824391 & 5652896 & $\mathrm{X}$ & $\mathrm{X}$ & $\mathrm{X}$ & \\
\hline CC394 & 1825022 & 5654221 & & & & \\
\hline CC396 & 1823636 & 5651680 & & & & \\
\hline CC397 & 1823616 & 5651806 & $\mathrm{X}$ & $X$ & $X$ & \\
\hline CC399 & 1823862 & 5652186 & & & & \\
\hline $\mathrm{CC} 400$ & 1824849 & 5653075 & & $\mathrm{X}$ & & \\
\hline $\mathrm{CC} 401$ & 1824907 & 5653373 & & & & \\
\hline $\mathrm{CC} 402$ & 1825456 & 5653620 & & $\mathrm{X}$ & & \\
\hline $\mathrm{CC} 403$ & 1825776 & 5653660 & & $\mathrm{X}$ & & \\
\hline $\mathrm{CC} 404$ & 1825731 & 5653888 & & $X$ & & \\
\hline $\mathrm{CC} 405$ & 1825984 & 5654050 & & $\mathrm{X}$ & & \\
\hline CC406 & 1827503 & 5654197 & & $\mathrm{X}$ & & \\
\hline $\mathrm{CC} 408$ & 1819238 & 5645274 & $\mathrm{X}$ & $\mathrm{X}$ & $\mathrm{X}$ & \\
\hline CC410 & 1819439 & 5644463 & & & & \\
\hline CC411 & 1817542 & 5652140 & & $\mathrm{X}$ & & \\
\hline $\mathrm{CC} 413$ & 1817926 & 5651815 & & $\mathrm{X}$ & & \\
\hline CC414 & 1817885 & 5651710 & $X$ & $\mathrm{X}$ & $X$ & \\
\hline $\mathrm{CC} 415$ & 1818006 & 5651290 & & $X$ & & $X$ \\
\hline $\mathrm{CC} 417$ & 1818070 & 5651189 & & & & \\
\hline $\mathrm{CC} 422$ & 1818090 & 5651564 & & $\mathrm{X}$ & & \\
\hline $\mathrm{CC} 423$ & 1818146 & 5651562 & & $X$ & & \\
\hline $\mathrm{CC} 424$ & 1818213 & 5651592 & $X$ & $\mathrm{X}$ & $\mathrm{X}$ & \\
\hline $\mathrm{CC} 425$ & 1817990 & 5651824 & & $\mathrm{X}$ & & \\
\hline $\mathrm{CC} 426$ & 1819936 & 5647798 & & $X$ & & \\
\hline $\mathrm{CC} 428$ & 1819787 & 5648150 & & & & \\
\hline CC429 & 1819461 & 5648128 & & & & \\
\hline $\mathrm{CC} 430$ & 1819461 & 5648128 & & $\mathrm{X}$ & & \\
\hline CC431 & 1819360 & 5648211 & & & & \\
\hline $\mathrm{CC} 432$ & 1819073 & 5648401 & & $\mathrm{X}$ & & \\
\hline CC433 & 1817349 & 5646279 & & & & \\
\hline $\mathrm{CC} 434$ & 1817685 & 5647357 & & $\mathrm{X}$ & $\mathrm{X}$ & \\
\hline $\mathrm{CC} 435$ & 1817753 & 5647275 & & & & \\
\hline CC436 & 1817783 & 5647423 & & & & \\
\hline CC438 & 1817784 & 5647604 & & & & \\
\hline $\mathrm{CC} 440$ & 1817879 & 5647669 & & & & \\
\hline CC441 & 1817672 & 5647593 & $X$ & $\mathrm{X}$ & $X$ & \\
\hline $\mathrm{CC} 442$ & 1820524 & 5649986 & & $X$ & & \\
\hline $\mathrm{CC} 443$ & 1820463 & 5649915 & & $X$ & & \\
\hline $\mathrm{CC} 444$ & 1820613 & 5649527 & & $\mathrm{X}$ & $\mathrm{X}$ & \\
\hline $\mathrm{CC} 445$ & 1820440 & 5649931 & & $X$ & & \\
\hline CC446 & 1820420 & 5650261 & & & & \\
\hline $\mathrm{CC} 447$ & 1820497 & 5653024 & & $\mathrm{X}$ & & \\
\hline $\mathrm{CC} 448$ & 1819789 & 5651259 & & $\mathrm{X}$ & & \\
\hline $\mathrm{CC} 449$ & 1819378 & 5650933 & & $\mathrm{X}$ & & \\
\hline CC450 & 1818861 & 5650724 & & & & \\
\hline $\mathrm{CC} 451$ & 1818724 & 5650762 & & $\mathrm{X}$ & $\mathrm{X}$ & \\
\hline $\mathrm{CC} 452$ & 1818271 & 5650595 & & $\mathrm{X}$ & & \\
\hline
\end{tabular}


Table A3.1. continued

\begin{tabular}{|c|c|c|c|c|c|c|}
\hline \multirow{2}{*}{$\begin{array}{l}\text { Sample } \\
\text { number }\end{array}$} & \multicolumn{2}{|c|}{ Location NZTM } & \multicolumn{4}{|c|}{ Analysis method } \\
\hline & East & North & $\mathbf{A r} / \mathbf{A r}$ & XRF & ICPMS & EPMA \\
\hline CC453 & 1819270 & 5651833 & $\mathrm{X}$ & $\mathrm{X}$ & $\mathrm{X}$ & \\
\hline $\mathrm{CC} 454$ & 1815985 & 5650091 & & $\mathrm{X}$ & & \\
\hline $\mathrm{CC} 455$ & 1816239 & 5650269 & & $\mathrm{X}$ & & \\
\hline $\mathrm{CC} 456$ & 1816510 & 5650166 & & & & \\
\hline $\mathrm{CC} 458$ & 1817151 & 5650302 & & & & \\
\hline $\mathrm{CC} 459$ & 1817494 & 5650379 & & & & \\
\hline $\mathrm{CC} 460$ & 1818227 & 5650299 & & $\mathrm{X}$ & & \\
\hline CC462 & 1818169 & 5650151 & $\mathrm{X}$ & $\mathrm{X}$ & $\mathrm{X}$ & \\
\hline $\mathrm{CC} 463$ & 1818573 & 5649911 & & & & \\
\hline CC464 & 1818670 & 5649741 & & $\mathrm{X}$ & & \\
\hline $\mathrm{CC} 465$ & 1818648 & 5649584 & & $\mathrm{X}$ & & \\
\hline CC466 & 1818224 & 5649696 & & $\mathrm{X}$ & & \\
\hline $\mathrm{CC} 467$ & 1817342 & 5650093 & & $\mathrm{X}$ & & \\
\hline CC468 & 1815977 & 5649551 & & $\mathrm{X}$ & & \\
\hline $\mathrm{CC} 469$ & 1816044 & 5649580 & & $\mathrm{X}$ & & \\
\hline CC470 & 1816307 & 5649444 & $\mathrm{X}$ & $\mathrm{X}$ & $\mathrm{X}$ & \\
\hline CC471 & 1816488 & 5649472 & & & & \\
\hline $\mathrm{CC} 472$ & 1816520 & 5649450 & & $\mathrm{X}$ & & \\
\hline $\mathrm{CC} 473$ & 1816520 & 5649450 & & $\mathrm{X}$ & & \\
\hline $\mathrm{CC} 474$ & 1816908 & 5649413 & & $\mathrm{X}$ & & \\
\hline $\mathrm{CC} 475$ & 1816908 & 5649413 & & $\mathrm{X}$ & & \\
\hline CC476 & 1817126 & 5649355 & & & & \\
\hline CC477 & 1816909 & 5649915 & & $\mathrm{X}$ & & \\
\hline CC478 & 1816893 & 5649902 & & & & \\
\hline $\mathrm{CC} 479$ & 1819009 & 5650243 & & $\mathrm{X}$ & $\mathrm{X}$ & $\mathrm{X}$ \\
\hline CC480 & 1819059 & 5650129 & & $\mathrm{X}$ & & \\
\hline CC481 & 1818949 & 5650028 & & $\mathrm{X}$ & & \\
\hline $\mathrm{CC} 482$ & 1818653 & 5650362 & & $\mathrm{X}$ & & \\
\hline CC483 & 1818528 & 5650394 & & $\mathrm{X}$ & & \\
\hline $\mathrm{CC} 484$ & 1818100 & 5650510 & & $\mathrm{X}$ & & \\
\hline $\mathrm{CC} 485$ & 1818022 & 5650505 & & & & \\
\hline $\mathrm{CC} 486$ & 1817971 & 5650555 & & $\mathrm{X}$ & & \\
\hline CC500 & 1818773 & 5653238 & & $\mathrm{X}$ & & \\
\hline CC503 & 1818793 & 5652631 & & & & \\
\hline CC504 & 1818640 & 5652207 & & & & \\
\hline CC506 & 1818562 & 5652221 & & & & \\
\hline CC507 & 1818609 & 5652813 & & & & \\
\hline CC508 & 1817506 & 5651423 & $\mathrm{X}$ & $\mathrm{X}$ & $\mathrm{X}$ & \\
\hline CC509 & 1816822 & 5651038 & & & & \\
\hline CC510 & 1816866 & 5650981 & & $\mathrm{X}$ & & \\
\hline CC511 & 1816776 & 5650850 & $X$ & $X$ & $\mathrm{X}$ & \\
\hline CC512 & 1817567 & 5650625 & & & & \\
\hline CC513 & 1819987 & 5650387 & & $\mathrm{X}$ & $X$ & \\
\hline CC514 & 1820170 & 5649430 & & $\mathrm{X}$ & & \\
\hline CC515 & 1819734 & 5649877 & & $\mathrm{X}$ & & \\
\hline CC516 & 1821253 & 5653765 & & & & \\
\hline CC517 & 1821268 & 5653684 & & & & \\
\hline CC518 & 1821154 & 5653389 & $X$ & $X$ & $X$ & \\
\hline CC519 & 1821140 & 5653233 & & $X$ & $X$ & \\
\hline CC520 & 1819308 & 5631051 & & & & \\
\hline CC521 & 1821274 & 5636222 & & $\mathrm{X}$ & & \\
\hline CC522 & 1822529 & 5636146 & & $X$ & & \\
\hline
\end{tabular}


Table A3.1. continued

\begin{tabular}{|c|c|c|c|c|c|c|}
\hline \multirow{2}{*}{$\begin{array}{l}\text { Sample } \\
\text { number }\end{array}$} & \multicolumn{2}{|c|}{ Location NZTM } & \multicolumn{4}{|c|}{ Analysis method } \\
\hline & East & North & Ar/Ar & XRF & ICPMS & EPMA \\
\hline CC523 & 1823155 & 5640122 & & & & \\
\hline CC524 & 1822967 & 5639972 & & $\mathrm{X}$ & & \\
\hline CC525 & 1825392 & 5640863 & & $\mathrm{X}$ & & \\
\hline CC526 & 1814089 & 5662959 & & & & \\
\hline CC528 & 1813894 & 5664267 & & & & \\
\hline CC529 & 1817751 & 5651586 & & & & \\
\hline CC531 & 1821066 & 5649986 & & $\mathrm{X}$ & & \\
\hline CC532 & 1821778 & 5649631 & & $\mathrm{X}$ & & \\
\hline CC533 & 1822108 & 5649887 & & $\mathrm{X}$ & & \\
\hline CC534 & 1821678 & 5650481 & & $\mathrm{X}$ & & \\
\hline CC535 & 1808791 & 5642539 & & $\mathrm{X}$ & & \\
\hline CC536 & 1809808 & 5641867 & & & & \\
\hline CC537 & 1809899 & 5641243 & & & & \\
\hline CC538 & 1810134 & 5642905 & & $\mathrm{X}$ & & \\
\hline CC539 & 1811311 & 5645002 & & $\mathrm{X}$ & & \\
\hline CC540 & 1809224 & 5643422 & & $\mathrm{X}$ & & \\
\hline CC541 & 1836234 & 5655610 & & & & \\
\hline CC542 & 1835384 & 5651562 & & $\mathrm{X}$ & & \\
\hline CC543 & 1816574 & 5648360 & & $\mathrm{X}$ & & \\
\hline CC545 & 1817495 & 5648804 & $\mathrm{X}$ & $\mathrm{X}$ & $\mathrm{X}$ & \\
\hline CC546 & 1817346 & 5649043 & & $\mathrm{X}$ & & \\
\hline CC547 & 1817623 & 5649236 & $\mathrm{X}$ & $\mathrm{X}$ & $\mathrm{X}$ & \\
\hline CC548 & 1818392 & 5649274 & & $\mathrm{X}$ & & \\
\hline CC549 & 1818580 & 5649177 & & $\mathrm{X}$ & & \\
\hline CC550 & 1818537 & 5649122 & & & & \\
\hline CC551 & 1818381 & 5649099 & & & & \\
\hline CC552 & 1818005 & 5648964 & $\mathrm{X}$ & $\mathrm{X}$ & $\mathrm{X}$ & \\
\hline CC553 & 1817994 & 5648883 & $\mathrm{X}$ & $\mathrm{X}$ & $\mathrm{X}$ & \\
\hline CC554 & 1816973 & 5648753 & & & & \\
\hline CC555 & 1818815 & 5647389 & & $\mathrm{X}$ & & \\
\hline CC556 & 1818585 & 5648075 & $\mathrm{X}$ & $\mathrm{X}$ & $\mathrm{X}$ & \\
\hline CC557 & 1818219 & 5648009 & & & & \\
\hline CC558 & 1818296 & 5648027 & & & & \\
\hline CC559 & 1818220 & 5648039 & & & & \\
\hline CC560 & 1822468 & 5657994 & & $\mathrm{X}$ & & \\
\hline CC561 & 1827131 & 5647968 & & & & \\
\hline CC562 & 1826576 & 5648175 & $\mathrm{X}$ & $\mathrm{X}$ & $\mathrm{X}$ & \\
\hline CC563 & 1825672 & 5649778 & & $\mathrm{X}$ & $\mathrm{X}$ & \\
\hline CC564 & 1825627 & 5649836 & & $\mathrm{X}$ & $\mathrm{X}$ & \\
\hline CC565 & 1824967 & 5650125 & & $\mathrm{X}$ & & \\
\hline CC566 & 1824551 & 5650286 & & $\mathrm{X}$ & & \\
\hline CC567 & 1823593 & 5650103 & & $X$ & & \\
\hline CC568 & 1823938 & 5650134 & & & & \\
\hline CC569 & 1824756 & 5648844 & $\mathrm{X}$ & $X$ & $\mathrm{X}$ & \\
\hline CC570 & 1822913 & 5654199 & $\mathrm{X}$ & $X$ & $\mathrm{X}$ & \\
\hline CC571 & 1822913 & 5654199 & & & & \\
\hline CC572 & 1823099 & 5654616 & & $\mathrm{X}$ & & \\
\hline GL1030 & 1821050 & 5652015 & $X$ & $\mathrm{X}$ & $\mathrm{X}$ & \\
\hline GL1983 & 1828506 & 5647559 & $\mathrm{X}$ & $\mathrm{X}$ & $\mathrm{X}$ & \\
\hline
\end{tabular}




\section{Appendix 4. ${ }^{40} \mathrm{Ar} /{ }^{39} \mathrm{Ar}$ geochronology data}

Radiometric ${ }^{40} \mathrm{Ar} /{ }^{39} \mathrm{Ar}$ dating was undertaken using crystalline groundmass material from lava flows. Sample preparation and analysis procedures are outline in Chapter 3. The full experiment information for age measurements is provided in this appendix.

Total gas, isochron and weighted mean plateau ages (WMPA) were calculated for each sample experiment. Total gas ages were calculated from the sums of all radiogenic ${ }^{40} \mathrm{Ar}$ and potassium-derived ${ }^{39} \mathrm{Ar}$ in all step-heating increments of the analysis. Isochron ages were calculated from ${ }^{40} \mathrm{Ar} /{ }^{36} \mathrm{Ar}$ versus ${ }^{39} \mathrm{Ar} /{ }^{36} \mathrm{Ar}$ correlation using the algorithm of York (1968). WMPA are the inverse-variance weighted means that were calculated for the steps of an age spectrum comprising contiguous gas fractions that represented $>50 \%$ of the total ${ }^{39} \mathrm{Ar}$ released from the sample.

WMPA represent the best age estimates for 43 samples, based on their concordant age spectra, and are indicated in bold as the accepted lava flow eruption ages in Table A4.1.

The isochron age was preferred as the accepted eruption age for one sample (CC545).

Two experiments resulted in recoil spectra patterns indicative of loss of ${ }^{39} \mathrm{Ar}$ during the nuclear irradiation procedure. To preclude an underestimation of the eruption age due reduced ${ }^{40} \mathrm{Ar} /{ }^{39} \mathrm{Ar}$ values at high temperature increments, recoil model ages were calculated from the entire spectra (100\% fraction of ${ }^{39} \mathrm{Ar}$ released) of the two affected samples (CC306, CC350) using the method outlined in Fleck et al. (2014).

This appendix provides the experiment information for each of the 46 age determinations recorded on the following sample sheets. Each sheet is divided into two main parts:

1. The age spectrum: values of $\mathrm{Cl} / \mathrm{K}$, radiogenic ${ }^{39} \mathrm{Ar} \%, \mathrm{~K} / \mathrm{Ca}$ and apparent age for each heating step during the experiment are plotted against the cumulative amount of ${ }^{39} \mathrm{Ar}$ released during heating. The temperature of the heating step is labelled beside each box. The range of heating steps used to calculate the weighted mean plateau age (WMPA) is indicated by the coloured arrows. The WMPA calculated from these is displayed beside the arrow, as is the proportion of ${ }^{39} \mathrm{Ar} \%$ released over the steps used and the mean square weighted deviation (MSWD). The total gas age is displayed in black text.

2. The isochron diagram: the coloured line and text represents the isochron age calculated taking into account the number of steps used to calculate the corresponding WMPA in the age spectrum diagram (1). The black text and line is the isochron age calculated for 100 $\%{ }^{39} \mathrm{Ar}$.

This information is summarised in Table A4.1. 
Table A4.1. Summary of ${ }^{40} \mathrm{Ar} /{ }^{39} \mathrm{Ar}$ geochronology data.

\begin{tabular}{|c|c|c|c|c|c|c|c|c|}
\hline \multirow[b]{2}{*}{ Sample } & \multirow[b]{2}{*}{ Fmtn-Package } & \multicolumn{4}{|c|}{ Plateau age } & \multirow{2}{*}{$\begin{array}{c}\text { Total gas age } \\
(\mathrm{ka}, \pm 2 \sigma)\end{array}$} & \multirow{2}{*}{$\begin{array}{c}\text { Isochron age } \\
(\mathrm{ka}, \pm \mathbf{2 \sigma})\end{array}$} & \multirow{2}{*}{$\begin{array}{c}{ }^{40} \mathrm{Ar}^{36} \mathrm{Ar}_{\mathrm{i}} \\
( \pm 2 \sigma)\end{array}$} \\
\hline & & $\mathbf{N}$ & ${ }^{39} \mathrm{Ar} \%$ & MSWD & $(\mathrm{ka}, \pm 2 \sigma)$ & & & \\
\hline GL1983 & WH-Crater Lake & 10 & 79.8 & 1.06 & $0.2 \pm 2.2$ & $1.8 \pm 2.2$ & $1.4 \pm 8.8$ & $294.3 \pm 9.9$ \\
\hline CC564 & WH-Iwikau & 7 & 86.0 & 0.67 & $0.8 \pm 5.6$ & $-0.8 \pm 5.6$ & $4 \pm 13.4$ & $293.3 \pm 9.5$ \\
\hline GL1030 & WH-Iwikau & 11 & 100.0 & 1.10 & $6.0 \pm 2.4$ & $6.5 \pm 2.4$ & $1.4 \pm 7.4$ & $298.4 \pm 5.2$ \\
\hline $\mathrm{CC} 279$ & WH-Iwikau & 12 & 63.9 & 0.79 & $8.8 \pm 2.8$ & $8.6 \pm 3.0$ & $10.5 \pm 17.2$ & $294.4 \pm 12.1$ \\
\hline CC569 & WH-Iwikau & 4 & 60.8 & 0.13 & $9.2 \pm 8.0$ & $-.03 \pm 8.6$ & $22.2 \pm 47.8$ & $287.6 \pm 33.9$ \\
\hline $\mathrm{CC} 236$ & WH-Turoa & 12 & 62.7 & 0.61 & $11.9 \pm 2.2$ & $9.3 \pm 2.2$ & $15.4 \pm 15.2$ & $291.8 \pm 19.1$ \\
\hline CC393 & WH-T ureiti & 10 & 100.0 & 0.65 & $11.9 \pm 2.8$ & $12.3 \pm 2.8$ & $11.9 \pm 8.8$ & $295.4 \pm 6.9$ \\
\hline CC397 & WH-Tureiti & 10 & 83.9 & 0.90 & $12.5 \pm 2.6$ & $10.2 \pm 2.6$ & $14.4 \pm 5.0$ & $293.2 \pm 6.0$ \\
\hline CC335 & WH-Paretetaitonga & 10 & 79.8 & 0.80 & $14.8 \pm 3.0$ & $22.1 \pm 3.0$ & $10.8 \pm 12.4$ & $299.5 \pm 14.7$ \\
\hline $\mathrm{CC} 130$ & WH-Turoa & 11 & 100.0 & 0.46 & $15.1 \pm 2.4$ & $15.2 \pm 2.4$ & $13.9 \pm 6.0$ & $296.3 \pm 2.9$ \\
\hline $\mathrm{CC} 226$ & MA-Makotuku & 10 & 100.0 & 0.34 & $17.8 \pm 2.2$ & $18.1 \pm 2.6$ & $16.8 \pm 4.2$ & $296.7 \pm 5.2$ \\
\hline $\mathrm{CC} 408$ & MA-Makotuku & 10 & 94.7 & 0.39 & $20.9 \pm 2.8$ & $19.6 \pm 3.0$ & $22.7 \pm 7.4$ & $293.9 \pm 7.3$ \\
\hline $\mathrm{CC} 143$ & MA-Waitonga & 11 & 99.5 & 0.80 & $23.0 \pm 1.6$ & $23.0 \pm 1.8$ & $22.2 \pm 4.6$ & $296.4 \pm 5.7$ \\
\hline CC513 & MA-Whakapapaiti & 3 & 67.9 & 0.50 & $25.7 \pm 3.8$ & $6.7 \pm 4.4$ & $39.4 \pm 28.6$ & $265.6 \pm 72.9$ \\
\hline $\mathrm{CC} 441$ & MA-Manganuioteao & 10 & 86.6 & 1.34 & $25.7 \pm 2.6$ & $20.3 \pm 2.8$ & $34.1 \pm 8.2$ & $286.6 \pm 9.9$ \\
\hline CC553 & MA-Manganuioteao & 10 & 100.0 & 0.40 & $27.2 \pm 4.8$ & $25.8 \pm 5.8$ & $29.0 \pm 7.2$ & $294.0 \pm 3.2$ \\
\hline $\mathrm{CC} 547$ & MA-Manganuioteao & 6 & 72.6 & 0.77 & $30.7 \pm 5.2$ & $43.9 \pm 4.6$ & $28.6 \pm 10.4$ & $296.6 \pm 21.5$ \\
\hline $\mathrm{CC} 462$ & MA-Manganuioteao & 10 & 94.6 & 0.54 & $30.9 \pm 2.2$ & $30.4 \pm 2.6$ & $30.8 \pm 5.4$ & $295.6 \pm 6.4$ \\
\hline CC508 & MA-Te Kohatu & 3 & 57.4 & 1.11 & $37.6 \pm 1.4$ & $46.2 \pm 1.4$ & $37.8 \pm 21.8$ & $294.4 \pm 109.2$ \\
\hline CC556 & MA-Ngahuinga & 7 & 90.8 & 0.53 & $38.3 \pm 3.4$ & $30.0 \pm 4.0$ & $37.9 \pm 8.4$ & $295.9 \pm 13$ \\
\hline $\mathrm{CC} 414$ & MA-Te Kohatu & 10 & 100.0 & 1.78 & $39.1 \pm 1.4$ & $40.7 \pm 1.4$ & $36.5 \pm 2.0$ & $302.2 \pm 5.1$ \\
\hline CC511 & MA-Te Kohatu & 9 & 97.7 & 0.44 & $39.2 \pm 2.0$ & $40.2 \pm 2.4$ & $38.4 \pm 3.6$ & $297.3 \pm 9.9$ \\
\hline $\mathrm{CC} 424$ & MA-Ngahuinga & 10 & 100.0 & 0.96 & $39.6 \pm 2.8$ & $40.3 \pm 3.2$ & $38.6 \pm 5.2$ & $296.2 \pm 4.0$ \\
\hline CC570 & MA-Mananui & 8 & 91.7 & 0.28 & $40.3 \pm 2.2$ & $37.7 \pm 2.6$ & $41.7 \pm 3.6$ & $291.5 \pm 9.6$ \\
\hline CC545 & MA-Mangaturuturu & 8 & 91.6 & 1.33 & $38.4 \pm 2.4$ & $35.9 \pm 2.6$ & $40.7 \pm 4.6$ & $290.0 \pm 10.9$ \\
\hline $\mathrm{CC} 470$ & MA-Mangaturuturu & 10 & 99.4 & 0.96 & $41.3 \pm 1.8$ & $41.2 \pm 2.0$ & $42.9 \pm 4.2$ & $292.9 \pm 6.7$ \\
\hline $\mathrm{CC} 140$ & MA-Mangaehuehu & 11 & 100.0 & 0.52 & $41.8 \pm 1.8$ & $41.2 \pm 2.0$ & $44.6 \pm 4.0$ & $293.3 \pm 3.3$ \\
\hline CC313 & MA-Te Kohatu & 10 & 70.5 & 1.73 & $42.6 \pm 1.8$ & $39.5 \pm 1.4$ & $49.6 \pm 7.0$ & $273.3 \pm 25.8$ \\
\hline $\mathrm{CC} 127$ & MA-Mangaehuehu & 11 & 84.4 & 0.66 & $42.8 \pm 1.0$ & $43.9 \pm 1.0$ & $42.9 \pm 2.2$ & $295.1 \pm 5.9$ \\
\hline $\mathrm{CC} 216$ & MA-Mangaehuehu & 12 & 100.0 & 1.32 & $43.1 \pm 1.4$ & $43.8 \pm 1.4$ & $41.5 \pm 2.6$ & $298.1 \pm 4.3$ \\
\hline $\mathrm{CC} 119$ & MA-Mangaehuehu & 11 & 100.0 & 1.46 & $43.3 \pm 1.6$ & $42.6 \pm 1.6$ & $45.3 \pm 2.4$ & $292.7 \pm 3.1$ \\
\hline CC552 & MA-Mangaturuturu & 6 & 91.8 & 0.68 & $43.4 \pm 2.4$ & $45.1 \pm 3.0$ & $41.9 \pm 6.0$ & $300.0 \pm 20.7$ \\
\hline $\mathrm{CC} 081$ & MA-Mangaehuehu & 11 & 86.7 & 1.17 & $44.2 \pm 1.8$ & $46.8 \pm 1.8$ & $41.9 \pm 6.2$ & $300.6 \pm 15.6$ \\
\hline $\mathrm{CC} 453$ & MA-Ngahuinga & 10 & 96.7 & 1.43 & $44.8 \pm 3.0$ & $45.4 \pm 2.8$ & $45.8 \pm 5.8$ & $294.3 \pm 5.9$ \\
\hline $\mathrm{CC} 089$ & MA-Mangaehuehu & 11 & 96.9 & 1.72 & $45.4 \pm 2.0$ & $46.0 \pm 1.6$ & $47.2 \pm 8.0$ & $293.2 \pm 10.2$ \\
\hline CC562 & WA & 6 & 83.7 & 0.51 & $88.1 \pm 6.4$ & $85.2 \pm 9.0$ & $85.0 \pm 19.4$ & $296.9 \pm 10.5$ \\
\hline CC350 & WA & 10 & 100.0 & recoil & $95.9 \pm 7.0$ & $95.5 \pm 4.2$ & $98.6 \pm 16.8$ & $293.8 \pm 9.3$ \\
\hline CC209 & WA & 10 & 98.9 & 0.75 & $120.7 \pm 4.0$ & $119.5 \pm 5.0$ & $123.6 \pm 5.4$ & $293.8 \pm 2.5$ \\
\hline $\mathrm{CC} 213$ & WA & 11 & 54.2 & 1.25 & $121.4 \pm 2.8$ & $122.2 \pm 2.4$ & $123.7 \pm 16.0$ & $292.2 \pm 25.2$ \\
\hline CC375 & WA & 10 & 89.2 & 1.64 & $121.7 \pm 4.2$ & $119.6 \pm 3.4$ & $125.8 \pm 9.8$ & $292.2 \pm 9.2$ \\
\hline $\mathrm{CC} 197$ & WA & 11 & 97.2 & 0.72 & $133.6 \pm 6.4$ & $136.0 \pm 6.8$ & $138.1 \pm 13.6$ & $293.6 \pm 5.7$ \\
\hline CC518 & $\mathrm{TH}$ & 10 & 100.0 & 0.36 & $158.8 \pm 8.2$ & $157.6 \pm 9.6$ & $158.9 \pm 13.4$ & $295.3 \pm 7.5$ \\
\hline CC322 & $\mathrm{TH}$ & 10 & 99.1 & 2.02 & $169.4 \pm 7.8$ & $171.0 \pm 6.0$ & $176.4 \pm 17.2$ & $291.0 \pm 10.7$ \\
\hline $\mathrm{CC} 276$ & $\mathrm{TH}$ & 12 & 94.5 & 0.86 & $174.6 \pm 3.4$ & $171.0 \pm 5.8$ & $169.2 \pm 7.2$ & $300.9 \pm 7.3$ \\
\hline CC348 & TH & 10 & 81.5 & 1.00 & $186.2 \pm 6.8$ & $173.1 \pm 7.2$ & $203.3 \pm 22.4$ & $287.7 \pm 11.5$ \\
\hline CC306 & $\mathrm{TH}$ & 10 & 100.0 & recoil & $187.9 \pm 34.4$ & $146.6 \pm 11.4$ & $207.5 \pm 22.2$ & $289.8 \pm 2.9$ \\
\hline
\end{tabular}

Formation abbreviations are: WH (Whakapapa); MA (Mangawhero); WA (Wahianoa); TH (Te Herenga). $\mathrm{N}$ is number of heating steps, $\%{ }^{39} \mathrm{Ar}$ is the proportion of released radiogenic gas, and MSWD is the mean standard weighted deviation of each age plateau calculation. Bold numbers are the preferred ages for each sample, which are all mean weighted plateau ages, except for CC545 where the isochron age was preferred.

Figure A4.1. Sample sheets for ${ }^{40} \mathrm{Ar} /{ }^{39} \mathrm{Ar}$ geochronology data. All sample sheets are provided on the following pages. 

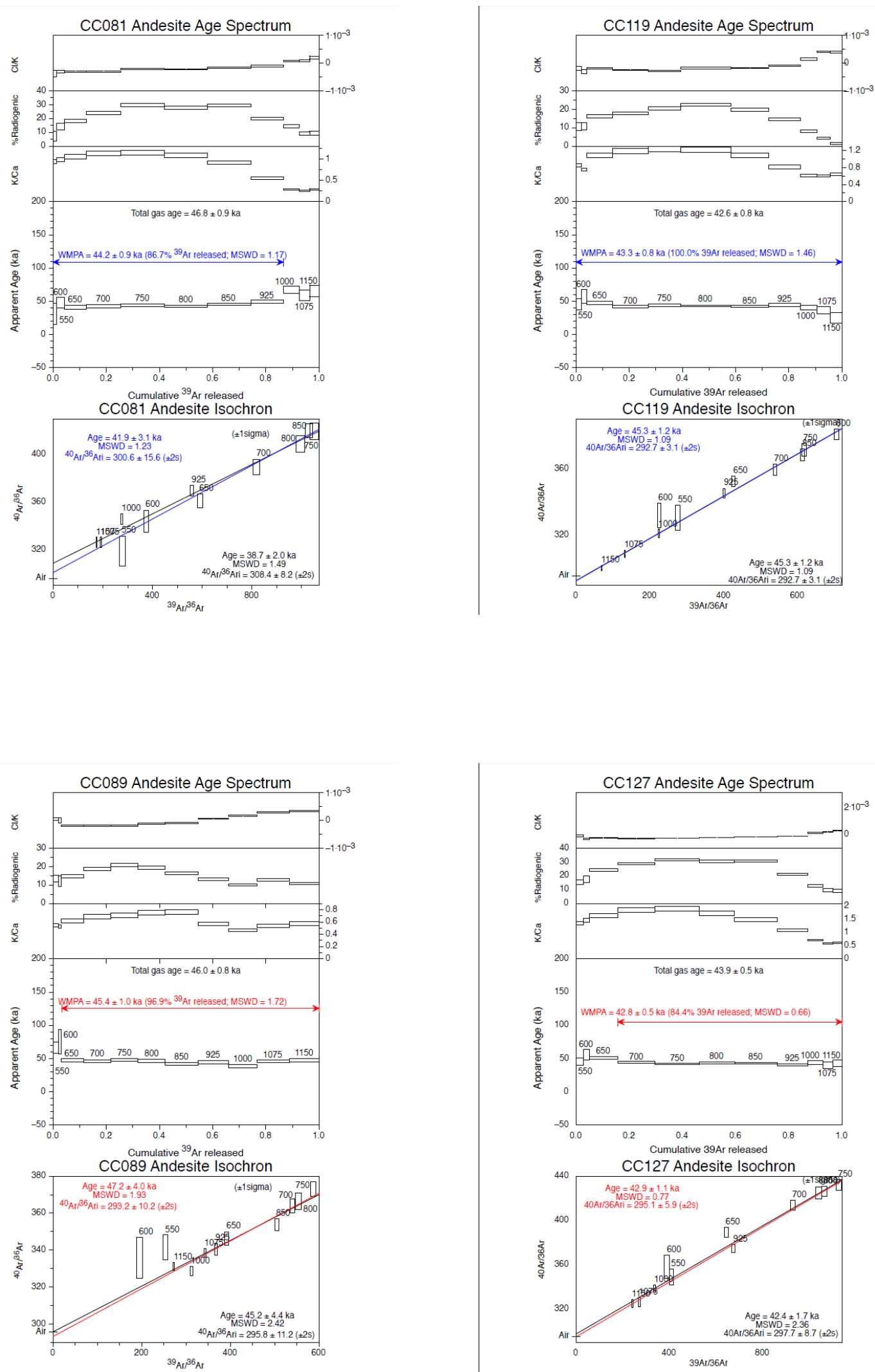

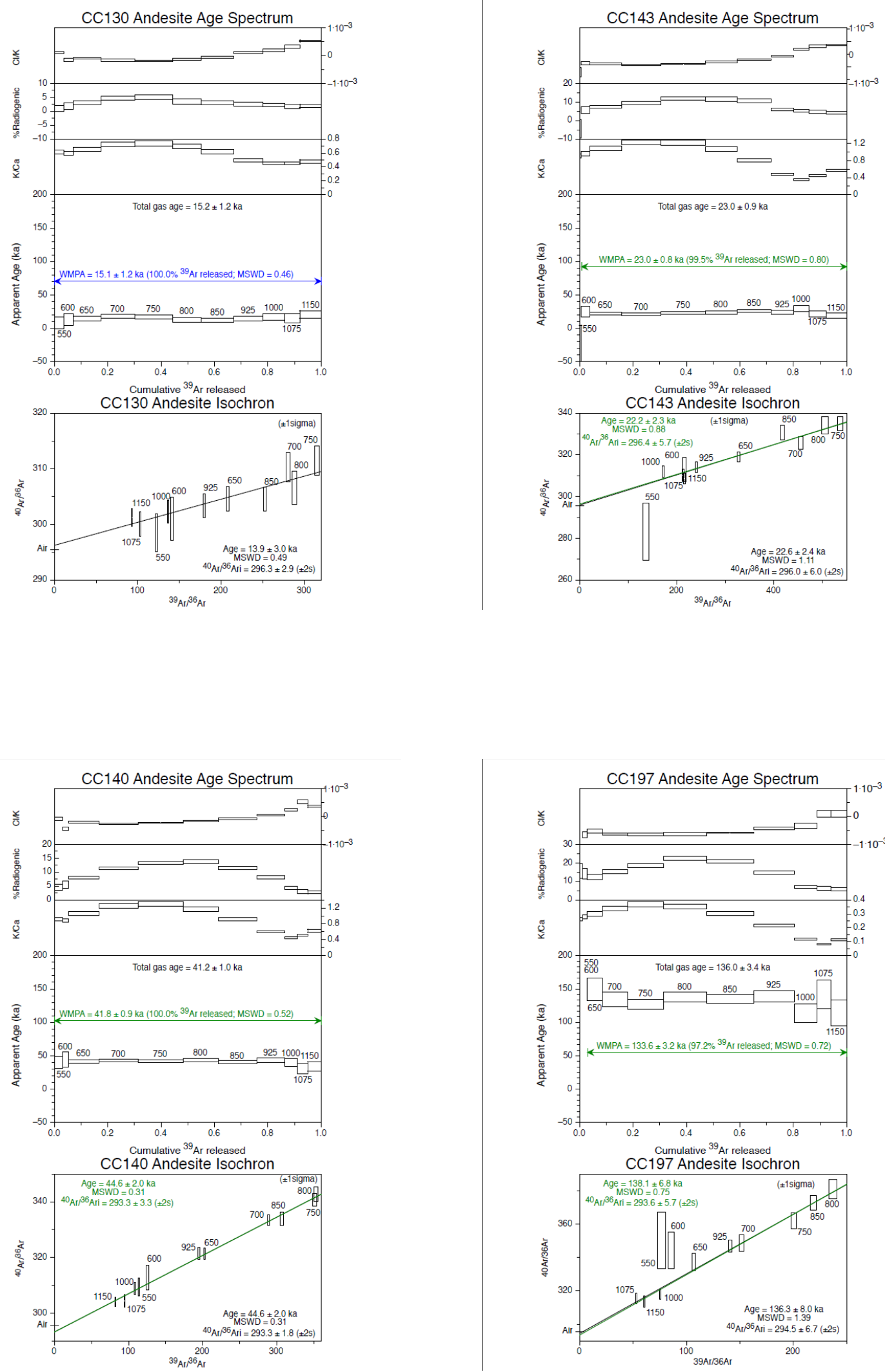

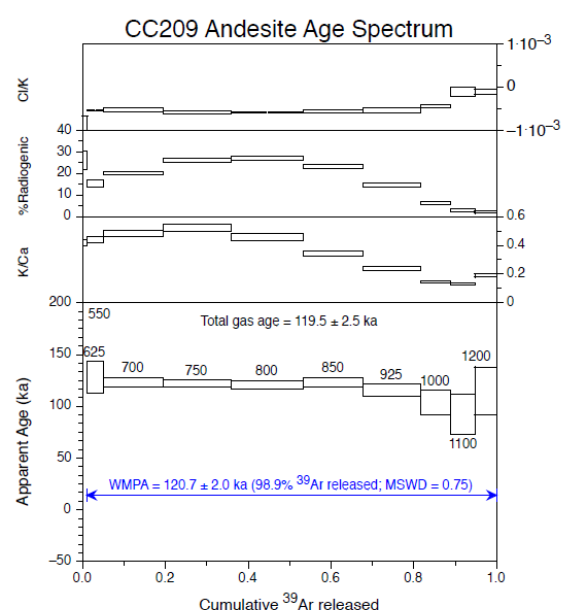
C2209 Andesite Isochron
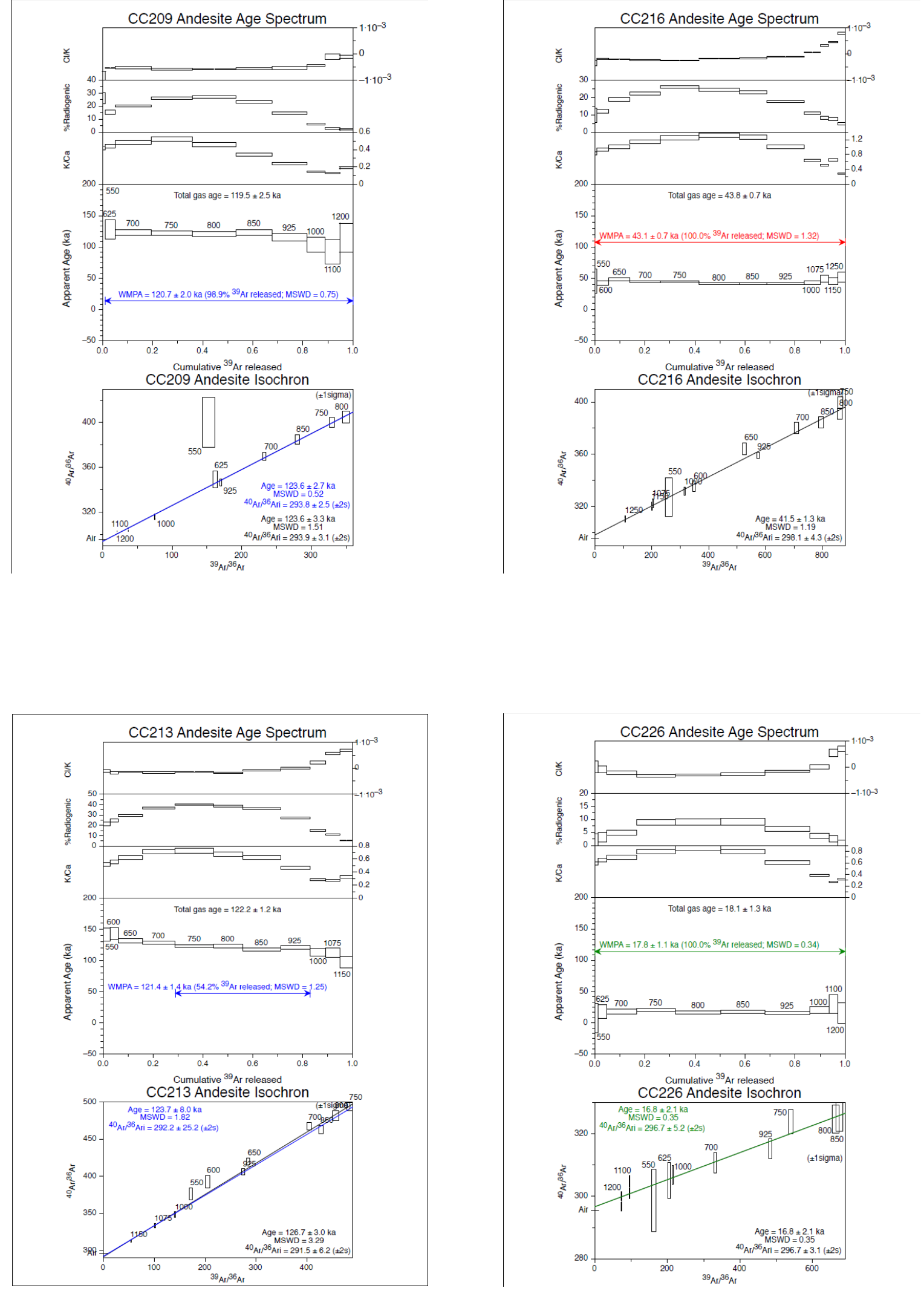

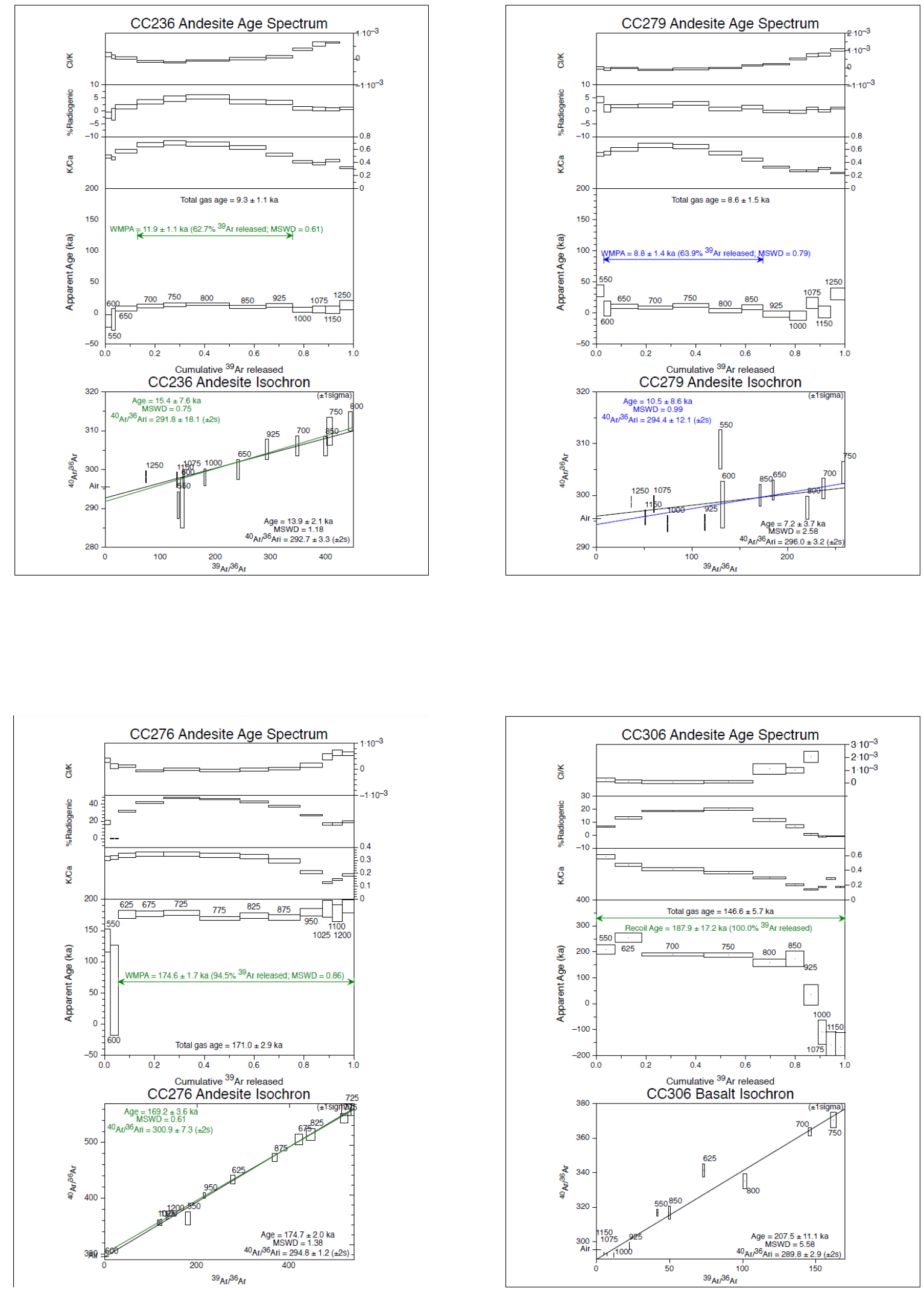

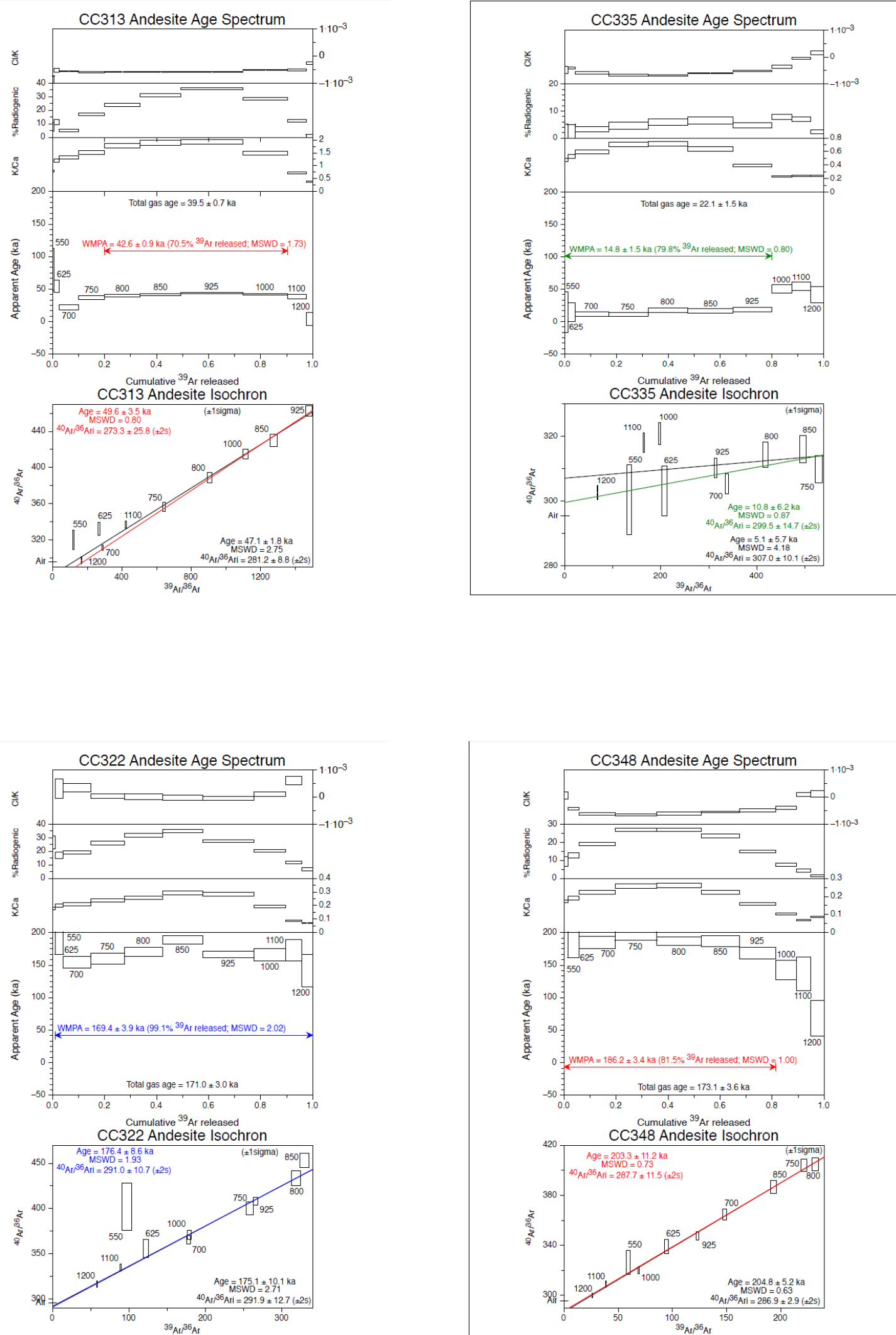

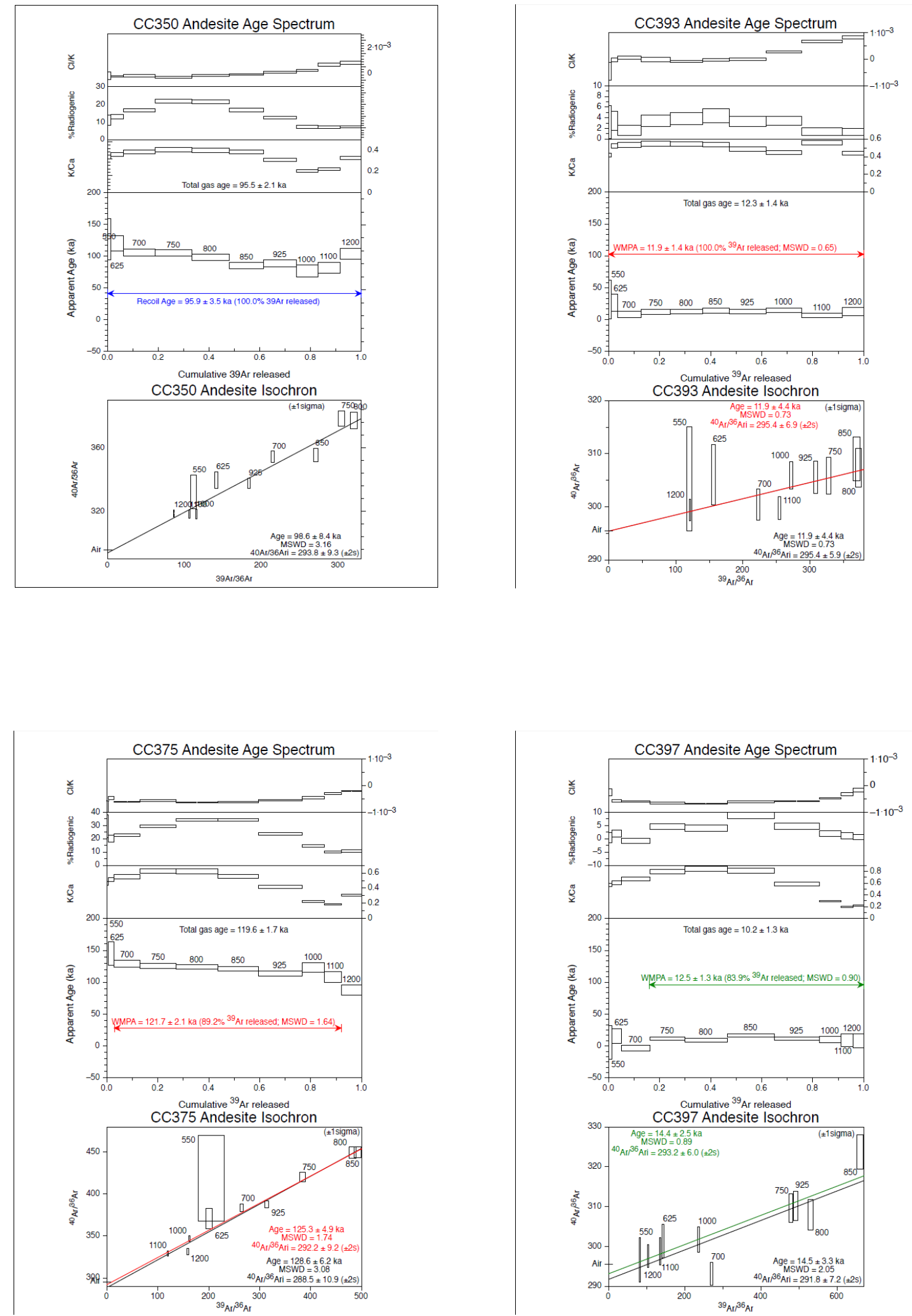

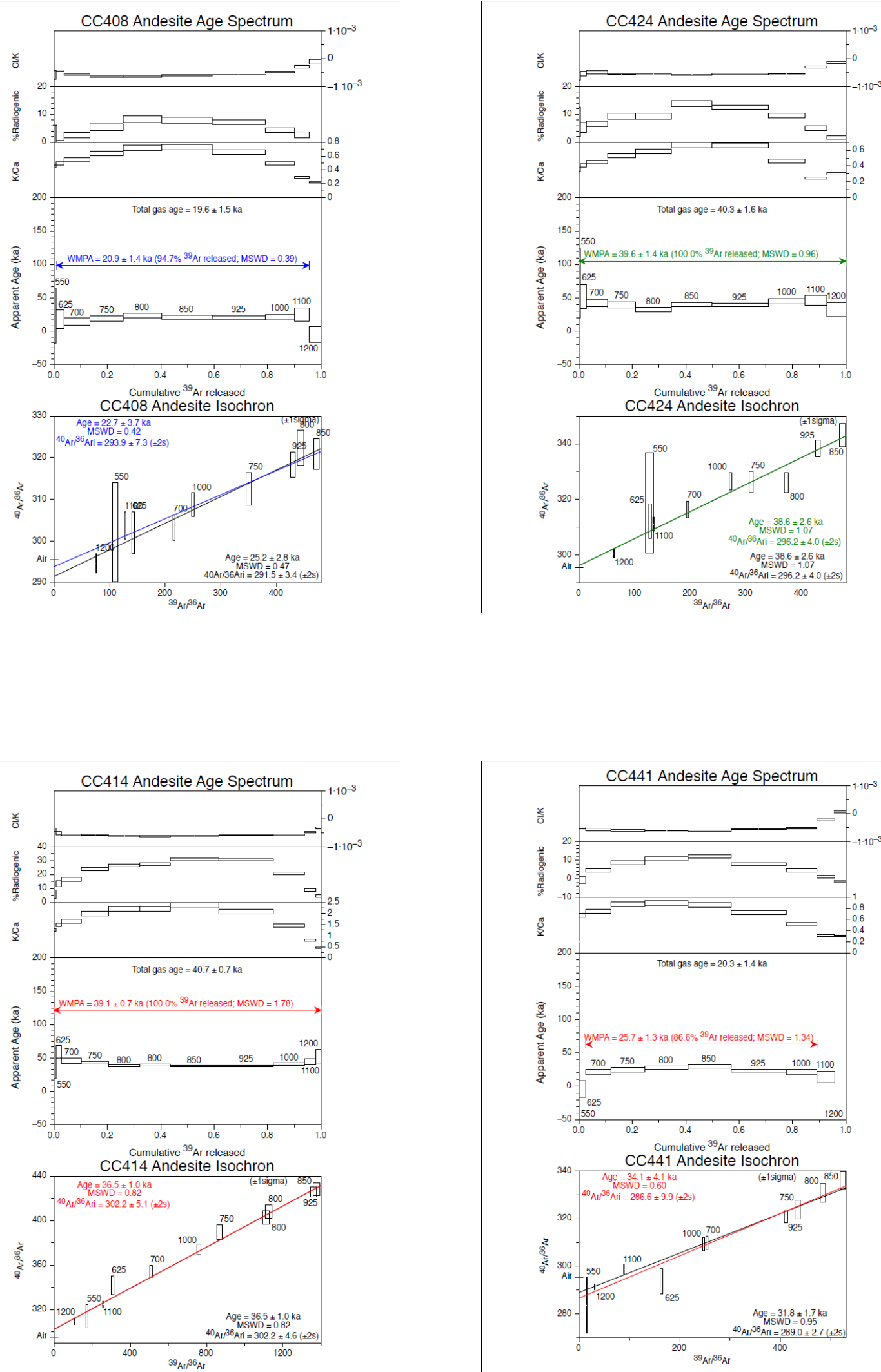

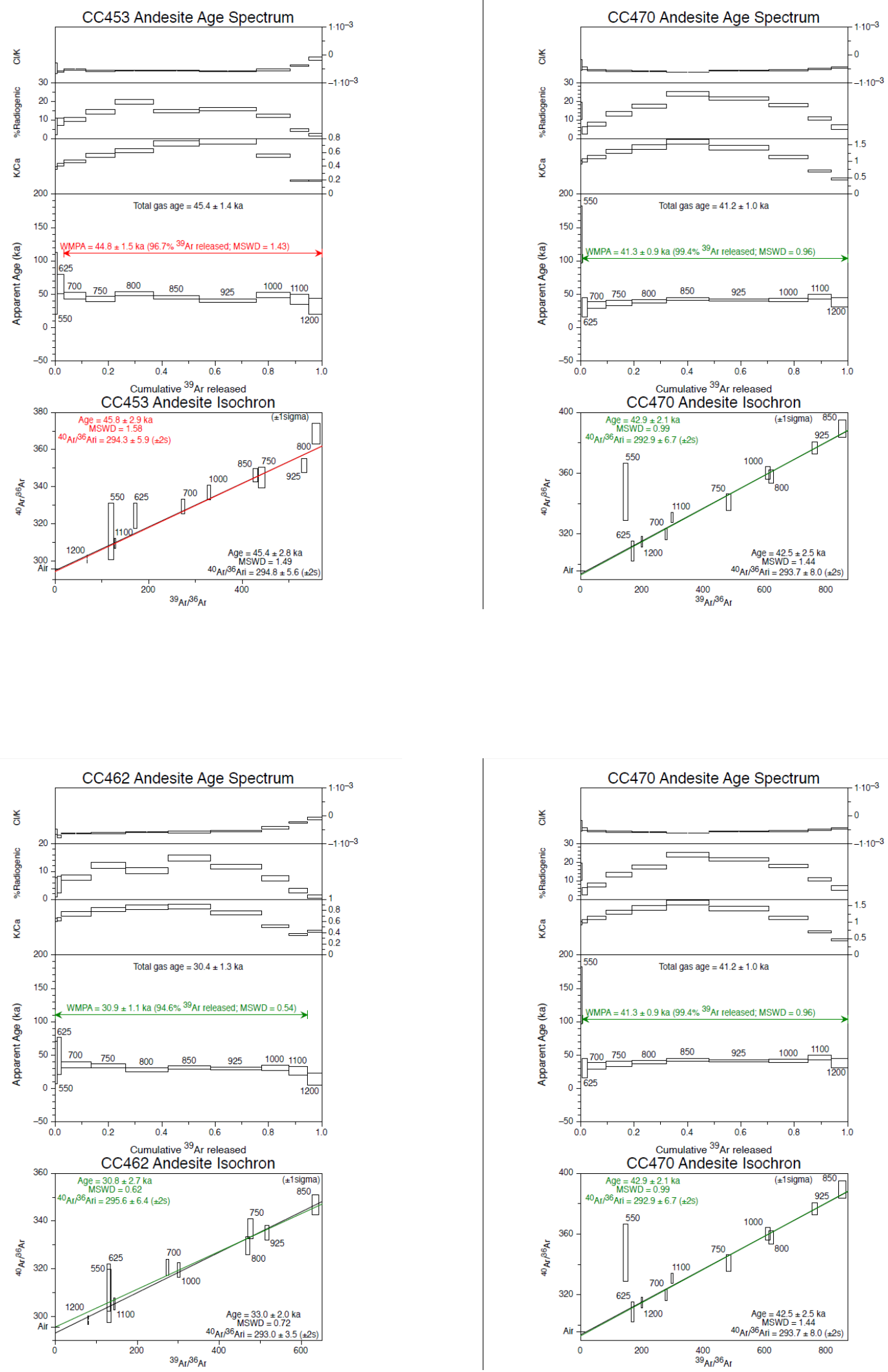

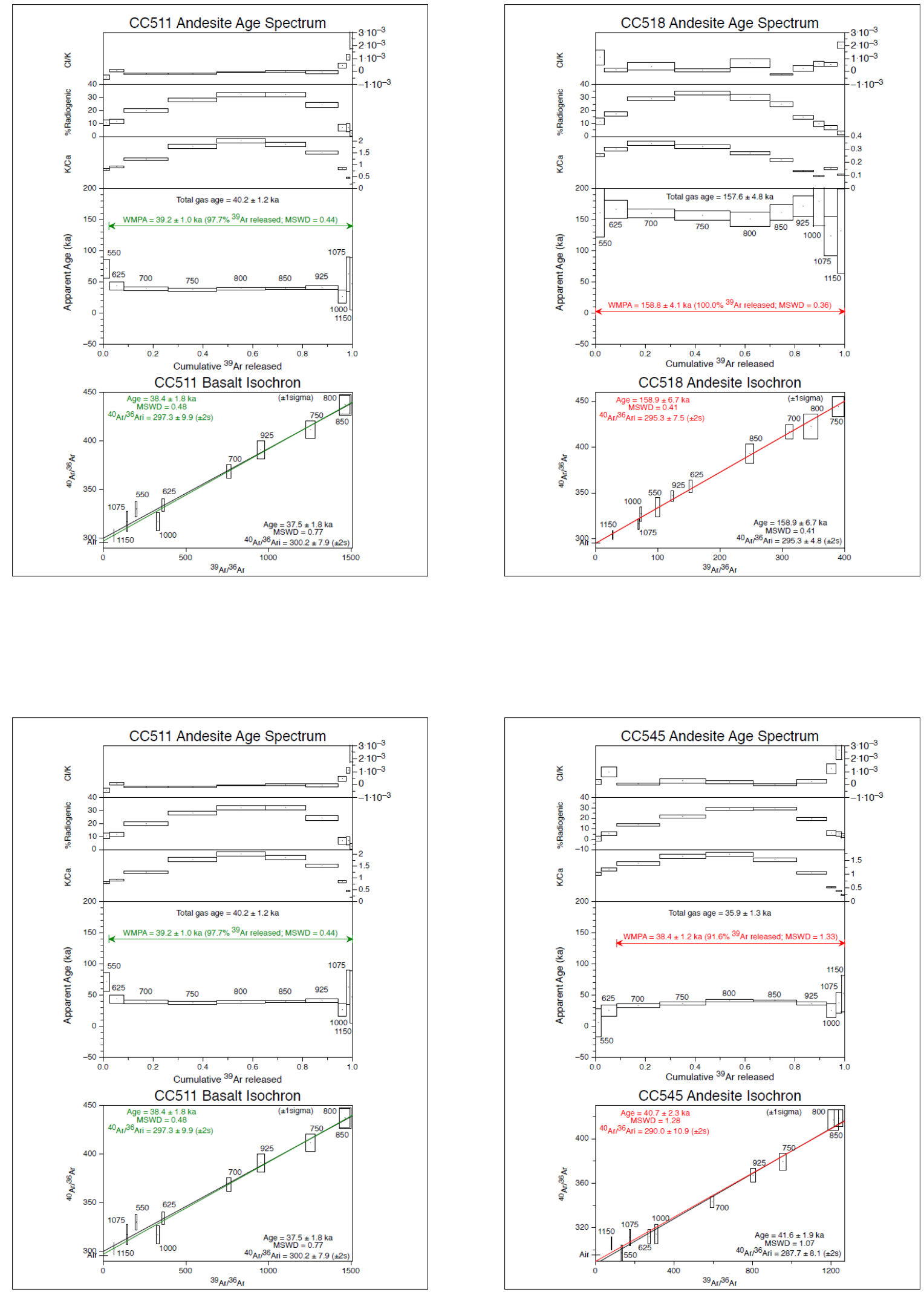

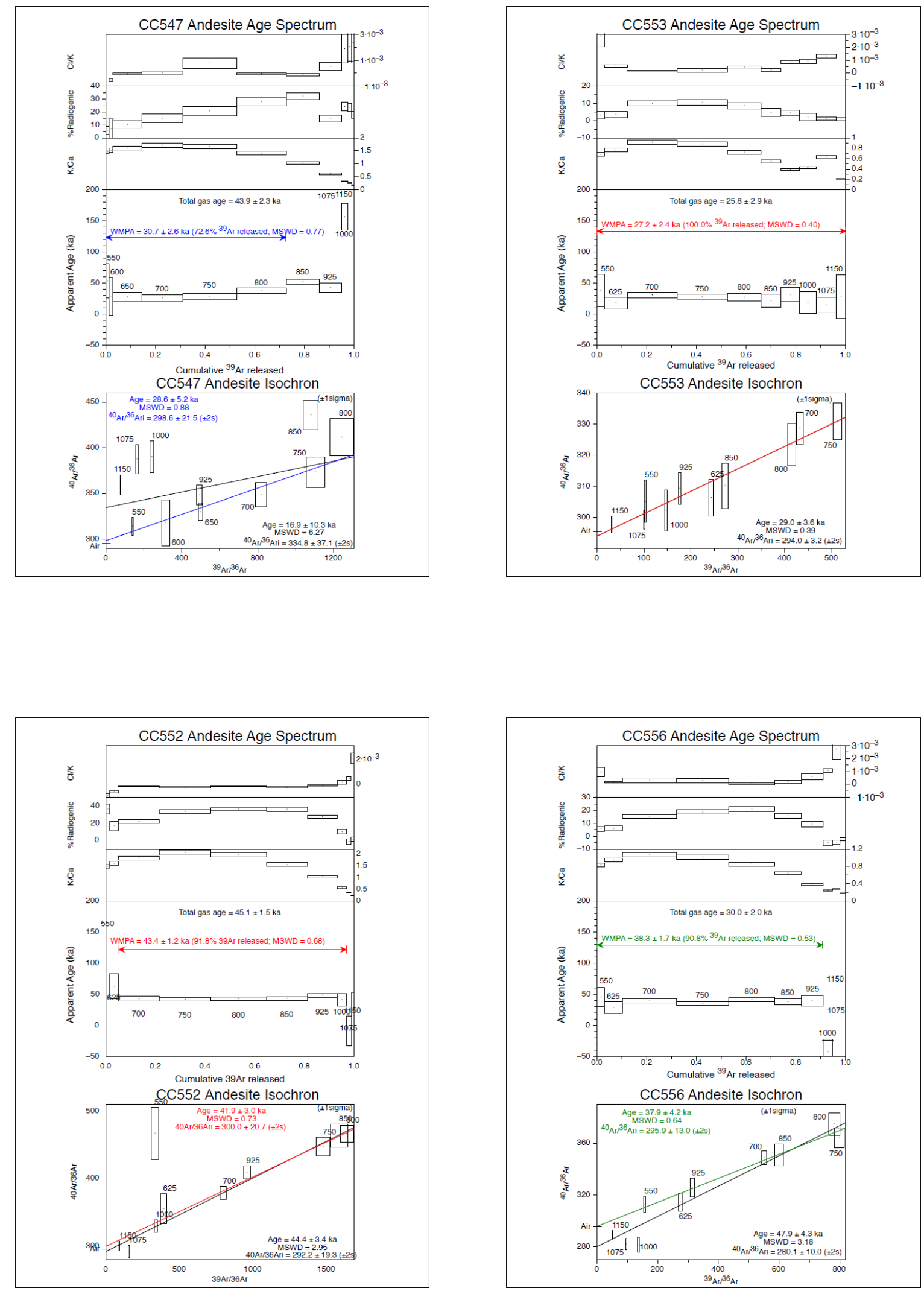

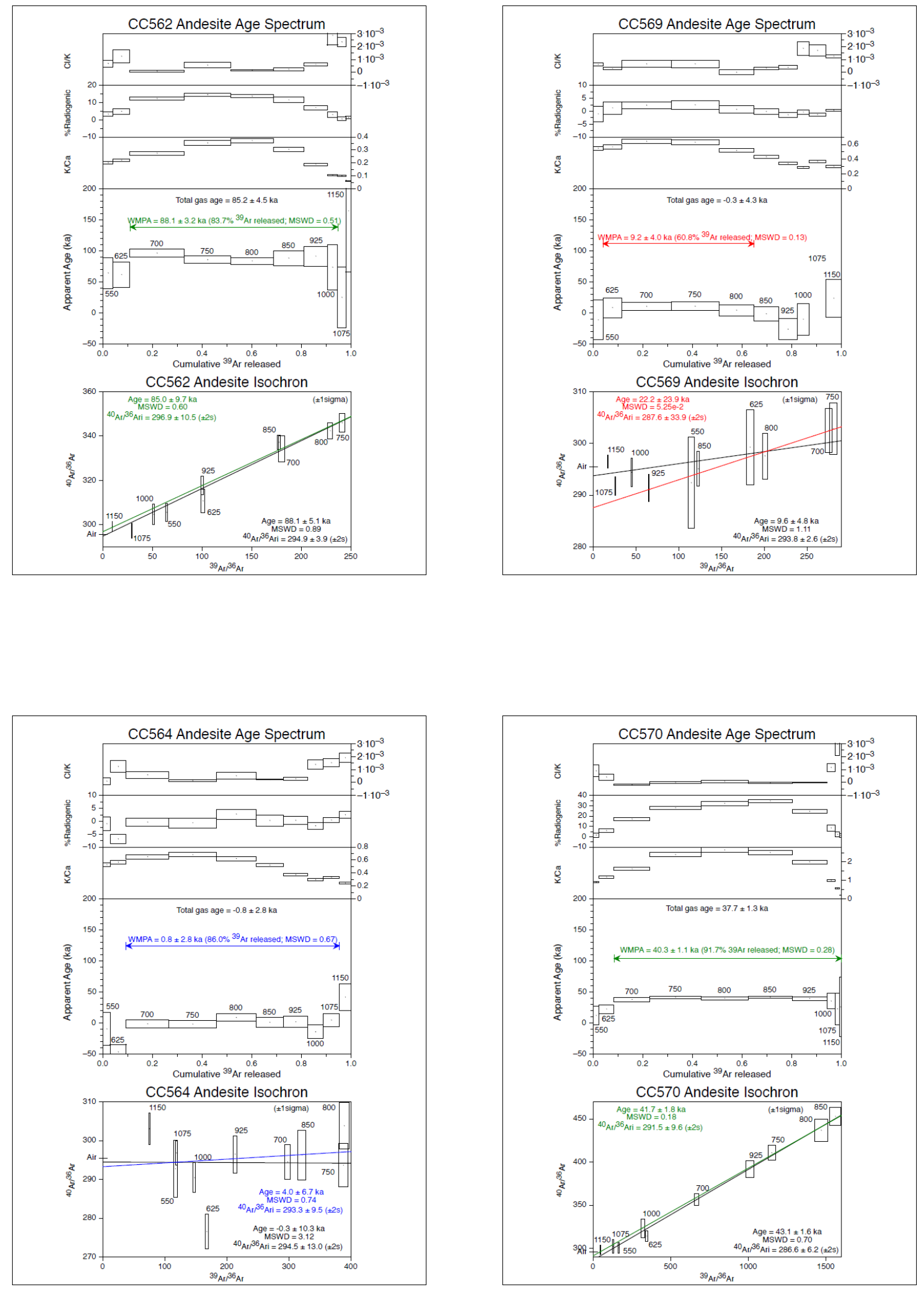


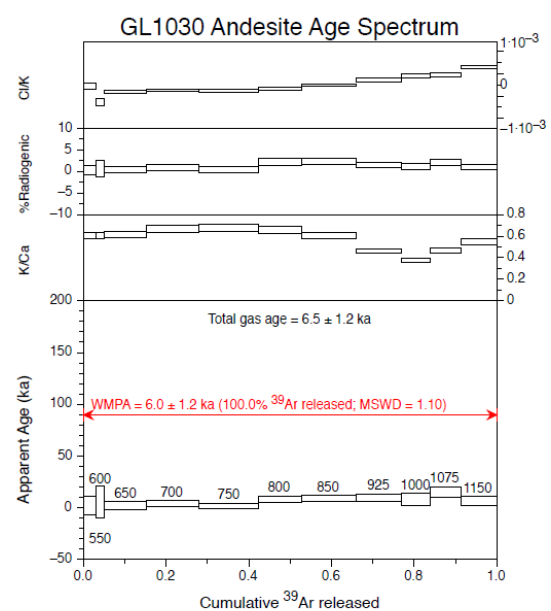

GL1030 Andesite Isochron

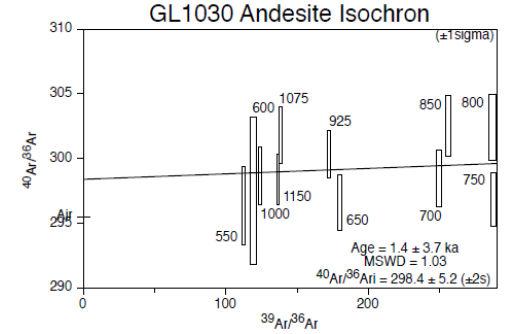

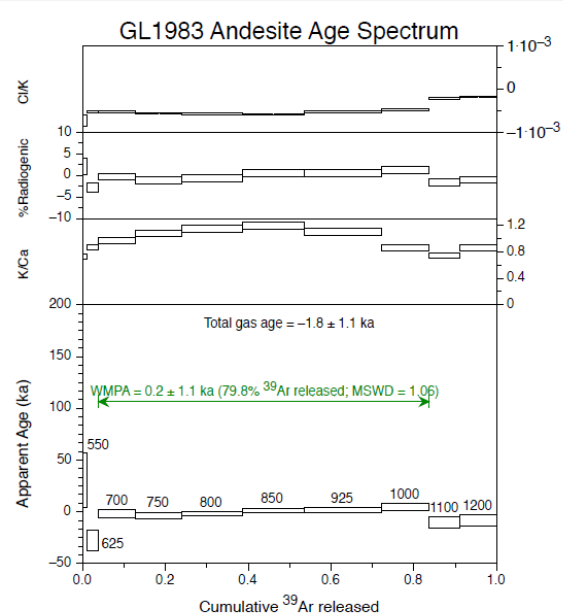

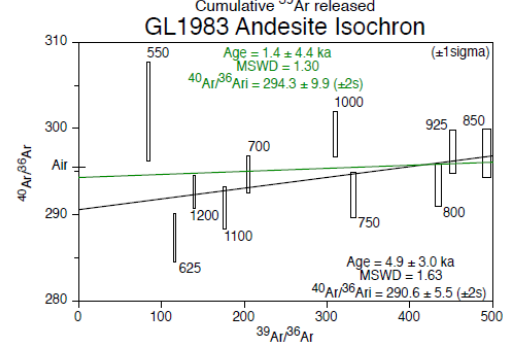




\section{Appendix 5. Whole-rock XRF standard data}

Lava samples were crushed and then milled using an agate or tungsten-carbide ring mill to form a whole-rock powder. Up to $400 \mathrm{mg}$ of material was powdered for each sample, from which a homogeneous aliquot was used for analysis.

Major element compositions for 238 whole-rock powder samples were determined using an $\mathrm{ARL}^{\circledR} 8420+$ dual goniometer wavelength dispersive X-ray fluorescence (XRF) spectrometer at the Open University, U.K. Fused lithium metaborate glass discs were prepared for each powder and analysed following the methods of Ramsey et al. (1995). Glass disks were formed by mixing 1 part by weight $(0.70 \mathrm{~g})$ of rock powder (dried at 110 ${ }^{\circ} \mathrm{C}$ ) with 5 parts by weight of dried lithium metaborate flux and fusing in a muffle furnace for 15 minutes at $1100{ }^{\circ} \mathrm{C}$ in $95 \% \mathrm{Pt}-5 \%$ Au crucibles. Loss-on-ignition (LOI) measurements were undertaken on dried rock powders by heating in a pre-ignited aluminium crucible to $1000{ }^{\circ} \mathrm{C}$ for $1 \mathrm{hr}$ and recording percentage weight loss. John Watson prepared the discs and undertook the XRF analyses. In addition to major oxides, concentrations were measured for trace elements $\mathrm{Ba}, \mathrm{Cr}$ and $\mathrm{Ni}$.

Internal standards WS-E (Whin Sill Dolerite) and OU-3 were analysed repeatedly throughout analysis sessions. Approximate 2 standard deviation ( $2 \mathrm{sd})$ analytical precisions are $<2$ relative $\%$ for major oxides (excepting those with concentrations $<0.5$ wt. \%) for the 22 replicate analyses of each standard. There is a close agreement (generally within $\sim 1 \%$ offset) between average values for the repeated standard analyses and recommended values for each element. Trace element analyses were accurate to $<4 \%$ for WS-E and relative 2 sd precisions are 5-7\%. Standard data for analyses of WS-E and OU-3 are provided in Tables A5.1 and A5.2.

Duplicate analyses of samples were undertaken during separate sessions to monitor instrument accuracy and check the homogeneity of sample powders and reliability of their preparation procedures (Table A5.3). Duplicate analyses yielded results that were accurate to within $\sim 2 \%$ offset of each other. Trace element analyses were accurate to $<6$ $\%$ for duplicate analyses, except $\mathrm{Ni}(<12 \%)$.

Full sample data are provided in the electronic appendix files. 


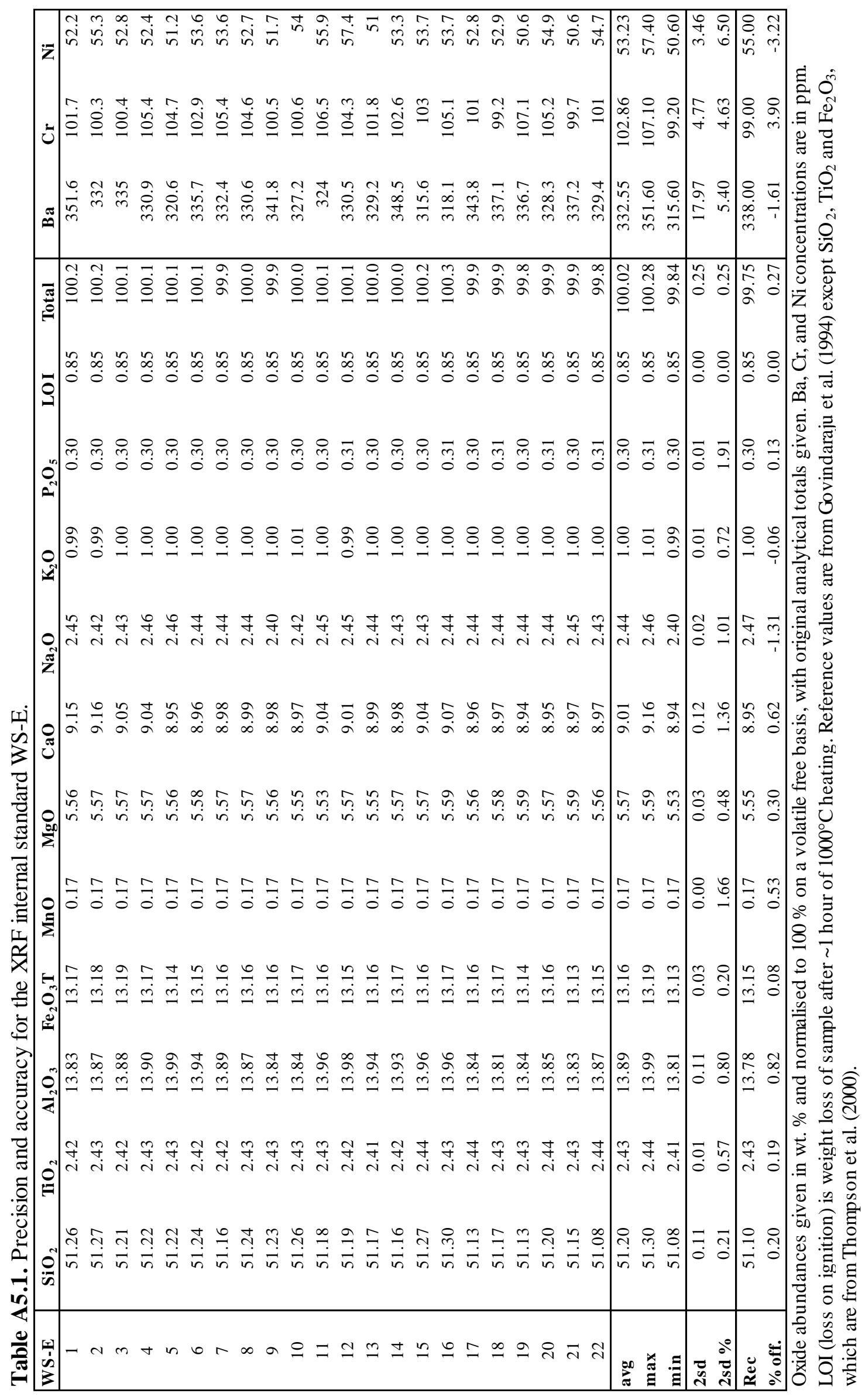




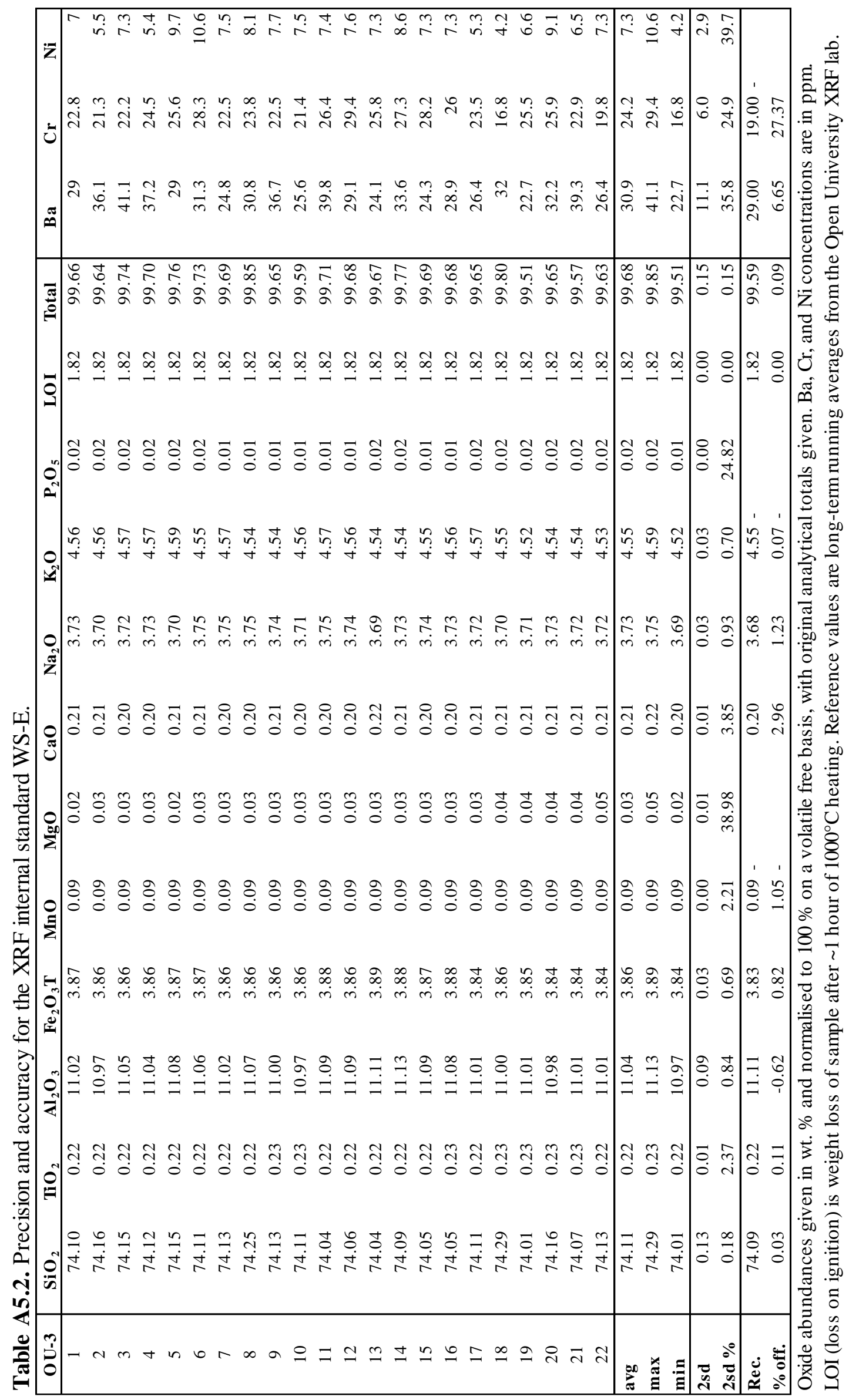




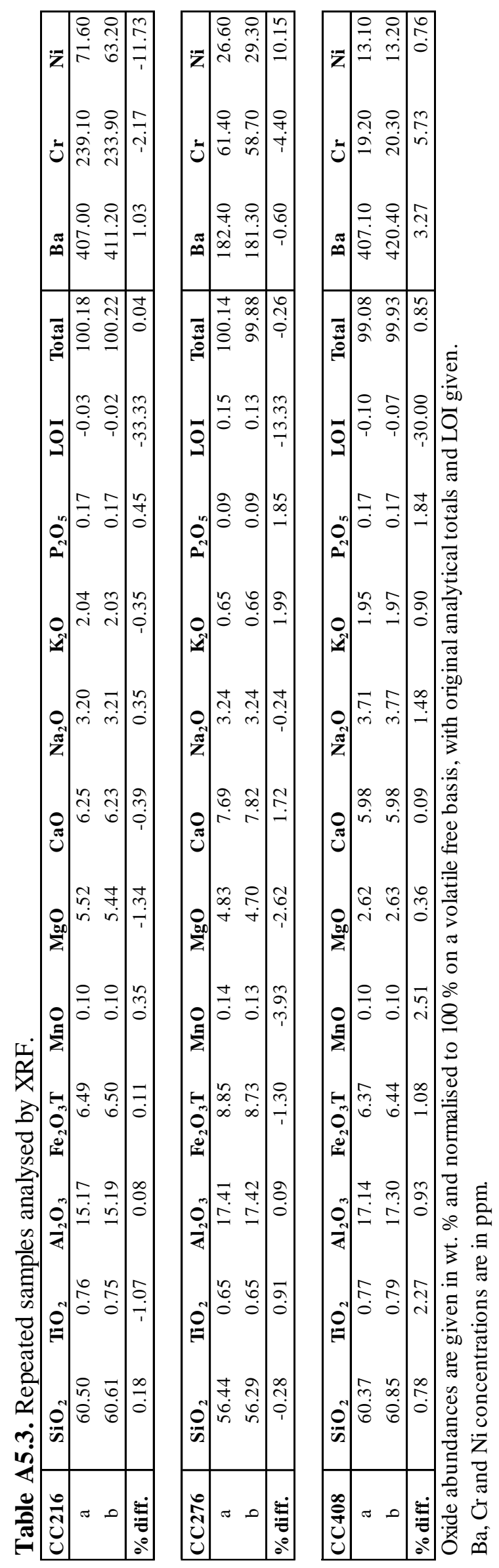




\section{Appendix 6. Whole-rock solution ICP-MS trace element standard data}

A subset of whole-rock powders were selected for trace element analysis. Samples were prepared for analysis in a PicoTrace Class 10 laminar flow workstation within the positively pressured ultra-clean chemical separation laboratory of the geochemistry facility at Victoria University of Wellington (VUW), New Zealand. SeaStar ${ }^{\mathrm{TM}}$ (SS) grade ultrapure acids (all key metals $<10 \mathrm{ppt}$ ) were used for trace element sample preparation. Analytical reagent (AR) grade acids, distilled to produce sub-boiled (SB) distilled acids were used in final stages of beaker preparation. Milli-Q water was used during beaker cleaning and acid dilution.

Aliquots of whole-rock powders prepared for XRF major element analysis were taken for trace element analysis. Approximately $50 \mathrm{mg}$ of sample was weighed on a high-precision balance to $\pm 0.0001 \mathrm{~g}$ in pre-cleaned $23 \mathrm{~mL}$ Savillex screw-top Teflon beakers. Samples and international reference materials were dissolved by conventional digestion methods using $\sim 2 \mathrm{~mL}$ concentrated hydrofluoric acid (29 M HF) and $0.5 \mathrm{~mL} \mathrm{HNO} 3\left(16 \mathrm{M} \mathrm{HNO}_{3}\right)$ in sealed beakers heated on a hotplate to $120^{\circ} \mathrm{C}$ for 3-4 days. Once the sample was completely digested, the solution was evaporated to incipient dryness, refluxed twice in $\sim 2 \mathrm{~mL}$ of concentrated $\mathrm{HNO}_{3}$ and evaporated again to incipient dryness. The sample cake was then refluxed in $\sim 5 \mathrm{~mL}$ of $6 \mathrm{M} \mathrm{HCl}$ overnight and the solution was checked to make sure the sample had completely dissolved. The $\mathrm{HCl}$ was evaporated and the sample cake was taken up again in $\sim 2 \mathrm{~mL}$ of concentrated $\mathrm{HNO}_{3}$ for two days. The sample was once again evaporated and then taken up in $9 \mathrm{~mL}$ of $1 \mathrm{M} \mathrm{HNO}_{3}$ to reflux for a further 2-3 days to form a final solution. The final solution was carefully and completely transferred from beakers into pre-cleaned $10 \mathrm{~mL}$ polyethylene centrifuge tubes and weighed on a highprecision balance. To form a dilution of the sample. A $50 \mu \mathrm{L}$ aliquot was transferred into another clean $10 \mathrm{~mL}$ centrifuge tube and weighed. The tube was then topped up with $\sim 9$ $\mathrm{mL}$ of $1 \% \mathrm{HNO}_{3}$ and weighed again so that a final dilution of the sample could be accurately calculated.

Whole-rock trace element analysis was carried out by solution inductively coupled plasma mass spectrometry (ICP-MS), using a Thermo-Fisher Element2 sector-field ICPMS equipped with an ESCI auto sampler at VUW using methods similar to those of Eggins et al. (1997). In this study ${ }^{43} \mathrm{Ca}$ was used for an internal correction, as $\mathrm{CaO}$ concentrations of sample powders had previously been determined to $\pm 2 \%$ by XRF. This method allows correction for any major changes or inconsistencies, which may be caused by sample loss during sample preparation. The ICP-MS was tuned using a $10 \mathrm{ppb}$ multi element standard diluted to $1 \mathrm{ppb}$, where instrumental conditions such as torch position and carrier/make-up gas flow were adjusted to achieve the lowest relative standard deviation (RSD), typically $<1-2 \%$, and to optimise sensitivity. This step was then repeated for the calibration standard, BHVO-2. Oxide generation was monitored during the tuning procedure using measured $\mathrm{UO}^{+} / \mathrm{U}^{+}$ratios $(<7 \%), \mathrm{BaO}^{+} / \mathrm{Ba}^{+}(<0.2 \%)$ and 
$\mathrm{Ba}^{++} / \mathrm{Ba}^{+}(<5 \%)$. To assess the quality of the data, multiple isotopes from some elements (e.g. ${ }^{90} \mathrm{Zr}$ and ${ }^{91} \mathrm{Zr}$ ) were included in the analysis, generally producing concentrations within $\pm 0.5 \%$. The Element 2 was operated at increased mass resolution for selected isotopes to resolve the elemental peak from common spectral interferences (e.g. ${ }^{45} \mathrm{Sc}$, ${ }^{47} \mathrm{Ti},{ }^{51} \mathrm{~V},{ }^{52} \mathrm{Cr},{ }^{59} \mathrm{Co},{ }^{60} \mathrm{Ni},{ }^{63} \mathrm{Cu},{ }^{66} \mathrm{Zn},{ }^{69} \mathrm{Ga}$ ) or to reduce counts in highly abundant isotopes (e.g. ${ }^{23} \mathrm{Na},{ }^{25} \mathrm{Mg},{ }^{27} \mathrm{Al},{ }^{43} \mathrm{Ca},{ }^{55} \mathrm{Mn}$ ). Each sample solution was measured for a total time of $240 \mathrm{~s}$. Prior to introduction of each sample the background counts were

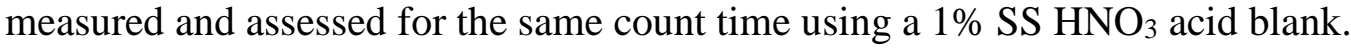

Following sample analyses, the auto sampler lines and ICP-MS were washed out in two consecutive rinse cycles in $1 \% \mathrm{SS} \mathrm{HNO}_{3}$ for $240 \mathrm{~s}$. Concentrations were calculated by sample-standard bracketing, thus the analysis sequence followed an order starting with the primary standard (BHVO-2), followed by 3 samples, the secondary standard (USGS standard BCR-2), and finishing back on the primary standard. Total procedural blanks for solution ICP-MS were within background count levels on all measured elements.

Trace element abundances in samples were calculated relative to the bracketing standard (BHVO-2) according to equations 1 and 2:

\section{Sample $C_{i}=\left(\right.$ Sample $\left._{C P S} / \mathrm{BHVO}_{\mathrm{CPS}}\right) \times\left(\right.$ Sample $\left._{\text {Dil }} / \mathrm{BHVO}_{\text {Dil }}\right) \times C_{\text {ref }}$ \\ 2. Sample $C_{i}($ Ca corrected $)=e q .1 \cdot x\left(C_{C a X R F} / C_{C a}\right.$ ICP-MS $)$}

Where $C_{i}, C_{r e f}$ and $C_{C a}$ are the concentrations of the measured isotope, the reference value for the bracketing standard and $\mathrm{Ca}$, respectively, the latter of which was determined by XRF and ICP-MS. Reference values for BHVO-2 were acquired from Georem preferred values (http://georem.mpch-mainz.gwdg.de/). $X_{D i l}$ is the concentration of material in the aliquot dilution.

International standard BCR-2 was analysed throughout analysis sessions in order to monitor the precision and accuracy of data acquired by solution ICP-MS (Table A6.1). Approximate $2 \mathrm{sd}$ analytical precisions calculated from 18 replicate analyses of BCR-2 are $<13$ relative $\%$ for all elements (most are $\sim 8-10 \%)$ except $\mathrm{Nb}(\sim 24 \%)$. Analyses of BCR-2 are accurate to within $5 \%$ of preferred values for all elements (most are within 1$2 \%)$, except $\mathrm{Cr}, \mathrm{U}(\sim 6 \%), \mathrm{Cu}(\sim 18 \%)$ and $\mathrm{Ni}(\sim 30 \%)$. The bulk powder (TPI) of a single large clast from Taupo ignimbrite was used as an additional secondary standard throughout analysis sessions. Approximate 2 sd analytical precisions calculated from 8 replicate analyses of TPI are 5-10 relative \% for most elements (Table A6.2) Separate dilutions from the same sample powders were also analysed to monitor reliability of the sample preparation procedure and homogeneity of powders. Values of 5-10\% offset for all elements from analyses of duplicate digestions further indicate high levels of reproducibility of the solution ICP-MS technique used in this study (Table A6.3). Sample data are displayed in Table A6.4. 


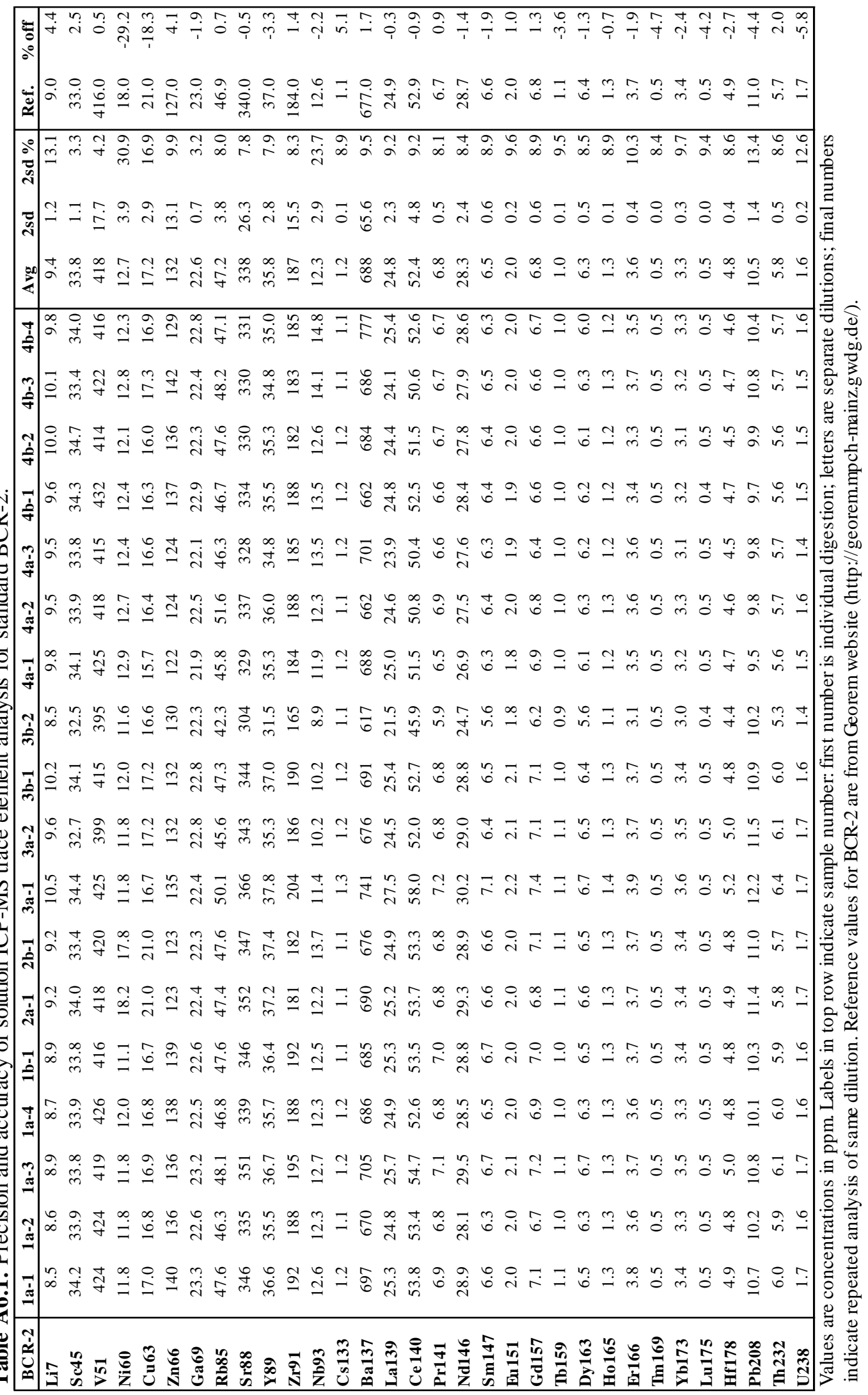




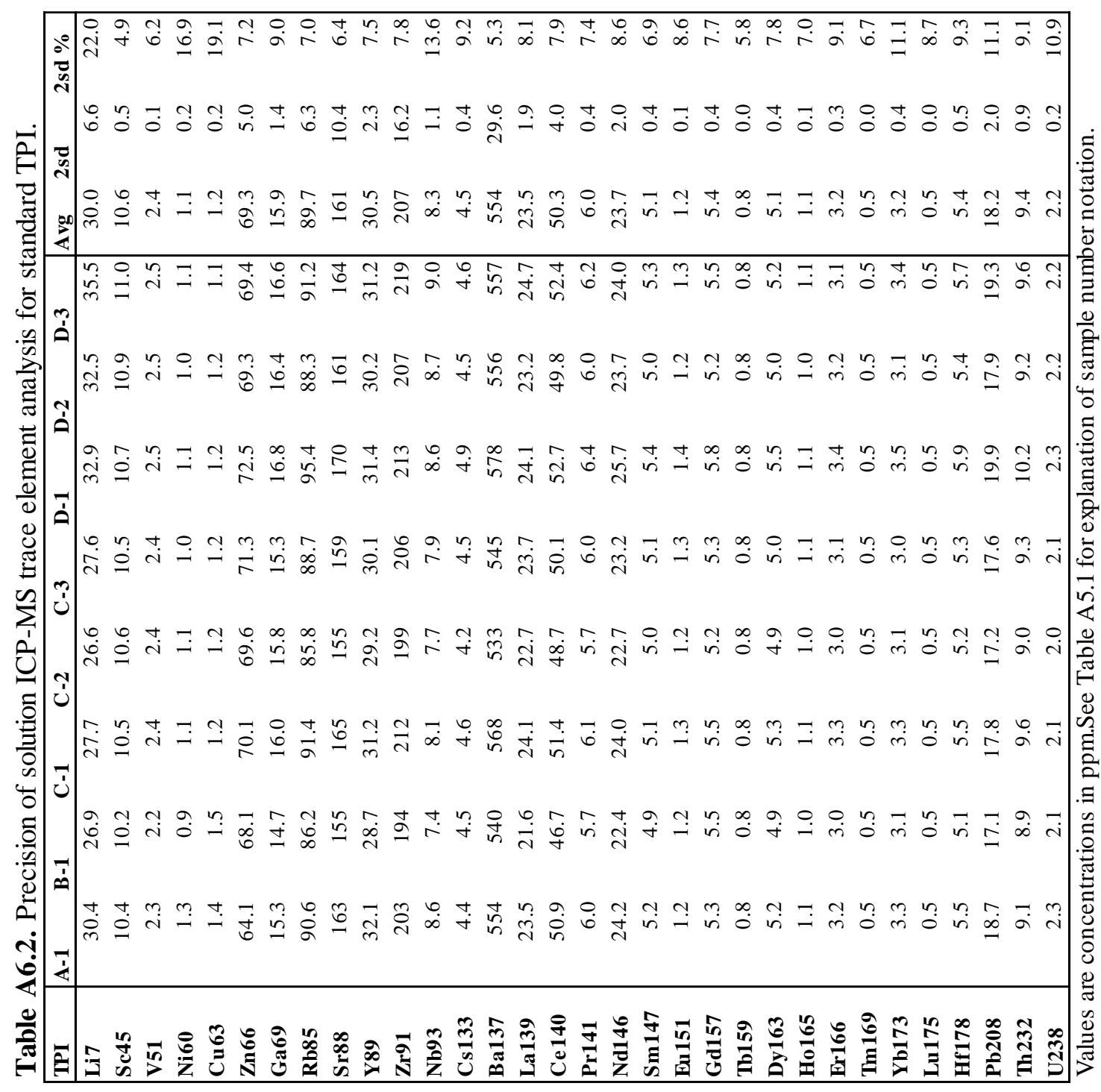




\begin{tabular}{|c|c|}
\hline & 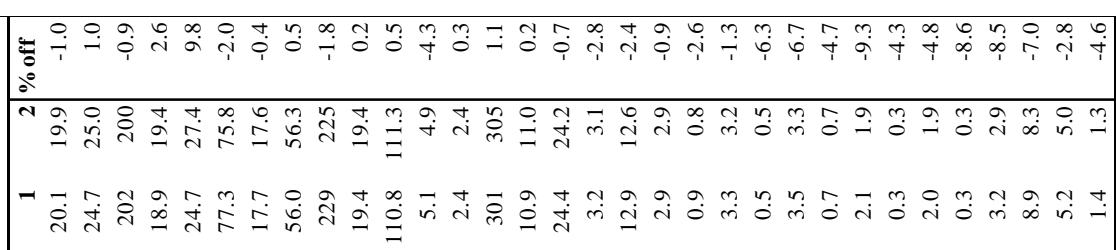 \\
\hline & 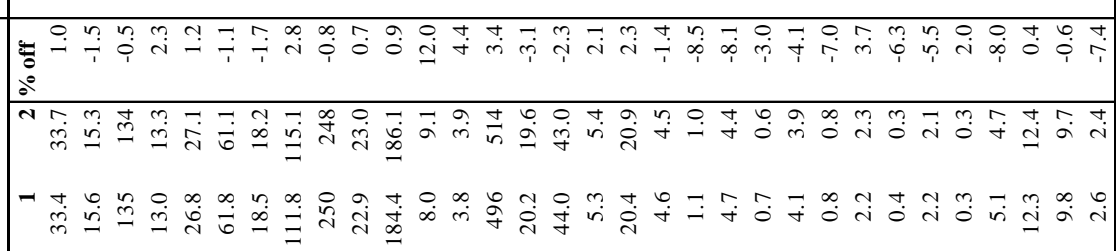 \\
\hline & 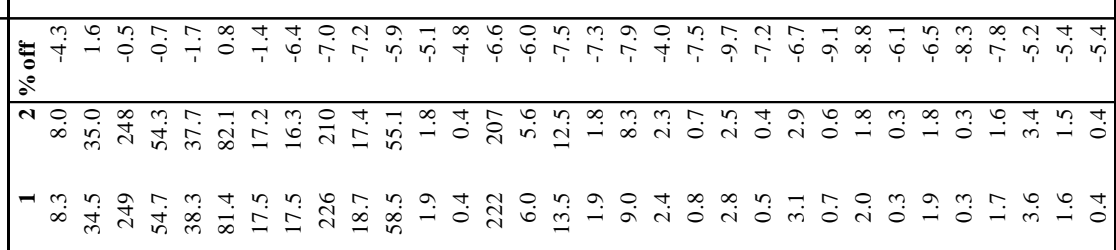 \\
\hline & 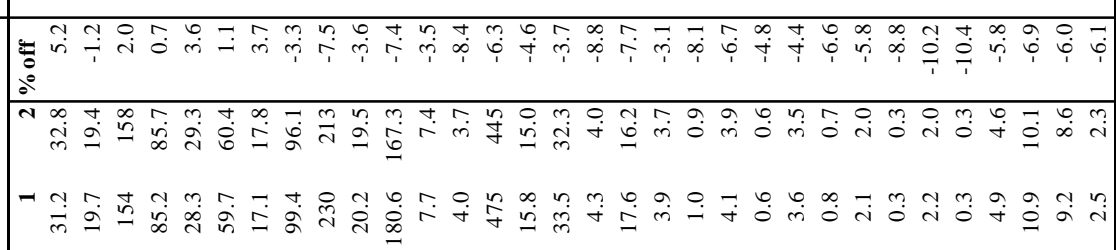 \\
\hline & 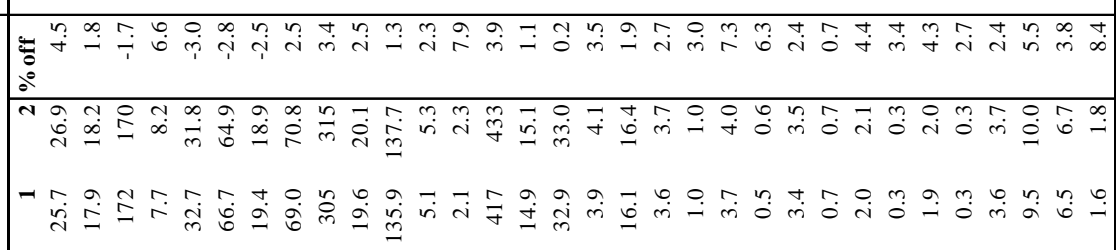 \\
\hline & 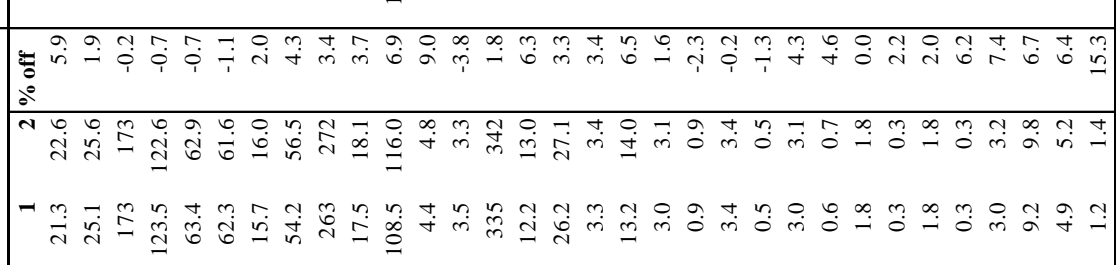 \\
\hline & 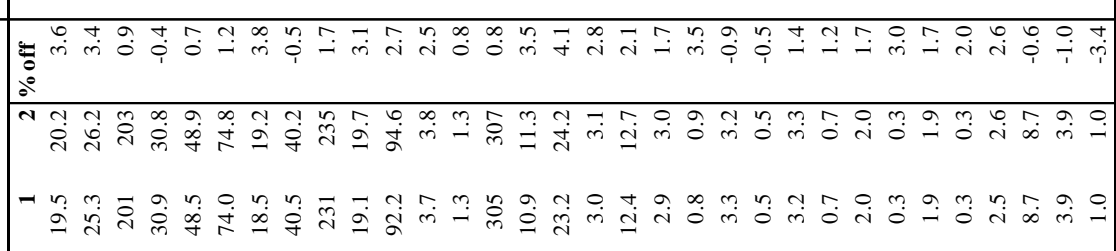 \\
\hline & 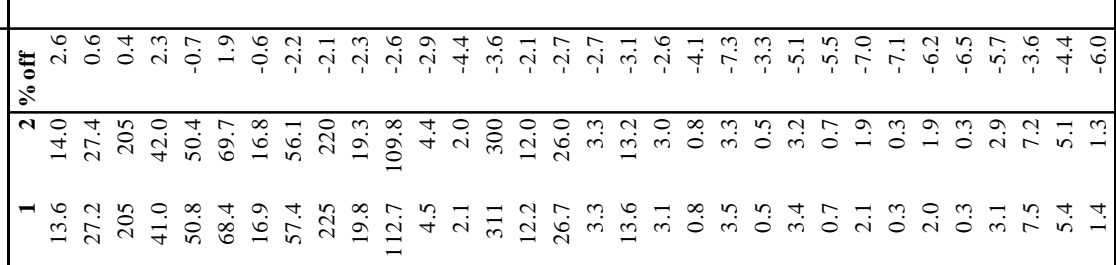 \\
\hline & 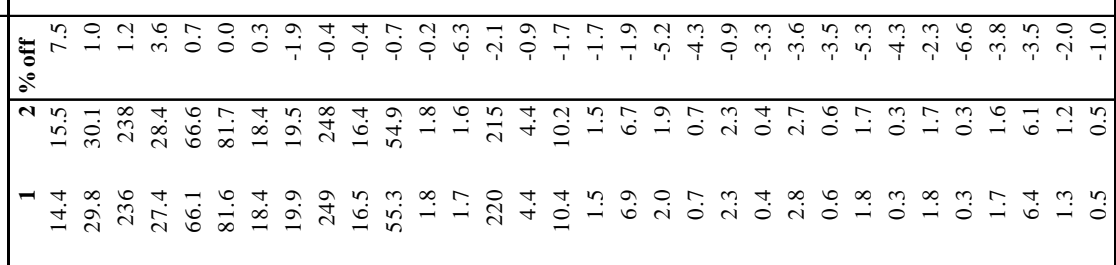 \\
\hline & \\
\hline
\end{tabular}




\section{A7. EPMA: glass major element standard and sample data}

Major element compositions for glass in 8 lava samples were analysed by electron probe microanalysis (EPMA) using the JEOL JXA 8230 instrument at VUW. This instrument is equipped with 5 wavelength dispersive X-ray spectrometers (WDS), an energy dispersive $\mathrm{X}$-ray spectrometer (EDS) and highly sensitive detectors for acquisition of back-scattered electron (BSE) images. Thin sections were prepared from lava samples and coated with a $\sim 25 \mathrm{~nm}$ film of carbon before analysis. For quantitative measurements of glass the instrument was calibrated using international glass standard VG-568 and synthetic oxides for elements in low abundance ( $<1 \mathrm{wt}$. \%). The instrument was operated using a $15 \mathrm{kV}$ accelerating voltage and $8 \mathrm{nA}$ probe current. Due to the commonly small sizes of melt inclusions and interstitial glass patches, a $5 \mu \mathrm{m}$-diameter beam was used (rather than 10 $\mu \mathrm{m})$. For each element, calibration was undertaken during a 30 seconds peak-search and a 15 seconds background measurement. Counting times for Na were reduced to 15 seconds on the peak and 10 seconds for the background to minimise potential devolatilisation. $\mathrm{Na}$ and $\mathrm{K}$ were measured first during glass analysis sequences also to minimise alkali loss. Element concentrations were calculated using the ZAF correction method (where $\mathrm{Z}$ is atomic number, $\mathrm{A}$ is absorption and $\mathrm{F}$ is fluorescence; Carpenter, 2008 and references therein).

Values of approximate 2sd measured from repeated analysis of glass standard VG-568 are within 1-5 relative \% for major element oxides $\mathrm{SiO}_{2}, \mathrm{Al}_{2} \mathrm{O}_{3}$ and $\mathrm{K}_{2} \mathrm{O}$, and $\sim 14 \%$ for $\mathrm{Na}_{2} \mathrm{O}$. Analyses are accurate to $\leq 2 \%$ for $\mathrm{SiO}_{2}, \mathrm{Al}_{2} \mathrm{O}_{3}$ and $\mathrm{K}_{2} \mathrm{O}$, and to $4 \%$ for $\mathrm{Na}_{2} \mathrm{O}$ of the preferred values of the standard. The level of analytical precision and accuracy is comparable to that obtained using a $10 \mu \mathrm{m}$-wide beam (Barker, 2015) and indicates that using a beam width of $5 \mu \mathrm{m}$ does not result in significant alkali loss under the analytical conditions used.

Table A7.1. Precision and accuracy of major element analyses of glass VG-568

\begin{tabular}{|l|rrrrrrrrrrr|}
\hline & $\mathbf{S i O}_{2}$ & $\mathbf{T i O}_{\mathbf{2}}$ & $\mathbf{A l}_{\mathbf{2}} \mathbf{O}_{\mathbf{3}}$ & $\mathbf{F e O}$ & $\mathbf{M n O}$ & $\mathbf{M g O}$ & $\mathbf{C a O}$ & $\mathbf{N a}_{2} \mathbf{O}$ & $\mathbf{K}_{2} \mathbf{O}$ & $\mathbf{C l}$ & Total \\
\hline Avg & 77.3 & 0.1 & 12.1 & 1.0 & 0.0 & 0.0 & 0.4 & 3.6 & 5.0 & 0.1 & 99.6 \\
Max & 78.3 & 0.1 & 12.4 & 1.6 & 0.1 & 0.1 & 0.5 & 4.1 & 5.3 & 0.1 & 101.3 \\
Min & 75.5 & 0.0 & 11.7 & 0.7 & 0.0 & 0.0 & 0.4 & 2.8 & 4.6 & 0.1 & 98.0 \\
2sd & 1.1 & 0.0 & 0.3 & 0.2 & 0.0 & 0.0 & 0.0 & 0.5 & 0.3 & 0.0 & 1.3 \\
2sd \% & 1.4 & 55.8 & 2.3 & 23.9 & 173.0 & 68.1 & 9.5 & 13.8 & 5.4 & 23.6 & 1.3 \\
\hline Ref & 76.7 & 0.1 & 12.1 & 0.8 & 0.0 & 0.1 & 0.5 & 3.8 & 4.9 & 0.1 & 99.6 \\
Off \% & -0.7 & 34.8 & -0.5 & -28.1 & 32.3 & 37.4 & 10.6 & 4.0 & -2.0 & 38.1 & -0.1 \\
\hline
\end{tabular}

Reference values from Jarosewich et al. (1980).

Abbreviations for over page: F-P (Formation-Package); WH (Whakapapa); MA (Mangawhero); TH (Te Herenga); RT (Rangataua); SC (Saddle Cone); PT (Paretetaitonga); TR (Turoa); TK (Te Kohatu); ME (Mangaehuehu); Sam (sample number); mi (melt inclusion); gm (groundmass); ig (interstitial glass); xg (xenolith glass). 
Table A7.2. Major element data for glass in Ruapehu lava samples

\begin{tabular}{|c|c|c|c|c|c|c|c|c|c|c|c|c|c|}
\hline F-P & Sam & Type & $\mathrm{SiO}_{2}$ & $\mathrm{TiO}_{2}$ & $\mathrm{Al}_{2} \mathrm{O}_{3}$ & $\mathrm{FeO}$ & MnO & MgO & $\mathrm{CaO}$ & $\mathrm{Na}_{2} \mathrm{O}$ & $\mathrm{K}_{2} \mathrm{O}$ & Cl & Total \\
\hline WH-RT & 193 & $\mathrm{mi}$ & 72.56 & 0.61 & 16.36 & 1.89 & 0.03 & 0.14 & 2.15 & 3.40 & 2.86 & 0.00 & 99.79 \\
\hline WH-RT & 193 & $\mathrm{mi}$ & 70.92 & 0.67 & 15.89 & 2.00 & 0.03 & 0.03 & 1.17 & 4.44 & 4.85 & 0.00 & 100.45 \\
\hline WH-RT & 193 & $\mathrm{mi}$ & 71.09 & 0.69 & 16.02 & 1.99 & 0.02 & 0.04 & 1.21 & 4.09 & 4.85 & 0.00 & 100.37 \\
\hline WH-RT & 193 & $\mathrm{mi}$ & 70.27 & 0.37 & 17.01 & 1.12 & 0.02 & 0.19 & 3.18 & 4.54 & 3.31 & 0.00 & 100.52 \\
\hline WH-RT & 193 & $\mathrm{mi}$ & 75.78 & 0.35 & 14.04 & 0.66 & 0.02 & 0.09 & 1.00 & 3.08 & 4.86 & 0.13 & 98.35 \\
\hline WH-RT & 193 & $\mathrm{mi}$ & 73.85 & 0.50 & 14.99 & 0.54 & 0.06 & 0.11 & 1.24 & 3.46 & 5.14 & 0.15 & 99.80 \\
\hline WH-RT & 193 & $\mathrm{mi}$ & 73.61 & 0.30 & 15.33 & 0.62 & 0.02 & 0.15 & 1.41 & 3.74 & 4.72 & 0.13 & 99.54 \\
\hline WH-RT & 193 & $\mathrm{mi}$ & 70.59 & 0.44 & 17.32 & 1.03 & 0.04 & 0.24 & 3.32 & 4.36 & 2.55 & 0.13 & 100.22 \\
\hline WH-RT & 193 & $\mathrm{mi}$ & 70.66 & 0.43 & 17.34 & 1.13 & 0.00 & 0.24 & 3.39 & 4.04 & 2.67 & 0.13 & 100.02 \\
\hline WH-SC & 281 & $\mathrm{mi}$ & 71.47 & 0.61 & 19.00 & 2.21 & 0.04 & 0.15 & 3.62 & 0.80 & 2.09 & 0.00 & 98.67 \\
\hline WH-SC & 281 & $\mathrm{mi}$ & 75.03 & 0.39 & 14.18 & 1.85 & 0.04 & 0.46 & 2.52 & 2.82 & 2.73 & 0.00 & 99.05 \\
\hline WH-SC & 281 & $\mathrm{mi}$ & 75.01 & 0.77 & 13.29 & 0.81 & 0.04 & 0.07 & 1.06 & 3.32 & 5.62 & 0.00 & 100.05 \\
\hline WH-SC & 281 & $\mathrm{mi}$ & 75.49 & 0.63 & 13.14 & 0.85 & 0.03 & 0.07 & 1.11 & 3.22 & 5.45 & 0.00 & 99.26 \\
\hline WH-SC & 281 & $\mathrm{mi}$ & 75.32 & 0.49 & 13.79 & 1.02 & 0.03 & 0.09 & 1.29 & 3.57 & 4.40 & 0.00 & 99.58 \\
\hline WH-SC & 281 & $\mathrm{mi}$ & 76.52 & 0.53 & 14.07 & 0.91 & 0.05 & 0.08 & 1.30 & 2.31 & 4.22 & 0.00 & 99.41 \\
\hline WH-SC & 281 & $\mathrm{mi}$ & 75.52 & 0.57 & 13.90 & 0.97 & 0.02 & 0.07 & 1.36 & 3.31 & 4.27 & 0.00 & 99.17 \\
\hline WH-SC & 281 & $\mathrm{mi}$ & 74.52 & 0.57 & 13.65 & 0.93 & 0.04 & 0.13 & 1.13 & 3.59 & 5.44 & 0.00 & 99.23 \\
\hline WH-SC & 281 & $\mathrm{mi}$ & 74.49 & 0.57 & 13.54 & 1.04 & 0.00 & 0.18 & 1.11 & 3.67 & 5.39 & 0.00 & 99.57 \\
\hline WH-SC & 281 & $\mathrm{mi}$ & 75.99 & 0.72 & 14.19 & 0.85 & 0.00 & 0.16 & 1.78 & 3.93 & 2.37 & 0.00 & 98.39 \\
\hline WH-SC & 281 & $\mathrm{mi}$ & 75.74 & 0.70 & 14.18 & 0.83 & 0.02 & 0.27 & 1.98 & 3.92 & 2.36 & 0.00 & 98.75 \\
\hline WH-SC & 281 & $\mathrm{mi}$ & 74.39 & 0.57 & 14.61 & 1.19 & 0.00 & 0.98 & 1.99 & 4.17 & 2.09 & 0.00 & 99.29 \\
\hline WH-SC & 281 & $\mathrm{mi}$ & 75.21 & 0.59 & 15.09 & 0.92 & 0.07 & 0.18 & 2.02 & 3.79 & 2.13 & 0.00 & 99.68 \\
\hline WH-SC & 281 & $\mathrm{mi}$ & 75.55 & 0.66 & 14.74 & 0.93 & 0.07 & 0.23 & 2.18 & 3.87 & 1.77 & 0.00 & 99.26 \\
\hline WH-SC & 281 & $\mathrm{mi}$ & 76.70 & 0.70 & 14.99 & 0.95 & 0.06 & 0.17 & 2.13 & 2.48 & 1.81 & 0.00 & 99.04 \\
\hline WH-SC & 281 & $\mathrm{mi}$ & 75.15 & 0.27 & 14.04 & 1.65 & 0.06 & 0.08 & 2.11 & 3.41 & 3.09 & 0.17 & 100.42 \\
\hline WH-SC & 281 & $\mathrm{mi}$ & 74.51 & 0.37 & 14.18 & 1.87 & 0.07 & 0.11 & 2.14 & 3.36 & 3.25 & 0.19 & 100.32 \\
\hline WH-SC & 281 & $\mathrm{mi}$ & 74.36 & 0.36 & 15.07 & 0.80 & 0.02 & 0.22 & 1.66 & 3.87 & 3.50 & 0.18 & 99.68 \\
\hline WH-SC & 281 & $\mathrm{mi}$ & 74.26 & 0.42 & 14.64 & 0.80 & 0.05 & 0.10 & 1.90 & 3.07 & 4.62 & 0.18 & 100.29 \\
\hline WH-SC & 281 & $\mathrm{mi}$ & 72.85 & 0.67 & 15.01 & 1.16 & 0.04 & 0.21 & 1.80 & 3.79 & 4.32 & 0.20 & 98.85 \\
\hline WH-SC & 281 & $\mathrm{mi}$ & 73.08 & 0.75 & 14.79 & 1.15 & 0.07 & 0.16 & 1.85 & 3.78 & 4.20 & 0.20 & 99.17 \\
\hline WH-SC & 281 & $\mathrm{mi}$ & 71.68 & 1.36 & 15.03 & 1.59 & 0.01 & 0.18 & 2.05 & 3.83 & 4.10 & 0.22 & 98.83 \\
\hline WH-SC & 281 & $\mathrm{mi}$ & 73.63 & 0.81 & 14.63 & 1.10 & 0.03 & 0.14 & 1.67 & 3.58 & 4.26 & 0.22 & 99.19 \\
\hline WH-SC & 281 & $\mathrm{mi}$ & 74.22 & 0.42 & 15.23 & 0.79 & 0.06 & 0.18 & 2.31 & 4.08 & 2.61 & 0.16 & 98.78 \\
\hline WH-SC & 281 & $\mathrm{mi}$ & 75.67 & 0.23 & 13.42 & 1.56 & 0.06 & 0.12 & 1.80 & 3.26 & 3.77 & 0.15 & 100.15 \\
\hline WH-SC & 281 & $\mathrm{mi}$ & 77.01 & 0.42 & 12.99 & 0.95 & 0.03 & 0.04 & 1.06 & 3.30 & 4.08 & 0.16 & 98.74 \\
\hline WH-SC & 281 & $\mathrm{mi}$ & 76.80 & 0.48 & 13.05 & 0.86 & 0.03 & 0.06 & 1.00 & 3.04 & 4.56 & 0.16 & 99.25 \\
\hline WH-SC & 281 & $\mathrm{mi}$ & 72.75 & 0.83 & 15.01 & 1.00 & 0.05 & 0.25 & 1.92 & 3.77 & 4.23 & 0.23 & 100.27 \\
\hline WH-SC & 281 & $\mathrm{mi}$ & 73.68 & 0.46 & 14.87 & 0.81 & 0.04 & 0.14 & 1.78 & 3.76 & 4.29 & 0.20 & 100.06 \\
\hline WH-SC & 281 & $\mathrm{mi}$ & 74.01 & 0.88 & 14.37 & 0.77 & 0.02 & 0.14 & 1.70 & 3.55 & 4.39 & 0.23 & 100.25 \\
\hline WH-SC & 281 & $\mathrm{mi}$ & 74.00 & 0.48 & 15.20 & 0.81 & 0.09 & 0.17 & 2.43 & 3.99 & 2.71 & 0.16 & 100.47 \\
\hline WH-PT & 335 & $\mathrm{mi}$ & 75.78 & 0.35 & 14.04 & 0.66 & 0.02 & 0.09 & 1.00 & 3.08 & 4.86 & 0.13 & 98.35 \\
\hline WH-PT & 335 & $\mathrm{mi}$ & 73.85 & 0.50 & 14.99 & 0.54 & 0.06 & 0.11 & 1.24 & 3.46 & 5.14 & 0.15 & 99.80 \\
\hline WH-PT & 335 & $\mathrm{mi}$ & 73.61 & 0.30 & 15.33 & 0.62 & 0.02 & 0.15 & 1.41 & 3.74 & 4.72 & 0.13 & 99.54 \\
\hline WH-PT & 335 & $\mathrm{mi}$ & 70.59 & 0.44 & 17.32 & 1.03 & 0.04 & 0.24 & 3.32 & 4.36 & 2.55 & 0.13 & 100.22 \\
\hline WH-PT & 335 & $\mathrm{mi}$ & 70.66 & 0.43 & 17.34 & 1.13 & 0.00 & 0.24 & 3.39 & 4.04 & 2.67 & 0.13 & 100.02 \\
\hline WH-TR & 260 & $\mathrm{gm}$ & 73.32 & 1.36 & 11.92 & 3.56 & 0.29 & 0.13 & 1.06 & 3.30 & 5.04 & 0.09 & 99.40 \\
\hline WH-TR & 260 & gm & 73.60 & 1.11 & 12.47 & 2.86 & 0.23 & 0.08 & 1.00 & 3.69 & 4.95 & 0.05 & 100.21 \\
\hline WH-TR & 260 & $\mathrm{gm}$ & 73.25 & 0.95 & 12.50 & 3.32 & 0.31 & 0.11 & 0.94 & 3.44 & 5.21 & 0.04 & 100.33 \\
\hline WH-TR & 260 & $\mathrm{gm}$ & 73.99 & 1.23 & 11.93 & 3.12 & 0.28 & 0.14 & 0.96 & 3.38 & 5.00 & 0.04 & 99.32 \\
\hline WH-TR & 260 & $\mathrm{gm}$ & 73.97 & 1.10 & 12.42 & 2.93 & 0.18 & 0.08 & 1.11 & 4.09 & 4.12 & 0.04 & 100.34 \\
\hline WH-TR & 260 & gm & 73.44 & 1.10 & 12.32 & 3.34 & 0.31 & 0.10 & 1.02 & 3.40 & 4.96 & 0.07 & 100.15 \\
\hline WH-TR & 260 & $\mathrm{gm}$ & 74.69 & 1.05 & 11.84 & 2.77 & 0.25 & 0.09 & 0.85 & 3.27 & 5.18 & 0.06 & 100.06 \\
\hline WH-TR & 260 & $\mathrm{gm}$ & 73.27 & 1.39 & 11.68 & 3.78 & 0.26 & 0.13 & 1.10 & 3.45 & 4.94 & 0.06 & 99.49 \\
\hline WH-TR & 260 & $\mathrm{gm}$ & 74.14 & 1.19 & 12.11 & 2.94 & 0.26 & 0.08 & 0.95 & 3.23 & 5.09 & 0.07 & 98.76 \\
\hline WH-TR & 260 & $\mathrm{gm}$ & 73.54 & 1.32 & 12.16 & 3.18 & 0.26 & 0.12 & 1.12 & 3.21 & 5.11 & 0.03 & 98.58 \\
\hline WH-TR & 260 & gm & 73.91 & 1.20 & 12.31 & 2.94 & 0.26 & 0.06 & 0.79 & 3.43 & 5.11 & 0.06 & 100.31 \\
\hline WH-TR & 260 & gm & 74.03 & 1.26 & 12.26 & 2.82 & 0.27 & 0.07 & 0.85 & 3.32 & 5.10 & 0.08 & 100.12 \\
\hline WH-TR & 260 & $\mathrm{gm}$ & 73.53 & 1.32 & 12.39 & 2.95 & 0.26 & 0.11 & 0.98 & 3.35 & 5.13 & 0.04 & 99.61 \\
\hline WH-TR & 260 & gm & 73.57 & 1.17 & 12.18 & 3.13 & 0.25 & 0.13 & 1.05 & 3.50 & 5.00 & 0.09 & 100.30 \\
\hline WH-TR & 260 & $\mathrm{gm}$ & 75.13 & 1.01 & 12.20 & 2.45 & 0.25 & 0.03 & 0.66 & 3.26 & 5.06 & 0.01 & 99.34 \\
\hline WH-TR & 260 & $\mathrm{gm}$ & 74.20 & 1.11 & 12.26 & 2.78 & 0.28 & 0.09 & 0.96 & 3.17 & 5.17 & 0.04 & 98.12 \\
\hline
\end{tabular}

Values are in in weight \%, normalised to anhydrous $100 \%$ totals. Abbreviations are on page 251. 
Table A7.2. (cont.) Major element data for glass in Ruapehu lava samples.

\begin{tabular}{|c|c|c|c|c|c|c|c|c|c|c|c|c|c|}
\hline F-P & Sam & Type & $\mathrm{SiO}_{2}$ & $\mathrm{TiO}_{2}$ & $\mathbf{A l}_{2} \mathbf{O}_{3}$ & $\mathrm{FeO}$ & MnO & MgO & $\mathrm{CaO}$ & $\mathrm{Na}_{2} \mathrm{O}$ & $\mathbf{K}_{2} \mathbf{O}$ & Cl & Total \\
\hline MA-TK & 415 & $\mathrm{mi}$ & 73.94 & 0.96 & 12.59 & 2.33 & 0.03 & 0.28 & 0.99 & 3.03 & 5.76 & 0.13 & 99.77 \\
\hline MA-TK & 415 & $\mathrm{mi}$ & 72.88 & 0.99 & 13.18 & 2.37 & 0.02 & 0.26 & 1.54 & 3.43 & 5.24 & 0.13 & 99.88 \\
\hline MA-TK & 415 & $\mathrm{mi}$ & 73.53 & 1.09 & 12.51 & 2.65 & 0.04 & 0.30 & 0.99 & 3.01 & 5.78 & 0.14 & 100.52 \\
\hline MA-TK & 415 & $\mathrm{mi}$ & 73.95 & 0.87 & 12.59 & 2.31 & 0.05 & 0.26 & 1.00 & 3.07 & 5.80 & 0.14 & 99.57 \\
\hline MA-TK & 415 & $\mathrm{mi}$ & 73.89 & 0.90 & 12.52 & 2.22 & 0.04 & 0.33 & 1.00 & 3.15 & 5.84 & 0.14 & 100.43 \\
\hline MA-TK & 415 & $\mathrm{mi}$ & 74.19 & 0.90 & 12.39 & 2.33 & 0.06 & 0.28 & 1.04 & 3.15 & 5.57 & 0.14 & 99.77 \\
\hline MA-TK & 415 & $\mathrm{mi}$ & 71.38 & 0.43 & 16.03 & 2.16 & 0.03 & 0.23 & 0.74 & 3.56 & 5.36 & 0.10 & 99.84 \\
\hline MA-TK & 415 & $\mathrm{mi}$ & 71.49 & 0.73 & 14.08 & 2.78 & 0.03 & 0.31 & 1.34 & 3.49 & 5.65 & 0.13 & 99.87 \\
\hline MA-TK & 415 & $\mathrm{mi}$ & 74.63 & 0.85 & 14.52 & 2.05 & 0.05 & 0.19 & 1.25 & 1.03 & 5.33 & 0.14 & 99.74 \\
\hline MA-TK & 415 & $\mathrm{mi}$ & 70.77 & 0.93 & 14.86 & 2.60 & 0.05 & 0.20 & 1.25 & 3.51 & 5.71 & 0.16 & 99.62 \\
\hline MA-TK & 415 & $\mathrm{mi}$ & 74.68 & 1.14 & 12.43 & 2.29 & 0.05 & 0.19 & 0.92 & 2.91 & 5.31 & 0.12 & 98.77 \\
\hline MA-TK & 415 & $\mathrm{mi}$ & 73.61 & 1.22 & 12.65 & 2.34 & 0.05 & 0.29 & 1.09 & 3.10 & 5.55 & 0.13 & 98.49 \\
\hline MA-TK & 415 & $\mathrm{mi}$ & 73.45 & 1.19 & 12.60 & 2.50 & 0.02 & 0.27 & 1.20 & 3.20 & 5.47 & 0.14 & 99.32 \\
\hline MA-TK & 415 & $\mathrm{mi}$ & 73.82 & 0.75 & 13.57 & 1.97 & 0.04 & 0.15 & 0.97 & 3.10 & 5.52 & 0.15 & 99.57 \\
\hline MA-TK & 415 & $\mathrm{mi}$ & 74.35 & 1.00 & 12.46 & 2.26 & 0.02 & 0.20 & 0.87 & 3.10 & 5.62 & 0.14 & 99.42 \\
\hline MA-TK & 415 & $\mathrm{mi}$ & 73.79 & 1.08 & 12.96 & 2.19 & 0.04 & 0.23 & 0.94 & 3.30 & 5.38 & 0.11 & 100.36 \\
\hline MA-TK & 415 & $\mathrm{mi}$ & 73.16 & 0.95 & 13.60 & 2.15 & 0.07 & 0.16 & 1.01 & 3.33 & 5.48 & 0.11 & 99.47 \\
\hline MA-TK & 415 & $\mathrm{mi}$ & 72.94 & 0.30 & 15.26 & 1.08 & 0.04 & 0.20 & 1.68 & 3.31 & 5.05 & 0.17 & 100.50 \\
\hline MA-TK & 415 & $\mathrm{mi}$ & 70.28 & 0.38 & 16.15 & 2.03 & 0.00 & 0.28 & 2.42 & 3.47 & 4.85 & 0.17 & 100.44 \\
\hline MA-TK & 415 & $\mathrm{mi}$ & 74.75 & 0.87 & 12.09 & 2.48 & 0.03 & 0.23 & 0.86 & 2.94 & 5.67 & 0.10 & 100.38 \\
\hline MA-TK & 415 & $\mathrm{mi}$ & 74.40 & 0.92 & 12.42 & 2.23 & 0.04 & 0.24 & 0.94 & 3.03 & 5.70 & 0.11 & 100.58 \\
\hline MA-TK & 415 & $\mathrm{mi}$ & 75.30 & 0.20 & 13.01 & 2.43 & 0.04 & 0.18 & 1.44 & 2.57 & 4.70 & 0.16 & 100.26 \\
\hline MA-TK & 415 & $\mathrm{mi}$ & 71.18 & 0.63 & 15.15 & 2.08 & 0.04 & 0.38 & 2.28 & 3.60 & 4.56 & 0.12 & 99.87 \\
\hline MA-TK & 415 & $\mathrm{mi}$ & 74.29 & 1.16 & 12.69 & 2.04 & 0.05 & 0.21 & 1.01 & 2.97 & 5.47 & 0.14 & 100.11 \\
\hline MA-TK & 415 & $\mathrm{mi}$ & 71.43 & 0.77 & 14.49 & 2.57 & 0.00 & 0.33 & 1.26 & 3.76 & 5.27 & 0.14 & 100.34 \\
\hline MA-TK & 415 & $\mathrm{mi}$ & 74.79 & 0.80 & 12.45 & 1.93 & 0.02 & 0.22 & 0.80 & 3.13 & 5.78 & 0.11 & 99.54 \\
\hline MA-TK & 415 & $\mathrm{mi}$ & 75.06 & 0.69 & 12.38 & 2.31 & 0.00 & 0.19 & 0.77 & 3.12 & 5.40 & 0.11 & 99.74 \\
\hline MA-TK & 415 & $\mathrm{mi}$ & 74.63 & 0.80 & 12.53 & 2.18 & 0.00 & 0.21 & 0.88 & 3.17 & 5.52 & 0.10 & 100.06 \\
\hline MA-TK & 415 & $\mathrm{mi}$ & 73.59 & 0.96 & 12.90 & 2.47 & 0.00 & 0.28 & 1.04 & 3.21 & 5.44 & 0.13 & 99.74 \\
\hline MA-TK & 415 & $\mathrm{mi}$ & 74.10 & 0.99 & 12.42 & 2.38 & 0.00 & 0.25 & 0.98 & 3.13 & 5.66 & 0.12 & 100.24 \\
\hline MA-TK & 415 & $\mathrm{mi}$ & 74.75 & 0.74 & 12.47 & 2.11 & 0.00 & 0.21 & 0.91 & 3.18 & 5.57 & 0.09 & 99.61 \\
\hline MA-TK & 415 & $\mathrm{mi}$ & 74.18 & 0.73 & 13.22 & 1.93 & 0.00 & 0.19 & 1.33 & 3.19 & 5.16 & 0.10 & 100.30 \\
\hline MA-TK & 415 & $\mathrm{mi}$ & 74.21 & 0.99 & 12.35 & 2.38 & 0.00 & 0.26 & 0.95 & 3.14 & 5.62 & 0.13 & 99.86 \\
\hline MA-TK & 415 & $\mathrm{mi}$ & 74.45 & 0.95 & 12.38 & 2.14 & 0.02 & 0.28 & 0.97 & 3.16 & 5.55 & 0.14 & 99.29 \\
\hline MA-TK & 415 & $\mathrm{mi}$ & 71.27 & 0.78 & 15.18 & 2.06 & 0.07 & 0.14 & 1.12 & 3.69 & 5.57 & 0.15 & 100.33 \\
\hline MA-TK & 415 & $\mathrm{mi}$ & 75.34 & 0.84 & 12.37 & 2.00 & 0.04 & 0.18 & 0.77 & 2.90 & 5.48 & 0.10 & 100.74 \\
\hline MA-TK & 415 & $\mathrm{mi}$ & 72.44 & 0.51 & 14.52 & 1.81 & 0.04 & 0.27 & 2.53 & 3.72 & 4.02 & 0.18 & 100.27 \\
\hline MA-TK & 415 & $\mathrm{mi}$ & 74.38 & 0.76 & 12.54 & 1.90 & 0.03 & 0.23 & 0.94 & 3.15 & 5.99 & 0.10 & 100.19 \\
\hline MA-TK & 415 & $\mathrm{mi}$ & 69.95 & 0.41 & 14.33 & 2.85 & 0.07 & 1.47 & 2.35 & 4.06 & 4.40 & 0.15 & 99.67 \\
\hline MA-TK & 415 & $\mathrm{mi}$ & 70.58 & 0.37 & 15.73 & 1.97 & 0.06 & 0.17 & 2.51 & 4.10 & 4.40 & 0.17 & 100.38 \\
\hline MA-TK & 415 & $\mathrm{mi}$ & 70.92 & 0.40 & 15.13 & 2.16 & 0.02 & 0.20 & 2.37 & 3.87 & 4.79 & 0.18 & 100.81 \\
\hline MA-TK & 415 & $\mathrm{mi}$ & 73.52 & 0.63 & 13.19 & 1.92 & 0.06 & 0.16 & 0.97 & 3.30 & 6.17 & 0.10 & 100.44 \\
\hline MA-TK & 415 & $\mathrm{mi}$ & 71.77 & 0.36 & 14.60 & 2.10 & 0.06 & 0.17 & 2.08 & 3.60 & 5.14 & 0.13 & 100.19 \\
\hline MA-TK & 415 & $\mathrm{mi}$ & 75.60 & 0.72 & 12.32 & 1.60 & 0.03 & 0.15 & 0.76 & 3.07 & 5.68 & 0.08 & 99.98 \\
\hline MA-TK & 415 & $\mathrm{mi}$ & 72.65 & 0.55 & 14.92 & 1.17 & 0.02 & 0.32 & 1.63 & 3.76 & 4.88 & 0.14 & 100.25 \\
\hline MA-TK & 415 & $\mathrm{mi}$ & 70.22 & 0.66 & 15.75 & 1.99 & 0.05 & 0.30 & 2.84 & 3.61 & 4.48 & 0.14 & 100.40 \\
\hline MA-TK & 415 & $\mathrm{mi}$ & 71.04 & 0.89 & 15.11 & 1.55 & 0.00 & 0.28 & 1.43 & 3.70 & 5.87 & 0.16 & 98.71 \\
\hline MA-TK & 415 & $\mathrm{mi}$ & 72.18 & 0.70 & 15.29 & 1.91 & 0.00 & 0.27 & 2.23 & 2.59 & 4.72 & 0.14 & 98.65 \\
\hline MA-TK & 415 & $\mathrm{mi}$ & 72.62 & 0.55 & 15.05 & 0.95 & 0.06 & 0.33 & 1.70 & 3.74 & 4.89 & 0.14 & 98.65 \\
\hline MA-TK & 415 & $\mathrm{mi}$ & 71.22 & 0.45 & 16.15 & 1.01 & 0.03 & 0.28 & 1.67 & 4.17 & 4.90 & 0.15 & 100.07 \\
\hline MA-TK & 415 & $\mathrm{mi}$ & 73.24 & 0.65 & 14.92 & 1.11 & 0.05 & 0.23 & 1.78 & 3.74 & 4.16 & 0.15 & 100.43 \\
\hline MA-TK & 415 & $\mathrm{mi}$ & 72.73 & 0.65 & 14.76 & 1.07 & 0.03 & 0.22 & 1.61 & 3.48 & 5.33 & 0.15 & 98.96 \\
\hline MA-TK & 415 & $\mathrm{mi}$ & 72.77 & 0.52 & 15.22 & 1.01 & 0.06 & 0.27 & 1.76 & 3.78 & 4.49 & 0.15 & 99.70 \\
\hline MA-TK & 415 & $\mathrm{mi}$ & 72.67 & 0.71 & 15.01 & 1.26 & 0.00 & 0.32 & 1.81 & 4.04 & 4.09 & 0.13 & 100.42 \\
\hline MA-TK & 415 & $\mathrm{mi}$ & 72.00 & 0.82 & 14.26 & 1.78 & 0.02 & 0.15 & 1.31 & 3.42 & 6.12 & 0.16 & 99.93 \\
\hline MA-TK & 415 & ig & 70.51 & 0.87 & 14.83 & 2.79 & 0.04 & 0.24 & 1.40 & 3.65 & 5.55 & 0.15 & 98.75 \\
\hline MA-TK & 415 & ig & 73.41 & 0.97 & 12.66 & 2.57 & 0.05 & 0.22 & 0.99 & 3.24 & 5.80 & 0.12 & 98.69 \\
\hline MA-TK & 415 & ig & 73.31 & 1.08 & 12.64 & 2.57 & 0.03 & 0.30 & 1.02 & 3.15 & 5.78 & 0.15 & 99.02 \\
\hline MA-TK & 415 & $\mathrm{xg}$ & 74.53 & 1.25 & 12.11 & 2.47 & 0.05 & 0.20 & 0.93 & 2.74 & 5.62 & 0.13 & 97.35 \\
\hline MA-TK & 415 & $\mathrm{xg}$ & 74.44 & 1.32 & 12.10 & 2.50 & 0.00 & 0.24 & 0.98 & 2.78 & 5.52 & 0.14 & 97.47 \\
\hline MA-TK & 415 & $\begin{array}{r}0 \\
\mathrm{xg}\end{array}$ & 73.98 & 1.24 & 12.11 & 2.45 & 0.05 & 0.23 & 1.09 & 2.90 & 5.85 & 0.14 & 97.14 \\
\hline
\end{tabular}

Values are in in weight \%, normalised to anhydrous $100 \%$ totals. Abbreviations are on page 251. 
Table A7.2. (cont.) Major element data for glass in Ruapehu lava samples.

\begin{tabular}{|c|c|c|c|c|c|c|c|c|c|c|c|c|c|}
\hline F-P & Sam & Type & $\mathrm{SiO}_{2}$ & $\mathrm{TiO}_{2}$ & $\mathbf{A l}_{2} \mathbf{O}_{3}$ & $\mathrm{FeO}$ & $\mathrm{MnO}$ & MgO & $\mathrm{CaO}$ & $\mathrm{Na}_{2} \mathrm{O}$ & $\mathbf{K}_{2} \mathbf{O}$ & $\mathrm{Cl}$ & Total \\
\hline MA-TK & 415 & $\mathrm{xg}$ & 73.76 & 1.15 & 12.38 & 2.48 & 0.05 & 0.26 & 1.00 & 3.04 & 5.75 & 0.16 & 97.71 \\
\hline MA-TK & 415 & $\mathrm{xg}$ & 74.03 & 1.20 & 12.13 & 2.56 & 0.02 & 0.27 & 1.02 & 2.98 & 5.71 & 0.12 & 97.06 \\
\hline MA-TK & 415 & $x g$ & 73.80 & 1.14 & 12.31 & 2.48 & 0.07 & 0.28 & 1.04 & 3.13 & 5.66 & 0.12 & 97.60 \\
\hline MA-TK & 415 & $x g$ & 75.12 & 0.81 & 12.08 & 1.76 & 0.03 & 0.27 & 0.95 & 2.91 & 5.97 & 0.12 & 98.05 \\
\hline MA-TK & 415 & $\mathrm{xg}$ & 75.18 & 0.77 & 12.07 & 1.75 & 0.05 & 0.23 & 0.92 & 3.09 & 5.84 & 0.12 & 98.35 \\
\hline MA-TK & 415 & $x g$ & 75.15 & 0.82 & 12.26 & 1.82 & 0.00 & 0.26 & 0.91 & 2.98 & 5.70 & 0.12 & 97.95 \\
\hline MA-TK & 415 & $x g$ & 74.92 & 0.83 & 12.15 & 1.84 & 0.04 & 0.27 & 0.96 & 2.92 & 5.97 & 0.13 & 97.96 \\
\hline MA-TK & 415 & $\mathrm{gm}$ & 75.04 & 0.79 & 12.03 & 2.22 & 0.05 & 0.20 & 0.82 & 2.99 & 5.77 & 0.10 & 101.59 \\
\hline MA-TK & 415 & $\mathrm{gm}$ & 71.72 & 0.62 & 15.10 & 1.75 & 0.00 & 0.15 & 2.34 & 3.82 & 4.44 & 0.06 & 101.81 \\
\hline MA-TK & 415 & $\mathrm{gm}$ & 75.10 & 0.77 & 12.08 & 2.18 & 0.00 & 0.17 & 0.80 & 2.95 & 5.85 & 0.10 & 101.03 \\
\hline MA-TK & 415 & $\mathrm{gm}$ & 75.00 & 0.79 & 12.32 & 2.19 & 0.00 & 0.17 & 0.97 & 2.93 & 5.54 & 0.10 & 100.66 \\
\hline MA-TK & 479 & $\mathrm{mi}$ & 73.74 & 0.46 & 12.11 & 3.27 & 0.01 & 1.23 & 0.87 & 2.90 & 5.35 & 0.09 & 99.77 \\
\hline MA-TK & 479 & $\mathrm{mi}$ & 70.50 & 0.78 & 15.04 & 2.05 & 0.04 & 0.40 & 1.79 & 3.40 & 5.88 & 0.15 & 100.16 \\
\hline MA-TK & 479 & $\mathrm{mi}$ & 71.69 & 0.34 & 14.17 & 2.33 & 0.01 & 0.35 & 1.36 & 3.48 & 6.15 & 0.16 & 100.12 \\
\hline MA-TK & 479 & $\mathrm{mi}$ & 73.44 & 0.93 & 12.80 & 2.27 & 0.03 & 0.34 & 1.15 & 3.15 & 5.80 & 0.13 & 100.08 \\
\hline MA-TK & 479 & $\mathrm{mi}$ & 71.73 & 0.31 & 15.00 & 2.34 & 0.00 & 0.32 & 1.22 & 2.97 & 6.01 & 0.14 & 99.38 \\
\hline MA-TK & 479 & $\mathrm{mi}$ & 74.99 & 0.84 & 12.61 & 2.28 & 0.02 & 0.32 & 0.95 & 2.42 & 5.51 & 0.10 & 98.69 \\
\hline MA-TK & 479 & $\mathrm{mi}$ & 71.37 & 0.33 & 14.68 & 2.22 & 0.00 & 0.31 & 1.42 & 3.42 & 6.15 & 0.12 & 99.61 \\
\hline MA-TK & 479 & $\mathrm{mi}$ & 72.80 & 1.08 & 13.96 & 2.07 & 0.02 & 0.29 & 1.07 & 2.77 & 5.86 & 0.13 & 99.64 \\
\hline MA-TK & 479 & $\mathrm{mi}$ & 71.60 & 0.54 & 14.72 & 2.54 & 0.00 & 0.24 & 1.17 & 2.86 & 6.23 & 0.11 & 99.55 \\
\hline MA-TK & 479 & $\mathrm{mi}$ & 74.82 & 0.68 & 12.38 & 2.01 & 0.00 & 0.21 & 0.88 & 3.04 & 5.90 & 0.10 & 100.17 \\
\hline MA-TK & 479 & $\mathrm{mi}$ & 72.67 & 0.98 & 13.77 & 2.01 & 0.00 & 0.21 & 0.88 & 3.26 & 6.12 & 0.14 & 100.25 \\
\hline MA-TK & 479 & $\mathrm{mi}$ & 72.93 & 1.06 & 13.71 & 1.90 & 0.03 & 0.18 & 1.94 & 3.04 & 5.13 & 0.10 & 99.72 \\
\hline MA-TK & 479 & ig & 70.66 & 0.74 & 15.48 & 2.40 & 0.02 & 0.36 & 1.19 & 3.17 & 5.87 & 0.15 & 98.25 \\
\hline MA-TK & 479 & ig & 72.85 & 0.91 & 13.12 & 2.37 & 0.02 & 0.30 & 1.08 & 2.96 & 6.28 & 0.15 & 98.33 \\
\hline MA-TK & 479 & ig & 73.67 & 0.90 & 12.78 & 2.45 & 0.01 & 0.29 & 1.08 & 3.05 & 5.66 & 0.13 & 98.55 \\
\hline MA-TK & 479 & ig & 74.55 & 0.91 & 12.34 & 2.18 & 0.00 & 0.26 & 0.90 & 2.80 & 5.96 & 0.12 & 98.29 \\
\hline MA-TK & 479 & $\mathrm{gm}$ & 75.01 & 0.82 & 12.19 & 2.24 & 0.03 & 0.22 & 0.92 & 2.90 & 5.59 & 0.09 & 100.34 \\
\hline MA-TK & 479 & gm & 74.95 & 0.81 & 12.22 & 2.23 & 0.03 & 0.23 & 0.95 & 2.84 & 5.68 & 0.08 & 101.11 \\
\hline MA-TK & 479 & gm & 75.05 & 0.82 & 12.06 & 2.28 & 0.02 & 0.22 & 0.89 & 2.81 & 5.77 & 0.09 & 101.15 \\
\hline MA-TK & 479 & $\mathrm{gm}$ & 74.67 & 0.82 & 12.40 & 2.13 & 0.04 & 0.21 & 1.15 & 2.95 & 5.56 & 0.07 & 100.83 \\
\hline MA-TK & 479 & $\mathrm{gm}$ & 75.38 & 0.78 & 12.04 & 2.08 & 0.00 & 0.21 & 0.92 & 2.78 & 5.76 & 0.09 & 100.81 \\
\hline MA-TK & 479 & $\mathrm{gm}$ & 75.00 & 0.76 & 12.31 & 2.13 & 0.00 & 0.22 & 0.97 & 2.75 & 5.79 & 0.10 & 100.80 \\
\hline MA-TK & 479 & $\mathrm{gm}$ & 73.13 & 0.83 & 12.69 & 2.75 & 0.04 & 0.60 & 1.68 & 3.15 & 5.05 & 0.11 & 100.94 \\
\hline MA-TK & 479 & $\mathrm{gm}$ & 73.42 & 0.80 & 13.25 & 2.24 & 0.03 & 0.25 & 1.46 & 3.28 & 5.20 & 0.09 & 100.58 \\
\hline MA-TK & 479 & gm & 73.57 & 0.79 & 13.31 & 1.98 & 0.03 & 0.22 & 1.65 & 3.25 & 5.13 & 0.10 & 101.28 \\
\hline MA-ME & 69 & gm & 69.38 & 1.83 & 13.18 & 4.87 & 0.11 & 0.52 & 2.55 & 4.52 & 2.98 & 0.08 & 99.66 \\
\hline MA-ME & 69 & $\mathrm{gm}$ & 68.96 & 1.81 & 12.32 & 5.84 & 0.10 & 0.87 & 2.63 & 4.11 & 3.32 & 0.07 & 100.16 \\
\hline MA-ME & 69 & $\mathrm{gm}$ & 70.10 & 1.71 & 13.26 & 4.33 & 0.09 & 0.46 & 2.38 & 4.55 & 3.09 & 0.06 & 99.95 \\
\hline MA-ME & 69 & $\mathrm{gm}$ & 69.22 & 1.74 & 12.74 & 5.44 & 0.12 & 0.79 & 2.67 & 4.56 & 2.65 & 0.09 & 99.70 \\
\hline MA-ME & 69 & $\mathrm{gm}$ & 69.79 & 1.77 & 12.52 & 5.19 & 0.13 & 0.64 & 2.41 & 4.37 & 3.12 & 0.10 & 99.99 \\
\hline MA-ME & 69 & $\mathrm{gm}$ & 69.33 & 1.73 & 12.82 & 5.37 & 0.12 & 0.64 & 2.41 & 4.41 & 3.14 & 0.06 & 100.36 \\
\hline MA-ME & 69 & $\mathrm{gm}$ & 69.04 & 1.64 & 13.23 & 5.15 & 0.12 & 0.66 & 2.49 & 5.03 & 2.56 & 0.10 & 99.77 \\
\hline MA-ME & 69 & $\mathrm{gm}$ & 69.39 & 1.75 & 13.38 & 4.75 & 0.12 & 0.64 & 2.51 & 4.79 & 2.62 & 0.09 & 100.00 \\
\hline MA-ME & 69 & $\mathrm{gm}$ & 69.33 & 1.59 & 13.83 & 4.45 & 0.11 & 0.50 & 2.73 & 4.36 & 3.05 & 0.08 & 99.84 \\
\hline MA-ME & 69 & $\mathrm{gm}$ & 69.73 & 1.71 & 13.14 & 4.92 & 0.11 & 0.66 & 2.92 & 4.13 & 2.64 & 0.06 & 99.85 \\
\hline MA-ME & 69 & $\mathrm{gm}$ & 68.97 & 1.79 & 12.70 & 5.48 & 0.13 & 0.68 & 2.39 & 4.41 & 3.42 & 0.07 & 100.08 \\
\hline MA-ME & 69 & $\mathrm{gm}$ & 69.69 & 1.61 & 12.70 & 5.12 & 0.14 & 0.69 & 2.43 & 4.59 & 2.99 & 0.06 & 99.32 \\
\hline MA-ME & 69 & $\mathrm{gm}$ & 69.10 & 1.66 & 13.11 & 5.19 & 0.12 & 0.65 & 2.56 & 4.60 & 2.96 & 0.08 & 99.87 \\
\hline MA-ME & 69 & $\mathrm{mi}$ & 68.27 & 1.30 & 16.30 & 3.04 & 0.14 & 0.19 & 2.99 & 3.99 & 3.74 & 0.06 & 100.41 \\
\hline MA-ME & 69 & $\mathrm{mi}$ & 67.81 & 1.23 & 17.11 & 2.74 & 0.14 & 0.20 & 3.60 & 3.99 & 3.17 & 0.05 & 99.11 \\
\hline MA-ME & 69 & $\mathrm{mi}$ & 67.56 & 1.29 & 17.06 & 2.95 & 0.15 & 0.67 & 3.57 & 3.38 & 3.34 & 0.05 & 100.20 \\
\hline MA-ME & 69 & $\mathrm{mi}$ & 71.16 & 0.78 & 14.88 & 2.86 & 0.14 & 0.18 & 2.60 & 3.46 & 3.91 & 0.05 & 100.20 \\
\hline MA-ME & 77 & $\mathrm{mi}$ & 71.58 & 0.92 & 15.54 & 1.23 & 0.15 & 0.07 & 1.98 & 4.20 & 4.35 & 0.01 & 100.34 \\
\hline MA-ME & 77 & $\mathrm{mi}$ & 72.65 & 0.60 & 15.40 & 0.69 & 0.12 & 0.16 & 1.71 & 3.43 & 5.23 & 0.03 & 99.55 \\
\hline MA-ME & 77 & $\mathrm{mi}$ & 72.66 & 0.81 & 14.87 & 1.40 & 0.15 & 0.04 & 1.70 & 3.98 & 4.39 & 0.03 & 100.02 \\
\hline MA-ME & 77 & $\mathrm{mi}$ & 72.54 & 0.84 & 15.02 & 1.35 & 0.16 & 0.07 & 1.51 & 4.01 & 4.53 & 0.02 & 100.55 \\
\hline MA-ME & 77 & $\mathrm{mi}$ & 72.89 & 0.45 & 15.29 & 1.07 & 0.13 & 0.08 & 2.28 & 4.27 & 3.49 & 0.07 & 100.37 \\
\hline MA-ME & 77 & $\mathrm{mi}$ & 74.32 & 1.86 & 12.96 & 1.44 & 0.15 & 0.12 & 0.56 & 3.03 & 5.60 & 0.00 & 99.35 \\
\hline MA-ME & 77 & $\mathrm{mi}$ & 75.40 & 0.65 & 14.02 & 0.48 & 0.13 & 0.07 & 1.58 & 3.75 & 3.90 & 0.05 & 99.71 \\
\hline MA-ME & 77 & $\mathrm{mi}$ & 76.62 & 0.59 & 13.28 & 0.44 & 0.14 & 0.07 & 1.12 & 3.73 & 3.98 & 0.05 & 99.84 \\
\hline
\end{tabular}

Values are in in weight \%, normalised to anhydrous $100 \%$ totals. Abbreviations are on page 251. 
Table A7.2. (cont.) Major element data for glass in Ruapehu lava samples.

\begin{tabular}{|c|c|c|c|c|c|c|c|c|c|c|c|c|c|}
\hline F-P & Sam & Type & $\mathrm{SiO}_{2}$ & $\mathrm{TiO}_{2}$ & $\mathrm{Al}_{2} \mathrm{O}_{3}$ & $\mathrm{FeO}$ & MnO & $\mathrm{MgO}$ & $\mathrm{CaO}$ & $\mathrm{Na}_{2} \mathrm{O}$ & $\mathbf{K}_{2} \mathbf{O}$ & $\mathrm{Cl}$ & Total \\
\hline MA-ME & 77 & $\mathrm{mi}$ & 69.36 & 0.77 & 17.49 & 1.10 & 0.16 & 0.15 & 3.12 & 4.56 & 3.30 & 0.02 & 100.41 \\
\hline MA-ME & 77 & $\mathrm{mi}$ & 69.28 & 1.53 & 16.03 & 1.72 & 0.07 & 0.15 & 2.59 & 4.89 & 3.72 & 0.03 & 00.56 \\
\hline MA-ME & 77 & $\mathrm{mi}$ & 69.50 & 0.83 & 16.12 & 1.50 & 0.03 & 0.14 & 0.66 & 7.15 & 4.07 & 0.01 & 100.24 \\
\hline MA-ME & 77 & $\mathrm{mi}$ & 71.13 & 1.58 & 15.11 & 1.42 & 0.08 & 0.11 & 2.85 & 3.82 & 3.89 & 0.02 & 99.44 \\
\hline MA-ME & 154 & $\mathrm{mi}$ & 73.85 & 0.13 & 15.08 & 1.02 & 0.12 & 0.04 & 1.53 & 3.84 & 4.38 & 0.02 & 99.56 \\
\hline MA-ME & 154 & $\mathrm{mi}$ & 73.84 & 0.10 & 14.96 & 0.91 & 0.13 & 0.04 & 1.77 & 3.87 & 4.39 & 0.01 & 100.05 \\
\hline MA-ME & 154 & $\mathrm{mi}$ & 73.60 & 0.14 & 15.24 & 1.01 & 0.14 & 0.06 & 1.50 & 3.92 & 4.40 & 0.02 & 100.22 \\
\hline MA-ME & 154 & $\mathrm{mi}$ & 73.71 & 0.15 & 15.13 & 1.17 & 0.13 & 0.04 & 1.46 & 4.00 & 4.24 & 0.01 & 100.27 \\
\hline MA-ME & 154 & $\mathrm{mi}$ & 74.21 & 0.19 & 14.56 & 0.71 & 0.15 & 0.05 & 1.68 & 3.76 & 4.70 & 0.01 & 99.02 \\
\hline MA-ME & 154 & $\mathrm{mi}$ & 75.17 & 0.15 & 14.41 & 0.73 & 0.12 & 0.05 & 0.94 & 3.68 & 4.76 & 0.00 & 100.40 \\
\hline MA-ME & 154 & $\mathrm{mi}$ & 74.98 & 0.12 & 14.47 & 0.66 & 0.12 & 0.04 & 1.28 & 3.64 & 4.66 & 0.05 & 99.85 \\
\hline MA-ME & 154 & $\mathrm{mi}$ & 74.98 & 0.14 & 14.50 & 0.86 & 0.12 & 0.07 & 1.59 & 3.54 & 4.19 & 0.03 & 100.08 \\
\hline MA-ME & 154 & $\mathrm{mi}$ & 75.24 & 0.13 & 14.21 & 1.00 & 0.14 & 0.04 & & 3.48 & 4.26 & 0.04 & 99.77 \\
\hline MA-ME & 154 & $\mathrm{mi}$ & 73.31 & 0.73 & 14.53 & & 6 & & & & 5.08 & 0.04 & 99.87 \\
\hline MA-ME & 154 & $\mathrm{mi}$ & 74.24 & 0.13 & 14.79 & 0.81 & 0.17 & 0.05 & 1.12 & 3.61 & 5.12 & 0.01 & 100.10 \\
\hline MA-ME & 154 & $\mathrm{mi}$ & 74.68 & 0.16 & 14.43 & 1.21 & 0.13 & 0.01 & 1.41 & 3.52 & 4.45 & 0.03 & 100.04 \\
\hline MA-ME & 154 & $\mathrm{mi}$ & 75.71 & 0.11 & 14.54 & 0.53 & 0.13 & 0.06 & 0.86 & 4.11 & 3.96 & 0.02 & 99.65 \\
\hline MA-ME & 154 & $\mathrm{mi}$ & 74.50 & 0.13 & 15.22 & 0.58 & 0.17 & 0.03 & 1.00 & 4.41 & 3.99 & 0.01 & 100.02 \\
\hline TH & 348 & $\mathrm{mi}$ & 70.22 & 0.40 & 17.16 & 1.08 & 0.05 & 0.07 & 2.53 & 5.93 & 2.42 & 0.18 & 99.30 \\
\hline $\mathrm{TH}$ & 326 & $\mathrm{mi}$ & 74.15 & 0.22 & 15.95 & 0.65 & 0.01 & 0.02 & & 5.01 & 2.50 & 0.14 & 100.07 \\
\hline TH & 326 & $\mathrm{mi}$ & 73.27 & 0.16 & 16.25 & & & & & & & 0.20 & 100.47 \\
\hline $\mathrm{TH}$ & 326 & $\mathrm{mi}$ & 74.77 & 0. & 13.45 & & & & & & & 6 & 99.01 \\
\hline $\mathrm{TH}$ & 326 & $\mathrm{mi}$ & 74.02 & 0.18 & 13.29 & 2.09 & 0.00 & & & 3.28 & 2.84 & 0.11 & 98.12 \\
\hline $\mathrm{TH}$ & 326 & $\mathrm{mi}$ & 75.52 & 0.10 & 14.50 & 1.48 & 0.06 & 0.09 & 1.91 & 4.18 & 2.04 & 0.18 & 98.78 \\
\hline $\mathrm{TH}$ & 326 & $\mathrm{mi}$ & 76.61 & 0.11 & 14.07 & 1.07 & 0.05 & 0.03 & 1.81 & 4.19 & 1.93 & 0.15 & 100.48 \\
\hline $\mathrm{TH}$ & 326 & $\mathrm{mi}$ & 77.45 & 0.11 & 13.49 & 1.06 & 0.03 & 0.04 & 1.70 & 3.81 & 2.21 & 0.14 & 100.71 \\
\hline $\mathrm{TH}$ & 326 & $\mathrm{mi}$ & 71.65 & 0.47 & 17.85 & 1.41 & 0.07 & 0.07 & 2.72 & 3.26 & 2.35 & 0.21 & 100.64 \\
\hline $\mathrm{TH}$ & 326 & $\mathrm{mi}$ & 78.70 & 0.12 & 13.97 & 0.93 & 0.02 & 0.00 & 1.61 & 1.62 & 2.96 & 0.10 & 98.21 \\
\hline $\mathrm{TH}$ & 326 & $\mathrm{mi}$ & 77.45 & 0.06 & 12.94 & 0.84 & 0.05 & 0.02 & 1.34 & 3.74 & 3.49 & 0.08 & 100.20 \\
\hline $\mathrm{TH}$ & 308 & $\mathrm{mi}$ & 74.86 & 0.29 & 15.43 & 0.9 & 0. & 0.08 & 2.15 & 4.21 & 1.85 & 0.16 & 99.81 \\
\hline $\mathrm{TH}$ & 308 & $\mathrm{mi}$ & 72.31 & 0. & & & & 0 & & & 2.34 & 0.18 & 100.37 \\
\hline $\mathrm{TH}$ & 308 & $\mathrm{mi}$ & 69.74 & 0.99 & 17.36 & 1.9 & & 0.08 & 4 & 4.57 & 2.22 & 0.19 & 100.74 \\
\hline $\mathrm{TH}$ & 30 & $\mathrm{mi}$ & 70.20 & 0.95 & 16.89 & 1.92 & 0.05 & 0.07 & 2.83 & 4.74 & 2.22 & 0.16 & 101.62 \\
\hline $\mathrm{TH}$ & 308 & $\mathrm{mi}$ & 70.54 & 0.93 & 16.73 & 1.78 & 0.03 & 0.10 & 2.68 & 4.71 & 2.35 & 0.17 & 101.27 \\
\hline $\mathrm{TH}$ & 308 & $\mathrm{mi}$ & 69.94 & 1.13 & 17.02 & 1.77 & 0.04 & 0.16 & 2.84 & 4.69 & 2.28 & 0.17 & 100.85 \\
\hline $\mathrm{TH}$ & 308 & $\mathrm{mi}$ & 71.03 & 1.06 & 16.51 & 1.63 & 0.04 & 0.07 & 2.63 & 4.57 & 2.34 & 0.17 & 101.49 \\
\hline $\mathrm{TH}$ & 308 & $\mathrm{mi}$ & 70.74 & 0.87 & 16.73 & 1.76 & 0.04 & 0.13 & 2.58 & 4.56 & 2.44 & 0.18 & 100.72 \\
\hline $\mathrm{TH}$ & 308 & $\mathrm{mi}$ & 70.60 & 0.99 & 17.00 & 1.45 & 0.04 & 0.11 & 2.68 & 4.62 & 2.36 & 0.18 & 100.66 \\
\hline TH & 308 & $\mathrm{mi}$ & 70.25 & 0.99 & 17.12 & 1.75 & 0.01 & 0.07 & 2.78 & 4.64 & 2.25 & 0.17 & 101.12 \\
\hline TH & 308 & $\mathrm{mi}$ & 70.56 & 1.03 & 16.62 & 1.70 & 0.02 & 0.06 & 2.66 & 4.83 & 2.38 & 0.16 & 101.75 \\
\hline $\mathrm{TH}$ & 308 & $\mathrm{mi}$ & 69.92 & 1.08 & 16.88 & 1.57 & 0.03 & 0.10 & 2.76 & 4.65 & 2.87 & 0.19 & 100.99 \\
\hline $\mathrm{TH}$ & 308 & $\mathrm{mi}$ & 69.90 & 0.39 & 17.50 & 2.13 & 0.03 & 0.05 & 3.45 & 4.71 & 1.74 & 0.13 & 101.31 \\
\hline
\end{tabular}

Values are in in weight \%, normalised to anhydrous $100 \%$ totals. Abbreviations are on page 251. 


\section{Appendix 8. EPMA: mineral major element standard data}

Major element compositions for minerals in 15 lava samples were analysed by electron probe microanalysis (EPMA) using the JEOL JXA 8230 instrument at VUW. This instrument is equipped with 5 wavelength dispersive X-ray spectrometers (WDS), an energy dispersive X-ray spectrometer (EDS) and highly sensitive detectors for acquisition of back-scattered electron (BSE) images. Thin sections were prepared from lava samples and coated with a $\sim 25 \mathrm{~nm}$ film of carbon before analysis. For quantitative measurements of pyroxene and plagioclase the instrument was calibrated using international mineral (Kakanui augite and labradorite plagioclase) standards of similar composition to the material being analysed for most elements and synthetic oxides for elements in low abundance $(<1 \mathrm{wt} . \%)$. For each element, calibration was undertaken during a 30 seconds peak-search and a 15 seconds background measurement. Analysis of crystal phases were performed using a focussed electron beam $(\sim 1 \mu \mathrm{m}$-wide) at a current of $12 \mathrm{nA}$ and accelerating voltage of $15 \mathrm{kV}$. Element concentrations were calculated using the ZAF correction method (where $\mathrm{Z}$ is atomic number, $\mathrm{A}$ is absorption and $\mathrm{F}$ is fluorescence; Carpenter, 2008 and references therein). Calibration and secondary standards were analysed as unknowns to monitor instrumental drift and precision and accuracy of the measurements throughout analytical sessions. Approximate 2 sd analytical precision from repeated analysis of mineral standards are generally $1-7$ relative $\%$ for major element oxides with concentrations $>0.5 \mathrm{wt}$. \% . Analyses of the standards are accurate to within 5 $\%$ of the preferred values for those major element oxides. Full sample data are provided in the electronic appendix files.

Table A8.1. Precision and accuracy of pyroxene major element analysis by EPMA:

Kakanui augite $\mathrm{n}=129$

\begin{tabular}{|l|rrrrrrrrrr|}
\hline & $\mathbf{S i O}_{2}$ & $\mathbf{T i O}_{2}$ & $\mathbf{A l}_{2} \mathbf{O}_{3}$ & $\mathbf{F e O}$ & $\mathbf{M n O}$ & $\mathbf{M g O}$ & $\mathbf{C a O}$ & $\mathbf{N a}_{2} \mathbf{O}$ & $\mathbf{C r}_{2} \mathbf{O}_{3}$ & Total \\
\hline Avg & 50.4 & 0.8 & 8.5 & 6.2 & 0.1 & 16.7 & 15.8 & 1.2 & 0.2 & 100.0 \\
Max & 51.1 & 0.9 & 8.8 & 6.7 & 0.2 & 17.4 & 16.1 & 1.3 & 0.2 & 101.1 \\
Min & 48.5 & 0.7 & 8.2 & 5.3 & 0.1 & 16.2 & 15.4 & 1.1 & 0.1 & 97.8 \\
2sd & 0.8 & 0.1 & 0.2 & 0.4 & 0.0 & 0.4 & 0.3 & 0.1 & 0.0 & 1.2 \\
2sd \% & 1.6 & 6.8 & 2.8 & 6.8 & 27.0 & 2.6 & 1.8 & 6.6 & 27.0 & 1.2 \\
\hline Ref & 50.7 & 0.7 & 8.7 & 6.3 & 0.1 & 16.7 & 15.8 & 1.3 & 0.2 & 100.6 \\
Off \% & 3.3 & -11.2 & 0.5 & 2.2 & -5.7 & -0.2 & 0.1 & 4.2 & -2.8 & 0.6 \\
\hline
\end{tabular}

Reference values from Jarosewich et al. (1980) and Klügel et al. (2005)

Table A8.2. Precision and accuracy of plagioclase major element analysis by EPMA: Labradorite plagioclase $\mathrm{n}=107$

\begin{tabular}{l|rrrrrrrrrr|}
\hline & $\mathbf{S i O}_{\mathbf{2}}$ & $\mathbf{T i O}_{\mathbf{2}}$ & $\mathbf{A l}_{\mathbf{2}} \mathbf{O}_{\mathbf{3}}$ & $\mathbf{F e O}$ & $\mathbf{M n O}$ & $\mathbf{M g O}$ & $\mathbf{C a O}$ & $\mathbf{N a}_{\mathbf{2}} \mathbf{O}$ & $\mathbf{K}_{2} \mathbf{O}$ & Total \\
\hline Avg & 51.1 & 0.0 & 30.8 & 0.4 & 0.0 & 0.1 & 13.4 & 3.4 & 0.2 & 99.5 \\
Max & 51.9 & 0.1 & 31.3 & 0.5 & 0.0 & 0.2 & 13.7 & 3.7 & 0.2 & 100.5 \\
Min & 50.0 & 0.0 & 30.2 & 0.3 & 0.0 & 0.1 & 13.0 & 3.1 & 0.1 & 97.7 \\
2sd & 0.9 & 0.0 & 0.6 & 0.1 & 0.0 & 0.0 & 0.4 & 0.2 & 0.1 & 1.2 \\
2sd \% & 1.7 & 86.7 & 1.9 & 19.6 & 209.9 & 17.2 & 3.0 & 6.6 & 29.4 & 1.2 \\
\hline Ref & 51.3 & 0.1 & 30.9 & 0.2 & 0.0 & 0.1 & 13.6 & 3.5 & 0.2 & 100.2 \\
Off \% & 0.3 & 48.8 & 0.5 & -177.8 & 15.9 & -5.1 & 1.6 & 0.8 & -0.7 & 0.7 \\
\hline
\end{tabular}
Reference values from Jarosewich et al. (1980)




\section{Appendix 9. LA-ICP-MS glass standard data}

Laser ablation (LA) ICP-MS analyses of interstitial glass and xenolith-hosted glass in dacite lava sample CC415 were carried out at VUW using a Resonetics RESOlution S155-SE laser ablation system equipped with an ATL ArF Excimer laser (wavelength 193 $\mu \mathrm{m}$ ) and coupled to an Agilent 7500CS ICP-MS. Instrument set-up and data processing are described in Chapter 4.

BHVO-2G and BCR-2G were analysed as secondary standards. Because the analysis session was intended as a preliminary exercise for collecting trace element data for Ruapehu glasses, only 2 spots on each standard, and 11 spots on samples were analysed. Analyses of standards were generally accurate to within $15 \%$ of reference values, and mostly $<5 \%$ for the light rare earth elements and elements of interest for the purposes of this study ( $\mathrm{Rb}, \mathrm{Sr}, \mathrm{Zr}, \mathrm{Ba}$ ). Exceptions to these values were calculated for $\mathrm{Tm}$ and $\mathrm{Hf}$ in BCR-2G and Cs, Eu and Lu in BHVO-2G (Table A9.1).

Table A9.1. Accuracy of LA-ICP-MS trace element analyses of BCR-2G and BHVO-2G.

\begin{tabular}{|c|c|c|c|c|c|c|c|c|c|c|c|}
\hline BCR-2G & Ref. & $\operatorname{std} 1$ & std 2 & Avg & $\%$ off & \begin{tabular}{|l} 
BHVO-2G \\
\end{tabular} & Ref. & std 1 & std 2 & Avg & $\%$ off \\
\hline Sc45 & 33 & 34.4 & 36.1 & 35.3 & 6.9 & Sc45 & 33 & 30.5 & 32.0 & 31.3 & -5.3 \\
\hline V51 & 425 & 456 & 444 & 450 & 5.9 & V51 & 308 & 337 & 311 & 324 & 5.1 \\
\hline Zn66 & 125 & 177 & 161 & 169 & 35.2 & Zn66 & 102 & 133.9 & 134.3 & 134.1 & 31.5 \\
\hline Rb85 & 47 & 47.5 & 43.8 & 45.7 & -2.8 & Rb85 & 9.2 & 10.4 & 8.5 & 9.4 & 2.6 \\
\hline Sr88 & 342 & 354 & 367 & 360 & 5.4 & Sr88 & 396 & 383 & 374 & 379 & -4.4 \\
\hline Y89 & 35 & 35.2 & 36.7 & 36.0 & 2.8 & Y89 & 26 & 26.3 & 23.0 & 24.7 & -5.2 \\
\hline Zr91 & 184 & 192 & 176 & 184 & 0.0 & Zr91 & 170 & 180 & 144 & 162 & -4.7 \\
\hline Nb93 & 12.5 & 10.5 & 12.0 & 11.2 & -10.2 & Nb93 & 18.3 & 16.7 & 15.6 & 16.2 & -11.7 \\
\hline Cs133 & 1.16 & 1.4 & 1.1 & 1.2 & 7.1 & Cs133 & 0.1 & bdl & 0.1 & 0.1 & -25.0 \\
\hline Ba137 & 683 & 703 & 699 & 701 & 2.6 & Ba137 & 131 & 110 & 123 & 116 & -11.2 \\
\hline La139 & 24.7 & 27.0 & 25.6 & 26.3 & 6.5 & La139 & 15.2 & 13.3 & 14.8 & 14.1 & -7.5 \\
\hline Ce140 & 53.3 & 51.7 & 56.4 & 54.0 & 1.4 & Ce140 & 37.6 & 37.9 & 34.9 & 36.4 & -3.2 \\
\hline Pr141 & 6.7 & 6.6 & 6.3 & 6.5 & -3.5 & Pr141 & 5.35 & 5.2 & 4.9 & 5.1 & -5.6 \\
\hline Nd146 & 28.9 & 26.3 & 27.5 & 26.9 & -6.9 & Nd146 & 24.5 & 24.0 & 21.9 & 22.9 & -6.4 \\
\hline Sm 147 & 6.59 & 8.7 & 6.2 & 7.5 & 13.1 & Sm 147 & 6.1 & 6.2 & 6.3 & 6.2 & 2.2 \\
\hline Eu151 & 1.97 & 2.4 & 2.1 & 2.2 & 13.6 & Eu151 & 2.07 & 1.3 & 1.9 & 1.6 & -20.6 \\
\hline Gd157 & 6.71 & 7.6 & 7.4 & 7.5 & 11.6 & Gd157 & 6.16 & 5.4 & 6.0 & 5.7 & -7.3 \\
\hline Tb159 & 1.02 & 0.7 & 1.2 & 1.0 & -5.2 & Tb159 & 0.92 & 0.8 & 0.9 & 0.8 & -8.6 \\
\hline Dy 163 & 6.44 & 7.7 & 7.1 & 7.4 & 15.3 & Dy 163 & 5.28 & 5.8 & 5.5 & 5.7 & 7.5 \\
\hline Ho165 & 1.27 & 1.0 & 1.1 & 1.1 & -13.9 & Ho165 & 0.98 & 0.7 & 0.9 & 0.8 & -16.7 \\
\hline Er166 & 3.7 & 3.2 & 3.5 & 3.4 & -8.5 & Er166 & 2.56 & 4.1 & 1.9 & 3.0 & 17.0 \\
\hline $\operatorname{Tm} 169$ & 0.51 & 0.3 & 0.4 & 0.4 & -26.1 & $\operatorname{Tm} 169$ & 0.34 & 0.4 & 0.3 & 0.4 & 9.7 \\
\hline Yb172 & 3.39 & 2.0 & 3.9 & 3.0 & -12.6 & Yb172 & 2.01 & 1.9 & 2.4 & 2.1 & 6.1 \\
\hline Lu 175 & 0.503 & 0.6 & 0.6 & 0.6 & 14.0 & Lu175 & 0.279 & 0.2 & 0.1 & 0.2 & -43.6 \\
\hline Hf178 & 4.84 & 6.2 & 5.8 & 6.0 & 24.1 & Hf178 & 4.32 & 4.0 & 4.1 & 4.1 & -6.1 \\
\hline
\end{tabular}

Values are concentrations in ppm. Reference values from Georem. 